

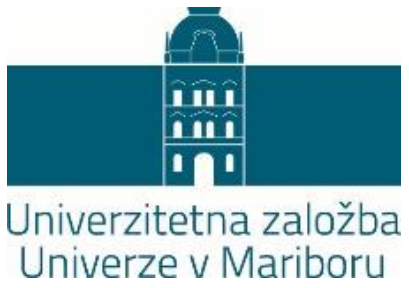




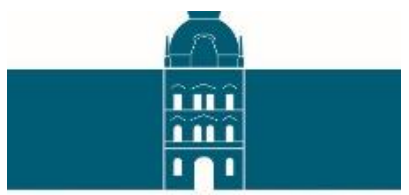

Univerzitetna založba

Univerze v Mariboru

\section{Geografije Podravja}

Uredniki:

dr. Vladimir Drozg

dr. Uroš Horvat

dr. Eva Konečnik Kotnik 
Naslov: Geografije Podravja

Title: The Geographies of the Podravje Region

Zbirka: Prostori

Uredniki: izr. prof. dr. Vladimir Drozg (Univerza v Mariboru, Filozofska fakulteta) doc. dr. Uroš Horvat (Univerza v Mariboru, Filozofska fakulteta) izr. prof. dr. Eva Konečnik Kotnik (Univerza v Mariboru, Filozofska fakulteta)

Strokovna recenzija: izr. prof. dr. Stane Pelc (Univerza na Primorskem, Pedagoška fakulteta) izr. prof. dr. Jernej Zupančič (Univerza v Ljubljani, Filozofska fakulteta)

Tehnični urednik: Jan Perša, mag. inž. prom. (Univerzitetna založba Univerze v Mariboru)

Avtorji slik: Avtorji prispevkov

\section{Izdajateljica:}

Univerza v Mariboru, Filozofska fakulteta Koroška cesta 160, 2000 Maribor, Slovenija tel. +386222938 40, faks +386222962 25 http://www.ff.um.si, ff@um.si

\section{Založnik:}

Univerzitetna založba Univerze v Mariboru Slomškov trg 15, 2000 Maribor, Slovenija tel. +386225042 42, faks +38622523245 http://press.um.si, zalozba@um.si

\section{Dostopno na: http://press.um.si/index.php/ump/catalog/book/262}

Izid: September 2017

\section{(c) Univerzitetna založba Univerze v Mariboru}

Vse pravice pridržane. Brez pisnega dovoljenja založnika je prepovedano reproduciranje, distribuiranje, predelava ali druga uporaba tega dela ali njegovih delov v kakršnemkoli obsegu ali postopku, vključno s fotokopiranjem, tiskanjem ali shranjevanjem v elektronski obliki.

Izid knjige sta finančno podprli Univerza v Mariboru in Filozofska fakulteta v Mariboru.

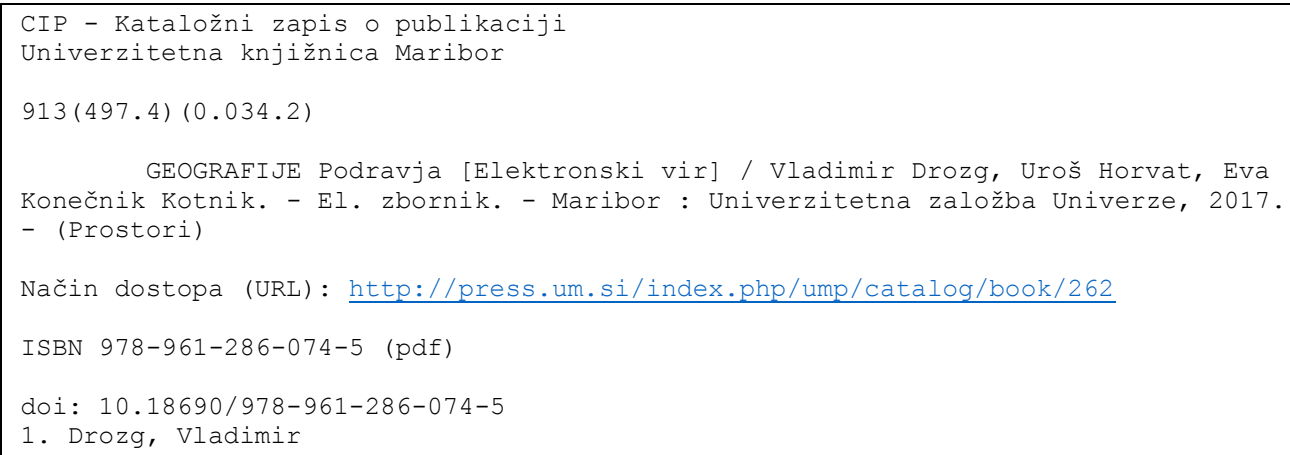

ISBN: $\quad 978-961-286-073-8$ (tiskan izvod) 978-961-286-074-5 (PDF)

DOI: https://doi.org/10.18690/978-961-286-074-5

Cena: Brezplačen izvod

Odgovorna oseba založnika: prof. dr. Igor Tičar, rektor Univerze v Mariboru 


\title{
Geografije Podravja
}

\author{
VladimiR DrozG, URoŠ HoRVAT, Eva KonEČNIK KOTNIK
}

Povzetek V monografiji je zbranih 19 znanstvenih prispevkov, ki obravnavajo aktualne teme o naravnih in družbenih značilnostih Podravja, med njimi je nekaj takih, ki si šele utirajo prostor v regionalni geografiji. V prispevkih so prikazane hidrološke razmere, ekosistemski pogled na pokrajino, spreminjanje rabe tal, degradirana območja, posledice gospodarske krize, prostorski razvoj naselij, vodno gospodarske ureditve vodotokov, politični profil volilnega telesa, demografske, gospodarske, bivalne in prometne razmere $\mathrm{v}$ Mariboru in ne nazadnje način, kako spoznanja o pokrajini prenesti v izobraževanje učencev in dijakov. Besedila so izdatno dokumentirana s tematskimi kartami in drugim empiričnim gradivom. Knjiga je zanimiva tudi zaradi koncepta nove regionalne geografije.

Ključne besede: • Podravje $\cdot$ Slovenija $・$ regionalna geografija $・$ fizična geografija $\bullet$ družbena geografija $\bullet$

\footnotetext{
NASLOVI UREDNIKOV: dr. Vladimir Drozg, izredni profesor, Univerza v Mariboru, Filozofska fakulteta, Oddelek za geografijo, Koroška cesta 160, 2000 Maribor, Slovenija, e-naslov: vlado.drozg@um.si. dr. Uroš Horvat, docent, Univerza v Mariboru, Filozofska fakulteta, Oddelek za geografijo, Koroška cesta 160, 2000 Maribor, Slovenija, e-naslov: uros.horvat@um.si. dr. Eva Konečnik Kotnik, izredna profesorica, Univerza v Mariboru, Filozofska fakulteta, Oddelek za geografijo, Koroška cesta 160, 2000 Maribor, Slovenija, e-naslov: eva. konecnik@um.si.
} 


\title{
The Geographies of the Podravje Region
}

\author{
VladimiR DroZG, URoŠ HoRVAT, EVA KONEČNIK KOTNIK
}

\begin{abstract}
The monograph contains 19 scientific contributions which discuss current topics on natural and social characteristics of Podravje; among them, some are pioneering in regional geography. The articles present the hydrological conditions, the ecosystem view of the landscape, the changes in soil use, the degraded areas, the consequences of the economic crisis, the spatial development of settlements, the water economic regulation of watercourses, the political profile of the electorate together with the demographic, economic, housing and traffic conditions of Maribor and, finally, the way of transferring knowledge of the landscape into the education of pupils and students. The texts are substantially supported by thematic maps and other empirical material. The book is also interesting due to the concept of new regional geography.
\end{abstract}

Keywords: • Podravje region $・$ Slovenia $・$ regional geography $\bullet$ physical geography $\bullet$ human geography $\bullet$

CoRrespondence AdDress: Vladimir Drozg, Ph.D., Associate Professor, University of Maribor, Faculty of Arts, Department for geogrpahy, Koroška cesta 160, 2000 Maribor, Slovenia, e-mail: vlado.drozg@um.si. Uroš Horvat, Ph.D., Assistant Professor, University of Maribor, Department for geogrpahy, Faculty of Arts, Koroška cesta 160, 2000 Maribor, Slovenia, e-mail: uros.horvat@um.si. Eva Konečnik Kotnik, Ph.D., Associate Professor, University of Maribor, Faculty of Arts, Department for geogrpahy, Koroška cesta 160, 2000 Maribor, Slovenia, e-mail: eva. konecnik@um.si. 


\section{Uvodnik}

Poznavanje življenjskega okolja je ključ za uspešen gospodarski in socialni razvoj skupnosti. Čeprav se v današnjem tehniziranem času zdi, da so tehnična, tehnokratska in ekonomistična merila dovolj za vsesplošen razvoj, razmere v prostoru opozarjajo na njihovo nezadostnost in parcialnost. Poznavanje naravnega okolja je pogoj za bivanje $\mathrm{v}$ sozvočju z naravo, poznavanje družbenega okolja pa je ključnega pomena za enakopraven gospodarski in socialni razvoj vseh prebivalcev in lokalnih okolij. In dalje, poznavanje naravnega in družbenega okolja je pogoj za kulturno osveščenost, s čemer je močno povezano naše delovanje v prostoru.

Namen geografije je čim boljši, torej verodostojen, objektiven in celovit prikaz življenjskega okolja. To smo geografi skušali doseči na različne načine. Sprva opisno, izhajajoč iz vzročno posledičnega odnosa med naravo in družbo, kasneje s kvantitativnimi metodami podprto in pod močnim vplivom funkcionalizma in pozitivizma, danes konceptualno zelo različno, vendar metodološko dovršeno, specializirano in v primerjavi s prejšnjimi pristopi, poglobljeno in aplikativno naravnano. Tudi teme - področja življenjskega okolja, ki nas zaposlujejo danes, se močno razlikujejo od nekdanjih. Obravnavajo ozko tematiko, večinoma posamezen pokrajinotvorni element, vendar z izdelanim znanstvenim aparatom, ali pa ponujajo nov pogled na razmere v pokrajini. Celovite opise pokrajin, kar je bilo nekdaj osredje geografije, najdemo zgolj še v učbenikih, potopisih in redkih monografijah. Vse jasneje in natančneje vidimo drevesa, podobo gozda pa vse težje sestavimo zaradi množice primerkov - dreves, številnih podob in številnih lastnosti oziroma podatkov.

Regionalni prikazi današnjega časa so tematsko, konceptualno in metodološko zelo raznoliki. Od nekdaj deklarirane enotnosti - povezanosti družbene in fizične geografije, ni ostalo veliko. Kljub vsebinski in teoretski raznolikosti spoznavanja prostora ni mogoče trditi, da se način obravnave posameznih pojavov odmika od geografije. Nikakor, gre le za drugačno geografijo! Geografijo, ki v pokrajini ne išče povezav med naravo in človekom, temveč skuša pojav spoznati, analizirati, čim globlje prodreti vanj, pokazati na povezave z drugimi relevantnimi elementi, ga čim bolje pojasniti in prikazati njegove prostorske razsežnosti. Ta odmik na simbolni ravni nakazuje tudi naslov publikacije - ne obstaja ena sama geografija, temveč več njih. Zaradi vse večje vsebinske ozkosti in poglobljenosti, je sintezni pogled na pokrajino vse težje dosegljiv, saj je vse bolj obremenjen $\mathrm{z}$ množico podatkov, ki zastirajo in otežujejo pogled na celoto. V strukturirani in heterogeni družbi je sinteza - podati skupne značilnosti obravnavanega območja, lahko zgolj zelo splošna, skoraj antropološkega značaja, ali pa meji na esejistični prikaz.

Sodobna geografija ima zato več obrazov. Je narativna veda, ki značilnosti pokrajine obravnavanega območja, prevede v obliko, ki je razumljiva uporabnikom. Pa to niso le učenci in dijaki, želeti je, da je med njimi tudi čim več odraslih - strokovnjakov in laikov. Je analitična veda, katere spoznanja so aplikativno naravnana. Kljub temu je med geografi zelo razširjeno mnenje, da te uporabnosti še niso prepoznali vsi, katerim je pravzaprav 
namenjena. Je interpretativna veda. Narava geografskih spoznanj, in v veliki meri velja to za celotno družboslovje je, da osvetljujejo problem, ga prikazujejo $\mathrm{v}$ novi luči, odkrivajo še neznane vsebine. Interpretativnost je v boljšem razumevanju pojmov, procesov, razmer in pokrajin. Boljše razumevanje pa je podlaga za boljše odločanje in kakovostnejše ravnanje. Izpostaviti je potrebno še eno posebnost geografskih prikazov: vsega, kar geografi prepoznamo v pokrajini, ni mogoče ponazoriti z besedami. Zato uporabljamo karte, ki so poseben medij informacij o prostoru in omogočajo boljše predstave o okolju v kakršnem živimo.

Območje med Pohorjem in Slovenskimi goricami je sicer bilo že večkrat predmet geografskih proučevanj, vendar zmeraj po posameznih pokrajinah. Leta 1959 je izšla razprava o Pohorskem Podravju, 1967 knjiga o vinorodnih Halozah, leta 1968 o območju med Muro in Dravo, istega leta še o Ljutomersko Ormoških goricah, leta 1969 o Dravskem polju, leta 1975 o Ptujskem polju, leta 1977 o Dravski dolini, 1982 o gozdnatih Halozah, 1985 o Dravinjskih goricah, leta 1978 je izšla publikacija o Mariboru, 1994 še ena, 1996 pa o Spodnjem Podravju. Tak poglobljen prikaz širšega območja - statistične regije Podravje je prvi, če odmislimo regionalno geografske opise, kakršne prinašajo monografije o Sloveniji. Pričujoča monografija je bolj kot iz regionalnega, zanimiva iz tematskega vidika. V njej je vrsta prikazov in novih spoznanj o posameznih področjih in značilnostih Podravja, med njimi je nekaj takih, ki si šele utirajo prostor v regionalni geografiji. Tako izvemo veliko o klimatskih spremembah, spreminjanju rabe tal, o degradiranih območjih, o posledicah gospodarske krize, o prostorskem razvoju naselij, vodno gospodarskih ureditvah vodotokov, o pedoloških značilnostih Pohorja, o političnem profilu volilnega telesa, o demografskih, gospodarskih, bivalnih in prometnih lastnostih Maribora in ne nazadnje, o načinu, kako spoznanja o pokrajini prenesti $v$ izobraževanje učencev in dijakov. Besedila so izdatno dokumentirana s tematskimi kartami in drugim empiričnim gradivom.

Zbranih je veliko prispevkov o posameznih pokrajinotvornih elementih, ob katerih si je mogoče ustvariti podobo o obravnavanem območju. Vendar med njimi ni nobenega o Podravju kot enoviti regiji. Slednje najbrž ni naključje, niti ni posledica pomanjkljive strokovnosti avtorjev, pač pa je odraz stanja $\mathrm{v}$ vedi in razumevanja pokrajine kot predmeta spoznavanja geografije. Celovita predstava o Podravju, v kolikor je ta sploh še mogoča, je prepuščena bralcem samim.

Izid knjige sta finančno podprli Univerza v Mariboru in Filozofska fakulteta v Mariboru, za kar se lepo zahvaljujemo. 


\section{Kazalo / Table of Contents}

GEOGRAFIJE NARAVNE POKRAJINE

THE GEOGRAPHIES OF NATURAL LANDSCAPE

Trendi vodne bilance v severovzhodni Sloveniji v obdobju 1961-2016

Trends of water balance in the northeastern Slovenia in the period

1961-2016

Igor Žiberna

Pohorje - slovenska pedološka posebnost

Pohorje - Slovenia's pedological exception

Blaž Repe

Ekosistemske značilnosti Dravinjskih goric

Ecosystem characteristics of Dravinjske gorice

Ana Vovk Korže

Celostno upravljanje rečnih koridorjev $\mathrm{v}$ teoriji in praksi - primer

koridorja ravninske Drave

Integrated river corridor management in theory and praxis - lowland

Drava river corridor example

Andrej Grmovšek, Simon Veberič

Motnost vode in premeščanje suspendiranih snovi v Podravju

Water turbidity and suspended sediment transport in Podravje

Florjana Ulaga

GEOGRAFIJE KULTURNE POKRAJINE

THE GEOGRAPHIES OF CULTURAL LANDSCAPE

Spreminjanje rabe tal na območju obpanonske severovzhodne Slovenije v obdobju 2000-2015

Land use changes in the subpanonian northeastern Slovenia between 2000 and 2015

Igor Žiberna

Ocena neizkoriščenega potenciala funkcionalno degradiranih območij

v Podravski statistični regiji

Assessment of functional untapped potential brownfield areas in the

Podravje statistical region

Barbara Lampič, Tatjana Kikec, Nejc Bobovnik 
Podravska regija v luči zadnje gospodarske krize

Podravje region in the light of the last economic crisis

Lucija Lapuh

Prostorski razvoj naselij v Podravju v zadnjih desetletjih

153

Spatial development of settlements in the Podravje region in last decades

Vladimir Drozg

Socialno-ekonomski razvoj naselij Cirkovce, Gorišnica, Stoperce in Sveti Tomaž po letu 1996

Socio-economic development of the villages Cirkovce, Gorišnica, Stoperce and Sveti Tomaž after the year 1996

Vladimir Korošec

Geografski vidiki volitev v Podravju

Geographic aspect of the elections in the Podravje region

Jernej Tiran, Boštjan Rogelj

GEOGRAFIJE URBANE POKRAJINE

THE GEOGRAPHIES OF URBAN LANDSCAPE

Maribor

Demographic development and population characteristics in the city of Maribor

Uroš Horvat

Industrializacija, deindustrializacija in regeneracija Maribora

Industrialization, deindustrialization and regeneration of Maribor Lučka Lorber

Kakovost bivalnega okolja v Mariboru

Quality of residential environment in Maribor

Jernej Tiran, Simon Koblar

Potovalne navade Mariborčanov - kaj je drugače kot v Ljubljani?

Travel patterns in Maribor: A comparison to Ljubljana

Marjan Lep, Beno Mesarec, Matej Gabrovec

Prostorsko-časovna razporeditev prometnih nesreč v Mariboru 
Samooskrba na enem hektarju (na primeru učnega poligona za samooskrbo Dole, Poljčane)

Self-sufficiency on one hectare of land (on the case of educational polygon Dole in Poljčane)

Ana Vovk Korže

Kompetence učiteljev in razvijanje lastne profesionalnosti za poučevanje geografije na prostem

Geography teachers competencies and developing their professionalism for outdoor teaching

Karmen Kolnik

Pokrajina - učiteljica geografije?

Landscape - a geography teacher?

Andrej Černe 
GEOGRAFIJE PODRAVJA

The GeOGRAPHIES OF THE PODRAVJe REGION 


\section{GEOGRAFIJE NARAVNE POKRAJINE}

\section{THE GEOGRAPHIES OF NATURAL \\ LANDSCAPE}





\title{
Trendi vodne bilance v severovzhodni Sloveniji v obdobju 1961-2016
}

\author{
IGOR ŽIBERNA
}

Povzetek Podnebne spremembe se na območju Slovenije manifestirajo na različne načine, eden od najizrazitejših so spremembe vodne bilance, ki so posledica manjšanja višine padavin in povečane evapotranspiracije. Zmanjševanje vodnih zalog se v pokrajini odraža s pojavom suš. V članku so analizirani trendi klimatske vodne bilance kot razlike med višino padavin in evapotransporacijo na osnovi podatkov klimatskih postaj Šmartno pri Slovenj Gradcu, Slovenske Konjice, Starše, Maribor, Lendava, Murska Sobota in Veliki Dolenci za obdobje 1961-2016. Prikazani so trendi temperatur zraka, višine padavin, evapotranspiracije in vodne balance.

Ključne besede: • višina padavin • evapotranspiracija • vodna bilanca • podnebne spremembe $\bullet$ severovzhodna Slovenija $\bullet$

NASLOV AVTORJA: dr. Igor Žiberna, izredni profesor, Univerza v Mariboru, Filozofska fakulteta, Oddelek za geografijo, Koroška cesta 160, 2000 Maribor, Slovenija, e-naslov: igor.ziberna@um.si. 


\title{
Trends of water balance in the northeastern Slovenia in the period 1961-2016
}

\author{
IGOR ŽIBERNA
}

\begin{abstract}
Climate change on the territory of Slovenia manifest themselves in different ways, one of the most typical are changes in the water balance, which are the result of lowering of the precipitation and the increased evapotranspiration. Reduction of water stocks is reflected with the occurrence of droughts. In the article we analysed the trends of climatic water balance as the difference between the precipitation and evapotranspiration on the basis of the data of the climate stations Šmartno pri Slovenj Gradcu, Slovenske Konjice, Starše, Maribor, Lendava, Murska Sobota and Veliki Dolenci for the period 1961-2016. Shown are the trends of air temperature, precipitation, evapotranspiration and water balance.
\end{abstract}

Keywords: • precipitation $\bullet$ evapotranspiration $\bullet$ watter balance $\bullet$ climate changes $\bullet$ northeastern Slovenia $\bullet$

CORRESPONDENCE ADDRESS: Igor Žiberna, Ph.D., University of Maribor, Faculty of Arts, Department for geography, Koroška cesta 160, 2000 Maribor, Slovenia, e-mail: igor.ziberna@um.si. 
GEOGRAFIJE PODRAVJA
I. Žiberna: Trendi vodne bilance v severovzhodni Sloveniji v obdobju 1961-2016

\section{Uvod}

Podnebne spremembe se na območju Slovenije manifestirajo na različne načine. Temperature zraka naraščajo, višina padavin nekoliko pada, veča se pogostost ekstremnih vremenskih dogodkov, spreminjajo se fenofaze itd. (Sušnik et al., 2003). Ena od najizrazitejših posledic podnebnih sprememb je vse pogostejši pojav suš, kar je posledica spremenjene vodne bilance (Ipavec, Kajfež Bogataj, 2008). Porazdelitev padavin v Sloveniji kaže na velike prostorske in časovne razlike, kar je posledica lege Slovenije in razgibanosti njenega površja. Največ padavin pade, ko nad Slovenijo z jugozahodnimi vetrovi priteka vlažen zrak. Ta se ob gorskih pregradah dviga in ohlaja. Pojavijo se padavine, ki se najprej izločijo na alpsko-dinarski gorski pregradi. Orografske padavine se nato ponovijo ob Kamniško-Savinjskih Alpah, tretjič pa na Pohorju. Severozahod Slovenije z nad $3000 \mathrm{~mm}$ letne višine padavin spada med bolj namočena območja Evrope.

Za padavinski režim v Sloveniji je značilno, da ne pozna izrazito suhega ali vlažnega obdobja. Območja zahodne Slovenije beležijo največ padavin v novembru ali oktobru. Višek padavin v vzhodni Sloveniji nastopa poleti in je posledica pogostih poletnih ploh v kontinentalnem delu. Trendi letne višine padavin v večini Slovenije niso statistično značilni, z izjemo Kočevja in Rateč, kjer je mogoče v zadnjih 50 letih zaznati statistično značilno upadanje višine padavin za $-16 \mathrm{~mm} \pm 10 \%$ oziroma za $-21 \mathrm{~mm} \pm 14 \%$. Prav tako ni mogoče opaziti bistvenih sprememb padavinskega režima. Rahlo narašča le intenziteta nalivov (Bergant et.al, 2004).

Eden od pokazateljev sušnih razmer je tudi vodna bilanca: razlika med višino padavin in evapotranspiracijo. Danes še vse postaje beležijo prebitek količine padavin nad evapotranspiracijo. Suficit je najvišji na Kredarici (1595, 3 mm), najmanjši pa v Murski Soboti $(66,9 \mathrm{~mm})$. Pomurje že sedaj zaznava deficit v pomladanskih in poletnih mesecih. Če k temu prištejemo še dejstvo, da se večina poljedelskih površin v Pomurju nahaja na plitvih prodnato peščenih tleh, je slika o vodni bilanci še manj ugodna. Trend vodne bilance je - razen na Kredarici - na vseh ostalih postajah negativen. Največje znižanje razlike med padavinami in evapotransporacijo beležimo v Slapu pri Vipavi $(-366,1 \mathrm{~mm})$ in v Ljubljani (-144,9 mm), veliko pa je tudi v severovzhodni Sloveniji, kjer znaša razlika v zadnjih 51 letih -75,4 mm (Sušnik et al., 2003).

Za zadnja desetletja je značilno pogostejše pojavljanje sušnih obdobij. Izrazite kmetijske suše se pojavljajo predvsem v jugozahodni in severovzhodni Sloveniji in sicer v obdobju vegetacije (med aprilom in septembrom), ko kulturne rastline tudi sicer potrebujejo največ vlage. V zadnjih štiridesetih letih so se kmetijske suše v ocenjenih dveh območjih pojavljale kar trideset krat, medtem ko je celotna Slovenija utrpela sušo v letih 1967, 1971,1973, 1977, 1983, 1992, 1993, 1994, 2000, 2001, 2003, 2006, 2007, 2009, 2012 in 2013 (Krajnik et al., 2015).

Naravne nesreče v Sloveniji v zadnjih letih povzročajo škodo v višini okoli 2 \% BDP, od tega so suše leta 2000 predstavljale $70 \%$, 2001, $57 \%$ leta 2003 pa celo $83 \%$ (Statistične informacije 378/2004). Suša leta 2003 je suša med vsemi naravnimi nesrečami povzročila 83,3 \% celotne škode, gozdni požari, ki so bili ena od posledic visokih temperatur pa nadaljnji 8,1 \%. Suša je največ škode naredila v Podravski in Pomurski regiji, medtem ko 
so gozdni požari najbolj oškodovali Osrednjeslovensko, Podravsko, Savinjsko in Goriško statistično regijo (Statistične informacije 378/2004).

Posledice sušnih obdobij se kažejo tudi v spremembi gladine podtalnice, govorimo o hidrološki suši. Hidrološka suša leta 2003 je predstavljala nadaljevanje sušnega obdobja, ki se je začelo že leta 2000. Prizadela je predvsem vodonosnike na prodnatih aluvialnih ravninah Prekmurja, Dravske in Ptujskega polja, kjer je trajala od januarja do novembra, $\mathrm{v}$ ostalih delih Slovenije pa se je pojavljala med junijem in septembrom. V Prekmurju so bile zabeležene najnižje gladine podzemne vode $\mathrm{v}$ zadnjih petdesetih letih. Veliko ročno izkopanih vodnjakov je presahnilo, nekateri prvič v celotni zgodovini obstoja. Vodnjaki so sicer presihali v Prekmurju, na Dravskem, Ptujskem in severnem delu Kranjskega polja. Vodnjaki na Kranjskem polju so presahnili prvič po umetnem dvigu gladine podtalnice leta 1986, zaradi zajezitve Save za Hidroelektrarno Mavčiče (Mikulič et al., 2003).

Napovedi glede spreminjanja višine padavin v Sloveniji v prihodnje so manj zanesljive. Pričakujemo lahko spremembe višine padavin v razponu od $+10 \%$ do $-30 \%$. Ob upoštevanju naraščanja temperatur in evapotranspiracije lahko pričakujemo neugodne spremembe $\mathrm{v}$ vodni bilanci in $\mathrm{s}$ tem povečanje potreb po kakovostnih vodnih virih.

Trenutno stanje kaže, da je v vegetacijski dobi (april-sepetember) $8 \%$ celotnega ozemlja Slovenije izpostavljeno suši. Če se omejimo le na tri poletne mesece (junij-avgust) se območje večje izpostavljenosti suši razširi na $15 \%$ celotne površine Slovenije. Upoštevajoč trende dviga temperature zraka za $2{ }^{\circ} \mathrm{C}$ se bo potencialno sušno območje razširilo že na $25 \%$ celotnega površja Slovenije. Če ob tem upoštevamo še verjetno 10 \% zmanjšanje višine padavin, se bo območje ogroženo s pojavom suše razširilo na 40 \% slovenskega ozemlja (Kajfež-Bogataj, Cegnar, 2005).

Pojav suše je sicer izjemno kompleksen pojav in je razen od podnebja odvisen tudi od litoloških, reliefnih, pedoloških in antropogenih dejavnikov. V našem primeru bomo za območje severovzhodne Slovenije obravnavali zgolj podnebne dejavnike, pri čemer bomo klimatsko vodno bilanco obravnavali kot razliko med višino padavin in evapotranspiracijo. Razlika med padavinami in evapotranspiracijo predstavlja osnovni okvir, ki določa količino razpoložljive vode v dani pokrajini oziroma zaloge vode v tleh.

Količina zalog $\mathrm{v}$ tleh je zanimiva iz treh vidikov:

- zadostna oskrba vode za kulturne rastline

- zadostna oskrba pitne vode

- ranljivost podtalnice (ta je večja, če so zaloge vode v tleh manjše).

Naslednji pomemben vidik pri obravnavi podtalnice s podnebnega vidika je njen letni režim, ki je odraz letnega padavinskega režima in letnega spreminjanja temperatur zraka ter drugih izbranih parametrov, ki vplivajo na evapotranspoiracijo. $Z$ vidika podnebnih sprememb je nujna analiza trendov vseh relevantnih podnebnih parametrov. 


\section{Metodologija}

Poenostavljena klimatska vodna bilanca je razlika med višino padavin in evapotranspiracijo (Ceglar, Kejfež Bogataj, 2008: 408). V našem primeru smo uporabili podatke s sedmih klimatskih postaj: Šmartno pri Slovenj Gradcu, Slovenske Konjice, Starše, Maribor, Lendava, Murska Sobota in Veliki Dolenci in sicer za obdobje 19612016 (Arhiv Urada za meteorologijo, ARSO 2016). Podatke smo analizirali na mesečnem, sezonskem in letnem nivoju. Žal so mnoge postaje prenehale $\mathrm{z}$ delovanjem $\mathrm{v}$ zadnjih dveh desetletjih, zato je nabor postaj omejen. Pri izračunu vodne bilance smo uporabili izmerjene podatke o višini padavin. Podatke o evapotranspiraciji smo modelirali s pomočjo Thornthwaitovega modela (Linacre, 1992):

$$
\boldsymbol{P E T}_{m}=1,6 \times\left(100 \times \frac{T_{m}}{I}\right)^{a}
$$

pri čemer pomenijo:

$\mathrm{T}_{\mathrm{m}}$ - povprečna mesečna temperatura $\mathrm{v}{ }^{\circ} \mathrm{C}$

I - člen, ki ga izračunamo po obrazcu:

$$
I=\sum_{m=1}^{12}\left(\frac{T_{m}}{5}\right)^{1,514}
$$

a - člen, ki ga izračunamo kot funkcijo I:

$$
a=\left(6,75 \times 10^{-7} \times I^{3}\right)-\left(7,7 \times 10^{-5} \times I^{2}\right)+\left(1,79 \times 10^{-2} \times I\right)+0,49
$$

\section{Trendi vodne bilance v Severovzhodni Sloveniji}

\section{Trendi temperatur zraka}

Temperature zraka so eden od klimatskih elementov, ki vplivajo na količino evapotranspirirane vlage: pri višjih temperaturah je evapotranspiracija višja. Temperatura tako posredno vpliva na vodno bilanco. Temperature v severovzhodni Sloveniji so rezultat povečane kontinentalnosti, hkrati pa nanje vpliva dvojni naravnogeografski značaj tega območja: zahodni del $\mathrm{s}$ hribovitim površjem in vmesnimi dolinami sodi $\mathrm{v}$ obalpsko severovzhodno Slovenijo, vzhodni del pa je gričevnato-ravninski in sodi v obpanonsko severovzhodno Slovenijo.

Kontinentalni značaj se v splošnem veča proti vzhodu, kar se odraža tudi na razporeditvi padavin. Povprečne letne temperature zraka so tam okoli $10{ }^{\circ} \mathrm{C}$, v Slovenj Gradcu, kjer na temperaturne razmere močno vpliva tudi kotlinska lega, pa le $8,3^{\circ} \mathrm{C}$. Na vseh postajah je najtoplejši mesec julij (okoli $20{ }^{\circ} \mathrm{C}$, v Šmartnem pri Slovenj Gradcu 18,3 ${ }^{\circ} \mathrm{C}$ ), najhladnejši pa januar, pri čemer povprečne temperature $\mathrm{v}$ tem mesecu nihajo med $0,1^{\circ} \mathrm{C}$ (Slovenske Konjice) in $-2,6^{\circ} \mathrm{C}$ (Slovenj Gradec). Zaradi lege na široki ravnini, kjer se pozimi pogosto pojavlja temperaturni obrat, so relativno nizke januarske temperature tudi na meteorološki postaji Murska Sobota (meteorološka postaja se v resnici nahaja $\mathrm{v}$ bližnjem Rakičanu) in znašajo $-1,3{ }^{\circ} \mathrm{C}$. 


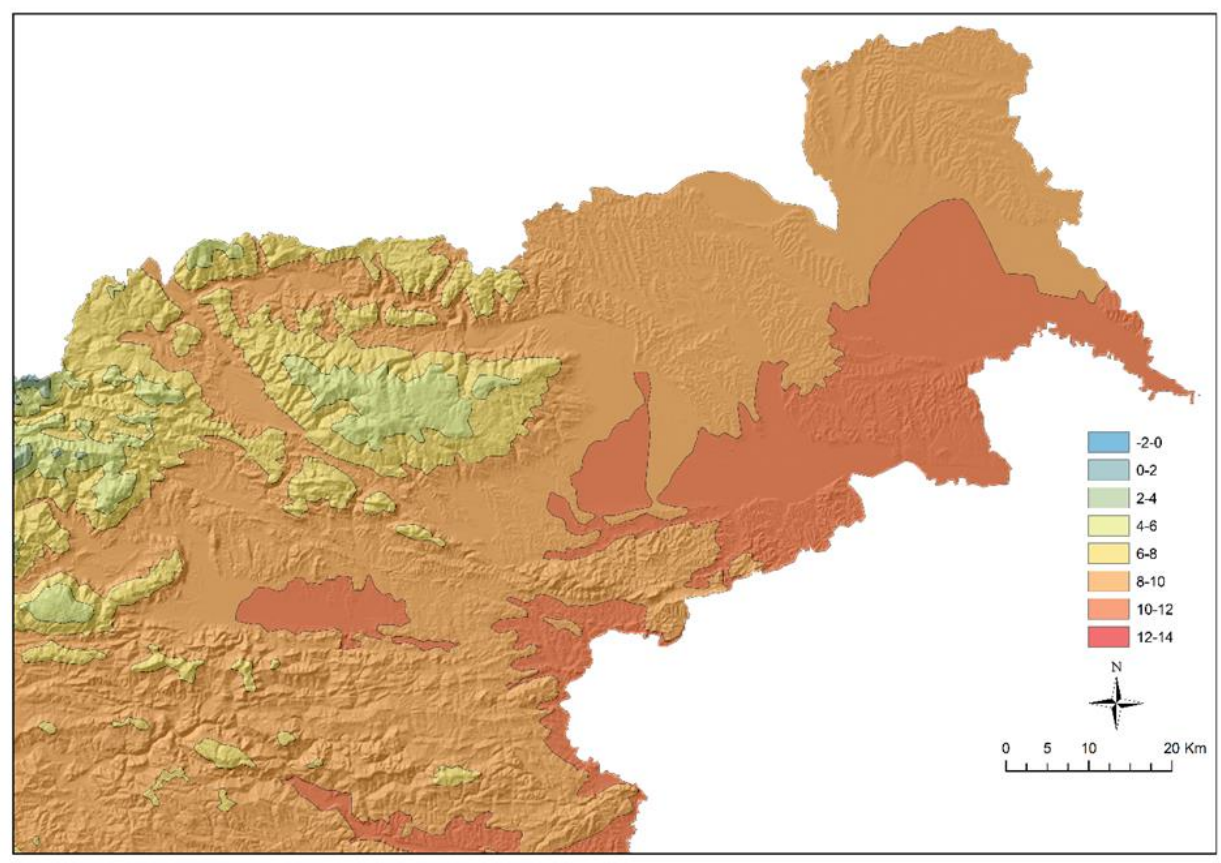

Povprečne letne temperature zraka na območju severovzhodne Slovenije v obdobju 1971-2000 $\left(v^{\circ} \mathrm{C}\right)$.

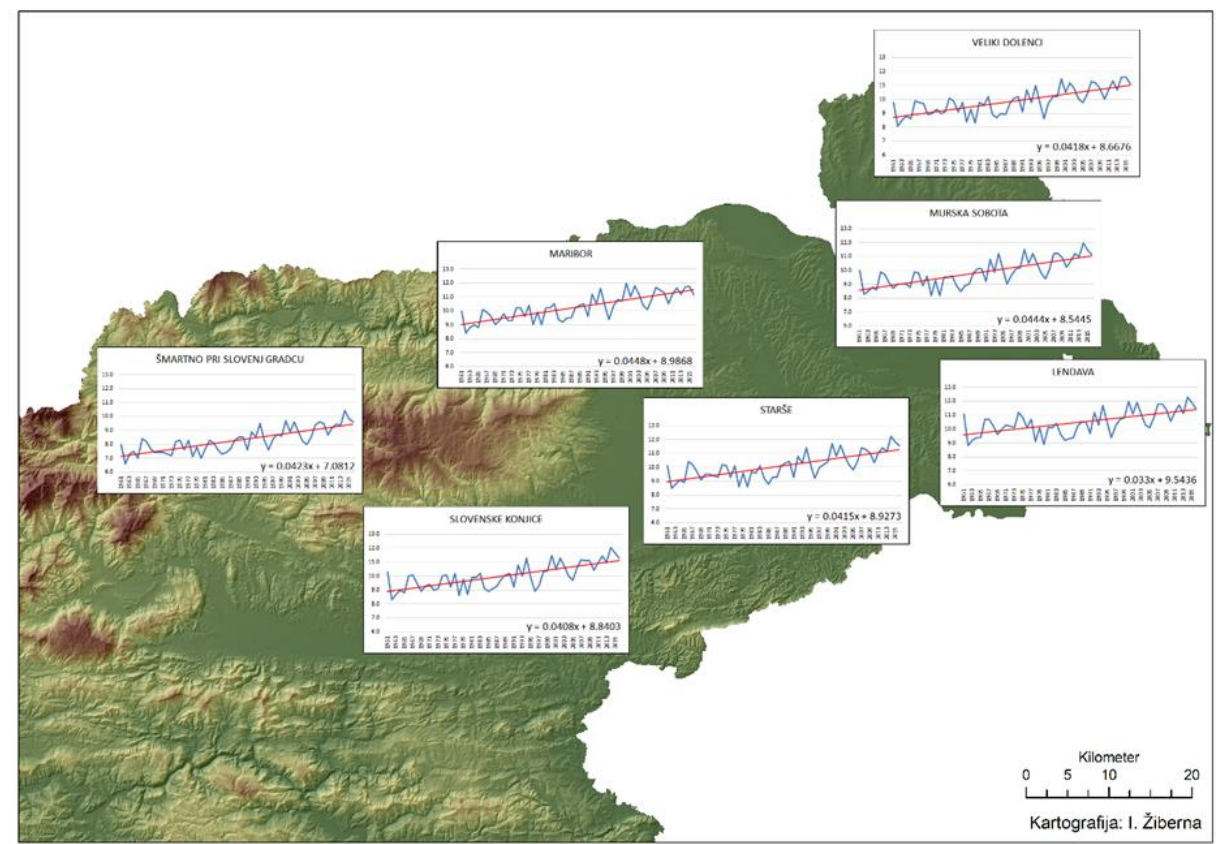

Trendi povprečnih letnih temperatur zraka na območju severovzhodne Slovenije v obdobju 1971-2000. 
Trendi povprečnih letnih temperatur zraka so na vseh postajah pozitivni. Najvišji so v Mariboru $\left(0,0448{ }^{\circ} \mathrm{C}\right.$ na leto), kar je zanesljivo posledica vpliva mestnega toplotnega otoka na temperaturne razmere (Žiberna, 2006). Na ostalih klimatskih postajah so povprečnih letnih temperatur zraka trendi naslednji: Slovenske Konjice 0,0408, Starše 0,0433, Šmartno pri Slovenj Gradcu 0,0423, Lendava 0,0330, Murska Sobota 0,0444 in Veliki Dolenci $0,0418^{\circ} \mathrm{C} /$ leto.

Med sezonskimi trendi so ti najvišji v poletju (junij, julij, avgust) in sicer med 0,0594 ${ }^{\circ} \mathrm{C} /$ leto (Maribor) in $0,0444^{\circ} \mathrm{C} /$ leto (Šmartno pri Slovenj Gradcu). Poleti nastopajo najvišji trendi v juliju (Maribor $0,0649^{\circ} \mathrm{C} /$ leto, Starše $0,0635{ }^{\circ} \mathrm{C} /$ leto, Murska Sobota $0,0621^{\circ} \mathrm{C} /$ leto), najnižji pa v Lendavi $\left(0,0483{ }^{\circ} \mathrm{C} /\right.$ leto). Sorazmerno visoki so trendi zimskih temperatur (december, januar, februar), ki se gibljejo med $0,0519{ }^{\circ} \mathrm{C} /$ leto $\mathrm{v}$ Murski Soboti in $0,0430{ }^{\circ} \mathrm{C} /$ leto v Staršah.

Zanimivo je, da se absolutno najvišji trendi pojavljajo v januarju v Murski Soboti (kar $0,0741{ }^{\circ} \mathrm{C} /$ leto), visoki pa so tudi v Slovenskih Konjicah $\left(0,0680{ }^{\circ} \mathrm{C} / \mathrm{leto}\right)$, in Šmartnem pri Slovenj Gradcu $\left(0,0633{ }^{\circ} \mathrm{C} /\right.$ leto $)$. Trendi spomladanskih (marec, april, maj) in jesenskih (september, oktober, november) temperatur so nižji, vendar spomladanski višji od jesenskih.

\section{Trendi povprečnih letnih in sezonskih temperatur zraka $v$ severovzhodni Sloveniji $v$ obdobju 1961-2016 ( ${ }^{\circ} \mathrm{C} /$ leto $)$.}

Vir: Arhiv Urada za meteorologijo ARSO, 2016 (lastni izračuni).

\begin{tabular}{|l|c|c|c|c|c|}
\hline Meteorološka postaja & Leto & Zima & Pomlad & Poletje & Jesen \\
\hline Slovenske Konjice & 0.0408 & 0.0484 & 0.0384 & 0.0526 & 0.0227 \\
\hline Starše & 0.0415 & 0.0430 & 0.0429 & 0.0577 & 0.0248 \\
\hline Maribor & 0.0448 & 0.0479 & 0.0426 & 0.0594 & 0.0292 \\
\hline Šmartno pri Sl.Gradcu & 0.0423 & 0.0458 & 0.0416 & 0.0522 & 0.0278 \\
\hline Lendava & 0.0330 & 0.0431 & 0.0269 & 0.0444 & 0.0174 \\
\hline Murska Sobota & 0.0444 & 0.0519 & 0.0409 & 0.0565 & 0.0292 \\
\hline Veliki Dolenci & 0.0418 & 0.0485 & 0.0389 & 0.0521 & 0.0272 \\
\hline
\end{tabular}

\section{Trendi višine padavin}

Tudi pri razporeditvi padavin na območju severovzhodne Slovenije lahko opazimo dvojni značaj letne razporeditve padavin: teh je več v obalpski severovzhodni Sloveniji (na območju Pohorja do $1600 \mathrm{~mm}$ ), medtem ko proti vzhodu višina padavin pade pod 900 $\mathrm{mm}$. Pri tem poteka izrazitejša meja med obalpskimi in obpanonskimi pokrajinami severovzhodne Slovenije. Delež padavin v času vegetacije (od aprila do septembra) od celotne količine padavin je že uveljavljen kriterij za določanje higrične kontinentalnosti.

Ugotovimo lahko, da imata najvišji delež padavin v času vegetacije meteorološki postaji Murska Sobota $(63,0 \%)$ in Veliki Dolenci (62,0 \%), najnižji delež padavin v istem obdobju pa postaje Jeruzalem $(59,1 \%)$, Lendava $(59,4 \%)$ in Turški Vrh (59,6 \%). Pri Lendavi in Jeruzalemu si lahko razlagamo manjši delež poletnih padavin z večjo količino padavin v času sekundarnega maksimuma novembra, ko nastopita v naših krajih dve padavinski singulariteti. Jeruzalem dobi novembra $10,0 \%$, Lendava pa $10,1 \%$ letne količine padavin. 
Primarni minimum padavin $\mathrm{v}$ severovzhodni Sloveniji nastopa bodisi $\mathrm{v}$ februarju ali $\mathrm{v}$ januarju. Zanimivo je, da je v maju mogoče opaziti nekoliko zmanjšan trend rasti mesečne količine padavin. Kar 7 postaj doseže primarni maksimum količine padavin $\mathrm{v}$ juliju (Slovenske Konjice, Pragersko, Radlje, Jeruzalem, Lendava, Murska Sobota in Veliki Dolenci). Zelo enotno nastopa sekundarni minimum na postajah severovzhodne Slovenije (na vseh postajah v oktobru, ki sledi relativno suhemu septembru). Na koncu lahko torej povzamemo, da letna količina padavin v severovzhodni Sloveniji pada od JZ proti SV. Količina padavin pada v treh stopnjah. Razporeditev padavin preko leta kaže dva maksimuma (julija oziroma junija, sekundarni novembra) in dva minimuma (primarni februarja oz. januarja, sekundarni oktobra) (Žiberna, 2000: 39-40).

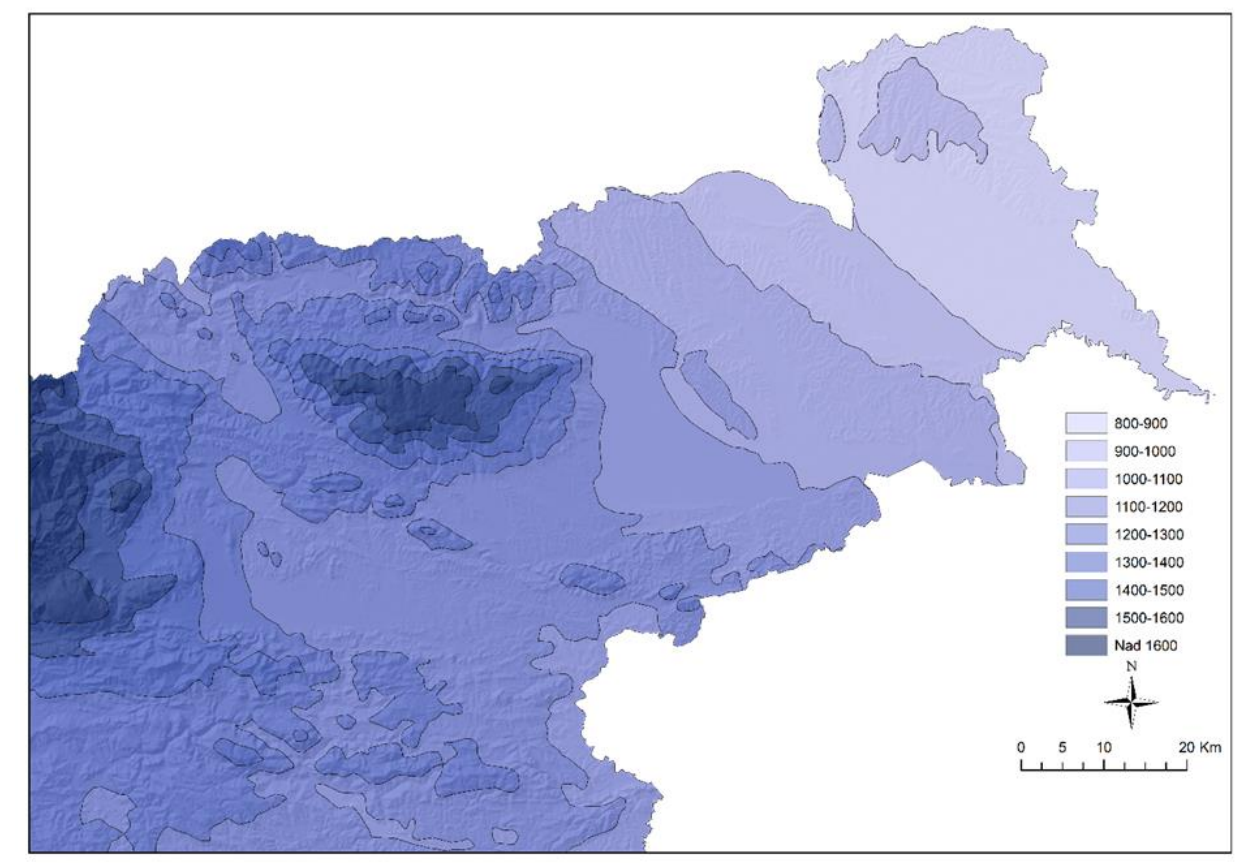

Povprečne letne višine padavin na območju severovzhodne Slovenije v obdobju 1971$2000(\mathrm{v} \mathrm{mm})$.

Vir: Medmrežje 1.

Variabilnost padavin v obdobju 1961-2016 je bila velika. Na najbolj namočeni postaji (Šmartno pri Slovenj Gradcu), ki prejme letno $1174,9 \mathrm{~mm}$ padavin, je letna višina padavin nihala med 1571,8 mm (leta 1965) in 761,0 mm (leta 1971). Na najmanj namočeni postaji (Veliki Dolenci), ki letno prejmejo 761,8 $\mathrm{mm}$ je bilo to nihanje med $1137,2 \mathrm{~mm}$ (leta 1965 ) in 490,1 $\mathrm{mm}$ (leta 2003). V povprečju pade največ padavin v poletnih mesecih (konvektivne padavine), najmanj pa $\mathrm{v}$ zimskih mesecih (frontalne padavine), pri čemer se prav v tem letnem času občasno zgodi, da cel mesec ne pade niti kaplja dežja.

Trendi letnih višin padavin so na območju celotne Slovenije manj signifikantni (Kajfež Bogataj, Bergant, 2005). Na vseh obravnavanih klimatskih postajah so trendi letne višine padavin negativni, najbolj v Veliki Dolencih $(-3,2241 \mathrm{~mm} / \mathrm{leto})$, najmanj pa v Šmartnem pri Slovenj Gradcu (-0,1783 mm/leto). 
Višina padavin se v splošnem najbolj niža v poletnih mesecih in spomladi, medtem ko so trendi $\mathrm{v}$ jesenskih in zimskih mesecih pretežno pozitivni. Tako stanje je neugodno zaradi več razlogov:

- zlasti obpanonska severovzhodna Slovenija ima ugodne možnosti za poljedeljstvo. Kulturne rastline potrebujejo največ vlage v fenofazi rasti, to je spomladi (npr. ječmen in pšenica) ter poleti (npr. koruza), ko so trendi višine padavin negativni.

- $\quad \mathrm{v}$ jesenskih mesecih se obdobje aktivne vegetacije zaključuje, zato rastline vežejo manj vlage, medtem ko so trendi višine padavin pozitivni.

- $\quad \mathrm{v}$ zimskih mesecih so $\mathrm{v}$ preteklosti padavine padale praviloma $\mathrm{v}$ trdi obliki (sneg), v zadnjih desetletjih pa zaradi pozitivnih temperaturnih trendov vedno pogosteje v tekoči obliki (dež), zaradi česar je, ob dejstvu, da pozimi rastline nase ne vežejo toliko vlage, nevarnost poplav večja.

Negativni trendi so najbolj izraziti v juliju (Slovenske Konjice -0,6634 mm/leto, Maribor $-0,5339 \mathrm{~mm} /$ leto) in juniju, medtem ko v avgustu Šmartno pri Slovenj Gradcu že beleži višanje višine padavin, na ostalih klimatskih postajah pa je trend še vedno negativen, a precej nižji. V septembru so na vseh klimatskih postajah trendi že pozitivni in se gibljejo med $0,7632 \mathrm{~mm} /$ leto in $0,5118 \mathrm{~mm} /$ leto. Tudi oktobra so trendi povsod še pozitivni, $\mathrm{v}$ novembru pa ponovno negativni. Slednje je z vidika običajnega padavinskega režima, ki je v kontinentalnem delu Slovenije beležil sekundarni višek padavin prav v novembru, pomembno. Podatki namreč nakazujejo na spremembe padavinskega vzorca $\mathrm{v}$ jesenskih mesecih, pri čemer bi lahko sklepali, da se višek padavin z novembra prestavlja na zgodnejši čas.

\section{Trendi povprečnih letnih in sezonskih višin padavin v severovzhodni Sloveniji v obdobju 1961-2016 (v mm/leto). \\ Vir: Arhiv Urada za meteorologijo ARSO, 2016 (lastni izračuni).}

\begin{tabular}{|l|c|c|c|c|c|}
\hline Meteorološka postaja & Leto & Zima & Pomlad & Poletje & Jesen \\
\hline Slovenske Konjice & -0.2920 & 0.2224 & -0.5437 & -0.6351 & 0.9027 \\
\hline Starše & -0.9440 & 0.1368 & -0.3767 & -1.1743 & 0.6964 \\
\hline Maribor & -2.5147 & -0.2069 & -0.8396 & -1.1333 & -0.1113 \\
\hline Šmartno pri Sl.Gr. & -0.1783 & 0.5913 & -0.7429 & -0.4687 & 0.6883 \\
\hline Lendava & -1.0758 & 0.2398 & -0.7267 & -0.8731 & 0.4526 \\
\hline Murska Sobota & -0.3554 & 0.1643 & -0.2846 & -0.5199 & 0.4522 \\
\hline Veliki Dolenci & -3.2241 & -0.5759 & -1.3123 & -0.9787 & -0.2040 \\
\hline
\end{tabular}

\section{Trendi potencialne evapotranspiracije}

$\mathrm{Na}$ začetku obravnave trendov potencialne evapotranspiracije je potrebno poudariti, da gre za izračunane in ne izmerjene vrednosti, pri čemer podel predvideva, da so tla dobro založena z vlago, kar pa zlasti v sušnih razmerah ne drži, zato so dejanske vrednosti evaporanspiracije lahko tudi nižje od potencialne evapotranspiracije. Povprečne letne vrednosti evapotranspiracije so pričakovano najnižje v obalpskem delu SV Slovenije (Šmartno pri Slovenj Gradcu 590,1 mm), medtem ko so te višje v obpanonskem delu (Lendava 929,0 mm, Maribor 891,9 mm, Starše 865,5 mm). 


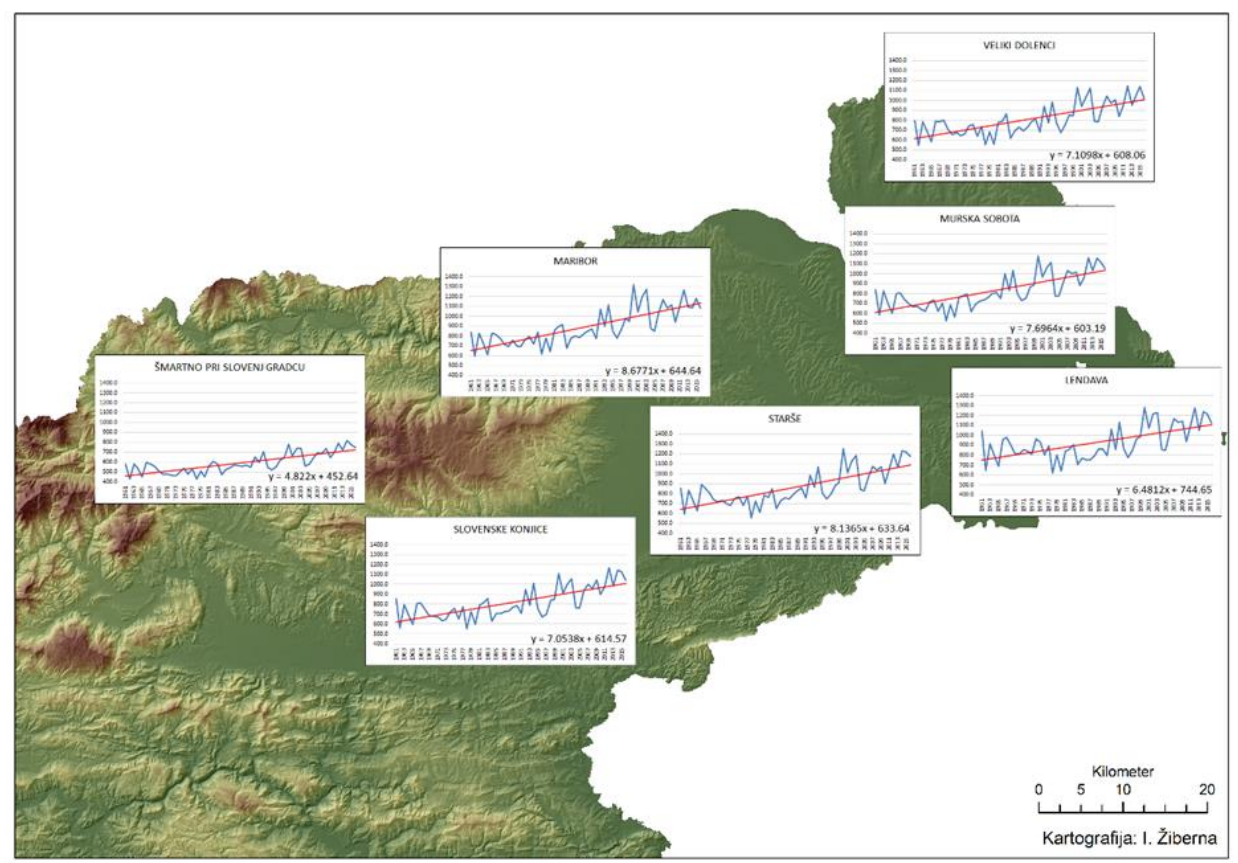

Trendi letne potencialne evapotranspiracije na območju severovzhodne Slovenije v obdobju 1971-2000.

Trendi letne in sezonske evapotranspiracije v severovzhodni Sloveniji v obdobju 1961-2016 (v mm/leto).

\begin{tabular}{|l|c|c|c|c|c|}
\hline Meteorološka postaja & Leto & Zima & Pomlad & Poletje & Jesen \\
\hline Slovenske Konjice & 7.0538 & 0.4853 & 1.6691 & 3.5857 & 1.3405 \\
\hline Starše & 8.1365 & 0.3292 & 1.9936 & 4.3024 & 1.5280 \\
\hline Maribor & 8.6771 & 0.3978 & 2.0521 & 4.5475 & 1.6987 \\
\hline Šmartno pri Sl.Gr. & 4.8220 & 0.1227 & 1.2281 & 2.4853 & 0.9878 \\
\hline Lendava & 6.4812 & 0.3886 & 1.4853 & 3.4385 & 1.1916 \\
\hline Murska Sobota & 7.6964 & 0.3384 & 1.8462 & 4.0113 & 1.5127 \\
\hline Veliki Dolenci & 7.1098 & 0.3744 & 1.6925 & 3.6460 & 1.4127 \\
\hline
\end{tabular}

Najvišje vrednosti evapotranspiracije se pojavljajo v poletnih mesecih, pri čemer juliju praviloma sledi avgust, temu pa junij. Najvišja julijska evapotranspiracija se pojavlja v Lendavi $(158,3 \mathrm{~mm})$, v Mariboru $(155,7 \mathrm{~mm})$ in Staršah $(151,1 \mathrm{~mm})$. Trendi evapotranspiracije se na letnem nivoju gibljejo med 4,8220 mm/leto (Šmartno pri Slovenj Gradcu) in 8,6771 mm/leto (Maribor). Visoke vrednosti evapotranspiracije v Mariboru so deloma tudi posledica višjih temperatur v mestu.

Med sezonami so najvišje vrednosti trendov evapotranspiracije v poletnih mesecih (med 2,4853 mm/leto v Šmartnem pri Slovenj Gradcu in 4,5475 mm/leto v Mariboru), sledijo pa pomladanski trendi (med 1,4 in $2 \mathrm{~mm} / \mathrm{leto}$ ), jesenski in zimski trendi. Trendi evapotranspiracije so najvišji v juliju, sledijo pa avgust in junij. 


\section{Trendi vodne bilance}

Povprečna letna vodna bilanca je na štirih postajah od sedmih še vedno pozitivna, negativna pa na vseh treh prekmurskih klimatskih postajah, od tega najbolj v Lendavi, kjer znaša letni deficit vlage 136,4 mm, v Velikih Dolencih pa še vedno 48,9 mm, medtem ko je v Murski Soboti primanjkljaj na letnem nivoju 14,1 mm. Primanjkljaji vlage se v poletnih mesecih pojavljajo na vseh klimatskih postajah, razen v Šmartnem pri Slovenj Gradcu, kjer je suficit vlage $117,3 \mathrm{~mm}$. Največji primanjkljaji v poletnih mesecih so $\mathrm{v}$ Lendavi $(-194,1 \mathrm{~mm})$, Velikih Dolencih $(-123,3 \mathrm{~mm})$, Murski Soboti $(-118,8 \mathrm{~mm})$ in Staršah $(-106,2 \mathrm{~mm})$. V pomladnih mesecih se primanjkljaji pojavljajo v Lendavi $(-48,8$ $\mathrm{mm})$, Murski Soboti $(-25,0 \mathrm{~mm})$ in Velikih Dolencih $(-23,7 \mathrm{~mm})$, medtem ko v jesenskih mesecih beležimo primanjkljaj le v Lendavi $(-0,6 \mathrm{~mm})$. Ob dejstvu, da je na območju severovzhodne Slovenije poljedelstvo pomembna gospodarska dejavnost, še bolj pa je ta pomembna v Prekmurju, stanje vodne bilance ni ugodno. V času aktivne vegetacije je primanjkljaj vlage že običajno stanje, trendi pa kažejo, da se stanje le še slabša.

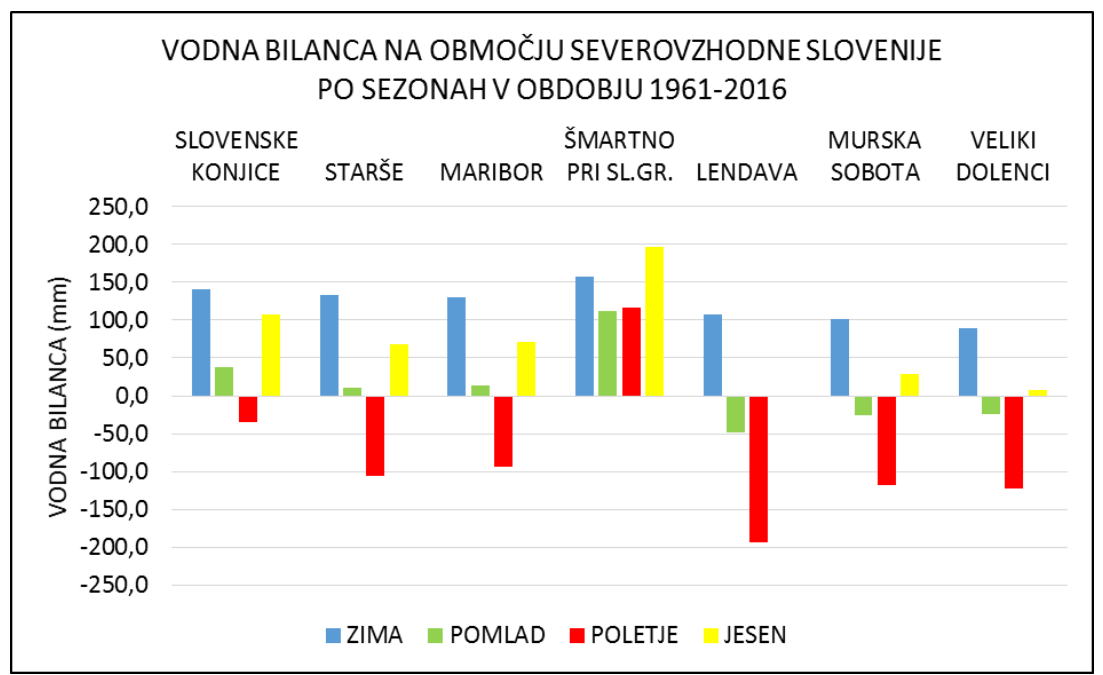

Vodna bilanca po sezonah na območju severovzhodne Slovenije v obdobju 1961-2016.

Letni trendi vodne bilance so na vseh klimatskih postajah negativni. Najnižji so v Šmartnem pri Slovenj Gradcu (-5,0003 mm/leto), najvišji pa v Mariboru (-11,1918 $\mathrm{mm} /$ leto ) in v Velikih Dolencih $(-10,3339 \mathrm{~mm} / \mathrm{leto})$. Kljub malemu številu klimatskih postaj lahko sklepamo, da so trendi vodne bilance v SV Sloveniji neugodni. Visokim negativnim vrednostim vodne bilance $v$ Mariboru v veliki meri botruje visoka potencialna evapotranspiracija, ki pa je v funkciji temperatur zraka, ki so v mestu nekoliko višje od okolice. Najvišje negativne vrednosti vodne bilance so v poletnih mesecih (Maribor $5,6907 \mathrm{~mm} /$ leto, Starše $-5,4767 \mathrm{~mm} / \mathrm{leto})$. Negativni trendi vodne bilance so izraziti tudi v pomladanskih mesecih, medtem ko so jeseni in predvsem pozimi nižji. V Šmartnem pri Slovenj Gradcu se v zimskih mesecih pojavlja celo pozitiven trend vodne bilance, kar je posledica sorazmerno visokega pozitivnega trenda višine padavin $\mathrm{v}$ tem obdobju (predvsem $\mathrm{v}$ februarju). Med meseci se negativni trendi vodne bilance pojavljajo 
predvsem $v$ juliju in juniju, torej $v$ mesecih, ko so potrebe večine vegetacije po vodi največje.

Trendi povprečne letne in sezonske vodne bilance v severovzhodni Sloveniji v obdobju 1961-2016 (v mm/leto).

\begin{tabular}{|l|c|c|c|c|c|}
\hline Meteorološka postaja & Leto & Zima & Pomlad & Poletje & Jesen \\
\hline Slovenske Konjice & -7.3458 & -0.2629 & -2.2128 & -4.2209 & -0.4377 \\
\hline Starše & -9.0805 & -0.1923 & -2.3703 & -5.4767 & -0.8316 \\
\hline Maribor & -11.1918 & -0.6048 & -2.8916 & -5.6807 & -1.8099 \\
\hline Šmartno pri Sl.Gr. & -5.0003 & 0.4686 & -1.9710 & -2.9540 & -0.2995 \\
\hline Lendava & -7.5570 & -0.1488 & -2.2120 & -4.3115 & -0.7390 \\
\hline Murska Sobota & -8.0518 & -0.1741 & -2.1308 & -4.5312 & -1.0606 \\
\hline Veliki Dolenci & -10.3339 & -0.9502 & -3.0048 & -4.6247 & -1.6167 \\
\hline
\end{tabular}

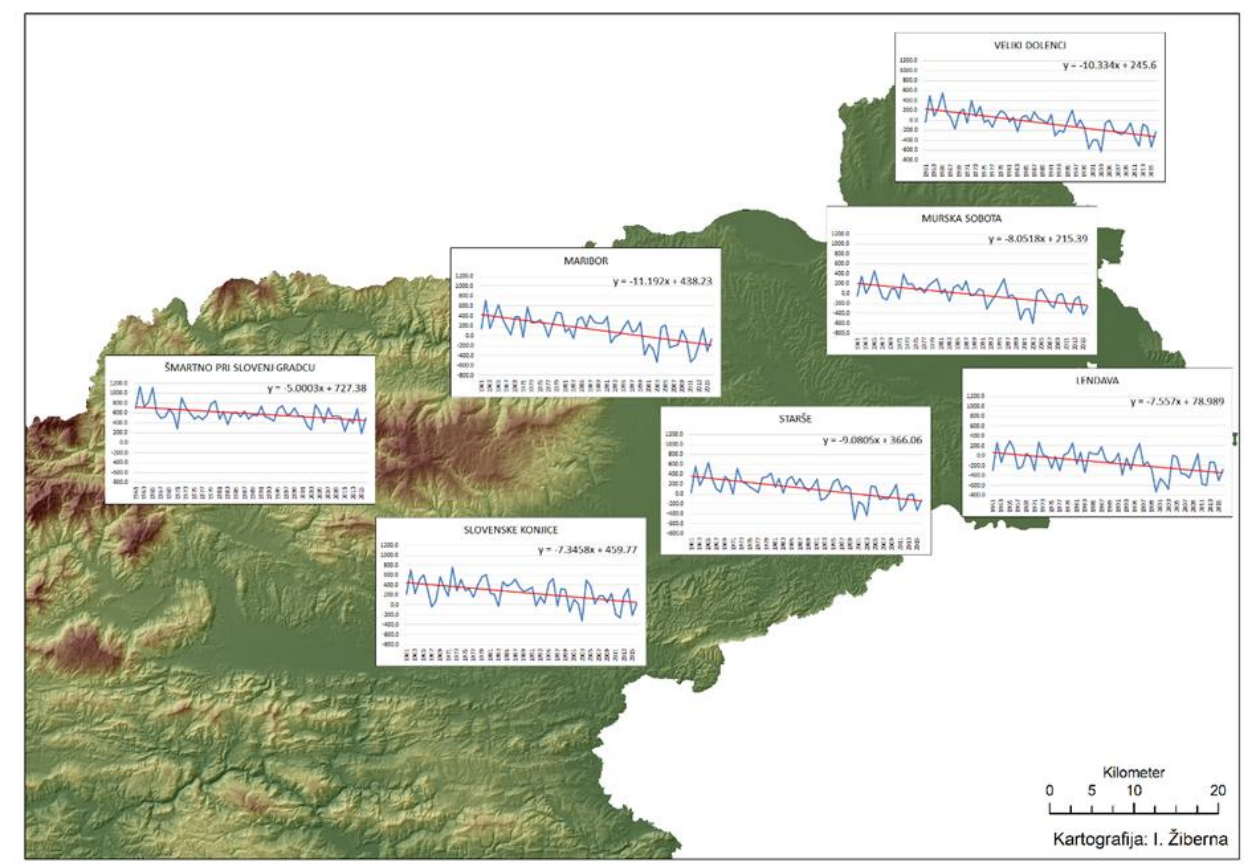

Trendi povprečne letne vodne bilance na območju SV Slovenije v obdobju 1971-2000.

\section{Zaključek}

Podnebne spremembe se v severovzhodni Sloveniji manifestirajo na različne načine, $\mathrm{z}$ vidika kmetijstva pa se le-te izkazujejo v spremembah vodne bilance. Ob rasti temperatur zraka se povečuje tudi evapotranspiracija, medtem ko višina padavin v splošnem nekoliko pada. Rezultat obeh procesov je vedno višja negativna bilanca, ki zlasti v Prekmurju v vegetacijski dobi postaja »normalno« stanje. V tej luči bi bilo - ob nadaljevanju obstoječih trendov- nujno potrebno razmisliti, ali je spekter kulturnih rastlin (̌̌e) primeren, pri čemer 
je najbolj na udaru koruza, katere fenofaza rasti sovpada z obdobjem primanjkljaja vlage in za nameček še z negativnimi trendi. Zaradi negativnih trendov v poletnih mesecih je nivo podtalnice nižji, njene samočistilne sposobnosti zmanjšane, zato so viri pitne vode bolj ranljivi ob morebitnih onesnaženjih.

Trendi vodne bilance so $\mathrm{v}$ zimskih mesecih povsod pozitivni, kar ob vedno višjih temperaturah predstavlja novo nevarnost. Padavine bodo $\mathrm{v}$ hladni polovici leta ob nadaljevanju trenutnih trendov vedno pogosteje nastopale v tekoči obliki, kar pomeni več vode $\mathrm{v}$ koritih in (zaradi manjše evapotranspiracije in manjših potreb rastlin po vodi) večjo nevarnost poplav. Pričakujemo torej lahko nasprotujoče si pojave v različnih delih leta (suša poleti, poplave jeseni in pozimi). Nekaj podobnega se je že zgodilo leta 2012, ko smo v severovzhodni Sloveniji v poletnih mesecih imeli katastrofalno sušo, le nekaj mesecev kasneje pa katastrofalne poplave. V naši analizi smo se omejili le na klimatsko sušo. Upoštevati pa je potrebno, da so zlasti ravninska območja zaradi plitvih prsti s slabšo vodno kapaciteto in neugodno litološko podlago (pesek, prod) še bolj občutljiva na pojav suše.

\section{Literatura in viri}

Arhiv Urada za meteorologijo, ARSO 2016.

Bergant K. et al. 2004: Spremembe podnebja in kmetijstvo v Sloveniji, MOP, Ljubljana.

Ceglar A., Kajfež Bogataj L. 2008: Obravnava meteorološke suše z različnimi indikatorji. Acta agriculturae Slovenica, $91-2$. Biotehniška fakulteta. Ljubljana.

Ipavec T., Kajfež Bogataj L. 2008: Možni vplivi podnebnih sprememb na vodno bilanco tal v Sloveniji, Acta agriculturae Slovenica, 91 - 2. Biotehniška fakulteta. Ljubljana.

Kajfež-Bogataj L., Ceglar K. 2005: Podnebne spremembe v Sloveniji in suša, Ujma 19. Ljubljana. Krajnik M., Sušnik A., Gregorič G., Bokal S. 2015: Suša in Vodna direktiva, ARSO. Ljubljana. Linacre E. 1992: Climate Data And Resources. A Reference And Guide. Routledge, London.

Medmrežje 1: Geoportal ARSO, 2016 http://gis.arso.gov.si/geoportal/catalog/main/home.page (12.12.2016)

Mikulič Z., Andjelov M., Robič M ., Trišoč N. 2003: Nizka vodna stanja v aluvialnih vodonosnikih Slovenije, 14. Mišičev vodarski dan, VGB Drava, Maribor.

Statistične informacije 378/2004. Urad za statistiko RS, 2004.

Sušnik A. et al. 2003: Ranljivost slovenskega kmetijstva in gozdarstva na podnebno spremenljivost in ocena predvidenega vpliva, ARSO, Ljubljana.

Žiberna, I. 2000: Geografski oris slovenskega Podravja. V: Drava nekoč in danes. Založba Obzorja, Maribor.

Žiberna I. 2006: Trendi temperatur zraka v Mariboru kot posledica razvoja mestnega toplotnega otoka. Revija za geografijo, Filozofska fakulteta. Maribor. 
GeOgRAFIJE PoDRAVJa

THE GeOgraPhies of the Podravje Region 


\title{
Pohorje - slovenska pedološka posebnost
}

\author{
BLAŽ REPE
}

Povzetek Zmerno in humidno podnebje vodi v Sloveniji v sorazmerno počasne pedogenetske procese, kar še posebej velja za preperevanje matične podlage in mineralov, ki jo sestavljajo. Minerali zato najpogosteje v obliki mehansko razdrobljenih meljnatih ali celo peščenih ter skeletnih delcev $\mathrm{v}$ pedosfero pogosto vstopajo kemično le delno ali celo povsem nespremenjeni. $\mathrm{S}$ tem neposredno zelo močno vplivajo na glavnino lastnosti samih prsti. Posledično uvrščamo matično podlago v Sloveniji med najpomembnejše pedogenetske dejavnike. Vendar je glede na najbolj osnovno delitev kamnin Slovenija geološko zelo malo pestra $(93 \%$ sedimentnih, $4 \%$ metamorfnih in $3 \%$ magmatskih kamnin). Za sedimentne kamnine nekarbonatnega izvora velja, da so mehansko malo odporne, zato jih kljub zelo razgibanemu površju praktično $\mathrm{v}$ celoti pokrivajo distrične rjave prsti (20,7\%), izjemno malo pa imamo rankerjev $(2,1 \%)$. Pohorje je $\mathrm{v}$ tem pogledu posebnost. Zavoljo zelo trdih in kompaktnih magmatskih ter metamorfnih silikatnih kamnine je delež prsti na nižji razvojni stopnji (rankerji) bistveno večji. Vendar nasproti temu zelo kisli produkti preperevanja matične podlage, v kombinaciji s hladnim gorskim podnebjem ter kisloljubnimi smrekovimi, jelovimi in bukovimi gozdovi pogojujejo tudi nastanek razvojno najstarejših opodzoljenih prsti. Posebnost so tudi organske šotne prsti visokega barja.

Ključne besede: $\bullet$ pedogenetski dejavniki $\bullet$ matična podlaga $\bullet$ podnebje $\bullet$ rankerji $\bullet$ šotne prsti $\bullet$ Pohorje $\bullet$

\footnotetext{
NAsLOV AVtoRJA: dr. Blaž Repe, docent, Univerza v Ljubljani, Filozofska fakulteta, Oddelek za geografijo, Aškerčeva cesta 2, 1000 Ljubljana, Slovenija, e-naslov: blaz.repe@ff.uni-lj.si. 


\title{
Pohorje - Slovenia's pedological exception
}

\author{
BLAŽ REPE
}

\begin{abstract}
Slovenia's moderate and humid climate causes relatively slow processes of soil formation. This is especially evident in mechanical and chemical weathering of parent material and its minerals. Minerals enter the pedosphere in the size class of silt, sand and even skeletal parts. They are chemically only partially changed or even completely unaltered. Parent material directly and heavily influences soil properties. The parent material is considered the most important of Slovenia's factors of soil formation. $93 \%$ of the Slovenian territory is composed of sedimentary rocks and only $4 \%$ belongs to the metamorphic group, while $3 \%$ is of magmatic origin. Silicate sedimentary rocks in Slovenia show relatively little resistance to mechanical weathering. The research area of the Pohorje Mountains is mainly composed of very hard and compact magmatic and metamorphic. The share of soil types that are on the lower stage of development (Dystric Leptosols) is considerably larger (nearly one fifth of the research area). Despite mountainous and hilly topography with steep slopes, there are two more exceptions. The small area of flat topography with impermeable clays contribute to presence of Histosols. The second exception is the presence of Podzols and extremely leached soils.
\end{abstract}

Keywords: • factors of soil formation $\bullet$ parent material $\bullet$ climate $\bullet$ Dystric Leptosols • Histosols • Pohorje mountains •

CorResPondence AdDREss: Blaž Repe, Ph.D., lecturer, University of Ljubljana, Faculty of Arts, Department for geograph, Aškerčeva cesta 2, 1000 Ljubljana, Slovenia, e-mail: blaz.repe @ff.uni-lj.si. 


\section{Uvod}

Pohorje sodi v severovzhodni del predalpskega hribovja, ki predstavlja razgibano površje, brez res izrazitih in izstopajočih vrhov. Današnjo podobo mu je dala pleistocenska poledenitev in vrsta vodotokov, ki so pohorska pobočja razrezali v pas manjših dolin in grap. Pripada skrajnemu Vzhodnemu delu Alp in je hkrati tudi najbolj vzhodna točka periadriatskega magmatizma. Geološko ga omejujejo Labotski prelom na zahodu in na jugu Periadriatski šiv. Pas metamorfnih kamnin je nadaljevanje zelo podobne zgradbe iz Avstrije na severu, od katerih jih loči ribniško-selniška antiklinala. Na vzhodu Pohorski masiv tone pod različne kvartarne sedimente (Zupančič, 2005). Podnebno je Ogrin (1996) osrednji in najvišji del uvrstil v podnebje nižjega gorskega sveta in vmesnih dolin severne Slovenije; nižji obrobni del pa v zmerno celinsko podnebje osrednje Slovenije.

Naravno prevladujejo kisloljubni bukovi, jelovi in smrekovi gozdovi. Vendar so bili zaradi preteklih človekovih dejavnosti (pridobivanje pašnih površin in sečnja za pridobivanje lesa, oglja in stekla) praktično povsem spremenjeni v čiste smrekove sestoje (Čarni, Marinček, 2002). Hiter pogled na pedološko karto Pohorja nam razkrije, da je območje z vidika prsti zelo pestro. Pedološko pestrost pogojuje široka paleta pedogenetskih dejavnikov, ki po raznolikosti nič kaj ne zaostajajo za pregovorno pestro Slovenijo.

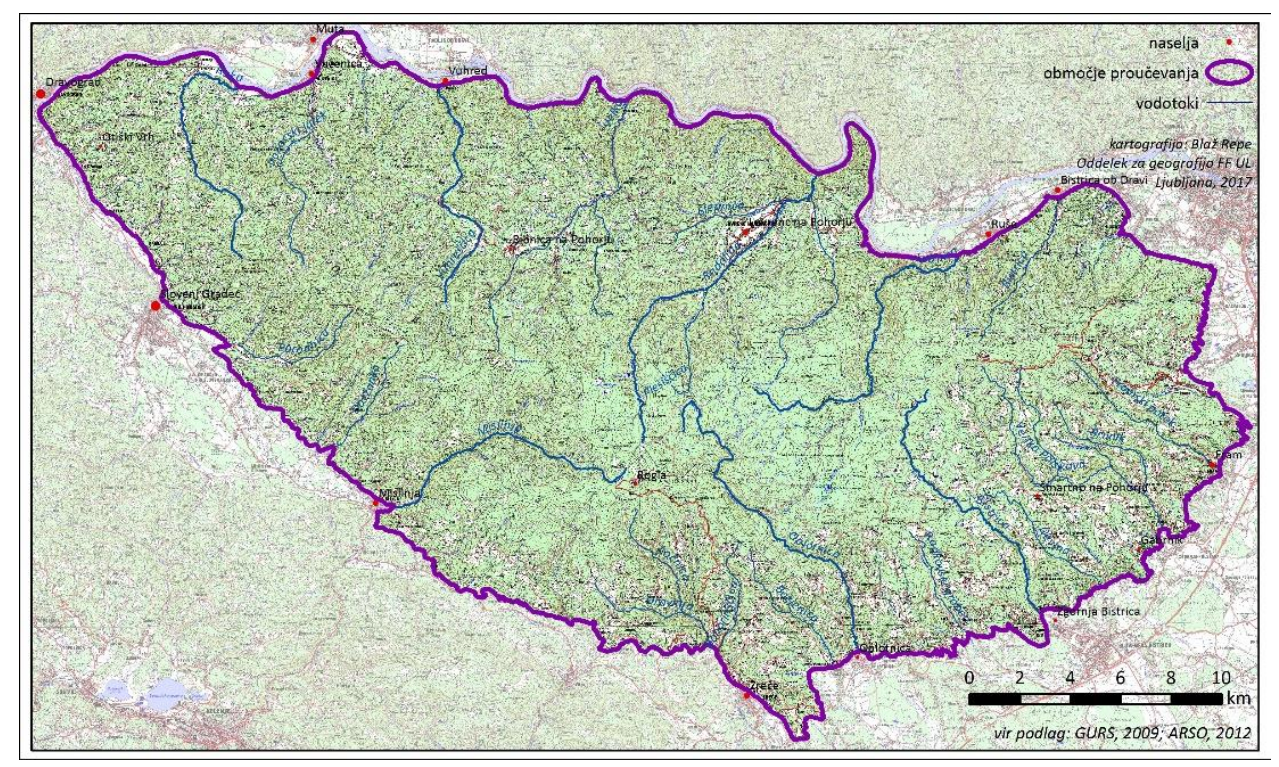

Proučevano območje Pohorja.

Natančneje meje proučevanega območja potekajo:

- Na severu območje omejuje dolina Drave. Med Dravogradom in Mariborom poteka meja po vznožjih pobočij, približno na nadmorski višini $350 \mathrm{~m}$.

- Na vzhodu je meja prav tako postavljena na vznožja pobočij. Med Mariborom in Oplotnico je le ta še na višini $350 \mathrm{~m}$, kjer se nato povzpne na $400 \mathrm{~m}$. Meja 
pri Zrečah zavije v dolino Dravinje in se pri Loški Gori pri Zrečah dvigne na $650 \mathrm{~m}$ ter obrne proti zahodu.

- Meja nadaljuje pot proti zahodu na nadmorski višini $650 \mathrm{~m}$ mimo Ljubnice, Pake, Spodnjega, Srednjega in Zgornjega Doliča.

- Pri Mislinji se ponovno spusti na vznožje doline (600 m). Meja nadaljuje pot proti severozahodu mimo Šmartnega pri Slovenj Gradcu (500 m), Gradišča v Slovenj Gradcu (400 m) in Šentjanža pri Dravogradu, kjer se ponovno spusti na 350 m nadmorske višine ter zaključi v Dravogradu.

- Dna in izhodi manjših dolin ter grap na pobočjih Pohorja so vključena v samo območje. Meja približno poteka na izhodu, v skladu s potekom pobočij. Mejo med ravnino in pobočjem (vznožje), smo kvantitativno določili na podlagi GISovske, clusterske analize površja.

Namen raziskave je bil s pomočjo geografskih informacijskih sistemov modelirati prostorske podatkovne baze podatkov (vektorskih in rastrskih) ter pridobiti nov zemljevid prsti proučevanega območja ter ga primerjati $\mathrm{z}$ obstoječim digitalnim pedološkim zemljevidom v merilu $1: 25.000$. Na podlagi primerjave smo želeli ugotoviti oziroma potrditi, da je proučevano območje (Pohorje) dejansko slovenska pedološka posebnost.

\section{Pedogenetski dejavniki proučevanega območja}

Vse, kar vpliva na nastanek, razvoj in lastnosti prsti ter istočasno na njihovo razširjenost, lahko strnemo pod pojmom pedogenetski (tlotvorni) dejavniki. Z vidika sistemske teorije so to dejavniki okolja oz. geografskega okolja, pokrajine, ki delujejo na proučevani podsistem, to je na prst (Lovrenčak, 1994). Do takšnih zaključkov se je dokopal že Dokučajev, temelje pa leta 1941 postavi Jenny (1941), ko je vpliv pedogenetskih faktorjev na nastanek in razvoj prsti zapisal v obliki formule:

$S=f(c l, o, r, p, t)$

kjer je prst $(S)$ funkcija $(f)$ pedogenetskih dejavnikov: podnebja $(\mathrm{cl})$ živega sveta $(o)$, reliefa $(r)$, matične podlage $(p)$ in časa $(t)$. Posledično smo poiskali, zbrali in ustvarili takšne prostorske baze podatkov, ki bi kar najbolje opisale in predstavile dogajanje $\mathrm{v}$ prsteh.

\section{Matična podlaga}

Kamninska oziroma matična podlaga spada $v$ Sloveniji med najpomembnejše pedogenetske dejavnike. Zaradi zmernega podnebja so pedogenetski procesi preperevanja dokaj počasni, zato matična podlaga $v$ ne popolnoma prepereli obliki vstopa $\mathrm{v}$ pedosfero in s tem s svojimi lastnostmi neposredno vpliva na lastnosti samih prsti. Po drugi strani neposredno vpliva na ostale pomembne pedogenetske dejavnike. Na prvem mestu vpliva na nastanek in izoblikovanost površja, ki potem naprej odreja delovanje, razporeditev in odtok vode ter tako na makro kot mikropodnebne dejavnike. Ker je pri nas skoraj polovica površja kraškega, je vpliv kamnin na vode tudi neposreden (Stritar, 1991; Lovrenčak, 1994; Kočevar, Vidic, 1998; Repe, 2006; Kralj, 2008). Več raziskav je potrdilo, da prav razporeditev geolitoloških tipov bistveno vpliva na prostorsko razporeditev prsti (Repe 2006), zato jo obravnavamo tudi prvo. 


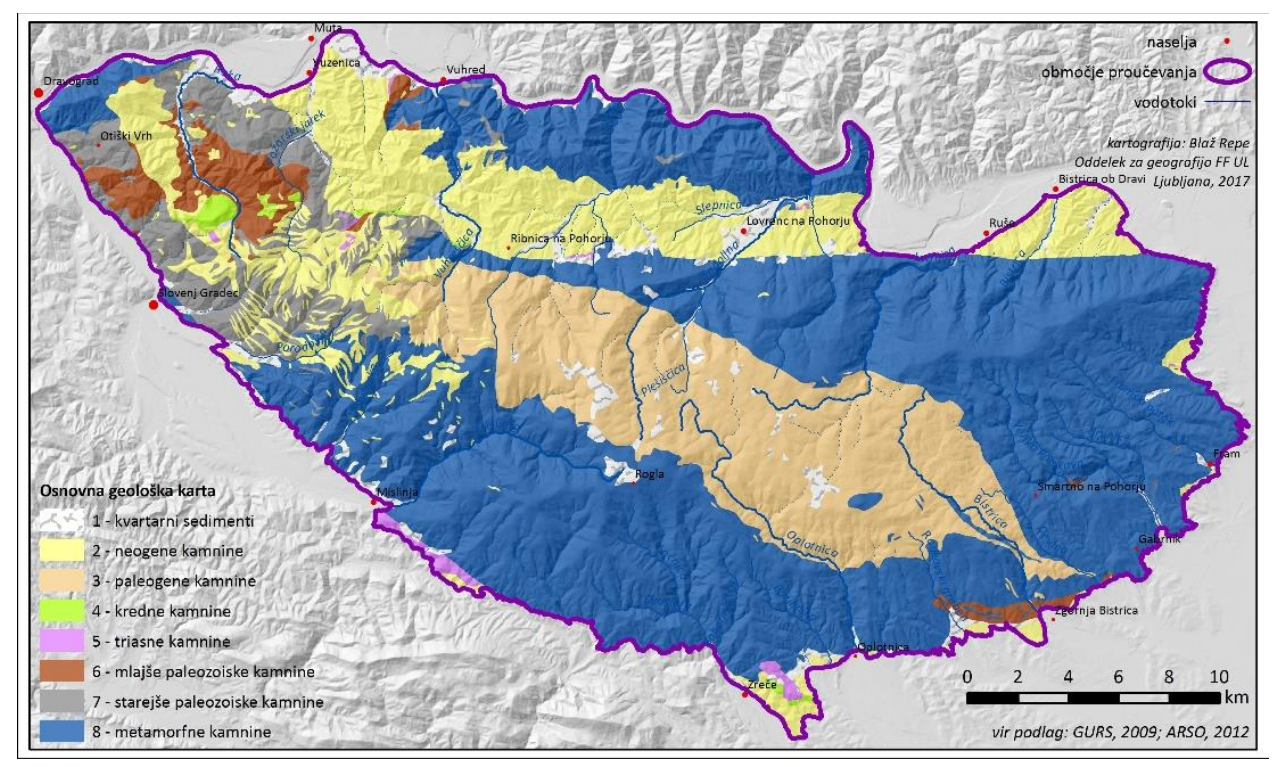

Osnovna geološka karta v merilu 1 : 100.000 (poenostavljene in združene enote).

$\mathrm{Na}$ proučevanem območju izrazito prevladujejo trde, kompaktne magmatske in metamorfne kamnine, kar je zelo neznačilno za Slovenijo. Magmatske in metamorfne kamnine namreč zavzemajo slabe $3 / 4$ ozemlja (71\%), mlajše kamnine in recentni sedimenti obsegajo $20 \%$, ki so vse po vrsti pretežno silikatnega izvora (izjema je marmor) in dajejo kisle produkte preperevanja. Na drugi je za Slovenijo tipičnih karbonatnih kamnin manj kot odstotek. Matično podlago kot pedogenetski dejavnik nam predstavlja osnovna geološka karta v merilu 1 100.000, lista Slovenj Gradec (OGK, 1972) in Maribor (OGK, 1989).

\section{Površje}

Površje v Sloveniji je odraz tektonsko-geoloških razmer. Zagotovo sodi med najpomembnejše naravne dejavnike ter Sloveniji daje pečat, ki se zrcali v vseh ostalih pokrajinskih elementih, tudi družbenih. Površje na samo pedogenezo vpliva posredno. V Sloveniji in tudi na proučevanem območju odločilno vpliva na vodne razmere v prsteh (količina, smer premikanja, učinki) ter na mikro in mezo podnebne razmere (količina in razporeditev padavin, temperature, prejeta količino sončevega obsevanja, vetrovi, ...) (Repe, Blatnik, 2013).

Proučevano območje uvrščamo med hribovje, ki prav tako ne sodi med najbolj značilna. Površje je razgibano, vendar ga ne zaznamujejo izraziti vrhovi. Nadmorske višine proučevanega območja od najmanj pod $250 \mathrm{~m}$ na izhodih dolin in grap (npr. Radoljna, Bistrica, Pekrski potok), najvišje na Črnem vrhu (1543 m). Skoraj polovica vseh nadmorskih višin $(49,1 \%)$ se nahaja med 400 in $800 \mathrm{~m}$. Ostala polovica je dokaj enakomerno razporejena nad $800 \mathrm{~m}$. 


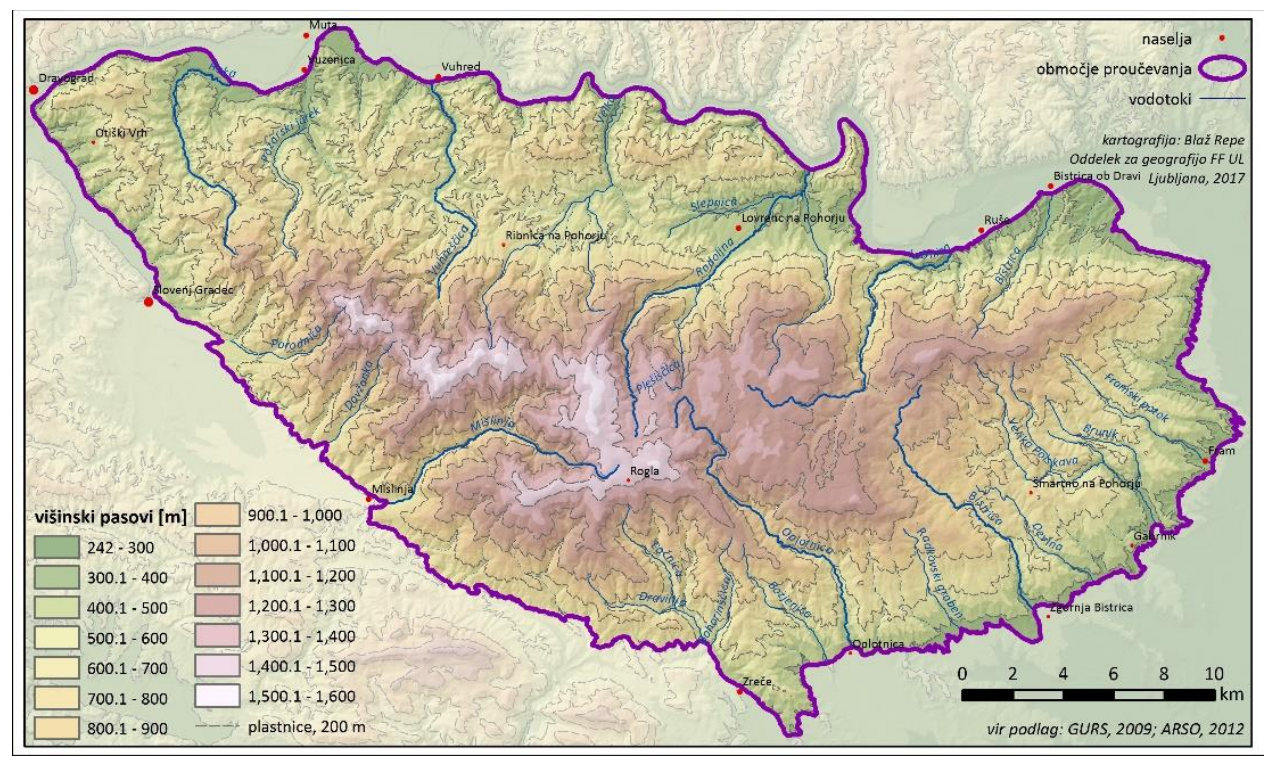

100 metrski višinski pasovi proučevanega območja.

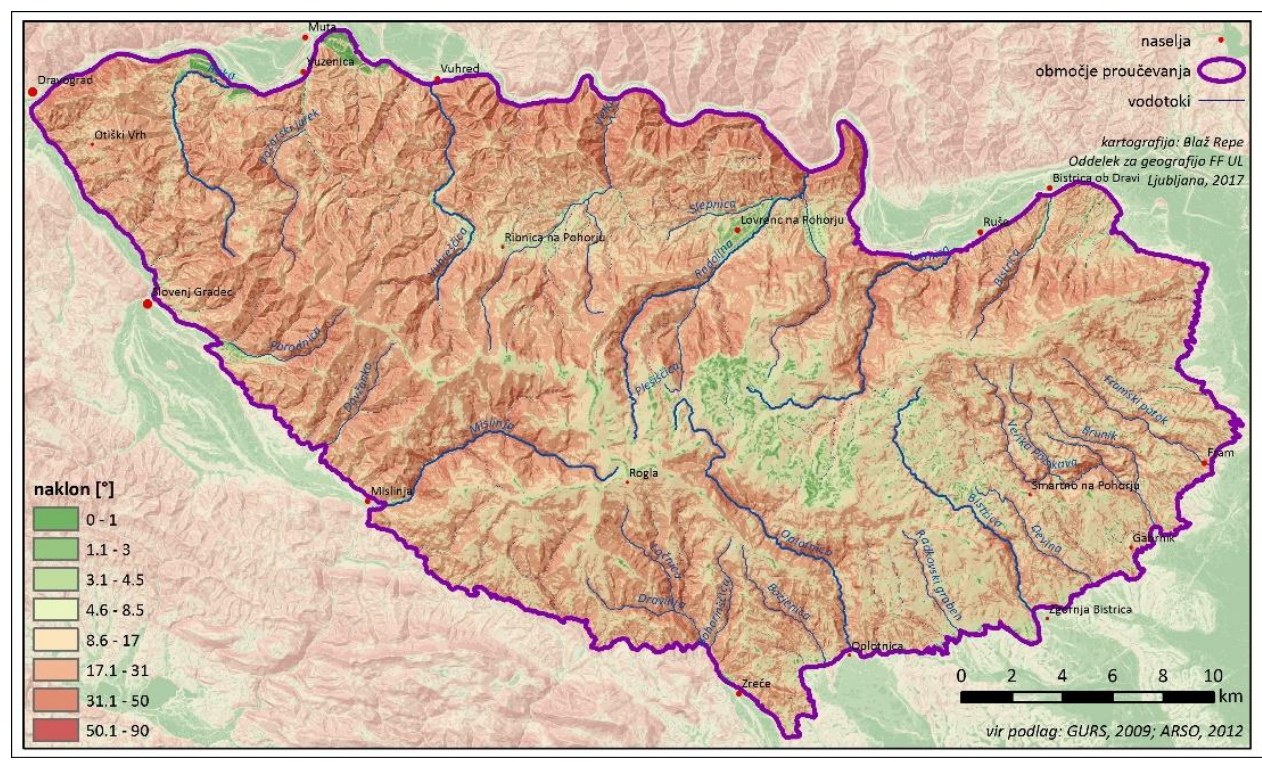

\section{Naklonski razredi proučevanega območja.}

$\mathrm{Z}$ vidika naklonov bi območje lahko razdelili na izrazito razgibano in strmo na eni $(57,5 \%)$ in dokaj uravnano, planotasto ali celo ravninsko $(42,5 \%)$ na drugi strani. Najbolj uravnani deli so na severnem obrobju ob naselju Trbonje, Muta, v notranjosti pri Lovrencu na Pohorju ter največje, v osrednjem delu ob pohorskih barjih in jezerih, severno in vzhodno od Rogle. 
Deleži posameznih naklonskih razredov proučevanega območja.

\begin{tabular}{|l|c|}
\hline Naklonski razred $\left({ }^{\circ}\right)$ & Delež \\
\hline $0.0-1.0$ & $0.33 \%$ \\
\hline $1.1-3.0$ & $1.74 \%$ \\
\hline $3.1-4.5$ & $2.13 \%$ \\
\hline $4.6-8.5$ & $8.52 \%$ \\
\hline $8.56-17.0$ & $29.79 \%$ \\
\hline $17.1-31.0$ & $46.84 \%$ \\
\hline $31.1-50.0$ & $10.63 \%$ \\
\hline $50.1-90.0$ & $0.02 \%$ \\
\hline
\end{tabular}

Med pomembnejše dejavnike, ki smo jih uporabili v nadaljnji analizi, smo uvrstili:

- ekspozicijo pobočij,

- ukrivljenost površja (ukrivljenost plastnic in profila),

- prejeto količino Sončevega obsevanja in

- reliefni indeks vlažnosti (TWI, topographic wettness index),

- klasifikacijo površinskih oblik (kategorije: 0 - vodotoki; 1 - manjše grape; 2 povirni deli potokov; 3 - doline; 4 - uravnave; 5 - pobočja, srednji in spodnji deli; 6 - pobočja, zgornji deli; 7 - lokalni grebeni; 8 - nižje vzpetine in grebeni, sredi pobočij; 9 - vrhovi in vršni grebeni).

Kar je zanimivo za proučevano območje Pohorja, so prevladujoče površinske oblike, ki se lepo odražajo v kasnejši razporeditvi prsti. Glavnina površja $(63,0 \%)$ med sodi bolj ali manj nagnjena pobočja, sledijo doline z vodotoki in manjše stranske grape $(20,8 \%)$, nižje vzpetine, grebeni, vrhovi obsegajo $11,6 \%$ in različna uravnave v višjih nadmorskih višinah $3,3 \%$.

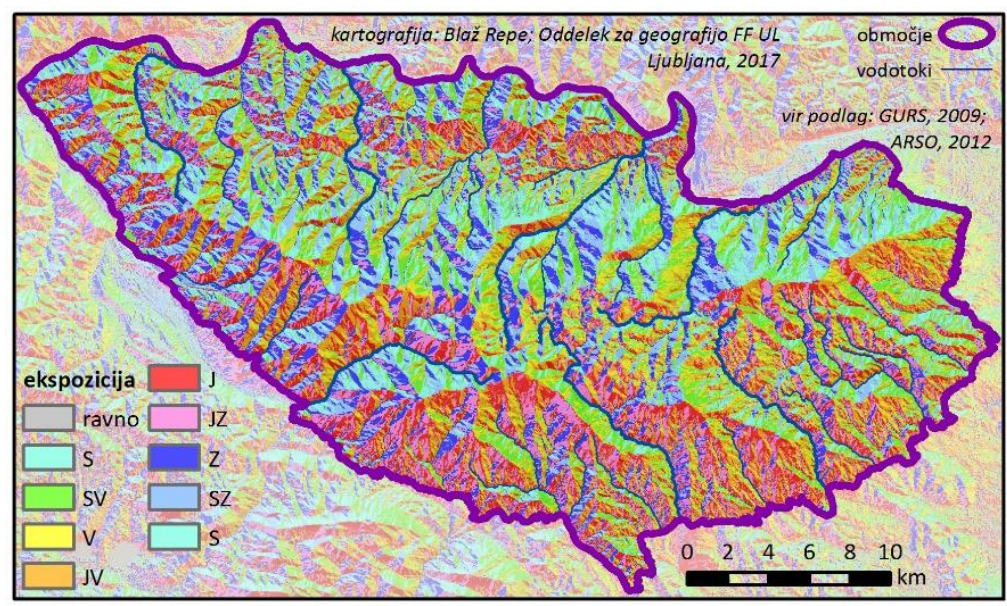

Dodatni digitalni sloji, uporabljeni v nadaljnjih analizah (ta in slike na naslednjih dveh straneh). 
The Geographies of the Podravje Region

B. Repe: Pohorje - Slovenia's pedological exception
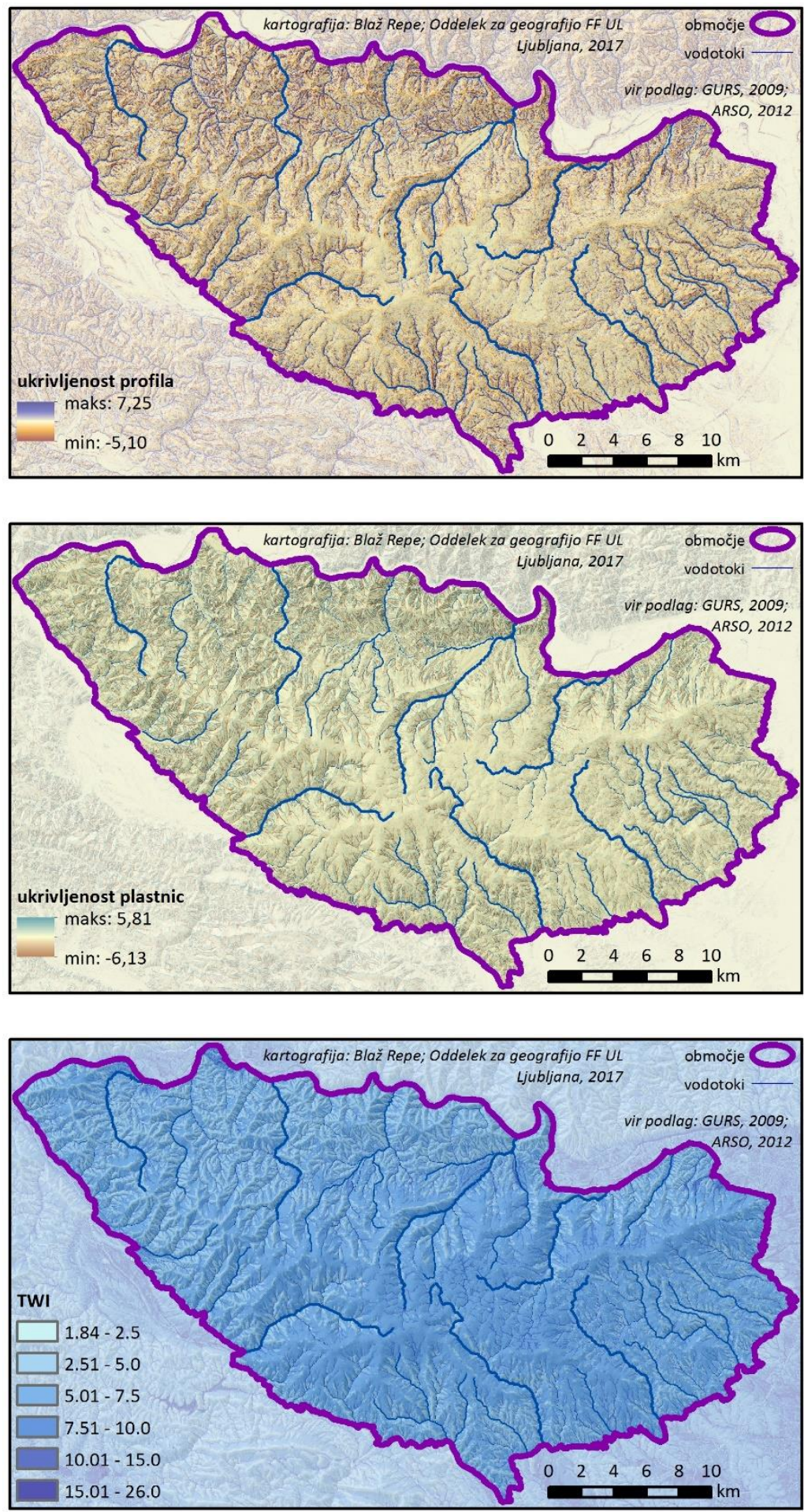

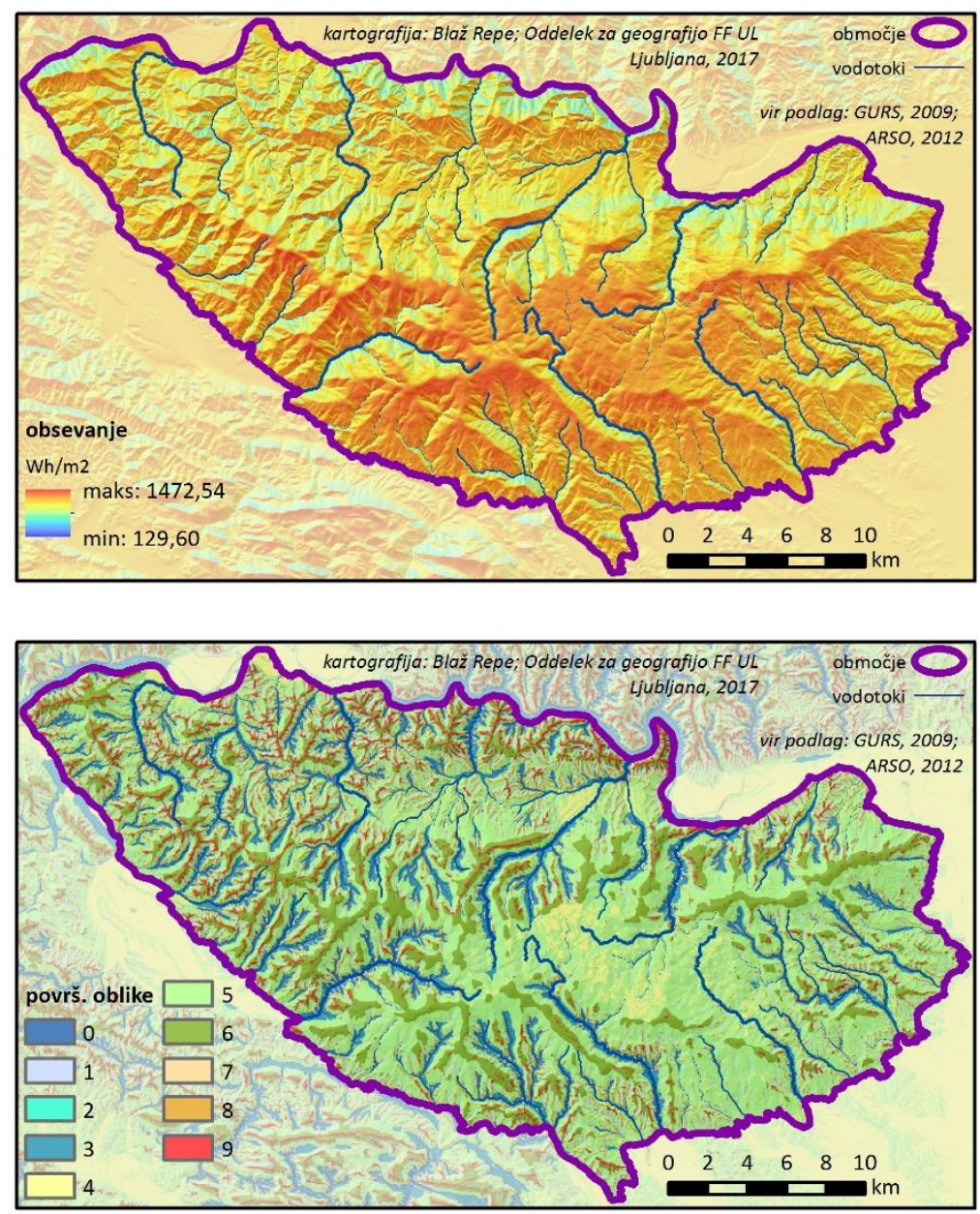

\section{Podnebje}

Podnebje spada med pedogenetske dejavnike, ki neposredno vpliva na hitrost in intenzivnost preperevanja ter zavira ali pospešuje pedogenetske procese (Stritar, 1990). Vzajemna zveza med podnebjem in pokrajinskimi sistemi je bila relativno zgodaj ugotovljena in velja predvsem za večje prostorske segmente, kjer podnebje po svoji funkciji prednjači pred ostalimi parametri okolja (Stritar, 1990). V prsteh Slovenije se še najbolj odraža vlažnost podnebja (Lovrenčak 1994).

Podnebje se tako zrcali predvsem v splošnih pedogenetskih procesih, ki so značilni za celotno Slovenijo (preperevanje matične podlage, argilogeneza in braunizacija, humifikacija, izpiranje baz (hranil) in glinastih delcev, oglejevanje in psevdoglejevanje) (Škorić, 1986; Lovrenčak, 1994; Repe, 2004). A vendar je na proučevanem območju tudi podnebje kot pedogenetski dejavnik nekoliko specifično. Pohorje namreč leži na stiku dveh velikih naravnogeografskih enot (Alpe, Panonska kotlina). Obe enoti sta si podnebno povsem različni in samosvoji, ki med seboj trčita prav na proučevanem območju. 

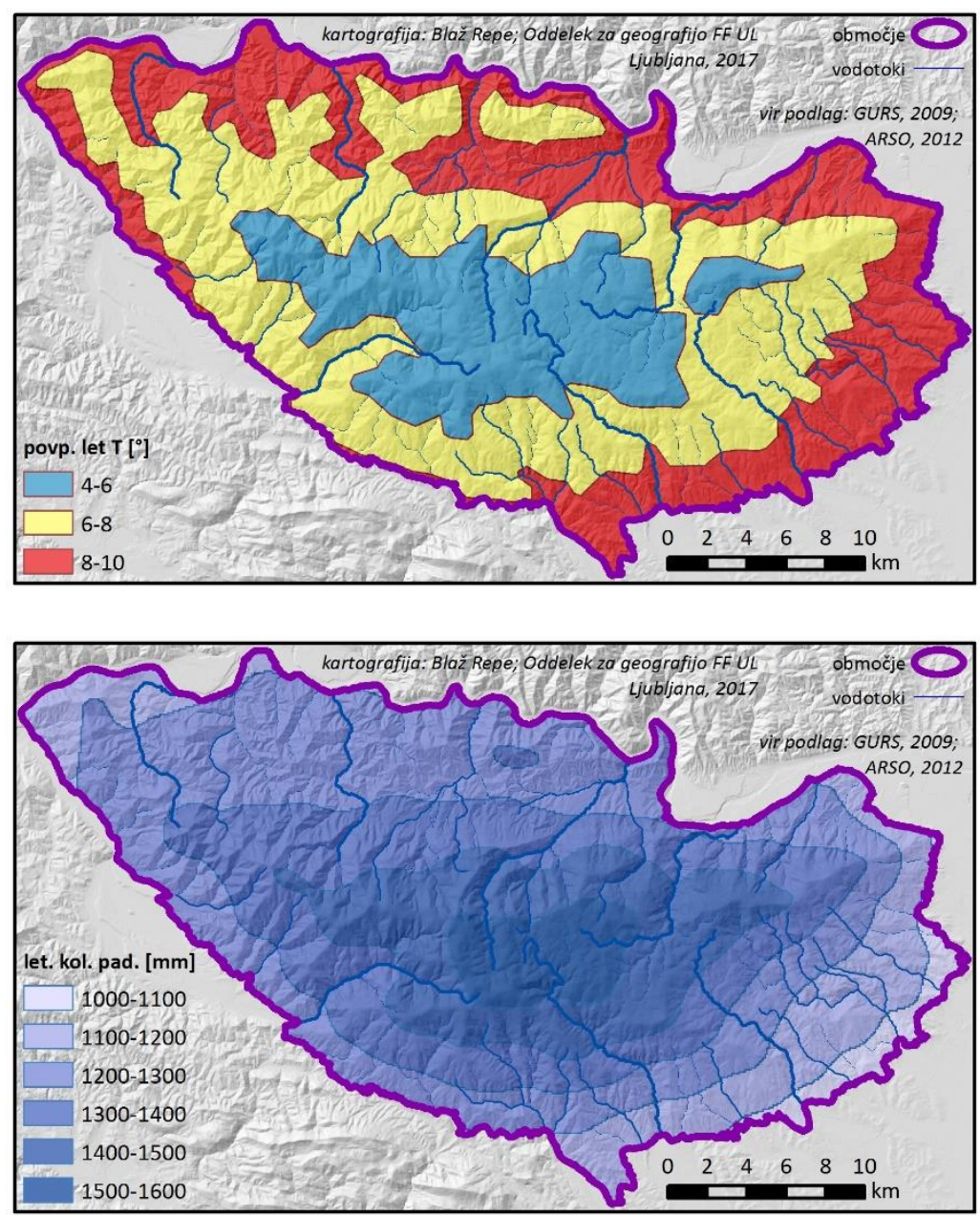

Povprečna letna temperatura in letna količina padavin proučevanega območja.

Glavnino območja lahko uvrstimo v zmerno celinsko podnebje, za katerega so značilni procesi, ki so tudi sicer značilni za celotno Slovenijo. Najvišji deli pa sodijo v milejšo različico gorskega podnebja, z večjo količino (orografsko pogojenih) padavin in nižjimi povprečnimi in absolutnimi temperaturami. To se posledično odraža $v$ počasnejših procesih preperevanja (plitvejše prsti, z več skeleta in manj glinastih delcev), kopičenja bolj surovih oblik humusa, intenzivnemu premeščanju in izpiranju hranil ter drobnih delcev, celo podzoljevanju ter nenazadnje, kjer nepropustna matična podlaga in uravnano površje dovoljujeta, tudi zastajanju vode in nastanku visokih barij (Škorić, 1986; Repe, 2006; Obu, 2009).

\section{Voda}

Voda predstavlja izjemno pomemben pedogenetski faktor, ki ima v slovenski klasifikaciji prsti še posebno težo, saj na prvem nivoju poteka delitev prsti na oddelke: avtomorfne in hidromorfne (tudi na subakvalne in halomorfne) prav na podlagi vpliva vode (Repe, 2004). Kljub vsemu pa se voda kot pedogenetski dejavnik ter njena vsebnost v prsteh 
pogosto ne obravnava samostojno, ampak v sklopu drugih dejavnikov, še posebej reliefa in podnebja. Če je tak pristop na globalnem nivoju ustrezen, pa moramo v regionalnem merilu vodo vsekakor posebej izločiti (Prus, 2000).

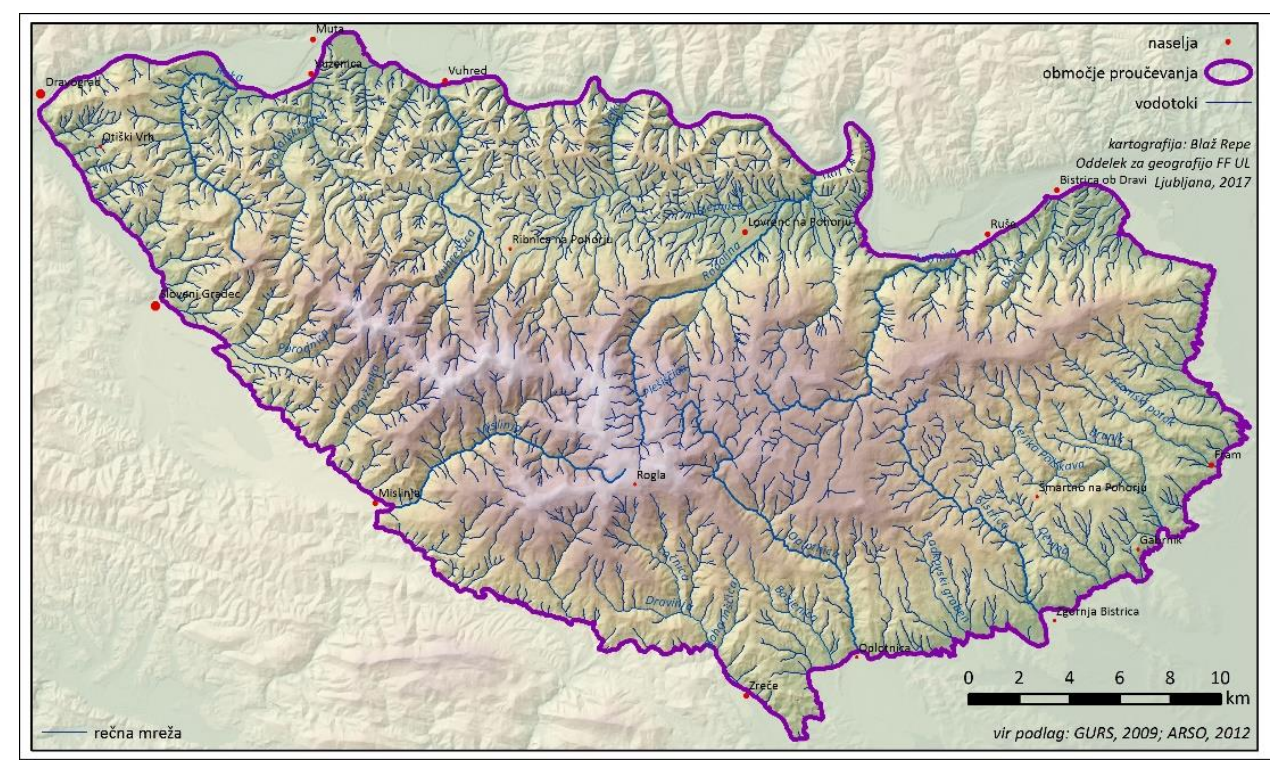

\section{Rečna mreža proučevanega območja.}

Za Slovenijo značilna prisotnost prepustnih, karbonatnih kamnin se na proučevanem območju praktično ne odraža. Močno prevladujejo nepropustne silikatne, magmatske in metamorfne kamnine z normalno razvito rečno mrežo. Mnogo pogosteje kot drugod v Sloveniji voda prej ali slej trči na nepropustno oviro in v kolikor je ta blizu površja, nastanejo pogoji tudi za hidromorfne razmere. Poleg zelo dobro razvite rečne mreže (v skupni dolžini $1.586 \mathrm{~km}$ ), na mnogo večjo prisotnost vode v prsteh kaže tudi reliefni indeks vlažnosti (TWI).

Poleg podnebnih pogojev, je za razlago razporeditve vode v prsteh, treba poleg splošnih hidroloških poznati predvsem reliefne razmere. Relief namreč v dobršni meri odloča, kako in kam se bosta premikali padavinska voda po površju in gravitacijska voda v prsti oziroma kje se bodo razvile avtomorfne in kje hidromorfne razmere (Repe, 2007a).

Kot glavno osnovo za oceno količine in razporeditve vode v prsti smo uporabili reliefni indeks vlažnosti (TWI) (Moore et al., 1993; Western et al., 1999). Reliefni indeks vlažnosti opredeljuje vrednosti, ki kažejo visoko korelacijo s pojavljanjem avtomorfnih (nižje vrednosti TWI) in hidromorfnih tipov prsti (višje vrednosti TWI). Tipične vrednosti reliefnega indeksa vlažnosti imajo razpon od 2 do 30 . Nižje vrednosti (pod 10) pomenijo zgornje, bolj strme dele pobočij in porečij od koder voda odteka. Tu pričakujemo sušnejše razmere $\mathrm{v}$ prsti, odnašanje prstenega materiala in posledično plitvejšo odejo prsti. Večje vrednosti reliefnega indeksa vlažnosti (nad 20) predstavljajo spodnje dele pobočij ali porečij, kjer se voda steka. Gre za ravninska ali uravnana območja, blizu lokalne erozijske baze in vodotokov. Značilni so nizki strmci, zastajanje 
vode in akumulacija prstene mase, zato so prsti debelejše in pogosto se pogosto razvijejo hidromorfne razmere (oglejevanje in psevdooglejevanje).

Če podrobno pogledamo vrednosti reliefnega indeksa vlažnosti, opazimo, da se višje in visoke vrednosti pojavljajo tudi v grapah, na uravnavah in konkavnih delih sredi pobočij ter tudi ponekod na grebenih, kjer so nakloni blažji. Čeprav so se na koncu teoretične predpostavke o reliefnem indeksu izkazale za točne, pa razporeditev indeksa kaže, da hidromorfnih prsti vseeno ni tako veliko, kljub nepropustni matični podlagi.

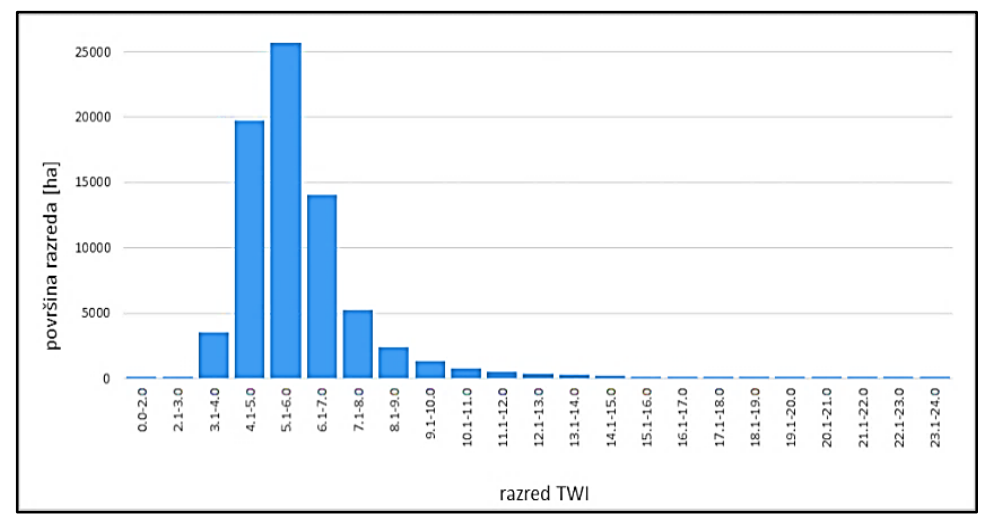

Razporeditev površin po posameznih razredih reliefnega indeksa vlažnosti (TWI).

\section{Rastlinstvo, človek in čas}

Glede na uporabljeno metodologijo (Repe, 2006) navedeni dejavniki iz različnih vzrokov niso bili neposredno vključeni $\mathrm{v}$ modeliranje pedogenetskih dejavnikov. Rastlinstvo lahko v pretežni meri smatramo kot posledico pedološke odeje, čeprav se zavedamo, da je vpliv tudi obraten, predvsem na oblike, tip, razvitost in količino organske snovi. Čas nam v pretežni meri odražajo dejavniki površja in matične podlage.

Zaradi razgibanosti površja ter trde matične podlage, je pričakovati mlajše in plitvejše tipe in oblike prsti, kar se je na koncu tudi potrdilo. Vpliva človeka nismo modelirali, je pa bil vključen povsem na koncu. Iz končnega prikaza razprostranjenosti prsti smo izvzeli in posebej prikazali antropogene rabe tal, kjer prsti bodisi ni (pozidano) ali kjer so prsti spremenjene do te mere, da ne kažejo več svojih naravnih značilnosti (njive in vrtovi) (MKGP, 2016).

Kisla in trda silikatna matična podlaga, hribovito in razgibano površje, hladno in vlažno podnebje, skupaj s kislimi in plitvimi prstmi odrejajo rabo tal na proučevanem območju. Območje je velikem delu ohranilo svoj kolikor toliko naravni značaj. Pozidanih površin je 2,9\%,2,0\% je različnih nasadov, še manj je njivskih površin, ki jih je zgolj 1,0\%. Nekoliko večji delež je travniških površin $(16,0 \%)$, ki kažejo na vpliv človeka predvsem zaradi krčenja gozdnih površin (MKGP, 2016). Da pa je človek vendarle bil prisoten na Pohorju ter v območje tudi aktivno posegal, kažejo gozdne združbe oziroma posamezne prevladujoče drevesne vrste. 

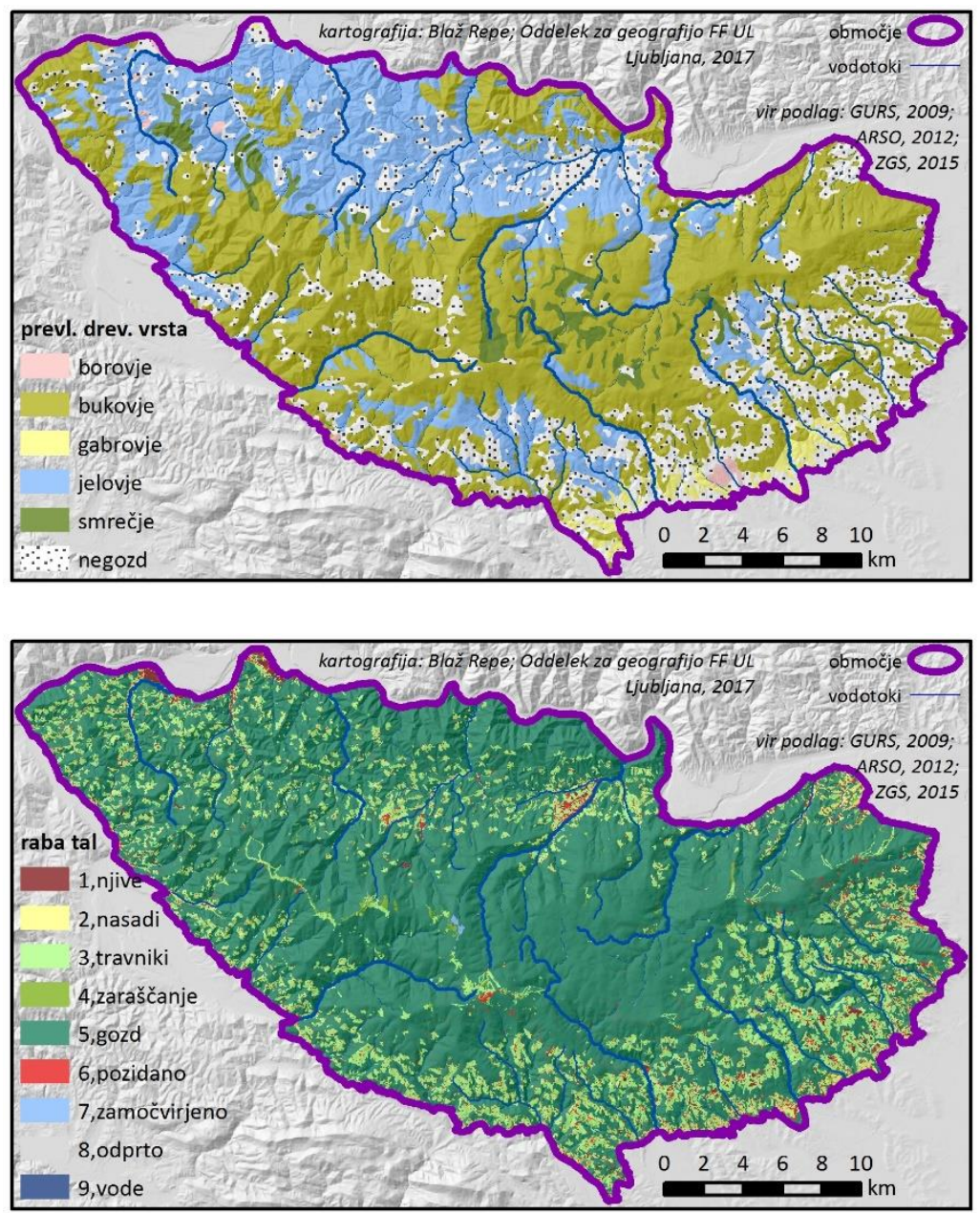

\section{Prevladujoča drevesna vrsta in poenostavljene kategorije rabe tal na proučevanjem območju.}

V preteklosti so močno prevladovali kisloljubni bukovi in jelovi gozdovi, ki pa so danes povsem premenjeni v skorajda povsem čiste smrekove gozdove. Naravno bi morala biti bukev prisotna na več kot 50 \% površja in jelka še na dodatni četrtini. Smreka je naravno prisotna zgolj na $3 \%$. Vsak obiskovalec Pohorja pa ve, da v marsikaterem delu smreka ne le prevladuje, ampak da je zaradi gospodarske pomembnosti praktično edina vrsta.

Na Pohorju prevladujejo iglavci, saj predstavljajo več kot tri četrtine lesne zaloge. Najpogostejša drevesna vrsta je smreka, ki zavzema več kot polovico v lesni zalogi. Pogosti sta še bukev in jelka ostale drevesne vrste pa predstavljajo manj kot $5 \%$ lesne zaloge.

Na Pohorju so spremenjeni gozdovi prisotni na več kot polovici območja (prisotnost tujih ali redko prisotnih drevesnih vrst je od 31 do $70 \%$ ), močno spremenjeni (tujih ali redko prisotnih drevesnih vrst je 71 do $90 \%$ ) in ohranjeni gozdovi (tujih ali redko prisotnih drevesnih vrst je do $30 \%$ ), pokrivajo slabo petino. To je posledica intenzivnejšega 
vnašanja smreke $\mathrm{v}$ ta prostor v preteklosti, saj so na golosečnih površinah in opuščenih kmetijskih zemljiščih sadili predvsem smreko.

Smreka prevladuje še posebej na zahodnem in južnem delu Pohorja. V severnem delu se ji pridružita jelka, nekaj pa je tudi delov, v katerih prevladuje bukev. Na vzhodnem Pohorju se prepletajo območja, v katerih prevladuje bukev, nižje pa bukev in ostali listavci. Območja, v katerih prevladujejo ostali iglavci (rdeči bor) najdemo predvsem na jugovzhodnem delu, nekaj pa tudi raztreseno po obronkih Pohorja. Razlog za takšno sliko najdemo v močnejšem pospeševanju smreke na zahodnem in južnem delu. Jelke je več na severnem delu, saj so tam zanjo najprimernejša rastišča, deloma je to tudi antropogeno pogojeno. V višjih nadmorskih višinah je smreke več, ker so zaradi ostrejših podnebnih razmer ostale drevesne vrste manj konkurenčne in ker je bila v preteklosti intenzivno umetno vnašana v to območje (Cenčič, 2010).

\section{Zemljevid prsti Pohorja}

Postopek izdelave podrobnega zemljevida razprostranjenosti prsti proučevanega območja Pohorja je obsegal več korakov:

- Zbiranje digitalnih prostorskih baz podatkov, kreiranje geografskega informacijskega sistema in osnovne prostorske, predvsem morfometrične analize.

- Standardizacija rastrskih podatkovnih slojev $\mathrm{v}$ ločljivosti $12,5 \times 12,5 \mathrm{~m}$ in izvedba nenadzorovane klasifikacije (cluster analiza).

- Določitev meja proučevanega območja.

- Interpretacija dobljenih rezultatov na podlagi podatkov profilov prsti (MKGP, 2007b), geološke karte $\mathrm{v}$ merilu 1:100.000, različnih morfometričnih parametrov (nadmorska višina, naklon...), indeksov (reliefni indeks vlažnosti, razgibanost površja, dolžina pobočja...), kompleksnega kazalca osnovnih površinskih oblik, podnebnih kazalcev (razporeditev temperatur in padavin).

- Ročna digitalizacija zamočvirjenih in barjanskih površin na podlagi topografskih zemljevidov in digitalnih ortofoto posnetkov.

- Izločitev njivskih, pozidanih in vodnih površin iz zemljevida prsti na podlagi dejanske rabe tal.

V nadaljevanju so predstavljeni zgolj nekateri ključni deli pridobivanja končnega zemljevida razprostranjenosti prsti na Pohorju.

Ker je območje proučevanja na eni strani sorazmerno veliko, po drugi pa primanjkuje zadostna količina neposrednih terenskih meritev prsti, je povsem nemogoče pripraviti zemljevid, ki bi povsem odražal stanje v pokrajini. Zato smo se lotili modeliranja obstoječih podatkovnih baz, ki predstavljajo pedogenetske dejavnike. Končni rezultat je približek dejanskemu stanju, ki se zanaša na točnost digitalnih baz podatkov. To je velika slabost prikazane metode in tudi končnega rezultata, česar se seveda zavedamo.

Za pedološko tipizacijo proučevanega območja potrebujemo vnaprej razmejene enote, kjer pričakujemo sorazmerno homogeno razporejanje pedogenetskih dejavnikov. Sorazmerno homogene enote, kjer prevladujejo enotni pedogenetski dejavniki, smo dobili postopkom nenadzorovanega razvrščanja $\mathrm{v}$ skupine (cluster analiza). Pri 
nenadzorovanih klasifikacijah postopek išče "naravne" skupine (grozde, ang. cluster), ki se pojavljajo v populaciji glede na izbrane spremenljivke. Klasifikacija je nenadzorovana, ker razen z izborom števila skupin ne moremo vplivati na razvrščanje. Klasifikacija je prostorsko neodvisna in sosednje enote ne vplivajo druga na drugo (Campbell, 2002).

Pri razvrščanju enot $\mathrm{v}$ skupine (skupine prsti) glede na pedogenetske dejavnike simuliramo izkustveni postopek, ki ga sicer miselno opravimo, ko razmejujemo skupine prsti na kartografski podlagi. Prednosti digitalnega razvrščanja so hitrost, nepristranskost, natančnost (kolikor so natančni vhodni podatki) in sposobnost iskanja podobnosti med skoraj poljubnim številom dejavnikov. Interpretacija dobljenih skupin poteka na podlagi statistične analize posameznih spremenljivk znotraj skupine. Pri tem postopku predpostavljamo dejstvo, da so na podobne skupine prsti vplivali isti dejavniki podobno ali enako močno. V kolikor izberemo prave dejavnike, bi morala klasifikacija izločiti naravna območja, kjer bi morali biti glede na vhodne podatke tudi skupine prsti sorazmerno homogeni (Repe 2007b).
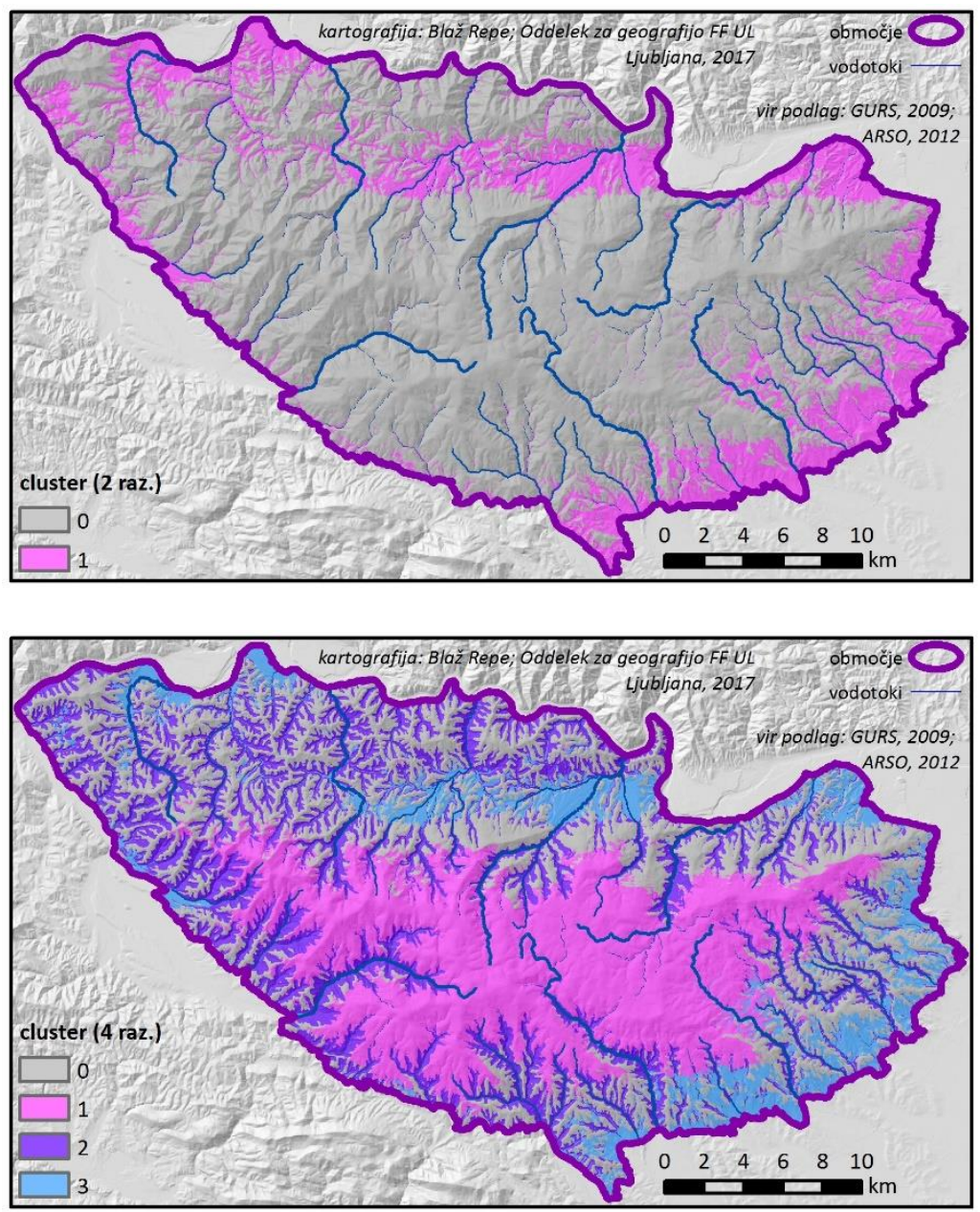

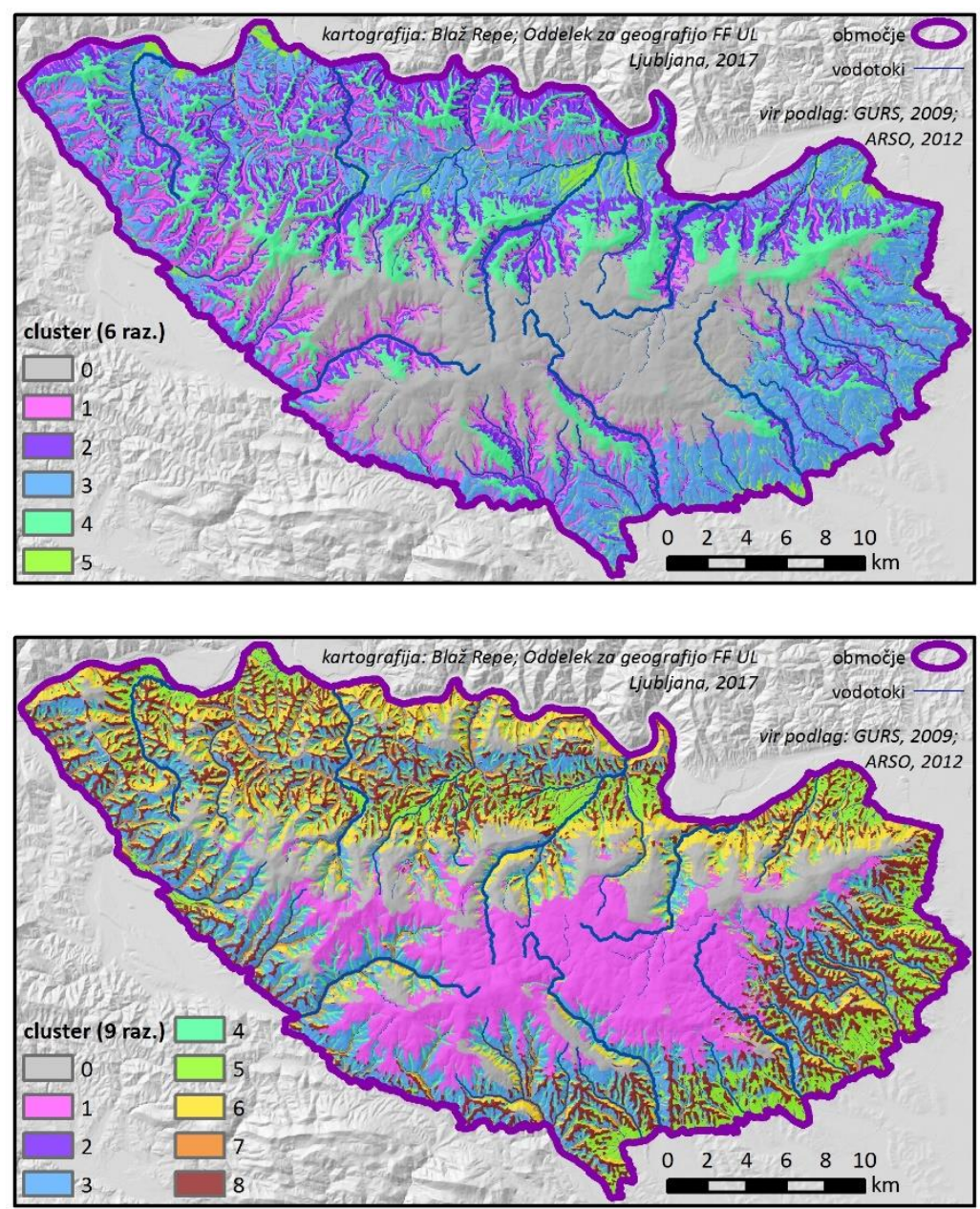

Rezultati nenadzorovanega razvrščanja rastrskih slojev podatkov v 2, 4, 6 in 9 skupin homogenih pedogenetskih dejavnikov (sliki na tej in na prejšnji strani).

Iz pridobljenih rezultatov smo nato skušali na podlagi uporabljenih osnovnih slojev prepoznati, izločiti in opredeliti različne tipe oziroma skupine prsti. Prepoznavanje je potekalo v več stopnjah.

Najprej smo določili osnovno razdelitev prsti na hidromorfni in avtomorfni oddelek, sledilo je delitev po razredih (6: humusnoakumulativne, kambične, izprane, obrečne, psevdooglejene, oglejene in šotne) in nato še na najbolj osnovne tipe (9: rankerji, rendzine, distrične in evtrične rjave, rjave pokarbonatne, izprane, obrečne, psevdooglejene, šotne), kar smo tudi primerjali z obstoječo digitalno pedološko karto, predvsem s podatki o pedoloških profilih. 

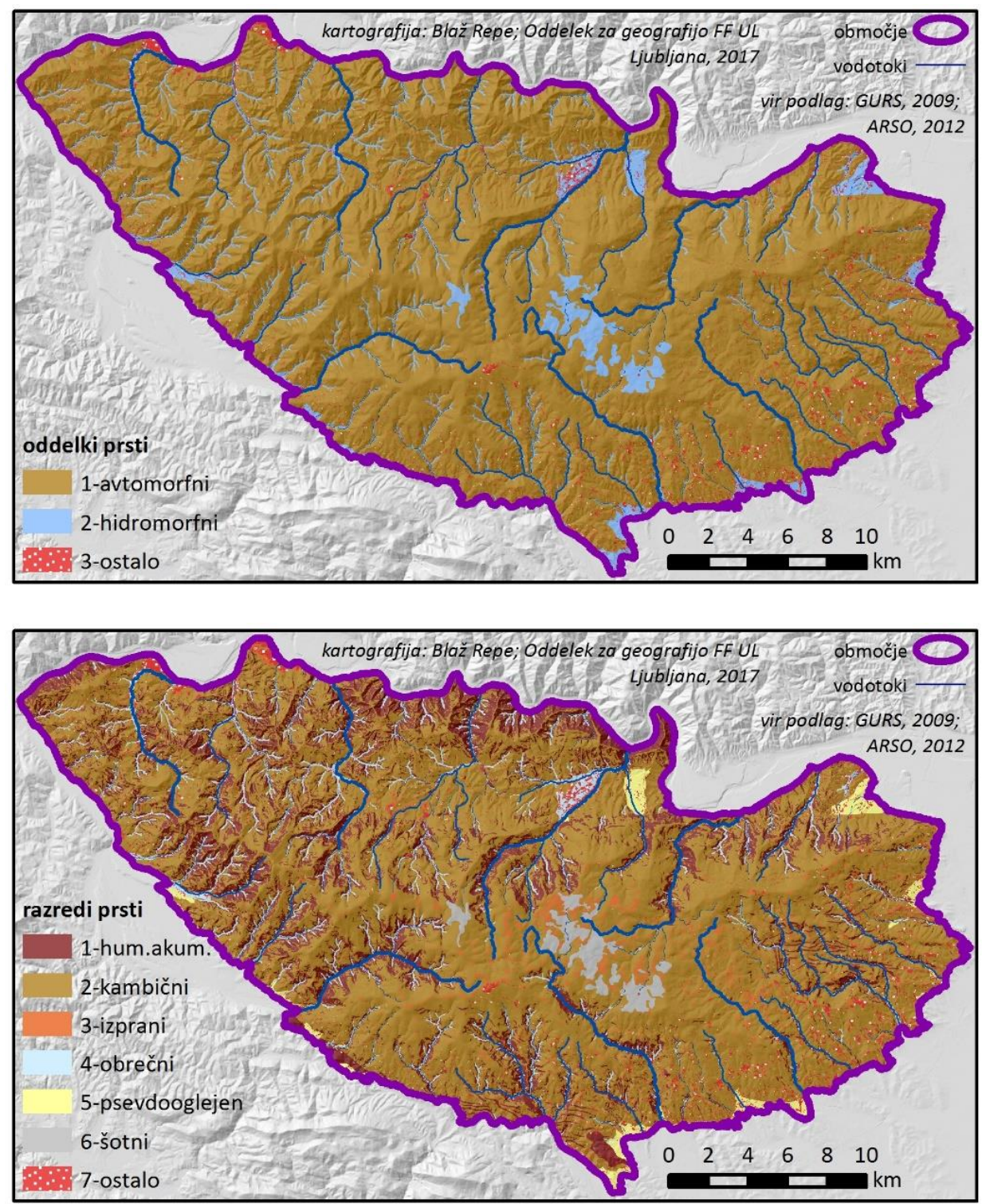

Oddelki in razredi prsti proučevanega območja.

Na podlagi dodatnih kriterijev smo skušali izločiti še bolj podrobne tipe, podtipe oziroma oblike prsti, kjer je to bilo mogoče oziroma smiselno. Na koncu smo tako izločili 15 različnih bolj ali manj podrobnih tipov. Kriterij za delitev je bil tudi razširjenost oziroma pogostost ter minimalna površina za obravnavo, ki je znašala $7000 \mathrm{~m}^{2}$. Predvsem prsti na karbonatni matični podlagi, psevdooglejene prsti niso bile podrobneje razdelane, saj bi drobljenje pomenilo območja $\mathrm{z}$ manjšo površino od minimalne. Manjše površine od minimalne so bile vključene v sosednje, večje. Izjema so končne vodne površine in antropogeni rabi, ki so bile vključene ne glede na velikost. Podrobnejši tipi prsti so bili izločeni po kriterijih, zapisanih v preglednici v nadaljevanju. 


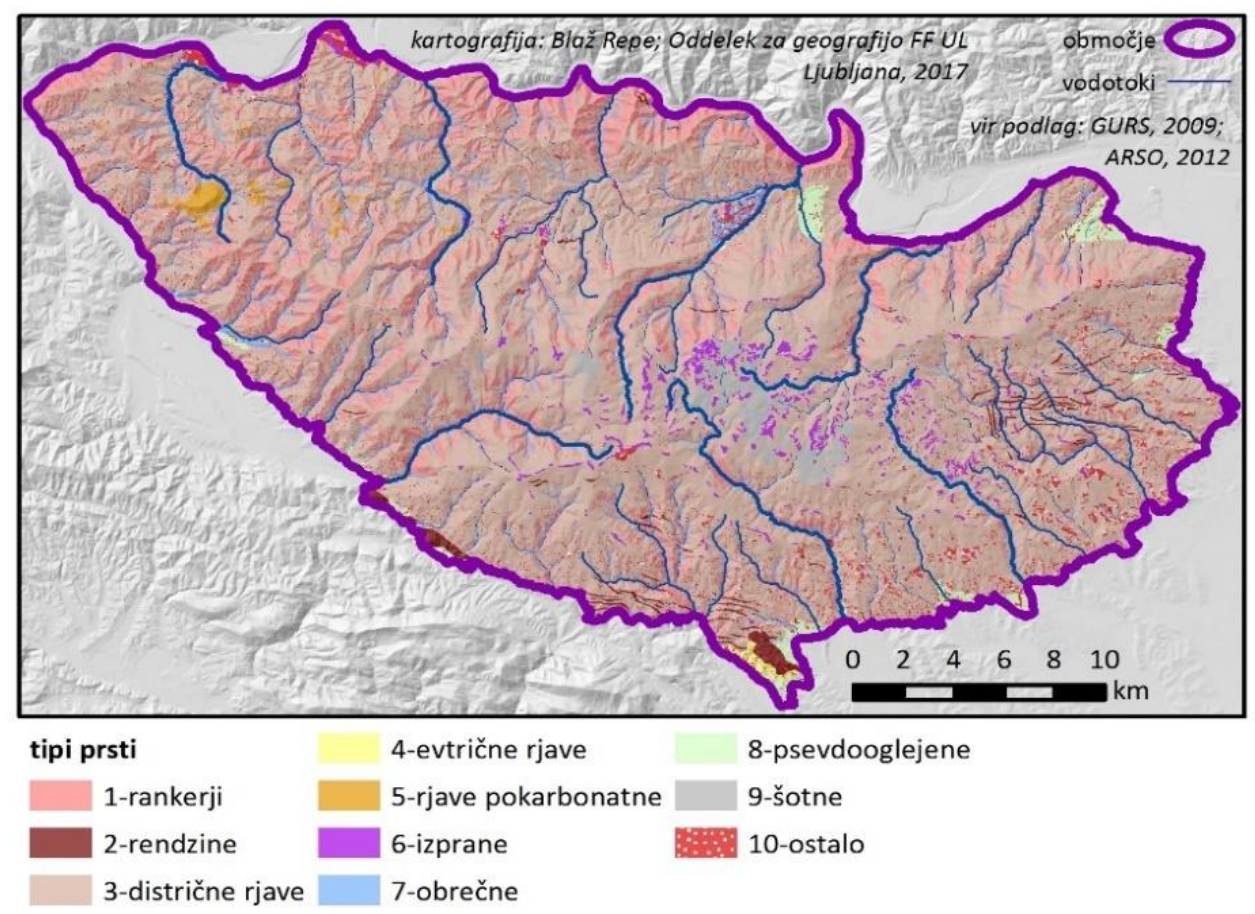

Osnovni tipi prsti proučevanega območja.

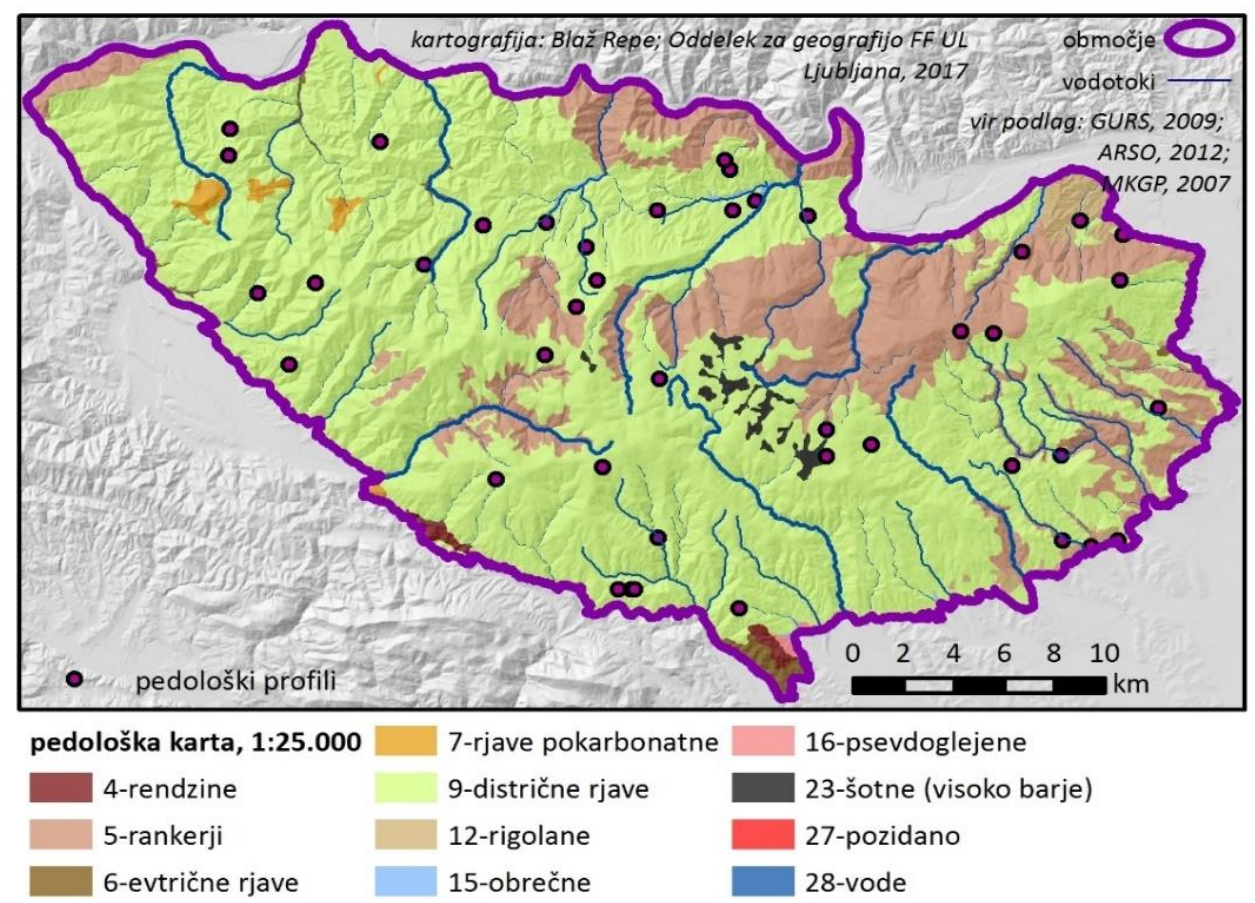

Digitalna pedološka karta, $1: 25.000$ s podatki profilov. 
Kriteriji za opredeljevanje prsti in ostalih kategorij na končnem podrobnem zemljevidu razprostranjenosti prsti Pohorja (vrstni red enot je enak vrstnemu redu opredeljevanja prsti).

\begin{tabular}{|c|c|}
\hline Poglavitni kriteriji za opredelitev & Enota prsti \\
\hline $\begin{array}{l}3 \text { razredi nenadzorovane klasifikacije; različne oblike pobočij; trda, } \\
\text { silikatna matična podlaga; naklon pobočij več kot } 30^{\circ} \text {. }\end{array}$ & $\begin{array}{l}\text { Rankerji, tipični, } \\
\text { mestoma } \\
\text { erozijski }\end{array}$ \\
\hline $\begin{array}{l}3 \text { razredi nenadzorovane klasifikacije; različne oblike pobočij; trda, } \\
\text { silikatna matična podlaga; naklon pobočij več med } 20^{\circ} \text { in } 30^{\circ} \text {. }\end{array}$ & $\begin{array}{l}\text { Rankerji, plitvi, } \\
\text { skeletni, erozijski }\end{array}$ \\
\hline $\begin{array}{l}2 \text { razreda nenadzorovane klasifikacije; uravnane oblike površja; } \\
\text { naklon pobočij manj kot } 3^{\circ} \text {; nadmorska višina manj kot } 1200 \mathrm{~m} \text {. }\end{array}$ & Izprane, tipične \\
\hline $\begin{array}{l}2 \text { razreda nenadzorovane klasifikacije; uravnane oblike površja; } \\
\text { naklon pobočij manj kot } 3^{\circ} \text {; nadmorska višina več kot } 1200 \mathrm{~m} \text {; } \\
\text { povprečna letna temperatura med } 4^{\circ} \text { in } 6^{\circ} \mathrm{C} \text {, letna količina padavin } \\
\text { nad } 1400 \mathrm{~mm} \text {; prevladujoč iglast gozd. }\end{array}$ & $\begin{array}{l}\text { Izprane, močno } \\
\text { (opodzoljene) }\end{array}$ \\
\hline $\begin{array}{l}1 \text { razred nenadzorovane klasifikacije; matična podlaga bodisi } \\
\text { koluvij, proluvij, peščenjak, lapor, glina ali peščena glina; oblika } \\
\text { površja zelo položna vznožja pobočij. }\end{array}$ & Psevdooglejene \\
\hline $\begin{array}{l}\text { Oblika površja dna rečnih dolin, doline in večje grape; reliefni } \\
\text { indeks vlažnosti nad 15; matična podlaga aluvij. }\end{array}$ & $\begin{array}{l}\text { Obrečne, } \\
\text { nerazvite }\end{array}$ \\
\hline $\begin{array}{l}\text { Oblika površja dna rečnih dolin, doline in večje grape; reliefni } \\
\text { indeks vlažnosti nad } 15 \text {; matična podlaga aluvij ali rečne terase; } \\
\text { naklon manjši od } 5^{\circ} \text {. }\end{array}$ & Obrečne, razvite \\
\hline $\begin{array}{l}1 \text { razred nenadzorovane klasifikacije; različne oblike pobočij; trda, } \\
\text { karbonatna matična podlaga; naklon večji od } 15^{\circ} \text {. }\end{array}$ & Rendzine \\
\hline naklon manjši od $10^{\circ}$. & Evtrične rjave \\
\hline $\begin{array}{l}\text { Različne oblike pobočij; trda, karbonatna matična podlaga; naklon } \\
\text { med } 8^{\circ} \text { od } 15^{\circ} \text {. }\end{array}$ & $\begin{array}{l}\text { Rjave } \\
\text { pokarbonatne, } \\
\text { plitve }\end{array}$ \\
\hline $\begin{array}{l}\text { Različne oblike pobočij in uravnav; trda, karbonatna matična } \\
\text { podlaga; naklon manjši od } 8^{\circ} \text {. }\end{array}$ & $\begin{array}{l}\text { Rjave } \\
\text { pokarbonatne, } \\
\text { tipične }\end{array}$ \\
\hline $\begin{array}{l}1 \text { razred nenadzorovane klasifikacije; uravnane oblike površja; } \\
\text { naklon manjši od } 3^{\circ} \text {; matična podlaga barjanski sedimenti; ročna } \\
\text { digitalizacija na podlagi TTN, TTK, DOF. }\end{array}$ & $\begin{array}{l}\text { Organomineralne } \\
\text { in šotne }\end{array}$ \\
\hline Vsa preostala območja; naklon večji od $15^{\circ}$. & $\begin{array}{l}\text { Distrične rjave, } \\
\text { plitve, skeletne }\end{array}$ \\
\hline Vsa preostala območja; naklon med $5^{\circ}$ in $15^{\circ}$. & $\begin{array}{l}\text { Distrične rjave, } \\
\text { tipične }\end{array}$ \\
\hline Vsa preostala območja; naklon manjši od $5^{\circ}$. & $\begin{array}{l}\text { Distrične rjave, } \\
\text { globoke, izprane }\end{array}$ \\
\hline $\begin{array}{l}\text { Ne glede na dejavnike in velikost izločena območja na podlagi rabe } \\
\text { tal MKGP (kategorije } 1100,1160,1180,1190,1211,1221) .\end{array}$ & $\begin{array}{l}\text { Njive, } \\
\text { sadovnjaki, } \\
\text { vinogradi }\end{array}$ \\
\hline $\begin{array}{l}\text { Ne glede na dejavnike in velikost izločena območja na podlagi rabe } \\
\text { tal MKGP (kategorija 3000). }\end{array}$ & Pozidano \\
\hline $\begin{array}{l}\text { Ne glede na dejavnike in velikost izločena območja na podlagi rabe } \\
\text { tal MKGP (kategorija 7000). }\end{array}$ & Vode \\
\hline
\end{tabular}




\section{Pedološke posebnosti Pohorja}

Na podlagi vseh opisanih postopkov in kriterijev smo izdelali podroben zemljevid prsti proučevanega območja Pohorja.

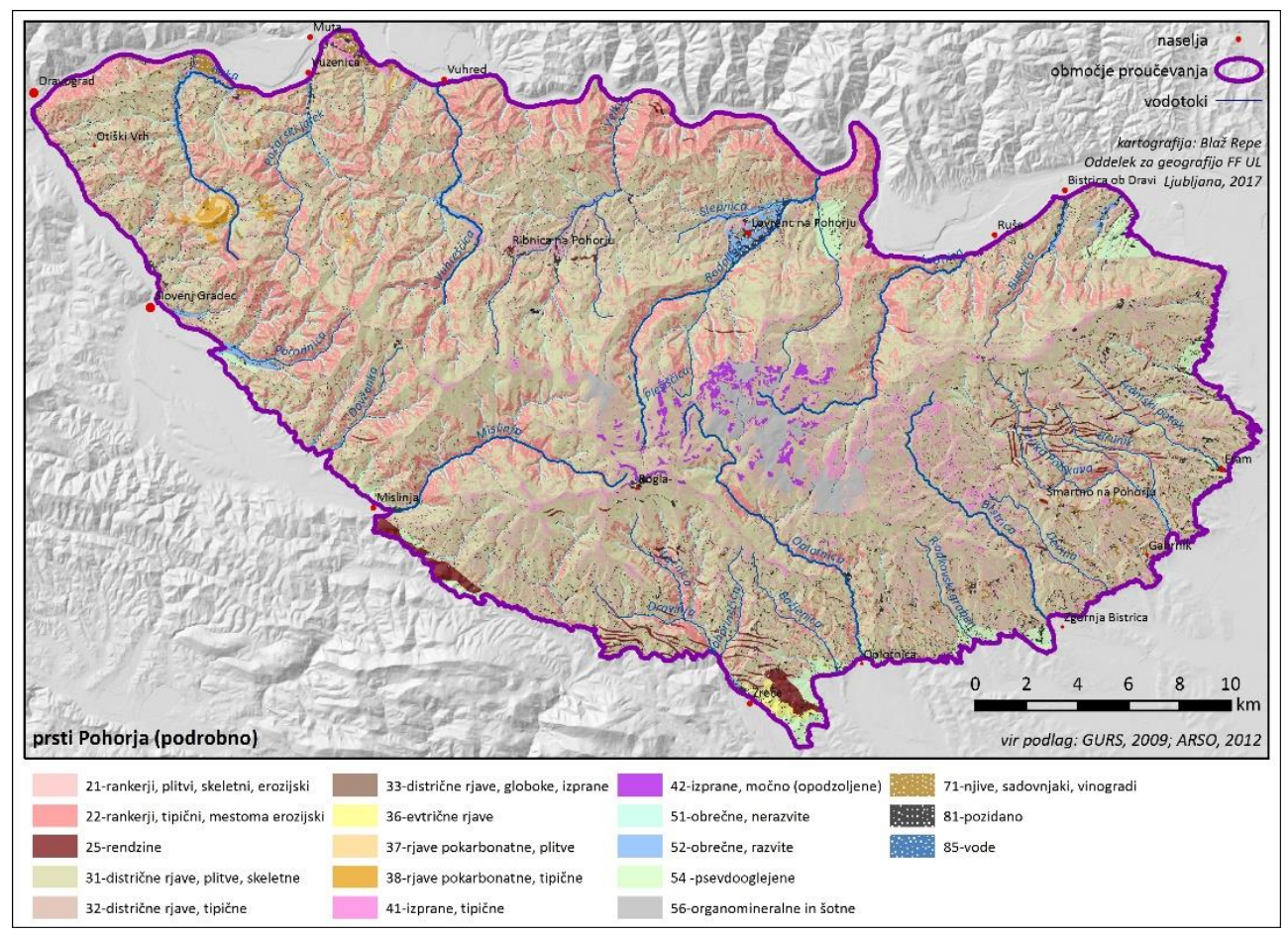

\section{Podroben prikaz prsti na obravnavanem območju Pohorja.}

Po prisotnosti se prepoznani osnovni razredi in tipi prsti ne razlikujejo bistveno od obstoječe digitalne pedološke karte $\mathrm{v}$ merilu $1: 25.000$ (Seznam pedosistemskih enot 1995). Vendar pa je bila metodologija izdelave obeh zemljevidov bistveno drugačna, zato se površine in meje med seboj do določene mere razlikujejo. Kar pa se tiče razlik, vseeno niso tako zelo velike, ampak bi lahko zaključili, da se zemljevida dopolnjujeta.

Pedološka karta ima na eni strani gotovo prednost $\mathrm{v}$ konkretnih podatkih izkopanih profilov in laboratorijskih analiz ter letih izkušenj in terenskega dela; po drugi strani pa je do določene mere zastarela, saj niso upoštevani in vključeni novejši in obstoječi digitalni podatki. S pričujočim zemljevidom prsti je ravno obratno. Prostorska natančnost je velika (minimalna površina), stopnja generalizacije je majhna, uporabili smo vse razpoložljive digitalne sloje podatkov.

Žal rezultati niso preverjeni neposredno na terenu in so zato povsem odvisni od kakovosti digitalnih slojev podatkov, med katerimi so nekateri tudi zelo generalizirani in premalo natančni (npr. geološka karta v merilu $1: 100.000$ ). 
Prepoznani razredi in osnovni tipi prsti na podlagi obstoječe pedološke karte proučevanega območja (MKGP, 2007a).

\begin{tabular}{|l|c|c|}
\hline Razred & $\begin{array}{c}\text { Površina } \\
\text { (ha) }\end{array}$ & $\begin{array}{c}\text { Delež } \\
(\%)\end{array}$ \\
\hline Humusnoakumulativne & 15563,57 & 20,93 \\
\hline Kambične & 56819,51 & 76,42 \\
\hline Obrečne & 248,79 & 0,33 \\
\hline Psevdooglejene & 130,66 & 0,18 \\
\hline Šotne & 541,37 & 0,73 \\
\hline Ostalo & 1052,54 & 1,42 \\
\hline
\end{tabular}

\begin{tabular}{|l|c|c|}
\hline Osnovni tip & $\begin{array}{c}\text { Površina } \\
\text { (ha) }\end{array}$ & $\begin{array}{c}\text { Delež } \\
(\%)\end{array}$ \\
\hline Rendzine & 291,65 & 0,39 \\
\hline Rankerji & 15271,92 & 20,54 \\
\hline Evtrične rjave & 556,75 & 0,75 \\
\hline Rjave pokarbonatne & 458,49 & 0,62 \\
\hline Distrične rjave & 55804,27 & 75,05 \\
\hline Obrečne & 248,79 & 0,33 \\
\hline Psevdogleji & 130,66 & 0,18 \\
\hline Šotne, visokega barja & 541,37 & 0,73 \\
\hline Ostalo & 1052,54 & 1,42 \\
\hline
\end{tabular}

Prepoznani razredi in osnovni tipi prsti na podlagi novega zemljevida prsti.

\begin{tabular}{|l|c|c|}
\hline Razred & $\begin{array}{c}\text { Površina } \\
\text { (ha) }\end{array}$ & $\begin{array}{c}\text { Delež } \\
(\%)\end{array}$ \\
\hline Humusnoakumulativne & 13840,0 & 18,61 \\
\hline Kambične & 49277,9 & 66,27 \\
\hline Izprane & 1295,0 & 1,74 \\
\hline Obrečne & 4542,1 & 6,11 \\
\hline Psevdooglejene & 1410,5 & 1,90 \\
\hline Šotne & 1106,2 & 1,49 \\
\hline Ostalo & 2891,5 & 3,89 \\
\hline
\end{tabular}

\begin{tabular}{|l|c|c|}
\hline Osnovni tip & $\begin{array}{c}\text { Površina } \\
\text { (ha) }\end{array}$ & $\begin{array}{c}\text { Delež } \\
(\%)\end{array}$ \\
\hline Rendzine & 781,7 & 1,05 \\
\hline Rankerji & 13058,3 & 17,56 \\
\hline Evtrične rjave & 122,8 & 0,17 \\
\hline Rjave pokarbonatne & 355,9 & 0,48 \\
\hline Distrične rjave & 48799,2 & 65,62 \\
\hline Izprane & 1295,0 & 1,74 \\
\hline Obrečne & 4542,1 & 6,11 \\
\hline Psevdoogleji & 1410,5 & 1,90 \\
\hline Šotne in mineral.-org. & 1106,2 & 1,49 \\
\hline Ostalo & 2891,5 & 3,89 \\
\hline
\end{tabular}

Primerjava obeh podatkovnih slojev nam razkrije nekaj podrobnosti. Če se osredotočimo zgolj na tipe je najbolj opazna razlika, da smo uspeli prepoznati izprane prsti, ki jih na pedološki karti ni. Druga večja razlika je v najbolj zastopanih razredih distričnih rjavih prsti in rankerjev. Oba razreda sta $\mathrm{v}$ primerjavi s pedološko karto izgubila na račun vseh ostalih tipov, ki smo jih očitno natančneje definirali in zato prepoznali večjo razširjenost (še posebej obrečnih in psevdooglejenih).

Izguba je nastala tudi zaradi doslednega upoštevanja kmetijske rabe, pozidanih in vodnih površin. Predvsem pri rjavih pokarbonatnih prsteh, ki imata najbolj podobne deleže, se pokaže vpliv istega vira podatkov, to je geološke karte.

Še bistveno večje razlike se pojavijo, če to primerjamo s celotno Slovenijo in potrjujejo tezo, da je proučevano območje (Pohorje) dejansko velika posebnost. 


\section{Zaključek}

Prepoznani osnovni tipi prsti na podlagi obstoječe pedološke karte za celotno območje Slovenije (MKGP, 2007a).

\begin{tabular}{|l|r|c|}
\hline Osnovni tip & Površina (ha) & Delež (\%) \\
\hline Kamnišča & 26214,4 & 1,29 \\
\hline Surove & 66,9 & 0,00 \\
\hline Koluvialno-deluvialne & 154,5 & 0,01 \\
\hline Rendzine & 583820,9 & 28,80 \\
\hline Rankerji & 42861,6 & 2,11 \\
\hline Evtrične rjave & 321555,6 & 15,86 \\
\hline Rjave pokarbonatne & 255328,5 & 12,59 \\
\hline Jerovice & 4161,3 & 0,21 \\
\hline Distrične rjave & 419186,5 & 20,68 \\
\hline Izprane & 48292,7 & 2,38 \\
\hline Podzoli & 144,7 & 0,01 \\
\hline Obrečne & 101511,7 & 5,01 \\
\hline Psevdogleji & 75983,9 & 3,75 \\
\hline Gleji & 85092,7 & 4,20 \\
\hline Šotne in mineral.-org. & 9505,9 & 0,5 \\
\hline Ostalo & 53436,9 & 2,6 \\
\hline \multicolumn{2}{|r}{} \\
\hline
\end{tabular}

Opomba: prsti, ki so zapisane ležeče, se pojavljajo tudi na karti obravnavanega območja Pohorja.

Prepoznani podrobni tipi prsti na podlagi novega zemljevida prsti na Pohorju.

\begin{tabular}{|l|r|c|}
\hline Podrobni tip prsti & Površina (ha) & Delež (\%) \\
\hline Rankerji, plitvi, skeletni, erozijski & 501,5 & 0,67 \\
\hline Rankerji, tipični, mestoma erozijski & 12556,8 & 16,89 \\
\hline Rendzine & 781,7 & 1,05 \\
\hline Distrične rjave, plitve, skeletne & 30533,0 & 41,06 \\
\hline Distrične rjave, tipične & 17521,6 & 23,56 \\
\hline Distrične rjave, globoke, izprane & 744,7 & 1,00 \\
\hline Evtrične rjave & 122,8 & 0,17 \\
\hline Rjave pokarbonatne, plitve & 143,7 & 0,19 \\
\hline Rjave pokarbonatne, tipične & 212,2 & 0,29 \\
\hline Izprane, tipične & 810,8 & 1,09 \\
\hline Izprane, močno (opodzoljene) & 484,2 & 0,65 \\
\hline Obrečne, nerazvite & 3948,5 & 5,31 \\
\hline Obrečne, razvite & 593,6 & 0,80 \\
\hline Psevdooglejene & 1410,5 & 1,90 \\
\hline Organomineralne in šotne & 1106,2 & 1,49 \\
\hline Ostalo & 2891,5 & 3,89 \\
\hline
\end{tabular}


Ugotovitve lahko strnemo:

- Zagotovo je ena pomembnejših razlik v odsotnosti karbonatnih kamnin, predvsem trdih. V Sloveniji so najbolj zastopan osnovni tip rendzine, ki jih je slaba tretjina. Na Pohorju jih je komaj za vzorec, približno en odstotek.

- Enako velja za rjave pokarbonatne prsti, ki jih je v Sloveniji slabih $12 \%$, na Pohorju pa jih je manj kot pol odstotka.

- Povsem isto lahko zaključimo tudi za evtrične rjave prsti, le da imamo v mislih mehke ali nesprijete karbonatne kamnine.

- Distrične rjave prsti so v Sloveniji zavoljo približne tretjinske prisotnosti, predvsem sedimentnih silikatnih kamnin zelo pogoste in predstavljajo dobro petino vseh prsti Slovenije. Na Pohorju so z naskokom najbolj zastopan tip, saj predstavljajo kar slabi dve tretjini vseh prsti. Ob tem jih pedološka karta prepozna še mnogo več.

- Zagotovo največjo razliko pripišemo veliki zastopanosti rankerjev. Kljub že omenjeni dobri zastopanosti kislih, silikatnih kamnin ter razgibanemu in pogosto strmemu površju predalpskega hribovja, pa so naše silikatne kamnine v dobršni meri sedimentnega izvora. So manj odporne proti mehanskemu in tudi kemičnemu preperevanju. $\mathrm{V}$ našem podnebju in na nizkih nadmorskih višinah zato v pedološko kratkem času nastajajo bolj razvite in različno debele, prav tako kisle distrične rjave prsti. Rankerji so zato precej redki, kot bi lahko na prvi pogled pričakovali na podlagi razširjenosti silikatnih kamnin. Pohorje je topogledno resnično velika izjema. Gre za največje območje trdih, kompaktnih, silikatnih kamnin v Sloveniji, na sorazmerno visokih, skoraj gorskih nadmorskih višinah in strmih pobočjih. Rankerji so zato drug najbolj zastopan tip prsti na Pohorju (17,6\%).

- Zagotovo so na Pohorju prisotna kamnišča, vendar se le ta genetsko pojavljajo na izjemnih naklonih in visokih nadmorskih višinah. Prepoznana območja kamnišč niso zadoščala minimalni površini, zato v končni zemljevid prsti niso vključena.

- Ker je območje hribovito in zelo razgibano, na karti prsti povsem manjkajo oglejene prsti, kljub nepropustni matični podlagi. Zagotovo bi jih ponekod v dnu manjših dolin odkrili s terenskim delom.

- Iz podobnega razloga je manj psevdooglejenih prsti, saj marsikje pobočje strmo prehaja $\mathrm{v}$ s prodom in peskom zasuto, propustno dolinsko dno.

- Specifične razmere uravnanega površja na visokih nadmorskih višinah in drobnozrnatih sedimentov so botrovale nastankom močvirij, barij in vodnih površin. Tudi $\mathrm{v}$ tem pogledu je Pohorje posebnost, saj delež šotnih prsti ter mokrotnih mineralno-organskih prsti nadpovprečen $(1,5 \%)$.

Za konec naj omenimo še eno, komajda zaznano posebnost Pohorja. To so podzoli, ki so v Sloveniji zelo redki. Podzoli sodijo med bolj razširjene skupine prsti na svetu (WRB, 2015). Značilni so višje geografske širine ali nadmorske višine, s hladnim podnebjem in veliko količino padavin. Poleg tega nastajajo na uravnanem površju, kjer je matična podlaga kisla, še najbolje pretrta ali celo peščena. In nenazadnje k procesu podzoljevanja pripomore rastlinstvo s težko razgradljivim odpadom, ki daje izjemne kisle oblike humusa. Vse to pripomore, da se pojavi ekstremno premeščanje in izpiranje delcev iz izbeljenega E horizonta in kopičenje v težkem, glinastem, spodičnem B horizontu (Prus, 2000; Prus et al., 2015). Takšna kombinacija dejavnikov je v Sloveniji izjemno redka, 
zato so tudi podzoli tako zelo redki. Pedološka karta na Pohorju ne vsebuje podzolov. Pedološki profili jih omenjajo zgolj v enem primeru in sicer, da gre za opodzoljen tip distričnih rjavih prsti. Vendar se podzoli ali vsaj izjemno močno izprane prsti na Pohorju gotovo pojavljajo, saj jih omenja razpoložljiva literatura (Perko, Orožen Adamič, 1998; Prus, 2000; Urbančič et al., 2005; Cenčič, 2010). Poleg tega je podzol zahodno od Mislinjske doline pri naselju Vrhe, v okviru svoje seminarske naloge našel Obu (2009). Omenjeni podzol se nahaja na temnem filitoidnem skrilavcu, na $425 \mathrm{~m}$ nadmorske višine, na naklonu $13^{\circ}$ in severni ekspoziciji, v podobnih razmerah, kot se uveljavljajo na Pohorju. Z našim modeliranjem pedogenetskih dejavnikov smo prepoznali 484,2 ha oziroma $0,65 \%$ celotnega območja, kjer lahko prihaja do izjemno močnega izpiranja in premeščanja delcev in posledično pojava opodzoljenih prsti ali tudi podzolov.

\section{Literatura in viri}

ARSO 2012: ARSO GIS portal. Klimatski in hidrološki podatki. http://gis.arso.gov.si/geoportal/catalog/main/home.page (citirano 5.3.2014).

Campbell, J.B. 2002: Introduction to Remote Sensing (2nd edition). Taylor \& Francis, London. 622 str.

Cenčič, L. 2010: Staranje gozdov in divjadi ter gozdarstva in lovstva na projektnem območju Pohorje. Strokovna študija. Zavod za gozdove Slovenije, Maribor. 77 str. http://www.natreg.eu/pohorje/uploads/datoteke/Studija\%20Gozdarstvo_Pohorje.pdf (citirano 20.1.2017)

Čarni, A., Marinček, L. 2002: Komentar k vegetacijski karti gozdnih združb Slovenije v merilu 1 : 400.000. Biološki inštitut Jovana Hadžija ZRC SAZU. Založba ZRC, Ljubljana. 79 str.

GURS, 2009: E-Geodetski podatki. http://egp.gu.gov.si/egp/ (citirano 2.1.2017)

Jenny H. 1941: Factors of Soil Formation. McGraw-Hill, New York. 191 str.

Kočevar H., Vidic, J.N. 1998: Izbrana poglavja iz geologije. Oddelek za agronomijo, Biotehniška fakulteta, Univerza v Ljubljani. Ljubljana. 156 str.

Kralj, T. 2008: Primerjava sistemov za razvrščanje tal na izbranih tleh v Sloveniji. Doktorska disertacija. Oddelek za agronomijo, Biotehniška fakulteta Univerze v Ljubljani. 413 str.

Lovrenčak F. 1994: Pedogeografija. Oddelek za geografijo Filozofske fakultete UL, Ljubljana. 187 str.

MKGP 2007a: Grafični in pisni podatki Pedološke karte. http://rkg.gov.si/GERK/ (citirano 19.12.2007).

MKGP 2007b: Grafični in pisni podatki pedoloških profilov. http://rkg.gov.si/GERK/ (citirano 19.12.2007).

MKGP 2016: Grafični podatki RABA za celo Slovenijo, 2016. http://rkg.gov.si/GERK/ (citirano 25.10.2016).

Moore, I.D., Gessler, P.E., Nielsen, G.A., Peterson, G.A. 1993: Soil attribute prediction using terrain analysis. Soil Science Society of America Journal 57. Str. 443-452.

Obu, J. 2009: Vpliv matične podlage na lastnosti prsti na izbranih kamninah. Seminarska naloga. Oddelek za geografijo Filozofske fakultete UL, Ljubljana. 30 str.

Ogrin D. 1996: Podnebni tipi v Sloveniji. Geografski vestnik 68 (1997). Zveza geografskih društev Slovenije. Ljubljana. Str. 39-56.

OKG 1972: Osnovna geološka karta, 1 : 100.000. List Slovenj Gradec. Zvezni geološki zavod, Beograd.

OKG 1989: Osnovna geološka karta, 1 : 100.000. List Maribor. Zvezni geološki zavod, Beograd.

Perko, D., Orožen Adamič, M. 1999: Slovenija - Pokrajine in ljudje. Ljubljana Mladinska knjiga. 735 str.

Prus T. 2000: Klasifikacija tal (študijsko gradivo). Center za pedologijo in varstvo okolja, Biotehnična fakulteta, Univerza $v$ Ljubljani.

http://www.bf.uni-lj.si/cpvo/Novo/PDFs/KlasifikacijaTal.pdf (citirano 7.6.2004). 
Prus, T., Kralj, T., Vrščaj, B., Zupan, M., Grčman, H. 2015: Slovenska klasifikacija tal (delovno gradivo). Univerza v Ljubljani, Biotehniška fakulteta.

http://www.mop.gov.si/fileadmin/mop.gov.si/pageuploads/zakonodaja/varstvo_okolja/tla/ Slovenska_klasifikacija_tal.pdf (citirano 1.3.2016).

Repe, B. 2004: Soils of Slovenia. Slovenia - A geographical overview. Zveza geografskih društev Slovenije. Založba ZRC, Ljubljana. str. 51-56.

Repe B. 2006: Pedogeografska karta in njena uporabnost v geografiji. Doktorska disertacija. Oddelek za geografijo, Filozofska fakulteta, Ljubljana. 432 str.

Repe, B. 2007a: Voda v prsti in ugotavljanje njenega razporejanja v odvisnosti od reliefa. Dela 28. Oddelek za geografijo Filozofska fakulteta Univerza v Ljubljani. Ljubljana. Str. 91-106.

Repe, B. 2007b: Geographical soil map - a different soil determination approach in Slovenia. Changing soils in a changing world: the soils of tomorrow : book of abstracts. 509 str.

Repe, B., Blatnik M. 2013: Višinska pasovitost rastlinstva na Gorenjskem. In: Gorenjska v obdobju glokalizacije (Mrak I., Potočnik Slavič I., Rogelj B., uredniki). Znanstvena založba Filozofske fakultete, Ljubljana. Str. 43-60.

Seznam pedosistemskih enot, 1995: Pedološka karta Slovenije. Center za pedologijo in varstvo okolja, Oddelek za agronomijo, Biotehniška fakulteta Univerze v Ljubljani. Ljubljana.

Stritar A. 1990: Pedologija (kompendij). Biotehniška fakulteta, Ljubljana. 122 str.

Stritar, A. 1991: Krajina, krajinski sistemi. Raba in varstvo tal v Sloveniji. Partizanska knjiga. Ljubljana. 173 str.

Škorić A. 1986: Postanak, razvoj i sistematika tla. Sveučilište u Zagrebu, Zagreb. 172 str.

Urbančič, M., Simončič, P., Prus, T., Kutnar, L. 2005: Atlas gozdnih tal Slovenije. Zveza gozdarskih društev Slovenije, Gozdarski vestnik in Gozdarski inštitut Slovenije,100 str. Ljubljana.

Western, A.W., Grayson, R.B., Bloschl, G., Willgoose, G.R., McMahon, T.A. 1999: Observed spatial organization of soil moisture and its relation to terrain indices. Water Resources Research 35(3). American Geophysical Union. Str. 797-810.

ZGS, 2015: Splošni podatki in dejstva o gozdovih v Sloveniji. http://www.zgs.si/slo/gozdovi_slovenije/o_gozdovih_slovenije/gozdnatost_in_pestrost/in dex.html (citirano 7.3.2017)

Zupančič, N. 2005: Geologija Pohorja. Posvetovanje slovenskih geomorfologov, Pohorje 2005. Vodnik po programu, ekskurzijah, predavanjih in povzetkih posterjev. Geomorfološko društvo Slovenije, Gorenje pri Zrečah. Str. 29-31. 
GEOGRAFIJE Podravja

THE GEOGRAPHIES OF THE PODRAVJe REgion 


\title{
Ekosistemske značilnosti Dravinjskih goric
}

\begin{abstract}
ANA VOVK KORŽE
Povzetek Ekosistemi povezujejo abiotske in biotske elemente v pokrajini in so pomembni življenjski prostori vseh živih bitij. Poznavanje lastnosti ekosistemov in procesov v njih omogoča varstveno načrtovanje rabe tal. $\mathrm{V}$ različnih pokrajinah izstopajo različni elementi pokrajin, v kmetijskih ekosistemih imajo pomembno vlogo prsti. Danes imajo prsti ne samo kmetijsko vlogo, ampak predvsem ekosistemsko, saj so sposobne zadrževati vodo, so dom mnogim organizmov. Zato avtorica osrednjo pozornost usmerja na prepoznavanju naravnih dejavnikov, ki soustvarjajo ekosisteme. Ta spoznanja so vse bolj pomembna pri iskanju odgovorov na prilaganje podnebnim spremembam in ohranjanju ekosistemskih storitev.
\end{abstract}

Ključne besede: • ekosistem • ekosistemske storitve • naravni viri • prsti - trajnostni razvoj • Dravinjske gorice •

NASLOV AVTORICE: ddr. Ana Vovk Korže, redna profesorica, Univerza v Mariboru, Filozofska fakulteta, Oddelek za geografijo, Koroška cesta 160, 2000 Maribor, Slovenija, e-naslov: ana.vovk@um.si. 


\title{
Ecosystem characteristics of Dravinjske gorice
}

\author{
ANA VOVK KORŽE
}

\begin{abstract}
Ecosystems are the ones connecting abiotic and biotic components of the landscape. They are an important habitat for all the living beings. Knowledge about ecosystems and their characteristics is essential for conservation planning of land use. Different landscapes consist of different landscape elements. Soil is a very important part of agricultural ecosystems. But the role of soils is far more than just agricultural. They are an important part of ecosystems as they have an ability of water retention and offer a home to various organisms. That is why this research has an emphasis on recognizing natural factors which help to create an ecosystem. This findings are becoming more and more important as we are searching for answers in order to adjust to the climate changes and try to preserve all of the ecosystem services.
\end{abstract}

Keywords: • ecosystem • ecosystem services • natural resources $\bullet$ soils $\bullet$ sustainable development $\bullet$ Dravinjske gorice $\bullet$

Correspondence Address: Ana Vovk Korže, Ph.D., Full Professor, Professor for Geography, University of Maribor, Faculty of Arts,Department for geography, Koroška cesta 160, 2000 Maribor, Slovenia, e-mail: ana.vovk@um.si. 


\section{Uvod}

Zaradi izgubljanja rodovitnosti prsti je vse več pozivov raziskovalcem, da naj namenijo posebno pozornost raziskavam tega neobnovljivega vira, ki je izredno pomemben za obstoj človeštva. Rodovitna zemlja ima obilo rastlinskih hranil, tudi dušika, fosforja in kalija. Vsebuje veliko mineralov, vključno z mikroelementi in sicer cink, mangan, bor, železo, žveplo, kobalt, baker, magnezij, molibden in klor. Ima veliko organske snovi in mikroorganizmov pa tudi bakterije, deževnike, glive in nematode. Rodovitna zemlja ima reakcijo $(\mathrm{pH})$ v razponu med 5.5 in 6.2 in ima dobro prezračenost (drenažo). Dosedanja spoznanja kažejo, če je zemlja prekrita z zastirko, je zaščitena pred izhlapevanjem in nastaja zgornja plast organske snovi, ki ima sposobnost zadrževanja vlage. Taka zemlja je veliko bolj rodovitna kot zemlja, ki jo orjejo in je odkrita. Kvaliteta pridelkov je neposredno odvisna od prsti, v kateri rastejo rastline. Rodovitnost je torej sposobnost zemlje za rast in podporo rastlinam (Medmrežje 1; Spaargaren, Deckers, 2013). Rodovitna zemlja je izhodišče za naše zdravje in zdravje ekosistemov, saj velja »zdrava zemlja - zdrave rastline - zdrave živali - zdravi ljudje«. Zemlja ni le rastišče za rastline, temveč ima s procesi razgradnje, presnove in izgradnje osrednjo vlogo pri prehrani. Živi organizmi v tleh (žuželke, črvi, mikroorganizmi) razgrajuje odpadne rastlinske in živalske produkte in $\mathrm{s}$ tem $\mathrm{v}$ njih vsebovane hranilne snovi spreminjajo $\mathrm{v}$ hrano $\mathrm{za}$ rastline. Osrednjo vlogo pri tem ima humus oziroma celotna organska snov v prsti.

Geografski dejavniki, ki vplivajo na prst so podnebje, rastlinstvo in živalstvo, vključno $\mathrm{s}$ človekom, matično podlago in časom. Le ti delujejo povezano in v kombinacijah ustvarjajo cone oz. regije, ki so prepoznane po določenih zakonitostih, zato jim pravimo tipi ekosistemov ali skupine ekosistemov. Med geografskimi faktorji, ki pomembno vplivajo na lastnosti območij s podobnimi ekosistemi je vse bolj prepoznan vpliv podnebja, predvsem razporeditev padavin. Daljša sušna obdobja izsušijo prsti do stopnje, da začne rastlinam primanjkovati vode.

Raziskava je namenjena analizi vpliva naravnih dejavnikov na območju Dravinjskih goric, ki veljajo za depopulacijsko območje. S ciljem, da bi lahko pojasnili pomembne naravne dejavnike, ki sovplivajo na sestavo ekosistemov, smo uporabili metodologijo prečnih presekov in dobili vpogled $v$ njihovo natančno sestavo predvsem na osnovi natančne analize prsti.

Raziskavo smo izpeljali na območje Dravinjskih goric, ki ležijo med zahodnimi Halozami na jugu, zahodnim Dravskim poljem na vzhodu in Dravinjsko dolino na severu, ki se stika z Bočem (del Vitanjskih Karavank) in Pohorjem. To je tipično gričevnato območje, ki je bilo v preteklosti znano kot manj razvito, danes pa se na območju občine Poljčane, ki v celoti leži v Dravinjskih goricah, vzpostavljajo številni ekološki projekti. Že Bračič je pred leti zapisal, da so Dravinjske gorice mlado, rahlo valovito gričevje, ki je nastalo v času ledene dobe (Bračič, 1985). Dravinjske gorice imajo ime po reki Dravinji, ki teče po skrajnem južnem delu goric. V Dravinjo se izlivajo manjši vodotoki kot so Oplotnica iz Pohorja, Brežnica iz severnega dela Dravinjskih goric, Ličnica prav tako iz severozahodnega dela goric in Ložnica, ki priteka v Dravinjo iz severovzhodnega dela Pohorja.

Litološko so Dravinjske gorice zgrajene iz pleistocenskih glinastih nanosov, ki zadržujejo vodo, kar povzroča nastajanje težke zbite prsti in počasno površinsko odtekanje vode, 
zato v ravninskih delih voda zaostaja. Na številnih mestih pa so to lastnost površja izkoristili za zadrževanje vode tako, da so uredili vodne zadrževalnike (ribniki pri Videžu, pri Jerneju, pri Pretrežu). Prav tako se voda zadržuje ob strugi Dravinje, kjer so ohranjeni mrtvi rokavi in mikrodepresije z značilnim vlagoljubnim rastjem.

Terenske raziskave vzorčenja prsti in njihovih analiz kažejo, da se na območju Dravinjskih goric pojavljajo naslednji tipi prsti:

- Obrečne, neoglejene na peščeno ilovnatih nanosih, z 19 \% vode, $142 \mathrm{~mm}$ poljske vodne kapacitete (PVK), peščeno glinasto in ilovnato (PGI) teksturo, globino do $70 \mathrm{~cm}$ in izrazito antropogeno rabo;

- Obrečne oglejene, na peščeno glinastih nanosih, z 23 \% vode, 135 mm PVK, glinasto ilovnato (GI) teksturo, globino do $50 \mathrm{~cm}$ in prevladujočo travniško rabo;

- Oglejene prsti na meljastih nanosih s $40 \%$ vode, $162 \mathrm{~mm}$ PVK in ilovnato glinasto (IG) teksturo, s povprečno globino $48 \mathrm{~cm}$ in prevlado vlagoljubnih travnikov;

- Evtrične prsti na laporju, 22 \% vode, $121 \mathrm{~mm}$ PVK, peščeno glinasto (PG) teksturo, globino do $70 \mathrm{~cm}$ in njivsko-travniško rabo, na reliefno razgibanih območjih uspeva združba bukve in širokolistne grašice;

- Evtrična rjava na pliocenskih in pleistocenskih sedimentih, $16 \%$ vode, $105 \mathrm{~mm}$ PVK, IG tekstura, globina profila prsti do $75 \mathrm{~cm}$, uspeva gozd bukve, kostanjev in hrastov;

- Evtrična rjava psevdooglejena na pliocenskih sedimentih, s $16 \%$ vode in 113 $\mathrm{mm}$ PVK in IG teksturo, globina do $100 \mathrm{~cm}$ in gozdna raba, uspeva acidofilni gozd bukve, kostanja in hrastov;

- Ravninskih psevdoglej na meljastih nanosih z 22 \% vode, 148 mm PVK, IG teksturo in povprečno globino profila do $100 \mathrm{~cm}$ ter gozdom doba $\mathrm{z}$ evropsko gomoljščico;

- Pobočni psevdoglej na plio-pleistocenskih sedimentih ob vznožju pobočij s 17 $\%$ vode, $143 \mathrm{~mm}$ PVK, IG teksturo in $60 \mathrm{~cm}$ globokim profilom, prevladujejo njivske in travniške površine.

Dravinjske gorice prekrivajo kisloljubni gozdovi bukve s kostanji in hrasti (Castaneo Fagetum sylvaticae). Ti gozdovi so razširjeni po osrednjem delu gričevja, kar je razvidno iz vegetacijske karte (Rokopisna karta gozdnih združb List Poljčane, 1:50:000, Biološki inštitut Jovana Hađija, Ljubljana). Ob povirjih vodotokov uspevata gozd belega gabra in čremse (Pruno padi - Carpinetum) in gozd belega gabra in dobra (Querco roboris Carpinetum). Na južnih pobočjih gričevij na miocenskih karbonatnih in nekarbonatnih kamninah so večje sklenjene površine subpanonskega podgorskega gozda bukve in širokolistne grašice (Vacio oroboidi - Fagetum). Toplim legam se umika združba bukve, jelke in gozdnega planiščka (Homogyne syvestris - Fagetum). Uspeva na evtričnih rjavih psevdoogljenih prsteh na severnih gričevnatih pobočij na zelo majhnih površinah. Na ovršjih slemen so združbe rdečega bora in borovničevja s primesjo domačega kostanja (Vaccinio myrtilli-Pinetum, geog. Var. Castanea sativa).

Oglejene prsti, nastale na deluviju porašča združba doba in evropske gomoljščice (Pseudostellario - Quercetum roboris). Ker so tovrstne prsti manj antropogeno rabljene, so se sklenjena območja tega gozda ohranila v dolini Ložnice v velikem kompleksu, 
vzhodni del pa je zaradi hidromelioracij v Ložniški dolini degradiran, saj je upadel vodni režim podtalnice (Gregori, 1990). Na zahodu se dobovemu gozdu pridružujejo mlajši, sekundarni gozdovi belega gabra in čremse (Pruno padi - Carpinetum) s primesjo smreke. Ti dobovi gozdovi so zaradi florističnih značilnosti in reprezentativnosti za ravninska območja zaščiteni v velikosti 10 ha. Vegetacija zelo nazorno odseva značilnosti prsti, predvsem vlažnost, zato je temeljna metoda raziskovanja prsti najprej opazovanje vegetacije. Vegetacija ima namreč pomembno vlogo pri zadrževanju vlage v prsti, ima varovalno vlogo za prsti (ščiti pred erozijo, denudacijo) in ekosistemski pomen, saj je gozd dom številnim živim bitjem.

Vegetacijo je človek spreminjal že tisočletja in tudi v Dravinjskih goricah je bilo tako. Zaradi drobne posestne zemljiške razdrobljenosti in razpršene poselitve ter vpliva antropogenih dejavnikov je bila vegetacija zelo zgodaj spremenjena. Naravne vegetacije v Dravinjskih goricah danes zato ni več. Njivske površine so iznad dolin, na vznožjih pobočij in na slemenih, v dolinah so vlagoljubni travniki. Vinogradov in sadovnjakov ni veliko, v sklenjenih površinah so le v Hošnici in v Vrholah ter v manjših površinah nad Lušečko vasjo in pri Studenicah. Skupni imenovalec vinogradniških površin je lapornata matična podlaga, kjer so nastale globoke evtrične rjave prsti z nasičenim sorptivnim delom z bazami, ki znaša na teh površinah nad 80 me/100 g, dodatno so tod večje strmine, ki povečujejo vpadni kot sončnih žarkov in so nad dolinskim dnom, kjer je pogost toplotni obrat.

\section{Metodologija}

Testno območje, kjer smo preverjali povezave med naravnogeografskimi dejavniki in značilnostmi prsti leži v osrednjem delu Dravinjskih goric. Med reliefnimi oblikami prevladuje nizko gričevje z absolutno nadmorsko višino 290 do 350 m, ki je zaradi mehke nesprijete kamninske osnove in številnih vodotokov močno razrezano. Najvišja nadmorska višina testnega območja je 358 m pri Jerneju nad Ločami, najnižja pa v dolini Ložnice pri Pretrežu in znaša $252 \mathrm{~m}$.

Terenske raziskave so obsegale analizo litološke osnove, reliefa, klimatskih razmer, vodne bilance, vegetacije in rabe tal kot elementov nastanka prsti. Za zbiranje podatkov o naravnih elementih smo uporabili tematske karte (geološke, vegetacijske, hidrološke) ter digitalne karte iz PISO baze. Vpliv naravnih dejavnikov na nastanek prsti smo ugotavljali iz povezav med značilnostmi prsti in zastopanostjo naravnih dejavnikov v gričevju tako, da smo prepoznavali odvisnosti posameznih lastnosti prsti od posameznih dejavnikov.

Za analizo prsti smo uporabili razpoložljive priročnike, ki vsebujejo standardizirane postopke (Vovk Korže, 2015). Opravili smo fizikalne in kemijske analize prsti ter podatke vključili v razumevanje ekosistemov.

Rezultat terenskega prepoznavanja naravnih dejavnikov je ugotavljanje povezav med t. i. tlotvornimi dejavniki v gričevju, ki pomembno vplivajo na nastanek prsti ter posledično lastnosti prsti, ki so občutljive na delovanje človeka. Poznavanje naravnih dejavnikov je okvir za prepoznavanje ekosistemov in njihove razširjenosti. 


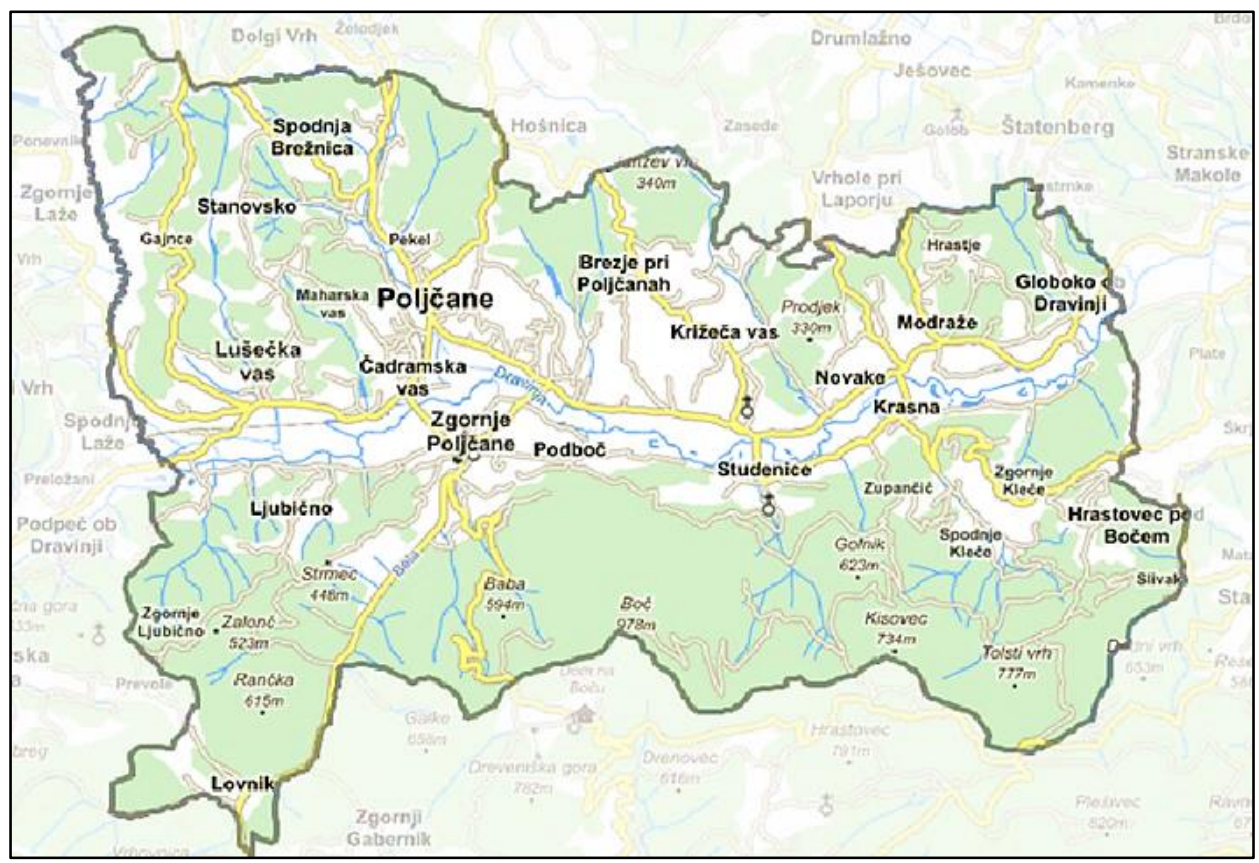

Območje raziskovanja v Dravinjskih goricah.

Vir: PISO, občina Poljčane, 2015

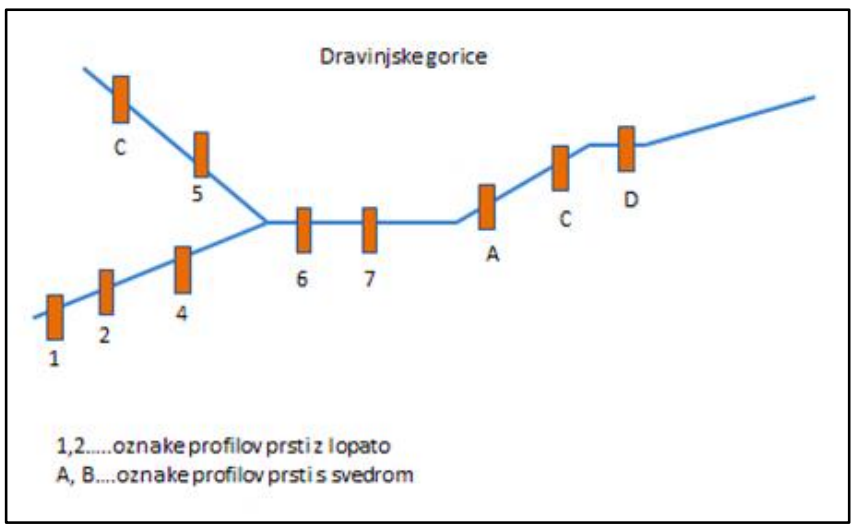

\section{Potek vzorčevalnih mest za prsti na izbranem območju}

Za določitev tipov, skupin in posameznih ekosistemov je bila uporabljena topografska karta 1: 25.000, na katero so bile prenešene meje upoštevanih naravnih dejavnikov in sicer matične (litološke) podlage, prsti, vegetacije in rabe tal. $\mathrm{Na}$ osnovi ujemanja na terenu teh štirih dejavnikov, so bili določeni tipi ekosistemov in nato skupine ekosistemov in posamezni ekosistemi. Za pridobitev kvantitativnih podatkov po izbranih ekosistemih je bil uporabljen linijski prikaz navpičnih presekov, kjer so bili izkopani profili prsti oz. odvzeti vzorci s pedološkim svedrom. 


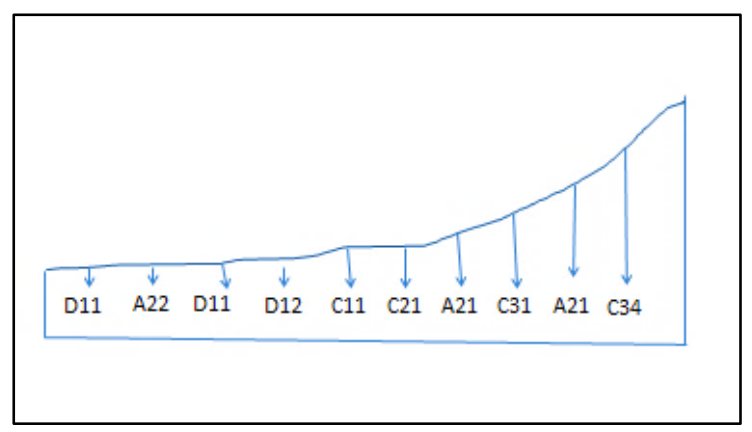

Za pridobitev podrobnih podatkov o ekosistemih smo uporabili vertikalni presek, ki se pogosto uporablja v geografiji za spremljanje razporeditve pojavov.

\section{Ugotovljeni ekosistemi v Dravinjskih goricah}

Uporaba tematskih kart za naravne vire ter podatki iz terena omogočajo tipizacijo Dravinjskih goric v 4 tipe ekosistemov:

- Ekosistemi ob dolinah ob manjših rekah in pritokih na nadmorski višini 250 do $270 \mathrm{~m}$ na holocenskih peščeno ilovnatih in peščeno glinastih naplavinah $\mathrm{z}$ recentno akumulacijo in občasnim vplivom podtalne vode. Prevladuje travniška raba.

- Ekosistemi v dolini reke Ložnice, na nadmorski višini 250 m, na pleistocenskih in holocenskih meljasto ilovnatih in meljasto glinasto ilovnatih nanosih, z rednim zastajanjem vode $\mathrm{v}$ hidromorfnih prsteh, $\mathrm{z}$ izrazitim procesom oglejevanja.

- Ekosistemi na reliefno razčlenjenem gričevju iz laporjev na južnem delu gričevja, na nadmorski višini 300 do $450 \mathrm{~m}$, z močno denudacijo zaradi slabe prepustnosti laporjev za vodo. Na distričnih in evtričnih prsteh je mešano njivsko travniška raba ter gozd.

- Ekosistemi na blago razrezanih gričevjih iz ilovic in peskov v osrednjem delu Dravinjskih goric $\mathrm{z}$ močno denudacijo na vršinah slemen in s procesi koluviacije ob vznožjih pobočij, procesi psevdoogljevanja in denudacijsko erozijskih procesih zaradi neodpornosti litološke osnove in humidne klime.

Navedene tipe ekosistemov smo razdelili na skupine ekosistemov in ekosisteme:

- A, B, C, D - tipi ekosistemov

- SE - skupina ekosistemov

- E- ekosistem

Tip A - Ekosistemi v ravnini, v dolini Dravinje in ob pritokih na nadmorski višini 250$270 \mathrm{~m}$, kjer so holocenske peščeno ilovnate in peščeno glinaste naplavine, nastale z recentno akumulacijo:

- SE A1: ob reki Dravinji in pritokih obrečni, plitve prsti ob tekočih vodah, neoogljene na peščeno ilovnatih naplavinah:

- E A11: travniki, občasno poplavljeni na plitvih obrečnih prsteh 
- E A12: njive na plitvih obrečnih prsteh

- SE A2: na hipogleju, globoko oglejeni, na obrobju dolin na peščeno glinastih naplavinah

- EA21: njive in travniki na hipogleju

- EA22: travniki na hipogleju

- EA23: pozidano

- SE A3: ravninski psevdogleji na peščeno glinastih naplavinah

- EA31: njive, travniki na ravninskem psevdogleju

- EA32: gozd belega gabra z belkasto bekico na ravninskem psevdogleju

- EA33: pozidano

- EA34: nerodovitno.

Tip B - Ekosistemi v dolini Ložnice: v ravnini ob reki Ložnici, na nadmorski višini 250 $\mathrm{m}$, na pleistocenskih in holocenskih meljasto ilovnatih in meljasto glinasto ilovnatih nanosih, ki povzročajo redno zaostajanje vode $\mathrm{v}$ prsti in razvoj hidromorfnih prsti $\mathrm{s}$ procesi oglejevanja:
- $\quad$ SE B1: amfiglej na meljasto ilovnatih nanosih
- $\quad$ EB11: hidromeliorirane njive na amfigleju
- $\quad$ EB12: travniki na amfigleju
- $\quad$ EB13: gozd črne jelše in podaljšanega šaša na amfigleju
- $\quad$ EB14: gozd doba na amfigleju
- $\quad$ SE B2: ravninski psevdoglej na meljasto glinastih in ilovnatih nanosih
- $\quad$ EB21: travnik na ravninskem psevdogleju
- $\quad$ EB22: gozd belega gabra s čremso na ravninskem psevdogleju.

Tip C - Ekosistemi v gričevju na laporju: so na reliefno razčlenjenim gričevju iz laporjev, na nadmorski višini 300 do $450 \mathrm{~m}$, z močno denudacijo, prsti so evtrične in distrične, namenjene mešani njivsko travniški in gozdni rabi:

- SE C1: Rigolane prsti na strmih pobočjih na laporju

- EC11: vinogradi na rigolanih prsteh

- SE C2: distrične rjave prsti na peščenih laporjih, na slemenih in vršinah slemen

- EC21: njivsko-travniška raba in razpršena poselitev na distričnih rjavih prsteh

- EC22: gozd belega gabra z belkasto bekico na distričnih rjavih prsteh

- EC23: gozd bukve s kostanji na distričnih rjavih prsteh

- SE C3: evtrične rjave na glinastih laporjih, ob vznožju pobočij koluvialne

- EC31: njivsko-travniška raba na evtričnih rjavih prsteh

- EC32: bukov gozd s tevjem a evtričnih rjavih prsteh

- EC33: gozd belega gabra in belkaste bekice na evtričnih rjavih prsteh

- E C34: gozd bukve s kostanji na evtričnih rjavih prsteh

- EC35: gozd hrasta doba in belega gabra na evtričnih rjavih prsteh.

Tip D - Ekosistemi na pleistocenskih ilovicah na blago razgibanih gričevjih, kjer je ilovicam primešan prod in pesek, na vršnih delih slemen je močna denudacija, ob znožjih pobočij koluvialne prsti, poteka psevdoogljevanje:

- SE D1: evtrična rjava prst in ranker na ilovicah s prodom in peskom 
51

- ED11: njivsko travniška raba na pobočjih na evtričnih rjavih prsteh

- ED12: acidofilni gozd bukve s kostanjem na vršinah slemen na rankerju

- SE D2: evtrično rjava psevdooglejena prst na položnih pobočjih in v povirju

- ED21: njivsko travniška raba in razpršena poselitev na evtrični rjavi psevdoogljeni prsti

- ED22: acidofilni gozd bukve in kostanja na evtrični psevdoogljeni prsti

- SE D3: pobočni psevdoglej na prehodu v iz gričevja v ravnino, na severnih ekspozicijah in meljastih sedimentih

- ED31: njivsko travniška raba na pobočnem psevdogleju

- ED32: acidofilni gozd bukve in kostanja na pobočnem psevdogleju

- ED33: pozidano.

Podatki o ekosistemih (izbran primer v Dravinjskih goricah).

\begin{tabular}{|c|c|c|c|c|}
\hline Ekosistemi & D11 & A22 & D12 & $\mathrm{C} 11$ \\
\hline Litološka osnova & $\begin{array}{l}\text { Ilovica s } \\
\text { peskom }\end{array}$ & Ilovnat pesek & $\begin{array}{l}\text { Ilovica s } \\
\text { peskom }\end{array}$ & lapor \\
\hline $\begin{array}{l}\text { Relief } \\
\text { Nadm. višina } \\
\text { Naklon } \\
\text { Ekspozicija }\end{array}$ & $\begin{array}{l}\text { Pobočje } \\
330 \mathrm{~m} \\
2-5^{\circ} \\
\text { JV }\end{array}$ & $\begin{array}{c}\text { Ravnina } \\
250 \mathrm{~m} \\
0-2^{\circ} \\
-\end{array}$ & $\begin{array}{l}\text { Pobočje } \\
330 \mathrm{~m} \\
5-10^{\circ} \\
\text { SV }\end{array}$ & $\begin{array}{c}\text { Pobočje } \\
345 \\
10-20^{\circ} \\
\text { J }\end{array}$ \\
\hline $\begin{array}{l}\text { Klima } \\
\text { Temperat. (leto) } \\
\text { Padavine } \\
\end{array}$ & $\begin{array}{c}9.3 \\
1050 \\
\end{array}$ & $\begin{array}{c}9.3 \\
1050 \\
\end{array}$ & $\begin{array}{c}9.3 \\
1050\end{array}$ & $\begin{array}{c}9.3 \\
1050\end{array}$ \\
\hline $\begin{array}{l}\text { Vodna bilanca } \\
\text { PE mm } \\
\text { Im }\end{array}$ & $\begin{array}{c}642,1 \\
63,3\end{array}$ & $\begin{array}{c}642,1 \\
63,3\end{array}$ & $\begin{array}{c}642,1 \\
63,3\end{array}$ & $\begin{array}{c}642,1 \\
63,3\end{array}$ \\
\hline $\begin{array}{l}\text { Prsti } \\
\text { Tip } \\
\text { Profil } \\
\text { Tekstura } \\
\end{array}$ & $\begin{array}{l}\text { Evtrična } \\
\text { A-Bv-C } \\
\text { Ilovica }\end{array}$ & $\begin{array}{l}\text { Hipoglej } \\
\text { A-Go } \\
\text { Meljasta } \\
\text { ilovica } \\
\end{array}$ & $\begin{array}{l}\text { Evtrična } \\
\text { A-Bv-C } \\
\text { Ilovica }\end{array}$ & $\begin{array}{l}\text { Rigolana } \\
\text { P-C } \\
\text { Glinasta } \\
\text { ilovica } \\
\end{array}$ \\
\hline $\begin{array}{l}\text { Vegetacija } \\
\text { Raba tal }\end{array}$ & $\begin{array}{l}\text { Njive in } \\
\text { travniki }\end{array}$ & Travniki & $\begin{array}{c}\text { Gozd bukve } \\
\text { s kostanji }\end{array}$ & Vinograd \\
\hline
\end{tabular}

Razporeditev ekosistemov je rezultat sovpada naravnih in družbenih dejavnikov, pri čemer običajno za družbene dejavnike upoštevamo le rabo tal. Če pogledamo primer tipa ekosistemov D vidimo, da se s kombiniranjem kart (podatkov) in terenskim delom zbere precej uporabnih podatkov:

Tip ekosistemov D: osrednji del Dravinjskih goric je površinsko najbolj obsežen in ima zastopan tip D ekosistemov. Prevladujoča nadmorska višina je 280 do $350 \mathrm{~m} \mathrm{z}$ blago zaobljenimi reliefnimi oblikami in naklonom velikih razlik med 5 in $20^{\circ}$. Zaradi razčlenjenosti površja so zastopane vse strani neba (ekspozicije). Humidna klima s presežkom vode $\mathrm{v}$ prsti in blago zaobljene reliefne oblike povzročajo občasno psevdooglejevanje, ki se kaže v Bv/g horizontu, saj prsti vsebujejo večji delež gline in so zato slabše prepustne za vodo.

Izračunani so bili determinacijski in korelacijski koeficienti, ki so kvantitativni kazalnik povezanosti naravnih dejavnikov in rabe tal. Med naravnimi dejavniki so upoštevane litološka osnova, reliefne oblike in prsti. Izračunani determinacijski koeficent $\mathrm{r}^{2}$ je izražen 
$\mathrm{v}$ odstotkih in predstavlja, koliko odstotkov razlik v zastopani rabi tal si lahko razlagamo $\mathrm{z}$ razlikami med naravnimi sestavinami. Kontingenčni korelacijski koeficent $r$ pa kaže stopnjo povezanosti naravnih sestavin $\mathrm{z}$ rabo tal in je izračunan na osnovi frekvenc po celicah.

Povezanost naravnih sestavin v ekosistemih z rabo tal v Dravinjskih goricah.

\begin{tabular}{|l|c|c|c|c|}
\hline Litološka osnova & Njive & Travniki & Vinograd & Gozd \\
\hline Ilovice s peski & 0,002 & 0,046 & 0,001 & 0,471 \\
\hline Lapor & 0,004 & 0,006 & 0,64 & 0,004 \\
\hline Holocenske naplavine & 0,516 & 0,229 & 0 & 0,001 \\
\hline Skupaj & 0,522 & 0,281 & 0,641 & 0,442 \\
\hline
\end{tabular}

Tip prsti in raba tal.

\begin{tabular}{|l|c|c|c|}
\hline Tip prsti & Njive & Travniki & Gozd \\
\hline Evtrične, distrične & 0,013 & 0,027 & 0,027 \\
\hline Rjave psevdooglejene prsti & 0,001 & 0,086 & 0,009 \\
\hline Psevdoglej & 0 & 0,073 & 0,402 \\
\hline Obrečne prsti & 0,008 & 0,158 & 0,017 \\
\hline Melioriran hipoglej & 0,8 & 0 & 0 \\
\hline Skupaj & 0,822 & 0,345 & 0,455 \\
\hline
\end{tabular}

$\mathrm{R} 2=34,8 \% \quad \mathrm{r}=0,59$

Poznavanje tipov in skupin ekosistemov ter njihovih značilnosti je pomembno za načrtovanje rabe tal in spremljanje sprememb, ki se dogajajo v naravi. Posamezne vrste rabe tal zahtevajo določene pogoje, ki jih soustvarjajo abiotski in biotski dejavniki. Z razmejitvijo ekosistemov dobimo vpogled v skladnost rabe tal s prirodnimi razmerami. Pokazala se je korelacija med rabo tal in naravnimi razmerami, natančnejša analiza pa je pokazala odstopanja v smeri uveljavljanja antropogenih posegov, ki usmerjajo rabo tal. Raba tal je različno intenzivno povezana s posameznimi naravnimi sestavinami.

Povezanost naravnih sestavni z rabo tal.

\begin{tabular}{|l|c|c|}
\hline Dravinjske gorice & r2 & r \\
\hline Litološka osnova & 59,2 & 0,769 \\
\hline Oblike reliefa & 56,8 & 0,754 \\
\hline Tipi prsti & 34,8 & 0,59 \\
\hline Zastopanost ekosistemov & 29,8 & 0,545 \\
\hline
\end{tabular}

Najtesnejša zveza obstaja med zastopanostjo ekosistemov in litološko, reliefno in pedološko sestavo, kar je tudi parameter določitve ekosistemov. Siva in rjava barva se v profilu psevdoglejev izmenjujeta, odvisno od trajanja suhega in vlažnega obdobja. V času oksidacije prevladuje rjava barva, v času redukcije pa siva. Podtalnica v te prsti ne seže, zato ni nikjer enotno sivega horizonta (Repe, 2010). Voda vedno priteka v profil od zgoraj navzdol. Na psevdoglejih so v preteklosti rastli gozdovi hrasta gradna, ki pa so večinoma izkrčeni. Za kmetijsko rabo te prsti niso ugodne, saj so v sušnem obdobju zelo trde, $v$ 
53

vlažnem pa mazave.

\section{Psevdooglejene prsti v Dravinjskih goricah}

Talni tip: psevdoglej ravninski, distričen, srednje globok

Pedogenetski dejavniki: makrorelief - dolinsko dno, litološka podlaga - fluvioglacialni nanosi ilovice in gline, kmetijska raba prvenstveno travnik, v zadnjih dveh letih njiva s plitvim oranjem in grede.

Opis horizontov:

- A horizont: $0-26 \mathrm{~cm}$, drobljiv, nelepljiv, neplastičen, suh, meljasta ilovica, grudičast, humozen, rjava barva, prekoreninjenost srednja $(10 \%$ korenin $\mathrm{v}$ velikost nad $2 \mathrm{~mm}$ ), biološka aktivnost slaba, rovi deževnikov zelo redki, konkrecij ni, prst je brez vonja, brez karbonatov in $\mathrm{pH}$ je 5,5, skeleta ni.

- Bg1: 26 - 45 cm: težko drobljiv, nelepljiv, neplastičen, suh, meljasto glinasta ilovica, debelo grudičast, slabo humozen, sivo rjava barva, prekoreninjenost slaba (pod $5 \%$ korenin v velikost nad $2 \mathrm{~mm}$ ), biološka aktivnost zelo slaba, rovi deževnikov niso vidni, konkrecije železa, prst ima vonj po zemlji, brez karbonatov in $\mathrm{pH}$ je 5,3, skeleta ni.

- $\operatorname{Bg} 2: 45$ - $56 \mathrm{~cm}$ : zelo težko drobljiv, nelepljiv, neplastičen, suh, meljasto glinasta ilovica, zelo debelo grudičast, nehumozen, temno sivo rjava barva, ni prekoreninjen, ni biološko aktiven, konkrecije železa, prst ima vonj po zemlji, brez karbonatov in $\mathrm{pH}$ je 5,0, skeleta ni.

Kmetijska stroka psevdogleje uvršča med srednje do slabše kakovosti na sicer ugodnem reliefu. Njihova glavna pomanjkljivost za kmetijsko rabo je izrazito slab vodno zračni režim. V deževnih obdobjih voda zaradi težko prepustnega $\mathrm{Bg}$ horizonta zaostaja na površini in prsti delujejo zamočvirjeno. V suhih obdobjih pa se zaradi zbitosti Bg horizonta vrhnji horizont močno izsuši in razpoka. Posevke zato suša močno prizadene. Obdobja z ugodnimi lastnostmi prsti za obdelavo so kratka. Na sposobnost zadrževanje vlage v prsti vplivajo prsti in njihove značilnosti.

Rezultati meritev lastnosti psevdooglejenih prsti v Dravinjskih goricah.

\begin{tabular}{|l|c|c|c|c|c|c|c|}
\hline Horizont & $\mathrm{Cm}$ & $\begin{array}{c}\mathrm{pH} \mathrm{v} \\
\mathrm{H}_{2} 0\end{array}$ & $\begin{array}{c}\text { Tekstura } \\
\mathrm{v} \% \\
\mathrm{Pe}-\mathrm{Me}-\mathrm{Gl}\end{array}$ & Razred & $\begin{array}{c}\text { Delež } \\
\text { vlage }\end{array}$ & $\begin{array}{c}\text { Delež } \\
\text { organ. } \\
\text { snovi }\end{array}$ & $\begin{array}{c}\mathrm{CaCO}_{3} \\
\%\end{array}$ \\
\hline $\mathrm{A}$ & $0-26$ & 5,5 & $7-75-18$ & MI & $10 \%$ & $8 \%$ & $<2 \%$ \\
\hline $\mathrm{Bg} 1$ & $26-45$ & 5,3 & $9-70-21$ & MGI & $10 \%$ & $5 \%$ & $<1 \%$ \\
\hline $\mathrm{Bg} 2$ & $45-56$ & 5,0 & $8-68-24$ & MGI & $12 \%$ & $2 \%$ & $<1 \%$ \\
\hline
\end{tabular}

Druge ugotovitve so:

- Raba tal je odvisna od prirodnih dejavnikov v manjših dolinah, v večjih dolinah in ravninah pa jo usmerjajo družbeni dejavniki.

- Ugodne naravne razmere kot so naklon, prsti, klima še ne pomenijo intenzivne rabe tal, tak primer so Dravinjske gorice. 
- Tudi na prirodno neugodnih legah se pojavljajo specifične vrste rabe tal in pogosto je dovolj prisotnost enega ugodnega dejavnika (npr. lapor kot matična podlaga).

Iz tega sledi, da je v Dravinjskih goricah raba tal delno skladna s prirodnimi elementi, saj je srednja povezanost 0,59 . Neskladnost rabe tal s prirodnimi elementi se kaže v različnih oblikah degradacije prsti:

- polzenje preperine na laporju, kjer so rjave psevdoogljene prsti z Bv/g horizontom in psevdogleji $\mathrm{z}$ Bg horizontom, ti preprečujejo avtomorfno odtekanje vode skozi prst, zato se voda ustavlja v B horizontu in povzroča drsenje;

- strojno obdelovanje amfiglejev povzroči zbitost zemlje, kar so pokazale laboratorijske meritve;

- intenzivna obdelava plitvih rankerjev ni $\mathrm{v}$ skladu $\mathrm{z}$ njihovo zadrževalno kapaciteto za vodo, saj imajo nizko, posledično je nizka kationska izmenjalna kapaciteta in prsti so zelo prepustne za vodo.

Prav zaradi zelo slabih naravnih lastnosti psevdooglejnih prsti, smo na kmetijsko rabljenih površinah uvedli uporabo zastirke tudi na učnem poligonu za samooskrbo Dole. $\mathrm{Z}$ dodajanjem zastirke povečujemo delež organske skozi (humusa) in na ta način zmanjšamo izhlapevanje iz površine prsti ter zaščitimo rastline pred zunanjimi vplivi (močan dež, veter). Rastlinska zastirka iz sena delno zakasni rast rastlin v prvih dveh tednih oz. v prvem mesecu rasti, po enem mesecu pa se te razlike izničijo (Ban, Sinčić Pulić, Oplanič, Borošić, Žnidarčič, 2009).

Ker ima organska snov pomembno vlogo pri nastajanju humusa in zadrževanju vlage $\mathrm{v}$ prsteh (Mahmood, R., Legates, D.R., Meo, 2004), kar ugodno vpliva tudi na druge lastnosti prsti, je pomembno varovati prst prav z zadrževanjem vlage $\mathrm{v}$ njih. $\mathrm{S}$ tem bi na eni strani vračali prsti organsko snov in na drugi strani povečevali njeno samozadrževalno sposobnost. Predvsem v Severovzhodni Sloveniji, ker so prsti kisle in z nizko vsebnostjo bazičnih kationov, bi pomembno prispevali tudi k rodovitnosti prsti. Zastiranje je namenjeno preprečevanju rasti plevelov in zadrževanju vlage $\mathrm{v}$ prsti. Zastirka ima tudi druge ugodne učinke, preprečuje erozijo in uravnava temperaturo prsti zaradi senčenja. $\mathrm{Z}$ razgrajevanjem zastirk iz organskih materialov se izboljša rodovitnost prsti (Kodeks ravnanja 2013: 4).

\section{Zaključek}

Opredelitev ekosistemov s številčnimi podatki kaže prednost $\mathrm{v}$ tem, da so ekosistemi prepoznani glede na razmerja, povezave med drugimi prirodnimi dejavniki in ne zgolj ploskovno po obsegu. S preučitvijo številnih parametrov iz narave je možno dokaj točno določiti meje med ekosistemi in njihove manjše enote. Poznavanje značilnosti ekosistemov je pogoj za določanje optimalne rabe tal glede na rastišče ter pogoj za obstoj ekosistemov na osnovi natančnega poznavanja prsti.

Pogoste so predpostavke, da raba tal ni vedno skladna $\mathrm{z}$ abiotskimi in biotskimi sestavinami pokrajine, ki v součinkovanju sestavljajo ekosisteme in da je zato moteno njihovo delovanje. Rezultati te raziskave kažejo, da lahko govorimo o popolni in delni 
skladnosti, kjer je statistično zelo visoka povezanost ter o neskladnosti, kjer povezanosti ni. To pa pomeni, da so naravni dejavniki neskladni z aktualno rabo v smislu pretirane rabe ali pa se raba tal ne odziva na razpoložljive pogoje, kot imamo primer v Dravinjskih goricah, kjer so naravno primerne prsti za kmetijstvo poraščene z bukovimi gozdovi.

\section{Literatura in viri}

Ban, D., Sinčić Pulić, B., Oplanič, M., Borošić, J., Žnidarčič, D. 2009: Vegetativna rast in pridelek semideterminantnega paradižnika (Lycopersicon esculentum Mill.) v odvisnosti od načina zastiranja tal, Acta agriculturae Slovenica, 93 - 3, str. 357 - 362,

Bračič, V. 1985: Dravinjske gorice, Založba Obzorja Maribor.

Gregori, J. 1990: Prispevek k poznavanju ekologije in favne ptičev na Cigonci, Zbornik Občine Slovenska Bistrica, Zveza kulturnih društev občine Slovenska Bistrica, Ljubljana, str. 473480.

Mahmood, R., Legates, D.R., Meo, M. 2004: The role of soil water availability in potential rainfed rice productivity in Bangladesh: applications of the CERES-Rice model, Applied Geography, Volume 24, Issue 2, str. 139-159.

Kodeks ravnanja za preprečevanje vplivov med kmetijstvom in podnebnimi spremembami, Kmetijstvo in podnebne spremembe, ACCERETE, Kodeks ravnanja, http://www.agrometeorology.org/files-folder/repository/code_of_attitudes_sl.pdf, 30.6.2017.

Marinček, L. 1984: Gozdne združbe Pohorja, Komentar h karti gozdnih združb 1:25.000, Ljubljana.

Medmrežje 1:

http://www.spodezelja.si/index.php?option=com_content\&view=article\&id=1788:leto2015--mednarodno-leto-tal\&catid=1:aktualno\&Itemid=592

PISO Prostorski informacijski sistem za občino Poljčane http://www.geoprostor.net/PisoPortal/Default.aspx?

Repe , B. 2010: Prepoznavanje osnovnih prsti slovenske klasifikacije, Dela 34, FF UL, str. 134166.

Rokopisna karta gozdnih združb List Poljčane, 1:50.000, Biološki inštitut Jovana Hađija, Ljubljana.

Rokopisna geološka karta List Poljčane, 1:25.000, Geološki zavod Ljubljana.

Spaargaren, O. C., Deckers, J. A. 2013: Soil geography and classification, encyclopedia of Life Support Systems, http://www.eolss.net/Sample-Chapters/C19/E1-05-07-04.pdf, 30.6.2017.

Vovk Korže, A. 2015: Metodologija preučevanja prsti v geografiji. Mednarodni center za ekoremediacije. Univerza v Mariboru, Filozofska fakulteta. 
GEOGRAFIJE PODRAVJA

tHe GEOGRAPHIES OF THE POdRAVJe Region 


\title{
Celostno upravljanje rečnih koridorjev v teoriji in praksi - primer koridorja ravninske Drave
}

\begin{abstract}
ANDREJ GRMOVŠEK, SIMON VEBERIČ
Povzetek Izraz »rečni koridor«, ki ga uporablja predvsem vodarska stroka, je še posebej priročen za upravljavce in upravljanje tovrstnih območij. V rečnih koridorjih prihaja do prepletanja številnih gospodarskih, družbenih, varstvenih in drugih interesov, posledično pa do številnih vplivov na stanje vodnega in obvodnega okolja. Sektorji oziroma strokovnjaki, ki na različne načine upravljajo dele oziroma elemente tega kompleksnega, a hkrati izrazito povezanega geografskega območja (prostorski načrtovalci, vodarji, gozdarji, kmetijci, naravovarstveniki in drugi) pogosto načrtujejo in upravljajo parcialno in neusklajeno. Zaradi tega prihaja do navzkrižij in nedoseganja ciljev upravljanja. Zavod RS za varstvo narave je z namenom zagotoviti skladno upravljanje varovanih območij narave, predvsem pa preseči slabe prakse in zagotoviti celostno upravljanje reke Drave in njenega obrečnega prostora, sodeloval pri več projektnih aktivnosti, ki so pripomogle $\mathrm{k}$ bistvenim spremembam. Projekt SEE River (Celostno upravljanje z mednarodnimi rečnimi koridorji v jugovzhodni Evropi) je uvedel sistemski pristop, ki vključuje dobre prakse ter sodobna strokovna spoznanja ter obsega medsektorsko usklajevanje in vključevanje deležnikov. Ob podroben opisu uporabljenega pristopa s časovno distanco ocenjujemo pozitivne premike, pa tudi pomanjkljivosti in težave omenjenega pristopa.
\end{abstract}

Ključne besede: $・$ celostno upravljanje $・$ rečni koridor $・$ regionalno načrtovanje $\bullet$ razvojni concept $\bullet$ Drava $\bullet$ Podravje $\bullet$

NASLOv AVTORJEv: Andrej Grmovšek, univ. dipl. geog., Zavod RS za varstvo narave, OE Maribor, Pobreška cesta 20,2000 Maribor, Slovenija, e-naslov: andrej.grmovsek@zrsvn.si. Simon Veberič, univ. dipl. biol., Zavod Republike Slovenije za varstvo narave, OE Maribor, Pobreška cesta 20, 2000 Maribor, Slovenija, e-naslov: simon.veberic@zrsvn.si. 


\title{
Integrated river corridor management in theory and praxis - lowland Drava river corridor example
}

\author{
ANDREJ GRMOVŠEK, SiMON VEBERIČ
}

\begin{abstract}
The term "river corridor" is mostly used by water management experts, but it is also useful for managers and management of those areas. Many interests interweave in river corridors, from economic, social, protectoral and other and they have numerous impacts on the state of water body and its riparian area. Sectors and experts who manage parts or elements of this complex, yet highly integrated geographical area (spatial planners, water managers, foresters, farmers, environmentalists), often plan and manage partially, and uncoordinated. This leads to conflicts, and the management objectives are not reached. Institute of the Republic of Slovenia for Nature Conservation participated in different project activities, in order to ensure coordinated management of nature protected areas, particularly to overcome bad practices and to ensure integrated management of the river Drava and its riparian area. Those project activities contributed to substantial changes. SEE River project (Integrated management of international river corridors in South-eastern Europe) introduced a systemic approach that includes best practices and modern know-how, cross-sectoral coordination and stakeholder involvement. Detailed description of the approach and time distant evaluation of positive development, as well as weaknesses and difficulties of this approach, are presented in this paper.
\end{abstract}

Keywords: • integrated management $\bullet$ river corridor $\bullet$ regional planning $\bullet$ development concept $\bullet$ Drava $\bullet$ Podravje $\bullet$

CORRESPONDENCE ADDRESS: Andrej Grmovšek, univ. dipl. geog., Institute of the Republic of Slovenia for Nature Conservation, Regional unit Maribor, Pobreška cesta 20, 2000 Maribor, Slovenia, e-mail: andrej.grmovsek@zrsvn.si. Simon Veberič, univ. dipl. biol., Institute of the Republic of Slovenia for Nature Conservation, Regional unit Maribor, Pobreška cesta 20, 2000 Maribor, Slovenia, e-mail: simon.veberic@zrsvn.si. 
GEOGRAFIJ PODRAvJA

A. Grmovšek, S. Veberič: Celostno upravljanje rečnih koridorjev v teoriji in praksi primer koridorja ravninske Drave

\section{Uvod}

Rečni koridor je $\mathrm{v}$ znanstvenih in strokovnih sferah že daljše obdobje priznana hidromorfološka kategorija (river corridor) (Bizjak, Grmovšek, Marolt, Skorza, Softić, Veberič, 2013: 265). Danes različne stroke in strokovnjaki ta termin pojmujejo nekoliko različno, najpogosteje pa ga uporabljajo vodarji in krajinski ekologi. Iz krajinsko ekološkega, pa tudi geografskega zornega kota ga lahko opredelimo kot območje struge vodotoka in območje vzdolž obeh bregov vodotoka, v katerem se voda stalno ali občasno zadržuje in / ali so vidne sledi delovanja vode (reke) in z vodo (reko) povezanih procesov, npr. hidroloških, hidromorfoloških, pedoloških, fitocenoloških itd.. (Bizjak, Grmovšek, Marolt, Skorza, Softić, Veberič, 2013: 265). V kontekstu prostorskih, pa tudi drugih sektorskih načrtovanj, lahko rečni koridor uporabimo tudi kot prostorsko plansko kategorijo za načrtovanje rabe območja na vodocentričnih izhodiščih. Za te namene je smiselno pri njegovi omejitvi upoštevati tudi vplivna območja gospodarskih ali socialnih dejavnikov ter privlačnosti prostora.

Rečni koridorji so specifičen del zemeljskega površja. Še posebej pomembni so z vidika omogočanja transporta in selektivnega prehajanja snovi, kot njihov vir ali ponor, pa tudi kot posebna in redka oblika habitata živalskih in rastlinskih vrst ter njihov migracijski koridor.

Zaradi pomembnosti vode kot vira za namakanje, rek kot transportnih poti, strateškega pomena in ribištva kot vira hrane so rečni koridorji že od začetka civilizacij tudi eno izmed območij najintenzivnejših družbenih interakcij. Ob pomembnosti vode in obvodnega prostora kot vira, v zadnjem času pa tudi zaradi privlačnosti vode in obvodnega sveta za preživljanje prostega časa, se v območjih rečnih koridorjev prepletajo interesi številnih sektorjev, družbenih skupin in posameznikov, ki mnogokrat negativno učinkujejo na stanje rečnih koridorjev, rečni režim in kakovost vodnega in obvodnega ekosistema.

Kljub temu so številna območja vzdolž rek v Sloveniji še relativno dobro ohranjena in uspešno zagotavljajo številne ekosistemske storitve, na primer zagotavljanje in čiščenje pitne vode, zadrževanje visokovodnih valov, pridelavo hrane, lesno pridelavo, proizvodnjo energije, turizem, rekreacijo in druge ter so območja visoke biotske raznovrstnosti.

Zaradi številnih družbenih interesov in ciljev, ki se prepletajo oziroma vplivajo na rečne koridorje in naravnih procesov, ki vplivajo na družbo $\mathrm{v}$ tem prostoru je potreba po upravljanju rečnih koridorjev zelo izrazita. V sodobni družbi pa ustreznega in učinkovitega upravljanja ni mogoče doseči brez strokovnega in usklajenega upravljanja. $\mathrm{Ob}$ upoštevanju sodobnih strokovnih spoznanj mora biti takšno upravljanje podprto $\mathrm{z}$ medsektorskim usklajevanjem in vključevanjem deležnikov na vseh ravneh, od lokalne, državne, in na mednarodnih rekah tudi čezmejne (Bizjak, Grmovšek, Marolt, Skorza, Softić, Veberič, 2013: 263). Takšen pristop imenujemo usklajeno celostno upravljanje z rečnimi koridorji. 
A. Grmovšek, S. Veberič: Integrated river corridor management in theory and praxis lowland Drava river corridor example

\section{Rečni koridor reke Drave}

Rečni koridor reke Drave v Sloveniji v toku do Maribora obsega le ozko območje ob reki, saj je le ta v velikem delu ujeta v sotesko, ki se razširi v širšo dolino le nad Dravogradom, pri Radljah ob Dravi in pri Rušah. Pod Mariborom Drava postane ravninska reka, njen rečni koridor pa se razširi na območje bolj ali manj pogosto poplavljene široke Dravske ravni. Do Ptuja koridor levobrežno mestoma omejuje gričevje Slovenskih goric, pod Markovci pa desnobrežno gričevnate Haloze, sicer pa predvsem meje poplavnih površin oziroma ježe nekdanjih rečnih teras.

Za namene prostorskega in razvojno varstvenega načrtovanja lahko koridor razširimo tudi na vplivna območja gospodarskih ali socialnih dejavnikov ter privlačnosti prostora oziroma v njegovo opredelitev vključimo družbeno geografske kazalnike.

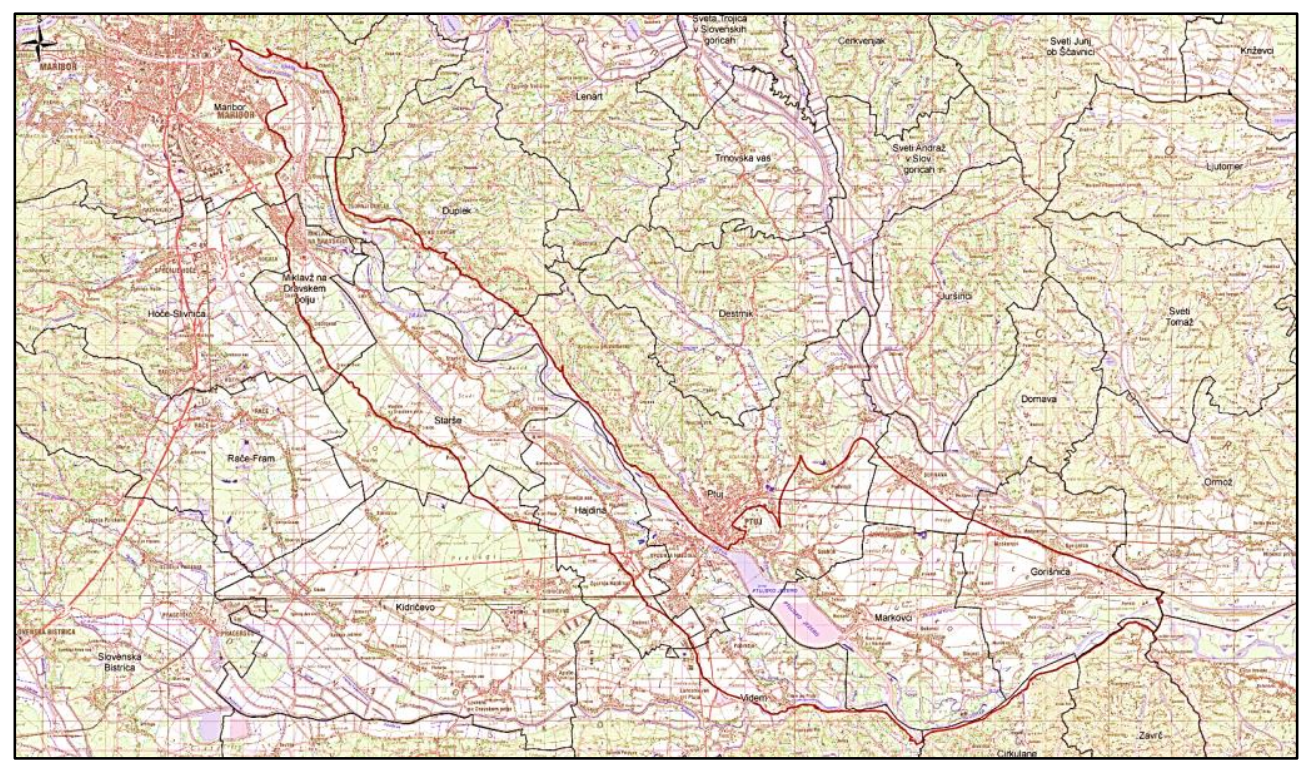

Rečni koridor Drave med Mariborom in Zavrčem, definiran za pripravo Razvojnega koncepta rečnega koridorja v sklopu projekta SEE River.

Na ravninskem delu dravskega rečnega koridorja, torej med Mariborom in slovensko hrvaško mejo, je prisotno največje navzkrižje interesov in ciljev, kar se odraža tudi v kompleksnosti in zahtevnosti upravljanja. Na tem območju je bilo v zadnjih desetletjih izvedenih več projektnih aktivnosti s ciljem izboljšanja medsektorskega upravljanja $\mathrm{z}$ reko in obrečnim prostorom. Ta del koridorja in omenjene projektne aktivnosti podrobneje obravnavamo $\mathrm{v}$ tem prispevku.

Za ravninski del dravskega rečnega koridorja sta bila nekoč značilna intenzivna rečna dinamika in hidromorfološka pestrost. Reka je svojo strugo stalno premeščala, širila in prebijala okljuke, ustvarjala stranske in mrtve rečne rokave in rečne otoke ter redno poplavljala obsežna območja. Zaradi izdatne prodonosnosti in rečne dinamike so stalno 
nastajala in izginjala prodišča, redno preplavljanje pa je upočasnjevalo njihovo zaraščanje (Sovinc, 1995: 49).

Raba rečnega koridorja je bila pretežno prilagojena raznolikim naravnim razmeram, predvsem poplavam. Vsaj dve tisočletji je kultura $\mathrm{v}$ poplavno območje reke Drave posegala le $\mathrm{z}$ varnih teras, vzdolž katerih so se vlekle večinoma enovrstne vasi (Štumberger, 1995: 7). Pretežni del poplavnega območja so namreč obsegali gozdovi in travniki, njivske površine in poselitev pa so bile umaknjene izven območja rednih poplav.

\section{Spremembe zaradi rabe vode in posegov $v$ prostor}

S postopnim utrjevanjem erozijskih brežin, ki se je intenziviralo in postalo bolj učinkovito v 19. stoletju se je začelo omejevati bočno erozijski potencial reke ter premeščanje struge. Izgradnja številnih hidroelektrarn na Dravi v 20. stoletju pa je povzročila bistveno zmanjšane prodonosnosti, saj je pretok proda (rinjenih plavin) preko zajezitev praktično ustavljen. Danes gorvodno od obravnavnega odseka deluje 18 hidroelektrarn na Dravi ter številne na njenih pritokih.
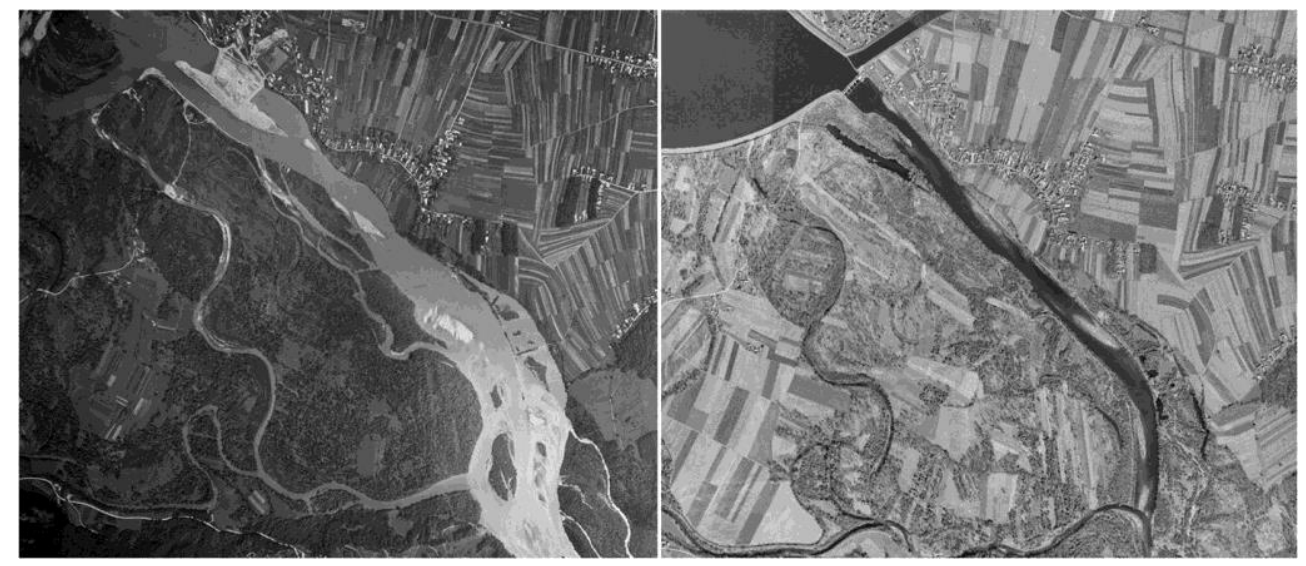

Območje Šturmovcev - spremembe morfologije po gradnji jezu v Markovcih.

Prav hidroelektrarne so močno vplivale na gospodarski in socialni razvoj Podravja, prav tako pa na stanje reke in njenega koridorja. Na obravnavanem ravninskem delu dravskega rečnega koridorja so bile izgrajene tri kanalske akumulacijske elektrarne. Z jezu v Melju tako ob normalnih hidroloških razmerah, srednji letni pretok Drave tukaj znaša približno $270 \mathrm{~m}^{3}$, glavnina dravske vode odteka po kanalu na leta 1969 izgrajeno HE Zlatoličje, po strugi pa se pretaka le določen ekološki minimum $10 \mathrm{~m}^{3}$ pozimi oziroma $20 \mathrm{~m}^{3}$ poleti. Voda se s HE Zlatoličje po iztočnem kanalu povrne v strugo Drave tik pred zajezitvijo v umetno akumulacijsko Ptujsko jezero.

Ptujsko jezero, največje slovensko jezero s površino $3,5 \mathrm{~km}^{2}$, je popolnoma spremenilo nekdaj izredno dinamičen del koridorja, kjer je bila širina prodišč in rednega premeščanja struge široka več sto metrov. Pod jezom Ptujskega jezera v Markovcih glavnina dravske vode teče po dovodnem kanalu v leta 1978 izgrajeno HE Formin, ekološki minimum $5 \mathrm{~m}^{3}$ 
A. Grmovšek, S. Veberič: Integrated river corridor management in theory and praxis lowland Drava river corridor example

pozimi oziroma $10 \mathrm{~m}^{3}$ poleti pa teče po strugi Drave, ki se z iztočnim kanalom HE Formin združi v umetnem akumulacijskem Ormoškem jezeru. Iz njega vodi dotočni kanal leta 1975 zgrajene HE Varaždin, po strugi mimo Središča ob Dravi pa deloma po slovenskem deloma po hrvaškem ozemlju teče pretežno 10 do $12 \mathrm{~m}^{3}$ ekološkega minimuma (Szalay, 2014: 10, 16).

Hidroenergetska raba in spremembe pretokov so povzročile izrazite morfološke spremembe rečnega koridorja. Večji del leta po strugi Drave teče približno 20 krat manjši pretok kot je pred izgradnjo elektrarn. To ima za posledico bistveno nižje gladine v strugi (na odseku med Markovci in Forminom v povprečju za 1,6 m) (Hojnik, 2004: 295).

Ocene kažejo, da se je transportna sposobnost Drave po izgradnji HE Formin zmanjšala za 400 krat (Sovinc, 1995: 54). Najbolj očitna morfološka sprememba je ožanje struge, kot posledica zaraščanja nekoč obširnih prodišč (oz. potopljenih površin) ter lokalno poglabljanje struge (Hojnik, 2004: 260). Vendar pa je za upad vodnih gladin v strugi Drave (in podtalnice) $2 \mathrm{x}$ krat bolj krivo zmanjšanje pretokov kot poglabljanje struge (Hojnik, 2004: 259).

Na odsekih pod zajezitvami je praviloma prišlo do poglabljanja struge, na odsekih nad zajezitvami pa do odlaganja proda, peska in mulja. Struga Drave se je ponekod zožala tudi na polovico nekdanje, kar ima velik vpliv na njeno pretočno sposobnost (Klaneček, Čuš, Hojnik, 2005: 58). Večina prodišč ter robnih delov struge se je zarastla s krajevno značilno lesno zarastjo. Vegetacija na prodiščih preprečuje mobilizacijo prodišč, obenem pa pospešuje usedanje lebdečih plavin (mulja) ob visokih vodah. Prodišča se zaradi zaraščanja lahko v kratkem času hitro zvišajo tudi za 1-2 m (Klaneček, Čuš, Hojnik, 2005: 63).

Povsem drugačno je stanje $\mathrm{v}$ strugi Drave $\mathrm{v}$ času visokih pretokov in poplavnih dogodkov. Takrat hidroenergetski sistem ne uspe pretakati vse vode, tako da v strugi in poplavljenem območju teče tudi več kot 100 krat več vode kot znaša ekološki minimum. V poplavnem dogodku novembra 2012 je pretok Drave na območju obravnave presegel $3000 \mathrm{~m}^{3}$ (Anzeljc, Kobold, 2013: 21). Osnovna rečna struga pod Dogošami pretežno več ne prevaja pretokov s petletno povratno dobo (Q5), oziroma pod Markovci celo dvoletno povratno dobo (Q2). V poplavnih razmerah se voda razlije po obsežnih, tudi več kilometrov širokih poplavnih površinah, ki so večinoma omejene $\mathrm{z}$ rečno teraso oziroma gričevjem. Sklepamo pa lahko, da obseg poplavnega območja danes ni bistveno drugačen od tistega pred izgradnjo elektrarn, spremenjena je le pokrovnost površin - prej večinoma vodno telo in tudi prodišča, danes lesna zarast (Klaneček, Čuš, Hojnik, 2005: 59).

Spremenjene hidrološke razmere, predvsem pa spremembe v družbi, so pripeljale tudi do velikih sprememb v rabi prostora. Sčasoma se je percepcija posameznika o reki Dravi zožila na reko za pridobivanje energije, njeni naravni procesi in potenciali pa so bili marginalizirani in zato verjetno v razvoju neopaženi in zanemarjeni (Bizjak, Grmovšek, Marolt, Softić, Veberič, 2013: 13). Urbanizacija, suburbanizacija, pa tudi drugačno družbeno dojemanje zajezene reke in njenih poplavnih dogodkov sta ob neučinkovitem prostorskem planiranju botrovali razmahu poselitve tudi v poplavnem območju rečnega koridorja. 
GEOGRAFIJE PODRAVJA

A. Grmovšek, S. Veberič: Celostno upravljanje rečnih koridorjev v teoriji in praksi primer koridorja ravninske Drave
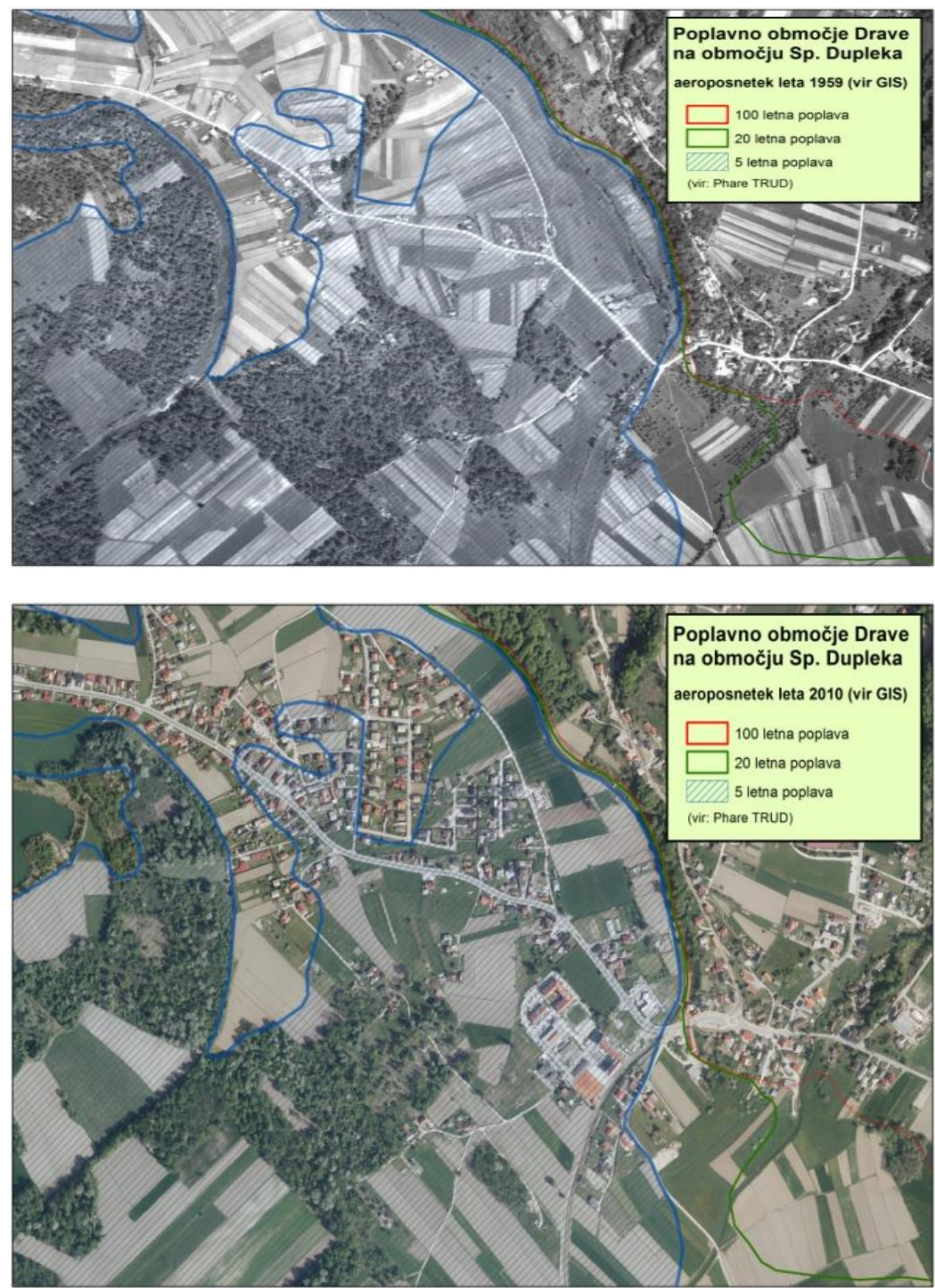

Razmah poselitve v poplavnem območju Spodnjega Dupleka med leti 1959 in 2010. Poplavno varnost tega območja je izboljšal visokovodni nasip zgrajen leta 2015, ki pa je zmanjšal retencijsko območje. 
A. Grmovšek, S. Veberič: Integrated river corridor management in theory and praxis lowland Drava river corridor example

Po drugi strani je modernizacija kmetijske proizvodnje in subvencijska kmetijska politika pripomogla $\mathrm{k}$ povečanju njivskih površin na račun travniških, pa tudi gozdnih. Po podatkih dejanske rabe GERK (Ministrstvo za kmetijstvo in okolje, marec 2014) je bilo kot kategorija voda znotraj območja 100 letnih poplav (Q100) opredeljeno približno 1330 ha površin, kar predstavlja ca. 14 \% celotne površine. Znotraj poplavnega območja so najpogosteje zastopane njive in vrtovi, ki obsegajo 4053 ha (42\%) ter gozdne površine na 2363 ha (24 \%). Kategorija pozidana in sorodna zemljišča obsega 453 ha, kar predstavlja $5 \% 100$ letnega poplavnega območja (Juvan, 2015: 32 ).

Seveda so ob poplavnih dogodkih škode $\mathrm{v}$ poljedelski pridelavi, predvsem pa na stanovanjskih objektih, bistveno večje kot na travnikih oziroma gozdovih. Hkrati ima intenzivno kmetijstvo $\mathrm{z}$ veliko uporabo mineralnih gnojil in fitofarmacevtskih sredstev $\mathrm{v}$ območju dravskega koridorja izrazito neugoden vpliv na kvaliteto podtalnice in deloma tudi vode $v$ reki. Podtalnica je je vir pitne vode, a je obremenjena predvsem z nitrati in pesticidi kmetijskega izvora (Lampič, Špes, 2011: 197).

Visokovodni dogodki vsakokrat znova povzročijo gospodarsko škodo in opozarjajo na potrebo po zmanjšanju poplavne ogroženosti. Po drugi strani pa posegi za zmanjšanju poplavne ogroženosti pogosto prizadenejo rečni ekosistem, zmanjšujejo biotsko pestrost in krnijo naravne vrednote tega območja. Danes regulacijski posegi v strugo reke Drave dodatno rušijo že tako močno okrnjeno rečno dinamiko, skupaj z uničevanjem že tako močno okrnjene rečne loke pa predstavljajo grožnjo za številne vrste ptic (Božič, 2003: 100) in drugih ogroženih vrst.

Reka Drava in njen koridor imata navkljub spremenjenim hidrološkim in morfološkim razmeram še vedno veliko biotsko pestrost. Širše območje reke Drave je življenjski prostor 270 vrst ptic, približno 50 vrst rib, okoli 40 vrst kačjih pastirjev, 30 vrst sesalcev, 14 vrst dvoživk, 9 vrst plazilcev in preko 600 različnih vrst rastlin. Predstavlja tudi pomembno prezimovališče in počivališče za številne migratorne vrste ptic, ki se na tem območju pojavljajo v jesenskih, zimskih in zgodnje spomladanskih mesecih (ZRSVN 2006, 13). Obrečni del koridorja je tako del evropskega omrežja ohranjanja biotske pestrosti - Območij Natura 2000 ter določen kot ekološko pomembno območje, reka in obrežna loka ter posamezna območja pa so določena za naravne vrednote in deloma zavarovana.

Kljub nadpovprečni privlačnosti vode in obrežnega prostora pa območje ravninskega dravskega rečnega koridorja ni pomembno rekreacijsko oziroma turistično območje. Izjemi predstavljata Ptujsko jezero, ki pritegne obiskovalce predvsem s plovbo ter termalno kopališče Terme Ptuj, ki se nahaja tik ob reki Dravi. Ob robu rečnega koridorja ležita staro meto Ptuj, ki je pomembna, predvsem kulturno turistična točka, pa tudi regionalno središče Maribor s svojo turistično ponudbo.

\section{Na poti $k$ celostnem upravljanju rečnega koridorja reke Drave}

$\mathrm{Na}$ območju ravninskega dravskega rečnega koridorja je v preteklosti potekalo več aktivnosti in projektov $\mathrm{z}$ namenom izboljšanja medsektorskega upravljanja $\mathrm{z}$ reko in prostorom. Prvi tovrsten projekt je bil projekt Trajnostno upravljanje območja reke Drave (TrUD), ki je potekal leta 2006. Namen projekta je bila zagotovitev dolgoročne ohranitve 
stanja vrst in habitatnih tipov na območju Natura 2000 Drava ter zvišanje stopnje informiranosti, osveščenosti in pripravljenosti vseh deležnikov za doseganje usklajenega in trajnostnega razvoja območja. Glavni rezultat projekta je bil Osnutek integralnega načrta upravljanja območja reke Drave.

Sistemsko je celoviti pristop $\mathrm{k}$ izboljšavi medsektorskega upravljanja na območju dravskega rečnega koridorja med leti 2012 in 2014 vpeljal projekt Celostno upravljanje mednarodnih rečnih koridorjev v jugovzhodni Evropi (SEE River). Glavni rezultat projekta na slovenskem pilotnem območju je bil Razvojni koncept rečnega koridorja Drave med Mariborom in Zavrčem. Le ta je ob sodelovanju raznovrstnih deležnikov dosegel usklajen splošni regionalni koncept varstva in razvoja rečnega koridorja.

$\mathrm{Na}$ temeljih obeh projektnih aktivnosti ter $\mathrm{z}$ njimi spodbujenega medsektorskega sodelovanja je bil v sklopu projekta Obnova rečnega ekosistema nižinskega dela Drave v Sloveniji (LIVEDRAVA), 2012-2017, med drugim pripravljen Program ukrepov za trajnostno upravljanje Drave na odseku od Maribora do Središča ob Dravi. Cilj te akcije je bila priprava usmeritev za trajnostno upravljanje nižinske Drave na način, ki bo hkrati zmanjševal poplavno ogroženost in zagotavljal doseganje ciljev območja Natura 2000 ter izboljšanje sodelovanja med ključnimi deležniki. Priprava programa ukrepov se je tematsko osredotočala na urejanje voda, zagotavljanje poplavne varnosti in zagotavljanje ohranjanja biotske pestrosti. Usmeritve za trajnostno upravljanje reke Drave so bile pripravljene $\mathrm{z}$ namenom umestitve slednjih v Načrt upravljanja voda za vodni območji Donave in Jadranskega morja za obdobje 2015-2021.

Po drugi strani se je na temelju razvojno - varstvenega povezovanja deležnikov, predvsem upravnih, razvojnih in turističnih institucij, ob zaključku projekta SEE River ustanovila neformalna Skupina za Dravo. Njene ključne naloge so trajno povezovanje deležnikov celotnega območja ob Dravi v Sloveniji, promocija in implementacija Razvojnega koncepta rečnega koridorja Drave med Mariborom in Zavrčem ter usklajeno delovanje razvojnih in varstvenih sektorjev ter ostalih deležnikov, predvsem z namenom priprave in izvedbe razvojnih in okoljevarstvenih projektov regije.

\section{Projekt SEE River - celostno upravljanje z mednarodnimi rečnimi koridorji}

$\mathrm{V}$ nadaljevanju podrobneje opisujemo proces in način celostnega upravljanja rečnega koridorja, kot ga je v sklopu priprave Razvojnega koncepta rečnega koridorja Drave med Mariborom in Zavrčem vpeljal projekt SEE River.

Prva faza projekta je obsegala določitev rečnega koridorja, ki je bil, predvsem zaradi razvojnega značaja končnih produktov, določen tudi ob upoštevanju vplivnih območij gospodarskih oziroma socialnih dejavnikov ter privlačnosti prostora. Sledila je poglobljena analiza stanja in zgodovinskih sprememb rečnega koridorja, načina sektorskega upravljanja in vpetosti le tega v nacionalni in evropski pravni red.

Že v najzgodnejši fazi smo v seriji vodenih delavnic pričeli z vključevanjem deležnikov $\mathrm{v}$ proces priprave Razvojnega koncepta. K sodelovanju smo povabili vse deležnike, ki so želeli sodelovati pri prihodnjem razvoju dravskega koridorja. Z nacionalne ravni (pristop z vrha navzdol, »top down«) so bili to predvsem predstavniki ministrstev ter državnih 
A. Grmovšek, S. Veberič: Integrated river corridor management in theory and praxis lowland Drava river corridor example

inštitucij, z območja koridorja (pristop od spodaj navzgor, »bottom up«) pa predstavniki občin, regionalnih agencij, inštitucij s področja vodarstva, naravovarstva, prostorskega načrtovanja, energetike, kmetijstva, gozdarstva, ribištva, turizma, gospodarstva ter lokalna turistična, lovska, ribiška in športna društva ter druga interesna združenja in posamezniki.

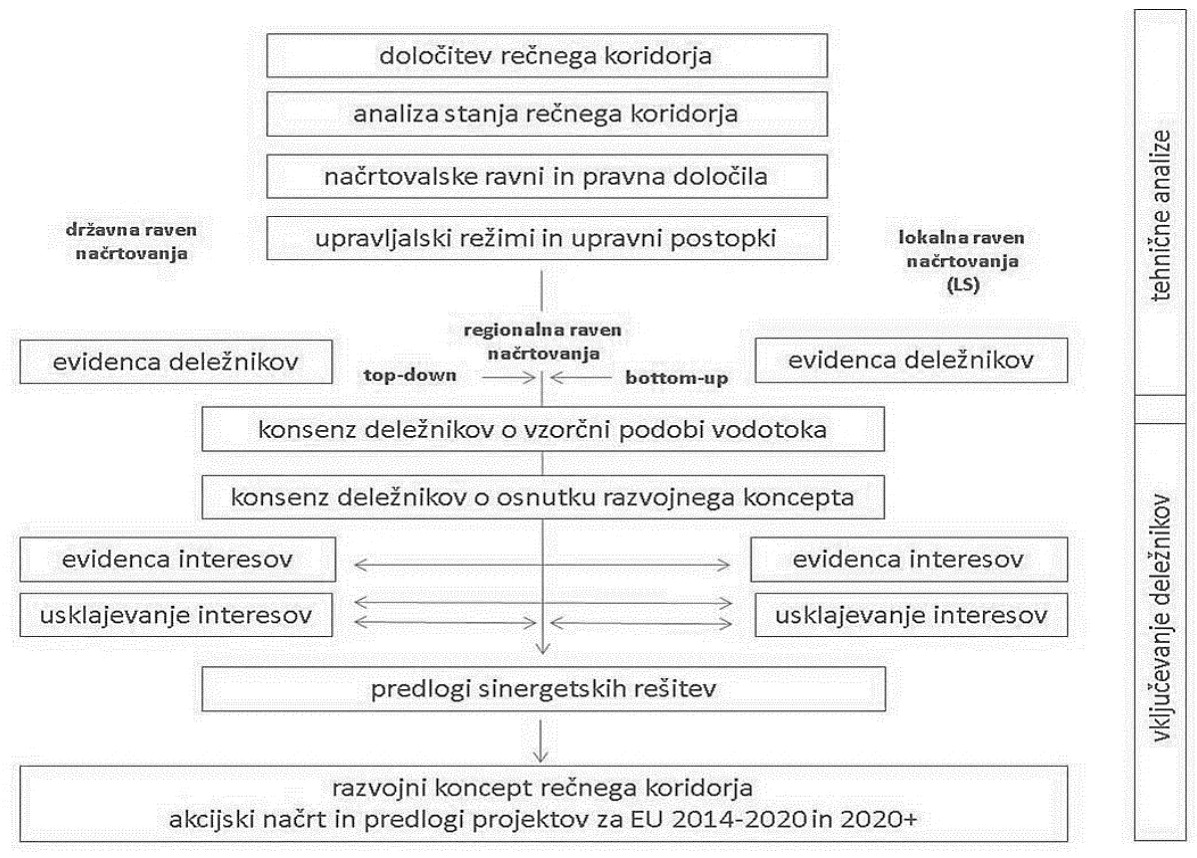

Proces priprave Razvojnega koncepta rečnega koridorja med Mariborom in Zavrčem Drave v projektu SEE River.

Tako smo skupaj s pisano paleto deležnikov najprej oblikovali Vizijo Drave 2030, skupno in usklajeno vzorčno podobo reke Drave in njenega obrečnega prostora (t.i. Leitbild). La ta je na eni strani temeljila na modernih strokovnih pogledih in zavezah mednarodne Dravske deklaracije iz leta 2008, ki zagovarjajo zmanjševanje poplavne ogroženosti, vračanje površin naravnim procesom ter povečevanje športno-rekreacijskih površin in zelenega turizma za oddih prebivalstva, ter na drugi strani na željah, potrebah in vizijah deležnikov.

Hkrati smo evidentirali interese, razvojne potrebe in varstvene cilje vseh deležnikov in pripravili t. i. karte interesov in navzkrižij, ki so ob oblikovani Viziji služile za pripravo osnutka Razvojnega koncepta rečnega koridorja Drave med Mariborom in Zavrčem. Le ta je upošteval tudi nacionalno in evropsko zakonodajo, ki ureja rabo prostora in izvajanje sektorskih ukrepov (urejanje voda, zagotavljanja poplavne varnosti, varstva narave, idr.). V nadaljnjem delu smo z ožjimi sestanki in dodatnimi delavnicami naredili več korakov $\mathrm{k}$ uskladitvi interesov med na videz antagonističnimi cilji in deležniki ter prišli do številnih sinergetskih rešitev. 
A. Grmovšek, S. Veberič: Celostno upravljanje rečnih koridorjev v teoriji in praksi primer koridorja ravninske Drave

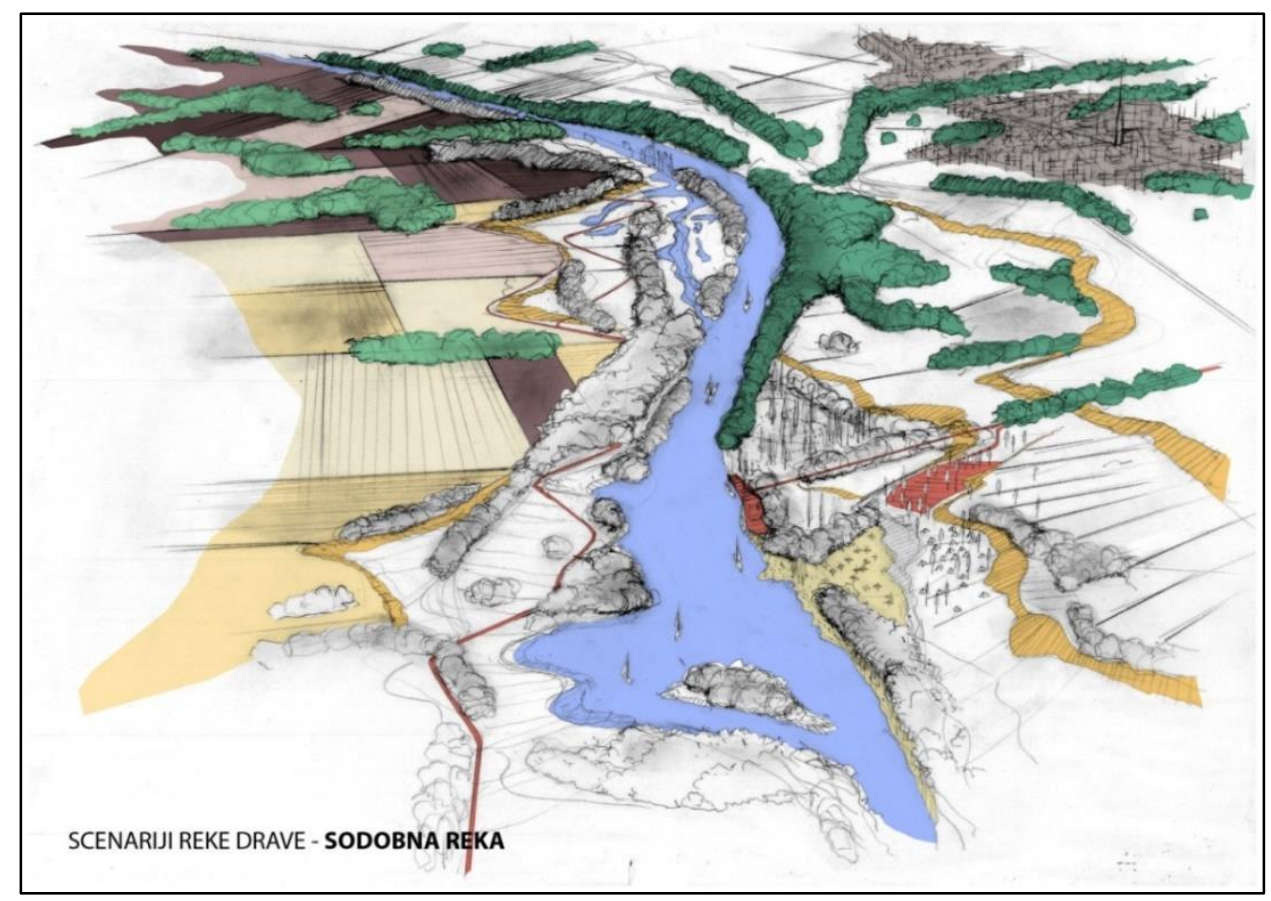

Vzorčna podoba koridorja reke Drave 2030: sodobna reka, ki umerjeno združuje razvojne in varstvene komponente razvoja.

Vir: SEE River, 2015.

Ob sodelovanju deležnikov smo v nadaljevanju pripravili usklajen Razvojni koncept rečnega koridorja Drave med Mariborom in Zavrčem. Ker je Drava mednarodna reka smo zagotavljali tudi čezmejno oziroma mednarodno usklajenost Razvojnega koncepta rečnega koridorja Drave med Mariborom in Zavrčem. Le to smo dosegali s srečanji in usklajevanji s projektnimi partnerji iz vseh dravskih držav. Skupaj smo oblikovali tudi Skupni akcijski plan za Dravo (Joint Drava Rivier Action Plan).

Razvojni koncept rečnega koridorja Drave med Mariborom in Zavrčem je strokovna podlaga za regionalni prostorski načrt, vsebuje pa tudi splošne usmeritve za nadaljnje podrobnejše načrtovanje rabe prostora, z namenom zagotavljanja poplavne varnosti in ohranjanja biotske raznovrstnosti. Je splošne narave in predstavlja podlago za konkretizacijo in udejanjenje predlaganih rešitev ter celovito medsektorsko upravljanje obravnavanega območja. Za učinkovitejšo implementacijo Razvojnega koncepta smo skupaj z deležniki pripravili še Akcijski načrt in predlog projektov, prednostno usmerjenih na razpise sredstev Evropske unije.

\section{Zaključek}

Uspešnost obravnavanih projektov in aktivnosti avtorji težko ocenjujemo objektivno, saj smo v delu aktivnosti sodelovali tudi sami. Kljub temu v nadaljevanju podajamo svoja opažanja in ugotovitve, ki temeljijo tudi na anketiranju deležnikov vključenih v projekte. 
A. Grmovšek, S. Veberič: Integrated river corridor management in theory and praxis lowland Drava river corridor example

Predstavljamo tudi povzetek izzivov in potencialov, kot so bili ob sodelovanju z deležniki spoznani ob projektnem in po projektnem delu na območju dravskega rečnega koridorja.

Na območju dravskega koridorja so bili izvedeni projekti pretežno strokovne narave in niso uspeli doseči popolnega konsenza med sektorskimi in lokalnimi politikami, vsekakor pa predstavljajo pomemben korak k doseganju tega cilja. Prvi izmed projektov, ki je na območju ravninskega rečnega koridorja Drave v Sloveniji na nek način oral ledino v smislu modernega celostnega upravljanja območja, je bil projekt TRUD. Projekt je sicer povezal razne sektorje (vodarsko gospodarstvo, kmetijstvo, gozdarstvo, prostorsko planiranje, naravovarstvo), ki vplivajo na ohranjanje biotske pestrosti, vendar pa pripravljeni Osnutek integralnega načrta upravljanja območja reke Drave ni nikoli zaživel. Tudi vključevanje deležnikov $\mathrm{v}$ proces njegove priprave je bilo relativno omejeno.

Projekt SEE River je na območju sistematično vpeljal proces celostnega, z vključevanjem najširšega kroga deležnikov podprtega, upravljanja rečnih koridorjev mednarodnih rek. Relativno uspešno je povezal vse sektorje, ki upravljajo oz. vplivajo na rečni koridor. Z ustrezno vodeno komunikacijo je uspel uskladiti oziroma omiliti nekatere že desetletja prisotne medsektorske in lokalne konflikte. Uspešen je bil tudi pri vključevanju in aktivaciji deležnikov, predvsem tistih z rekreacijsko - turistično - razvojnimi interesi, tudi lokalnih skupnosti. Prav preko tega skupnega interesa je projekt spodbudil njihovo povezovanje, ustanovitev Skupine za Dravo, in pripravo in izvajanje regionalnih in medregionalnih razvojnih projektov.

Med njimi izstopata urejanje Dravske kolesarske poti (od avstrijske do hrvaške meje), poti ki naj bi predstavljala »hrbtenico« in povezovalca turističnega produkta Dravskega rečnega koridorja, ter organizacija Drava Festivala. Festival, ki je pod okriljem Skupine za Dravo prvič potekal leta 2016, združuje številne izobraževalno ter rekreacijskoturistične dogodke na celotnem območju ob Dravi v Sloveniji. Cilj festivala je Dravo in njene številne danosti približati lokalnim prebivalcem, dvigniti zavest o kakovostnem življenjskem okolju, ki ga reka omogoča ter o pomenu njegovega ohranjanja ter spodbuditi sodelovanje za skupen trajnostni razvoj in promocijo območja reke Drave v Sloveniji. Žal pa glavni lokalni rezultat projekta SEE River, torej Razvojni koncept rečnega koridorja Drave med Mariborom in Zavrčem ni bil nadgrajen z regionalnim prostorskim načrtom, pa tudi na sektorsko načrtovanje ni imel bistvenega vpliva. V Slovenija je regionalna raven prostorskega načrtovanja skoraj povsem neaktivna in tudi projekt ni uspel spremeniti tega dejstva.

Še najuspešneje je bil Razvojni koncept rečnega koridorja Drave med Mariborom in Zavrčem implementiran pri pripravi Programa ukrepov za trajnostno upravljanje Drave na odseku od Maribora do Središča ob Dravi, ki je bil pripravljen v sklopu projekta LIVEDRAVA. Program je sicer vodarsko - naravovarstveni načrt, ki konkretizira del vsebin Razvojnega koncepta, in služi kot osnova za pripravo izvedbenih načrtov.

Ravninski dravski rečni koridor je energetsko - kmetijsko - poselitveno območje, podvrženo izrazitim hidrološkim spremembam, hkrati pa ekosistemsko pomembno območje z visoko biotsko pestrostjo. Kljub opisanim negativnim posledicam rabe vode in prostora ima območje več razvojnih priložnosti. Mednje sodi vsekakor razvoj na vodo 
GEOGRAFIJ Podravja

A. Grmovšek, S. Veberič: Celostno upravljanje rečnih koridorjev v teoriji in praksi primer koridorja ravninske Drave

in obrežje vezane, predvsem longitudinalne rekreacije (obvodne kolesarske, pohodne poti, plovba in obrežna rekreacija), povezane s kvalitetno interpretacijo okoljske in naravovarstvene pomembnosti reke in obrečnega prostora ter kulturne dediščine tega območja. Kmetijstvo se bi lahko preusmerjalo v lokalno oskrbno, okoljsko manj obremenjujoče, ekološko kmetijstvo z bogato dopolnilno turistično in gostinsko ponudbo na kmetijah. Pomembna je povezava turističnih produktov v koridorju, predvsem pa tudi njihova navezava na termalni, kulturni, vinski in gorski turizem širše regije. Ob ohranjanju in izboljševanju stanja okolja ter zmanjševanju poplavne ogroženosti se bo ob prej opisanem razvoju hkrati povečevala privlačnosti prostora, kar lahko posledično pripomore tudi $\mathrm{k}$ spodbujanju drugih, na naravnogeografske dejavnike manj vezanih oblik razvoja.

Prihodnost dravskega rečnega koridorja je v rokah odločanja in aktivnosti na nacionalni ravni, sektorskih upravljavcev, predvsem pa v rokah lokalnih skupnosti, gospodarskih subjektov, interesnih združenj in lokalnega prebivalstva. Kljub spremembam in posameznim pozitivnim trendom se slednje še vedno premalo zaveda potrebe in možnosti kreiranja razvoja in varovanja svojega domačega območja.

\section{Literatura in viri}

Anzeljc, D., Kobold M. 2013: Hidrološka analiza poplavnega dogodka na Dravi 5.11.2012. Zbornik elaboratov Mišičevega vodarskega dne 2013. Maribor.

Bizjak, A., Grmovšek, A., Marolt, L., Softić, M., Veberič, S. 2013: Kako do usklajenega medsektorskega upravljanja rečnih koridorjev sodobnih rek - primer spodnje Drave. Ekolist 10. Maribor.

Bizjak, A., Grmovšek, A., Marolt, L., Skorza, A., Softić, M., Veberič, S. 2013: Izdelava razvojnega koncepta rečnega koridorja na primeru reke Drave od Maribora do Zavrča. Zbornik elaboratov Mišičevega vodarskega dne 2013. Maribor.

Božič, L. 2003: Mednarodno pomembna območja za ptice v Sloveniji 2. Predlogi Posebnih zaščitenih območij (SPA) v Sloveniji. Ljubljana.

Grmovšek A., Softić M., Bizjak A. 2015: Ohranjanje in obnavljanje rečnih morfoloških procesov - zakaj in kako? Primer spodnje Drave - Projekt SEE River. Poster, Zavod RS za varstvo narave. Maribor.

Hojnik, T. 2004: Ureditev reke Drave med državno mejo in jezom na Ptujskem jezeru. Zbornik referatov z Mišičevega vodarskega dne 2004. Maribor.

Juvan, S. 2015: Program ukrepov za trajnostno upravljanje Drave na odseku od Maribora do Središca ob Dravi. Elaborat, Vodnogospodarski biro Maribor. Maribor.

Klaneček, M., Čuš, I., Hojnik, T. 2005: Prodišča na Dravi med Markovci in Zavrčem ter možnosti učinkovitejših vzdrževalnih ukrepov. Acta hydrotehnica 23/38. Ljubljna.

Lampič, B. 2011: Spremembe v kulturni pokrajini. Spodnje Podravje pred izzivi trajnostnega razvoja, GeograFF 9. Ljubljana.

Lampič, B., Špes, M. 2011: Izstopajoči okoljski problemi kot ovira »ekoregije«. Spodnje Podravje pred izzivi trajnostnega razvoja, GeograFF 9. Ljubljana.

SEE River 2015: www.see-river.net, 27.2.2017.

Sovinc A. 1995: Hidrološke značilnosti reke Drave. Acrocephalus 16. Ljubljana.

Szalay, M. 2014: SEE River Joint Drava River Corridor Analysis Report, Preparation of the Drava River Framework Analysis of the International Drava River Corridor, SEE River. Elaborat, National Institute for Eviroment, Hungary. Budimpešta.

Štumberger, B. 1995: Drava med Mariborom in Središčem ob Dravi - področje konflikta

med varstvom narave in razvojno politiko. Acrocephalus 16. Ljubljana. 
The GeOgraphIES OF THE PodRAVJe REgion

A. Grmovšek, S. Veberič: Integrated river corridor management in theory and praxis lowland Drava river corridor example

ZRSVN 2006: Osnutek integralnega načrta upravljanja območja reke Drave, TRUD. Elaborat, Zavod RS za varstvo narave. Maribor. 


\title{
Motnost vode in premeščanje suspendiranih snovi v Podravju
}

\author{
FLORJANA ULAGA
}

Povzetek Povzetek Premeščanje hribinskega materiala je eden od dejavnikov, ki vplivajo na obseg in intenziteto učinkov voda. Spremljanje erozije in dinamike sedimentov $\mathrm{v}$ rekah prinaša oceno količine snovi, ki se premesti prek izbranega mesta $\mathrm{v}$ vodotoku $\mathrm{v}$ določeni časovni enoti. Največ suspendiranih snovi se $\mathrm{v}$ rekah premesti ob izrednih hidroloških razmerah, ko se poleg povečanega pretoka rek in prodonosnosti močno poveča tudi motnost vode oziroma količina suspendiranih snovi v vodi. Posledica premeščanja suspendiranih snovi $\mathrm{v}$ reki je zapolnjevanje akumulacijskih bazenov, zablatenje rečnega dna, otežen naravni ciklus kroženja vode zaradi slabšega dreniranja $\mathrm{v}$ vodonosnike ter prenos kemijskega onesnaženja. V okviru hidrološkega monitoringa površinskih voda je spremljanje premeščanja suspendiranih snovi v Podravju v preteklih šestih desetletjih potekalo na dvanajstih merilnih mestih. Spremljanje stanja sedimentov v rekah je tudi zakonodajna obveza držav članic Evropske unije.

Ključne besede: - motnost vode $\cdot$ suspendirane snovi $\cdot$ hidrološki monitoring • okoljska zakonodaja • Podravje •

NASLOV AVTORICE: Florjana Ulaga, mag., univerz. dipl. geograf, etnolog, kulturni antropolog, Agencija Republike Slovenje za okolje, Vojkova 1b, 1000 Ljubljana, Slovenija, e-naslov: florjana.ulaga@ gov.si. 


\title{
Water turbidity and suspended sediment transport in Podravje
}

\author{
FLORJANA ULAGA
}

\begin{abstract}
Movement of material is one of the factors that affect the scope and intensity of the effects of water. Monitoring of erosion and sediment dynamics in rivers is the calculation of the total quantity of the substance that is transported through the selected profile in the stream per unit of time. Most suspended solids in rivers moved in exceptional hydrological situations where, in addition to increasing the flow of rivers and debris transport, greatly increase the turbidity of the water and the amount of suspended solids. The concenquence of movements of suspended solids in the river is filling the reservoirs, soil sealing of the river bottom, difficult natural cycle of water circulation due to deterioration in the draining aquifers, and the transfer of chemical contamination. In the context of the hydrological monitoring of the surface water monitoring of suspended solids in the Podravje held at twelve measuring points over the past six decades.
\end{abstract}

Keywords: - water turbidity • suspended sediment - hydrological monitoring • environmental legislation • Podravje •

CORRESPONDENCE ADDRESS: Florjana Ulaga, M.S., univerz. dipl. geograf, etnologist, cultural antropologist, Slovenian Environment Agency, Vojkova 1b, 1000 Ljubljana, Slovenia, e-mail: florjana.ulaga@gov.si. 


\section{Uvod}

Dinamiki gibanja plavin $\mathrm{v}$ vodi sledimo $\mathrm{z}$ merjenjem vsebnosti snovi, iz katere izračunamo premeščanje kot produkt s pretokom vode. Meritev vsebnosti suspendiranega materiala je namenjena izračunu skupne množine suspendirane snovi v vodi, ki se premesti preko izbranega prereza vodotoka v določenem času. Na podlagi izmerjenih količin po reki premeščenega sedimenta ugotavljamo erozijske značilnosti porečja ter spremembe $\mathrm{v}$ rečni strugi in na rečnem bregu, poznavanje hitrosti premeščanja suspendiranih snovi pa pripomore $\mathrm{k}$ boljši oceni dinamike morebitnega kemijskega onesnaženja.

Večje količine premeščenih sedimentov povzročajo zapolnjevanje akumulacij in zablatenje rečnega dna ter s tem oteženo naravno pronicanje vode v podtalje, ob znatno povečanih količinah suspendiranih snovi v vodi pa je oteženo tudi pronicanje svetlobe $\mathrm{v}$ globino, kar otežuje rast rečne vegetacije ter poslabšuje življenjske pogoje rib ter drugih vodnih organizmov. S poznavanjem količin in hitrosti premeščanja ter kakovostnega stanja suspendiranih snovi lažje in pravilneje ugotavljamo kakšne so ekološke razmere reke ali rečnega odseka in katere ukrepe bi morali smiselno izvajati za izboljšanje stanja ekosistemov.

\section{Monitoring vsebnosti suspendiranih snovi}

Začetek monitoringa vsebnosti in premeščanja suspendiranih snovi v Sloveniji sega glede na arhivske podatke Agencije Republike Slovenije za okolje v leto 1955. Najprej so z vzorčenjem in izračunom količin premeščanja suspendiranih snovi pričeli na vodomernih postajah v Radečah in v Šentjakobu na Savi in v Velikem Širju na Savinji. V naslednjem letu so monitoring vzpostavili tudi na Dravi na Ptuju in na Muri v Petanjcih. Temu so sledile uvedbe meritev na vseh večjih rekah, krajše obdobje pa je odvzem vzorcev potekal tudi na manjših rekah, kot so Ložnica, Pesnica, Tržiška Bistrica. Najkasneje so z vzorčenjem pričeli na rekah jugozahodne Slovenije, na Reki leta 2001, na Dragonji in Rižani pa leta 2006. V 60 letnem nizu je bilo skupno v monitoring Agencije vključenih 44 vodomernih postaj. Na nekaterih postajah odvzem vzorcev ni potekal celotno obdobje, postaja je lahko delovala nekaj let, nato več let ni bilo odvzema vzorcev, kasneje pa je bil monitoring ponovno vzpostavljen (Ulaga, 2011).

Monitoring vsebnosti suspendiranih snovi se v Sloveniji izvaja po priporočilih Svetovne meteorološke organizacije in ob upoštevanju standardov:

1. ISO 11923:1997 Determination of suspended solids by filtration through glass-fibre filters

2. ISO 5667-17:2000 Guidance on sampling of suspended sediments

3. ISO 5667/PRF-17 Guidance on sampling of bulk suspended solids

4. EPA 180.1 Turbidity measurement standard

$\mathrm{Na}$ izbranih vodomernih postajah poteka odvzem vzorca vode. Odvzeti vzorci z volumnom 1 litra so analizirani v laboratoriju po klasični filtracijski metodi. Rezultati analiz so izmerjene vsebnosti suspendiranega materiala (c), izražene $\mathrm{v} g / \mathrm{m}^{3}$ vode. 
Zaradi erozivnih lastnosti padavin in spiranja sedimentov v rečne struge, se največje količine suspendiranih snovi skozi rečni profil premestijo ob visokovodnem stanju. Zato je poznavanje hidroloških razmer in vzorčenje vode takrat najbolj pomembno. Pogostost vzorčenja je tako odvisna od količine padavin oziroma od višine vode v strugi oziroma od pretoka vode. $V$ izrednih hidroloških razmerah, ko je hitrost vode izjemna ali ko reka prestopi bregove, klasičen ročen odvzem vzorcev pogosto ni mogoč. Tako so največje vsebnosti in količine premeščenih suspendiranih snovi v resnici lahko še nekoliko večje, kot to lahko ugotovimo na podlagi ročno odvzetih vzorcev.

Največje vrednosti premeščenih suspendiranih snovi v celotnem obdobju opazovanj so bile izmerjene leta 1958 v Muri v Petanjcih, kar 11658 kg/s, v Savi v Hrastniku, ko so septembra 2007 v vzorcu izmerili dobrih $7500 \mathrm{~kg} / \mathrm{s}$, in v Drava v Ptuju septembra 1965 skoraj $5000 \mathrm{~kg} / \mathrm{s}$ (Arhiv, 2017).

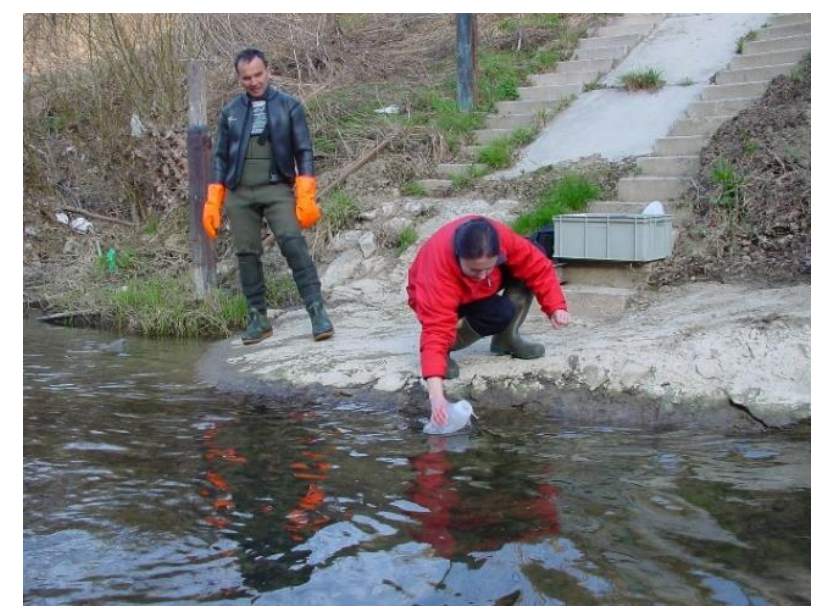

Ročni odvzem vzorca vode.

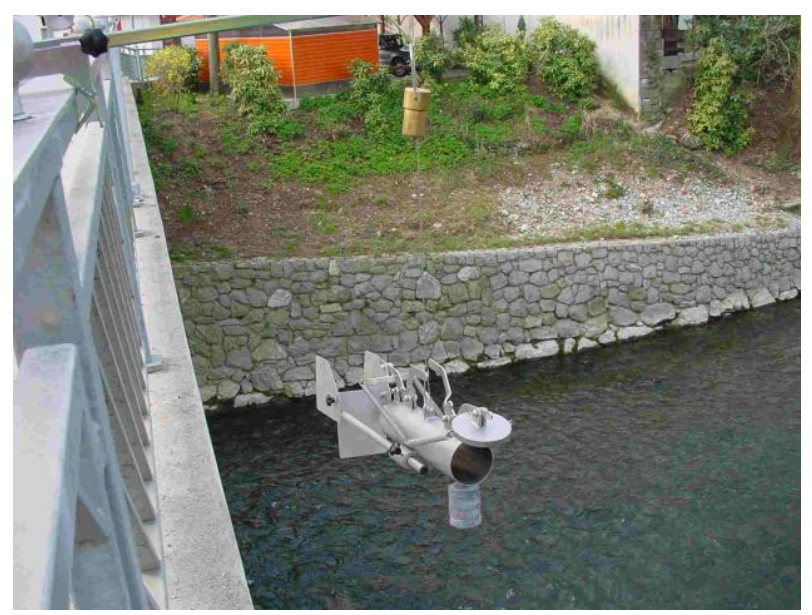

Odvzem vode z batometrom. 
Predvidevanje vsebnosti suspendiranih snovi v reki je težavno. Upoštevati je treba $\mathrm{v}$ katerem delu vodozbirnega zaledja so bile padavine, kakšna je geološka sestava tal na tem območju, predhodno namočenost zemljišča pa tudi čas od zadnjega visokovodnega vala.

\section{Motnost vode}

Motnost vode lahko interpretiramo kot merjenje relativne čistosti vode, v kateri so prisotni disperzni in suspendirani delci. Motnost merimo s turbidimetri v enotah FNU (Formazin nephelometric unit). Prisotni delci onemogočajo direkten prehod svetlobnega žarka, saj se ta lomi, odbija in absorbira. Motnost je torej odraz vpliva prisotnih delcev na razpršenje svetlobnega žarka, ne gre pa za neposredno merjenje vsebnosti suspendiranih snovi. Raztros svetlobnega žarka je odvisen od množine delcev, njihove oblike, sestave in sposobnosti absorbiranja svetlobe ter po drugi strani od valovne dolžine vpadne svetlobe. $Z$ naraščanjem števila delcev v vodi prihaja do kombiniranega raztrosa in velike absorbcije svetlobe. Pri določeni količini suspendiranih snovi v vodi se detekcija prepuščene in sipane svetlobe $\mathrm{v}$ hipu zniža. Ta vrednost označuje zgornjo mejo merljivosti motnosti vode.

Motnost vode se v okviru hidrološkega monitoringa na Agenciji Republike Slovenije meri z avtomatskim optičnim merilnikom SOLITAX-sc (Hach Lange Company). Merilna metoda merilnika je sestavljena iz klasične nefelometrične metode in dodatnega senzorja v glavi merilnika, ki meri sipanje svetlobe in posledično izračun motnosti vode. Merilnik se je na podlagi rezultatov testnih meritev izvedenih na ARSO v letu 2007 izkazal kot primeren za spremljanje meritev motnosti, saj se je ob povečanju motnosti v vodotoku ustrezno odzval (Ravnik, Ulaga, 2010). Delovanje merilnika je bilo preverjeno s sočasnim ročnim odvzemom vzorca vode in kasnejšo laboratorijsko analizo.

Za dobro poznavanje motnosti vode je neobhodno urno spremljanje spreminjanja parametra. Primerjava izmerjenih vrednosti na večih merilnih mestih iste reke pripomore $\mathrm{k}$ boljšemu poznavanju dejanskega dogajanja v reki. Sočasno poznavanje ostalih parametrov, kot sta npr. pretok in temperatura vode, pa omogočajo odkrivanje dogajanja v celotnem porečju. Zlasti natančna analiza izrednih hidroloških stanj, tako visokovodnih valov kot daljšega sušnega obdobja omogoča prepoznavanje izrednega dogajanja v reki.

\section{Odnos med vsebnostjo suspendiranih snovi in motnostjo vode}

Vsebnost suspendiranih snovi v vodi in motnost vode razumemo kot enoznačno, saj oboje predstavlja količino lebdečih delcev v vodi. Pa vendar je vzpostavitev odnosa motnost vsebnost suspendiranih snovi težava, na katero naletimo pri analizi rezultatov motnosti. Motnost je ovrednotena na osnovi sipanja in presevanja svetlobe, nanjo vpliva več faktorjev in zato ni enolične povezave $\mathrm{z}$ vsebnostjo snovi v vzorcu, ki ji določamo težo in jo izražamo $\mathrm{v} g / \mathrm{m}^{3}$.

Dobra korelacija med motnostjo in vsebnostjo suspendiranih snovi je možna v primeru, ko so delci relativno homogene zrnavosti in sestave. Merjenje motnosti prinaša takojšnjo oceno o relativni vsebnosti suspendiranih snovi, vendar je treba opraviti dodatne meritve za izdelavo kalibracijske krivulje, s katero poskušamo transformirati izmerjeno motnost v vsebnost. Zato je za vsako reko oziroma za vsako merilno mesto pred vzpostavitvijo 
realnega odnosa med vsebnostjo suspendiranih snovi v vodi in motnostjo treba opraviti umerjanje merilnika $\mathrm{s}$ pomočjo ročnega odvzema vzorcev in izvajanja meritev $\mathrm{v}$ laboratoriju. Pri ugotavljanju korelacije je poleg hidroloških značilnosti treba upoštevati tudi geološke značilnosti porečja in številne druge vplivne parametre (Ravnik, Ulaga, 2010).

Ugotavljanje odnosa med motnostjo in vsebnostjo suspendiranih snovi je v okviru državnega hidrološkega monitoringa potekalo na vodomerni postaji na reki Sori v Suhi, v padavinskem obdobju novembra 2007. Izbrani obdobji sta predstavljali reprezentativno padavinsko obdobje za potek dogajanja ob prehodu slabega vremena. Vidni so vrhovi v signalu za motnost in istočasno vrhovi vsebnosti suspendiranih snovi. Potek motnosti je precej v skladu tudi s potekom signala za pretok. Merilnik motnosti se je v obeh padavinskih obdobjih odzval na padavinski signal ter posledično povišanje vsebnost suspendiranih snovi v skladu s pričakovanji. Dogajanje pred intenzivnimi padavinami je nekoliko nekonsistentno.

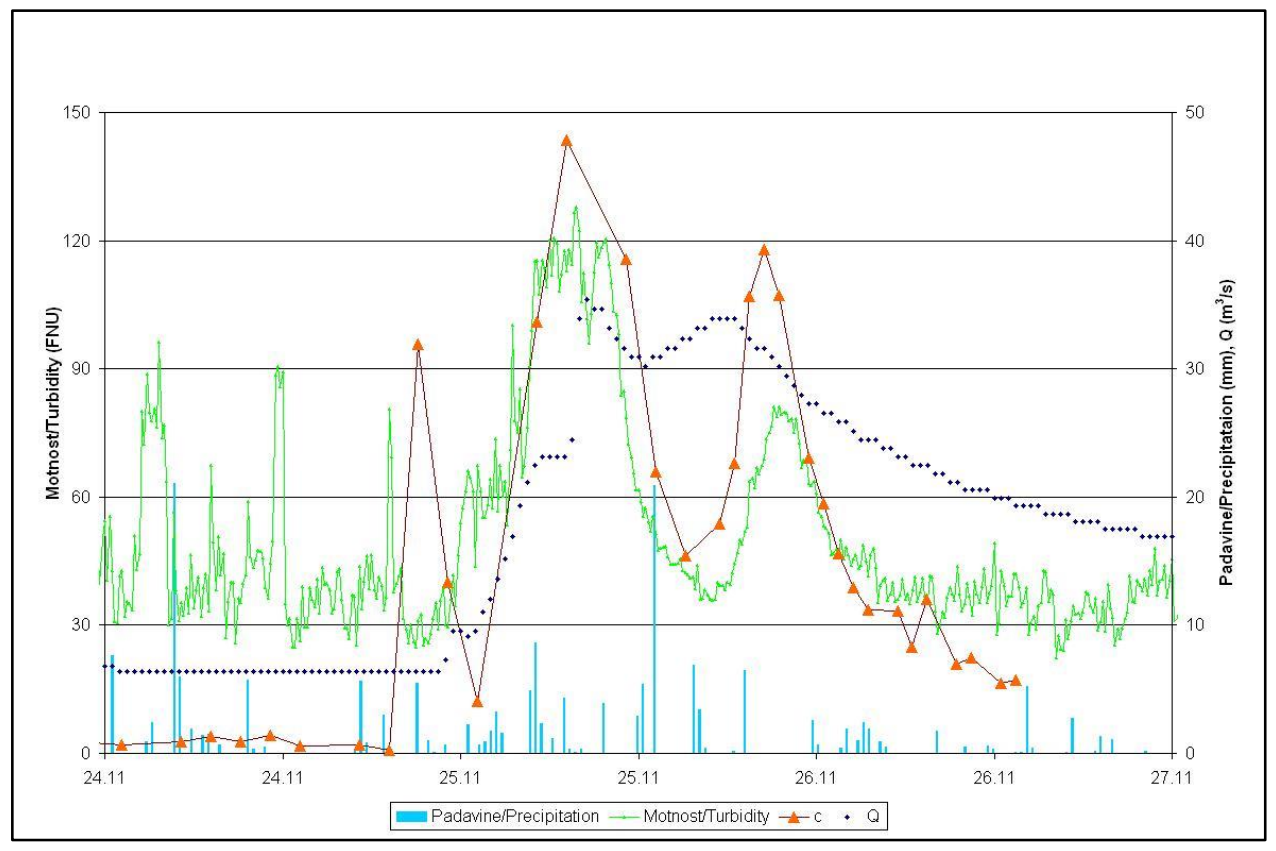

Rezultati meritev motnosti, vsebnosti suspendiranih snovi (c), pretoka $(Q)$ in padavin med izrednima padavinskima dogodkoma na Sori, novembra 2007.

\section{Monitoring suspendiranih snovi v Podravju}

V Podravju se je v preteklih desetletjih monitoring suspendiranih snovi izvajal na osmih vodomernih postajah med leti 1956 in 2006. Najdaljše obdobje monitoringa je bilo na vodomernih postajah Zamušani na Pesnici (31 let), Videm na Dravinji, ter Ptuj na Dravi. Odvzem vzorcev ni bil zvezen. Na vodomerni postaji Ptuj na Dravi je odvzem vzorcev suspendiranih snovi potekal nezvezno 12 let, med leti 1965 in 1975. Največja vsebnost suspendiranih snovi je bila izmerjena ob visoki vodi 20.8.1966, $2802 \mathrm{~g} / \mathrm{m}^{3}$. 


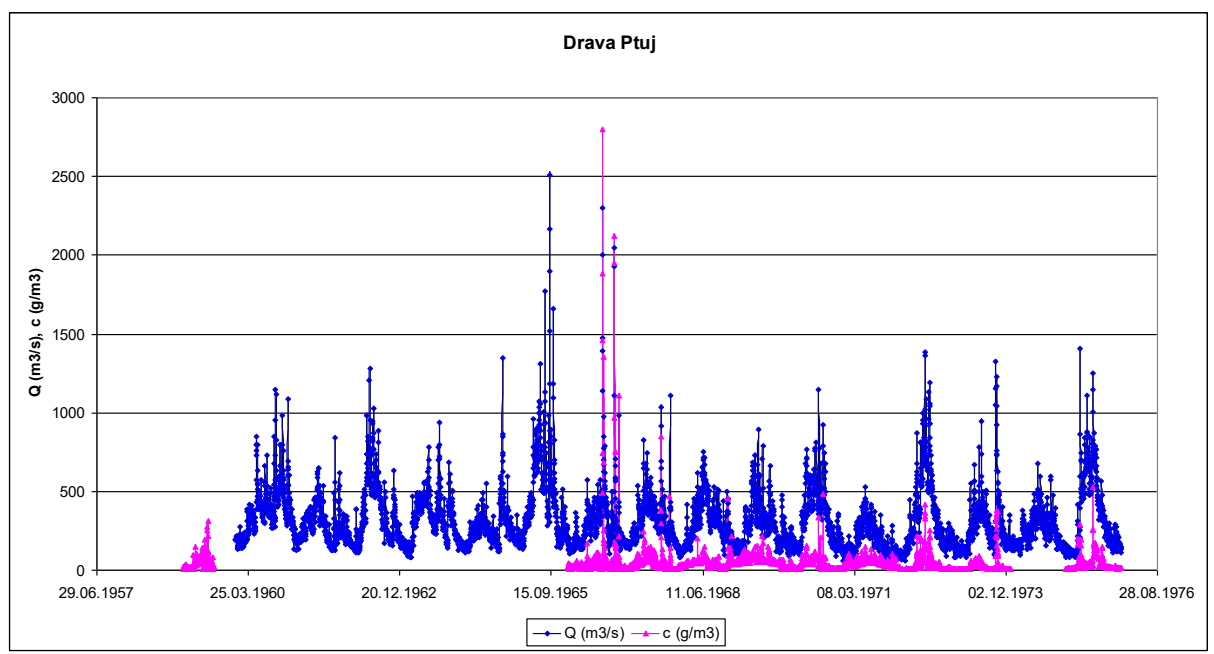

Pretok $(Q)$ in vsebnost suspendiranih snovi ( $c$ ) na vodomerni postaji Ptuj na Dravi med leti 1965 in 1975.

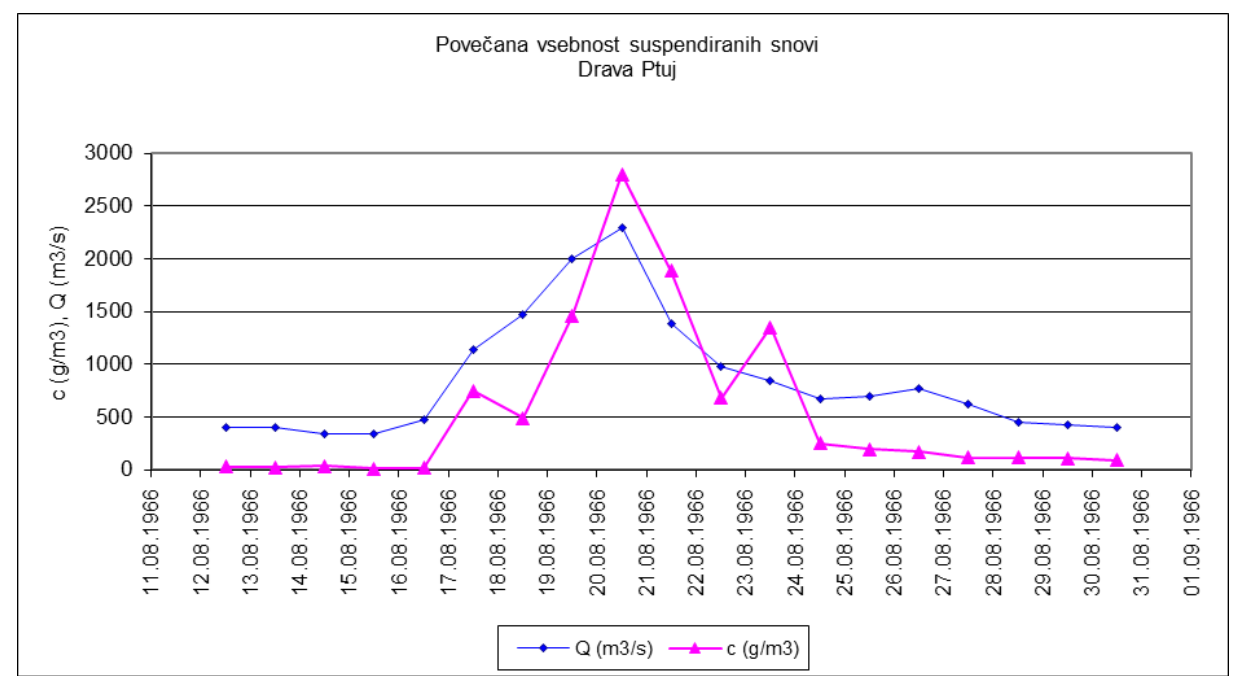

Povečana vsebnost suspendiranih snovi ob visoki vodi.

Dosedanje analize suspendiranih snovi so pokazale, da se približno $70 \%$ celotnega materiala premesti ob visokovodnih dogodkih. Največja vsebnost suspendiranih snovi je bila največkrat izmerjena tik pred največjim izmerjenim pretokom oziroma ob največjem izmerjenem pretoku vode. Vendar pa ob vsakem visokovodnem valu ni nujno močno povečana tudi vsebnost suspendiranih snovi, saj je dinamika plavin odvisna od celotnega hidrološkega dogajanja $\mathrm{v}$ reki, od predhodnega hidrološkega stanja, od intenzivnosti padavin v zaledju in od številnih drugih dejavnikov. Korelacija med izmerjeno vsebnostjo suspendiranih snovi in pretokom v preteklih desetletjih na vodomerni postaji Ptuj je prikazana na sliki spodaj. Vrednosti so prikazane na podlagi dnevnih vzorcev in povprečnih dnevnih pretokov. 


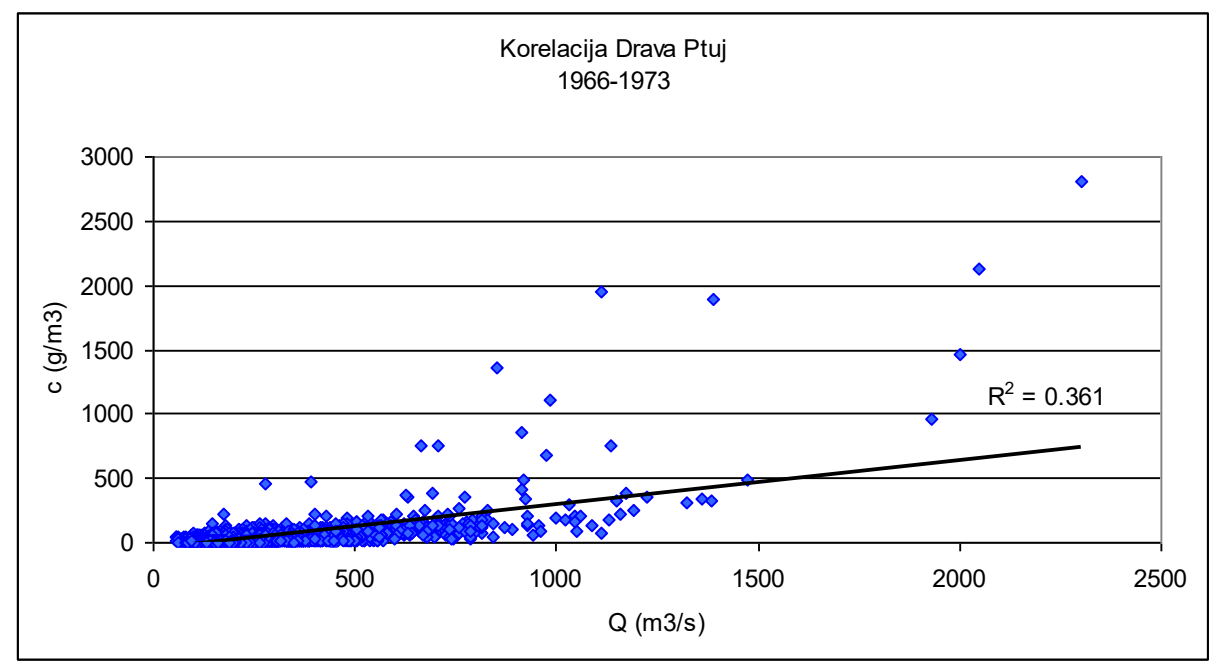

\section{Odnos med pretokom in vsebnostjo suspendiranih snovi Drave na Ptuju}

Za boljše poznavanje dejanske soodvisnosti hidroloških parametrov bi potrebovali bolj natančne meritve oz. poznavanje urnih vrednosti. Izračun celotne transportirane količine suspendiranih snovi je na podlagi pomanjkljivih podatkov in le občasnih odvzemov vzorcev otežen, potrdimo lahko le povečano dinamiko transporta sedimentov ob povečanem pretoku vode $\mathrm{v}$ merskem profilu.

\section{Motnost na merilnih mestih na Dravi}

Meritve motnosti Drave izvajajo Dravske elektrarne Maribor (DEM) z merilnikom Solitax-sc na štirih merilnih mestih akumulacij hidroelektrarn: HE Dravograd, HE Vuzenica, HE Mariborski otok in HE Markovci. Najprej so $\mathrm{z}$ meritvami pričeli v akumulaciji HE Dravograd v letu 2011. Meritve so potekale zvezno, vendar so v začetku izvajanja meritev merilniki delovali slabše in s prekinitvami. V analizo smo vključili podatke merilnikov motnosti na treh merilnih mestih v obdobju 1.1.2014 - 31.12.2016. Podatki o motnosti in pretoku na HE Dravograd so v nadaljevanju prikazani podrobneje.

Na merilnem mestu HE Dravograd je bila v obdobju 38. mesecev največja zabeležena vrednost motnosti 9698 NTU, kar presega merilno območje merilnika, ki je 0 - 4000 NTU. V letu 2015 je bilo merilno območje merilnika preseženo 19.2. ter 24.3. in v obdobju od 23.9. do 17.11. Ti podatki so napačni in jih ne moremo upoštevati pri analizi stanja motnosti reke Drave. Izredno povečana motnost, nad 1000 NTU, je bila zabeležena večkrat v pomladnih mesecih, od februarja do maja ter poleti od julija do septembra 2015. Tudi v letu 2016 je bila motnost Drave na merilnem mestu HE Dravograd večkrat povečana. Januarja, aprila, maja in decembra je pogosta presegala 1000 NTU.

Povečana motnost vode ni nujno povezana s povečanim pretokom na merilnem mestu. Vzrok je lahko tudi spiranje zemljin $\mathrm{v}$ zaledju ob lokalnih padavinah. Ob takšnih padavinskih dogodkih pretok vode $\mathrm{v}$ akumulaciji ni nujno povečan. 


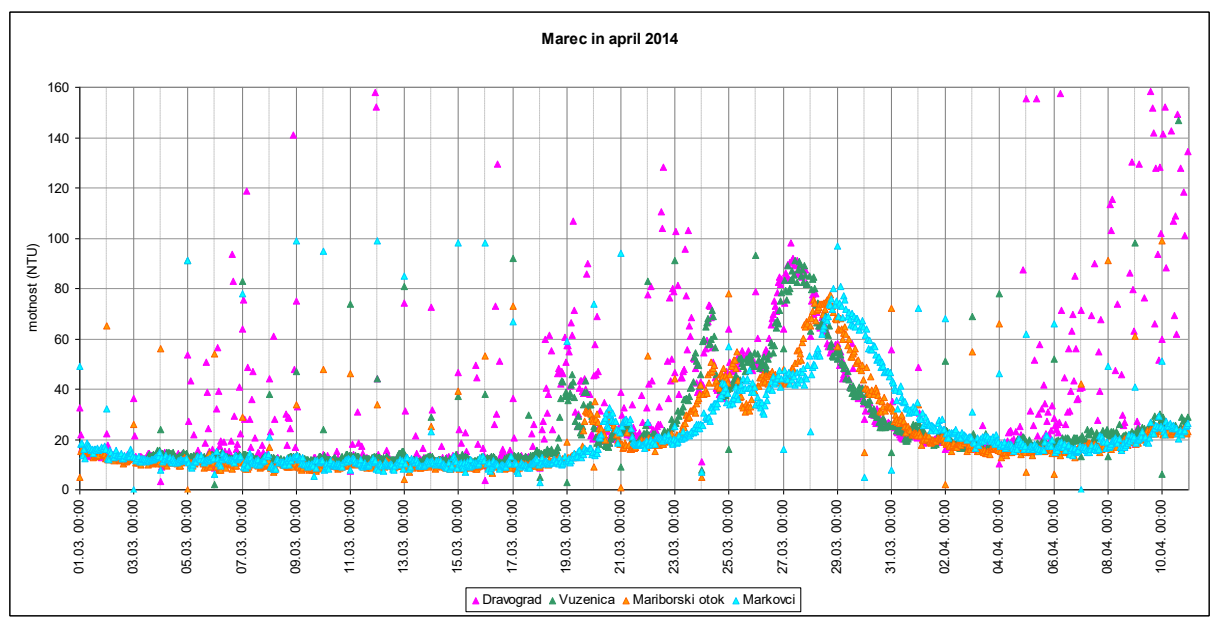

Motnost na merilnih mestih Drave, marec in april 2014. Meritve motnosti so na merilnih mestih usklajene.

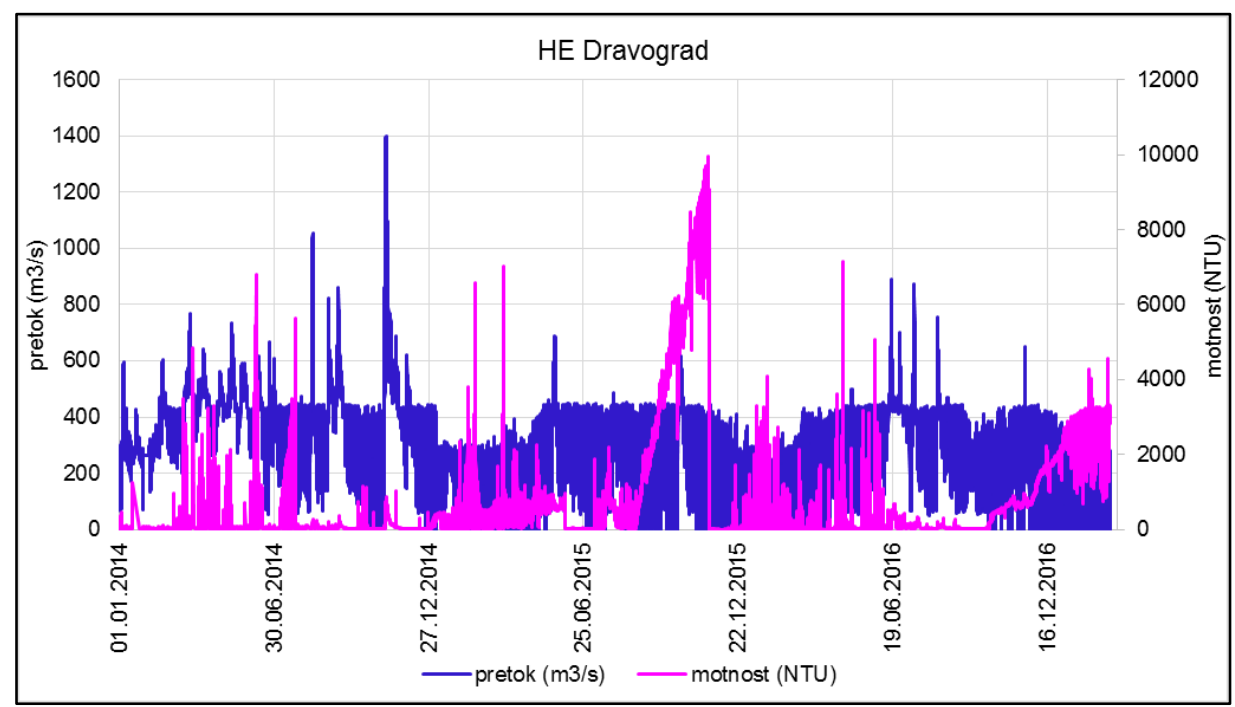

Pretok in motnost na merilnem mestu HE Dravograd.

V letu 2016 je bila motnost Drave občasno povečana tudi v primeru, ko na nobeni padavinski postaji Avstrijske hidrološke in meteorološke službe (Amt der Kärntner Landesregierung) niso izmerili padavin in ko tudi pretok Drave ni bil povečan. Takšen dogodek smo opazili julija na merilnem mestu HE Dravograd. Pri analizi naravnega spiranja sedimentov upoštevamo podatke o padavinah in eroziji. Po ugotovljenih naravnih lastnostih porečja pa lahko ugotavljamo, kje in v kolikšni meri so na spremembo režima hidroloških parametrov vplivali antropogeni dejavniki. 


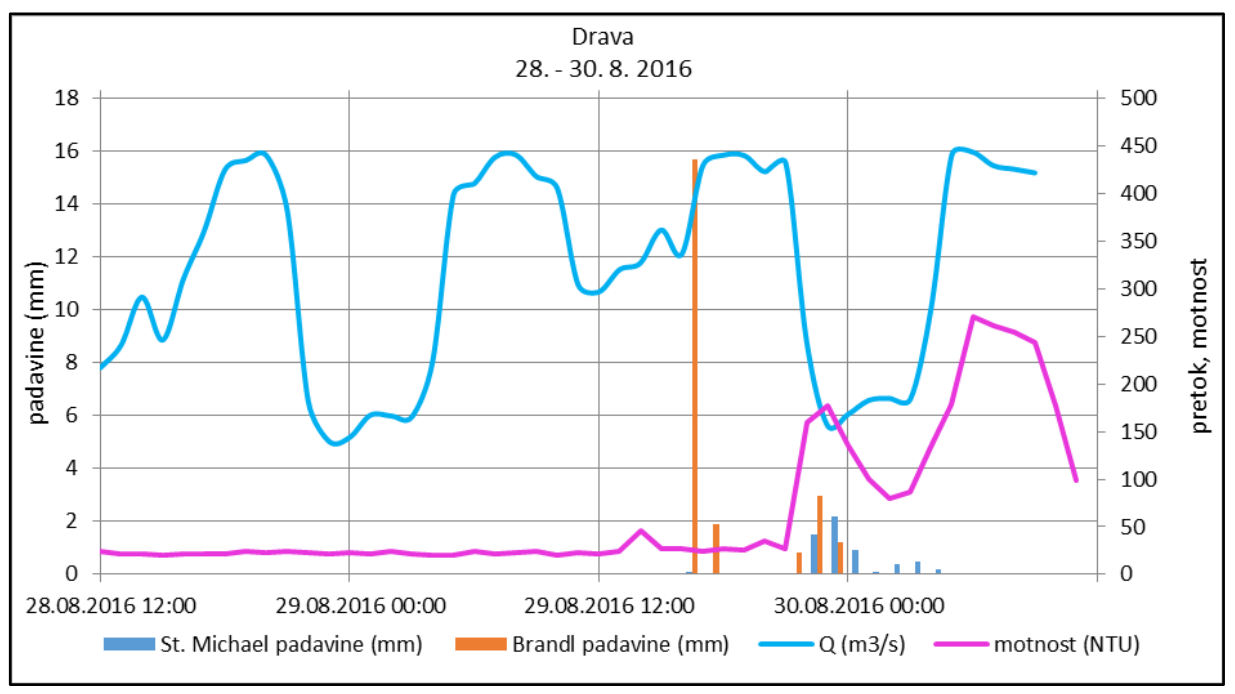

Povečana motnost Drave ne sovpada s povečanim pretokom na merilnem mestu, pač pa je lahko odraz padavin $v$ zaledju.

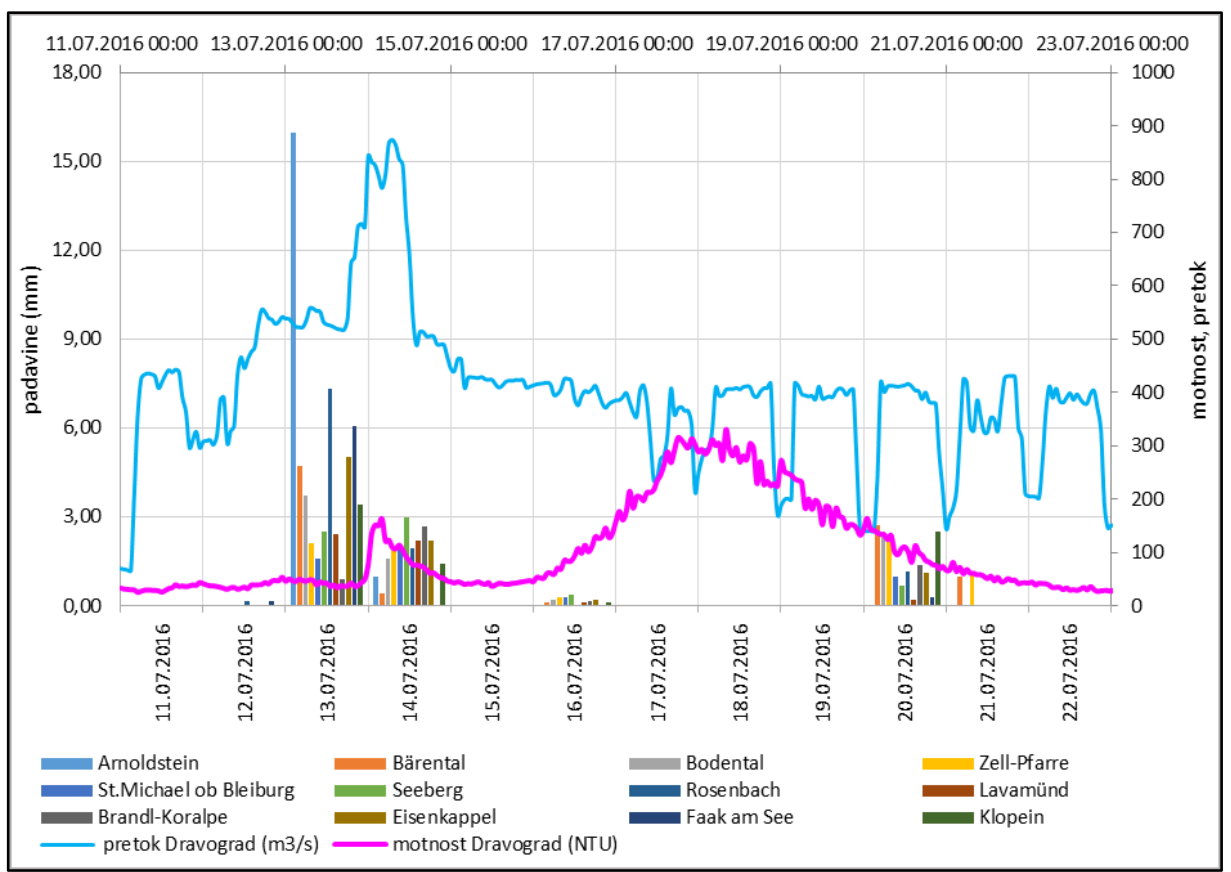

Pretok in motnost v akumulaciji HE Dravogradu ter padavine na dvanajstih postajah $v$ Avstriji. Kljub temu, da padavin v Avstriji niso namerili, je bila motnost Drave 18. julija 2016 precej povečana.

Povečana motnost vode ni nujno povezana s povečanim pretokom na merilnem mestu. Vzrok je lahko tudi spiranje zemljin $\mathrm{v}$ zaledju ob lokalnih padavinah. Ob takšnih padavinskih dogodkih pretok vode $\mathrm{v}$ akumulaciji ni nujno povečan. 
V letu 2016 je bila motnost Drave občasno povečana tudi v primeru, ko na nobeni padavinski postaji Avstrijske hidrološke in meteorološke službe (Amt der Kärntner Landesregierung) niso izmerili padavin in ko tudi pretok Drave ni bil povečan. Takšen dogodek smo opazili julija na merilnem mestu HE Dravograd. Pri analizi naravnega spiranja sedimentov upoštevamo podatke o padavinah in eroziji. Po ugotovljenih naravnih lastnostih porečja pa lahko ugotavljamo, kje in v kolikšni meri so na spremembo režima hidroloških parametrov vplivali antropogeni dejavniki.

Motnost na merilnem mestu HE Dravograd je bila večkrat povečana tudi, ko meritve motnosti na ostalih merilnih mestih niso izkazovale povečanih vrednosti, kar je lahko posledica izrednega dogajanja v odseku Drave pred HE Dravograd.

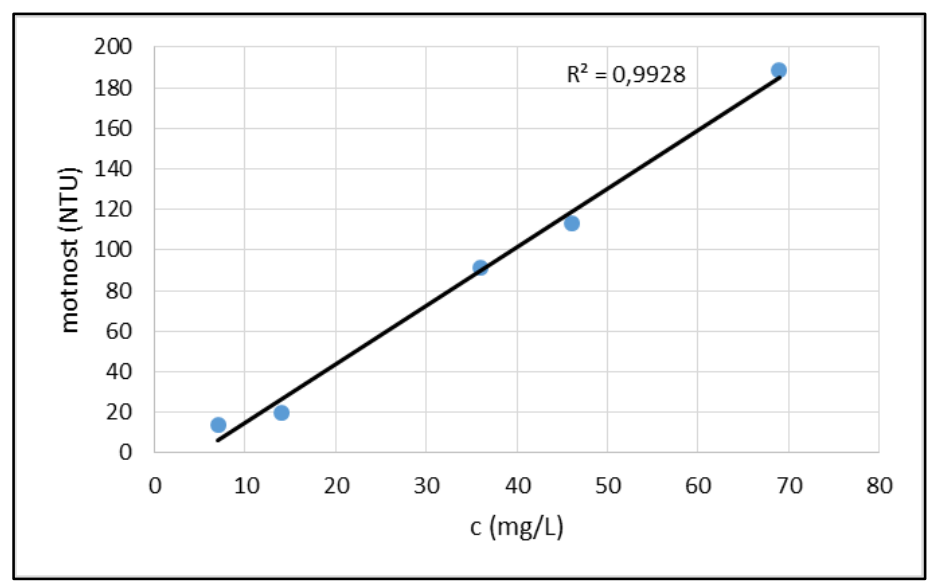

Razmerje med vsebnostjo suspendiranih snovi in motnostjo v Dravi

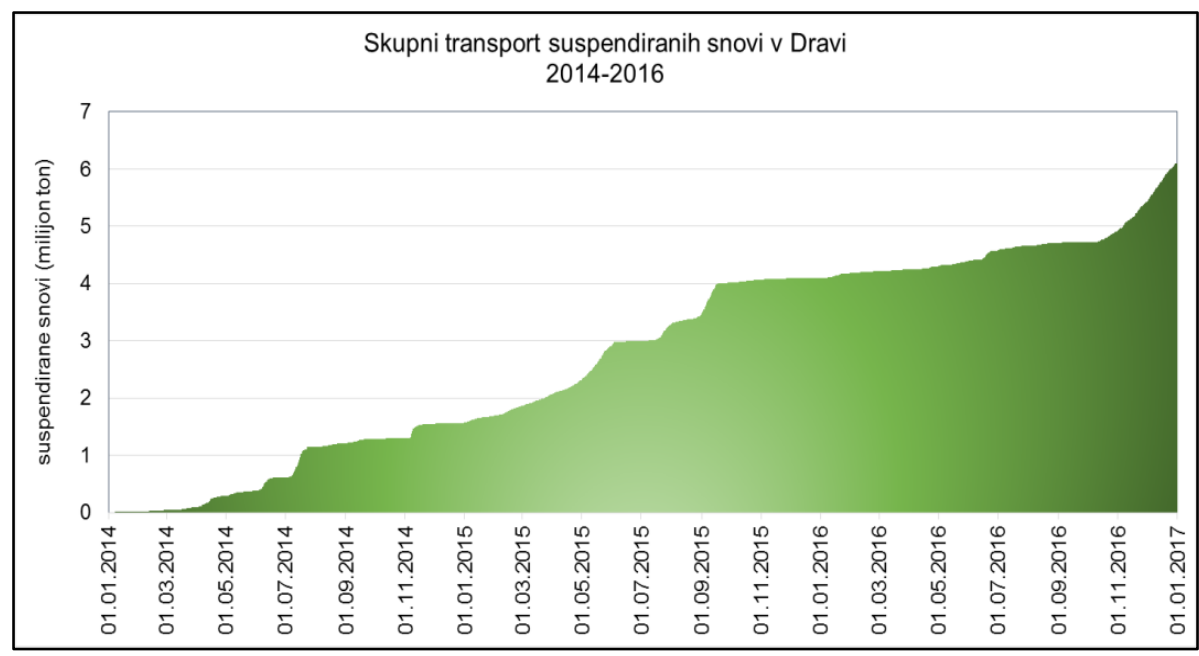

Drava je v triletnem obdobju transportirala skozi HE Dravograd 6 milijonov ton suspendiranih snovi. 


\section{Rezultati meritev motnosti in suspendiranih snovi}

Za preverjanje ustreznosti delovanja merilnika motnosti so bili v letih 2014 in 2015 odvzeti vzorci vode. Analize vsebnosti suspendiranih snovi so bile opravljene v laboratoriju Agencije Republike Slovenije za okolje. Odnos med obema parametroma kaže ujemanje, kar nakazuje, da nekoliko okorne in časovno zamudne meritve suspendiranih snovi na podlagi odvzetih vzorcev, lahko nadomestimo z meritvami motnosti s samodejnim merilnikom.

Rezultati laboratorijskih analiz odvzetih vzorcev in motnosti

\begin{tabular}{|l|c|c|c|c|}
\hline Merilno mesto & $\begin{array}{c}\text { Datum } \\
\text { odvzema }\end{array}$ & $\begin{array}{c}\text { Čas } \\
\text { odvzema }\end{array}$ & $\begin{array}{c}\text { Suspendirane } \\
\text { snovi (g/m3) }\end{array}$ & $\begin{array}{c}\text { Motnost } \\
\text { (NTU) }\end{array}$ \\
\hline HE Dravograd & 18.8 .2014 & $11: 00$ & 69.1 & 189 \\
\hline HE Dravograd & 27.8 .2014 & $10: 25$ & 6.92 & 14 \\
\hline HE Mariborski otok & 18.8 .2014 & $9: 45$ & 35.9 & 91 \\
\hline HE Mariborski otok & 27.8 .2014 & $9: 10$ & 13.9 & 20 \\
\hline HE Dravograd & 11.8 .2015 & $9: 00$ & 45.61 & 113 \\
\hline
\end{tabular}

Na podlagi sicer majhnega števila ročno odvzetih vzorcev in dobrega ujemanja med podatki obeh parametrov, lahko ugotavljamo, kolikšna je skupna količina premeščenih suspendiranih snovi v reki. Na merilnem mestu HE Dravograd se je v 36-ih mesecih premestilo 6 milijonov ton, na HE Vuzenica 9 milijonov ton in na HE Mariborski otok 16 milijonov ton suspendiranih snovi. Skupna količina premeščenih suspendiranih snovi se po reki navzdol povečuje, s tem pa se spreminjajo tudi ekološke razmere v reki.

\section{Zaključek}

Vsebnost suspendiranih snovi oziroma motnost Drave na merilnih mestih Dravskih elektrarn Maribor se spremlja šele krajše obdobje. Glavne ugotovitve po pregledu rezultatov meritev s samodejnim merilnikom so sledeče:

- podatki ročno odvzetih vzorcev na podlagi katerih se analizira vsebnost suspendiranih snovi v vodi in podatki o motnosti vode, pridobljeni s pomočjo merilnika motnosti, izkazujejo dobro ujemanje;

- nihanje pretoka in motnosti na merilnem mestu ni vedno usklajeno; kljub dejstvu, da je motnost ob večjem pretoku običajno večja, pa je nenaden porast motnosti odvisen od mnogih dejavnikov in ni vedno posledica povečanega pretoka;

- motnost $\mathrm{v}$ reki je lahko povečana tudi zaradi izrednih in nenadnih padavin $\mathrm{v}$ zaledju;

- izjemno velike vrednosti motnosti so pogosto nenadne in se največkrat pojavijo le na enem od merilnih mest;

- najpogosteje je bila nadpovprečna nepričakovana motnost izmerjena na merilnem mestu HE Dravograd, zlasti v poletnih mesecih;

- občasno je motnost $\mathrm{v}$ reki lahko povečana tudi zaradi antropogenega vpliva, saj za njen porast ne najdemo naravnih hidroloških vzrokov;

- dnevni potek srednjih vrednosti motnosti je med merilnimi mesti dokaj usklajen; 
- skupna količina premeščenih suspendiranih snovi se po reki navzdol povečuje, $\mathrm{s}$ tem pa se spreminjajo tudi ekološke razmere v reki.

Države članice Evropske unije morajo na področju varstva okolja spoštovati in upoštevati določila strateških dokumentov in okoljske zakonodaje. Poleg nacionalne zakonodaje področje varstva voda in vodnih organizmov urejata Vodna direktiva (Water Framework Directive; 2000/60/EC), katere osrednji cilj je vzpostaviti okvir za varstvo površinskih in podzemnih voda na celotnem ozemlju EU. Habitatna direktiva (Direktiva sveta Evrope 92/43/EGS o ohranjanju naravnih habitatov ter prosto živečih živalskih in rastlinskih vrst), ki opredeljuje živalske vrste v interesu Evropske skupnosti, za ohranjanje katerih je treba določiti posebna ohranitvena območja ter živalske vrste v interesu Evropske skupnosti, pri katerih za odvzem iz narave in izkoriščanje lahko veljajo ukrepi upravljanja.

Glavni okoljski cilj do leta 2020 je doseganje in ohranjanje dobrega stanja vseh površinskih in podzemnih voda, kar pomeni predvsem njihovo dobro ekološko stanje, dobro kemijsko in količinsko stanje, ugodno stanje za habitate in vrste ter zagotovitev ukrepov, ki bodo preprečili slabšanje ali zagotavljali ohranitev visoke kakovosti vodnih ekosistemov, kjer je ta že prisotna.

Med pomembnimi ukrepi za doseganje zgoraj navedenih ciljev je tudi ohranjanje vodnih habitatov in vodnega življa. $Z$ ne dovolj premišljenimi in strokovno nepodprtimi posegi $\mathrm{v}$ reke se lahko od tega cilja močno oddaljimo. $Z$ neustreznimi posegi v porečju in v reki lahko namreč močno, v nekaterih primerih pa tudi usodno, vplivamo na biotsko in kemijsko kakovost le-teh ter na stanje hidromorfoloških elementov.

\section{Literatura in viri}

Arhivski podatki, Amt der Kärntner Landesregierung.

Arhivski hidrološki podatki, Agencija Republike Slovenije za okolje.

Arhivski podatki motnosti in pretoka, Dravske elektrarne Maribor.

Ravnik, L., Ulaga, F. (2010) Vrednotenje vsebnosti suspendiranega materiala s pomočjo merilnika Solitax-sc, Hidrološki letopis Slovenije 2007, Agencija Republike Slovenije za okolje.

Ulaga F. (2011). Premeščanje suspendiranih snovi v slovenskih rekah, Hidrološki letopis Slovenije 2008, Agencija Republike Slovenije za okolje. 
GeOgRAFIJE PoDRAVJa

THE GeOgraPhies of the Podravje Region 


\section{GEOGRAFIJE KULTURNE POKRAJINE}

\section{THE GEOGRAPHIES OF CULTURAL \\ LANDSCAPE}





\title{
Spreminjanje rabe tal na območju obpanonske severovzhodne Slovenije v obdobju 2000-2015
}

\author{
IGOR ŽIBERNA
}

\begin{abstract}
Povzetek Avtor analizira rabo tal v letu 2000 in 2015 ter spremembe v rabi tal na območju obpanonske severovzhodne Slovenije. V prikaz smo zajeli enajst kategorij rabe tal: njive in vrtove, vinograde, sadovnjake, ostale trajne nasade, travnike, zemljišča $\mathrm{v}$ zaraščanju, mešano rabo zemljišč, gozd, pozidane in sorodne površine, ostale površine in vodne površine. Analizirane so tudi smeri prememb rabe tal, pri čemer smo velik poudarek dali spremembam obdelovalnih površin $\mathrm{v}$ neobdelovalne in obratno. Podatki so obdelani na nivoju celotne makroregije in 26 mikroregij.
\end{abstract}

Ključne besede: • raba tal $\bullet$ spremembe rabe tal $\bullet$ kmetijstvo $\bullet$ obpanonska severovzhodna Slovenija • GIS •

NASLOV AVTORJA: dr. Igor Žiberna, izredni profesor, Univerza v Mariboru, Filozofska fakulteta, Oddelek za geografijo, Koroška cesta 160, 2000 Maribor, Slovenija, e-naslov: igor.ziberna@um.si. 


\title{
Land use changes in the subpanonian northeastern Slovenia between 2000 and 2015
}

\section{IGOR ŽIBERNA}

\begin{abstract}
The author presents the results of the analysis of land use changes in the area of the subpanonian northeastern Slovenia between 2000 and 2015. In the analysis we cover the eleven categories of land use: arable land and gardens, the vineyards, the orchards, other permanent plantations, meadows, overgrowing areas, mixed land use, forests, builtup and related areas, other areas and the water areas. Analyzed are also the direction of the land use changes, while great emphasis was given to changes of the cultivated areas in the uncultivated and vice versa. Data are processed at the level of the entire macro-region and 26 micro-regions.
\end{abstract}

Keywords: • land use $\bullet$ land use changes $\bullet$ agriculture $\bullet$ subpanonian northeastern Slovenia $\bullet$ GIS • 


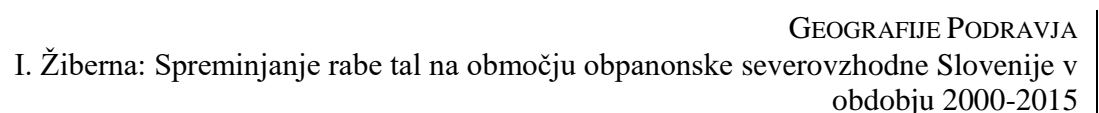

\section{Uvod}

Raba tal je koriščenje zemljišč, povzročeno s človekovo dejavnostjo v pokrajini in je eden od dobrih kazalcev pokrajinskih struktur in procesov (Kladnik, 1999: 192). Kot taka je odsev vzajemnega součinkovanja naravnih, zgodovinskih in socialno ekonomskih dejavnikov (Gabrovec, Kladnik, 1997: 11). Raba tal in njene spremembe so tudi odraz spremenjenih splošnih vrednot v družbi. Človek je s svojo dejavnostjo od začetka civilizacije rabo tal prilagajal svojim potrebam. Ena od najpomembnejših funkcij rabe tal je bila že od začetka kultiviranje zemljišč in proizvodnja hrane, ki je ena od najpomembnejših dobrin in zagotavlja obstoj posameznika in človeške vrste.

Za zagotavljanje primerne blaginje dane družbe je potrebna harmonija med zadovoljstvom z življenjem, zdravjem, možnostjo vseživljenjskega učenja, družabnim življenjem, občutkom varnosti in primernim okoljem (Vrabič, Kek, 2012: 26). Zagotavljanje kakovostne zdrave hrane v ustreznih količinah sodi zagotovo med enega od pomembnih kazalcev kakovosti življenja. V zadnjih nekaj letih se je trend svetovnih presežkov hrane obrnil v pomanjkanje hrane, kar je posledica rasti prebivalstva in dviga standarda v nekaterih razvijajočih se državah, ob tem pa še podnebnih sprememb in s tem povezanih vremenskih ujm in ekoloških nesreč.

Med enega od najpomembnejših vzrokov za pomanjkanje hrane sodi spreminjanje rabe tal, predvsem zmanjševanje obdelovalnih površin bodisi zaradi pozidave, ozelenjevanja ali ogozdovanja. Posledica teh procesov je zmanjševanje prehranske varnosti ne le v nerazvitih državah, pač pa utegne v spremenjenih gospodarskih in ekonomskih razmerah ogrožati tudi razvite države. Prehranska varnost zagotavlja, da imajo vsi ljudje v vsakem trenutku s fizičnega, družbenega in gospodarskega stališča dostop do zadostnih količin varne in hranljive hrane, s katero lahko zadovoljijo svoje prehranske potrebe in želje, ki jim omogočajo aktivno in zdravo življenje.

V preteklih nekaj desetletjih je bila pridelava hrane večja od rasti svetovnega prebivalstva, vendar je bila hrana neenakomerno razporejena zaradi česar se je število lačnih povečevalo. Leta 2009 je bila lačna ena milijarda ljudi, kar je največ po letu 1960 (Plut, 2012: 8). Kmetijstvo je tista dejavnost, katere glavni cilj je proizvodnja hrane, ob tem pa ima še druge funkcije, kot so ohranjanje kulturne pokrajine, ohranjanje poselitvenega vzorca, da ohranjanja kulturne identitete sploh ne omenjamo. V pogojih nezanesljive oskrbe s hrano na planetarni ravni in zaradi negativnih ekoloških posledic medcelinskih transportov hrane (promet postaja eden od najpomembnejših virov toplogrednih plinov), postaja zavedanje o pomenu lokalne samooskrbe s hrano eno ključnih strateških in političnih poudarkov pri načrtovanju razvoja družbe (Perpar, Udovč, 2010).

Rabe tal na območju Slovenije v primerjavi z ostalimi državami EU kaže na trende, ki v luči samooskrbnosti niso ugodni. Podatke o rabi tal na območju Evropske skupnosti (EU) sistematično zbira statistična pisarna Eurostat, ki deluje v okviru Evropske komisije. Podatki o rabi tal se zbirajo dvoplastno: v biogeografskem (land cover) in socioekonomskem (land use) pogledu. Leta 2009 je Eurostat za države Evropske skupnosti začel objavljati letne statistične preglede rabe tal v okviru projekta LUCAS. 
Prvo poročilo je zajelo le 23 članic EU, brez Bolgarije, Romunije, Cipra in Malte. Podatki o rabi tal so razvrščeni v naslednje razrede: gozdovi, obdelovalne površine (kamor so uvrščene njive, vrtovi in trajni nasadi), travniki, grmičevje, pozidane in ostale antropogene površine, gole površine in vodne površine. Metodologija se sicer nekoliko razlikuje od tiste, ki jo na Ministrstvu za kmetijstvo redno objavljajo pod naslovom kmetijska raba tal (slovenska metodologija je bistveno natančnejša), vendar pa nudi dovolj dober vpogled v stanje rabe tal na območju Evropske skupnosti, predvsem pa omogoča primerjalno analizo med državami.

Na območju obravnavanih držav EU med oblikami rabe tal prevladujejo gozdne površine (39 \%), sledijo obdelovalne površine $(24 \%)$, travniki $(20 \%)$, grmičevje $(6 \%)$, vodne površine $(5 \%)$, pozidane in ostale antropogene površine $(4 \%)$ in gole površine $(2 \%)$. Gozdnatost je najvišja v Skandinaviji (Finska 68 \%, Švedska 66 \%), na tretjem mestu pa se nahaja Slovenija s 63 \% gozdnih površin. Nad 50 \% gozdnih površin imata še Estonija (55\%) in Latvija (52\%). Sosednja Avstrija ima z gozdom pokritega $47 \%$ svojega površja.

Delež obdelovalnih površin je praviloma obratno sorazmeren z gozdnatostjo. Najmanj obdelovalnih površin so po metodologiji LUCAS leta 2009 beležile Švedska (4 \%), Irska (5\%), Finska (6\%) in Slovenija (11\%). Daleč najvišji delež obdelovalnih površin sta beležili Danska (48 \%) in Madžarska (47\%), sledile pa so Poljska (36 \%), Češka (35 \%) ter Nemčija in Italija s po $33 \%$ obdelovalnih površin. Povprečni delež obdelovalnih površin v obravnavanih 23 državah EU je znašal 24 \%. Sosednja gorata Avstrija je imela $17 \%$ obdelovalnih površin.

Ugotovimo torej lahko, da ima Slovenija v primerjavi z ostalimi državami EU visoko nadpovprečni delež gozdnih površin in podpovprečen delež obdelovalnih površin. Velika gozdnatost je sama po sebi sicer lahko ugodna, saj gozdovi predstavljajo pomemben ponor $\mathrm{CO}_{2}$ kot toplogrednega plina, $\mathrm{z}$ energetskega in ekonomskega vidika pa les predstavlja pomemben obnovljiv vir in surovino, ki bi ji v lesni industriji morali zvišati dodano vrednost. Kot bomo videli kasneje, pa imamo visok delež gozdnatosti v Sloveniji v veliki meri na račun zmanjševanja obdelovalnih površin. Po mnenju Pluta (2012) bi za stabilno prehransko, ekosistemsko in lesno uravnoteženost na ozemlju Slovenije zadostovala okoli $50 \%$ pokritost z gozdovi.

Še boljši kazalec samooskrbnosti posamezne države je primerjava obdelovalnih površin na prebivalca. Po ocenah bi v našem klimatskem območju za prehransko neodvisnost potrebovali okoli 0,3 ha obdelovalnih površin na prebivalca (Perpar, Kovačič, 2006: 64). Stanje v državah EU je glede tega neugodno. Le tretjina obravnavanih držav EU je leta 2009 izpolnjevala ta pogoj. Slovenija je v primerjavi z ostalimi obravnavanimi državami z 0,0858 ha obdelovalnih površin na prebivalca na samem dnu. Slabše stanje sta beležili le še Nizozemska in Belgija, pri čemer povprečje v EU znaša 0,2178 ha obdelovalnih površin na prebivalca. Problematika prehranske varnosti se torej dotika večine držav EU, pri čemer je stanje v Sloveniji med najslabšimi. Tudi znotraj Slovenije se pojavljajo velike razlike v obdelovalnih površinah na prebivalca. najvišje vrednosti so prav na območju severovzhodne Slovenije, kar je še eden od motivov za preučevanje sprememb rabe tal na tem območju. 


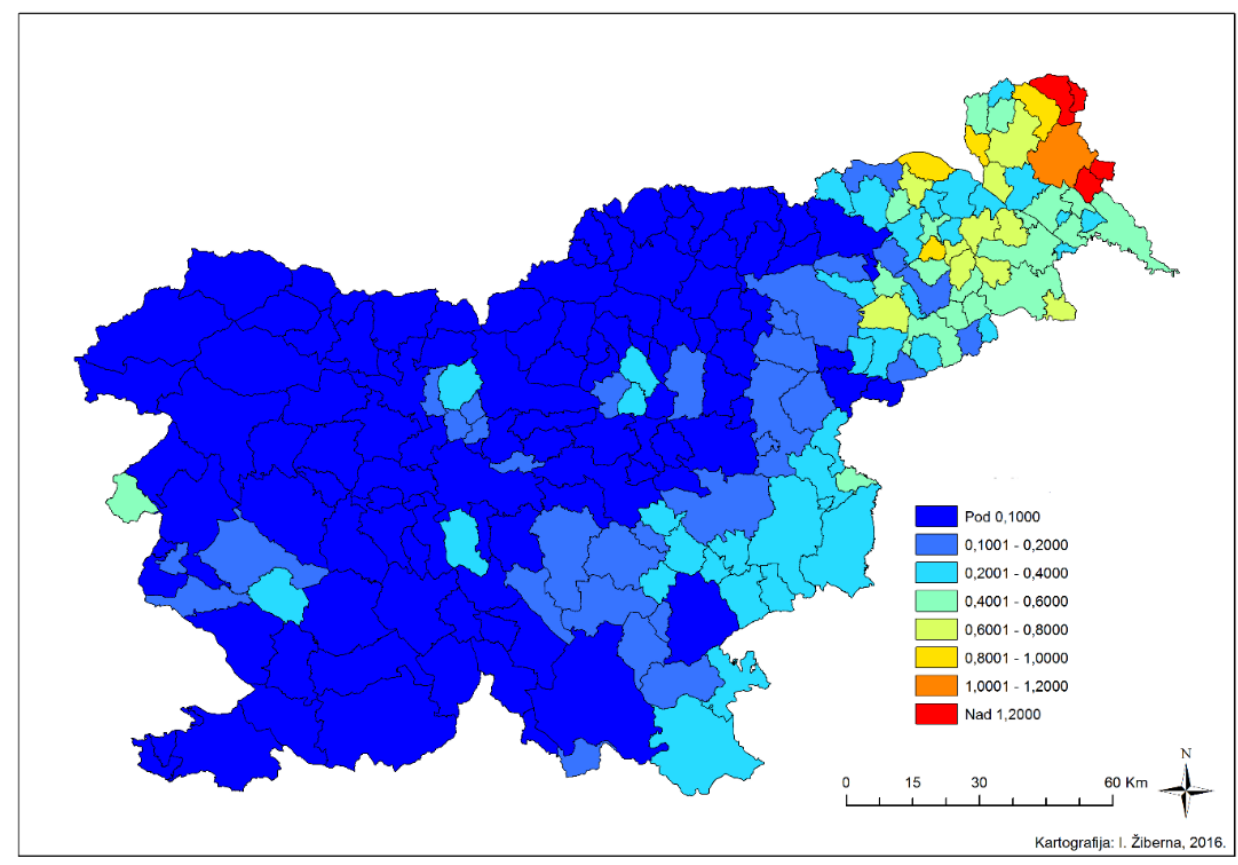

Obdelovalne površine na prebivalca (ha/preb.) po občinah v Sloveniji leta 2015.

\section{Metodologija}

V Sloveniji so v času po letu 1991 na voljo različne digitalne podatkovne zbirke o rabi tal. Pri naši analizi smo se naslonili na podatke o dejanski rabi kmetijskih in gozdnih zemljišč, katere evidenco je leta 2000 začelo uvajati tedanje Ministrstvo za kmetijstvo, gozdarstvo in prehrano. Metodologija se je vmes nekoliko spremenila, leta 2008 sprejeti Pravilnik o evidenci dejanske rabe kmetijskih in gozdnih zemljišč pa je jasno definiral 25 kategorij rabe tal (Pravilnik... 2008). Za naše potrebe smo uporabili digitalne podatke o rabi tal za leti 2000 in 2015. Podatki o rabi tal so v osnovi predstavljeni s poligoni, za lažjo analizo sprememb rabe tal pa smo vektorske podatke pretvorili $\mathrm{v}$ rastrske $\mathrm{z}$ velikostjo celice $5 \mathrm{~m}$ x $5 \mathrm{~m}$. Zaradi preglednejše analize smo skupine rabe tal generalizirali v 11 razredov: njive in vrtovi, vinogradi, sadovnjaki, ostali trajni nasadi, travniki, zemljišča $\mathrm{v}$ zaraščanju, mešana raba zemljišč, gozd, pozidana in sorodna zemljišča, ostalo in vodne površine.

\section{Geografski pregled}

Območje severovzhodne Slovenije po novejši geografski regionalizaciji Slovenije delimo v obalpsko severovzhodno Slovenijo in obpanonsko severovzhodno Slovenijo. Za prvo je značilen hribovit značaj z vmesnimi dolinami, prisotnost predvsem metamorfnih in magmatskih kamnin, podnebne poteze, ki predvsem s temperaturami in višino padavin nakazujejo prehod v gorati alpski svet, nadpovprečno visok delež gozda in gospodarska usmerjenost v živinorejo, gozdarstvo in industrijo, na območju Pohorja pa v zadnjih desetletjih tudi vse bolj v turizem. Za obpanonsko severovzhodno Slovenijo je značilno 

2015

prepletanje gričevnatega in ravninskega reliefa, ki ga sestavljajo mlajše terciarne in kvartarne kamnine. Podnebne značilnosti so izrazito obpanonske z zmerno celinskimi potezami. Naravno rastje je panonskega tipa, vendar je pokrajina usmerjena pretežno $\mathrm{v}$ kmetijstvo, predvsem $\mathrm{v}$ poljedelstvo in živinorejo, $\mathrm{v}$ gričevju pa $\mathrm{v}$ vinogradništvo in sadjarstvo. Pokrajina v preteklosti - razen v mestih - ni bila izrazito industrijska (Belec, 1994: 1).

$\mathrm{V}$ zadnjih desetletjih tudi ta makroregija $\mathrm{v}$ veliki meri sodi bodisi močno urbanizirani obmestni ali urbanizirani, prehoden ali stabilno podeželski tip pokrajine, vendar pa ob tem na območju srednjih Slovenskih goric, Haloz in Prekmurja obstaja še ogrožen in odmirajoči podeželski tip pokrajine (Kladnik, Ravbar, 2003: 26-27).

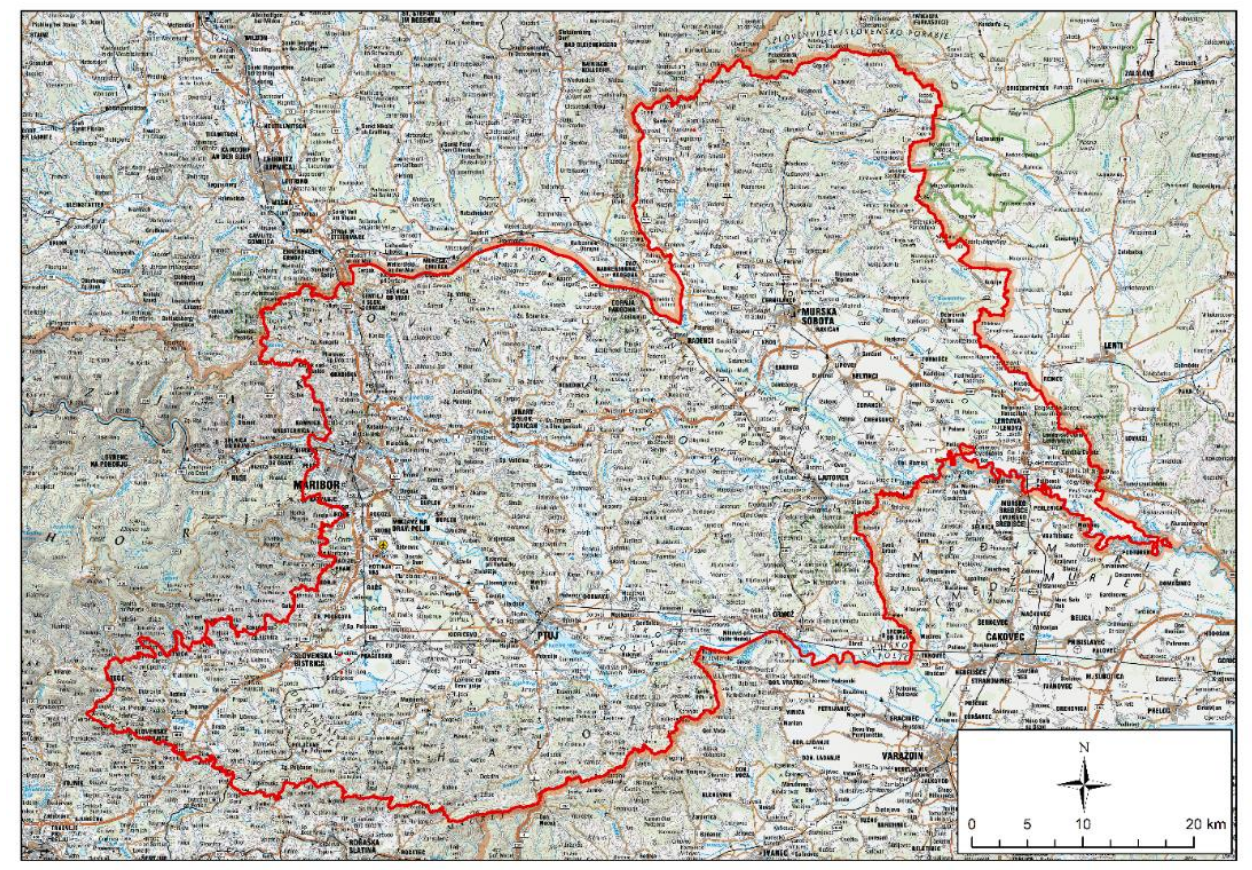

\section{Pregledna karta obpanonske severovzhodne Slovenije. Vir: DTK 250, GURS, 2016.}

Območje obpanonske Slovenije delimo v šest mezoregij in sicer dve nižinski (Podravska ravnina in Pomurska ravnina) ter štiri gričevnate (Dravinjske gorice, Haloze, Slovenske gorice in Goričko). Na najnižji ravni pokrajino delimo na 26 mikroregij: Zahodno Goričko, Srednje Goričko, Severovzhodno Goričko, Jugovzhodno Goričko, Lendavske gorice, Ravensko, Dolinsko, Apaško polje, Mursko polje, Zahodne Slovenske gorice, Mariborske gorice, Osrednje Slovenske gorice, Radgonsko-Kapelske gorice, Ptujske gorice, Spodnja Ščavniška dolina, Zahodne Ljutomersko-Ormoške gorice, Vzhodne Ljutomersko-Ormoške gorice, Dobrava s Središkim poljem, Dravsko polje, Ptujsko polje, Gozdnate (Zahodne) Haloze, Vinorodne (Vzhodne) Haloze, Dravinjske gorice Podpohorske gorice, Savinsko in Mariborska mestna regija (Belec, 1994a, Belec, 1994b, Belec, Bračič, 1994, Pak, 1994, Kert, 1994a, Kert, 1994b, Olas, 1994a, Olas, 1994b). 
Za naše potrebe smo prevzeli zgoraj omenjeno omejitev območja obpanonske severovzhodne Slovenije in členitev na mikroregije. Ker je bila členitev mikroregij in celotne obpanonske severovzhodne Slovenije naslonjena na meje katastrskih občin (k.o.), pač zaradi lažje obdelave statističnih podatkov, meja celotnega območja ponekod zaide v že hribovito območje, kar je najbolj očitno predvsem na območju Vitanjskih Karavank, Pohorja in vzhodnih obronkih Kozjaka. Kljub vsemu gre pri tej regionalizaciji vendarle za posrečen splet naravnih in družbeno geografskih kriterijev.

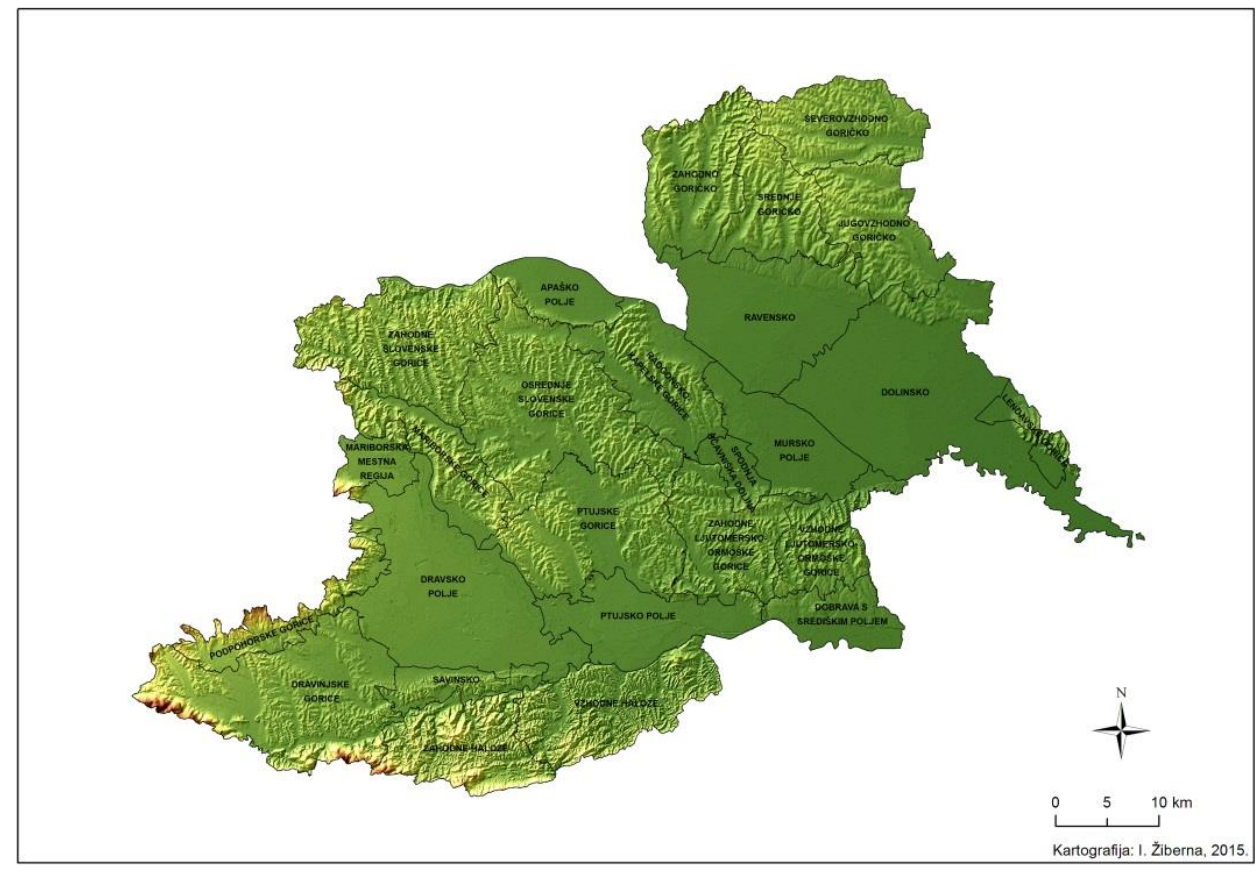

Obseg in členitev obpanonske severovzhodne Slovenije na mikroregije.

Vir: DMV5, GURS 2005; Belec, 1994a, Belec, 1994b, Belec, Bračič, 1994, Pak, 1994, Kert, 1994a, Kert, 1994b, Olas, 1994a, Olas, 1994 b.

$\mathrm{Na}$ celotnem območju prevladujejo predvsem terciarni in kvartarni sedimenti. Med terciarnimi so v ospredju miocenski lapor, peščen lapor, peščenjak, konglomerat in ponekod celo apnenec, ter pliocenski pesek, prod, konglomerat in glina. Ravninska območja gradijo kvartarni pesek, prod, konglomerat in glina. Ob vznožju Pohorja in na območju severovzhodnega Goričkega se nahajajo paleozojske metamorfne kamnine, na jugovzhodnem vznožju Pohorja med drugim tudi serpentinit (Mioč, Žnidarčič, 1989: 1722, 25-32).

Podnebne značilnosti so eden od najpomembnejših dejavnikov, ki vpliva na rabo tal. Po Koppenovi podnebni tipizaciji spada Slovenija v klimatski tip Cfb (zmernotopli podnebni tip), v katerem je srednja temperatura najtoplejšega meseca nižja od $22,0{ }^{\circ} \mathrm{C}$, najmanj štirje meseci pa imajo srednjo mesečno temperaturo nad $10,0{ }^{\circ} \mathrm{C}$. 

2015

Obpanonska severovzhodna Slovenija kaže v podnebnem smislu prehoden značaj, saj se na tem ozemlju mešajo osrednjeslovenski in panonski podnebni vplivi. Za večino Slovenije velja, da nastopijo najnižje oz. najvišje temperature v mesecu, ki sledi zimskemu oz. poletnemu solsticiju, t. j. v januarju in juliju. Glede na to, da obravnavano ozemlje zajema zelo majhen del zemeljskega površja, faktorji kot sta geografska širina ali oddaljenost od morja, ne prihajajo tako močno do izraza, pač pa ima večji pomen relativna višina. Najnižje srednje januarske temperature imajo meteorološke postaje, ki ležijo bodisi na dnu kotlin in dolin ali nad termalnim pasom, ki se pričenja $30 \mathrm{~m}$ nad dnom kotlin oziroma dolin in sega do približno $200 \mathrm{~m}$ relativne višine. Murska Sobota ima srednjo januarsko temperaturo $-2,5{ }^{\circ} \mathrm{C}$, $\mathrm{k}$ čemur pa poleg majhne relativne višine prispevajo povečane kontinentalne podnebne poteze.

$\mathrm{Na}$ vseh meteoroloških postajah v obpanonski severovzhodni Sloveniji nastopa kot najtoplejši mesec julij. Opazimo lahko, da poleg mikrolokacije meteorološke postaje na srednjo julijsko temperaturo vpliva tudi stopnja kontinentalnosti. Najvišjo srednjo julijsko temperaturo ima Turški Vrh v Halozah $\left(20,1{ }^{\circ} \mathrm{C}\right)$, sledijo pa mu Lendava $(19,7$ $\left.{ }^{\circ} \mathrm{C}\right)$, Jeruzalem $\left(19,5^{\circ} \mathrm{C}\right)$ in Maribor $\left(19,5^{\circ} \mathrm{C}\right)$. Razlika med srednjo aprilsko in srednjo oktobrsko temperaturo je eden od dobrih kazalcev kontinentalnih potez podnebja nekega kraja. Morje se spomladi namreč segreva počasneje kot kopno, zato nekoliko zavira segrevanje kopnega. Jeseni pa morje dodatno blaži učinke sicer hitro ohlajajočega se kopnega. V kontinentalnem delu Slovenije tega efekta ni, zato višje temperature v aprilu označujejo močnejše kontinentalne poteze nekega kraja.

V severovzhodni Sloveniji lahko lepo opazujemo naraščajočo kontinentalnost v smeri od zahoda proti vzhodu. Najvišje razlike $\mathrm{v}$ temperaturi $\mathrm{v}$ prid meseca aprila imajo postaje Murska Sobota $\left(0,3{ }^{\circ} \mathrm{C}\right)$, Lendava $\left(0,2^{\circ} \mathrm{C}\right)$ in Veliki Dolenci na Goričkem, oziroma Pragersko $\left(0,1^{\circ} \mathrm{C}\right)$. V Mariboru je oktober za $0,2{ }^{\circ} \mathrm{C}$ toplejši, kar pomeni, da kontinentalni vplivi močneje zajamejo južni del Dravskega polja kot severni. Ta je preko Ptujskega polja bolj izpostavljen vplivom iz Panonske nižine. Večje temperaturne razlike v prid oktobra so v zahodnem delu obravnavanega ozemlja.

Večina meteoroloških postaj v severovzhodni Sloveniji ima srednje letne temperature med 9 in $10^{\circ} \mathrm{C}$. Izstopata predvsem meteorološki postaji Turški Vrh $\left(10,0{ }^{\circ} \mathrm{C}\right)$ in Lendava $\left(10,1^{\circ} \mathrm{C}\right.$ ) (obe postaji ležita $\mathrm{v}$ termalnem pasu). Podobno kot pri srednjih mesečnih temperaturah lahko tudi pri srednjih mesečnih ekstremnih temperaturah opazimo odvisnost le teh od relativne višine. Najnižje srednje januarske minimalne temperature beleži postaja Murska Sobota $\left(-6,7^{\circ} \mathrm{C}\right)$. Nizke srednje minimalne januarske temperature so posledica inverzije v Dravski dolini in na večjih ravninskih območjih (Dravsko, Ptujsko, Središko in Mursko polje. Julijske temperature so najvišje na postaji Lendava $\left(25,8{ }^{\circ} \mathrm{C}\right.$ ), sledijo pa ji postaje Pragersko in Turški Vrh (obe $25,5^{\circ} \mathrm{C}$ ), Murska Sobota $\left(25,3^{\circ} \mathrm{C}\right)$ in Maribor $\left(25,1^{\circ} \mathrm{C}\right)$.

V splošnem lahko pri srednjih maksimalnih julijskih temperaturah opazimo relativno izenačenost. Podobno kot pri srednjih mesečnih temperaturah tudi tukaj najtoplejšemu juliju sledijo avgust, junij, september in maj. Srednje maksimalne temperature v oktobru so v celotni SV Sloveniji višje od tistih v aprilu, vendar pa je v Prekmurju ta razlika manjša (v Murski Soboti le $0,3{ }^{\circ} \mathrm{C}$ v prid oktobra) kot v subalpskem delu SV Slovenije (v Radljah kar $1,1^{\circ} \mathrm{C}$ v prid oktobra). Nekaj $\mathrm{k}$ temu gotovo prispevajo singularitete 
\begin{tabular}{r|r} 
GEOGRAFIE PODRAVJA & \\
I. Žiberna: Spreminjanje rabe tal na območju obpanonske severovzhodne Slovenije v \\
obdobju 2000-2015
\end{tabular}

jasnega in sorazmerno toplega vremena v oktobru ("babje poletje") (Žiberna, 2000: 3940).

Zmanjševanje padavin od zahodnega proti vzhodnemu delu Slovenije je znano dejstvo. Podobno sliko kot za celo Slovenijo dobimo v nekoliko manjših dimenzijah tudi v severovzhodni Sloveniji. Letno prejmejo največ padavin postaje Radlje ob Dravi (1216,2 $\mathrm{mm}$ ) in Šmartno pri Slovenj Gradcu (1210,1 mm). Med 1200 in $1000 \mathrm{~mm}$ padavin prejmejo postaje Turški Vrh (1168,0 mm), Slovenske Konjice (1068,8 mm) in Maribor (1038,9 mm). Pod $1000 \mathrm{~mm}$ padavin letno pa prejmejo postaje Pragersko $(999,2 \mathrm{~mm})$, Jeruzalem $(953,0 \mathrm{~mm})$, Veliki Dolenci $(816,0 \mathrm{~mm})$, Lendava $(808,7 \mathrm{~mm})$ in Murska Sobota $(807,0 \mathrm{~mm})$.

Opazimo lahko torej pasovitost v smeri od jugozahoda proti severovzhodu:

- V prvem pasu ležita najbolj namočeni postaji v severovzhodni Sloveniji: Šmartno pri Slovenj Gradcu in Radlje ob Dravi (nad $1200 \mathrm{~mm}$ padavin).

- V drugem, prehodnem pasu (med 1200 in $1000 \mathrm{~mm}$ padavin letno) ležijo postaje Slovenske Konjice, Maribor in Turški Vrh,

- V tretjem, najmanj namočenem delu (pod $1000 \mathrm{~mm}$ padavin letno), pa ležijo postaje Pragersko, Jeruzalem, Lendava in Veliki Dolenci.

Opazimo lahko, da po Ptujskem polju kontinentalni podnebni vplivi segajo še na južno Dravsko polje, kar smo ugotovili že pri temperaturnih razmerah, zato ima Pragersko letno za slabih $40 \mathrm{~mm}$ manj padavin kot okoli $15 \mathrm{~km}$ severneje ležeči Maribor in za slabih 70 mm manj padavin kot okoli 20 km zahodneje ležeče Slovenske Konjice.

Naslednji zelo pomemben naravni dejavnik rabe tal so prsti. Na ravninah na karbonatnem produ prevladuje rendzina, na silikatnih usedlinah pa kisla rjavica. V splošnem je za kmetijsko rabo primernejša rendzina, kar se kaže tudi v gostejši poselitvi na takih tleh. Ob vznožju so potoki nasipavali finejši material, zato so tam nastale vlažnejše ilovnate prsti, primerne za travnike. Tla so ponekod postala vlažnejša tudi tam, kjer so posekali gozd na ilovnati podlagi. Na poplavnih ravnicah, kjer so tla nerazvita in plitva, se najpogosteje pojavljajo obrečni logi ali gozdovi - dobrave, čeprav danes v njih ne prevladuje več hrast.

V obpanonski severovzhodni Sloveniji lahko izločimo tri pedogeografske regije:

- Holocenske ravnice s prevlado obrečnih in oglejenih prsti. Ta regija se deli na enote nižjega reda ob Dravi, Dravinji in levih pritokih Drave, ob Muri in Ščavnici. Prsti ob Dravi so plitve do srednje globoke in globoke. Na plitvih prsteh se pojavljajo predvsem logi, globlje pa so že dovolj kvalitetne za travnike in pašnike. Nekoliko bolj stran od reke se je usedala tudi ilovica, zato so tam zaradi zadrževanja podtalnice nastale obrečne oglejene prsti, ki so primerne za travnike. Ob Dravinji se je sedimentiral ilovnati material, v katerem pogosto zastaja talna voda, zato so tu nastale oglejene prsti, primerne predvsem za travnike. Podobne prsti - evtrični hipoglej - so se razvile tudi ob Pesnici, Rogoznici in Grajeni. Tudi tukaj na dnu doline prevladujejo travniki. Večji pas distričnega hipogleja se nahaja v pasu ob Ledavi na Ravenskem, ter 
I. Žiberna: Land use changes in the subpanonian northeastern Slovenia between 2000 and 2015

v ozkem pasu ob Veliki Krki in Dolenskem potoku na severovzhodu Goričkega.

- Pleistocenske terase s prevlado distričnih rjavih prsti, rankerjev in psevdogleja se pojavljajo na višjih terasah ob Dravi, tam kjer le-te sestavljajo kremenovi prodniki in prodniki iz metamorfnih in magmatskih kamnin. Na takih usedlinah so se razvile distrične rjave prsti in distrični ranker, ki sta primerna za poljedelske površine. V okolici Dornave so se na pleistocenski ilovici razvile evtrične rjave prsti, ki so na obrobju proti dolinama Pesnice in Rogoznice oglejene in primerne za travnike in njive. Na široki terasi Središkega polja je na pleistocenskih ilovicah nastal psevdoglej, ki je za kulturne rastline neprimeren, zato se na njih pojavlja predvsem gozd. Pobočni in ravninski psevdoglej se v širokem pasu nahaja na Ravenskem (med Ledavo in vznožjem Goričkega) in Dolinskem.

- Terciarne gorice s prevlado rendzine, evtričnih in distričnih rjavih prsti in psevdogleja. Prsti se pojavljajo v Slovenskih goricah, Halozah in Dravinjskih goricah s slemenom Savinskim. V osrednjih Halozah se na laporju pojavljata rendzina in evtrična rjava prst, na obrobju Haloz pa distrični ranker in distrična rjava prst. Prsti so primerne za gojenje posebnih kultur (vinska trta, sadno drevje). Na odrastku Dravinjskih goric - na slemenu Savinsko - se na pliocenski glini ter pesku in produ pojavljajo evtrične rjave prsti in ravninski ter pobočni psevdoglej. V osrednjih Slovenskih goricah se na nekarbonatnih kamninah pojavlja distrična rjava prst, ponekod pa psevdoglej. Na obeh tipih je na položnem svetu možno gojiti njivske kulture, na distrični rjavi prsti pa na strmejšem terenu tudi vinsko trto in sadno drevje. V vzhodnih Slovenskih goricah se na laporju pojavljajo evtrične rjave prsti, na katerih so pretežno vinogradi in sadovnjaki. Na Goričkem in v Lendavskih goricah se izmenjujeta evtrična in distrična rjava prst na ilovicah in glinah (Grčman idr., 2015).

Vlada RS je novembra 2016 sprejela Uredbo o območjih za kmetijstvo in pridelavo hrane, ki so strateškega pomena za Republiko Slovenijo (UL 71 2016). V uredbi so območja, pomembna za pridelavo hrane razvrščena v štiri kategorije: izjemno pomembna območja, zelo pomembna območja, pomembna območja in ostala območja. Delež izjemno pomembnih območij na območju obpanonske severovzhodne Slovenije pokriva 124304,2 ha ali 39,9 \% površja, delež zelo pomembnih območij pa 151030,4 ha ali 48,4 \% površja. Obe kategoriji skupaj torej predstavljata kar 88,3 \% obpanonske severovzhodne Slovenije, kar temu območju z vidika prehranske varnosti daje zelo velik pomen. To je tudi eden od razlogov, da smo se $\mathrm{v}$ naši razpravi osredotočili prav na obpanonsko severovzhodno Slovenijo.

Med vsemi mikroregijami v obpanonski severovzhodni Sloveniji znotraj kategorije »Izjemno pomembna območja za pridelavo hrane« največji deleži površja odpadejo na Dolinsko (19,1 \%), Dravsko polje (16,1 \%), Ravensko (12,7\%), Ptujsko polje (7,1 \%) in Mursko polje (6,5\%). Znotraj posameznih mikroregij pa kategorija »Izjemno pomembna območja za pridelavo hrane « pokriva največji delež površja te mikroregije na Ravenskem (kar 90,8 \%), Murskem polju (87,3 \%), Ptujskem polju (85,4 \%), Apaškem polju $(83,1$ $\%)$, Dravskem polju (80,6\%), in Dolinskem (79,1\%). 


\section{I. Žiberna: Spreminjanje rabe tal na območju obpanonske severovzhodne Slovenije v 97 obdobju 2000-2015 \\ Spreminjanje rabe tal na območju obpanonske severovzhodne Slovenije v obdobju 2000-2015}

Na območju obpanonske severovzhodne Slovenije so leta 2000 njive in vrtovi pokrivali 114370,5 ha površin in so s 36,2 \% predstavljali najpogostejšo obliko rabe tal na tem območju. Vinogradi so tega leta pokrivali 9140,9 ha (2,9\%), sadovnjaki 7015,6 ha (2,2 \%), ostali trajni nasadi pa 9,5 ha. Travniki so pokrivali 48829,4 ha $(15,5 \%)$ zemljišča $\mathrm{v}$ zaraščanju 1962,0 ha (0,6 \%), mešana raba zemljišč 4144,3 ha (1,3\%), gozdovi 100383,7 ha $(31,8 \%)$, pozidane in sorodne površine 25992,5 ha $(8,2 \%)$, ostale površine 273,8 ha $(0,1 \%)$, vodne površine pa 3837,1 ha $(1,2 \%)$. Obdelovalne površine so tega leta torej pokrivale 130536,6 ha ali $41,3 \%$ površja.

Leta 2015 se je na območju obpanonske severovzhodne Slovenije nahajalo 106856,0 ha $(33,8 \%)$ njiv in vrtov, 6790,8 ha $(2,1 \%)$ vinogradov, 8118,4 ha $(2,6 \%)$ sadovnjakov, in 165,1 ha $(0,1 \%)$ ostalih trajnih nasadov. Travniki so pokrivali 50122,3 ha $(15,9 \%)$ površja, zemljišča v zaraščanju 7670,6 ha $(2,4 \%)$, gozdne površine pa 106736,4 ha $(33,8$ \%) površja. Pozidane in sorodne površine so se nahajale na 25277,4 ha $(8,0 \%$ \%) površin, ostale površine na 515,7 ha $(0,2 \%)$ vodne površine pa na 3706,7 ha $(1,2 \%)$ površja.

Obdelovalne površine so tega leta pokrivale 121930,3 ha $(38,6$ \%) površja, kar glede na leto 2000 pomeni zmanjšanje za 8606,3 ha (ali za 2,7 odstotne točke). Velika večina tega zmanjšanja gre na račun njiv in vrtov (zmanjšanje za 7514,6 ha ali za 2,4\%) in vinogradov (zmanjšanje za 2350,1 ha ali za $0,7 \%$ ). sadjarske površine so se $\mathrm{v}$ tem obdobju celo povečale (za 1102,8 ha ali za $0,3 \%$ ).

Največje spremembe - razen pri njivah in vrtovih - beležimo pri gozdnih površinah (povečanje za 6352,7 ha ali za 2,0 \%), zemljiščih v zaraščanju (povečanje za 5708, 6 ha ali za 1,8 \%) in pri mešani rabi zemljišč (zmanjšanje za 4144,3 ha ali za 1,3 \%, vendar tem spremembam botruje spremenjena metodologija zajemanja podatkov v obeh letih). Zmanjšanje pozidanih in sorodnih zemljišč za 715,2 ha ali za $0,2 \%$ gre seveda na račun »sorodnih zemljišč« kot pritiklin k pozidanim zemljiščem. Žal metodologija zajemanja podatkov ne dopušča samostojne obravnave pozidanih zemljišč.

Analiza smeri sprememb rabe tal v obdobju 2000-2015 kaže, da so najpogostejše spremembe naslednje: njiva in vrt $\mathrm{v}$ travnik (11825,2 ha), travnik v njivo in vrt $(8369,1$ ha), travnik v gozd (3776,9 ha), travnik v zemljišče v zaraščanju (3551,4 ha), pozidana in sorodna zemljišča $v$ travnik (3230,6 ha), mešana raba zemljišč v gozd (2377,9 ha), njiva in vrt $v$ pozidana in sorodna zemljišča (2346,5 ha), sadovnjak v travnik (1930,0 ha), vinograd $v$ travnik $(1750,6$ ha), travnik v sadovnjak (1746,1 ha), pozidana in sorodna zemljišča v sadovnjak (1660,9 ha), travnik v pozidana in sorodna zemljišča $(1655,3 \mathrm{ha})$, njiva in vrt v zemljišče v zaraščanju (1528,4 ha), gozd v travnik $(1472,4$ ha), njiva v gozd (1442,4 ha) in zemljišče $v$ zaraščanju $v$ gozd $(1159,5$ ha), če omenimo le tiste smeri sprememb rabe tal, ki znašajo nad 1000 ha. 
The GeOgRaPhiES OF THE PODRAvJe Region

I. Žiberna: Land use changes in the subpanonian northeastern Slovenia between 2000 and 2015

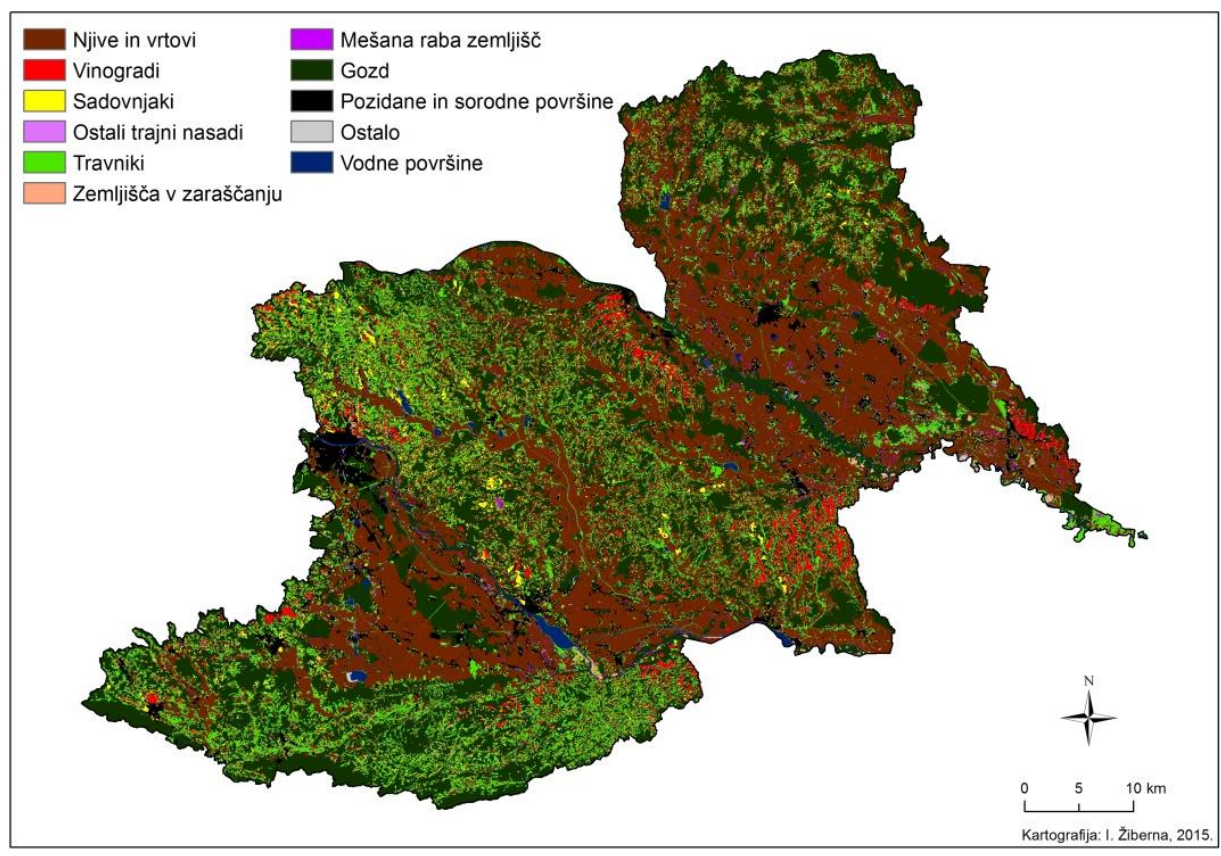

Raba tal na območju obpanonske severovzhodne Slovenije leta 2000. Vir: MKGP, 2000.

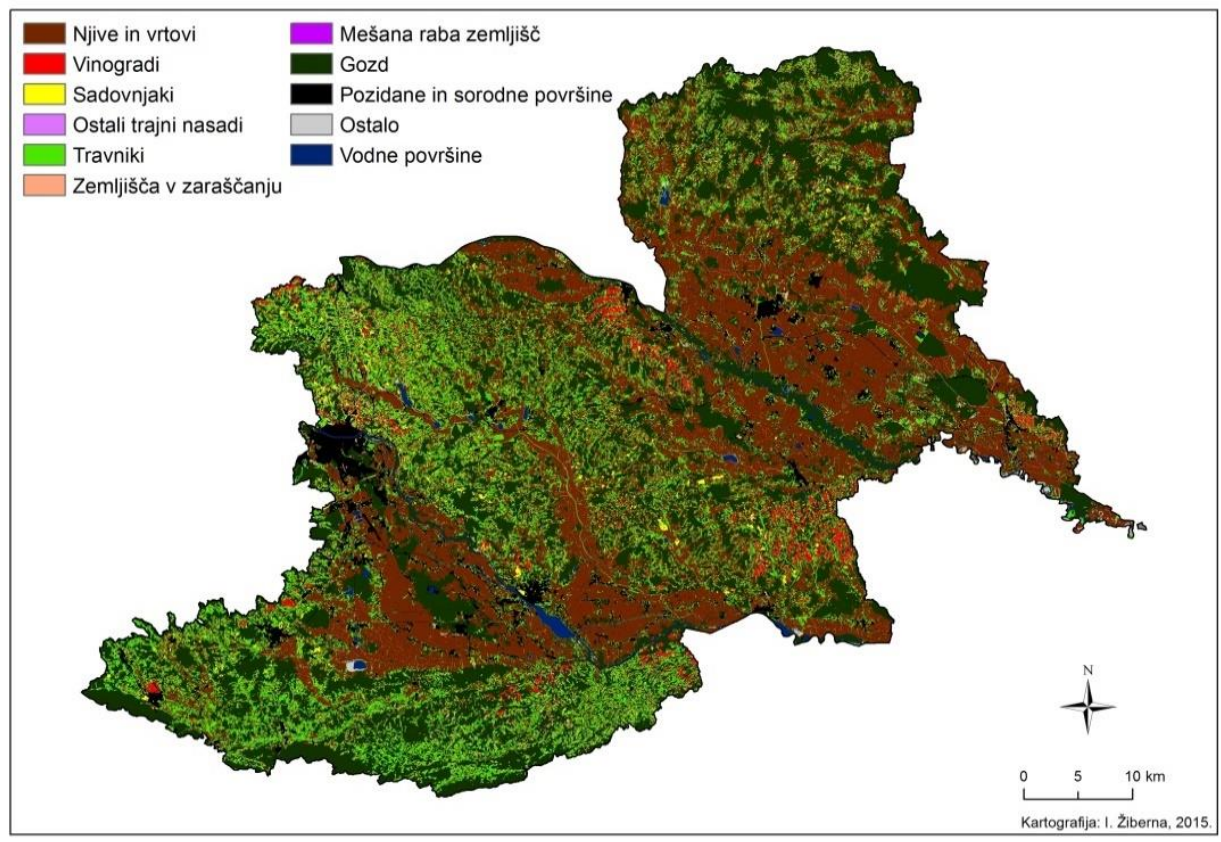

Raba tal na območju obpanonske severovzhodne Slovenije leta 2015.

Vir: MKGP, 2015. 
Najpogostejše smeri sprememb rabe tal po kategorijah so naslednje: njive in vrtovi so v obravnavanem obdobju najpogosteje prehajali v travnike (11825,2 ha), pozidane površine $(2346,5$ ha) in zemljišča $\mathrm{v}$ zaraščanju $(1528,4$ ha). Vinogradi so prehajali $\mathrm{v}$ travnike (1750,6 ha), njive in vrtove (447,0 ha) in sadovnjake (373,1 ha), sicer pa še v gozd (353,0 ha) in zemljišča v zaraščanju (315,9 ha). Sadovnjaki so najpogosteje prehajali v travnike (1930,0 ha), njive in vrtove $(553,0 \mathrm{ha})$ in pozidane in sorodne površine (429,8 ha). Travniške površine so prehajale $v$ njive in vrtove $(8369,1 \mathrm{ha})$, gozd $(3776,9 \mathrm{ha})$ in zemljišča $\mathrm{v}$ zaraščanju (3551,4 ha). Zemljišča $\mathrm{v}$ zaraščanju so najpogosteje prehajala $\mathrm{v}$ gozd (1159,5 ha), travnike (200,9 ha) in ostale površine (64,1 ha). Gozd je prehajal v travnike $(1472,4 \mathrm{ha})$, pozidane in sorodne površine $(909,8 \mathrm{ha})$ in zemljišča $v$ zaraščanju (690,0 ha).

Oglejmo si še obratne procese. 8369,1 ha ali 7,8 \% današnjih njiv in vrtov so leta 2000 predstavljali travniki, medtem ko so ostale spremembe v njive in vrtove bistveno manjše in enakomerneje razporejene po oblikah rabe tal. 414,7 ha $(6,1 \%)$ današnjih vinogradov je bilo leta 2000 pod travniki, 370,0 ha $(5,4 \%)$ pod njivami in vrtovi, 186,8 ha $(2,8 \%)$ pa pod sadovnjaki. 3249,8 ha $(21,5 \%)$ današnjih sadovnjakov je bilo leta 2000 pod travniki, 1660,9 ha $(20,5 \%)$ pa pod pozidanimi in sorodnimi površinami. Pri sadovnjakih se ob tako veliki dinamiki zastavlja vprašanje metodologije zajemanja podatkov. $\mathrm{Na}$ 11825 ha $(23,6 \%)$ današnjih travnikov so bili leta 2000 njive in vrtovi, na 3230,6 ha $(6,4$ \%) pa pozidane in sorodne površine. Na kar 3551,4 ha (46,3 \%) današnjih zemljišč v zaraščanju so bili na začetku obravnavanega obdobja travniki, na 1528,4 ha (19,9\%) pa njive in vrtovi. Gozdne površine so bile najstabilnejša kategorija rabe tal, saj se je kar $90,3 \%$ gozdnih površin ohranilo. Današnji gozdovi so se večali na račun travnikov (3776,9 ha ali 3,5 \%), mešane rabe zemljišč (1159,5 ha ali 2,2 \%) ter njiv in vrtov $(1442,4$ ha ali $1,4 \%$ ), današnje pozidane in sorodne površine pa so nastajale na nekdanjih njivah $(2346,5$ ha ali $9,3 \%)$, travnikih (1655,3 ha ali 6,5\%) in gozdnih površinah $(909,8$ ha ali $3,6 \%)$.

Spremembe rabe tal smo na nivoju obpanonske severovzhodne Slovenije obravnavali tudi na splošnejšem nivoju. Oblike rabe tal smo z vidika pridelave hrane združili v intenzivne površine (kamor smo uvrstili njive in vrtove, vinograde, sadovnjake in ostale trajne nasade) in ekstenzivne oblike (vse ostale). Pri tem smo smeri sprememb generalizirali v naslednje kategorije:

- spremembe rabe tal, vendar znotraj obdelovalnih površin (npr. njiva v vinograd ali vinograd v sadovnjak)

- spremembe rabe tal, vendar znotraj neobdelovalnih površin (npr. travnik v pozidane površine ali zemljišče $\mathrm{v}$ zaraščanju $\mathrm{v}$ gozd)

- spremembe rabe tal iz neobdelovalnih $\mathrm{v}$ obdelovalne površine ali intenzifikacija (npr. travnik v vinograd ali zemljišče v zaraščanju v njivo)

- spremembe rabe tal iz obdelovalnih $\mathrm{v}$ neobdelovalne površine ali ekstenzifikacija (npr. njiva v zemljišče v zaraščanju ali vinograd v travnik).

$\mathrm{Na}$ območju obpanonske severovzhodne Slovenije so se oblike rabe tal ohranile na 253070,1 ha $(80,1 \%$ površja). Do sprememb oblik rabe tal, vendar znotraj obdelovalnih površin je prišlo na 2734,6 ha $(0,9 \%)$, do sprememb, vendar znotraj ekstenzivnih oblik pa na 22958,5 ha $(7,3 \%)$. 


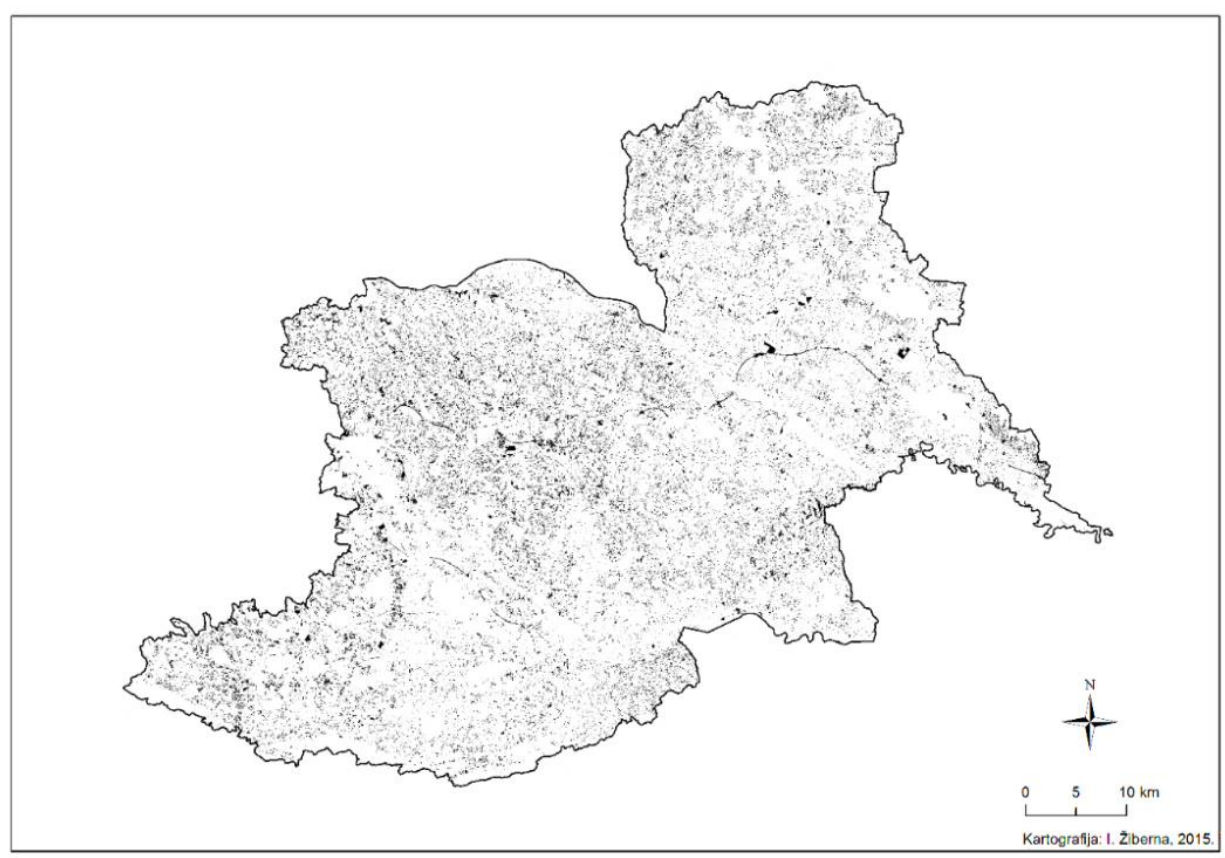

Območja umika obdelovalnih površin v obdobju 2000-2015.

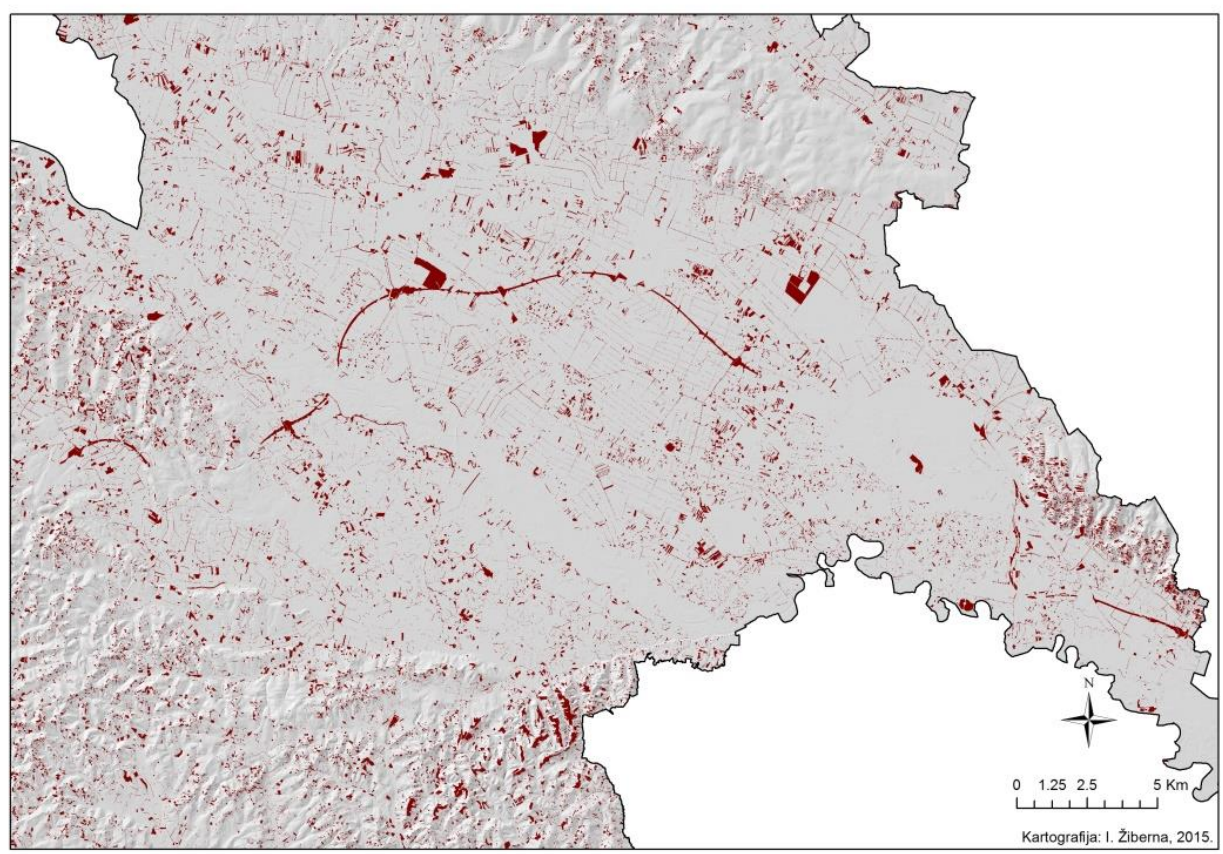

Območja umika obdelovalnih površin v obdobju 2000-2015 (izsek). 
GEOGRAFIJE PODRAVJA

I. Žiberna: Spreminjanje rabe tal na območju obpanonske severovzhodne Slovenije v obdobju 2000-2015

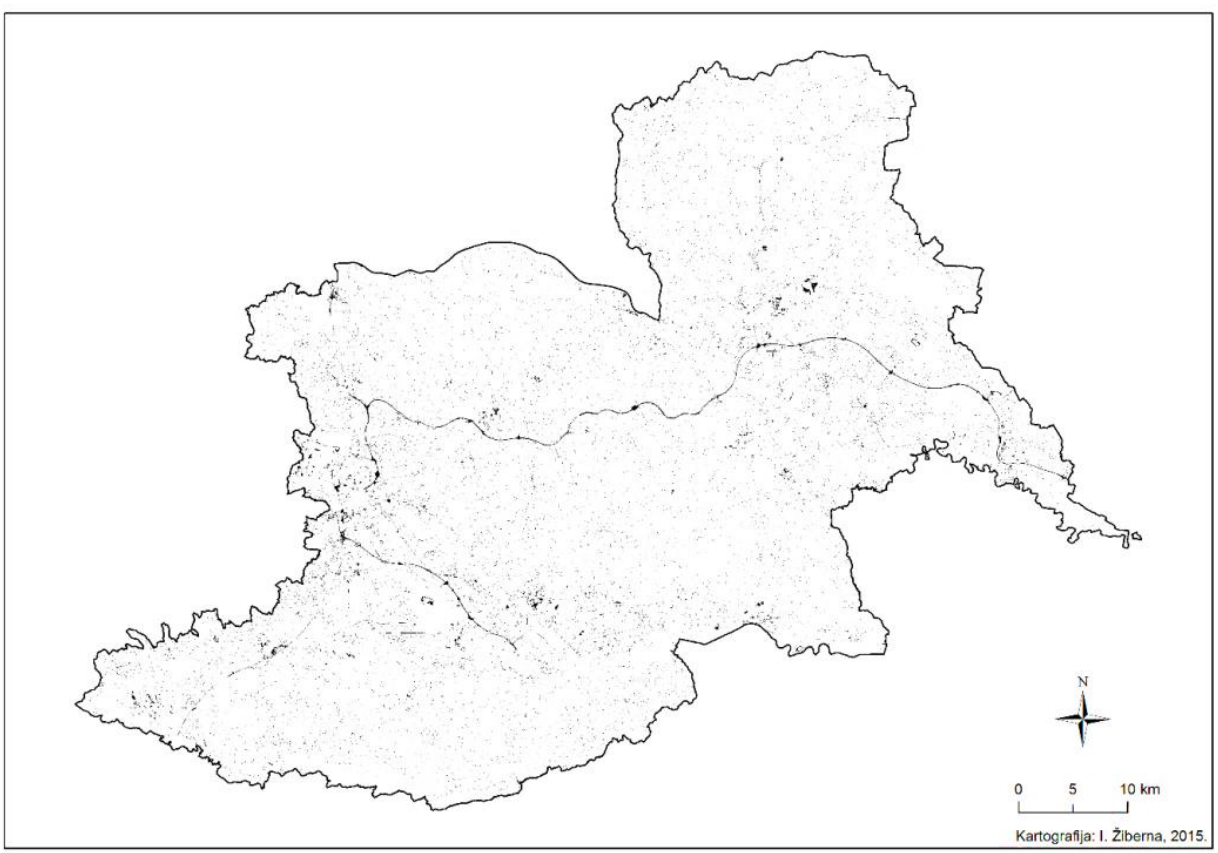

Območja novonastalih pozidanih in sorodnih površin v obdobju 2000-2015.

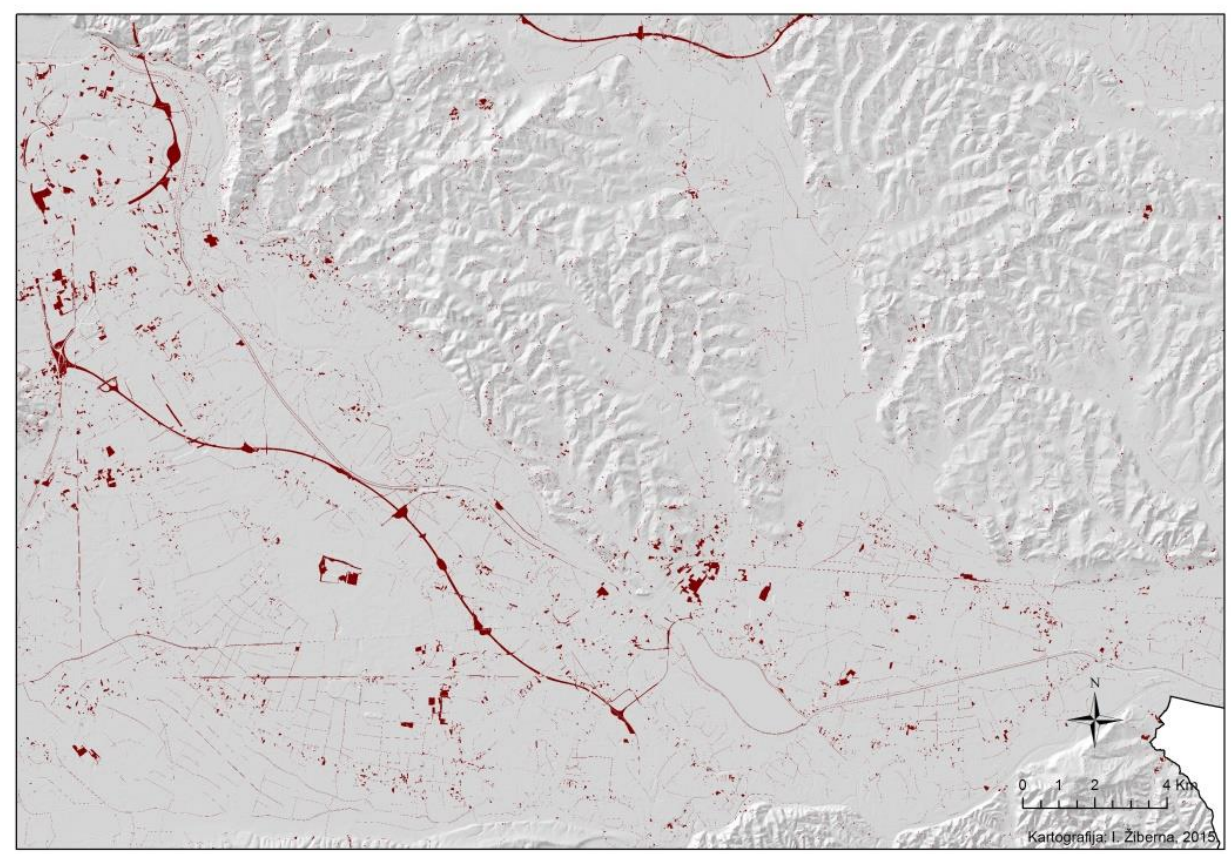

Območja novonastalih pozidanih in sorodnih površin v obdobju 2000-2015 (izsek). 

2015

Spremembe iz neobdelovalnih $\mathrm{v}$ obdelovalne površine so se zgodile na 14295,0 ha $(4,5$ \%), obdelovalnih v neobdelovalne površine pa na 22901,2 ha (7,2 \%). Razmerje med procesi ekstenzifikacije in intenzifikacije na območju celotne obpanonske severovzhodne Slovenije torej znaša $1: 1,60$. Na vsak novo nastali hektar obdelovalnih površin smo v obravnavanem obdobju dobili 1,60 ha novih neobdelovalnih površin. Najvišji indeks imajo Lendavske gorice $(2,60)$, Mariborska mestna regija $(2,53)$, Ravensko $(2,44)$, Dravsko polje $(2,39)$, Zahodno Goričko $(2,22)$, Radgonsko-Kapelske gorice $(1,88)$ in Podpohorske gorice $(1,88)$.

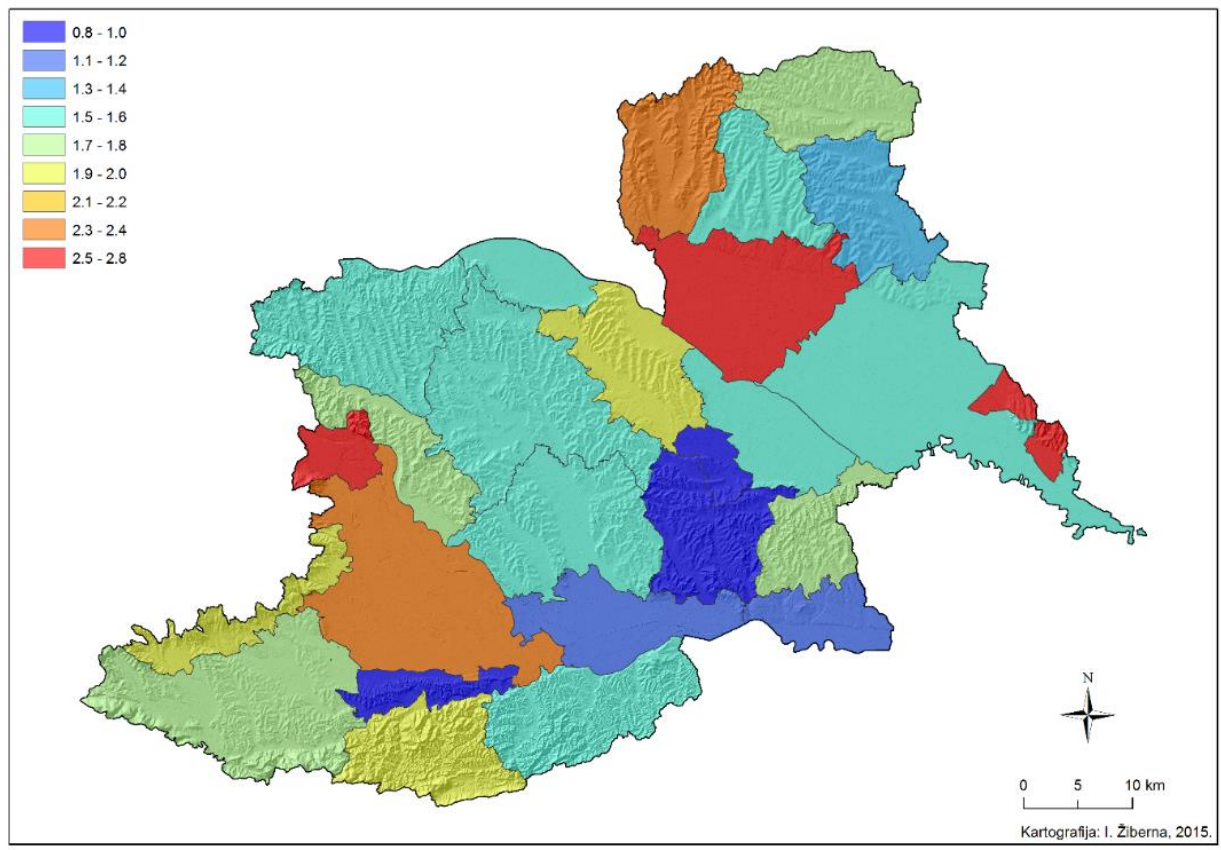

Indeks ekstenzifikacije po mikroregijah obpanonske severovzhodne Slovenije v obdobju 2000-2015.

\section{Spreminjanje rabe tal po mikroregijah obpanonske severovzhodne Slovenije}

Med 26 mikroregijami obpanonske SV Slovenije je bilo leta 2000 največ njiv in vrtov na Dolinskem (16384,4 ha ali 52,6 \% celotnega površja mikroregije), na Dravskem polju (14259,1 ha ali 57,5\%), Ravenskem (11621,4 ha ali 65,0 \%), Osrednjih Slovenskih goricah $(7667,4$ ha ali $32,9 \%$, predvsem na račun šroke Pesniške doline v srednjem toku), Ptujskih goricah $(6697,1$ ha ali $38,3 \%$, prav tako na račun široke Pesniške doline v spodnjem toku) in Ptujskem polju (6491,5 ha ali 57,4 \%). Vrstni red mikroregij glede na delež njiv in vrtov v letu je nekoliko drugačen. Največji delež pod njivami in vrtovi je bil na Ravenskem (61,3 \%), Ptujskem polju (56,8 \%), Apaškem in Murskem polju (v obeh primerih po 55,9 \%), Spodnji Ščavniški dolini $(54,9 \%)$ in na Dravskem polju $(53,6 \%)$. Leta 2015 je bilo največ njiv in vrtov na Dolinskem $(15856,1$ ha ali 51,0 \% površja mikroregije), Dravskem polju (13305,7 ha ali 53,6 \%), Ravenskem (10953,9 ha ali 61,3 $\%)$, v Osrednjih Slovenskih goricah (6957,6 ha ali 29,9\%), na Ptujskem polju (6423,3 ha 
I. Žiberna: Spreminjanje rabe tal na območju obpanonske severovzhodne Slovenije v 103 obdobju 2000-2015

ali 56,8 \%) in Ptujskih goricah (6293,6 ha ali 36,0\%).

V obdobju 2000-2015 so se v vseh mikroregijah, razen v Zahodnih LjutomerskoOrmoških goricah, Savinskem in Spodnji Ščavniški dolini njive in vrtovi zmanjšali. Največji umik te kategorije je zaznaven na Dravskem polju (953,4 ha), Osrednjih Slovenskih goricah (709,8 ha), Zahodnem Goričkem (708,9 ha) in Ravenskem (667,5 ha). V letu 2015 se je med vsemi površinam njiv in vrtov v obpanonski SV Sloveniji največ teh nahajalo na Dolinskem (14,8 \%), Dravskem polju (12,5\%), Ravenskem (10,3 \%), Osrednjih Slovenskih goricah (6,5 \%), Ptujskem polju $(6,0 \%)$ in Ptujskih goricah $(5,9$ $\%)$.

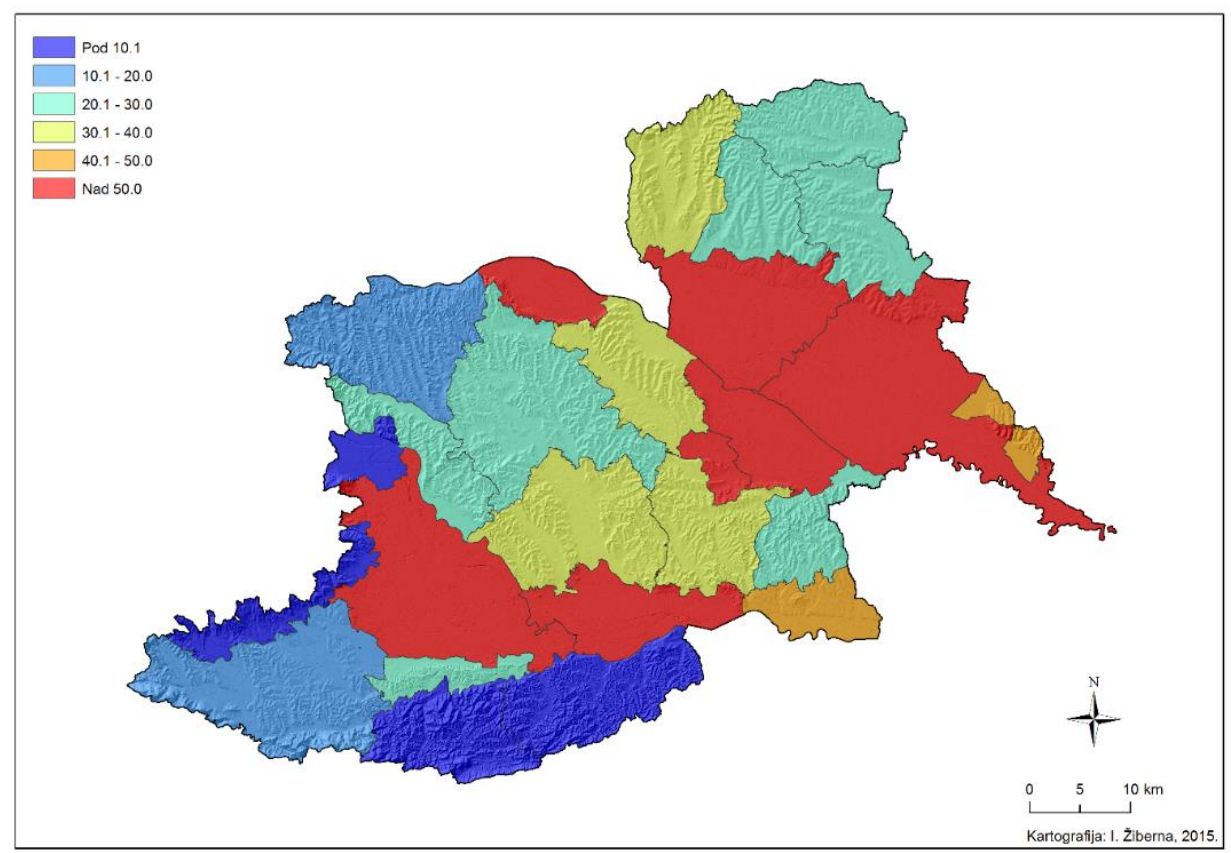

Delež njiv in vrtov po mikroregijah obpanonske SV Slovenije leta 2015 (v\%).

Največ vinogradniških površin se je leta 2000 nahajalo na območju Vzhodnih Ljutomersko-Ormoških goric (1529,6 ha, kar je predstavljalo 19,7 \% površja te mikroregije), Vzhodnih (Vinorodnih) Haloz (1227,8 ha ali 8,8 \%), Radgonsko-Kapelskih goricah (935,3 ha ali 7,9\%), Zahodnih Slovenskih goricah (827,3 ha ali 4,7\%), Ptujskih goricah (569,3 ha ali 3,3\%) in Mariborskih goricah (533,4 ha ali 6,1\%). V relativnem smislu so vinogradi pokrivali največje deleže površja v Vzhodnih Ljutomersko-Ormoških goricah (19,7 \%), Vzhodnih (Vinorodnih) Halozah (8,8 \%), Lendavskih goricah (8,4 \%), Radgonsko-Kapelskih goricah (7,9\%) ter v Podpohorskih goricah in Mariborskih goricah (v obeh po 6,1\%). Leta 2015 se je največ vinogradniških površin nahajalo še vedno v Vzhodnih Ljutomersko-Ormoških goricah (1253,7 ha ali 16,2 \% površja mikroregije), sledile pa so Radgonsko-Kapelske gorice (909,8 ha), Vinorodne Haloze (810,7 ha ali 5,8 $\%)$, Zahodne Slovenske gorice $(655,4$ ha ali 3,7 \%), Ptujske gorice $(423,5$ ha ali $2,4 \%)$, Zahodne Ljutomersko-Ormoške gorice (388,4 ha ali 3,4 \%) in Mariborske gorice $(384,4$ 
ha ali $4,4 \%)$.

Tudi leta 2015 so bile makroregije glede na delež vinogradov razporejene nekoliko drugače: delež vinogradniških površin je bil najvišji v Vzhodnih Ljutomersko-Ormoških goricah (16,2 \%), Radgonsko-Kapelskih goricah (7,7 \%), Vzhodnih (Vinorodnih) Halozah (5,8 \%), Lendavskih goricah (5,2 \%), Mariborskih goricah (4,4 \%), Podpohorskih goricah (4,1\%) in Zahodnih Slovenskih goricah $(3,7 \%)$.

Vinogradniške površine so se zmanjšale v vseh mikroregijah, razen na Apaškem polju, kjer je bilo leta 2015 za 4,1 ha več vinogradov kot leta 2000. Daleč največji umik je bilo zaznati v Vzhodnih (Vinorodnih) Halozah (za 417,1 ha), Vzhodnih LjutomerskoOrmoških goricah (275,9 ha), Dravinjskih goricah (173,1 ha), Zahodnih Slovenskih goricah (171,9 ha), Dolinskem (160,4 ha, predvsem na račun dejstva, da po regionalizaciji k Dolinskemu pripadajo jugovzhodni obronki Lendavskih goric), Zahodnih LjutomerskoOrmoških goricah (149,9 ha), Mariborskih goricah (149,0 ha), Ptujskih goricah (145,8 ha) in Podpohorskih goricah (131,2 ha). Leta 2015 se je med vsemi vinogradniškimi površinami obpanonske severovzhodne Slovenije največji delež le teh nahajal v Vzhodnih Ljutomersko-Ormoških goricah (18,5 \%), Radgonsko-Kapelskih goricah (13,4 \%), Vzhodnih (Vinorodnih) Halozah (11,9\%), Zahodnih Slovenskih goricah (9,7 \%), Ptujskih goricah (6,2 \%), Zahodnih Ljutomersko-Ormoških goricah in Mariborskih goricah (po 5,7 \%) in Dravinjskih goricah (4,6\%).

Sadjarske površine so se leta 2000 nahajale predvsem na območju Zahodnih Slovenskih goric (1154,0 ha oziroma 6,6 \% površja te mikroregije), Osrednjih Slovenskih goric (920,3 ha ali 4,0 \%), Dravinjskih goric (614,7 ha ali 2,7\%), Ptujskih goric (534,7 ha ali $3,1 \%$ ) in Mariborskih goric (522,4 ha ali 5,9\%). Glede na delež sadjarskih površin od vseh površin so prednjačile Zahodne Slovenske gorice $(6,6 \%)$, Mariborske gorice $(5,9$ $\%)$, Osrednje Slovenske gorice $(4,0 \%)$, Podpohorske gorice $(3,4 \%)$ in Ptujske gorice (3,1\%). Tudi leta 2015 se je največ sadjarskih površin nahajalo na območju Zahodnih Slovenskih goric (1027,5 ha ali 5,9\%), Osrednjih Slovenskih goric (790,4 ha ali 3,4 \%), Dravinjskih goric (646,2 ha ali 2,8 \%), Mariborskih goric (636,2 ha ali 7,2\%) in Ptujskih goric $(584,0$ ha ali 3,3\%). V relativnem smislu so bili tega leta najvišji deleži sadjarskih površin na območju Mariborskih goric (7,2 \%), Zahodnih Slovenskih goric (5,9 \%), Podpohorskih goric (4,3 \%), Vzhodnih Ljutomersko-Ormoških goric $(3,6 \%)$ in Osrednjih Slovenskih goric $(3,4 \%)$.

Sadjarske površine so - poleg ostalih trajnih nasadov, ki pa se v obpanonski severovzhodni Sloveniji ne pojavljajo $\mathrm{v}$ tako veliki meri - oblika rabe tal med obdelovalnimi površinami, kjer v obdobju 2000-2015 beležimo povečanje in sicer $\mathrm{s}$ 7015,6 ha $(2,2 \%)$ na 8118,4 ha $(2,6 \%)$ ali za 1102,8 ha. Zanimivo je, da največje povečanje sadjarskih površin beležimo na območju Vzhodnih (Vinorodnih) Halozah (za 231,8 ha), sicer pa še na Dolinskem (za 177,8 ha), v Mariborskih goricah (za 113,8 ha) in v Vzhodnih Ljutomersko-Ormoških goricah (za 107,8 ha). Največji umik sadovnjakov je bilo zaznati v Osrednjih Slovenskih goricah (za 130,0 ha) in v Zahodnih Slovenskih goricah (za 126,4 ha). Med 8118,4 ha vseh sadjarskih površin se jih je 12,7 \% nahajalo v Zahodnih Slovenskih goricah, 9,7 \% v Osrednjih Slovenskih goricah, 8,0 \% v Dravinjskih goricah, 7,8 \% v Mariborskih goricah in 7,2 \% v Ptujskih goricah. 


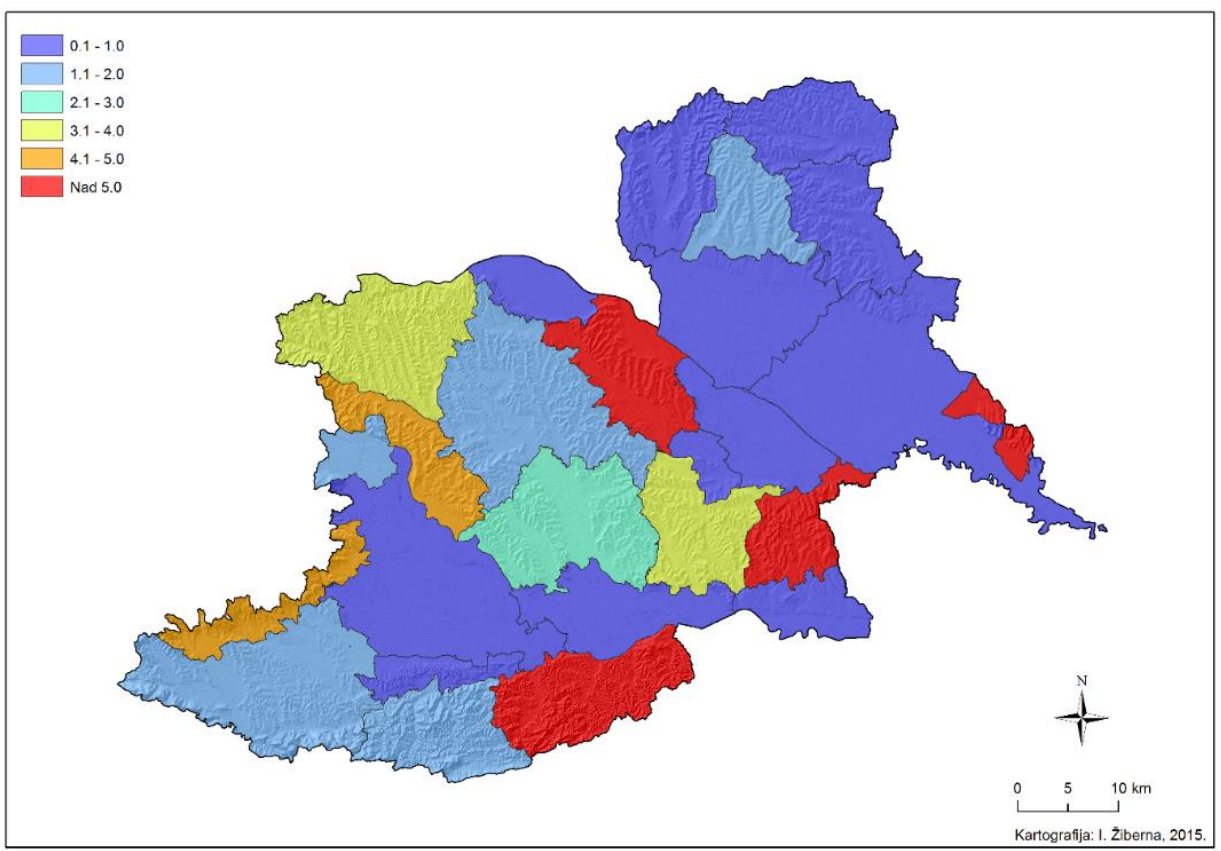

Delež vinogradniških površin po mikroregijah obpanonske severovzhodne Slovenije leta 2015 (v\%).

Strukturo neobdelovalnih površin po mikroregijah si bomo ogledali v bolj splošnih potezah. Travniške površine so pokrivale največ površja $\mathrm{v}$ Zahodnih Slovenskih goricah (5515,8 ha ali 31,4 \%), Osrednjih Slovenskih goricah (5004,4 ha ali 21,5\%), Dravinjskih goricah (4921,6 ha ali 21,4 \%) in Vzhodnih (Vinorodnih) Halozah (4120,6 ha ali 29,6 \%). Leta 2015 je bilo največ travniških površin v Osrednjih Slovenskih goricah $(5714,2$ ha ali 24,5\%), Dravinjskih goricah (5676, 0 ha ali 24,6 \%), Zahodnih Slovenskih goricah (5372,4 ha ali 30,6 \%) in Vinorodnih Halozah (3659,0 ha ali 26,3 \%). Travniške površine so se najbolj povečale v Dravinjskih goricah (za 754,4 ha), Osrednjih Slovenskih goricah (za 709,9 ha) in Ptujskih goricah (za 406,8 ha), najbolj pa zmanjšale na Dolinskem (za 826,0 ha) in Vinorodnih Halozah (za 461,6 ha). Med vsemi travniškimi površinami obpanonske severovzhodne Slovenije se jih je leta 2015 nahajalo največ v Osrednjih Slovenskih goricah (11,4\%), Dravinjskih goricah (11,3\%), Zahodnih Slovenskih goricah $(10,7 \%)$ in Vzhodnih Halozah (7,3\%).

Zemljišča $\mathrm{v}$ zaraščanju so se $\mathrm{v}$ obdobju $2000-2015$ povečala $\mathrm{v}$ vseh mikroregijah, najbolj pa v Zahodnih Slovenskih goricah (z 184,2 ha na 846,1 ha ali za 661,8 ha), na Dolinskem (z 318,2 ha na 872,1 ha ali za 553,9 ha), na Severovzhodnem Goričkem (s 42,1 ha na 467,9 ha ali za 425,8 ha) in na Jugovzhodnem Goričkem (z 23,5 ha na 392,1 ha ali za 368,5 ha). Delež zemljišč v zaraščanju je bil leta 2015 najvišji v Zahodnih Slovenskih goricah (4,8 \%), Vzhodnih (Vinorodnih) Halozah (4,7 \%), Severovzhodnem Goričkem $(4,3 \%)$, na Jugovzhodnem Goričkem, Lendavskih goricah in Mariborskih goricah (v vseh po $3,6 \%)$. 


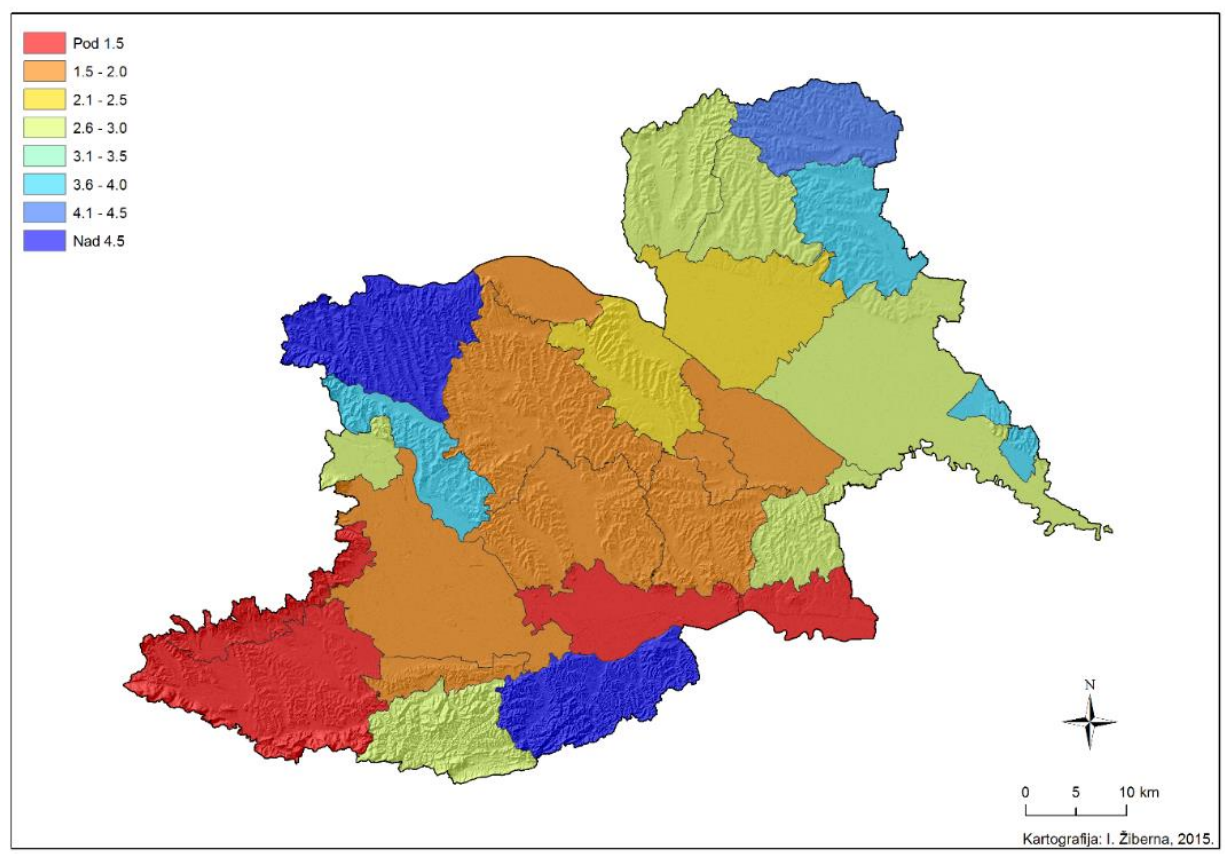

Delež zemljišč v zaraščanju po mikroregijah obpanonske severovzhodne Slovenije leta $2015(v \%)$.

Gozdne površine so se zmanjšale le na območju Dravinjskih goric (za 30,9 ha), najbolj pa povečale na Dolinskem (za 1079,0 ha), Vzhodnih (vinorodnih) Halozah (za 780,0 ha), v Zahodnih Slovenskih goricah (za 535,2 ha), Vzhodnih Ljutomersko-Ormoških goricah (za 388,9 ha) in na Severovzhodnem Goričkem (za 350,5 ha). Leta 2015 je bil najvišji delež gozdnih površin v Zahodnih (Gozdnatih) Halozah (63,0 \%), na Jugovzhodnem Goričkem (50,6 \%), na Severovzhodnem Goričkem (49,9 \%), Vzhodnih (Vinorodnih) Halozah (48,8 \% !!!) in na Srednjem Goričkem (47,5 ha).

Pozidane površine so se najbolj povečale na Dravskem polju (z 2984,1 ha na 3372,5 ha ali za 478,4 ha), na Dolinskem (z 2141,6 ha na 2367,6 ha ali za 226,0 ha) in na Ravenskem (s 1557,8 ha na 1751,8 ha ali za 194,1 ha). Med vsemi pozidanimi površinami celotne makroregije se najvišji delež le-teh nahaja na Dravskem polju (13,3 \%), Dolinskem $(9,4$ $\%)$, Dravinjskih goricah $(8,3 \%)$ in na Ravenskem (6,9 \%), torej pretežno na ravninskih mikroregijah.

Za konec pregleda sprememb rabe tal po mikroregijah si oglejmo še prevladujoče smeri sprememb vseh obdelovalnih površin $\mathrm{v}$ ostale oblike neobdelovalnih površin, pri čemer so nas zanimali predvsem prehodi v travnike, zemljišča $v$ zaraščanju, gozdne površine in pozidane in sorodne površine. Na območju celotne makroregije je iz obdelovalnih površin $\mathrm{v}$ travnike prešlo 15507,9 ha, $\mathrm{v}$ zemljišča $\mathrm{v}$ zaraščanju $2102,5 \mathrm{ha}$, $\mathrm{v}$ gozdne površine 2193,3 ha in v pozidane površine 2941,1 ha. Po površinah je bil prehod iz obdelovalnih površin v travnike najbolj intenziven v Osrednjih Slovenskih goricah (2009,6 ha), Dravinjskih goricah (1475,5 ha), Zahodnih Slovenskih goricah (1372,6 ha) in Ptujskih 
goricah $(1155,6$ ha). Prehod obdelovalnih površin $\mathrm{v}$ zemljišča $\mathrm{v}$ zaraščanju je bil najintenzivnejši na Dolinskem (203,2 ha), v Zahodnih Slovenskih goricah (192,2 ha), na Severovzhodnem Goričkem (167,7 ha), Ravenskem (137,0 ha), v Vzhodnih (Vinorodnih) Halozah (130,3 ha), Osrednjih Slovenskih goricah (124,7 ha) in na Jugovzhodnem Goričkem (113,0 ha).

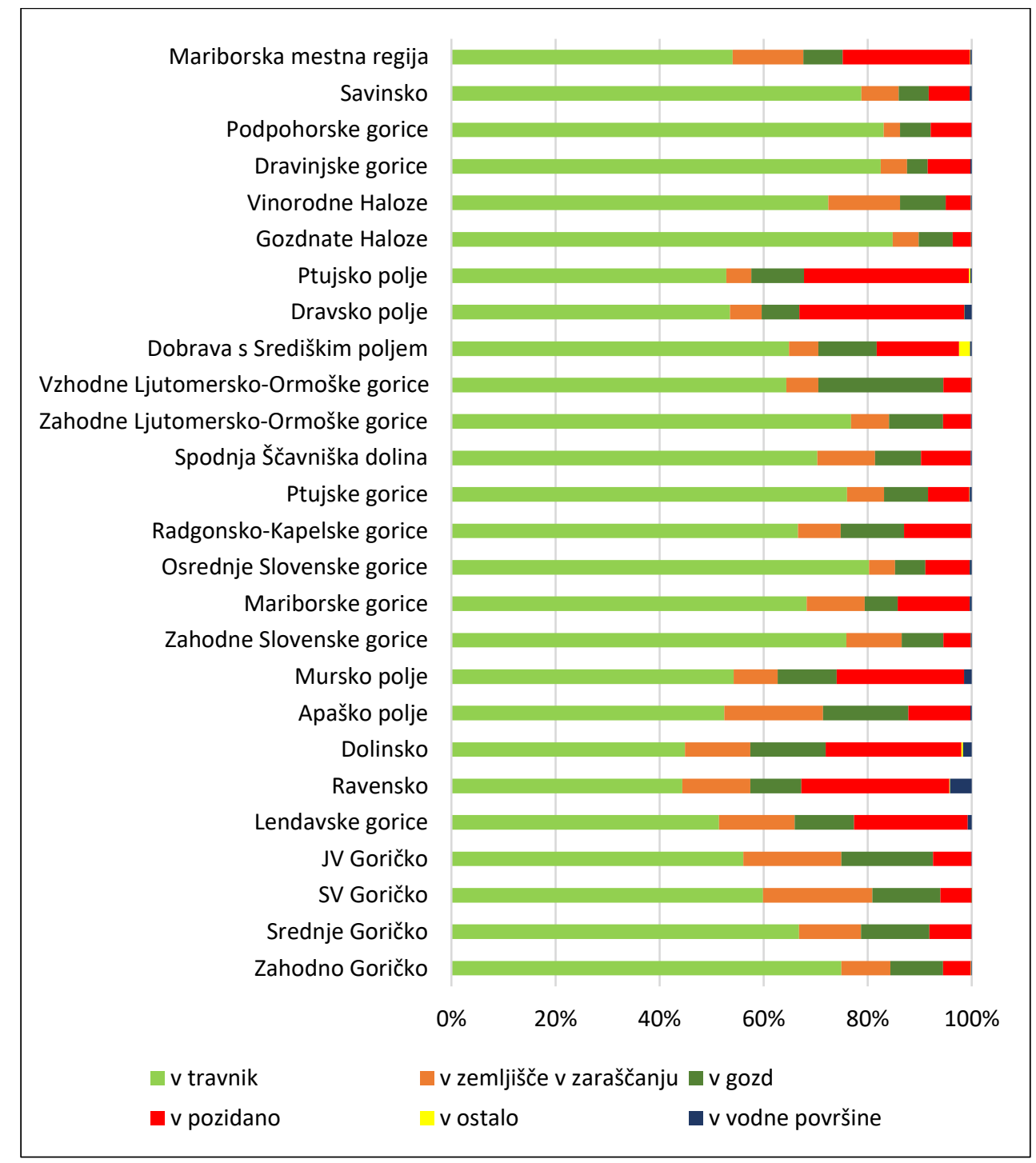

Struktura novo nastalih neobdelovalnih površin v obdobju 2000-2015 po mikroregijah $(v \%)$.

Za konec pregleda sprememb rabe tal po mikroregijah si oglejmo še prevladujoče smeri sprememb vseh obdelovalnih površin $\mathrm{v}$ ostale oblike neobdelovalnih površin, pri čemer so nas zanimali predvsem prehodi $v$ travnike, zemljišča $v$ zaraščanju, gozdne površine in 
pozidane in sorodne površine. Na območju celotne makroregije je iz obdelovalnih površin v travnike prešlo 15507,9 ha, $v$ zemljišča $\mathrm{v}$ zaraščanju 2102,5 ha, v gozdne površine 2193,3 ha in v pozidane površine 2941,1 ha. Po površinah je bil prehod iz obdelovalnih površin v travnike najbolj intenziven v Osrednjih Slovenskih goricah (2009,6 ha), Dravinjskih goricah (1475,5 ha), Zahodnih Slovenskih goricah (1372,6 ha) in Ptujskih goricah (1155,6 ha). Prehod obdelovalnih površin $\mathrm{v}$ zemljišča $\mathrm{v}$ zaraščanju je bil najintenzivnejši na Dolinskem (203,2 ha), v Zahodnih Slovenskih goricah (192,2 ha), na Severovzhodnem Goričkem (167,7 ha), Ravenskem (137,0 ha), v Vzhodnih (Vinorodnih) Halozah (130,3 ha), Osrednjih Slovenskih goricah (124,7 ha) in na Jugovzhodnem Goričkem (113,0 ha).

Oglejmo si še deleže površin, na katerih se je odvijal proces ekstenzifikacije (prehod obdelovalnih v neobdelovalne površine). Med vsemi mikroregijami je med površinami s procesom ekstenzifikacije prehod $\mathrm{v}$ travniške površine najbolj izrazit $\mathrm{v}$ Zahodnih (Gozdnatih) Halozah (84,8 \%), Podpohorskih goricah $(83,1 \%$ ), Dravinjskih goricah $(82,5 \%)$, Osrednjih Slovenskih goricah $(80,3 \%)$ in v Savinskem $(78,8 \%)$. Prehod iz obdelovalnih površin $v$ zemljišča $v$ zaraščanju je med vsemi procesi ekstenzifikacije najizrazitejši v Severovzhodnem Goričkem (21,0 \%), Apaškem polju $(19,0 \%)$, Jugovzhodnem Goričkem (18,9 \%) in Lendavskih goricah (14,5\%). Prehod iz obdelovalnih površin $\mathrm{v}$ gozd je $\mathrm{v}$ relativnem smislu najintenzivnejši $\mathrm{v}$ Vzhodnih Ljutomersko-Ormoških goricah $(24,0 \%)$, na Jugovzhodnem Goričkem $(17,6 \%)$, Apaškem polju (16,4 \%), Dolinskem (14,4 \%) in Srednjem Goričkem (13,2 \%). Prehod iz obdelovalnih površin v pozidane in sorodne površine je bil najizrazitejši na Ptujskem polju in Dravskem Polju (v obeh mikroregijah po $31,7 \%$ ), Ravenskem (28,5\%), Dolinskem (26,1 \%) in v Mariborski mestni regiji (24,5\%).

Na osnovi ugotovljenega lahko ugotovimo, da so smeri prehoda obdelovalnih površin v neobdelovalne vsaj dvosmerne: po eni strani gre za prehod v travnike, zemljišča $\mathrm{v}$ zaraščanju ali gozd (na območju mikroregij, ki imajo marginalni položaj ali demografsko neugodno starostno strukturo, kot so Goričko in Haloze), ali v pozidane in sorodne površine (na območju ravnin, kjer je intenziven proces suburbanizacije, hkrati pa so prav ta območja pomembna za pridelavo hrane).

\section{Zaključek}

Obpanonska severovzhodna Slovenija ima zaradi naravnih pogojev zelo velik pridelovalni potencial. Kot taka je prepoznana kot območje, kjer je v času, ko samooskrba z (zdravo) hrano postaja strateškega pomena, zaščita kmetijskih površin posebnega pomena. Kar 39,9 \% celotnega površja sodi v izjemno pomembno območje za kmetijstvo in pridelavo hrane, nadaljnjih $48,4 \%$ pa sodi v zelo pomembno območje za kmetijstvo in pridelavo hrane. Na žalost je opuščanje obdelovalnih površin najbolj prisotno prav na tem območju. Obdelovalne površine v marginalnih in demografsko problematičnih območjih prehajajo $\mathrm{v}$ travnike, površine $\mathrm{v}$ zaraščanju ali gozd, na ravninskih območjih pa zaradi suburbanizacije in gradnje avtocestnih krakov pa $\mathrm{v}$ pozidane in sorodne površine. Zaradi nizke stopnje samooskrbnosti v Sloveniji bo v prihodnje potrebno najbolj kakovostne obdelovalne površine zaščititi v večji meri kot do sedaj. 
GEOGRAFIJE PODRAVJA 109

I. Žiberna: Spreminjanje rabe tal na območju obpanonske severovzhodne Slovenije v obdobju 2000-2015

\section{Literatura in viri}

Belec, B. 1994: Subpanonska severovzhodna Slovenija. Regionalna geografska monografija Slovenije. Elaborat. Raziskovalni inštitut Pedagoške fakultete. Maribor.

Belec, B., Bračič, V. 1994: Haloze. Regionalna geografska monografija Slovenije. Elaborat. Raziskovalni inštitut Pedagoške fakultete. Maribor.

Gabrovec M., Kladnik D. 1997: Some New Aspects of Land Use in Slovenia. Acta Geographica XXXVII. Ljubljana.

Grčman, H., Vidic, N. J., Zupan, M., Lobnik F., Jones A., Montanarella L. (ur.), 2015: Tla Slovenije s pedološko karto v merilu 1: 250 000. Evropska komisija, Skupni raziskovalni center.

Kert, B. 1994a: Zahodne Slovenske gorice. Regionalna geografska monografija Slovenije. Elaborat. Raziskovalni inštitut Pedagoške fakultete. Maribor.

Kert, B. 1994b: Srednje Slovenske gorice. Regionalna geografska monografija Slovenije. Elaborat. Raziskovalni inštitut Pedagoške fakultete. Maribor.

Kladnik, D. 1999: Leksikon geografije podeželja. Inštitut za geografijo. Ljubljana.

Kladnik, D., Ravbar M. 2003: Členitev slovenskega podeželja. Geografija Slovenije 8. Geografski inštitut Antona Melika ZRC SAZU. Ljubljana.

Mioč, P., Žnidarčič, M. 1989: Osnovna geološka karta 1:100 000. List Maribor-Leibnitz. Tolmač. Zvezni geološki zavod SFRJ. Beograd.

Olas, L. 1994a: Prekmurske gorice. Regionalna geografska monografija Slovenije. Elaborat. Raziskovalni inštitut Pedagoške fakultete. Maribor.

Olas, L. 1994b: Prekmurska ravnina. Regionalna geografska monografija Slovenije. Elaborat. Raziskovalni inštitut Pedagoške fakultete. Maribor.

Pak, M. 1994: Dravska ravnina. Regionalna geografska monografija Slovenije. Elaborat. Raziskovalni inštitut Pedagoške fakultete. Maribor.

Perpar, A., Udovč, A. 2010: Realni potencial za lokalno oskrbo s hrano v Sloveniji. Dela 34. Oddelek za geografijo. Filozofska fakulteta. Univerza v Ljubljani. Ljubljana.

Perpar, A., Kovačič, M. 2006: Prostorski vidiki razvoja kmetij. Dela 25. Oddelek za geografijo. Filozofska fakulteta. Univerza v Ljubljani. Ljubljana.

Plut, D. 2012: Prehranska varnost in Slovenija. Dela 38. Oddelek za geografijo. Filozofska fakulteta. Univerza v Ljubljani. Ljubljana.

Uredba o območjih za kmetijstvo in pridelavo hrane, ki so strateškega pomena za Republiko Slovenijo Uradni list RS, 71. 15.11.2016.

Vrabič Kek, B. 2012: Kakovost Življenja. SURS. Ljubljana. 2012.

Žiberna, I. 2000: Geografski oris slovenskega Podravja. V: Drava nekoč in danes. Založba Obzorja, Maribor. 
GEOGRAFIJE PODRAVJA

THE GeOgraphies of THE Podravje Region 


\title{
Ocena neizkoriščenega potenciala funkcionalno degradiranih območij v Podravski statistični regiji
}

\author{
BARBARA LAMPIČ, TATJANA KIKEC, NEJC BOBOVNIK
}

Povzetek V prispevku predstavljamo aktualno stanje o lokacijah, vrstah, velikosti in drugih značilnostih funkcionalno degradiranih območij (FDO) v Podravski statistični regiji ter podajamo oceno njihovega razvojnoprostorskega potenciala. Podatki temeljijo na terenskem evidentiranju in zbiranju podatkov, ki so del rezultatov projekta Ciljnega raziskovalnega programa (CRP) in nastajajoče nacionalne evidence degradiranih območij Slovenije. Na osnovi terenskega zajema poleti 2016 in nadgraditve $\mathrm{z}$ drugimi relevantnimi informacijami smo v Podravski regiji (v 21 od skupaj 41 občin) evidentirali 84 FDO na skupni površini 213,86 ha. Prve tovrstne podatke za regijo interpretiramo $\mathrm{z}$ vidika možnosti njihove reaktivacije ter najnovejših načrtovanih posegov v prostor.

Ključne besede: • funkcionalno degradirano območje $\cdot$ prostorsko načrtovanje $\cdot$ trajnostni prostorski razvoj $\cdot$ sanacija $\cdot$ reaktivacija $\bullet$ Podravje •

\footnotetext{
NASLOV AVTORJEv: dr. Barbara Lampič, višja znanstvna sodelavka, Univerza v Ljubljani, Filozofska fakulteta, Oddelek za geografijo, Aškerčeva 2, 1000 Ljubljana, Slovenija, e-naslov: barbara.lampic@ff.uni-lj.si.dr. Tatjana Kikec, sodelavka, Juša Kramarja 19, 9000 Murska Sobota, Slovenija, e-naslov: tatjana.kikec@ gmail.com. Nejc Bobovnik, univ. dipl, geogr, sodelavec, Univerza v Ljubljani, Filozofska fakultetam Oddelek za geografijo, Aškerčeva 2, 1000 Ljubljana, Slovenija, enaslov: bobovnik.nejc@gmail.com.
} 


\title{
Assessment of functional untapped potential brownfield areas in the Podravje statistical region
}

\author{
BARbara LAMPIČ, TATJANA KIKEC, NEJC BOBOVNIK
}

\begin{abstract}
The authors represent the current situation concerning the location, type, size and other characteristics of functional degraded areas in the Podravje statistical region and represent an estimate of their development and spatial potential. The data are based on field data collection and recording, which are part of the project Target Research Program (CRP) and emerging national record of degraded areas Slovenia. Based on fieldwork in summer 2016 and includes upgrades to other relevant information in the Podravje region (in 21 out of 41 municipalities) recorded $84 \mathrm{FDO}$ in a total area of 213.86 ha.
\end{abstract}

Keywords: • degraded functional area $\bullet$ planning $\bullet$ sustainable spatial development $\bullet$ renewal $\bullet$ reactivation $\bullet$ Podravje region $\bullet$

CORRESPONDENCE AdDRESS: Barbara Lampič, Ph.D., Senior Research Fellow, University of Ljubljana, Faculty of Arts, Department for geography, Aškerčeva 2, 1000 Ljubljana, Slovenia, e-mail: barbara.lampic@ff.uni-lj.si. Tatjana Kikec, Ph.D., Juša Kramarja 19, 9000 Murska Sobota, Slovenia, email: tatjana.kikec@gmail.com. Nejc Bobovnik,univ. dipl. geogr., coworker, University of Ljubljana, Faculty of Arts Department for geography, Aškerčeva 2, 1000 Ljubljana, Slovenia, e-mail: bobovnik.nejc@gmail.com. 


\section{Uvod}

Po letu 2000 smo bili v Sloveniji priče precejšnjim prostorskim spremembam. Sprva hiter gospodarski razvoj je potreboval nov prostor za razvojne projekte oz. investicije in pogosto ni upošteval načel trajnostnih usmeritev pri umeščanju novih dejavnosti. Zaradi številnih potreb, neusklajenosti delovanja lokalne, regionalne in nacionalne ravni ter različnih parcialnih interesov, je prihajalo do prednostnih širitev dejavnosti (trgovine, poslovno-obrtne in industrijske dejavnosti ter tudi poselitve) na kmetijska in gozdna zemljišča. Nekatere začete investicije so bile nedomišljene, velikokrat plod »ad hoc« pobud različnih posameznikov, pogosto vezane na razmeroma lahko dostopna evropska in tudi nacionalna sredstva. V zadnjih letih, izraziteje pa po letu 2010, so se vplivi gospodarske krize pričeli jasno kazati tudi v prostoru. Nadaljevalo se je postopno zapiranje različnih gospodarskih podjetij, istočasno pa so ostajale nedokončane številne druge razvojne pobude (npr. gradnje novih stanovanjih sosesk, novih poslovnih con idr.).

Konec leta 2016 in v začetku 2017 je bila Podravska regija, natančneje Občina Hoče Slivnica, izjemno odmevno prisotna $\mathrm{v}$ različnih medijih zaradi pobude po vzpostavitvi nove, 94 hektarjev velike proizvodne cone Hoče - Slivnica, kamor se bo umestil industrijski obrat Magne Styer (Cirman, Vuković, 2017; Hoški svetniki ..., 2017; Gole et al., 2017). Izkazan tuj interes je najprej prepričal lokalno skupnost, nato pa tudi odgovorne resorje, da so po hitrem postopku sprejeli tako spremembe oz. dopolnitve Občinskega prostorskega načrta občine kot tudi Zakon o zagotavljanju pogojev za izvedbo strateške investicije na območju Občine Hoče - Slivnica.

Trenutno v Sloveniji ne razpolagamo z ustreznimi informacijami relevantnih resorjev ali prostorsko bazo, ki bi stroki omogočali vpogled $\mathrm{v}$ ažurne razmere na področju degradiranih območij. Tako tudi nimamo mehanizma za nadzor oz. spremljanje izvajanja »trajnostnega« prostorskega načrtovanja (na lokalni ali nacionalni ravni). Prav tako nimamo orodja, s katerim bi načrtovalce na vseh ravneh spodbudili (ali pa tudi »prisilili«), da bi pri umeščanju določenih dejavnosti najprej poiskali »prostorske rezerve« na obstoječih površinah niti možnosti širšega javnega ozaveščanja, ki bi temeljilo na ažurnih in javno dostopnih podatkih.

Vzpostavitev in delovanje ažurne evidence funkcionalno degradiranih območij (v nadaljevanju FDO), ki naj bi v prihodnosti prerasla v nacionalni register in dolgoročno postala sestavni del nastajajočega E-PROSTORA-a, je eden od rezultatov projekta Ciljnega raziskovalnega programa »Celovita metodologija za popis in analizo degradiranih območij, izvedba pilotnega popisa in vzpostavitev ažurnega registra« (št. V6-1510, naročnik Ministrstvo za gospodarski razvoj in tehnologijo).

Projekt predstavlja pomemben prispevek $\mathrm{k}$ večjemu aktiviranju in sistemskemu vključevanju degradiranih območij v (prostorski) razvoj. S takšnim pristopom bomo lahko omejiti nove posege in investicije na kmetijska in gozdna zemljišča, kar bi morala biti ena prednostnih usmeritev prav v Podravski regiji. Slednja je prepoznana kot izrazito kmetijska (njive $\mathrm{z}$ vrtovi obsegajo kar $22,3 \%$ površine), ki pa ima, v primerjavi s preostalimi slovenskimi regijami (in skupaj z Osrednjeslovensko), daleč največji delež $(8,4 \%)$ že pozidanih površin (Grafični podatki ..., 2016). 
Prav zaradi tega so ustrezno načrtovanje in umeščanje dejavnosti v prostor, učinkovita raba obstoječih stavbnih zemljišč ter aktiviranje oz. boljša izraba funkcionalno izpraznjenega (degradiranega) prostora ključni (in najcenejši) ukrepi za trajnostni prostorski razvoj regije.

\section{Neenotne opredelitve in razumevanje degradiranih območij}

Izhodišče pri pripravi opredelitve FDO predstavlja definicija Alkerjeve et al. (2000), ki kot degradirano (angl. brownfield ali greyfield) območje opredeljujejo vsako zemljišče (lahko tudi objekti), ki je že bilo v rabi ( razvito) in trenutno ni v celoti v uporabi, čeprav je lahko delno zasedeno ali izkoriščeno. To območje je lahko tudi prazno, opuščeno ali onesnaženo. Da je lahko definicija degradiranega območja nekoliko bolj omejena, kaže njegova opredelitev v Kanadi. Degradirana območja definirana so opredeljena kot opuščena, neizrabljena ali le delno uporabljena trgovska, komercialna ali industrijska posest, na kateri so pretekle aktivnosti povzročile okoljsko kontaminacijo in kjer je prisoten potencial za ponovni razvoj (Dasgupta, Tam, 2009).

V Sloveniji trenutno nimamo enotne, splošno sprejete opredelitve oz. definicije degradiranega območja. V preteklosti je bilo izvedenih več projektov, ki so se ukvarjali z izbranimi tipi degradacije ali so se osredotočili na določena degradirana območja (CABERNET 2006; COBRAMAN 2009; Špes et al., 2012) in so za svoje potrebe oblikovali ožjo definicijo, ki ni prešla v širšo uporabo niti v zakonodajo.

Uradno degradirana območja opredeljuje prostorska in okoljska zakonodaja. Tako so degradirana območja v Sloveniji v Zakonu o prostorskem načrtovanju (2007, 2. člen) zelo celovito opredeljena kot: »del naselja oziroma območje zunaj naselja, v katerem so zmanjšane tehnične, prostorsko oblikovalske, bivalne, gospodarske, socialne, kulturne in ekološke razmere do stanja neuporabnosti in je prenova za oživitev nujna oziroma je območje zunaj naselja, na katerem je zaradi človekove dejavnosti ali opustitve le-te prišlo do degradacije in je njena sanacija nujna«. Širša opredelitev pa ne pojasnjuje s kakšnimi merili ali kriteriji lahko ta območja $\mathrm{v}$ prostoru dejansko prepoznamo in prostorsko opredelimo.

Na strateški ravni so degradirana območja definirana v Strategiji prostorskega razvoja Slovenije (Bartol et al., 2004: 9) kot tista, »kjer je potencial za rabo in dejavnost zmanjšan ali omejen zaradi emisijskih, ekoloških, vizualnih ali drugih vplivov na obstoječo rabo. Degradirana območja so posledica lastninskega in ekonomskega preurejanja, to je opuščanja aktivne rabe kmetijskih zemljišč ali celo njihovega namernega opuščanja«. Ločeno so opredeljena tudi degradirana urbana območja kot »opuščena območja industrije, gradbeništva, skladišč, rudarstva, vojske, železnice, mestnih komunalnih služb, barakarska naselja, že iztrošena, neustrezna stanovanjska območja v predmestjih ali soseskah brez zgodovinske vrednosti ipd. ali zaradi dejavnosti onesnažena območja Omeniti velja še tretjo opredelitev degradiranih območij in sicer v Zakonu o varstvu okolja (2006). Kot je razvidno, so degradirana območja opredeljena na zelo »načelni« ravni, njihova podrobnejša, konkretna opredelitev pa je (bila) prepuščena prostorskim in razvojnim načrtovalcem (ki so se jim v preteklosti raje »izogibali«), inovativnosti in poskusom različnih raziskav (diplomske, magistrske naloge in disertacije) ter potrebam različnih, pretežno evropskih projektov. 


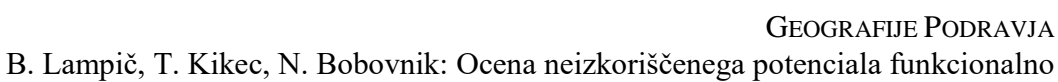
degradiranih območij v Podravski statistični regiji

Trenutno poteka proces celovite prenove predvsem prostorske zakonodaje, v procesu priprave pa sta tudi nova temeljna strateška dokumenta, Strategija razvoja Slovenije in Strategija prostorskega razvoja Slovenije. V času priprave prispevka še ni povsem jasno, $\mathrm{v}$ kakšnem obsegu in na kakšen način bodo degradirana območja vključena $\mathrm{v}$ vse omenjene dokumente, kaže pa, da se bo do določene mere spremenila terminologija, kar bo prispevalo k boljšemu razumevanju degradiranih območij.

V nadaljevanju omenjamo nekaj nacionalnih študij, ki so se že ukvarjale z različnimi vidiki degradiranosti v prostoru. Tako je že Špesova (1998) preučevala onesnaževanje okolja na primeru štirih najbolj degradiranih in s človekovimi posegi preoblikovanih slovenskih območij: Celju, Trbovljah, Mežiški dolina in Jesenicah. Koželj et al. (1998) so se $\mathrm{v}$ istem času ukvarjali $\mathrm{z}$ degradiranimi urbanimi območji, ki so posledica ekonomskih, tehnoloških in socialnih sprememb mest in regij. Prepoznali so jih kot območja, ki predstavljajo potencial za prostorski razvoj naselij, prostorsko preurejanje dejavnosti znotraj naselij in urbanistične inovacije. Ugotavljajo, da območja, podvržena daljšemu propadanju, postanejo fizična in funkcionalna ovira za razvoj sosednjih območij in izvajanje načrtovane rekonstrukcije mesta.

V okviru projekta Sonaravna sanacija okoljskih bremen kot trajnostno razvojna priložnost Slovenije je bil leta 2011 izveden prvi sistematičen popis degradiranih območij in vzpostavljena evidenca, ki je vključevala štiri tipe degradiranih območij (industrijska, vojaška, transportna in infrastrukturna ter rudarska območja) (Špes et al., 2012). Rezultati projekta, ki ga je financiralo Ministrstvo za gospodarski razvoj in tehnologijo, so opozorili na prostorski potencial izpraznjenih območij, zaradi časovnih in finančnih omejitev pa je bila vzpostavljena evidenca pomanjkljiva.

Omeniti velja še projektno nalogo Merila in kriteriji za določitev degradiranih urbanih območij (Koželj et al., 2016), katere osrednji cilj je opredelitev, lociranje in analiza stanja t.i. nerevitaliziranih območij v 11 mestnih občinah Slovenije. Ministrstvu za okolje inprostor, kot naročniku raziskave, bodo podatki o nerevitaliziranih območjih v prihodnje neposredno služili za izvajanje finančnih ukrepov, ki jih predvideva instrument kohezijske politike v programskem obdobju 2014-2020.

\section{Opredelitev FDO in metode dela}

Opredelitev FDO je nastala v okviru projekta CRP (Celovita metodologija ... 2017) in izhaja tako iz dosedanjih rezultatov raziskav kot tudi iz pregleda obsežne znanstvene in strokovne literature. Slednja med številnimi definicijami kot prevladujoče značilnosti degradiranega prostora najpogosteje prepoznava: nezadostno izkoriščenost območja (skupaj z njegovo zmanjšano vrednostjo), prisotnost različnih oblik onesnaženosti, stanje zapuščenosti in zanemarjenosti, očiten vpliv predhodne rabe, prostorski in razvojni potencial, potrebo po sanaciji, revitalizaciji itd.

Pri opredelitvi FDO nismo izhajali iz različnih oblik degradacije prostora temveč smo z definiranjem kriterijev za določitev FDO zožili obravnavo zgolj na funkcionalno izpraznjen, lahko rečemo tudi razvrednoten prostor. Tako opredeljena območja je tudi najlaže prostorsko zamejiti ter v nadaljevanju, z izbranimi ukrepi, z novimi dejavnostmi tudi oživiti. 
FDO tako predstavlja nezadostno izkoriščeno ali zapuščeno območje z vidnim vplivom predhodne rabe in zmanjšano uporabno vrednostjo, ki lahko predstavlja potencial za razvoj. FDO razvojno aktiviramo s sektorsko usklajenimi predpisi in ukrepi za prenovo in reaktivacijo oz. lahko območje $\mathrm{z}$ določenimi ukrepi povrnemo $\mathrm{v}$ stanje pred izvajanjem dejavnosti (Lampič et al., 2016; Celovita metodologija ..., 2017).

Dejansko je opredelitev posameznega FDO mogoča šele s pomočjo kriterijev, vrsta FDO pa z določitvijo ustreznega tipa. Zaradi potrebe, da se evidenca FDO v prihodnje uveljavi kot javno dostopna, se sproti posodablja in nadgrajuje, so kriteriji za njihovo opredelitev $\mathrm{v}$ prostoru enostavni in maloštevilni. Osnovna kriterija za opredelitev FDO sta kriterij opuščenosti in kriterij zajema, posebni kriterij (čas opuščenosti) pa se upošteva le za FDO prehodne rabe. Trije t. i. dopolnilni kriteriji še dodatno osvetljujejo razmere na območju FDO (informacije o vzdrževanosti območja, prisotnosti socialne in okoljske degradacije) in nimajo neposredne vloge za prostorsko opredelitev.

Izhodišče za evidentiranje FDO v prostoru je opredelitev tistih območij, ki so brez funkcije oz. se določena funkcija/dejavnost izvaja v omejenem obsegu. Tako s kriterijem opuščenosti (ki odraža t. i. funkcionalno degradacijo prostora) določimo:

- Opuščeno območje (100 \%): na območju se ne izvaja nobena dejavnost in je v celoti opuščeno;

- Pretežno opuščeno območje (50 do 99 \%): območje (tudi z objekti) je v večjem delu opuščeno, v delu pa še potekajo določene dejavnosti;

- Delno opuščeno (10 do 50 \%): območje, ki je v večjem delu še v funkciji, del območja oz. objektov pa je opuščeno in brez funkcije;

- Ni opuščeno (0 do $10 \%$ ): ta kategorija je lahko pripisana le podtipu FDO stara dotrajana območja (prisotna izrazita fizična degradacija, poslabšane razmere za bivanje) ali podtipu FDO staro mestno ali vaško jedro (prisotna izrazita fizična degradacija).

Območja, kjer zaznamo opuščenost prostora in/ali objektov do $10 \%$ celotne površine, nismo uvrstili med FDO. Da se območje lahko opredeli kot FDO, mora ustrezati tudi minimalnemu velikostnemu kriteriju. Kriterij zajema $\mathrm{v}$ mestih in mestnih naseljih (upoštevana opredelitev SURS 2003) je minimalna površina 0,2 ha, ostala območja (odprti prostor) pa morajo obsegati najmanj 0,5 ha površine. Zaradi nadaljnje povezljivosti evidence FDO $\mathrm{z}$ drugimi prostorskimi podatki ter dolgoročne vizije vključevanja baze v E-PROSTOR je pomembna tudi natančna prostorska zamejitev FDO po mejah parcel. Uskladitev meje FDO s parcelami bo ob izvajanju vseh nadaljnjih ukrepov pomembno olajšala nadaljnje postopke v sistemu sanacije in revitalizacije FDO.

Za FDO prehodne rabe smo dodali še t. i. posebni kriterij in sicer čas opuščenosti. Podtip FDO opuščeno gradbišče evidentiramo takrat, kadar gradbišče oz. območje miruje vsaj eno leto. FDO značilne prehodne rabe pa upoštevamo v primeru, kadar se prehodna (začasna) raba na območju odvija do treh let. Kadar je začasna raba prisotna več kot tri leta (se uveljavi v prostoru) območje ne uvrstimo med FDO. S tremi dopolnilnimi kriteriji vsak FDO še podrobneje označimo in opozorimo na različne vrste degradacije, ki bodo pomembne predvsem pri načrtovanju sanacije območja. 
Za vsako območje smo opredelili stopnjo vzdrževanosti območja (in objektov), zabeležili morebitno prisotnost socialne degradacije (prisotnost vandalizma, zmanjšana varnost, prisotnost kriminala, getoizacija) in okoljske degradacije (ocena potencialnih negativnih vplivov na posamezne sestavine okolja) (Lampič et al., 2016).

Pri določanju tipa posameznemu FDO smo izhajali iz predhodne dejavnosti v prostoru in Pravilnika o vsebini, obliki in načinu priprave občinskega prostorskega načrta (Pravilnik ..., 2007), na osnovi katerega smo uskladili terminologijo FDO. Če smo v raziskavi Sonaravna sanacija okoljskih bremen kot trajnostno razvojna priložnost Slovenije (Špes et al., 2012) definirali 4 tipe degradiranih območij, smo tokrat s celovitejšo opredelitvijo želeli pokriti vse vrste rabe/dejavnosti. Določili smo 9 osnovnih tipov FDO, 5 tipom FDO pa smo določili tudi podtipe (15 podtipov FDO).

Tipi in podtipi FDO.

\begin{tabular}{|c|c|}
\hline Tip FDO & Podtip FDO \\
\hline \multicolumn{2}{|l|}{ 1. FDO kmetijske dejavnosti } \\
\hline \multirow[t]{3}{*}{ 2. FDO storitvenih dejavnosti } & 2.1 FDO javnih storitev \\
\hline & $\begin{array}{l}\text { 2.2 FDO poslovnih, trgovskih in drugih storitvenih } \\
\text { dejavnosti }\end{array}$ \\
\hline & 2.3 FDO starega mestnega ali vaškega jedra \\
\hline \multicolumn{2}{|c|}{$\begin{array}{llr}\text { 3. } & \text { FDO turistične, športno- } & \\
\text { rekreacijske in športne dejavnosti }\end{array}$} \\
\hline \multicolumn{2}{|l|}{$\begin{array}{l}\text { 4. FDO industrijskih in obrtnih } \\
\text { dejavnosti }\end{array}$} \\
\hline \multicolumn{2}{|l|}{$\begin{array}{l}\text { 5. FDO obrambe, zaščite in } \\
\text { reševanja }\end{array}$} \\
\hline \multirow{4}{*}{$\begin{array}{l}\text { 6. FDO pridobivanja mineralnih } \\
\text { surovin }\end{array}$} & 6.1 FDO rudnika \\
\hline & 6.2 FDO kamnoloma, peskokopa \\
\hline & 6.3 FDO gramozne jame \\
\hline & $\begin{array}{l}6.4 \text { FDO ostala območja pridobivanja mineralnih } \\
\text { surovin }\end{array}$ \\
\hline \multirow[t]{4}{*}{ 7. FDO infrastrukture } & 7.1 FDO prometne infrastrukture \\
\hline & 7.2 FDO okoljske infrastrukture \\
\hline & 7.3 FDO ostale gospodarske javne infrastrukture \\
\hline & 7.4 FDO zelene infrastrukture \\
\hline \multirow[t]{2}{*}{ 8. FDO prehodne rabe } & 8.1 FDO opuščenega gradbišča \\
\hline & 8.2 FDO značilne prehodne rabe \\
\hline \multirow[t]{2}{*}{ 9. FDO za bivanje } & $\begin{array}{l}9.1 \text { FDO za bivanje - nedograjena stanovanjska } \\
\text { območja }\end{array}$ \\
\hline & 9.2 FDO za bivanje - stara dotrajana območja \\
\hline
\end{tabular}

Metoda pridobivanja podatkov je bila terenska. Delo na terenu (obisk občin in vsake posamezne lokacije zaznanega FDO) je potekalo od marca do julija leta 2016. Poleg poznavanja obstoječe planske rabe na ravni posamezne občine, informacij o degradiranih območjih, ki so bila evidentirana leta 2011 (Špes et al., 2012) ter podrobnim pregledom 
ortofoto posnetkov, smo FDO najprej poskušali identificirati skupaj s predstavniki občin.

Pripravili smo nabor potencialno relevantnih območij, ki smo jih skupaj preverili in glede na kriterije vključili v evidenco. Istočasno smo na občini pridobili tudi ostale relevantne podatke o območjih (leto izgradnje, čas opuščenosti, lastništvo, razvojni načrti idr.). Sledil je terenski popis in natančna opredelitev meje v prostoru. Na terenu smo preverili tudi nekatere druge značilnosti FDO (pogosto na občinah niso imeli na voljo vseh podatkov oz. jih niso poznali), vsako območje smo fotografirali in po potrebi pridobili dodatne informacije bodisi od okoliškega prebivalstva ali lastnikov.

V praksi se je pokazalo, da smo po terenskih ogledih in dodatnih informacijah zabeležili še dodatne FDO-je, kar je potrdilo našo izhodiščno trditev, da je dinamika v prostoru velika, in da pogosto niti občinske službe ne morejo slediti procesom v prostoru.

Za potrebe projekta je bila vzpostavljena aplikacija za vnos in pregledovalnik FDO (Lampič et al., 2016)). Vse popisane podatke smo vnesli v aplikacijo, dodatno pa smo vključili še, v geografskih informacijskih sistemih izrisana, vektorska območja vseh FDO ter fotografije. Aplikacija je izdelana na način, da omogoča neposreden izvoz podatkov za nadaljnje analize, nekaj osnovnih prikazov in izračunov na ravni regije ali občine pa je mogočih tudi v obstoječem pregledovalniku.

Pomemben metodološki doprinos je tudi zasnova modela za reaktivacijo FDO. V razpravi sicer zgolj nakazujemo potencial za reaktivacijo območij v Podravski regiji. Na osnovi štirih različnih kriterijev smo določili stopnjo primernosti posameznega FDO za reaktivacijo. Upoštevani so bili kriterij opuščenosti, lastništva, načrtovalsko-razvojni kriterij in varstveno-okoljski kriterij, vsak kriterij pa je bil definiran s konkretnimi kazalniki (podatki). Vhodni podatki za analizo so vezani na individualne značilnosti vsakega posameznega degradiranega območja.

Informacije so bile zbrane s terenskim popisom (stopnja opuščenosti, čas opuščenosti, ocena suma na okoljsko degradacijo, definiranost razvojnega načrta idr.) ali pa smo jih pridobili iz relevantnih baz podatkov (namenska raba prostora, prisotnost režima varovanja (območje Natura 2000, Register nepremične kulturne dediščine, vodovarstveno območje) idr.). Podrobneje je metodologija predstavljena $v$ internem gradivu projektne dokumentacije (Celovita metodologija ..., 2017) in vmesnih poročilih (Lampič et al., 2016).

\section{Stanje FDO v Podravski regiji}

$\mathrm{Na}$ osnovi podrobnega pregleda ortofoto posnetkov in drugih prostorskih podatkov, razgovorov na občinah ter dela na terenu smo, upoštevajoč kriterije in uporabljeno tipologijo, v 21 od 41 občin v regiji popisali in ovrednotili 84 FDO na skupni površini 213,9 ha. Večina identificiranih FDO se nahaja na območju Maribora z okolico, na Dravskem polju, zahodno od Maribora proti Rušam (v Dravski dolini) ter na Ptujskem polju (med Slovensko Bistrico in Ptujem). 
B. Lampič, T. Kikec, N. Bobovnik: Ocena neizkoriščenega potenciala funkcionalno degradiranih območij v Podravski statistični regiji

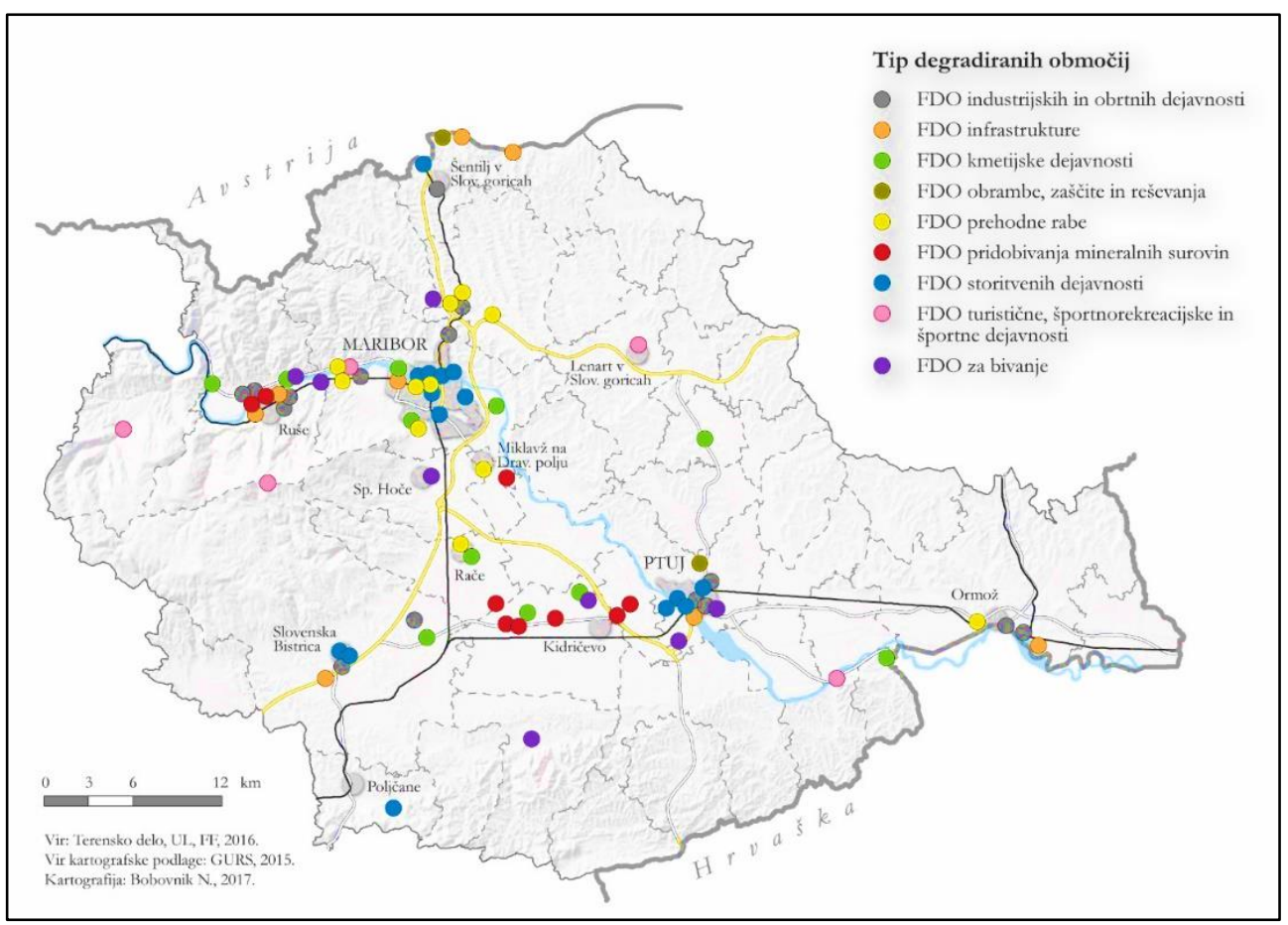

Razporeditev in tipi FDO v Podravski statistični regiji junija 2016.

Pregled FDO po številu in površini.

\begin{tabular}{|l|c|c|c|}
\hline Tip FDO & Število FDO & $\begin{array}{c}\text { Površina } \\
\text { FDO (ha) }\end{array}$ & $\begin{array}{c}\text { Delež (\%) } \\
\text { površine FDO }\end{array}$ \\
\hline FDO industrijskih in obrtnih dejavnosti & 15 & 49,03 & 22,9 \\
\hline FDO storitvenih dejavnosti & 15 & 33,12 & 15,5 \\
\hline FDO kmetijske dejavnosti & 11 & 17,41 & 8,1 \\
\hline FDO prehodne rabe & 11 & 23,10 & 10,8 \\
\hline FDO pridobivanja mineralnih surovin & 9 & 51,48 & 24,1 \\
\hline FDO infrastrukture & 8 & 24,73 & 11,6 \\
\hline FDO za bivanje & 8 & 6,64 & 3,1 \\
\hline $\begin{array}{l}\text { FDO turistične, športnorekreacijske in } \\
\text { športne dejavnosti }\end{array}$ & 5 & 6,13 & 2,9 \\
\hline FDO obrambe, zaščite in reševanja & 2 & 2,23 & 1,0 \\
\hline Skupaj & 84 & 213,86 & 100,0 \\
\hline
\end{tabular}

Med devetimi različnimi tipi FDO po številu prevladujejo FDO industrijskih in obrtnih dejavnosti ter FDO storitvenih dejavnosti (15 območij). Sledijo FDO kmetijske dejavnosti in FDO prehodne rabe (11 območij), FDO pridobivanja mineralnih surovin (skupaj 9, od tega je 8 gramoznih jam), FDO infrastrukture in FDO za bivanje (8 območij), FDO turistične, športnorekreacijske in športne dejavnosti (5 območij), evidentirali pa smo tudi dve FDO obrambe, zaščite in reševanja. Bolj kot samo število je 
pomembna skupna površina FDO, kjer največ, 51,5 ha, predstavljajo FDO pridobivanja mineralnih surovin, 49,0 ha pa predstavljajo FDO industrijskih in obrtnih dejavnosti.

Za nadaljnje razvojno načrtovanje igra pomembno vlogo opuščenost degradiranih območij. Odsotnost dejavnosti oz. njihova zastopanost v omejenem obsegu je temeljni kriterij za opredelitev funkcionalno degradiranega prostora. Če gre za območja, kjer se človekove dejavnosti ne odvijajo, lahko to na eni strani predstavlja prednost, saj se pri umeščanju novih dejavnosti ni potrebno prilagajati obstoječim delujočim aktivnostim. Po drugi strani pa dolgoletna opuščenost navadno kaže na različne lastniške težave, stara okoljska bremena ali pa npr. neustrezno lokacijo in nakazuje, da bo umeščanje novih dejavnosti povezano z dodatnimi vlaganji, časovno pa je lahko zelo zamudno. Med vsemi popisanimi FDO se je pokazalo, da so v večji meri pretežno opuščena (48 \% vseh popisanih površin FDO) in povsem opuščena (42\%).

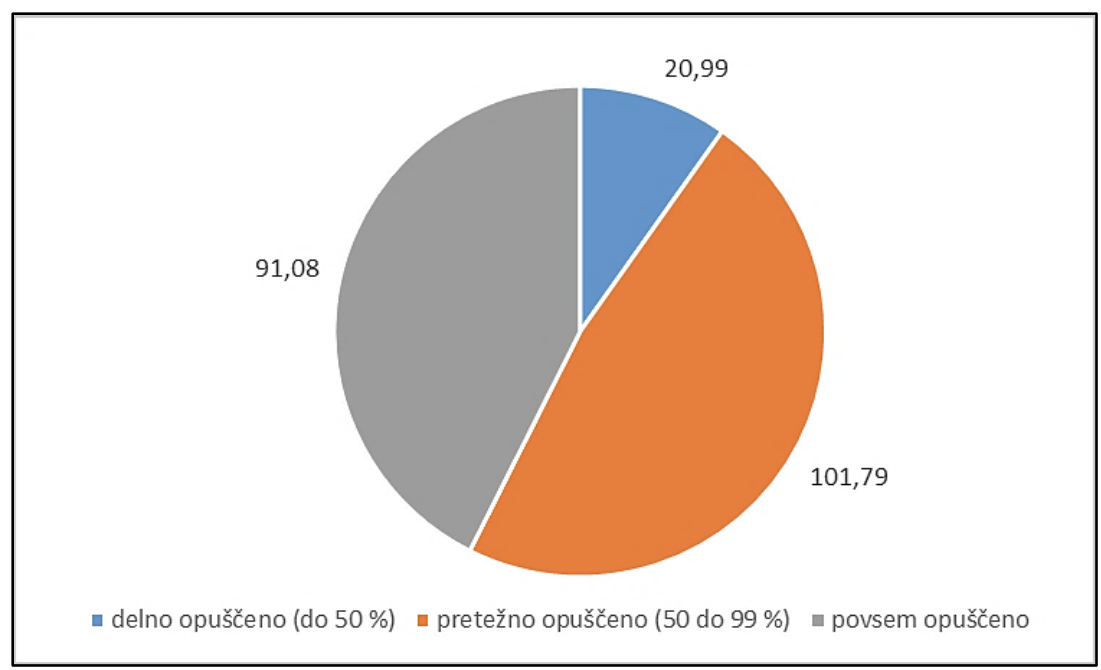

FDO Podravske regije (skupna površina v ha) po stopnji opuščenosti.

Večje so razlike glede opuščenosti posameznih tipov FDO. Med povsem opuščenimi prevladujejo območja pridobivanja mineralnih surovin in območja prehodne rabe. $\mathrm{Za}$ FDO industrijskih in obrtnih dejavnosti ugotavljamo, da je povsem izpraznjenih območij razmeroma malo (skupaj predstavljajo 11,8 ha, mednje sodijo Steklarna Luminus v Slovenski Bistrici, Techcenter na Ptuju, Podjetje Kristal v občini Selnica ob Dravi). Za industrijska območja je namreč značilno, da se vsaj del dejavnosti v prostoru še odvija, zato prevladujejo pretežno opuščena območja $(35,9$ ha).

Posebej velja izpostaviti FDO prehodne rabe. Prav v Podravski regiji smo evidentirali razmeroma številna opuščena gradbišča, največ smo jih zabeležili na območju občine Maribor in Pesnica. Prevladujejo opuščena gradbišča, kjer so se načrtovale nove stanovanjske soseske (npr. stanovanjska soseska v Račah, Laznici, Pesnici in v Miklavžu), sledijo načrtovane poslovne cone (npr. poslovna cona Spodnje Dobrenje, Pesniški Dvor). 
Prav za FDO prehodne rabe bi moralo do neke mere veljati, da je ponoven zagon investicije najbolj realen, saj je za podtip FDO opuščenih gradbišč navadno vzrok finančne narave oz. stečaj podjetij. Tako moramo opozoriti, da so se v vmesnem času npr. na območju načrtovane stanovanjske soseske v Pesnici že začele določene aktivnosti, medtem ko večina opuščenih gradbišč še vedno sameva.

Omeniti velja še evidentirana FDO infrastrukture in FDO storitvenih dejavnosti. Pri teh dveh tipih območij je delež delno opuščenih površin razmeroma visok. Predvsem številna območja storitvenih dejavnosti opozarjajo, da v prostoru prihaja do precejšnje dinamike pri zagotavljanju različnih storitvenih dejavnosti, še največ pri podtipu FDO poslovnih, trgovskih in drugih storitvenih dejavnosti.

Tipi FDO (skupna površina v ha) po stopnji opuščenosti.

\begin{tabular}{|l|c|c|c|c|}
\hline Tip FDO & $\begin{array}{c}\text { Povsem } \\
\text { opuščeno }\end{array}$ & $\begin{array}{c}\text { Pretežno } \\
\text { opuščeno } \\
(50 \text { do 99 \% })\end{array}$ & $\begin{array}{c}\text { Delno } \\
\text { opuščeno } \\
\text { (do 50 \% })\end{array}$ & $\begin{array}{c}\text { Skupaj } \\
\text { površina } \\
\text { FDO (ha) }\end{array}$ \\
\hline $\begin{array}{l}\text { FDO industrijskih in } \\
\text { obrtnih dejavnosti }\end{array}$ & 11,81 & 35,86 & 1,36 & 49,03 \\
\hline FDO infrastrukture & 8,59 & 5,00 & 11,14 & 24,73 \\
\hline FDO kmetijske dejavnosti & 10,05 & 7,36 & - & 17,41 \\
\hline $\begin{array}{l}\text { FDO obrambe, zaščite in } \\
\text { reševanja }\end{array}$ & 1,69 & 0,54 & - & 2,23 \\
\hline FDO prehodne rabe & 22,30 & 0,80 & - & 23,10 \\
\hline $\begin{array}{l}\text { FDO pridobivanja } \\
\text { mineralnih surovin }\end{array}$ & 23,85 & 27,63 & - & 51,48 \\
\hline FDO storitvenih dejavnosti & 3,43 & 21,20 & 8,48 & 33,12 \\
\hline $\begin{array}{l}\text { FDO turistične, športno- } \\
\text { rekreacijske in športne } \\
\text { dejavnosti }\end{array}$ & 5,26 & 0,87 & - & 6,13 \\
\hline FDO za bivanje & 4,11 & 2,53 & - & 6,64 \\
\hline Skupaj & 91,08 & 101,79 & 20,99 & 213,86 \\
\hline
\end{tabular}

Z vidika reaktivacije FDO in umeščanja novih dejavnosti v funkcijsko izpraznjen prostor je ključnega pomena lastništvo. Neurejeno lastništvo, več lastnikov, mešano javnozasebno lastništvo, dolgotrajni stečajni postopki ipd., predstavljajo pogosto skoraj nerešljive prepreke pri poskusih iskanja rešitev za reaktivacijo FDO. Že študija Špesove je opozorila, da je lastništvo eden temeljnih problemov pri reševanju degradiranih območij pri nas (Špes et al., 2012).

V zadnjih nekaj letih je opazno predvsem povečanje števila FDO v zasebni lasti in velika razdrobljenost lastništva, oboje pa, skupaj z dolgotrajnimi stečajnimi postopki, tudi danes predstavlja najpogostejše vzroke za odsotnost ustreznih sanacijskih in reaktivacijskih načrtov. Ob pregledu vrste lastništva med FDO v Podravski regiji izrazito prevladujejo tista v zasebni lasti (tako po številu kot po površini), v mešani, javno-zasebni lasti je 13 območij oz. 52,4 ha površin FDO, najmanj pa jih je v celoti v občinski ali v državni lasti. 
B. Lampič, T. Kikec, N. Bobovnik: Assessment of functional untapped potential brownfield areas in Podravje statistical region

Obravnavana FDO glede na lastništvo.

\begin{tabular}{|l|c|c|c|}
\hline Vrsta lastništva & Število FDO & Površina FDO (ha) & Delež (\%) površine \\
\hline Državno & 5 & 18,47 & 8,6 \\
\hline Občinsko & 7 & 6,81 & 3,2 \\
\hline Zasebno & 59 & 136,17 & 63,7 \\
\hline Javno-zasebno & 13 & 52,41 & 24,5 \\
\hline Skupaj & 84 & 213,86 & 100,0 \\
\hline
\end{tabular}

Pri vrednotenju značilnosti FDO velja omeniti tudi njihovo velikost. Določeni projekti, ki so sicer redki, zahtevajo velika in prostorsko homogena območja, ki nudijo zadostne površine za izvajanje določenih dejavnosti (npr. večji industrijski obrati s proizvodnjo, skladišči, ustreznimi parkirnimi prostori). $\mathrm{V}$ praksi pa so razvojne potrebe in tudi zmožnosti posameznih investitorjev praviloma manjše in jim za razvoj dejavnosti ustrezajo tudi manjša območja.

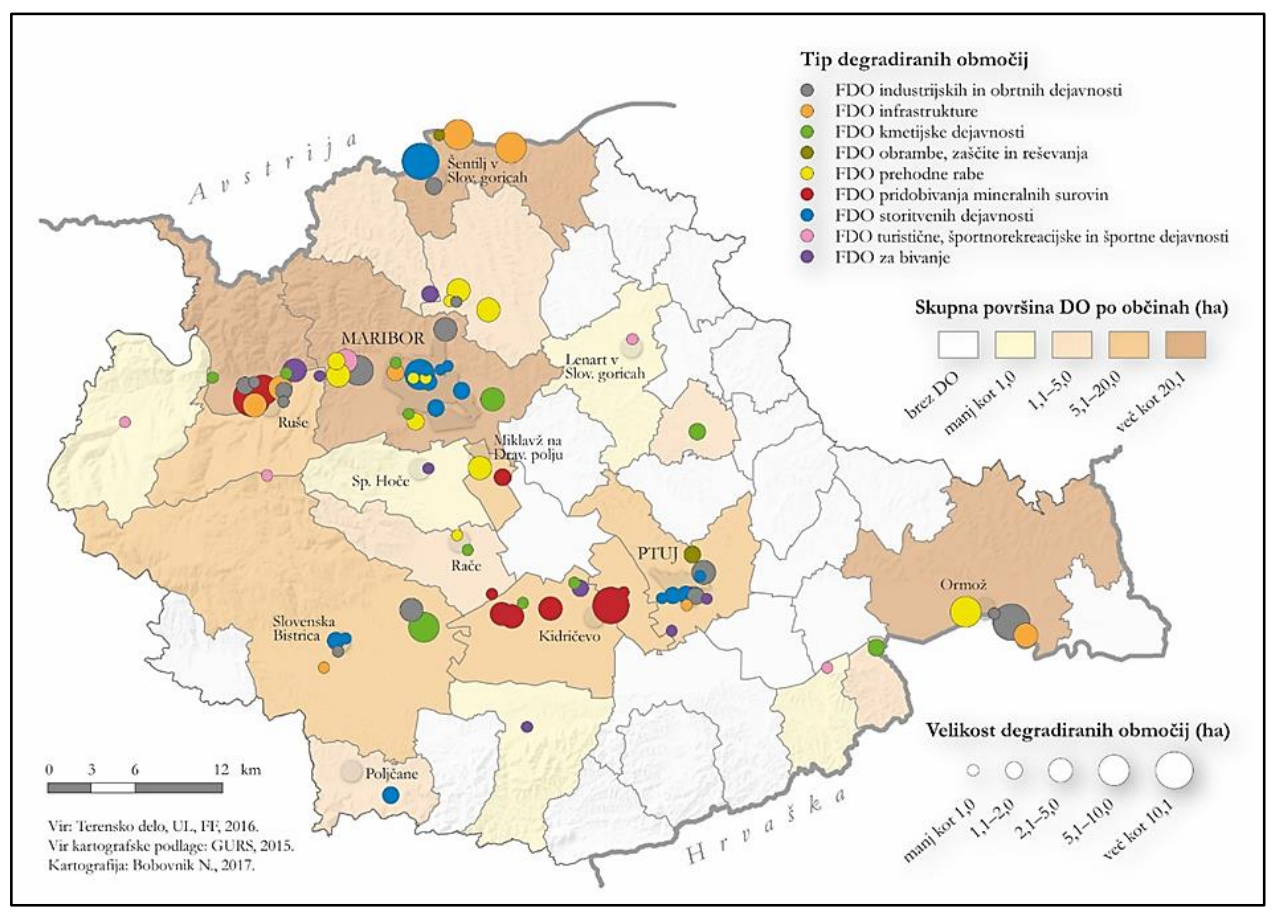
FDO Podravske regije po tipih, velikosti in prikazom skupnih funkcionalno
degradiranih površin na ravni posamezne občine.

Med vsemi 84 evidentiranimi FDO jih je bilo 11 večjih od 5 ha (največje je 25,5 ha veliko območje pretežno opuščenega FDO Tovarne sladkorja Ormož), kar 37 območij pa je bilo manjših od 1 ha. Veliko število razmeroma majhnih FDO je značilno za severovzhodno Slovenijo, saj se Podravska regija z zgolj 2,5 ha povprečno velikim FDO med sedmimi popisanimi statističnimi regijami uvršča samo pred Pomursko, kjer je povprečna velikost 
popisanih FDO le 1,5 ha, medtem ko je na ravni popisanih regij povprečno velikost FDO 3,8 ha.

Zelo poveden je tudi prikaz trenutnega stanja FDO po občinah skupaj s celotno razpoložljivo površino slabše oz. neizkoriščenih zemljišč. V 21 občinah Podravske regije smo evidentirali 213,9 ha funkcionalno degradiranih površin. Največ v Mestni občini Maribor (36,8 ha) in občini Ormož (36,4 ha), večje površine FDO so še v občinah Selnica ob Dravi in Šentilj. Medtem ko občini Maribor in Ptuj beležita večje število FDO (vsaka preko 10), pa smo jih v kar 9 občinah zabeležili le po eno, v 20 občinah regije pa FDO, ki bi ustrezali našim kriterijem, nismo zaznali.

Število in površine FDO po občinah Podravske regije.

\begin{tabular}{|l|c|c|}
\hline Občina & Število FDO & Površina FDO (ha) \\
\hline Maribor & 19 & 36,84 \\
\hline Ormož & 4 & 36,30 \\
\hline Selnica ob Dravi & 7 & 30,95 \\
\hline Šentilj & 5 & 28,54 \\
\hline Hajdina & 2 & 14,02 \\
\hline Ptuj & 11 & 13,82 \\
\hline Kidričevo & 6 & 11,78 \\
\hline Slovenska Bistrica & 6 & 11,66 \\
\hline Ruše & 6 & 9,15 \\
\hline Miklavž na Dravskem polju & 2 & 6,82 \\
\hline Pesnica & 4 & 4,71 \\
\hline Rače-Fram & 3 & 2,00 \\
\hline Trnovska vas & 1 & 1,47 \\
\hline Poljčane & 1 & 1,29 \\
\hline Zavrč & 1 & 1,12 \\
\hline Kungota & 1 & 1,08 \\
\hline Cirkulane & 1 & 0,92 \\
\hline Lovrenc na Pohorju & 1 & 0,62 \\
\hline Majšperk & 1 & 0,30 \\
\hline Lenart & 1 & 0,25 \\
\hline Hoče-Slivnica & 1 & 0,23 \\
\hline Skupaj & 84 & 213,86 \\
\hline
\end{tabular}

\section{Možnosti za oživitev FDO}

Pomemben vidik trajnostnega prostorskega načrtovanja je tudi prednostno usmerjanje razvoja na predhodno že aktivirana zemljišča in načrtno izogibanje t. i. greenfield investicijam. Velik del popisanih FDO moramo tako obravnavati kot razvojni potencial - z različnimi ukrepi in mehanizmi jih je mogoče aktivirati ter jih ponovno oživiti, z novo funkcijo v prostoru pa predstavljajo novo razvojno središče, vir novih delovnih mest itd. Prednostno pa moramo biti seznanjeni z morebitnimi obstoječimi načrti. Izhajajoč iz informacij, ki smo jih pridobili na občinah, so za 16 območij (19\% degradiranih površin) že sprejeti načrti in pričakovati je, da bodo ta območja v razmeroma kratkem času ponovno delujoča, prostor pa bo iz funkcionalno degradiranega, izpraznjenega območja 
ponovno prešel v aktivno rabo. Bolj zaskrbljujoče pa je dejstvo, da za kar polovico vseh popisanih FDO občine nimajo razvojnih načrtov, niti niso seznanjene z nikakršnimi pobudami, hkrati pa že sami ugotavljajo, da so ta območja zaradi različnih dejavnikov (razdrobljeno lastništvo, različni režimi varovanja itd.) brez realnih možnosti za razvoj. Za dobro petino FDO imajo občine ali pa lastniki območij že načrte za njihovo reaktivacijo in nadaljnji razvoj, ki pa še niso definirani v načrtovalskem ali pa časovnem kontekstu. Številni primeri in izkušnje pri prenovi in umeščanju novih dejavnosti na območja FDO namreč kažejo, da se lahko v procesih prenove prvotni načrti hitro (in celo večkrat) spremenijo, končna rešitev pa se posledično odmika tudi v časovnem smislu.

Načrti občin glede usmerjanja razvoja FDO.

\begin{tabular}{|l|c|c|c|}
\hline $\begin{array}{l}\text { Načrti občin glede prihodnjega razvoja } \\
\text { FDO }\end{array}$ & $\begin{array}{c}\text { Stevilo } \\
\text { FDO }\end{array}$ & $\begin{array}{c}\text { Površina FDO } \\
\text { (ha) }\end{array}$ & $\begin{array}{c}\text { Delež FDO } \\
(\%)\end{array}$ \\
\hline Imamo že sprejet načrt za območje & 16 & 41,27 ha & $19,1 \%$ \\
\hline $\begin{array}{l}\text { Imamo načrte, ideje, realizacija pa še ni } \\
\text { definirana }\end{array}$ & 17 & 38,87 ha & $20,2 \%$ \\
\hline $\begin{array}{l}\text { Nimamo pravih oprijemljivih načrtov, } \\
\text { zgolj pobude }\end{array}$ & 9 & 49,47 ha & $10,7 \%$ \\
\hline $\begin{array}{l}\text { Nimamo nobenih načrtov, ni nobenih } \\
\text { možnosti sprememb, razvoja }\end{array}$ & 42 & 84,26 ha & $50,0 \%$ \\
\hline Skupaj & 84 & 213,86 ha & $100,0 \%$ \\
\hline
\end{tabular}

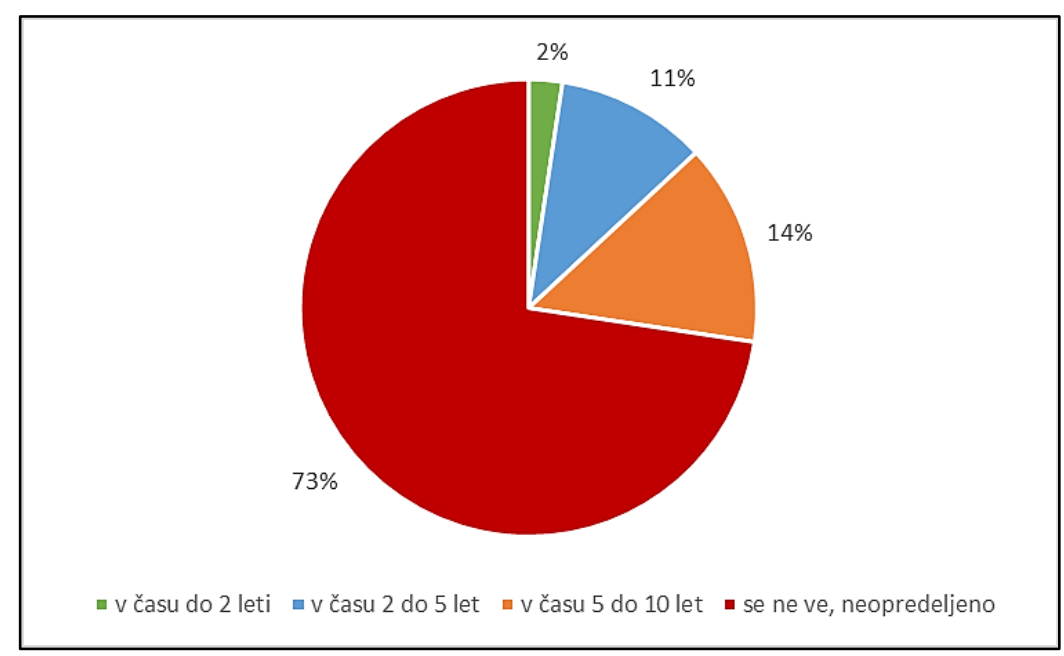

Razvojni načrti glede na časovno možnost obnove FDO.

Predstavljeni rezultati kažejo, da ima Podravska regija precej težav z načrtovanjem prenove degradiranih območij, kar dodatno potrjuje tudi časovni okvir sanacije oz. reaktivacije. Najmanj sanacij (samo za dve območji) je predvidenih v roku dveh let, največ odgovorov s strani občin pa je bilo, da se ne ve, kdaj bodo pogoji ustrezni za nadaljnjo sanacijo in reaktivacijo. Naj poudarimo, da so podobne razmere pri načrtovanju sanacije FDO tudi v drugih statističnih regijah Slovenije. 
B. Lampič, T. Kikec, N. Bobovnik: Ocena neizkoriščenega potenciala funkcionalno degradiranih območij v Podravski statistični regiji

\section{Časovni okvir prenove po tipih FDO v Podravski regiji.}

\begin{tabular}{|c|c|c|}
\hline Časovni okvir prenove po tipih FDO & Število FDO & Površina FDO \\
\hline FDO industrijskih in obrtnih dejavnosti & 15 & 49,03 ha \\
\hline $\mathrm{v}$ času 2 do 5 let & 2 & 1,78 ha \\
\hline v času 5 do 10 let & 3 & 7,09 ha \\
\hline se ne ve, neopredeljeno & 10 & 40,17 ha \\
\hline FDO infrastrukture & 8 & 24,73 ha \\
\hline $\mathrm{v}$ času 2 do 5 let & 1 & 2,17 ha \\
\hline se ne ve, neopredeljeno & 7 & 22,56 ha \\
\hline FDO kmetijske dejavnosti & 11 & 17,41 ha \\
\hline v času 5 do 10 let & 1 & 0,80 ha \\
\hline se ne ve, neopredeljeno & 10 & 16,61 ha \\
\hline FDO obrambe, zaščite in reševanja & 2 & 2,23 ha \\
\hline se ne ve, neopredeljeno & 2 & 2,23 ha \\
\hline FDO prehodne rabe & 11 & 23,10 ha \\
\hline $\mathrm{v}$ času 2 do 5 let & 1 & 0,80 ha \\
\hline v času 5 do 10 let & 3 & 2,78 ha \\
\hline se ne ve, neopredeljeno & 7 & 19,52 ha \\
\hline FDO pridobivanja mineralnih surovin & 9 & 51,48 ha \\
\hline v času do 2 leti & 1 & 2,29 ha \\
\hline $\mathrm{v}$ času 5 do 10 let & 2 & 15,38 ha \\
\hline se ne ve, neopredeljeno & 6 & 33,81 ha \\
\hline FDO storitvenih dejavnosti & 15 & 33,12 ha \\
\hline v času do 2 leti & 1 & 1,12 ha \\
\hline $\mathrm{v}$ času 2 do 5 let & 3 & 2,13 ha \\
\hline v času 5 do 10 let & 2 & 2,87 ha \\
\hline se ne ve, neopredeljeno & 9 & 27,00 ha \\
\hline $\begin{array}{l}\text { FDO turistične, športnorekreacijske in športne } \\
\text { dejavnosti }\end{array}$ & 5 & 6,13 ha \\
\hline v času 2 do 5 let & 1 & 0,87 ha \\
\hline se ne ve, neopredeljeno & 4 & 5,26 ha \\
\hline FDO za bivanje & 8 & 6,64 ha \\
\hline $\mathrm{v}$ času 2 do 5 let & 1 & 0,23 ha \\
\hline $\mathrm{v}$ času 5 do 10 let & 1 & 1,08 ha \\
\hline se ne ve, neopredeljeno & 6 & 5,33 ha \\
\hline Skupna vsota & 84 & 213,86 ha \\
\hline
\end{tabular}

Vzroki za (ne)uspešno obnovo FDO, ki jih občine najpogosteje navajajo, so neodvisni od tipa FDO, konkretno pa se je v Podravski regiji pokazalo sledeče:

- Pomanjkanje finančnih sredstev, pogosto zaradi stečajev podjetij, ki so investirala $\mathrm{v}$ izgradnjo novih stanovanjskih območij ali območij različnih centralnih dejavnosti. Srečujemo se tudi s preveč ambicioznimi projekti (predvsem investicijsko), za katere pa ni dovolj finančnih virov (in zato ni interesa za sanacijo takšnih FDO).

- Razdrobljeno lastništvo (več lastnikov, mešano javno in zasebno lastništvo) in številni stečajni postopki (učinki gospodarske krize). 
B. Lampič, T. Kikec, N. Bobovnik: Assessment of functional untapped potential brownfield areas in Podravje statistical region

- Ovire za sanacijo območij so lahko vezane na različna varstvena območja (postopki priprave sanacijskih načrtov in nato sanacije lahko precej zavlečejo) ali pa na pogoje za obnovo kulturne dediščine (zopet ključen problem zadostni dodatni finančni viri).

- Prihaja do neusklajenih interesov vlagateljev z določbami OPN ali druge zakonodaje, zato želena dejavnost na območju ni izvedljiva.

- Postopki spreminjanja namenske rabe prostora in postavljanje dodatnih pogojev za izvajanje dejavnosti.

- Pomanjkanje idej in nezainteresiranost lastnikov.

Številni vzroki, ki prispevajo k upočasnjenosti reaktivacije FDO (oz. jo lahko celo povsem zaustavijo) so zelo povedni in razvidni tudi iz odgovorov glede časovnega okvira prenove po posameznih tipih FDO.

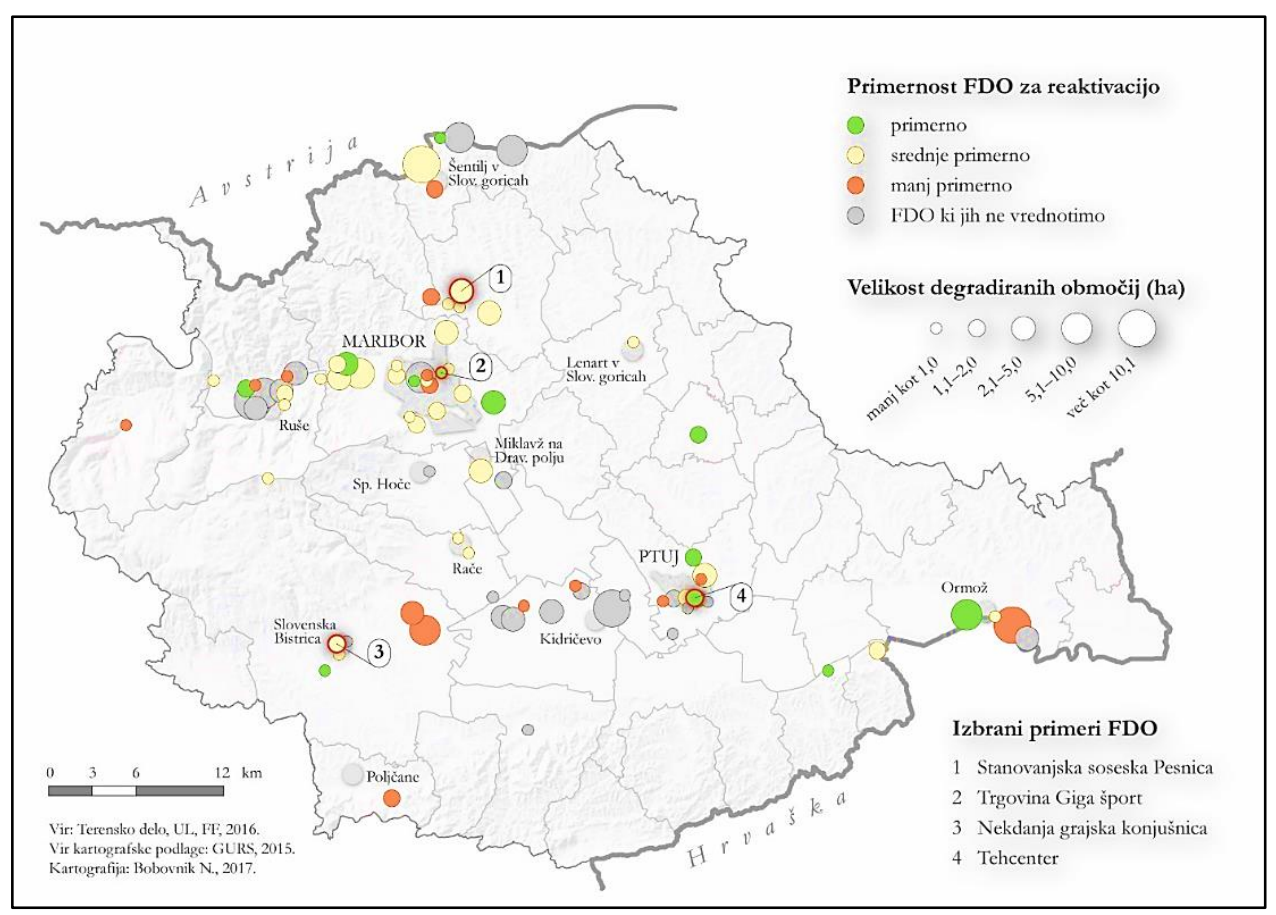

\section{Primernost evidentiranih FDO za reaktivacijo.}

Ker smo na podlagi razgovorov s predstavniki občin ugotovili, da za več kot $60 \%$ vseh evidentiranih FDO nimajo rešitve (niti pobude ali ideje) glede njihove reaktivacije, še bolj pa je njihova oživitev nedefinirana $\mathrm{v}$ časovnem smislu, smo $\mathrm{v}$ okviru projekta CRP oblikovali razmeroma enostaven model za oceno prednostne reaktivacije FDO. Pri ugotavljanju primernost za reaktivacijo smo izločili tiste FDO, ki zaradi svoje predhodne funkcije in rabe ne predstavljajo prostorskega potenciala, kamor bi lahko umeščali nove dejavnosti. Tako smo izločili območja, ki so uvrščena v podtipe: FDO stara mestna ali vaška jedra, FDO kamnoloma, peskokopa, FDO gramozne jame, FDO ostala območja pridobivanja mineralnih surovin, FDO okoljske infrastrukture, FDO zelene infrastrukture 


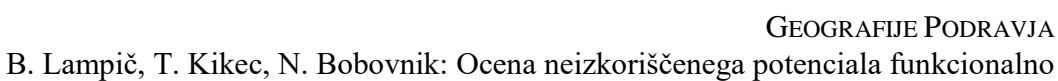
degradiranih območij v Podravski statistični regiji

ter FDO za bivanje - stara dotrajana območja. V Podravski regiji smo tako ovrednotili 60 od skupaj 84 FDO.

Za doseganje trajnostnega prostorskega razvoja ima, po mnenju Kokot Krajnčeve (2014), revitalizacija starih industrijskih območij največji potencial. To se v veliki meri potrjuje tudi v Podravski regiji, kjer skupen obseg površine tega tipa FDO predstavlja 39 \% vseh vključenih površin, med 15 FDO industrijske in obrtne dejavnosti pa jih je 11 primernih oz. srednje primernih za reaktivacijo.

Na naslednji sliki so prostorsko prikazani rezultati modela - katera območja bi bilo na podlagi ocene modela smiselno prednostno reaktivirati. Povzemamo samo prvo analizo prednostne revitalizacije obravnavanih 60 območij, kjer se je pokazalo, da je 13 območij primernih, 32 pa srednje primernih za reaktivacijo.

\section{Nekateri primeri značilnih FDO skupaj s prikazom reaktivacije degradiranih območij}

V povezavi z modelom za prednostno oz. hitrejšo in enostavnejšo reaktivacijo različnih FDO ter $\mathrm{v}$ luči hitrih prostorskih sprememb, je gotovo zanimiva tudi predstavitev nekaterih konkretnih primerov FDO, ki so od terenskega popisa junija 2016 do začetka leta 2017 že doživeli določene spremembe. Konkretna predstavitev izbranih FDO je tudi priložnost, da spoznamo različne tipe FDO ter raznotere dejavnike, ki so vplivali na razvoj teh območij. Izbrali smo štiri območja, dva primera FDO storitvenih dejavnosti (primer podtipa FDO poslovnih, trgovskih in drugih storitvenih dejavnosti ter primer podtipa FDO javnih storitev), en primer FDO industrijskih in obrtnih dejavnosti ter primer FDO prehodne rabe (podtip FDO opuščenega gradbišča). V okviru projekta sta bili dve območji po modelu ocenjeni kot primerni za reaktivacijo in dve kot srednje primerni (Celovita metodologija ..., 2017).

Občina Slovenska Bistrica je na primeru nekdanje grajske konjušnice v Slovenski Bistrici dokazala, da se da z ustreznim pristopom in določenim zneskom finančnih sredstev (financiranje odkupa in sanacije), FDO ponovno aktivirati (tip FDO storitvenih dejavnosti, podtip FDO javnih storitev). Na območju konjušnice na skupni površini $11.150 \mathrm{~m}^{2}$, ki je od leta 2008 v lastni občine (prej je problem predstavljalo lastništvo), se nahajata dva večja objekta. Objekt v zahodnem delu je pretežno opuščen in ni vzdrževan, v manjšem delu ga uporablja Rdeči križ kot skladiščni prostor. Glavni, večji objekt, ki je bil leta 2002 razglašen kot kulturni spomenik državnega pomena, občina postopno obnavlja in sanira, prostore $\mathrm{v}$ notranjosti so že uredili, postopno poteka tudi obnova zunanjosti objekta. Kljub skromnejšemu interesu za najem prostorov, čeprav so le-ti v centru mesta, je občina $v$ zadnjih dveh letih uspela najti najemnike za veliko večino prostorov v objektu. Objekt je tako skorajda v celoti zaseden. Prevladujejo manjša socialna podjetja (Mesto ponovne uporabe, Ropotarnica, časopis Panorama idr.), v njem imajo prostore različna neprofitna društva (Avto moto klub Klasik idr.), del prostorov pa uporabljata kot skladišče vrtec in občina. Če je bilo območje v času popisa še pretežno (50-99 \%) opuščeno, je danes opuščeno le še delno (10-50 \%). Vizualno degradacijo predstavlja le še pretežno opuščen objekt. Občina ima jasno vizijo glede ureditve območja in sprejete načrte, za katere računajo, da jih bodo realizirali v roku dveh let. Glede na 
pozitivne spremembe od popisa 2016 do začetka leta 2017 je pričakovati, da jih bodo uspeli realizirati, kot največjo oviro vidijo zagotovitev potrebnih finančnih sredstev.

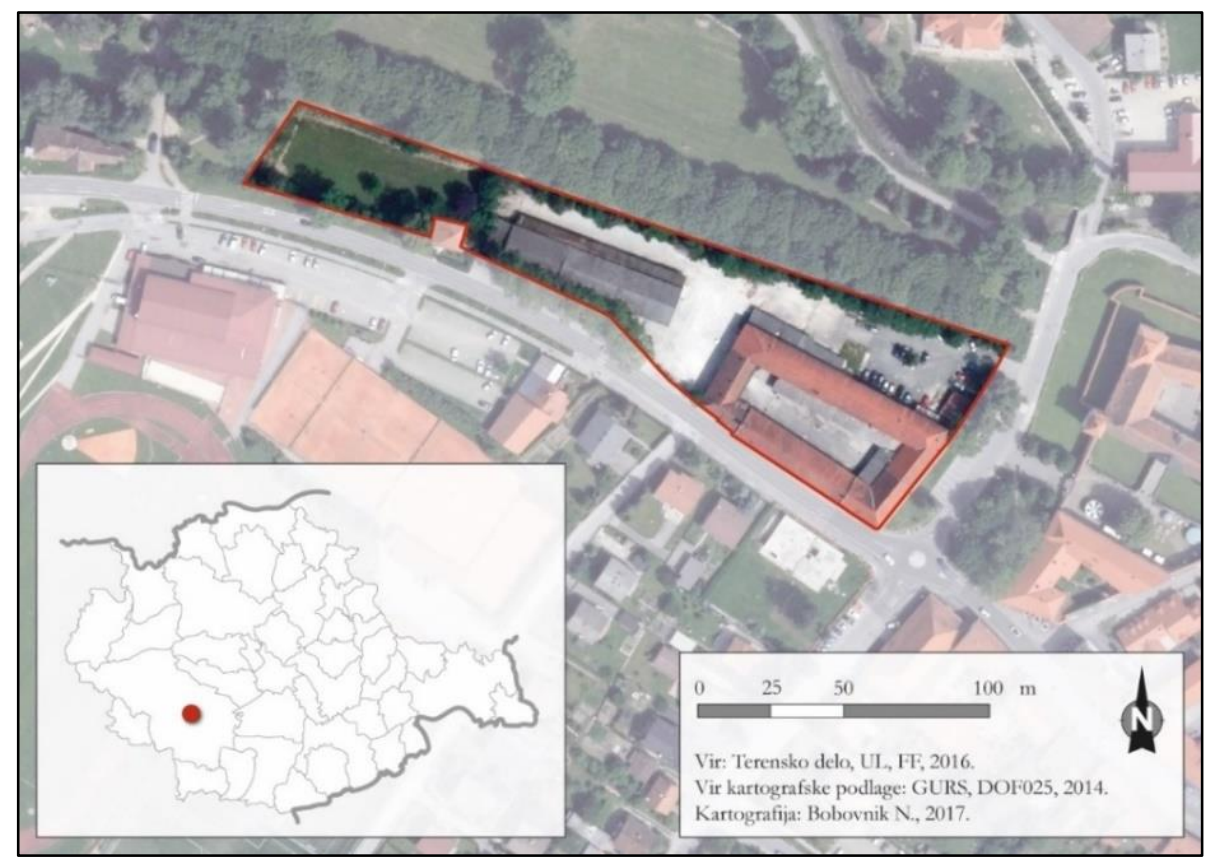

Občina je v nekdanji grajski konjušnici v Slovenski Bistrici v zadnjem času uspela prostore obnoviti do te mere, da so zanimivi za različne najemnike.

Kot drugi primer FDO storitvenih dejavnosti, ki pa predstavlja podtip FDO poslovnih, trgovskih in drugih storitvenih dejavnosti, navajamo primer Trgovine Giga šport na Industrijski ulici v Mestni občini Maribor. Do zaprtja trgovine je prišlo sredi leta 2014, poleg poslovalnice $\mathrm{v}$ Mariboru so zaradi sprememb poslovnih načrtov avstrijskega lastnika družbe Kastner \& Öhler zaprli tudi poslovalnici v Celju in Ljubljani. Gre za večji objekt $\mathrm{v}$ katerem so po zaprtju omenjene trgovine $\mathrm{v}$ delu stavbe še naprej obratovali trgovini Tedi in Kik ter na manjši površini Cafe Giga. Ob koncu leta 2016 so vrata zaprle tudi te dejavnosti in objekt je postal v celoti neizkoriščen. Objektu pripada tudi večje parkirišče neposredno ob objektu, ki je trenutno $\mathrm{v}$ uporabi, dostop je omejen z zapornico in je plačljiv. Območje FDO je tako pretežno (50-99 \%) opuščeno, njegova površina pa skoraj $8.000 \mathrm{~m}^{2}$. Zemljišče s pripadajočim objektom je v lastni nepremičninske hiše iz Avstrije, ki ga že nekaj časa neuspešno poskuša prodati. Manjši del zemljišča (ob cesti) ostaja v občinski lasti. Glede na velikost in vrsto objekta, pripadajočega parkirišča in lego neposredno ob mestni obvoznici, na občini ostaja ideja o ohranitvi trgovske dejavnosti, vendar še nimajo nobenih konkretnih načrtov. Objekt je v relativno dobrem stanju, večja obnova ob aktivaciji še ne bi bila potrebna, pričakovati pa je, da bo ob neuporabi s časom pričel postopno propadati. V kolikor bi se našel primeren kupec, bi objekt lahko $\mathrm{v}$ relativno kratkem času ponovno uporabili. Glede na trenutne razmere in ocene pa bi se to lahko zgodilo $v 2$ do 5 letih. 
V Mariboru je trenutno kar nekaj nekdanjih praznih trgovskih objektov na prodaj oz. se iščejo najemniki (npr. poslopje nekdanjega Merkurja ob Ptujski cesti na Teznem idr.), kar kaže na trenutno manjše povpraševanje po tovrstnih objektih pa tudi na prenasičenost s trgovinsko dejavnostjo. Prav povsem ali delno izpraznjena FDO poslovnih, trgovskih in storitvenih dejavnosti sicer predstavljajo velik prostorski potencial, ki bi se ga dalo, glede na razmeroma dobro stanje objektov, reaktivirati v relativno kratkem času in brez večjih finančnih vložkov ponovno aktivirati. Največja oviro pri njihovi reaktivaciji pogosto prestavlja lastništvo.

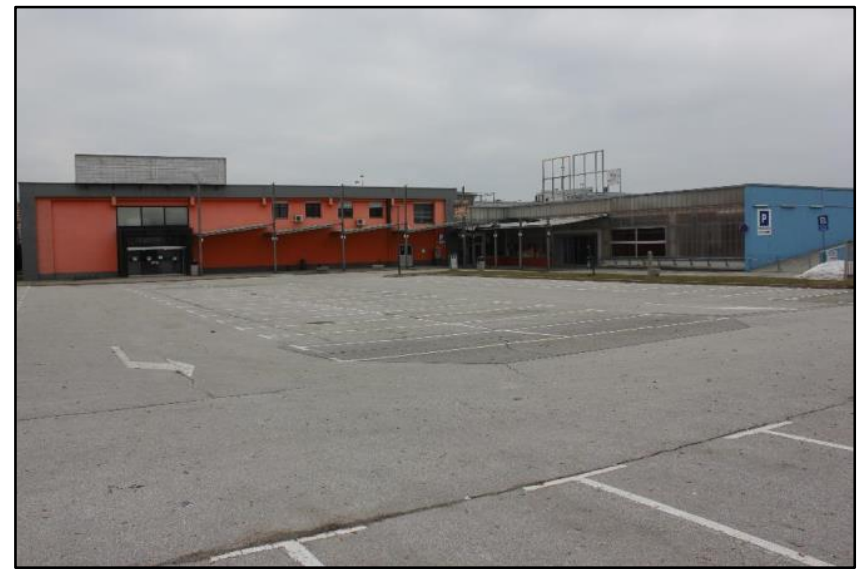

Povsem opuščeni objekti Trgovine Giga šport s parkiriščem v Mestni občini Maribor, ki pa je še v uporabi. FDO poslovnih, trgovskih in drugih storitvenih dejavnosti (Foto: $T$. Kikec).

V občini Pesnica v naselju Pesnica pri Mariboru je podjetje Komunaprojekt d. d. načrtovalo velikopotezni projekt - Stanovanjsko sosesko Pesnica. Načrtovana investicija je bila do danes realizirana le deloma, v prostoru pa je ostalo opuščeno gradbišče (FDO prehodne rabe, podtip FDO opuščenega gradbišča). Na pobudo investitorja je občina spremenila prostorski načrt in mu omogočila gradnjo na nekdanjih kmetijskih zemljiščih. Zgradili so večji poslovni objekt, v katerem imajo danes prostore občina, pošta, Mercator, bife idr. Pričeli so tudi z gradnjo predvidene stanovanjske soseske, vendar se je projekt leta 2009 (po izgradnji treh enostanovanjskih hiš) zaradi pomanjkanja finančnih sredstev, zaustavil. V tem času so uspeli le eno od treh zgrajenih hiš prodati, dve sta še vedno na trgu. V drugi polovici leta 2016 so, po večletnem premoru, pričeli z gradnjo še ene enostanovanjske hiše. Na območju površine 2,1 ha je sicer predvidena gradnja skupno 23-ih vrstnih hiš in dveh večstanovanjskih blokov. Urejena je vsa potrebna gradbena dokumentacija, vse parcele so komunalno opremljene, urejena je tudi cesta. Zaradi posega $\mathrm{v}$ okolje in poznejše opustitve dejavnosti je območje površinsko (narejenih je nekaj manjših izkopnih jam, navoženi so kupi zemlje) in s tem tudi vizualno degradirano, postopno se zarašča, v manjšem obsegu se na njem že pojavljajo manjša divja odlagališča. Na načrtovano gradnjo nakazuje le zbledela informacijska tabla izvajalca projekta. Celotno območje opuščenega gradbišča sicer leži na poplavnem območju potoka Cirknica, kjer so v preteklosti z različnimi ukrepi že poskušali (neuspešno) reševati težave s poplavami. Zadnje poplave so se na tem območju pojavile leta 2009. 
The GeOgraphies of the Podravje Region

B. Lampič, T. Kikec, N. Bobovnik: Assessment of functional untapped potential brownfield areas in Podravje statistical region

Poleg zmanjšanja povpraševanja po nakupu individualnih hiš v stanovanjskih soseskah v širšem suburbanem zaledju mesta Maribor, predstavlja največji problem lastništvo FDO ter pomanjkanje finančnih sredstev investitorja za realizacijo načrtovane gradnje. Kdaj bi lahko prišlo do reaktivacije območja oz. nadaljevanje začete investicije je težko reči, pričakujemo pa, da se bo to zgodilo postopoma.

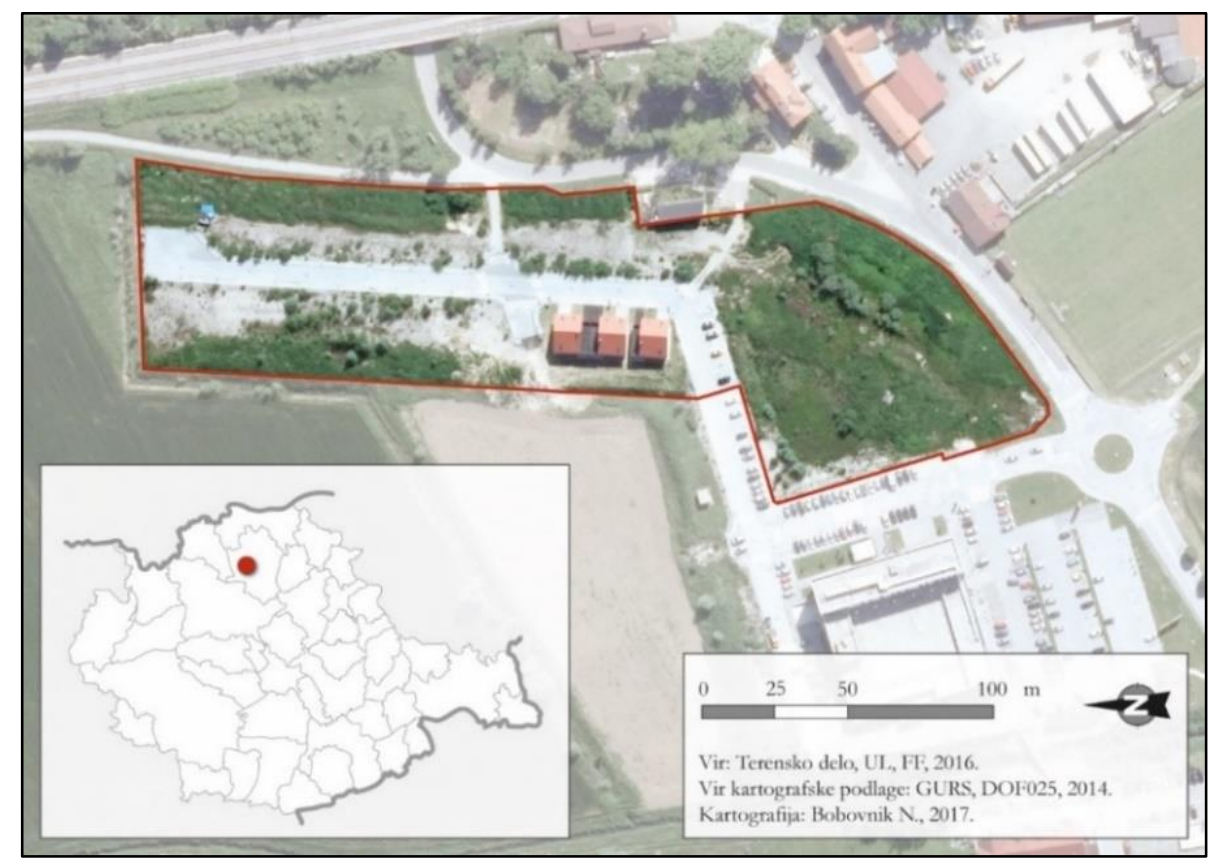

Prikaz FDO načrtovane Stanovanjske soseske Pesnica v občini Pesnica, ki je v veliki meri ostala nerealizirana.

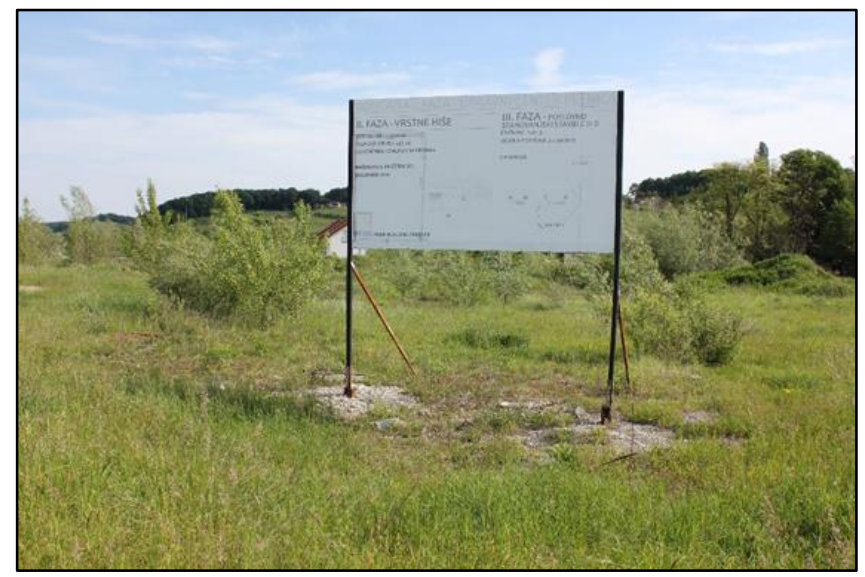

Opuščeno gradbišče načrtovane Stanovanjske soseske v Pesnici pri Mariboru se v večjem delu postopoma zarašča, območje pa je v celoti komunalno opremljeno. 
$\mathrm{Na}$ hitre spremembe FDO-jev nam kaže primer Tehcentra (tip FDO industrijskih in obrtnih dejavnosti). Leta 2000 zgrajen objekt na Puhovi ulici na Ptuju je bil še do nedavnega v lasti Tehcentra d. o. o., zaradi stečaja podjetja pa ni bil v funkciji od junija 2014. Podjetje se je ukvarjalo s kovinarstvom, vendar je po 25-ih letih delovanja šlo v stečaj. Objekt se nahaja na parceli površine $15.981 \mathrm{~m}^{2}$, je v razmeroma dobrem stanju, vendar se ni vzdrževal, prav tako se ni urejala njegova okolica. Največjo oviro pri reaktivaciji FDO je prestavljalo lastništvo podjetja in s tem povezan stečajni postopek. Objekt je bil naprodaj in čeprav se je predpostavljajo, da bo FDO možno reaktivirati šele v obdobju 5-10 let, so objekt uspeli prodati v roku dobrih dveh let. Po informacijah stečajnega upravitelja podjetja je avgusta 2016 objekt odkupilo podjetje MARK Metal d. o. o. avstrijskega lastnika, ki je doslej imelo v najemu prostore na Bregu v Občini Majšperk. Podjetje, ki se ukvarja s proizvodnjo natančnih delov za avtomobilsko in elektroindustrijo, medicinske dele in potrošne dobrine se je že lotilo prenove hale in bi naj še spomladi pričelo s proizvodnjo na novi lokaciji. Na prvotni lokaciji na Bregu pri Majšperku so imeli težave s prostorsko stisko, vendar so se namesto izgradnje nove hale na isti lokaciji raje odločili za odkup in selitev v že obstoječi večji objekt na Ptuju. Posledično je postal prazen objekt na Bregu, ki je del večjega kompleksa v lasti Albin promotion d. o. o., ki se ukvarja s kovinskimi izdelki in opremo. Podjetje načrtuje objekt v nekaj mesecih oddati ponovno v najem, interes kažeta podjetji iz Avstrije in Nemčije, del objekta pa bodo verjetno uporabili sami za širjenje obstoječe dejavnosti.

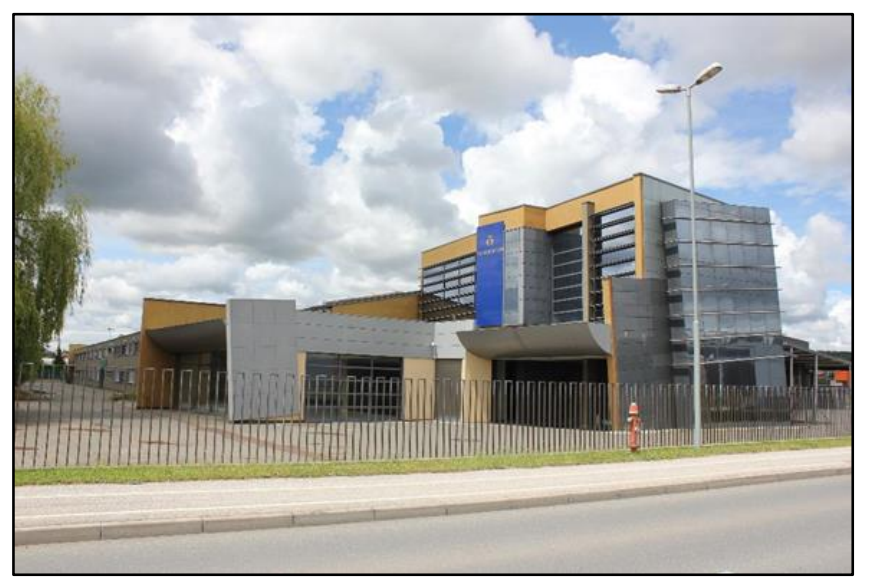

Dobro ohranjen objekt nekdanjega Tehcentra na Ptuju.

\section{Zaključek}

Kljub razmeroma velikemu številu zabeleženih FDO na območju Podravske regije (skupaj 84 v 21 od skupaj 42 občin) ter njihovemu skupnemu obsegu (skoraj 215 ha) ugotavljamo, da je razvojno-prostorski potencial obstoječih FDO razmeroma skromen. To lahko pripišemo precejšnji razdrobljenosti obstoječih FDO, saj so številna razmeroma majhna, kar 37 popisanih FDO je manjših od 1 ha, povprečna velikost FDO pa je komaj 2,5 ha. Nadalje velja izpostaviti lastništvo, ki, podobno kot drugod po Sloveniji, kroji usodo številnih FDO, najpogosteje zaradi velikega števila lastnikov posameznega območja ter posledično težav pri nadaljnjem odločanju. Na FDO izrazito prevladujejo 
zasebni lastniki, katerih interesi so pogosto nerazvojno naravnani. Z lastništvom je pogosto povezana tudi nezainteresiranost za sanacijo in pomanjkanje finančnih sredstev (številni stečaji podjetij). Hitrejša reaktivacija FDO je omejena tudi zaradi dolgotrajnih postopkov spreminjanja namenske rabe prostora sprejemanja OPN-jev), pogosto proces hromijo tudi različni varstveni režimi, srečujemo pa se tudi z dejanskim pomanjkanjem idej in razvojnih pobud.

Dosedanji prostorski razvoj na širšem območju Podravske regije kaže izrazito prostorsko netrajnostne prakse načrtovanja in umeščanja (novih) dejavnosti v prostor. Kot regija z najvišjim deležem pozidanih površin ter tista, ki je samo v letih 2012-2016 povečala obseg pozidanih površin za 771 ha (Evidenca dejanske rabe ..., 2016), tudi v zadnjem obdobju ne izkazuje bolj odločne usmerjenosti v varovanje dragocenih nepozidanih zemljišč. Ena od posledic netrajnostnega ravnanja s prostorom so gotovo tudi številna FDO. Njihov skupen obseg in število kažeta na veliko prostorsko razpršenost, priosotnost ne le v mestnih naseljih ampak tudi v odprtem prostoru, zastopanost prav vseh devetih tipov FDO pa tudi na dejstvo, da je prišlo do pomembnih strukturnih sprememb ter potreb pri izvajanju različnih človekovih dejavnostih v prostoru.

Novi, t. i. razvojni projekti, se še naprej usmerjajo na kmetijski/gozdni prostor, »greenfield investicije« ostajajo marsikje še vedno prednostna pobuda. Že pred leti smo bili priča nekaterim velikopoteznim »razvojnim « idejam oz. projektom (npr. Univerziada v letu 2013, v okviru katere je bila predvidena izgradnja celovitega sistema športne in turistične infrastrukture, od Univerzitetne športne vasi, Skakalnega centra, sistema tekaških prog idr. (Stalicky, 2008)), trenutno aktualen projekt pa je »strateška investicija« na območju občine Hoče-Slivnica (prilagojeno že znanemu investitorju Magna Styer).

Slednja je prepoznana kot investicija nacionalnega pomena, saj po sprejetem Zakonu o zagotavljanju pogojev za izvedbo strateške investicije na razvojnem območju v Občini Hoče - Slivnica, dolgoročno zagotavlja večje število delovnih mest, ohranitev proizvodnje na lokaciji (vsaj 10 let od sklenitve pogodbe), zaradi prostorskih, tehnoloških in logističnih potreb pa je označena kot »primerna za umestitev v razvojno območje in pospešuje gospodarsko rast in zaposlovanje ter skladen regionalni razvoj« (Zakon o zagotavljanju pogojev ..., 2017). Glede na pretekle izkušnje in nekatere sorodne pobude (npr. izgradnja poslovne cone Komenda $\mathrm{v}$ Osrednjeslovenski statistični regiji) si zastavljamo vprašanje, ali se bo številnim manjšim izpraznjenim območjem v prihodnje pridružilo še kašno večje.

Trenutno se pripravlja celovita prenova prostorske zakonodaje. $\mathrm{V}$ pripravi je tudi strategija prostorskega razvoja (do leta 2050), ravno tako je v pripravi nov Zakon o prostorskem načrtovanju. Novi strateški dokumenti bodo generirali nove zakonske in podzakonske akte na različnih področjih, ki so relevantna tudi za smotrno ravnanje s prostorom, premišljen razvoj dejavnosti in načrtno oživljanje funkcionalno izpraznjenih, degradiranih območij. Spodbujanje razvoja antropogeno že preoblikovanega, a neizkoriščenega prostora ter $\mathrm{s}$ tem ohranjanje kmetijskih in gozdnih zemljišč pa mora prerasti v skupen interes in cilj na lokalni, regionalni in državni ravni. 
GEOGRAFIJE PODRAVJA 133

B. Lampič, T. Kikec, N. Bobovnik: Ocena neizkoriščenega potenciala funkcionalno degradiranih območij v Podravski statistični regiji

\section{Literatura in viri}

Alker, S., Joy, V., Roberts, P., Smith, N. 2000: The Definition of Brownfield. Journal of Environmental Planning and Management, 43, 1, str. 49-69. http://dx.doi.org/10.1080/09640560010766 (23. 12. 2015).

Bartol, B. et al. (ur.) 2004: Strategiji prostorskega razvoja Slovenije. Ministrstvo za okolje, prostor in energijo, Direktorat za prostor, Urad za prostorski razvoj, Ljubljana, 75 str. http://www.espon-interstrat.eu/admin/attachments/SPRS_slo.pdf (12. 10. 2016).

CABERNET 2006: Sustainable Brownfield Regeneration, CABERNET Network Report. University of Nottingham, Nottingham, 134 str.

http://www.palgo.org/files/CABERNET\%20Network\%20Report\%202006.pdf (12. 4.2016).

Celovita metodologija za popis in analizo degradiranih območij, izvedba pilotnega popisa in vzpostavitev ažurnega registra (V6-1510). Projekt CRP. Interno gradivo 2017. Gradivo hrani avtor.

Cirman, P. in Vuković, V. 2016: Država dveh hitrosti: z Magno se tako mudi, da so spregledali. http://siol.net/posel-danes/novice/drzava-dveh-hitrosti-z-magno-se-tako-mudi-da-sospregledali-432137 (5. 1. 2017).

COBRAMAN 2009: Manager Coordinating Brownfield Redevelopment Activities. http://www.cobraman-ce.eu/ (15. 4. 2016).

Dasgupta, S., Tam, E. K. L. 2009: A Comprehensive Review of Existing Classification Systems of Brownfield Sites. Environmental Practice, 11, 4, str. 285-300.

EPA, United States Environmental Protection Agency. Brownfield Overviev and Definition. http://www.epa.gov/brownfields/brownfield-overview-and-definition （9.12. 2015).

Ferber, U. (ur.), Grimski, D. (ur.), Millar, K. (ur.), Nathanail, P. (ur.) 2006: Sustainable brownfield regeneration. University of Nottingham, CABERNET Coordination Team, Nottingham, 134 str.

Gole, N., Milošič, F., Bizovičar, M., Stergar, A., Grgič, M. 2017: Magna: spodbudna investicija, a tudi nekaj negotovosti. http://www.delo.si/gospodarstvo/podjetja/magna-spodbudnainvesticija-a-tudi-nekaj-negotovosti.html (17. 1. 2017).

Grafični podatki RABA za celo Slovenijo, 2016. Ministrstvo za kmetijstvo, gozdarstvo in prehrano, Ljubljana. http://rkg.gov.si/GERK/ (25. 4. 2016).

Hoški svetniki potrdili občinski prostorski načrt za Magno. https://maribor24.si/lokalno/hoskisvetniki-potrdili-obcinski-prostorski-nacrt-za-magno/ (22. 2. 2017).

Kokot Krajnc, M. 2014: Kazalniki trajnosti pri revitalizaciji starih industrijskih območij. Doktorska disertacija. Filozofska fakulteta, Univerza v Ljubljani, 257 str.

Koželj, J., Ažman Momirski, L., Maligoj, T., Omerzu, B. 1998: Degradirana urbana območja. Ministrstvo za okolje in prostor, Urad RS za prostorsko planiranje, Ljubljana, 252 str.

Koželj, J. et al. 2016: Merila in kriteriji za določitev degradiranih urbanih območij (DUO 2) z nadgradnjo Določitev nerevitaliziranih urbanih območij (NERUO). http://www.mop.gov.si/si/delovna_podrocja/urbani_razvoj_in_zemljiska_politika/merila_ in_kriteriji_za_dolocitev_degradiranih_urbanih_obmocij_strokovna_studija/ $\quad(10 . \quad 11$. 2016).

Lampič, B., Cigale, D., Krevs, M., Kušar, S., Potočnik Slavič I., Foški, M., Zavodnik Lamovšek A., Barborič, B., Mesner, N., Meža, S., Radovan, D. 2016: Celovita metodologija za popis in analizo degradiranih območij: izvedba pilotnega popisa in vzpostavitev ažurnega registra. Vmesno poročilo (obdobje 15. 3. 2016-15. 9. 2016). Filozofska fakulteta, Univerza v Ljubljani, Ljubljana, 51 str.

Odločba za spremembe in dopolnitve občinskega prostorskega načrta občine Hoče - Slivnica, 2016.

http://www.mop.gov.si/fileadmin/mop.gov.si/pageuploads/podrocja/cpvo/odlocbe/obcins ki_prostorski_nacrti/I_stopnja/2016/33.pdf (3. 1.2017). 
B. Lampič, T. Kikec, N. Bobovnik: Assessment of functional untapped potential brownfield areas in Podravje statistical region

Pravilnik o vsebini, obliki in načinu priprave občinskega prostorskega načrta ter pogojih za določitev območij sanacij razpršene gradnje in območij za razvoj in širitev naselij, 2007. Uradni list RS, št. 99/07. http://www.pisrs.si/Pis.web/pregledPredpisa?id=PRAV8105 (13. 10. 2016).

Skalicky, S. 2008: Mestni arhitekt in arhitektura mesta. AR arhitektura, raziskave, 8, 2, Fakulteta za arhitekturo, Ljubljana. http://www.dlib.si/details/URN:NBN:SI:DOC-N4ULZLT6/ (22. 2. 2017).

Špes, M. 1998: Degradacija okolja kot dejavnik diferenciacije urbane pokrajine. Geographica Slovenica, 30. Inštitut za geografijo, Ljubljana, 199 str.

Špes, M., Krevs, M., Lampič, B., Mrak, I., Ogrin, M., Plut, D., Vintar Mally, K., Vovk Korže, A. 2012: Sonaravna sanacija okoljskih bremen kot trajnostno razvojna priložnost Slovenije, Degradirana območja. Ciljni raziskovalni program (CRP) "Konkurenčnost Slovenije 20062013”. Zaključno poročilo. Oddelek za geografijo Filozofske fakultete Univerze v Ljubljani, Ljubljana, 66 str.

Zakon o prostorskem načrtovanju, 2007. Uradni list RS, št. 33/07. http://www.pisrs.si/Pis.web/pregledPredpisa?id=ZAKO4675 (14. 2. 2016).

Zakon o varstvu okolja, 2006. Uradni list RS, št. 39/2006. http://www.pisrs.si/Pis.web/pregledPredpisa?id=ZAKO1545 (2. 2. 2017).

Zakon o zagotavljanju pogojev za izvedbo strateške investicije na razvojnem območju v Občini Hoče - Slivnica, 2016. Uradni list RS, št. 85/16. http://www.pisrs.si/Pis.web/pregledPredpisa?id=ZAKO7620 (2. 2. 2017). 


\section{Podravska regija v luči zadnje gospodarske krize}

\section{LUCIJA LAPUH}

Povzetek Na gospodarstvo podravske regije, ki je bilo že v preteklosti zaznamovano z vzponi in padci, je leta 2009 vplivala tudi svetovna gospodarska kriza. Avtorica predstavlja vpliv gospodarske krize na to regijo in njene občine ter kako so se nanjo odzvali ter okrevali. V prispevku so bile s pomočjo statističnih podatkov pojasnjene medobčinske razlike družbeno-gospodarske sestave pred zadnjo gospodarsko krizo. Posebna pozornost je bila na podlagi intervjujev namenjena delovanju deležnikov. Preverili smo vpliv strukturnih lastnosti občin pred gospodarsko krizo na njen vpliv in sposobnost okrevanja ter ugotovitve teoretično podkrepili z novejšim konceptom prožnosti, ki proučuje odziv na nenadne spremembe in okrevanje po njih.

Ključne besede: - Podravska statistična regija • občine - recesija • prožnost • družbeno-gospodarska sestava •

NASLOV AVTORICE: dr. Lucija Lapuh, Fakulteta za informacijske študije, Inštitut za inovacije in tehnologije v regionalnem razvoju, Ljubljanska cesta 31a, 8000 Novo mesto, Slovenija, e-naslov: lucija.lapuh@fis.unm.si. 


\title{
Podravje region in the light of the last economic crisis
}

\author{
LUCIJA LAPUH
}

\begin{abstract}
The world's economic crisis in 2009 also influenced the Podravje region, which had as well been influenced with rises and falls in the past. The purpose of this article is to introduce the influence of economic crisis on this region and its municipalities, how they responded to it and recovered from it. In this article inter-municipal differences in socio-economic structure have been explained with statistical data. Based on the interviews special attention was paid to stakeholders' functioning. Structural characteristics before the economic crisis have been examined. The findings have been evidenced by newer concept of resilience, which investigate response to sudden interruptions and recovery after then.
\end{abstract}

Keywords: - Podravje statistical region $\bullet$ municipalities $・$ recession • resilience $\bullet$ socio-economic structure $\bullet$

CORRESPONDENCE AdDRESS: Lucija Lapuh, Ph.D., Researcher, Faculty of information studies, Institute for innovations and technology in the regional development, Ljubljanska cesta 31a, 8000 Novo mesto, Slovenia, e-mail: lucija.lapuh@ fis.unm.si. 


\section{Uvod}

Gospodarstvo Podravske regije je bilo že pred zadnjo svetovno gospodarsko krizo, ki se je v Sloveniji pojavila po letu 2009, zaznamovano z gospodarskim nazadovanjem in porastom števila brezposelnih. Nekoč industrijsko močna Podravska regija se je v času tranzicije spopadala s prestrukturiranjem proizvodnih dejavnostih: od 1988 do 1995 avtomobilske, od 1992 do 1996 investicijske opreme in od 1995 do 2005 tekstilne dejavnosti (Lorber 2006). Podjetja, ki se med tranzicijo niso uspešno in primerno prestrukturirala, so propadla (Slatinek, 2014). Zaostanek v razvoju gospodarstva Lorberjeva (2006) pripisuje nizkemu investicijskemu vlaganju, nizki dodani vrednosti, neugodni demografski sestavi in pomanjkanju dolgoročnih strategij.

Analiza se osredotoča na Podravsko regijo v obdobju po letu 2007, preden je svetovna gospodarska kriza vplivala na Slovenijo in posledično tudi na to regijo in njene občine, ki so predmet raziskave. Podravska regija je druga največja regija v Sloveniji in tretja najgosteje naseljena $\mathrm{z}$ regionalnim središčem Maribor kot drugim največjim mestom $\mathrm{V}$ državi. Regijo tvori enainštirideset občin, kar predstavlja največjo razdrobljenost občin v Sloveniji.

Sposobnost prilagajanja gospodarstva v regijah je odvisna od gospodarkih lastnosti pred krizo (Martin, 2012). Za razumevanje posledic gospodarske krize v regiji in razvoja po njej je pomembno s kakšnimi družbeno-gospodarskimi značilnostmi je Podravska regija pričakala zadnjo gospodarsko krizo.

Kako se regije oziroma občine odzovejo na izredne dogodke, kot je gospodarska kriza, in kakšen je njihov nadaljnji razvoj, pojmujemo s pojmom prožnost. Prožnost definiramo kot sposobnost območij, da se v čim krajšem času zoperstavijo negativnemu zunanjemu vplivu, ga absorbirajo in premagajo (Economic Crisis ..., 2013; Folke, 2006), kar predstavlja odgovor na povzročeno spremembo z iskanjem prilagoditve (Christopherson, Michie, Tyler, 2010; Christmann, Ibert, 2012), pri čemer je pomemben zgodovinski razvoj regije (Dawley, Pike, Tomaney, 2010).

\section{Metodologija}

Ker po prilagoditveni razlagi prožnosti lastnosti gospodarstva pred gospodarsko krizo vplivajo na sposobnost prilagajanja gospodarstva (Martin, 2012), so bile najprej raziskane družbeno-gospodarske značilnosti občin Podravske regije, preden je nanje vplivala gospodarska kriza. Za predstavitev družbeno-gospodarskih značilnosti občin Podravske regije, preden je nanje vplivala zadnja gospodarska kriza, so bili najprej na podlagi literature o prožnosti opredeljeni družbeno-gospodarski dejavniki (stopnja gospodarske razvitosti, specializacija, izvozna usmerjenost, družbena sestava in infrastruktura), nato pa še kazalniki, ki jih opredeljujejo.

$\mathrm{V}$ raziskavo so bili vključeni podatki za leto 2008, razen podatkov za prometno dostopnost, ki so bili dostopni za leto 2005 in 2006. Vrednosti posameznih kazalnikov, pridobljenih iz statističnih podatkov, so bile standardizirane in preračunane npr. na 1000 prebivalcev ali na površino regije $\left(\mathrm{km}^{2}\right)$, da so postale primerljive. 
Kazalniki družbeno-gospodarskih dejavnikov občin pred gospodarsko krizo. Vir podatkov: AJPES, 2015; DURS, SURS, izračuni UMAR, 2014; Gabrovec et al., 2008;

Kozina, 2010.

\begin{tabular}{|l|l|}
\hline $\begin{array}{l}\text { Stopnja } \\
\text { gospodarske } \\
\text { razvitosti }\end{array}$ & $\begin{array}{l}\text { Bruto dodana vrednost na zaposlenega (v EUR) } \\
\text { Število podjetij na } 1000 \text { prebivalcev } \\
\text { Število oseb, ki delajo, na podjetje } \\
\text { Investicije na } 1000 \text { prebivalcev (v EUR) } \\
\text { Število velikih gospodarskih družb na } 10.000 \text { prebivalcev } \\
\text { Čisti dobiček oz. čista izguba gospodarskih družb glede na število } \\
\text { gospodarskih družb (v EUR) }\end{array}$ \\
\hline Specializacija & Koeficient specializacije \\
\hline $\begin{array}{l}\text { Izvozna } \\
\text { usmerjenost }\end{array}$ & $\begin{array}{l}\text { Delež čistih prihodkov od prodaje na tujih trgih v prihodkih skupaj } \\
\text { (\%) }\end{array}$ \\
\hline $\begin{array}{l}\text { Gostota prebivalcev (preb./km²) } \\
\text { Stopnja registrirane brezposelnosti }(\%) \\
\text { razmere }\end{array}$ & $\begin{array}{l}\text { Indeks starosti } \\
\text { Delež delovno aktivnega prebivalstva }(\%) \\
\text { Indeks delovne migracije } \\
\text { Stevilo diplomantov na } 1000 \text { prebivalcev } \\
\text { Naravni prirast na } 1000 \text { prebivalcev } \\
\text { Selitveni prirast s tujino na } 1000 \text { prebivalcev } \\
\text { Selitveni prirast med občinami na } 1000 \text { prebivalcev }\end{array}$ \\
\hline Infrastruktura & $\begin{array}{l}\text { Gostota avtocestnega omrežja na } 100 \mathrm{~km}{ }^{2}\left(\mathrm{~km} / \mathrm{km}^{2}\right) \\
\text { Povprečni potovalni čas z osebnim avtomobilom do najhitreje } \\
\text { dostopnega priključka na avtocesto ali hitro cesto }(\mathrm{v} \text { min.) } \\
\text { Delež prebivalcev, ki živijo znotraj radija } 500 \mathrm{~m} \mathrm{od} \mathrm{postajališča} \\
\text { javnega potniškega prometa }(\%)\end{array}$ \\
\hline
\end{tabular}

Zaradi primerljivosti stopnje razvitosti podravskih občin z ostalimi občinami v Sloveniji so bile vse slovenske občine s pomočjo dvostopenjske metode razvrščanja $\mathrm{v}$ skupine za vsak družbeno-gospodarski dejavnik, predstavljen v preglednici, z izbranimi kazalniki, ki posamezen dejavnik opredeljujejo, s programom SPSS razdeljene na pet tipov (Lapuh, 2017). Posamezni tipi po dejavnikih so bili poimenovani na podlagi značilnosti opisnih statistik - na podlagi povprečij kazalnikov znotraj posameznih tipov (Lapuh, 2017). Značilnosti občin Podravske regije po družbeno-gospodarskih dejavnikih so v nadaljevanju kartografsko prikazane.

Gospodarstvo ne raste enakomerno, saj je zaznamovano z vzponi in padci. Gospodarski cikel je gibanje gospodarske aktivnosti med obdobjem rasti in obdobjem stagnacije (Finančni slovar, 2012). Vrh konča rast, dno določa obdobje gospodarske krize.

Ker se vpliv gospodarske krize najbolj odraža $v$ nižanju gospodarske aktivnosti in povišanju stopnje registrirane brezposelnosti, je bil vpliv gospodarske krize na občine Podravske regije ugotovljen s pomočjo kazalnikov bruto dodana vrednost (BDV) na zaposlenega in stopnja registrirane brezposelnosti. Upoštevali smo gospodarski cikel vsake občine in izračunali odstotno spremembo obeh kazalnikov. 
Glede na vpliv gospodarske krize so bile slovenske občine na podlagi srednje vrednosti in standardnega odklona razdeljene na tri tipe (največji, srednji, najmanjši vpliv gospodarske krize) (Lapuh, 2017), tako da je vpliv občin Podravske regije primerljiv z ostalimi. Večina občin je doživela dno leta 2009, leto okrevanja pa se od občine do občine razlikuje.

Z istima kazalnikoma so bile občine Podravske regije glede na zmožnost okrevanja razdeljene na pet tipov: odporne; okrevale in dosegle vrednosti pred recesijo; okrevale, vendar ponovno nazadujejo; niso okrevale, vendar beležijo postopno izboljšanje; niso okrevale in nazadujejo. Upoštevani so bili zadnji dostopni podatki obeh kazalnikov za leto 2015. Z opisnimi statistikami je bila narejena primerjava med družbeno-gospodarsko sestavo občin pred gospodarsko krizo s samim vplivom in nato še z okrevanjem. Izračunane so bile povprečne vrednosti kazalnikov po tipih občin glede na vpliv in glede na okrevanje. Kako so gospodarsko krizo občutili v Podravski regiji in se nanjo odzvali izbrani regionalni deležniki Podravske regije smo preverili s pomočjo intervjujev $\mathrm{s}$ predstavnikoma Mariborske razvojne agencije (Keuc, 2015) in Štajerske gospodarske zbornice (Podgornik, 2015).

\section{Družbeno-gospodarska sestava občin Podravske regije pred gospodarsko krizo}

V nadaljevanju so predstavljene razlike v gospodarski razvitosti, specializaciji, izvozu, družbeni sestavi in prometni infrastrukturi Podravske regije in njenih občin pred gospodarsko krizo.

\section{Značilnosti Podravske regije glede na ostale slovenske regije.} Vir: SURS, 2017.

\begin{tabular}{|l|l|}
\hline Bruto domači proizvod na prebivalca & povprečen \\
\hline Število podjetij na 1000 prebivalcev & povprečno \\
\hline Koeficient specializacije & zelo podpovprečen \\
\hline Izvoz & povprečen \\
\hline Dostopnost priključka na avtocesto ali hitro cesto & povprečna \\
\hline Stopnja registrirane brezposelnosti & visoko nadpovprečna \\
\hline Indeks delovne migracije & nadpovprečen \\
\hline Naravni prirast na 1000 prebivalcev & povprečen \\
\hline
\end{tabular}

\section{Gospodarska razvitost}

Podravska regija je pred zadnjo gospodarsko krizo v Sloveniji sodila med regije z nižjim dobičkom gospodarskih družb in manj podjetji na 1000 prebivalcev. Pred gospodarsko krizo so imele najugodnejšo gospodarsko sestavo občine: Hajdina, Hoče-Slivnica, Kungota, Ormož, Ruše, Selnica ob Dravi in Slovenska Bistrica. Zanje je bila značilna boljša gospodarska razvitost (višja BDV na zaposlenega), več velikih gospodarskih družb na 10.000 prebivalcev (povprečno število delavcev v poslovnem letu presega 250), višji čisti dobiček gospodarskih družb glede na število gospodarskih družb, vendar manj investicij na 1000 prebivalcev, kot pri občinah z najmanj ugodno gospodarsko sestavo: Duplek, Gorišnica, Miklavž na Dravskem polju, Pesnica, Ptuj, Rače-Fram in Starše. 
L. Lapuh: Podravje region in the light of the last economic crisis

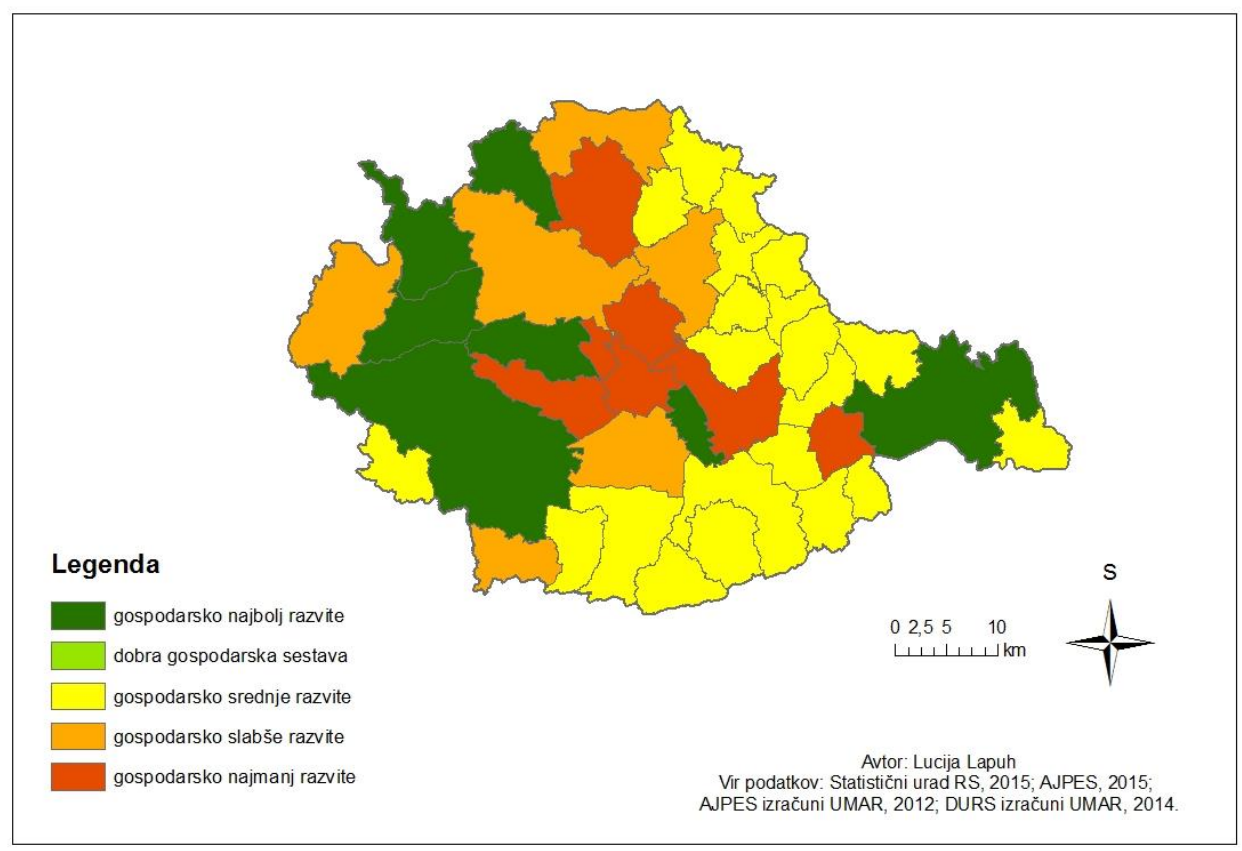

Tipi občin Podravske regije glede na gospodarske kazalnike pred gospodarsko krizo.

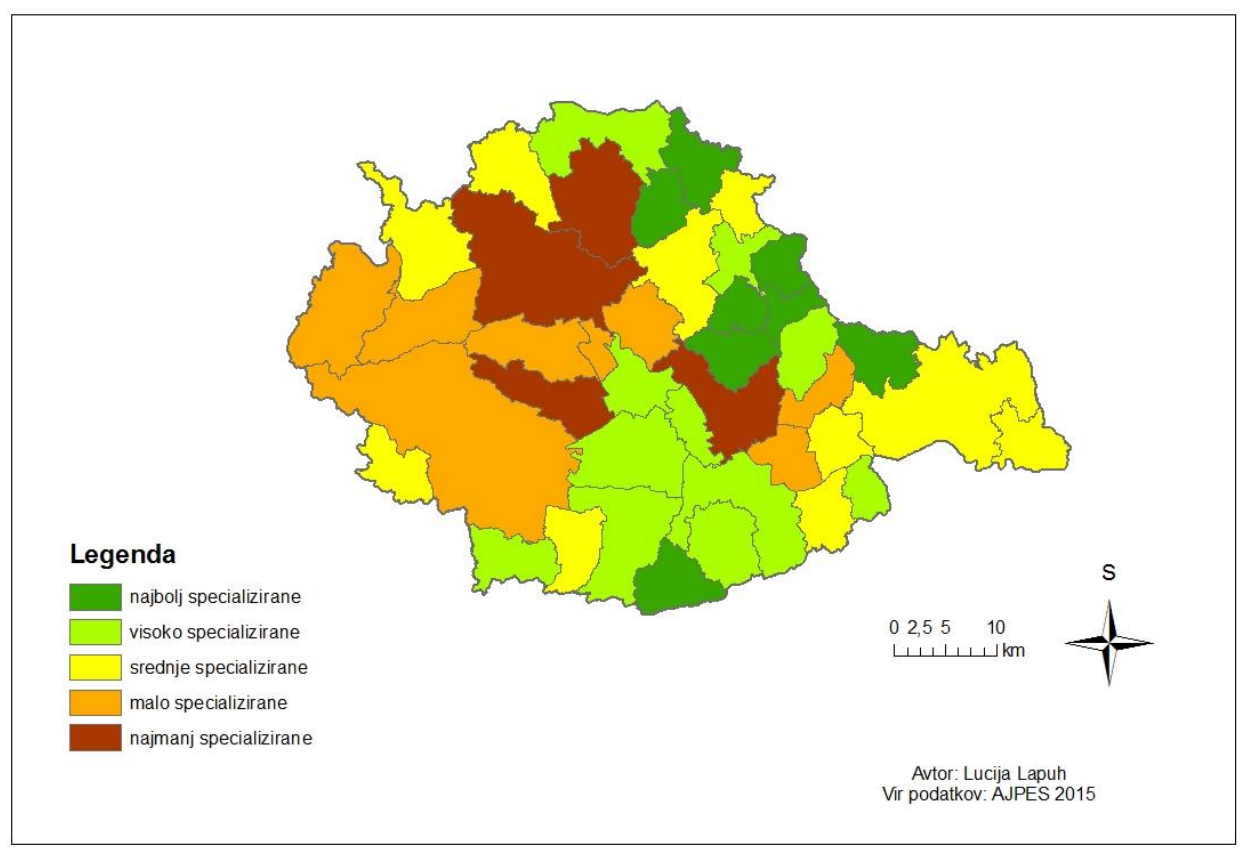

Tipi občin Podravske regije glede na specializacijo občin pred gospodarsko krizo. 


\section{Specializacija}

Podravska regija je bila najmanj specializirana regija v Sloveniji. Največ ljudi je bilo zaposlenih v predelovalnih dejavnostih, ki so jim sledile dejavnosti trgovina, gostinstvo in promet ter skupina dejavnosti uprava in obramba, obvezna socialna varnost, izobraževanje in zdravstvo (Statistični urad ..., 2017). Največ prihodkov so ustvarile kovinsko-predelovalna, kemična in prehrambena industrija (Podgornik 2015). Ta regija je bila v Sloveniji na drugem mestu po številu gospodarskih družb v kmetijskih dejavnostih (AJPES, 2015). $\mathrm{V}$ tej regiji so bili glede na razmerje zaposlenosti po dejavnosti v državi največji zaposlovalci s področja prometa in skladiščenja (lokacijski kvocient 1,6) ter drugih raznovrstnih poslovnih dejavnosti (lokacijski kvocient 1,5).

Najbolj so bile pred gospodarsko krizo specializirane občine: Cerkvenjak, Destrnik, Sveta Ana, Sveti Andraž v Slovenskih goricah, Sveti Jurij v Slovenskih goricah, Sveti Tomaž, Trnovska vas in Žetale. To so občine z le nekaj delovnimi mesti. V gradbeništvu je bilo zaposlenih največ v občini Žetale in Sveti Tomaž, v dejavnosti trgovine v občinah Destrnik, Trnovska vas in Sveti Jurij v Slovenskih goricah, ter v Cerkvenjaku poslovanje z nepremičninami. Najmanj specializirane občine so bile: Maribor, Pesnica, Ptuj in RačeFram.

\section{Izvozna usmerjenost}

Večino izvoza so predstavljali polizdelki kovinsko predelovalne industrije. Največji izvozniki in hkrati tudi največji investitorji v regiji so bila podjetja, ki so jih prevzeli tujci (Keuc, 2015). Tudi majhna podjetja so izvažala, saj ima Slovenija majhen trg. Največ (30 \%) so izvažali v Nemčijo, sledijo Avstrija, Italija, Češka in Francija (Podgornik, 2015). Izvoz regijo rešuje tako v gospodarski krizi kot v konjunkturi (Podgornik, 2015).

Pred gospodarsko krizo so bile najbolj izvozno usmerjene občine: Cirkulane, Kidričevo, Ruše, Hoče-Slivnica, Lenart, Majšperk, Ormož, Selnica ob Dravi, Slovenska Bistrica, Sveti Andraž v Slovenskih goricah, Šentilj in Zavrč. Občine Hoče-Slivnica, Ormož, Selnica ob Dravi, Slovenska Bistrica imajo tako najugodnejšo gospodarsko sestavo, kot so tudi največje izvoznice. Pred gospodarsko krizo so bile najmanj izvozno usmerjene občine: Destrnik, Duplek, Hajdina, Kungota, Miklavž na Dravskem polju, Središče ob Dravi, Starše in Trnovska vas. Od naštetih občin imajo občine Duplek, Miklavž na Dravskem polju in Starše tudi najmanj ugodno gospodarsko sestavo.

\section{Družbena sestava}

Podravska regija je bila tretja najbolj poseljena regija v Sloveniji. Leta 2008 je imela drugo najvišjo stopnjo registrirane brezposelnosti v državi, vendar je bila ena izmed treh slovenskih regij, ki je imela več prostih delovnih mest na 1000 prebivalcev, kot je bilo slovensko povprečje. Regija je bila glede na indeks delovne migracije uvrščena med zmerno delovne regije, kar pomeni, da se je več ljudi vozilo na delo v to regijo, kot iz te regije v druge regije. Podravska regija je imela drugi najnižji selitveni prirast s tujino. Je ena izmed treh regij v Sloveniji, v katero se je priselilo več prebivalcev iz ostalih regij, kot se jih je iz Podravske preselilo v druge regije. Regija je imela nizek delež prebivalcev brez izobrazbe oziroma $\mathrm{z}$ nepopolno osnovnošolsko izobrazbo, vendar poleg pomurske regije najmanj diplomantov visokošolskega dodiplomskega izobraževanja. 


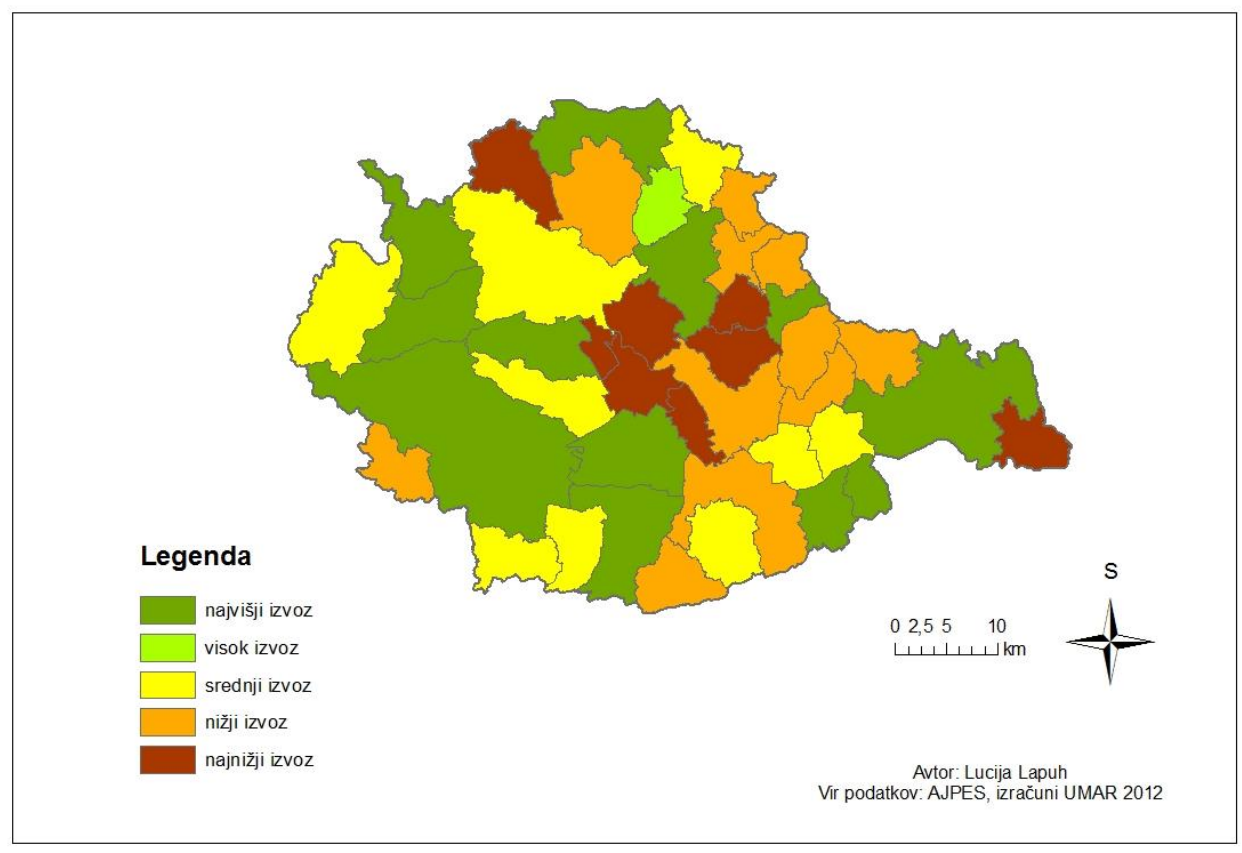

Tipi občin Podravske regije glede na izvoz pred gospodarsko krizo.

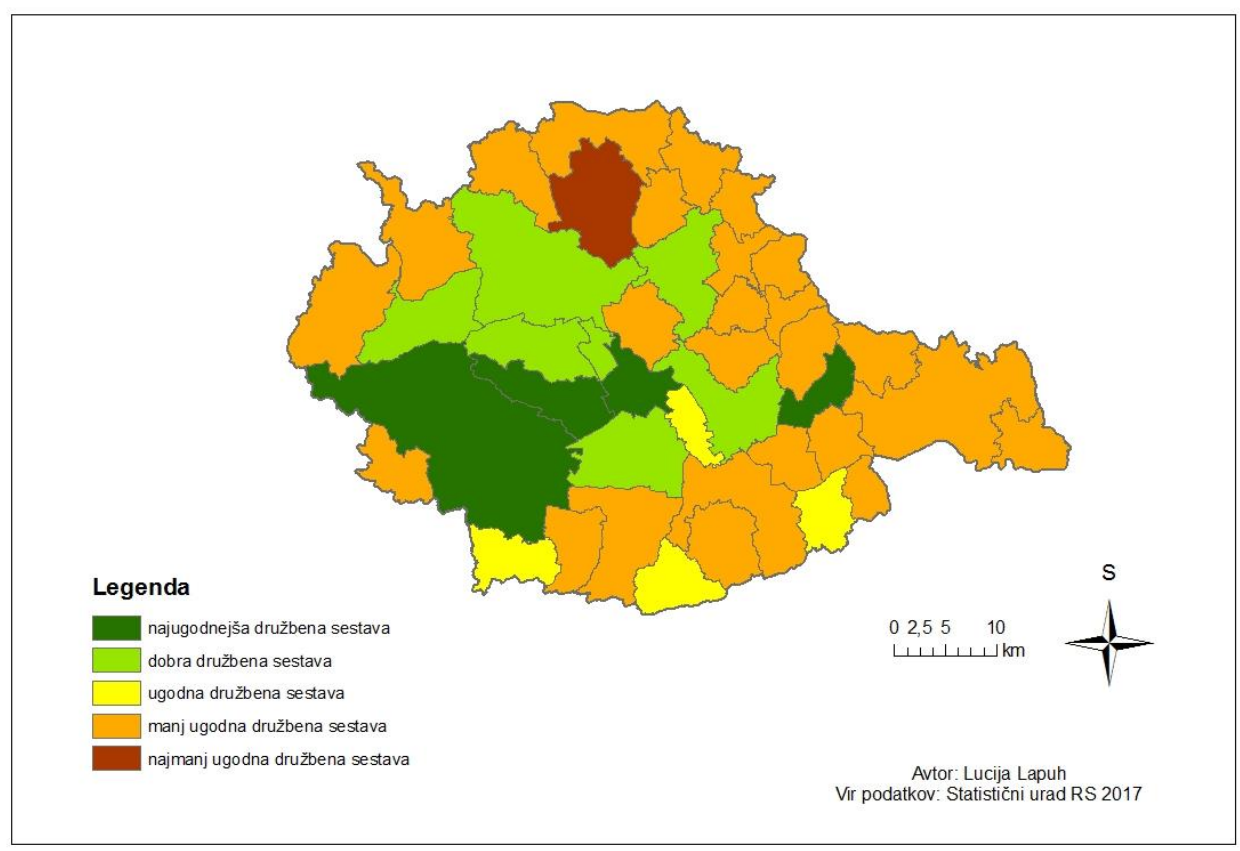

Tipi občin Podravske regije glede na družbene kazalnike pred gospodarsko krizo.

$\mathrm{Na}$ podlagi družbenih kazalnikov je bila opredeljena tipologija občin, iz katere je razvidno, da so imele pred gospodarsko krizo najugodnejšo družbeno sestavo občine: 
Dornava, Rače-Fram, Slovenska Bistrica in Starše. Te občine so imele nižjo stopnjo registrirane brezposelnosti, mlajše prebivalstvo (nižji indeks starosti), višji delež delovno aktivnega prebivalstva, imele so več delovnih mest (višji indeks delovne migracije), več diplomantov na 1000 prebivalcev, višji naravni prirast na 1000 prebivalcev ter več priseljenih iz tujine in drugih občin kot odseljenih, kot občina Pesnica, ki je imela najmanj ugodno družbeno sestavo.

\section{Prometna infrastruktura}

Podravska regija je imela dobro prometno dostopnost. Gostota avtocestnega omrežja je bila malenkost večja od državnega povprečja. Povprečni potovalni čas z osebnim avtomobilom do najhitreje dostopnega priključka na avtocesto ali hitro cesto je bil za 1,4 minute krajši od državnega povprečja. $60 \%$ prebivalcev Podravske regije je živelo znotraj radija 500 metrov od postajališča javnega potniškega prometa, kar je nad državnim povprečjem.

Pred gospodarsko krizo so imele najboljšo prometno dostopnost občine ob avtocesti treh vej petega pan-evropskega prometnega koridorja: Cerkvenjak, Hoče-Slivnica, Kungota, Lenart, Pesnica, Rače-Fram, Slovenska Bistrica, Sveta Trojica v Slovenskih goricah, Šentilj. Najslabšo prometno dostopnost so imele odročnejše podeželske občine: Benedikt, Cirkulane, Dornava, Gorišnica, Lovrenc na Pohorju, Markovci, Ormož, Podlehnik, Zavrč, Žetale.

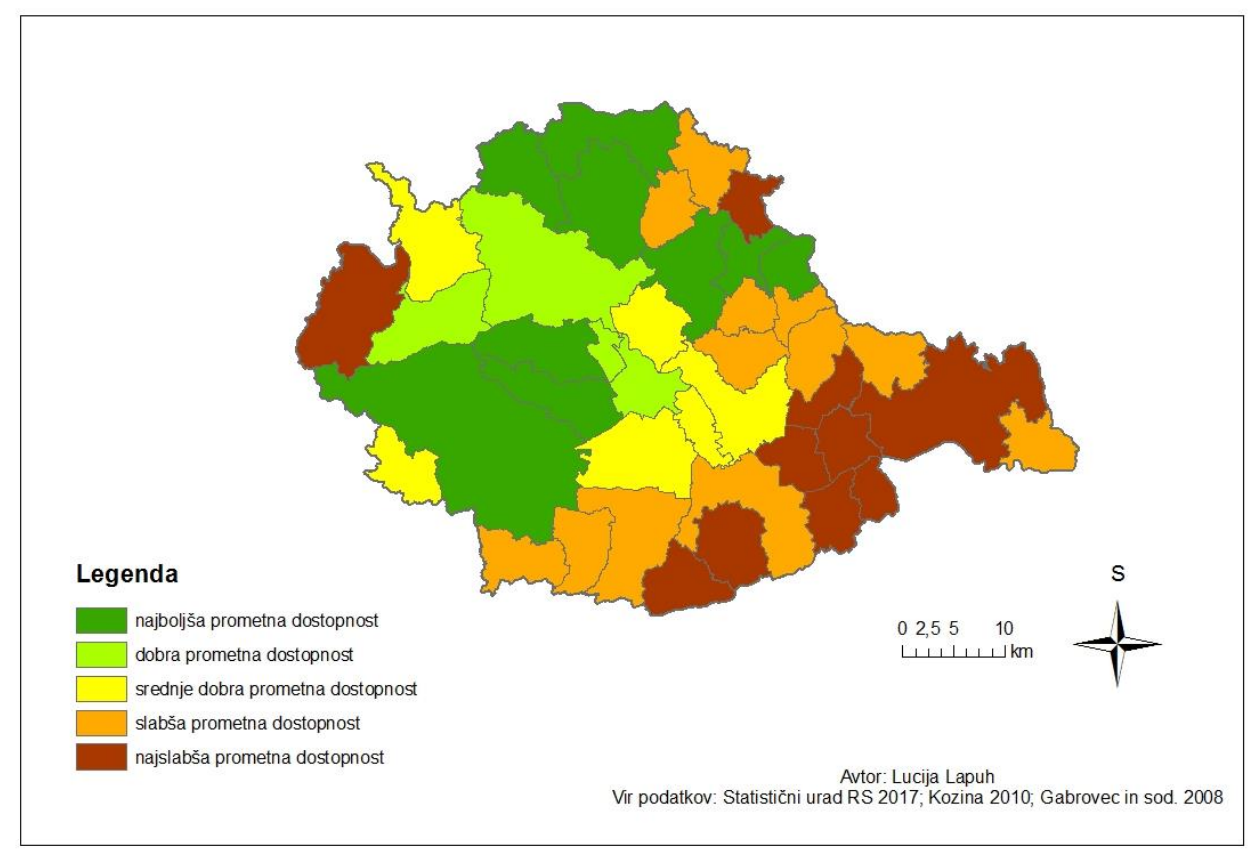

Tipi občin Podravske regije glede na kazalnike infrastrukture pred gospodarsko krizo. 


\section{Vpliv gospodarske krize na občine Podravske regije in njihova prožnost, merjeno z BDV na zaposlenega}

Vpliv gospodarske krize se je v Sloveniji občutil od leta 2009, ko je prišlo do nižanja gospodarske aktivnosti in do porasta števila brezposelnih. Podravska regija je imela v primerjavi s celotno Slovenijo podpovprečen gospodarski razvoj in višjo stopnjo registrirane brezposelnosti tako pred, kot tudi po gospodarski krizi. Podravska regija je leta 2015 skoraj dosegla vrednosti, kot so bile pred gospodarsko krizo leta 2008, in tako skoraj okrevala.

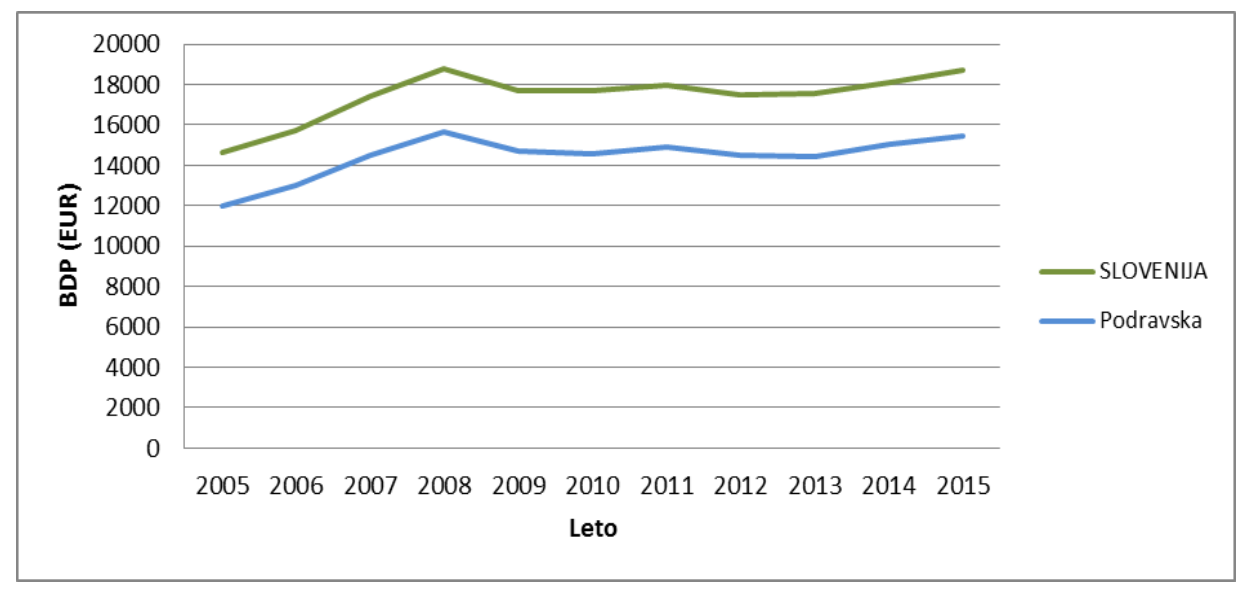

Sprememba bruto domačega proizvoda na prebivalca zaradi gospodarske krize. Vir: SURS 2017.

Občine, ki so zaradi gospodarske krize doživele najvišje znižanje BDV na zaposlenega, so: Dornava, Hajdina, Podlehnik, Selnica ob Dravi, Sveta Ana, Sveti Andraž v Slovenskih goricah, Sveti Tomaž. Te občine so bile pred gospodarsko krizo gospodarsko najbolj razvite, imele so največ diplomantov in najvišji naravni prirast ter najnižji selitveni prirast med občinami na 1000 prebivalcev. Te občine niso imele avtocestne povezave, za njihova podjetja pa je bilo značilno, da so najmanj izvažala.

Gospodarska kriza na gospodarstvo občin Juršinci, Majšperk in Sveta Trojica v Slovenskih goricah ni vplivala. Te občine so bile leta 2008 gospodarsko šibkejše z najnižjo BDV na zaposlenega, $\mathrm{z}$ najmanj podjetji na 1000 prebivalcev, ki so poslovale $\mathrm{z}$ najnižjim dobičkom in najnižjimi investicijami na 1000 prebivalcev ter brez velikih gospodarskih družb. Te tri občine so imele najnižjo gostoto prebivalstva, najnižjo stopnjo registrirane brezposelnosti, več mlajšega prebivalstva kot starejšega (najnižji indeks starosti), najnižji delež delovnega intenzivnega prebivalstva, najnižji indeks delovne migracije, najmanj diplomantov, negativni naravni prirast in najnižji selitveni prirast $\mathrm{s}$ tujino na 1000 prebivalcev. Zanje je bila značilna največja dolžina avtocest, največji povprečni potovalni čas z osebnim avtomobilom do najhitreje dostopnega priključka na avtocesto ali hitro cesto in najmanjši delež prebivalcev, ki živijo znotraj radija $500 \mathrm{~m}$ od postajališča javnega potniškega prometa. 


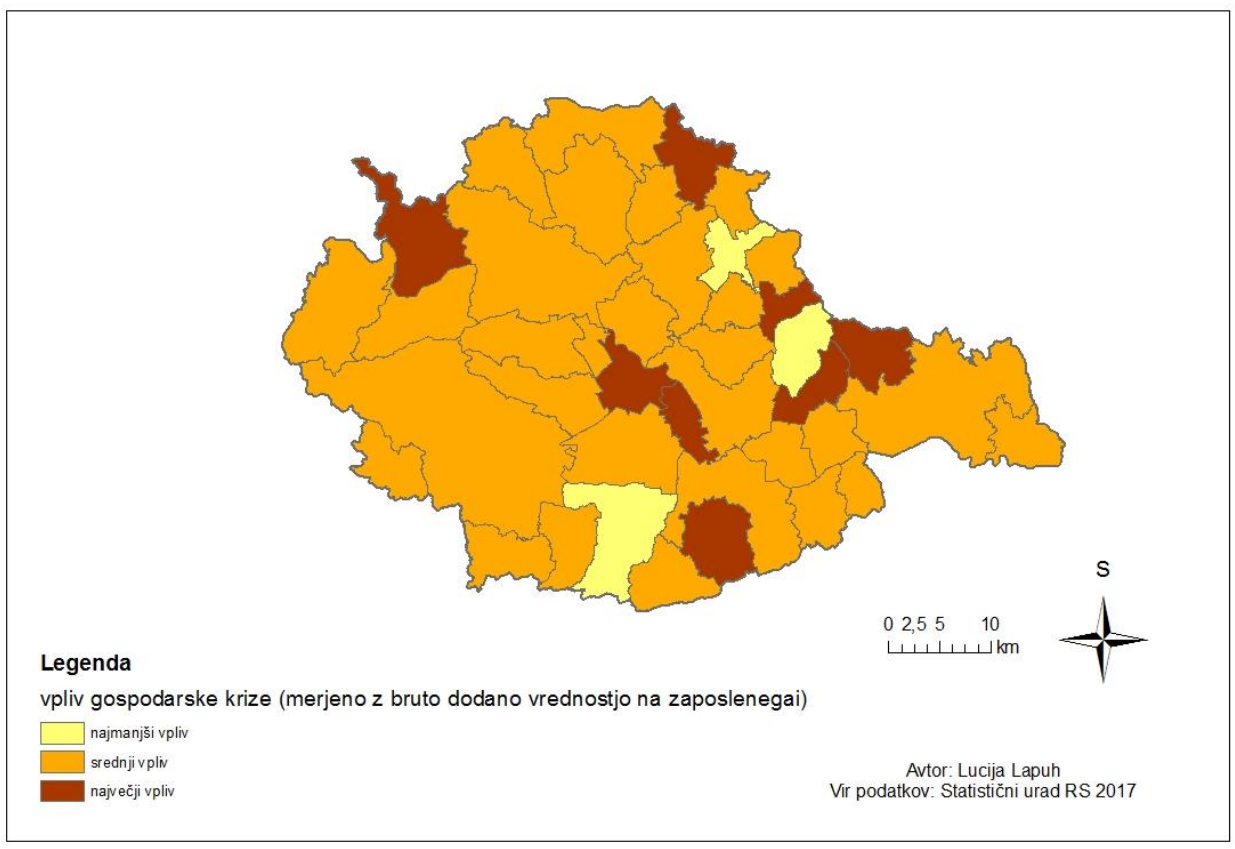

Vpliv gospodarske krize na občine Podravske regije, merjeno z bruto dodano vrednostjo na zaposlenega.

Podjetja delovno intenzivnih panog so bila bolj povržena vplivu gospodarske krize in so pogosteje propadla. Močno sta bila prizadeta gradbeni sektor in predelovalna industrija (Slatinek, 2014). Največje propadlo gradbeno podjetje je bilo CMP, ki je povečalo število brezposelnih oseb v regiji za 473 (Slatinek, 2014). Zadnja kriza je bila usodna predvsem za mala podjetja (Težki poosamosvojitveni ..., 2017). Največ podjetij je propadlo prvo leto gospodarske krize - leta 2009 je v Podravski regiji prenehalo poslovati 1535 podjetij, največ iz gradbeništva, trgovine, vzdrževanja in popravil motornih vozil ter strokovnih, znanstvenih in tehničnih dejavnosti (Slatinek 2014).

V obdobju gospodarske krize so podjetja omejila najemanje kreditov (Podgornik, 2015) (gospodarska kriza se je razvila iz finančne krize). Nova KBM je bila pred stečajem ena večjih sofinancerjev Podravskega gospodarstva skupaj s Probanko (Keuc, 2015). Podjetja bi se s finančno pomočjo lahko začela sanirati in tako konkurirati na tujih trgih. Dobra podjetja načeloma potrebujejo zelo malo podpore bank. Kjer podjetja večji del prihodkov vlagajo v svoje tekoče poslovanje, jim zmanjka za razvoj - podjetje brez razvoja pa dolgoročno ne more uspevati (Podgornik, 2015). Podjetja rezerv v znižanju cene dela nimajo več. Brez tujih in tudi domačih investicij v regijo ni možnosti nadomestiti skoraj 20.000 brezposelnih (Keuc, 2015).

Največji gospodarski potencial predstavljajo večja podjetja z razvojem: Impol, Talum, Dravske elektrarne, Pošta Slovenije (ki je ena izmed redkih državnih institucij s sedežem v regiji), Elektro Maribor, Perutnina Ptuj, Ecolab, Plinarna, Paloma, Swatycomet. Izgubili so nekaj velikih podjetij in na ta račun pridobili kar nekaj malih podjetij (Podgornik, 2015). V regiji je energetika zelo močna. Dravske elektrarne, ki imajo v regiji svoj sedež, 
ustvarjajo tretjino elektrike v Sloveniji (Podgornik, 2015).

Gospodarstvo štirih občin v Podravski regiji (Juršinci, Lenart, Majšperk, Sveta Trojica v Slovenskih goricah) je bilo na gospodarsko krizo odporno. Te občine so imele pred gospodarsko krizo najnižjo stopnjo registrirane brezposelnosti, največ delovno aktivnega prebivalstva, negativni naravni prirast in največ dnevne mobilnosti na delo v druge občine. Te občine so imele tudi najboljšo povezavo $\mathrm{z}$ avtocesto in so bile največje izvoznice.

\section{Prožnost občin merjena z BDV na zaposlenega.}

\begin{tabular}{|l|l|}
\hline Odporne & Juršinci, Lenart, Majšperk, Sveta Trojica v Slovenskih goricah \\
\hline $\begin{array}{l}\text { Okrevale (dosegle } \\
\text { vrednosti pred recesijo) }\end{array}$ & $\begin{array}{l}\text { Benedikt, Cerkvenjak, Cirkulane, Dornava, Duplek, Gorišnica, } \\
\text { Kungota, Lovrenc na Pohorju, Makole, Maribor, Markovci, } \\
\text { Miklavž na Dravskem polju, Oplotnica, Pesnica, Poljčane, } \\
\text { Ptuj, Ruše, Slovenska Bistrica, Središče ob Dravi, Starše, Sveti } \\
\text { Jurij v Slov. goricah, Šentilj, Trnovska vas, Zavrč, Žetale }\end{array}$ \\
\hline $\begin{array}{l}\text { Okrevale, a ponovno } \\
\text { nazadujejo }\end{array}$ & Rače - Fram, Sveti Tomaž \\
\hline $\begin{array}{l}\text { Niso okrevale, vendar so } \\
\text { že dosegle dno in } \\
\text { beležijo postopno rast }\end{array}$ & $\begin{array}{l}\text { Destrnik, Hajdina, Hoče - Slivnica, Kidričevo, Ormož, } \\
\text { Podlehnik, Selnica ob Dravi, Sveta Ana, Sveti Andraž v } \\
\text { Slovenskih goricah, Videm }\end{array}$ \\
\hline $\begin{array}{l}\text { Niso okrevale in še } \\
\text { vedno nazadujejo }\end{array}$ & - \\
\hline
\end{tabular}

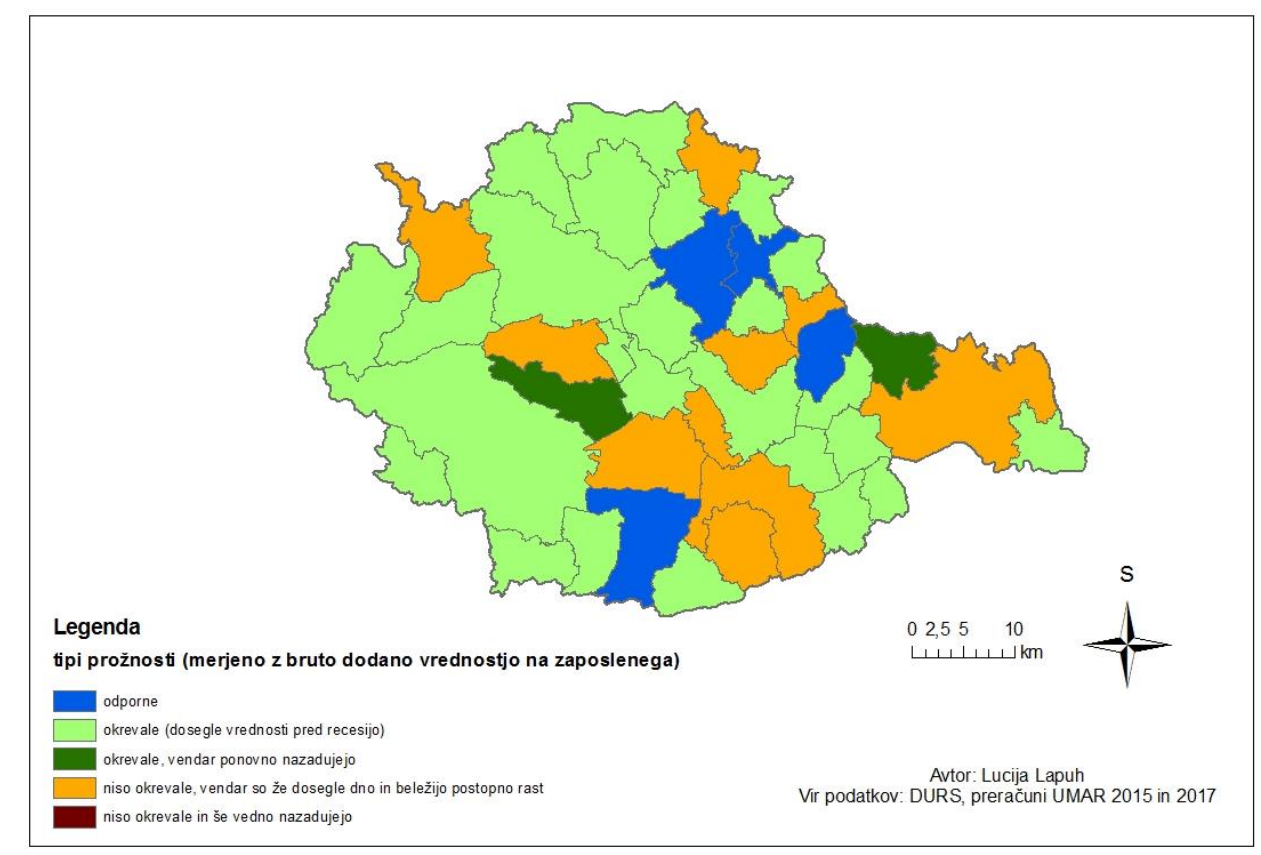

Prožnost občin Podravske regije, merjena z bruto dodano vrednostjo na zaposlenega $v$ EUR. 
Dobra tretjina občin Podravske regije je uspela okrevati po gospodarski krizi. Te občine so bile najgosteje poseljene, več ljudi se je priselilo v te občine, kot iz njih odselilo, imele so največ investicij na 1000 prebivalcev in bile najmanjše izvoznice ter imele najboljši dostop do postajališč javnega prometa. Občine predvsem z območja Slovenskih goric, ki niso okrevale, so imele največ diplomantov in več mlajšega kot starejšega prebivalstva (višji naravni prirast), zanje je bilo značilno več odseljevanja v druge občine, kot priseljevanja. Te občine so imele največ velikih gospodarskih družb, ki so zaposlovala največ ljudi in poslovale $\mathrm{z}$ največjim dobičkom.

\section{Vpliv gospodarske krize na občine Podravske regije in njihova prožnost, merjeno s stopnjo registrirane brezposelnosti}

Stopnja registrirane brezposelnosti je naraščala od leta 2009 do leta 2013, sledilo je le rahlo znižanje, tako da Slovenija, kot tudi ne Podravska regija z vidika zaposlenosti nista okrevali. Najvišja stopnja registrirane brezposelnosti v Podravski regiji je bila 14,7 leta 2013.

Občina, ki je v Podravski regiji doživela najvišje povišanje stopnje registrirane brezposelnosti, je Središče ob Dravi. Najmanj se je število brezposelnih povišalo na območju Slovenskih in Dravinjskih goric ter Dravsko-Ptujskega polja (občine Cerkvenjak, Destrnik, Gorišnica, Kidričevo, Lovrenc na Pohorju, Majšperk, Makole, Pesnica, Starše, Sveti Jurij v Slovenskih goricah, Šentilj, Žetale).

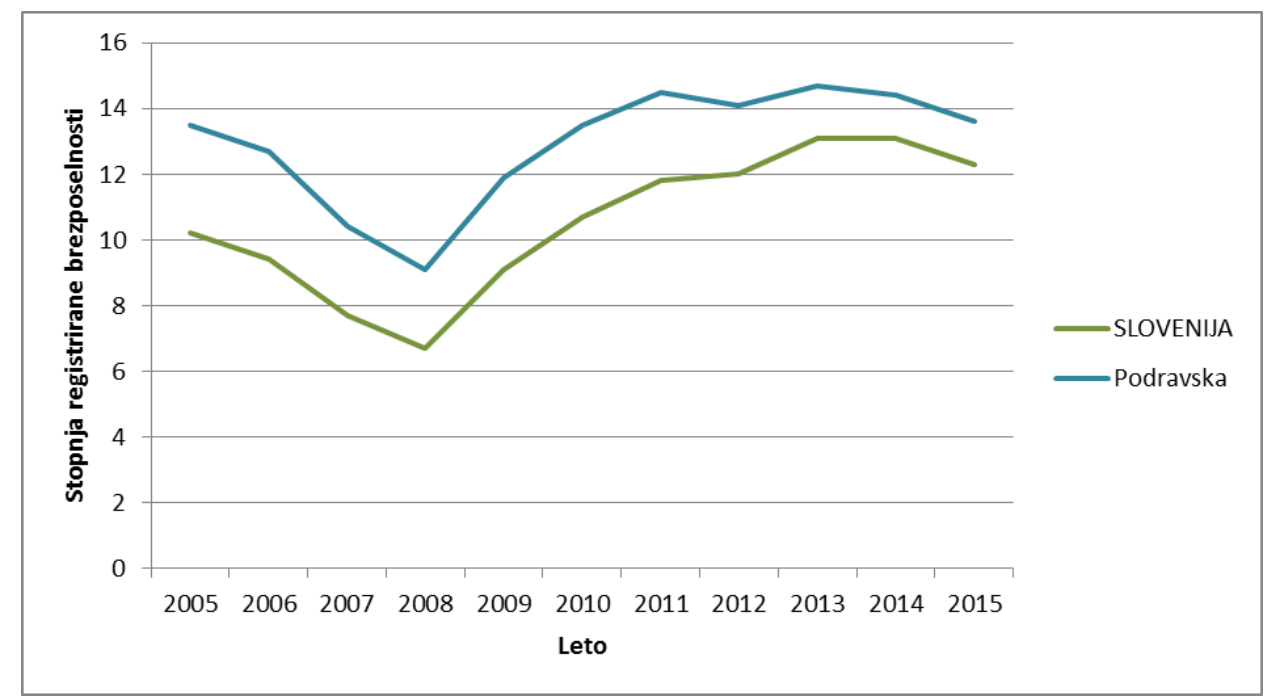

Sprememba stopnje registrirane brezposelnosti zaradi gospodarske krize. Vir: SURS 2017.

Večina občin Podravske regije z vidika zaposlenosti ni okrevala, vendar so že dosegle dno in beležijo postopno rast, medtem ko občina Lovrenc na Pohorju še vedno beleži najvišjo stopnjo registrirane brezposelnosti. V treh občinah Gorišnica, Šentilj in Žetale je stopnja registrirane brezposelnosti padla pod vrednosti, ki so bile pred gospodarsko krizo, v vseh preostalih občinah je brezposelnost ostala višja, kot je bila pred gospodarsko krizo. 


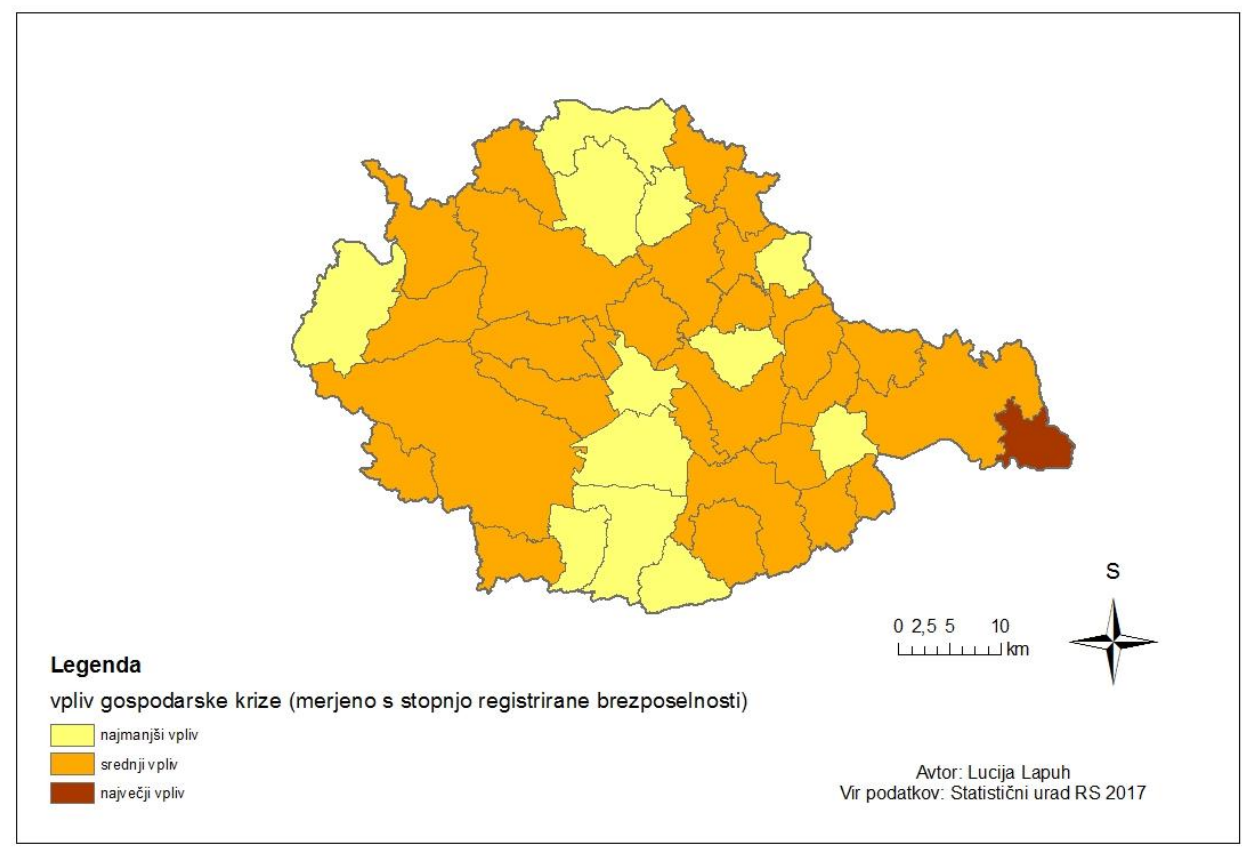

Vpliv gospodarske krize na občine Podravske regije, merjeno s stopnjo registrirane brezposelnosti.

Legenda

tipi prožnosti (merjeno s stopnjo registrirane brezposelnosti)

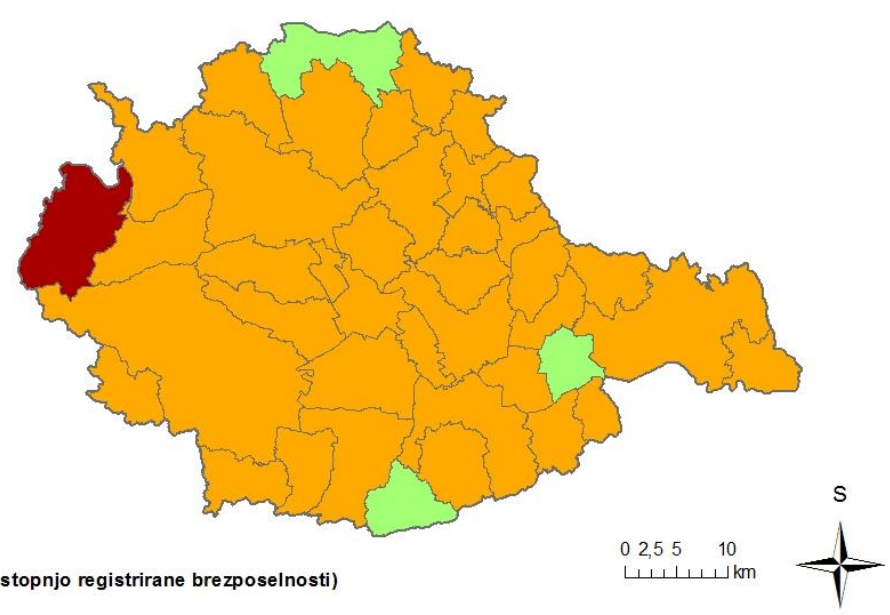

okrevale (dosegle vrednosti pred recesijo)

okrevale, vendar ponovno nazadujejo

niso okrevale, vendar so že dosegle dno in beležijo postopno rast

Avtor: Lucija Lapuh

Vir podatkov: Statistični urad RS 2017

niso okrevale in še vedno nazadujejo

Prožnost občin Podravske regije, merjena s stopnjo registrirane brezposelnosti. 


\section{Izbrane posebnosti Podravske regije in njenih občin pri odzivu na gospodarsko krizo - problemsko območje Maribor s širšo okolico}

V nadaljevanju so predstavljene zakonodajne spremembe $\mathrm{z}$ dodatnimi spodbudami za razvoj v Podravski regiji. Zakon o regionalnem razvoju omogoča, da se lahko na območju znotraj regije ali pa v celotni regiji oblikuje problemsko območje, ki dobi pomoč s strani države. Vlada Republike Slovenije je 20. junija 2013 na redni seji sprejela Sklep o dodatnih začasnih ukrepih razvojne podpore za problemsko območje $\mathrm{z}$ visoko brezposelnostjo Maribor s širšo okolico. Problemsko območje je bilo oblikovano skladno z Zakonom o skladnem regionalnem razvoju na podlagi visoke stopnje registrirane brezposelnosti, ki je več zaporednih mesecev presegala $17 \%$. V problemsko območje je vključenih šest občin iz Podravja: Maribor Hoče-Slivnica, Kungota, Pesnica, Ruše, Selnica ob Dravi ter tri občine iz koroške regije: Ribnica na Pohorju, Podvelka in Radlje ob Dravi (Sklep o dodatnih ..., 2013). Program spodbujanja konkurenčnosti Maribora s širšo okolico, ki je bil 10. oktobra 2013 potrjen na seji Vlade Republike Slovenije, v obdobju 2013-2018 zagotavlja določene pogoje za okrevanje gospodarstva.

Problemsko območje se sooča s strukturno brezposelnostjo, starajočim se prebivalstvom, visoko brezposelnostjo med mladimi in posledično njihovim odhajanjem v druge regije, kjer imajo boljše pogoje. Sooča se tudi z nizko stopnjo inovativnosti, nizko dodano vrednostjo in nekonkurenčnostjo gospodarstva. Večina predlaganih instrumentov predstavlja državno pomoč. Izvajali se bodo naslednji instrumenti: ustvarjanje in ohranitev delovnih mest $\mathrm{s}$ spodbujanjem novih vlaganj ali razširitvijo dejavnosti obstoječih podjetij; spodbujanje mikro in malih podjetij z mikrokrediti in subvencijo obrestne mere za komercialne kredite; spodbujanje podjetniške dejavnosti in ustvarjanje novih delovnih mest; podpora poslovanju in razvoju podjetij; promocija gospodarstva in območja Podravske in Koroške regije za privabljanje tujih in domačih vlagateljev (Program spodbujanja ..., 2015).

Razpise pripravljata Mariborska razvojna agencija in Ministrstvo za gospodarski razvoj in tehnologijo (Podgornik, 2015). Vendar na Mariborski razvojni agenciji ugotavljajo, da kapacitete gospodarstva ne dovoljujejo visokih kriterijev koriščenja neposrednih spodbud, saj podjetja niso kreditno sposobna in nimajo lastnega deleža investicij (Keuc, 2015). Slatinek (2014) poudarja počasnost izvajanja ukrepov. Ukrepi vključujejo davčne olajšave za zaposlovanje in investicije, spodbude za trajnostni razvoj itd. Rezultati sredstev iz evropskih skladov so vidni bolj na lokalnem nivoju $\mathrm{v}$ infrastrukturi (komunalna infrastruktura, objekti), manj pa $\mathrm{v}$ novih produktih, $\mathrm{v}$ znanstveno raziskovalni in programski opremi (Keuc, 2015), kot podpori gospodarstvu.

Program se mora kazati dolgoročno v zmanjšanju brezposelnosti, učinki morajo biti v zaposlitvah, na višji razvojni in dodani vrednosti, da podjetja tudi finančno rastejo. (Podgornik 2015).

Za načrtovanje regionalne politike in izvajanje nalog regionalnega razvoja so pristojne država in občine (Zakon o spodbujanju ..., 2011). Kljub temu da lahko regionalni in lokalni deležniki s takojšnjimi ukrepi pripomorejo k manjšemu vplivu gospodarske krize, sistematičnih ukrepov in strategij na ravni regij kot odgovora na krizo ni bilo.

Država je v preteklosti imela kar nekaj ukrepov, eden izmed njih je bil ukrep za 
samozaposlitev, kar pomeni, da so brezposelni dobivali določene subvencije za ustanovitev podjetja. Na Podravski gospodarski zbornici niso najbolj zadovoljni, kaj se je s temi podjetji dogajalo. »Po navadi se greš podjetništvo, če imaš dobro idejo in skozi to skušaš nekaj ustvariti in narediti, ne pa, ker dobiš subvencijo. Velikokrat se je zgodilo, da so po dveh letih prejemanja subvencije ponovno pristali na Zavodu za zaposlovanje še malo bolj zadolženi, kot so bili« (Podgornik, 2015).

\section{Selitev kot priložnost za povečevanje zaposlitvenih možnosti}

Selitev je lahko možna prilagoditev posameznika na gospodarsko krizo, saj poveča zaposlitvene možnosti (Slatinek 2014). Iz Podravske regije se je odseljevanje v tujino po letu 2008 trikratno povečalo - iz 500 državljanov Republike Slovenije pred gospodarsko krizo na dobrih 1500 letno.

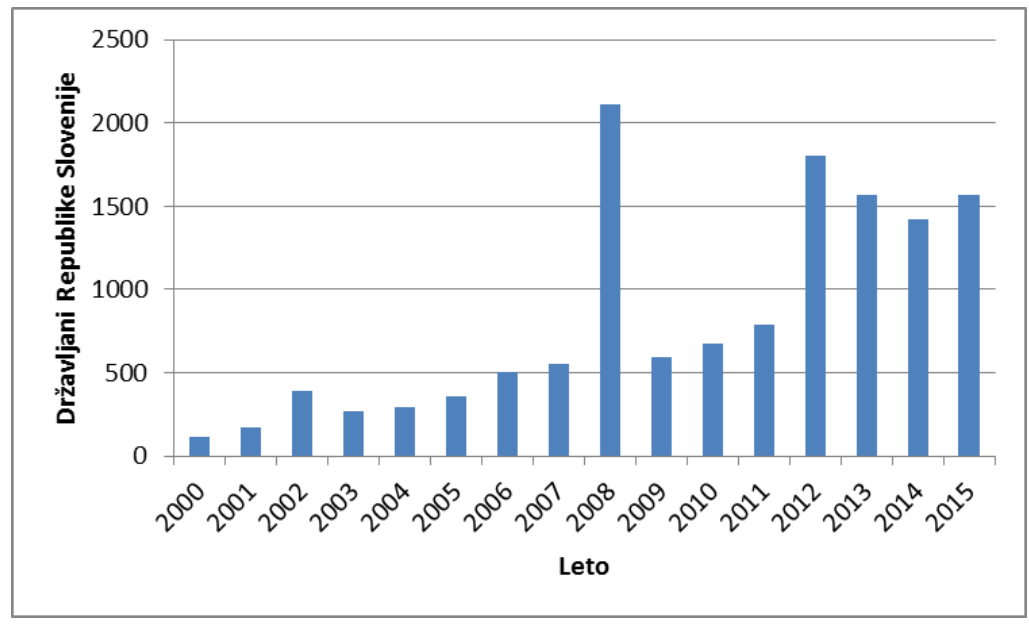

Odseljeni državljani Republike Slovenije iz Podravske regije v tujino. Vir: SURS, 2017.

Posebnost te regije je bližina avstrijske meje. Po slovenskih ocenah se dnevno vozi v Avstrijo 8000 ljudi (Podgornik, 2015) do 10.000 ljudi (Keuc, 2015), po avstrijskih celo 20.000 (Podgornik, 2015). V Avstriji za boljše plačilo kot v Sloveniji zaposlujejo delavce s poklicno izobrazbo, deficitarne poklice, mojstrske poklice (tehnike, negovalke), ki jih trenutno tudi $\mathrm{v}$ slovenskem gospodarskem prostoru manjka. »Zastonj so pridobili izobražen, usposobljen kader« (Keuc, 2015).

»Avstrijske firme, ki imajo v Sloveniji podjetja, štipendirajo slovenske otroke, cel razred vozijo v Cmurek v avstrijsko šolo, da jih izobrazijo za njihove potrebe pri nas. Naučijo se tudi nemško in so takoj potencialni delavci preko meje, če v Sloveniji ne bodo dobili dela« (Keuc, 2015). Avstrijci so največji investitorji v regiji. Delovna sila v Sloveniji je cenejša, saj morajo Slovence, če delajo v Avstriji, plačati po avstrijskih kolektivnih pogodbah (Keuc, 2015). Podjetje Magna v južnem predmestju Gradca zaposluje preko 10.000 zaposlenih. Podjetje je 50 kilometrov oddaljeno od slovenskega mejnega prehoda Šentilj. »Če se kar koli zgodi, tam zaposlene ljudi, ki se dnevno vozijo iz Slovenije, dobijo v regijo nazaj« kot brezposelne (Podgornik, 2015). 


\section{Povezava raziskav z gospodarstvom}

Ena od prioritet Podravske regije je povezava med raziskovalno sfero in gospodarstvom. Univerza v Mariboru si prizadeva sistemsko povezati gospodarstvo $\mathrm{z}$ razvojnimi oddelki in $\mathrm{z}$ raziskovalci, da bi naredili čim bolj aplikativne $\mathrm{v}$ prakso orientirane raziskave po potrebi gospodarstva (Podgornik, 2015), saj mala in srednje velika podjetja skoraj nimajo svojih raziskovalnih enot (Keuc, 2015).

Univerza je skupaj z gospodarstvom in razvojnimi institucijami leta 2013 pristopila $\mathrm{k}$ večjemu projektu Inovativne odprte tehnologije, kjer izhajajo iz potreb gospodarstva Vzhodne kohezijske regije (Keuc, 2015). V projekt je vključenih več kot 18 večjih podjetij ter ostali deležniki v regiji. Cilj je povišanje dodane vrednosti in nove zaposlitve. Univerza poskrbi za razvojno opremo, ki jo podjetja potrebujejo - razvojni oddelki skupaj $\mathrm{z}$ univerzo (Podgornik, 2015). Univerza se vključuje tudi skozi projekt Demola. Podjetje, ki ima neke razvojne težave, pristopi k projektu. Univerza poišče mentorja in študente, ki bi jih to zanimalo, ter skupaj iščejo rešitve. Tako se študentje ukvarjajo z realnimi problemi in hkrati spoznavajo gospodarsko okolje v svoji regiji in obratno - gospodarsko okolje spoznava dobre, pametne, inovativne in ustvarjalne študente (Keuc, 2015).

\section{Zaključek}

Podravska regija se je že pred zadnjo svetovno gospodarsko krizo, ki je v Sloveniji vplivala od leta 2009 , soočala $\mathrm{z}$ gospodarskim nazadovanjem in porastom števila brezposelnih, saj je bila proizvodno in predelovalno naravnana, te dejavnosti pa po osamosvojitvi niso bile več konkurenčne. Zadnja gospodarska kriza se je pokazala med drugim v zmanjšanju gospodarske aktivnosti in porastu števila brezposelnih, ki je bila že pred zadnjo gospodarsko krizo nad državnim povprečjem.

S pomočjo kazalnikov so bile preverjene družbeno-gospodarske lastnosti občin pred gospodarsko krizo. Občine na zahodu Podravske regije so bile gospodarsko bolj razvite. Podravska regija je bila najmanj specializirana regija v Sloveniji. Večino izvoza so predstavljali polizdelki kovinsko predelovalne industrije. Manj ugodno družbeno sestavo so imele periferne, obmejne občine. Pred gospodarsko krizo so imele najboljšo prometno dostopnost občine ob avtocesti treh vej petega pan-evropskega prometnega koridorja.

Gospodarska kriza ni vplivala na gospodarsko šibkejše regije brez velikih gospodarskih družb. V dobri tretjini občin Podravske regije je gospodarstvo uspelo okrevati po gospodarski krizi. Te občine so bile najgosteje poseljene, več ljudi se je priselilo $v$ te občine, kot iz njih odselilo, imele so največ investicij na 1000 prebivalcev in bile najmanjše izvoznice ter imele najboljši dostop do postajališč javnega prometa. Podravska regija z vidika zaposlenosti ni okrevala, okrevale so le tri občine Gorišnica, Šentilj in Žetale.

Zadnja gospodarska kriza je močno prizadela gradbeni sektor in predelovalno industrijo. V Podravski regiji so se naučili, da gospodarstvo ne sme biti odvisno le od ene dejavnosti, saj če ta propade, to vpliva na celotno regijo (Keuc 2015). Kot dodatni začasni ukrep razvojne podpore območju z visoko brezposelnostjo je država ustanovila Problemsko območje Maribor s širšo okolico. Posebnost regije je tudi delovna mobilnost v Avstrijo in sodelovanje gospodarstva z raziskovalci na Univerzi Maribor. 


\section{Literatura in viri}

AJPES, Podatki iz bilance stanja in izkaza poslovnega izida družb za leto 2011-2013, izračuni UMAR (osebni vir, 10. 3. 2015). Ljubljana.

Christmann, G. B., Ibert, O. 2012: Vulnerability and resilience in a socio-spatial perspective. Raumforschung und Raumordnung, 70, 4.

Christopherson, S., Michie, J., Tyler, P. 2010: Regional Resilience: Theoretical and Empirical Perspectives. Cambridge Journal of Regions, Economy and Society, 3, 1. Cambridge.

Dawley, S., Pike, A., Tomaney, J. 2010: Towards the Resilient Region?: Policy Activism and Peripheral Region Development. Serc discussion paper, 53. URL: http://eprints.lse.ac.uk/33523/1/sercdp0053.pdf

DURS, SURS, izračuni UMAR - Bruto dodana vrednost na zaposlenega. (osebni vir, 7. 2. 2014). Ljubljana.

DURS, SURS, izračuni UMAR - Bruto dodana vrednost na zaposlenega. (osebni vir, 19. 1. 2017). Ljubljana.

Economic Crisis: Resilience of Regions, 2013. Espon \& Cardiff University, ECR2. Revisited Interim Report, Version 20/05/2013.

http://www.espon.eu/export/sites/default/Documents/Projects/AppliedResearch/ECR2/EC R2_Revised_Interim_Report.pdf

Finančni slovar 2012. http://www.financnislovar.com/

Folke, C. 2006: Resilience: The emergence of a perspective for social-ecological systems analyses. Global Environmental Change, 16.

Gabrovec, M., Kotar, M., Bole, D., Fridl, J., Razpotnik, N., Hostnik, D., Gostič, K. 2008: Izdelava conskega sistema v Republiki Sloveniji. Končno poročilo. Ljubljana.

Keuc, B. 2015: Vpliv recesije na Podravsko regijo (osebni vir, 15. 1. 2015). Maribor.

Kozina, J., 2010: Prometna dostopnost. Georitem, 14, Ljubljana.

Lapuh, L. 2016: Ekonomskogeografsko vrednotenje prožnosti regij v času recesije. Doktorska disertacija, Filozofska fakulteta Univerze v Ljubljani. Ljubljana.

Lapuh, L. 2016: Merjenje vpliva recesije in sposobnosti okrevanja slovenskih statističnih regij. Acta geographica Slovenica, 56, 2. Ljubljana.

Lapuh, L. 2017: Socio-economic characteristics of resilient localities - experiences from Slovenia. Regional Studies Regional Science. London. (v recenziji).

Lorber, L. 2006: Strukturne spremembe mariborskega gospodarstva po letu 1991. Revija za geografijo, 1-1. Maribor.

Martin, R. 2012: Regional Economic Resilience, Hysteresis and Recessionary Shocks. Journal of Economic Geography 12, 1.

Podgornik, A. 2015: Vpliv recesije na Podravsko regijo (osebni vir, 15. 1. 2015). Maribor.

Program spodbujanja konkurenčnosti 2015: Mariborska razvojna agencija. http://mra.si/programspodbujanja-konkurencnosti/

Sklep o dodatnih začasnih ukrepih razvojne podpore za problemsko območje $\mathrm{z}$ visoko brezposelnostjo Maribor s širšo okolico, 2013. Uradni list RS, 53.

Slatinek, K. 2014: Vpliv gospodarske krize na brezposelnosti v Podravski regiji. Magistrsko delo. Ljubljana.

Statistični urad Republike Slovenije 2015. URL: www.stat.si

Statistični urad Republike Slovenije 2017. URL: www.stat.si

Težki poosamosvojitveni desetletji za mariborsko gospodarstvo. Sistory zgodovina Slovenije. http://www.sistory.si/hta/tranzicija/index-vpni.php?d=soocanje-s-tranzicijo-na-regionalniravni--primer-mariborske-obcine.html

Zakon o spodbujanju skladnega regionalnega razvoja. Uradni list Republike Slovenije. 20/2011. Ljubljana. 


\title{
Prostorski razvoj naselij v Podravju v zadnjih desetletjih
}

\author{
VLADIMIR DROZG
}

Povzetek Avtor prikazuje značilnosti prostorskega razvoja naselij $\mathrm{v}$ Podravju v letih 1960-2015. Prostorski razvoj pomeni širjenje in izgrajevanje naselij ter obsega morfološki in oblikovni vidik. Razlikovati je mogoče med izgrajevanjem naselja navznoter, širjenjem na površine $v$ okolici ter dograjevanjem, ki se nanaša na prenovo objektov. V oblikovnem smislu pa je mogoče razlikovati med skladno in raznoliko podobo objektov ter naselja. Prostorski razvoj naselij v Podravju je bil najbolj intenziven v letih 1960-1980, ko se je v polovici naselij število stanovanj več kot podvojilo. Po letu 1991 se je obseg stanovanjske gradnje močno zmanjšal. $\mathrm{V}$ prvem obdobju je prevladovalo širjenje na nove površine zunaj naselij, $\mathrm{v}$ drugem pa prevladuje zapolnjevanje površin znotraj naselij. V oblikovnem smislu je prostorski razvoj naselji zelo heterogen, kar pomeni, da so objekti v morfološkem smislu povsem različni, nekoč skladna podoba pa je zelo raznolika.

Ključne besede: $\cdot$ poselitev $\cdot$ naselje $・$ prostorski razvoj $・$ Podravje $•$ Slovenija •

NASLOV AVTORJA: dr. Vladimir Drozg, izredni profesor, Univerza v Mariboru, Filozofska fakulteta, Oddelek za geografijo, Koroška cesta 160, 2000 Maribor, Slovenija, e-naslov: vlado.drozg@um.si. 


\title{
Spatial development of settlements in the Podravje region in last decades
}

\author{
VLADIMIR DROZG
}

\begin{abstract}
Article deals with the spatial development of settlements in Podravje region between the years 1960 - 2015. The spatial development means widening and building settlements; it also includes the morphological and design aspects. One can differentiate between building the settlement inside the village, spreading to the surface in the immediate surroundings and upgrading the existing settlement, which refers to the renovation of buildings. In the sense of design, it is possible to distinguish between consistent and diverse image of buildings and the settlement. The spatial development of settlements in Podravje region was most intensive between the years 1960 - 1980, when the number of the flats/houses more than doubled. After 1991, the volume of new construction decreased considerably. In the first period it was mostly spread to new areas outside the settlements, while in the second one it was dominated by filling spaces within the settlements. The spatial development of settlements is in the formative sense very heterogeneous, which means that the objects in the morphological sense are completely different, and once consistent image is very diverse.
\end{abstract}

Keywords: - Settlement pattern - settlement - spatial development • Podravje • Slovenia •

CORRESPONDENCE ADDRESS: Vladimir Drozg, Ph.D., associate professor, University of Maribor, Faculty of Arts, Department for geography, Koroška cesta 160, 2000 Maribor, Slovenia, e-mail: vlado.drozg@um.si. 


\section{Uvod}

Prostorski razvoj naselij pomeni izgrajevanje in širjenje pozidanega območja. Vključuje vse vrste objektov, ne glede na namembnost in velikost, izgradnjo tehnične infrastrukture, na primer prometnic ter urejanje zemljišč, ki so kakorkoli povezana $\mathrm{z}$ dejavnostmi v naselju. Poleg tega vključuje še oblikovno plat razmeščanja objektov ter njihovo oblikovanje.

Prostorski razvoj poteka na več načinov in različno intenzivno. V prvi vrsti je odraz širših družbenih razmer, hkrati odraža lokalne posebnosti in hkrati je odraz interesov in osveščenosti posameznikov, graditeljev. Prostorski razvoj naselij je posledica gospodarskih razmer, socio-ekonomskih lastnosti prebivalcev, pa tudi kulture družbe in lokalne skupnosti, kar vse vpliva na to, kako bodo dejavnosti umeščene v naselje in kako bodo oblikovane. Prostorski razvoj naselij je posledica potreb tamkajšnjega prebivalstva ter (kulturnih, ekoloških, tehničnih) predstav o načinih in možnostih, kako določeno potrebo umestiti v prostor in kako prostor oblikovati. $\mathrm{V}$ tem je kulturna poanta te teme in zato jo je vredno in potrebno obravnavati.

Širjenje in izgrajevanje naselij je tema, ki se dotika kulturne pokrajine, poleg naselij, seveda. Če gledamo na naselja iz časovne perspektive, ni mogoče spregledati preloma, ki se je zgodil po razpadu agrarne družbe. Do takrat so se naselja izgrajevala in širila drugače, kot se izgrajujejo in širijo danes. Nekdanja povezanost med naravo in družbo je tudi na tem področju pričela bledeti in razpadati. Če za pretekli razvoj naselij ugotavljamo, da je ta potekal organsko, ko se je položaj novega objekta prilagajal položaju sosednjega in tistim v bližnji okolici in ko so bile naravne razmere največja omejitev pri umeščanju objektov, je danes način širjenja povsem drugačen, zato so drugačne tudi oblike, ki ob tem nastajajo. Novi ali preurejeni deli naselij so že tako veliki, da nekdanja agrarna zasnova v podobi in morfologiji skoraj ni več razpoznavna. Središča nekdanjih vasi so zaradi modernizacije stanovanjskih in gospodarskih objektov tako spremenjena, da jih je mogoče označiti kot urbanizirana podeželska naselja ali urbanizirana nekdaj agrarna naselja. Še več: nekdanja agrarna naselja so morfološko, socialno in funkcijsko tako spremenjena, da je podoba agrarnih naselij, kakršno nosimo v podzavesti, najbrž nepovratna.

Seveda lahko obžalujemo številne ne dovolj premišljene posege v nekoč agrarna naselja in nepotrebno degradacijo njihove zasnove in podobe, vendar je potrebno sprejeti »novo realnost «, prenehati objokovati izgubo idiličnih vasi ter postaviti nova merila in nov okvir za spoznavanje in urejanje naselij na podeželju. Namen znanosti in geografije v sklopu nje, je odkrivanje skritega, še nepoznanega. Iz poznavanja prostorskega razvoja naselij dobimo vpogled $\mathrm{v}$ oblike širjenja in izgrajevanja naselij ter intenzivnost procesa urbanizacije, s tem pa osnovo za načrtovanje prihodnjega razvoja. Način širjenja naselij kaže na morfološko transformacijo in ustroj posameznega naselja, intenzivnost prostorskega razvoja pa prikazuje diferenciranost pokrajine. Tudi to sta dejavnika pri načrtovanju prihodnosti in razumevanju sedanjosti, saj se neredko problema zavemo šele, ko ga vidimo iz novega-drugačnega zornega kota. Vsekakor dovolj razlogov za prikaz tematike.

V nadaljevanju želimo prikazati oblike širjenja in izgrajevanja naselij v Podravju, pokazati intenzivnost prostorskega razvoja v preteklih šestih desetletjih ter ovrednotiti 
širjenje naselij iz vidika oblikovne in prostorske skladnosti. Časovni presek sega v šestdeseta leta preteklega stoletja, ko je območje zajela urbanizacija in s tem intenzivna gradnja stanovanj, do obdobja, ko je urbani način življenja vsesplošno razširjen. Posebej poudarjamo - prostorski razvoj naselij ne želimo (o)vrednotiti iz vidika avtohtonega stavbarstva, o tem je bilo zapisanega že dovolj, zato bi bile ugotovitve znane že v naprej. Prikazati želimo razmere $\mathrm{v}$ novih, transformiranih naseljih, ki so večinoma že nadomestila nekdanje agrarne vasi. Ne nazadnje, evidentiranje sprememb v prostoru je eno od osnovnih poslanstev geografije, o oblikah novejšega prostorskega razvoja naselij pa sistematičnih in regionalno zasnovanih prikazov ni veliko.

\section{Pojasnila o metodi in konceptu}

Prostorski razvoj naselij obsega štiri področja, ki so med seboj sicer neločljivo povezana: položaj območja širjenja in izgrajevanja, velikost območja, razmestitev objektov na območju širjenja in izgrajevanja ter na obliko objektov. Prvi dve vsebini bi lahko imenovali prostorski vidik širjenja in izgrajevanja, drugi dve pa oblikovni vidik. Razlikovati jih je primerno zaradi sistematičnosti prikaza in zaradi vsebinsko metodološke jasnosti.

Prostorski razvoj naselij ugotavljamo s primerjanjem pozidanih površin v dveh časovnih obdobjih. V ta namen smo primerjali stanje pozidanih površin leta 1964 , ko je bila izdana prva serija temeljnih topografskih načrtov, dejansko je prikazano stanje nekaj let starejše, s stanjem leta 1991, ko je bila vzpostavljena baza podatkov, imenovana kataster stavb. Pozidane površine leta 1991 smo primerjali s stanjem pozidanih površin leta 2015, in sicer s primerjanjem katastra stavb iz obeh obdobij. Kaj primerjati, je težje vprašanje, saj smo pri izboru omejeni na podatke, ki jih je mogoče razbrati iz tlorisa. Element, ki kaže oblike prostorskega razvoja, je položaj novih objektov glede na obstoječe objekte in glede na strnjeno pozidan del naselja. Drugi element, ki ga je mogoče razbrati iz tlorisa je število novogradenj oziroma velikost območja. Poleg časa nastanka sta položaj in število objektov ključna elementa za spoznavanje oblik prostorskega razvoja. $\mathrm{Na}$ ta način prepoznamo naslednje oblike umeščanja objektov v naselje: objekti lahko stojijo na robu ali znotraj naselja, lahko stojijo na samem, lahko jih je več skupaj, lahko tvorijo sosesko. Uporabljena metoda ni povsem neoporečna. Posamezna novogradnja je lahko v prvem opazovanem obdobju uvrščena $\mathrm{v}$ drugo kategorijo, kot v drugem. To je posledica izgrajevanja naselja, kjer se število objektov tekom let povečuje od prvega, edinega, do skupine objektov. Oblikovni vidik prostorskega razvoja je deloma sicer razpoznaven v tlorisu, a je za podrobnejši prikaz potrebno podatke zbrati na kraju samem. S kartiranjem pridobimo podatke o načinih razmestitve objektov, podatke o tipu objektov in oblikovnih značilnostih novih stanovanjskih hiš.

Prostorski razvoj naselij je mogoče spoznavati in prikazati le na konkretnih primerih ter jih v nadaljevanju združiti v splošnejše kategorije, ki veljajo za večino naselij. Na regionalnem nivoju pa lahko pojav pokažemo s posrednimi kazalci, na primer intenzivnostjo demografskega razvoja in intenzivnostjo gradnje stanovanj.

\section{Oblike poselitve v Podravju}

Podravje je pokrajinsko zelo raznolika regija. Obsega hribovje, ravnino, gričevje in široke doline. Zato so tudi avtohtone oblike poselitve tako po položaju kot po morfoloških 
značilnostih zelo raznovrstne, saj je morfologija naselja tesno povezana $\mathrm{z}$ naravnimi razmerami, predvsem s površjem. V hribovju, na Pohorju, se pojavljata obliki poselitve v samotnih kmetijah ter gručasta naselja, na vzhodnem vznožju Pohorja so tudi razložena naselja. Na ravnini so obcestna naselja, v gričevju pa razložena naselja, zaselki in gručasta naselja. Po tipologiji, ki sloni na socialnih in ekonomskih značilnostih naselij, lahko Podravje razdelimo na mesta, obmestja, bolj urbanizirano podeželje, manj urbanizirano podeželje ter neposeljena območja (Drozg, 1999: 21). Območja se med seboj razlikujejo predvsem po socialnih in ekonomskih lastnostih prebivalstva, gospodarski usmerjenosti ter intenzivnosti gradnje stanovanj.

$\mathrm{V}$ naseljih, ki so nastala $\mathrm{v}$ agrarni fazi razvoja družbe, je povezava med tlorisom in površjem zelo očitna, pri novejših naseljih oziroma delih naselij pa manj. Oblika novih naselij je vse manj povezana $z$ naravnimi razmerami in vse bolj z dejavniki, ki so odraz individualizma, potrebe po zasebnosti, potrebe po enostavni dostopnosti, potrebe po tehnični opremljenosti zemljišča $\mathrm{z}$ infrastrukturnimi sistemi (vodovod, elektrika, kanalizacija), pa tudi z lastništvom zemljišč. Prav ti dejavniki ustvarjajo nov poselitveni vzorec in zaradi skoraj nepremostljivih razlik med novimi in starimi, je današnja podoba naselij na podeželju vse večji preplet med agrarno in urbano industrijsko kulturo. Pri tem druga, novejša, vse bolj prevladuje nad prvo, starejšo. Posledica je nova ali vsaj močno spremenjena kulturna pokrajina, v kateri se ne spreminjajo le poselitvene razmere, tudi raba zemljišč, pejsaž, simbolno pomembni objekti ter identiteta pokrajine. Nove oblike prostorskega razvoja so začetek in hkrati vrhunec procesa izgube nekdanje identitete podeželja oziroma spreminjanja in nastajanja nove. Podeželje je hibridni prostor, je zapisal M. Klemenčič, preplet starega in novega, kjer nove strukture še niso povsem vzpostavljene, stare pa še niso povsem spremenjene (Klemenčič, 2006: 162).

\section{Načini širjenja in izgrajevanja naselij}

Pri pregledu tlorisov številnih naselij smo prepoznali tri osnovne načine širjenja, vsak se pojavlja v več variantah. Trije osnovni načini so zapolnjevanje, širjenje in dograjevanje. Zapolnjevanje pomeni izgrajevanje naselja navznoter, na nepozidana zemljišča, obdana z drugimi objekti ali na funkcionalna zemljišča stanovanjskih hiš. Širjenje je oblika prostorskega razvoja na površine zunaj strnjeno pozidanega območja, večinoma na robu naselja ali v neposredni bližini. Novi del naselja je jasno ločen od starega. Dograjevanje je oblika prostorskega razvoja, pri katerem je gradbena dejavnost omejena na obstoječe objekte oziroma na njihova funkcionalna zemljišča. Pri tem ne gre za pozidavo novih površin ali zgolj v minimalnem obsegu, temveč za preurejanje obstoječega stavbnega fonda.

Vsaka od navedenih oblik ima več variant. Pri vsakem načinu je potrebno razlikovati še število objektov, ki označujejo posamezen način širjenja. Razlikovati je potrebno med posameznimi objekti, skupino objektov ter sosesko - skupino objektov, ki je v prostor umeščena na podlagi prostorskega načrta. V vsakem naselju lahko soobstajajo vse oblike. Podobne načine prostorskega razvoja navaja tudi Rebernik, le da jih je formuliral nekoliko drugače (Rebernik, 2011: 68).

Zapolnjevanje kot oblika prostorskega razvoja naselij se pojavlja v naslednjih variantah:

- Posamezni objekti znotraj grajene strukture naselja. Objekti so postavljeni na 
nepozidano zemljišče, $\mathrm{v}$ soseščini je en ali več stanovanjskih objektov. Novogradnje so pogosto na dvoriščih (funkcionalnih zemljiščih) kmečkih hiš. $\mathrm{V}$ tem primeru je dostop do novega objekta speljan preko funkcionalnega zemljišča obstoječe hiše. Pogosto pa je dostop do stanovanjske hiše urejen iz druge, »zadnje « strani. Med to obliko gradbenega razvoja naselij uvrščamo tudi novogradnje v sklopu samotnih kmetij in kmečkih gospodarstev v razloženih naseljih.

- Skupina objektov znotraj grajene strukture. To je podobna oblika gradbenega razvoja kot prejšnja, le da je novogradenj več. Njihova funkcionalna zemljišča se stikajo, hiše so na različne načine postavljene druga ob drugo. Prav sosedstvo (bližina) več novogradenj je ključni razlikovalni element od prejšnje oblike. Hiše tudi niso postavljene na funkcionalnih zemljiščih starih, že obstoječih hiš, temveč zasedajo nepozidana zemljišča, nekdanje vaške gmajne, mokrotna zemljišča, kmetijske površine med prometnicami in podobno, vendar znotraj pozidanega območja. Ker je pozidava potekala postopoma, tudi prometno omrežje ni celovito zasnovano; pojavljajo se slepe ulice, brez krožnega prometa, obračališč in parkirnih površin.
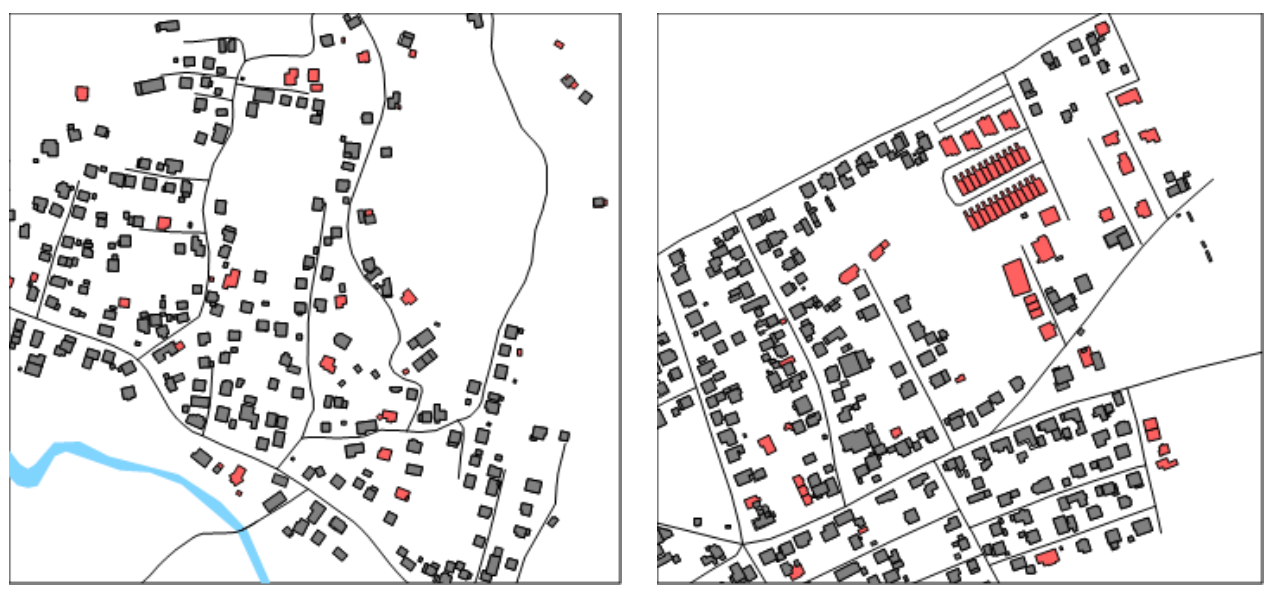

Spodnje Poljčane (slika levo). Novogradnje, nastale med leti 1992 - 2015 so zapolnile nepozidane površine v delu naselja, ki je bilo zgrajeno v letih $1954-1991$. Razviden je obseg širjenja v obdobju 1960 - 1990 ter zapolnjevanje v naslednjem obdobju. Rogoza (slika desno) je naselje južno od Maribora. Vobmestnih naseljih je pogosta gradnja sosesk enodružinskih hiš znotraj pozidanega območja.

- Soseska stanovanjskih hiš znotraj grajene strukture naselja. Za to obliko širjenja naselij je značilno, da je nepozidano zemljišče znotraj grajene strukture naselja zapolnjeno s stanovanjskimi objekti, in sicer na podlagi celovitega urbanističnega dokumenta. Objekti so na enak način umeščeni v prostor, oblikovno so enaki, prometno omrežje je celovito zasnovano, brez slepih ulic in nepreglednih križišč. Takšno obliko gradnje imenujemo tudi organizirana stanovanjska gradnja. Najpogosteje se pojavlja $\mathrm{v}$ obmestnih naseljih in $\mathrm{v}$ mestih, na podeželju pa redkeje. 

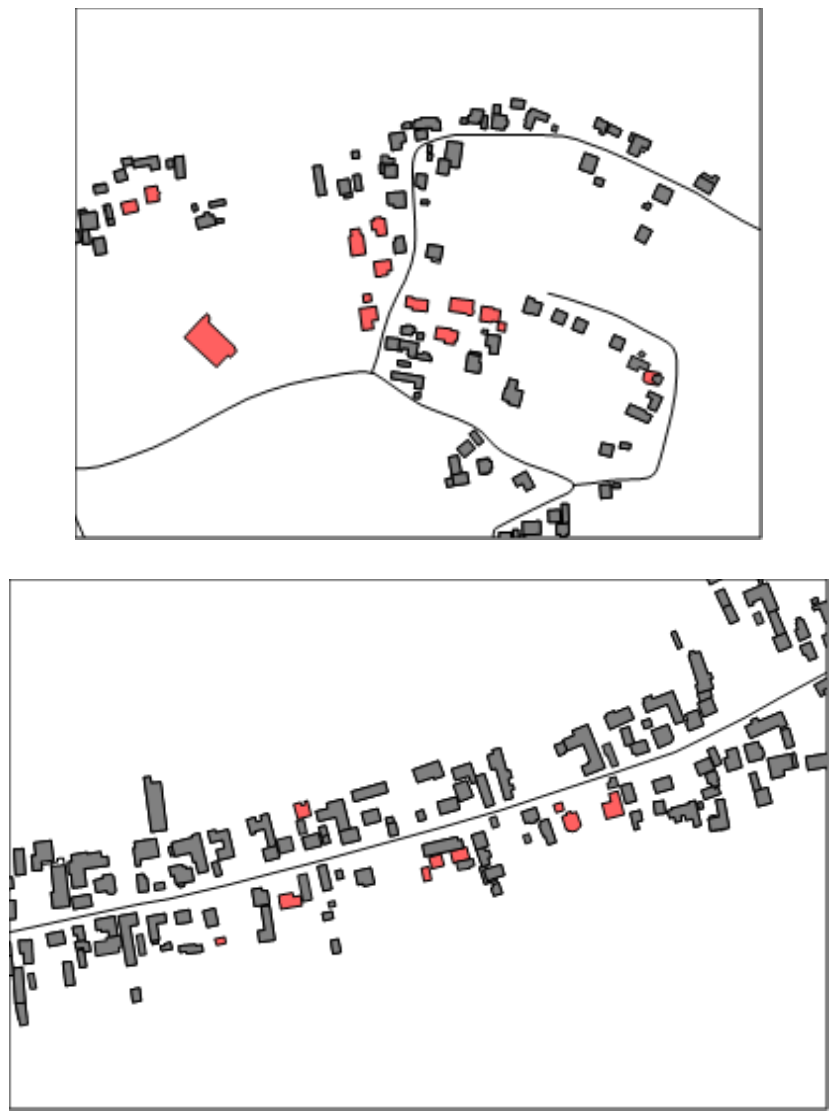

Širjenje na način skupine objektov znotraj naselja na Pobrežju v Slovenskih goricah (slika zgoraj) ustvarja kmetijska zemljišča znotraj naselja in neenotno obliko zazidanosti. Izsek iz tlorisa Muretincev (slika spodaj) prikazuje zapolnjevanje grajene strukture naselja s stanovanjskimi objekti na funkcionalnih zemljiščih kmečkih hiš.

Širjenje naselja na nove površine v okolici poteka na tri načine:

- Posamezni objekti zunaj grajene strukture naselja. Pri tej obli ki prostorskega razvoja je nov objekt postavljen na rob strnjeno pozidanega območja. Vsaj dve stranici funkcionalnega zemljišča sta »odprti« proti kmetijskim zemljiščem nepozidani pokrajini, pogosto tudi vse štiri. Stanovanjski objekt je pogosto postavljen ob vpadnici v naselje, lahko pa odpira novo zazidalno območje ob stranski cesti. Na ta način so $\mathrm{v}$ naselje pogosto umeščene ne stanovanjske dejavnosti, recimo proizvodne hale, trgovski objekti ali objekti namenjeni kmetijstvu. Na tak način postopoma nastajajo novi deli naselij, kjer v soseščini enega stanovanjskega objekt nastane še drugi, tretji in tako dalje. Zgradbe so različno umeščene $\mathrm{v}$ prostor, slemena streh so pogosto različno orientirana, tudi glede etažnosti in velikosti objektov so razlike, kar lahko deluje neskladno, tako v tlorisu, še bolj pa v veduti naselja. 
V. Drozg: Spatial development of settlements in the Podravje region in last decades
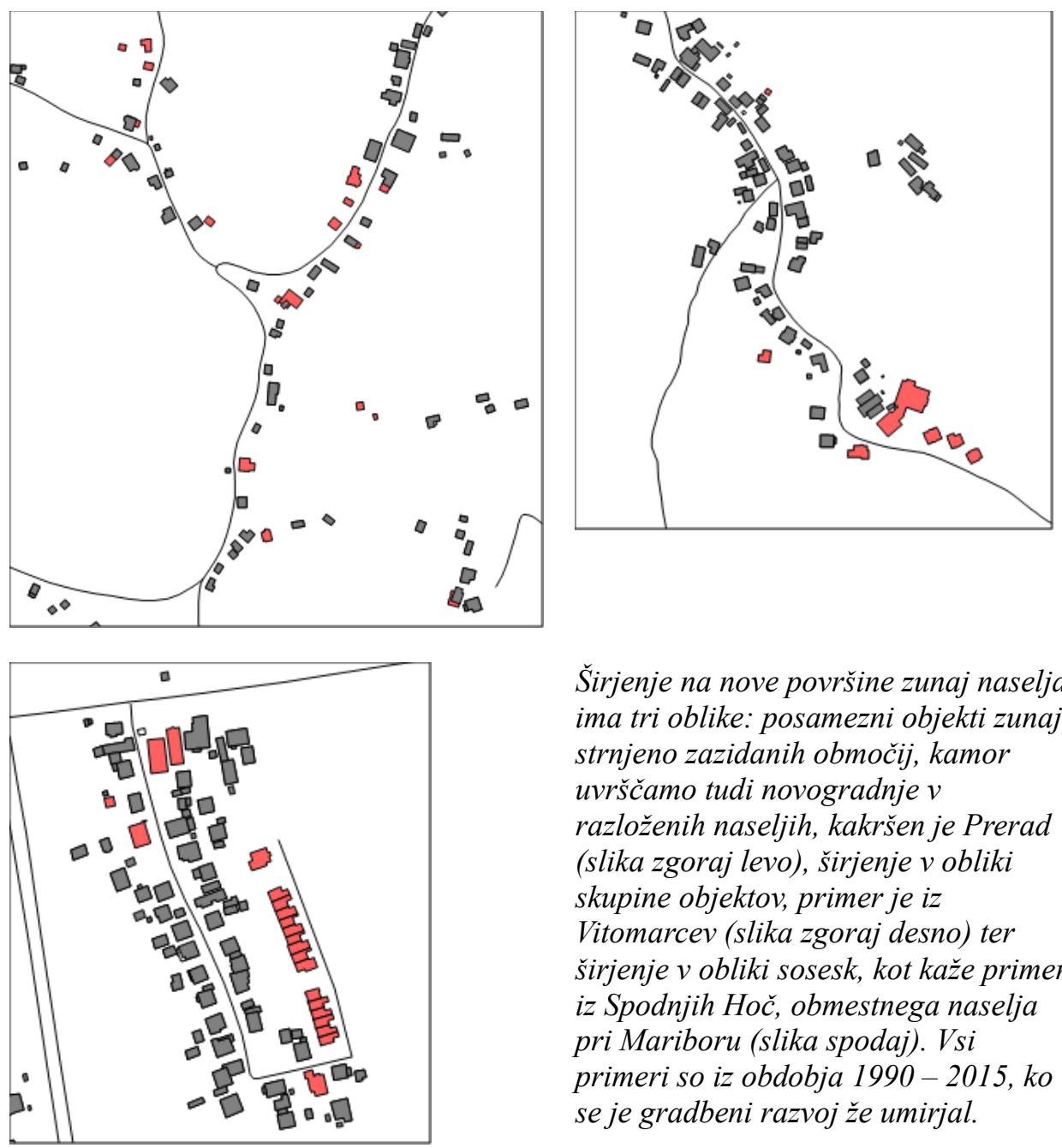

Širjenje na nove površine zunaj naselja ima tri oblike: posamezni objekti zunaj strnjeno zazidanih območij, kamor uvrščamo tudi novogradnje $v$ razloženih naseljih, kakršen je Prerad (slika zgoraj levo), širjenje v obliki skupine objektov, primer je iz Vitomarcev (slika zgoraj desno) ter širjenje v obliki sosesk, kot kaže primer iz Spodnjih Hoč, obmestnega naselja pri Mariboru (slika spodaj). Vsi primeri so iz obdobja 1990 - 2015, ko se je gradbeni razvoj že umirjal.

- Skupina objektov zunaj grajene strukture naselja. Prejšnja oblika prostorskega razvoja naselja se pogosto spremeni v slednjo - stanovanjskih objektov zunaj naselja je toliko, da prerastejo $\mathrm{v}$ skupino, $\mathrm{v}$ novi del naselja. Pogosto si novogradnje sledijo $\mathrm{v}$ nizu ob vpadnici, ali pa so nastale na zaključenem območju »za« naseljem. Objekti so različno oddaljeni drug od drugega, tudi velikost parcel je različna. Značilno je nepovezano prometno omrežje, brez krožnih poti, saj so prometnice nastajale sproti, tako kot so nastajali stanovanjski objekti. Dodati je še potrebno, da je ta oblika nastajala daljše obdobje, prvemu objektu zunaj grajene strukture so sledili novi in postopoma je nastala skupina objektov.

- Soseska stanovanjskih hiš zunaj grajene strukture. Podobna oblika prostorskega razvoja kot prejšnja, le da je razmestitev objektov načrtna, razpoznaven je geometrijski prostorski vzorec, v katerem so odmiki med objekti enaki, objekti so lahko zamaknjeni drug proti drugemu ali postavljeni v nizu, prometno omrežje je racionalno, omogočen je krožni promet, dovoznih 
poti je toliko, kot jih je potrebno. Soseske so običajno umeščene nekoliko stran od strnjenega dela naselja, a $\mathrm{v}$ bližino primarne prometnice. Umestitev objektov $\mathrm{v}$ prostor je poenotena, kar pomeni, da so slemena streh orientirana $\mathrm{v}$ isto smer in enako oddaljena od prometnice.

Dograjevanje naselja se pojavlja v naslednjih oblikah:

- Prenova objektov je posebna oblika prostorskega razvoja naselij. Čeprav s prenovo ni povezano novo stavbno zemljišče, je pomembna v toliko, ker se obstoječa grajena struktura obnavlja, prenovi, s čemer se izboljša videz naselja. Bistvo prenove je ohranitev stavbnega fonda ter izboljšanje podobe objekta, pa tudi naselja.

- Adaptacija in preurejanje je zelo pogosta oblika prostorskega razvoja naselij. Preureditev objekta običajno pomeni izgradnjo prizidka, nadgradnjo in spremembo tlorisa objekta. Ob adaptaciji stanovanjskega objekta se povečata pozidano in funkcionalno zemljišče, pogosto se z gradbenimi posegi spremeni podoba starega objekta, vendar $\mathrm{v}$ oblikovnem pogledu ne vedno na bolje. Pogosto je namen adaptacije stanovanjskega objekta enostanovanjsko hišo preurediti v dvostanovanjsko.

- Nadomestna gradnja pomeni novogradnjo na mestu, kjer je že stala stanovanjska hiša. Ta oblika gradbeno prostorskega razvoja je, podobno kot druge iz te skupine, dobro vidna $\mathrm{v}$ podobi naselja, manj pa $\mathrm{v}$ tlorisu.

Posledica gradbenega razvoja so večje ali manjše skupine novih objektov ter več ali manj posameznih objektov, ki se pojavljajo ob in med starejšimi, avtohtonimi stavbami. V posameznem naselju se lahko pojavljajo vse navedene oblike gradbenega razvoja, Ker te oblike nimajo regionalnih obeležij, niso regionalno različne, je mogoče govoriti samo o večji ali manjši stopnji transformacije avtohtonih naselij oziroma o intenzivnosti gradbenega razvoja.

\section{Intenzivnost prostorskega razvoja}

Intenzivnost prostorskega razvoja pomeni število novogradenj v določenem časovnem obdobju. Nanjo lahko sklepamo iz podatkov o demografski rasti v naseljih, rasti števila stanovanj ter iz povečanja pozidane površine naselij. Če opazujemo rast števila stanovanj po desetletjih opazimo, da je bil gradbeni razvoj najbolj intenziven med leti 1960 in 1990, kasneje pa se je intenzivnost zmanjšala. Pri tem je mogoče prepoznati nekaj regionalnih razlik: iz kartografskih prikazov je razvidno, da je bila rast števila novih stanovanj v obdobju 1960 - 1990 intenzivna v večini naselij, tudi tistih, kjer število prebivalcev ni naraščalo. To je zagotovo posledica ugodnih pogojev za gradnjo stanovanjskih objektov, slabih bivalnih razmer, pomanjkanja stanovanj, pa tudi splošne družbene klime, ko je bila gradnja hiše samoumevna nuja za vsako družino. Posebej intenzivna je bila gradnja v obmestjih, v lokalnih središčih in naseljih ob regionalnih prometnicah.

V obdobju med 1990 in 2015 se je gradbeni razvoj pričel umirjati, podobno pa velja tudi za demografsko rast. V naseljih okoli Maribora ter v naseljih ob regionalni prometnici proti Ptuju in Slovenski Bistrici, sta bila demografski in gradbeni razvoj najintenzivnejša, 
kar pomeni, da so bile tudi spremembe poselitvenih razmer tam največje. Drugače je na redko poseljenih delih Pohorja, Slovenskih goric in Haloz, kjer so, spremembe poselitvenih razmer manjše, čeprav tako obsežne, da so prvotne poselitvene oblike močno spremenjene.
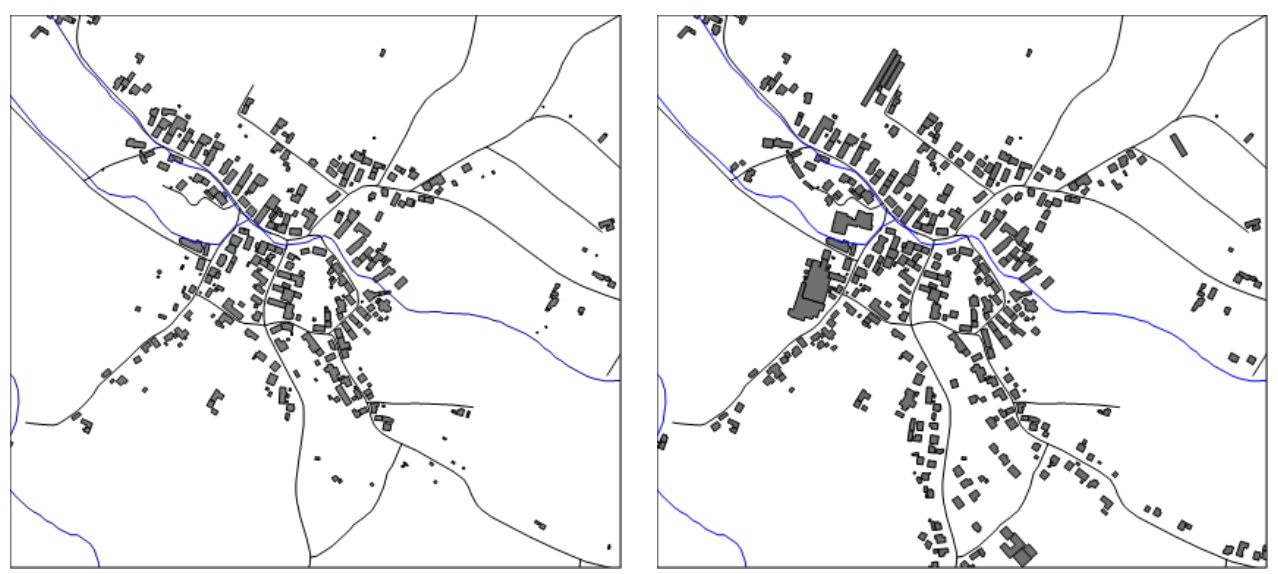

Tloris Spodnje Polskave leta 1960 (levo) in 2015 (desno), naselje se je razširilo na račun skupin objektov zunaj naselja, ob vpadnicah. Veliko racionalnejša in oblikovno ustreznejša bi bila soseska ob robu naselja.

Različna intenzivnost gradbenega razvoja je razvidna tudi v oblikah prostorskega širjenja naselij. V večini naselij avtohtona zasnova in podoba nista več opazni. Redke stare hiše se izgubijo v množici novogradenj in prenovljenih objektov. Novi deli naselij nekaj krat presegajo površino starejših. Število stanovanj se je od leta 1961 do 2015 povečalo s (približno) 46.223 (popis 1961) na 105.291 (popis leta 1991) na 136.627 leta 2015 (Medmrežje 1).

Med oblikami prostorskega razvoja je bila v prvem obdobju najpogostejša gradnja zunaj strnjenega naselja, na njegovem robu ter ob vpadnicah. Začetek urbanizacije podeželja je bil povsem v znamenju gradnje posameznih objektov zunaj grajene strukture, s čemer se je ustvarjal vzorec, ne le prostorski tudi miselni vzorec nadaljnjega širjenja naselja. Do danes je ta oblika marsikje prerasla v skupino novih objektov na robu naselja. Širjenje naselij v obliki skupine objektov je bilo v prvem obdobju zelo izjemno, še bolj pa gradnja stanovanjskih sosesk na robu naselij. Po letu 1991 se je razmerje med oblikami gradbeno prostorskega razvoja pričelo spreminjati. Gradnja posameznih objektov zunaj območja strnjene pozidanosti je postajala vse manj množična, naraščalo pa je število novogradenj znotraj naselja, na funkcionalnih zemljiščih obstoječih hiš, število nadomestnih gradenj, število prenovljenih objektov ter število adaptacij.

\section{Oblikovni vidik izgrajevanja in širjenja naselij}

Oblikovna dimenzija izgrajevanja in širjenja naselij se kaže v razmestitvi objektov, obliki objektov ter podobi naselja ali vsaj dela naselja, kakršna je ob tem nastala. Obliko stanovanjskih objektov je potrebno upoštevati tudi zato, ker lahko na ta način ocenimo obseg dograjevanja, kot tretjega načina širjenja in izgrajevanja naselij. 


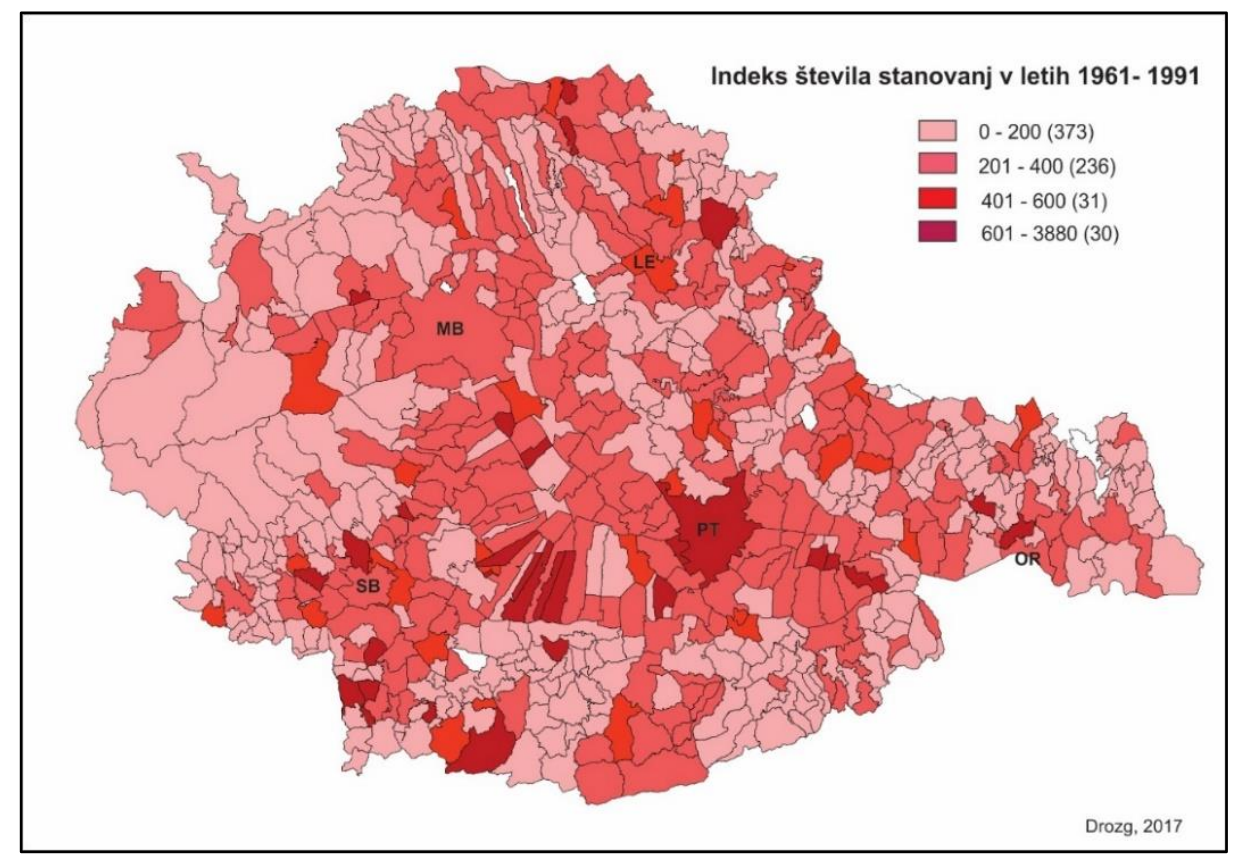

Rast števila stanovanj je bila v letih 1961-1991 zelo intenzivna, v 30 naseljih je indeks povečanja večji od 600, v slabi polovici naselij pa je večji od 200. Opomba: Za 54 naselij, ki ob popisu leta 1961 še niso obstajala, se podatki o številu stanovanj nanašajo na leto 1971.

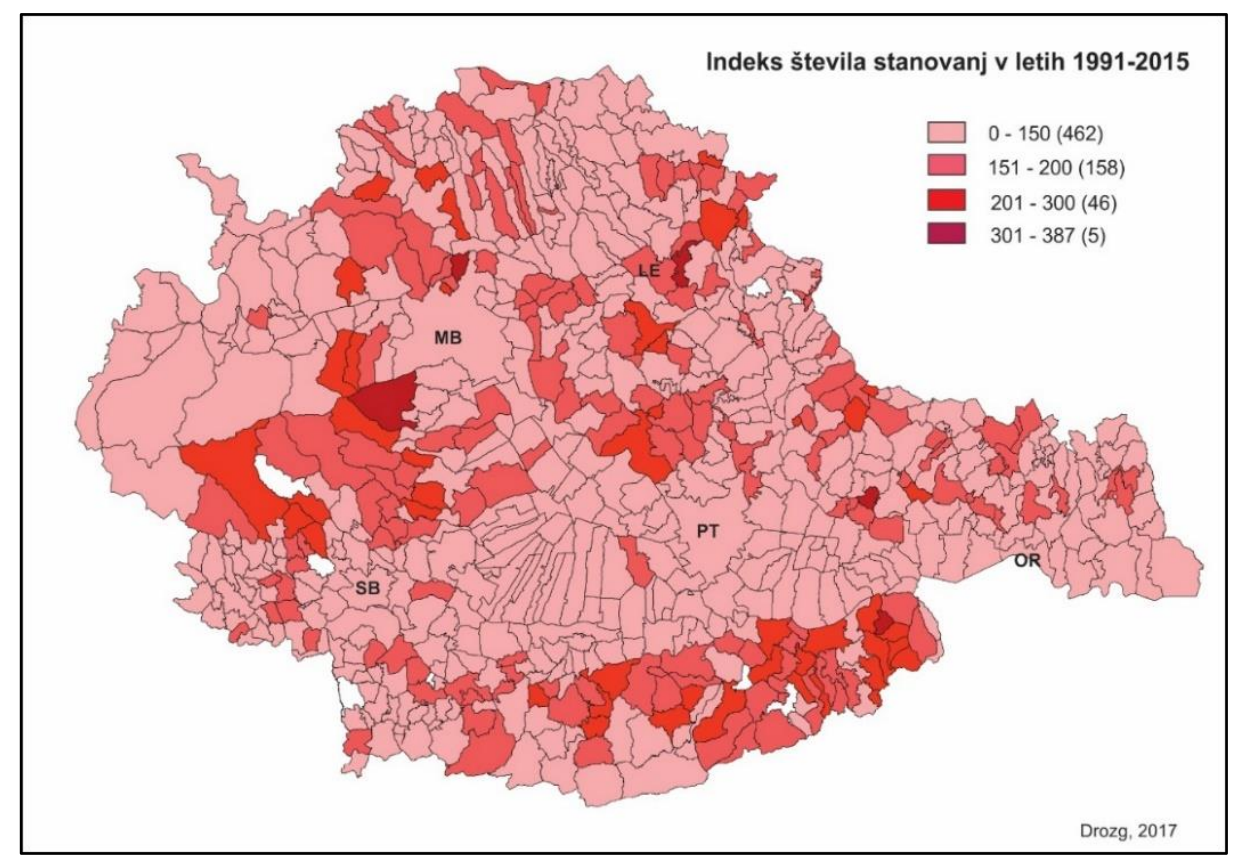

Vobdobju 1991-2015 se je rast stanovanj umirila, najbolj intenzivna je bila $v$ obmestnih naseljih ter naseljih, kjer je več počitniških stanovanj (Haloze, Pohorje). 
Način razmestitve objektov $\mathrm{v}$ novih delih naselij je mogoče razvrstiti $\mathrm{v}$ dve skupini: enovita razmestitev in raznolika razmestitev. Pri prvi so stanovanjski objekti umeščeni v prostor enako - enako so oddaljeni med seboj, enako orientirani, dostop do prometnice je enak. Pri raznoliki razmestitvi so objekti umeščeni v prostor podobno, ne pa enako. Upoštevana so osnovna zakonska določila, kot je oddaljenost od sosednjega objekta, vendar v različnem razponu, kar ustvarja oblikovno neenakost oziroma raznolikost. Pri nekaterih je sleme strehe vzporedno s prometnico, pri drugih pravokotno, pri tretjih pa nekaj vmes. Nekateri objekti omejujejo prometnico, sosednji so lahko od prometnice bolj ali manj oddaljeni. Enovitost v splošnem, v podrobnostih pa raznolikost, označuje ta način. V prvem primeru je videz novega dela naselja enoten, $v$ drugem pa se enotnost pri množici objektov spremeni v neenotnost, ki pogosto preide v stihijskost.

Pri obliki novogradenj se omejujemo na tipe stanovanjskih objektov. Ti se prvenstveno razlikujejo glede na čas nastanka, s čemer je povezan tloris, nadstropnost, naklon strehe, gradbeni material, okrasni ter konstrukcijski stavbni členi. Glede na to je mogoče razlikovati naslednje tipe stanovanjskih objektov: avtohtona kmečka hiša, modificirana avtohtona hiša, nova mestna hiša, moderna urbana hiša, modernizirana avtohtona hiša (Drozg, 2013). Dodali smo kategorijo »nadomestni stanovanjski objekt«, saj je tako mogoče pokazati obseg dograjevanja in izgrajevanja naselij, predvsem na račun kmečkih hiš. Tipe objektov je mogoče razvrstiti v dve večji skupini: skupina objektov z (večinoma) enotno in raznoliko podobo. Enotna podoba vključuje objekte istega ali zelo podobnega tlorisa, nadstropnosti ter okrasnih in konstrukcijskih stavbnih členov, predvsem sta pomembna naklon strehe in barva fasade. Raznolika podoba naselja pa je posledica različnih tipov stanovanjskih hiš v soseščini.
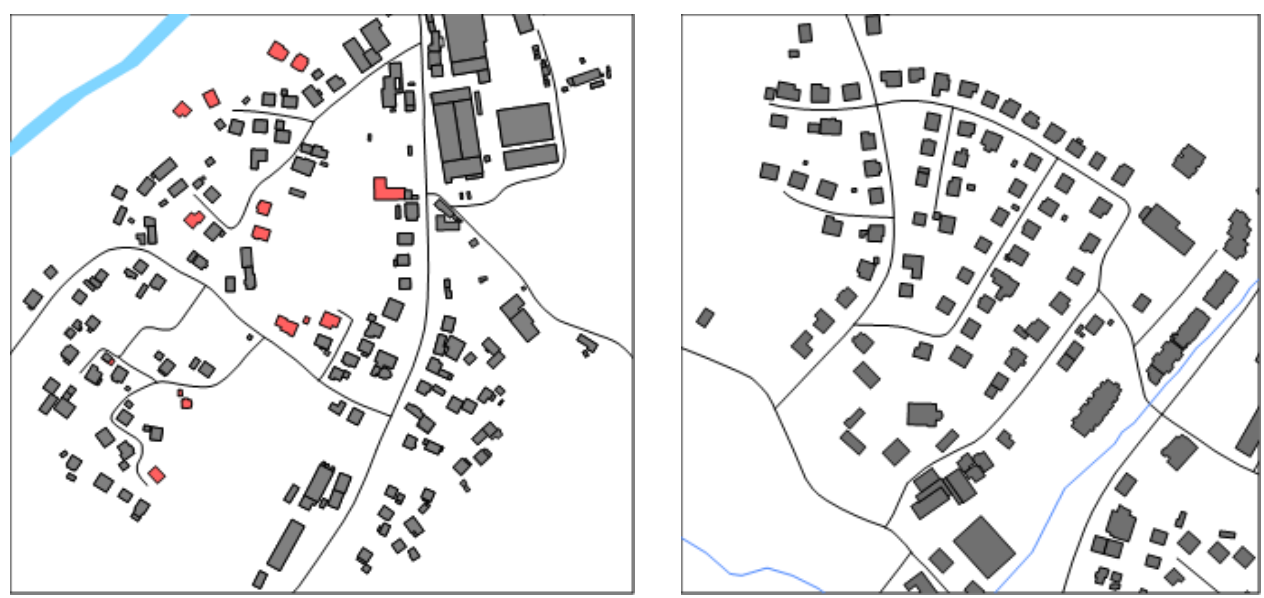

Posledica raznolike (slika levo; Majšperk) in enovite (slika desno; Benedikt) razmestitve objektov je različna racionalnost rabe prostora, različni stroški komunalne infrastrukture ter različna podoba naselja.

Ugotovimo lahko, da je avtohtonih (kmečkih) hiš v večini naselij le še za vzorec. Največji delež odpade na nove mestne stanovanjske hiše, ki so se gradile v letih 1960 do 1985 . Prevladujejo v novih delih naselij, zelo pogosto so nadomestile avtohtone kmečke hiše, zato dajejo podobo tudi nekdanjim agrarnim vasem in vaškim središčem. Vse več je tudi moderniziranih avtohtonih hiš, ki so postale bolj pogost tip stanovanjske hiše po letu 
1990. Za ta tip je značilno upoštevanje regionalnih posebnosti avtohtonega stavbarstva, predvsem kar se nadstropnosti, tlorisa in naklona strehe tiče. V obmestnih naseljih je vse več modernih urbanih hiš, na urbaniziranem podeželju, predvsem v ravninskih pokrajinah Podravja, pa je pogost tip hiše bungalov.

Posebna kategorija so nestanovanjski objekti. Objekti javnih dejavnosti (šole, vrtci, upravne zgradbe, trgovine) so večinoma tipski, in jih je mogoče postaviti v vsako okolje. Nimajo regionalnih obeležij, v prostoru delujejo nevtralno, a v primerjavi s starejšimi objekti, tuje. Posebna skupina so proizvodni objekti, med katere uvrščamo tudi sodobna poslopja za kmetijsko dejavnost. Dimenzije objektov so vse bolj podobne industrijskim halam in zato v velikem neskladju z bližnjimi stanovanjskimi hišami.

\section{Značilnosti prostorskega razvoja naselij v zadnjih desetletjih}

Najpomembnejša značilnost je velika ekstenzivnost prostorskega razvoja. Slednje razumemo kot neusmerjan, spontan razvoj, kjer so se razvijala vsa naselja, ne glede na stopnjo centralnosti, ne glede na naravne omejitve, ne oziraje se na kulturno dediščino, varovanje naselbinske podobe, racionalnost prometne dostopnosti, možnost komunalnih priključkov in kar je še omejitev pri prostorskem razvoju.

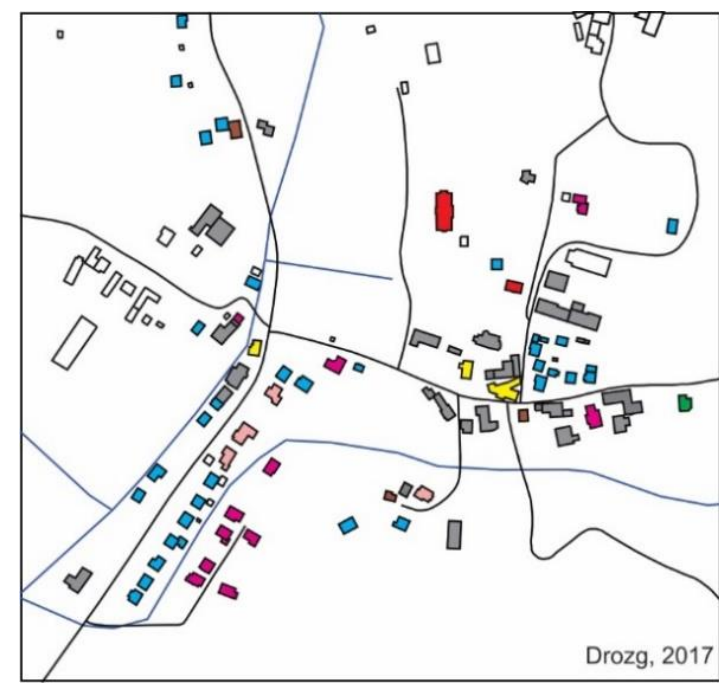

\section{Tipi stanovanjskih objektov}

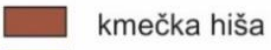

$\square$ trška hiša

nova mestna hiša

modernizirana kmečka hiša

bungalov

moderna urbana hiša

stanovanjski blok

ne stanovanjski objekt

V naselju Juršinci prevladujejo novi stanovanjski objekti, kmečkih hiš skoraj ni več. Stavbna dediščina se izgublja in postaja muzejski eksponat. Staro središče določa le

bolj strnjena zazidanost ter nekaj objektov (cerkev, župnišče, gostilna), nekdanje

kmečke hiše so nadomestile nove mestne hiše. Del naselja, kjer prevladujejo nove mestne hiše ima dokaj enotno podobo, staro središče naselja pa zaradi številnih tipov, raznoliko.

Posledica ekstenzivnosti je pojav razpršene gradnje, oblikovna degradacija pokrajine in naselij, draga komunalna infrastruktura in, v določenih območjih, velika izpostavljenost naravnim nesrečam, predvsem plazovom in poplavam. 


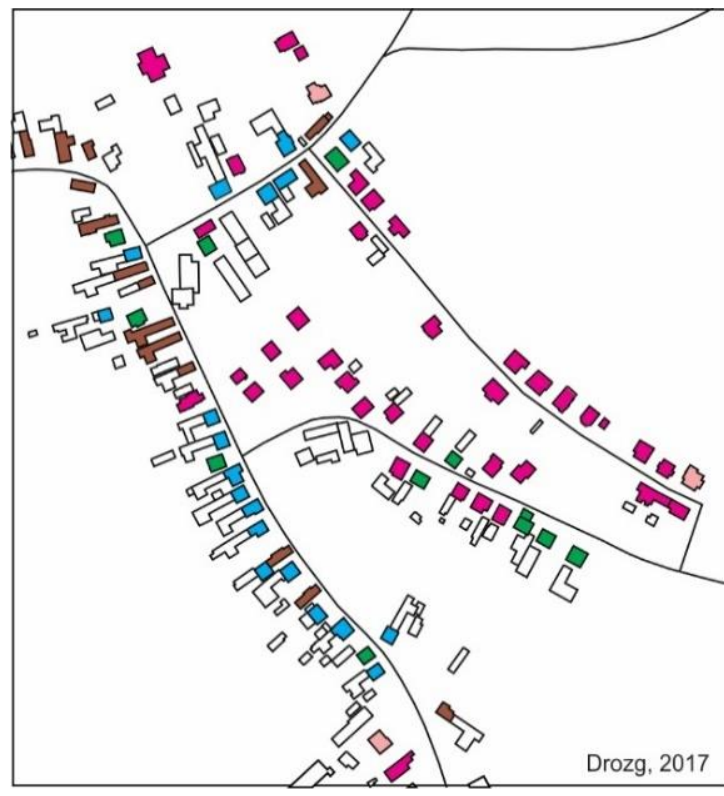

\section{Tipi stanovanjskih objektov}

$\square$ kmečka hiša
nova mestna hiša
nadomestni objekt
nova mestna hiša
modernizirana kmečka hiša
bungalov

Tipi stanovanjskih objektov v delu naselja Gerečja vas. Kmečkih hiš je le še za vzorec. V 60-ih in 70-ih letih so jih kot nadomestne gradnje nadomestile nove mestne hiše, kasnejši objekti pa sodijo v tip modernizirane kmečke hiše, za katero je značilno povzemanje oblikovnih elementov avtohtonega stavbarstva. Po obliki novogradenj je naselje zelo raznoliko.

Z ekstenzivnostjo je povezana parcialnost prostorskega razvoja naselij. Širjenje naselij je temeljilo, pa še danes je tako, na umeščanju enega, posameznega objekta v prostor. Namesto obravnave več objektov hkrati, je poseg omejen samo na en objekt, brez upoštevanja drugega dela naselja in sosednjih objektov. Posledica tega je neenotnost, nepovezanost grajene strukture, objekti so različno oddaljeni od prometnice in med seboj, različno orientirani (nekateri so $\mathrm{z}$ daljšo, drugi pa s krajšo stranico obrnjeni proti prometnici), oblikovno niso enotni (razlikujejo se po tloris in volumnu).

Umestitev objektov $\mathrm{v}$ naselje se je $\mathrm{v}$ preteklem obdobju pogosto ravnala po željah investitorjev, ne pa po strokovni presoji. Hiše so dodane druga drugi, tak aditivni način izgrajevanja naselij pa ima veliko negativnih posledic. Med objekti ostajajo večje nepozidane površine, kar ustvarja redko pozidanost in s tem neracionalno rabo prostora, tudi prometno omrežje ni racionalno zasnovano.

V takih razmerah je najpogostejša oblika prostorskega razvoja »posamezni objekti znotraj grajene strukture« ter »posamezni objekti zunaj grajene strukture«, najredkejša pa je oblika »soseska stanovanjskih objektov zunaj grajene strukture« ter » soseska stanovanjskih hiš znotraj grajene strukture«. Bolj kot oblika prostorskega razvoja je pri parcialnem urejanju sporen oblikovni vidik izgrajevanja in širjenja. Ker je vsak objekt izgrajen posebej, se med seboj zelo razlikujejo, kar ustvarja neskladno podobo naselja in kulturne pokrajine. 


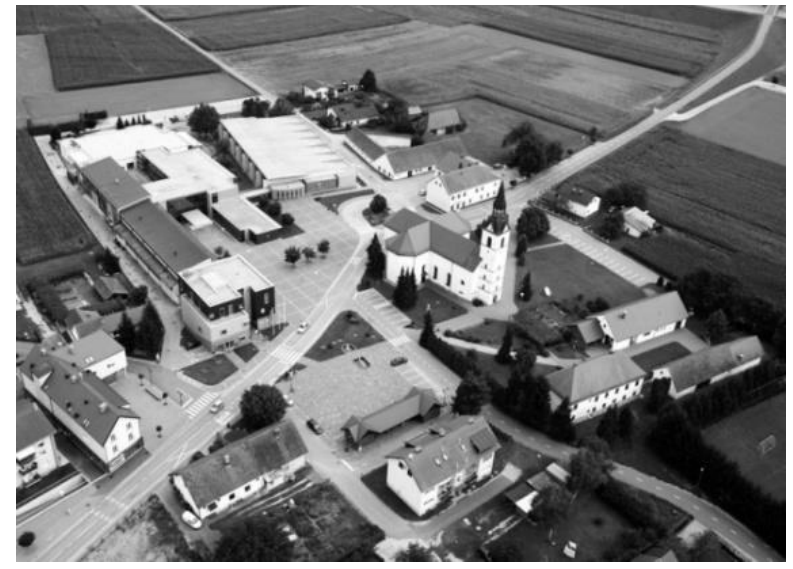

Gorišnica pri Ptuju je eno redkih naselij, kjer je nastalo novo središče, in sicer kot spoj starih in novih objektov. Nastal je kvaliteten socialni prostor, ki vzpostavlja identiteto kraja.

Blizu ekstenzivnosti in parcialnosti je še ena značilnost: prostorski razvoj naselij se je nanašal prvenstveno na stanovanjska območja, deloma še na obrtne (proizvodne) cone ter območja storitvenih dejavnosti (predvsem trgovine, vzgoje in izobraževanja ter uprave). Zelo redki so primeri izgradnje središča kraja, ureditve javnih odprtih površin, socialnih prostorov, zelenih površin, vključevanja kulturne dediščine v strukturo kraja. Naselja, še posebej tista na podeželju, so tako omejena na funkcijo stanovanja, ne pa tudi bivanja.
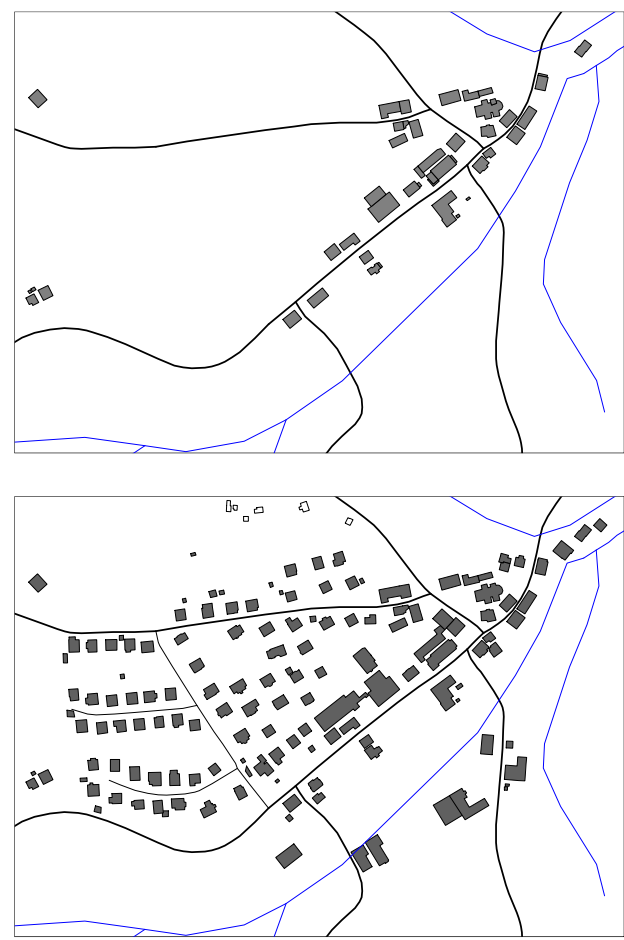

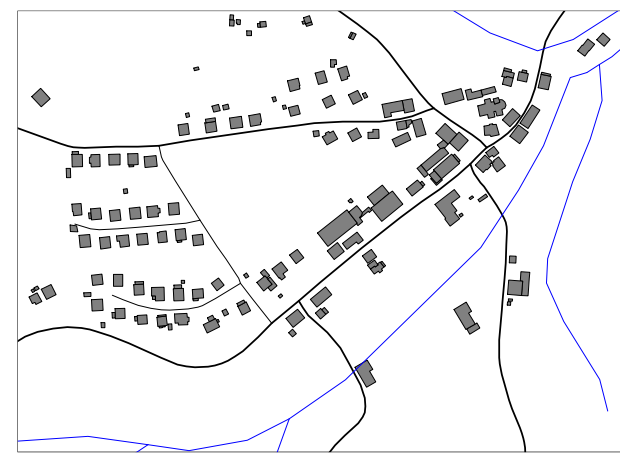

Naselje Zgornja Voličina je lokalno središče v Slovenskih goricah. Do leta 1960 je obsegalo le nekaj objektov (slika zgoraj levo), med leti 1960 in 1990 se je razširilo na račun soseske stanovanjskih hiš (slika zgoraj desno), na isti način se je izgrajevalo tudi po letu 1990 (slika spodaj).

Naslednja značilnost se nanaša na razpršenost poselitve. V gričevju in hribovju se je poselitveni vzorec še bolj razpršil, v ravninskih naseljih pa zgostil (Borko, Drozg, 2011).

Niti prva, niti druga oblika nista optimalni. Prva je problematična iz ekoloških in 
infrastrukturnih razlogov, druga iz bivalnih, saj so objekti postavljeni preblizu, zato je funkcionalno zemljišče majhno, to pa vpliva na kakovost bivalnega okolja. Iz tlorisov naselij je mogoče razbrati veliko nepozidanih zemljišč, ki jih je še mogoče pozidati. To je posledica parcialnega urejanja in odsotnosti zemljiške politike. Danes se zato naselja prvenstveno izgrajujejo z zapolnjevanjem prostih zemljišč. Kakršnokoli nadaljnje širjenje naselij na račun kmetijskih zemljišč v okolici oziroma zunaj strnjenega območja, kar je, kot smo zapisali, marsikje še prevladujoča oblika prostorskega razvoja, je zato težko razumljivo. Predpostavljamo, da je vzrok temu, način pridobivanja stavbnih zemljišč, ki je prepuščen investitorju, ne pa načrtnemu pridobivanju stavbnih zemljišč na ravni ustanove, ki je zadolžena za urejanje prostora.

Prepoznati je mogoče dve obdobji prostorskega razvoja naselij. V prvem, med leti 1960 in 1990, je prevladovalo širjenje na nove površine zunaj strnjenega naselja, dokaj množična je bila tudi nadomestna gradnja. V drugem obdobju, po letu 1990, pa je postalo pogostejše izgrajevanje naselij. Stanovanjska gradnja zunaj strnjeno pozidanega naselja se pojavlja zgolj še v obmestnih naseljih, v podeželskih naseljih pa izjemoma. V drugem obdobju prostorskega razvoja se je povečal delež prenove, čeprav je ta oblika izgrajevanja še vedno skromno zastopana.
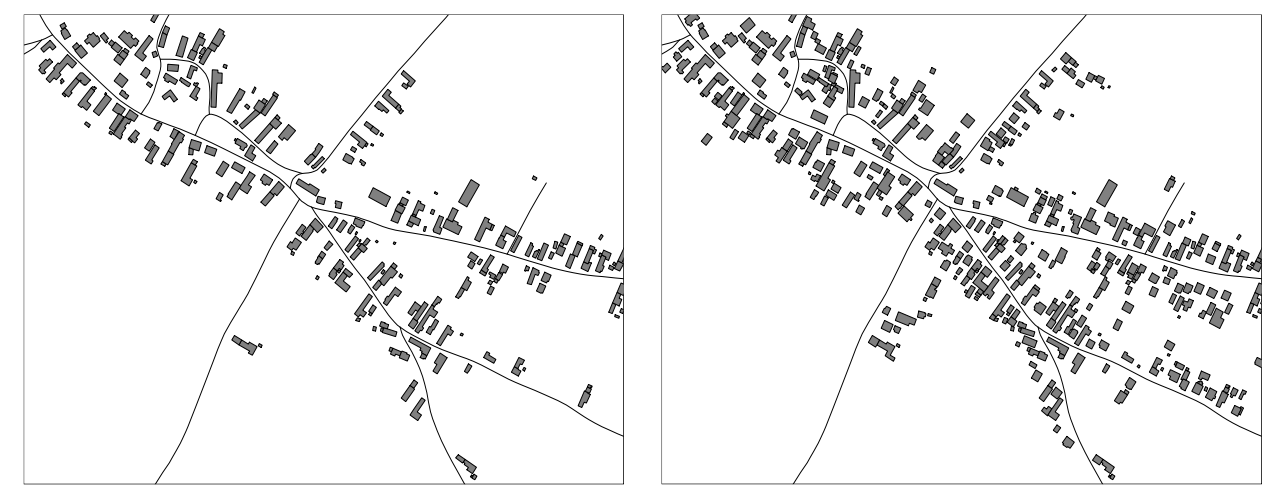

Predvsem v naseljih v ravnini je bilo zapolnjevanje in s tem zgoščanje grajene strukture najpogostejši način izgrajevanja. Na dvoriščih kmečkih hiš so nastali novi stanovanjski objekti, gospodarski in pomožni objekti.

Nemalokrat gre tovrstno zgoščanje na škodo kakovosti bivalnega okolja zaradi visokih gostot pozidanosti.

Oblike prostorskega razvoja naselij se le deloma povezujejo z naravnimi razmerami, še najbolj $\mathrm{z}$ reliefom. Tako sta $\mathrm{v}$ gričevnatih pokrajinah in $\mathrm{v}$ hribovju pogostejši obliki širjenja na način posameznih objektov znotraj grajene strukture ter posameznih objektov zunaj grajene strukture, v ravnini pa se pogosteje pojavlja skupina objektov znotraj grajene strukture ter skupina objektov zunaj grajene strukture. Eden od razlogov za to je velikost naselij, v večjih naseljih je praviloma več prostih zemljišč znotraj naselja in v okolici. Na ravnini so naselja praviloma večja kot v gričevju in hribovju, pa še naravnih omejitev za umestitev objektov je v ravnini manj, zato je tudi možnosti za stanovanjsko gradnjo več. 

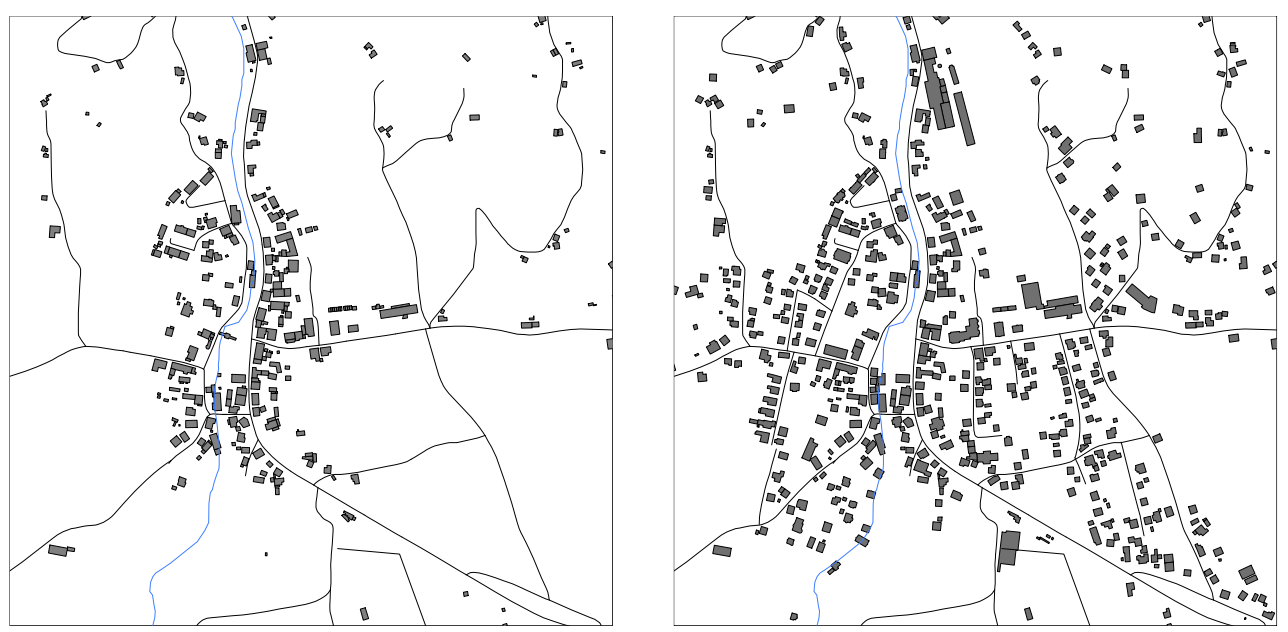

Širjenje Oplotnice je potekalo na račun skupin objektov zunaj strnjenega naselja. Naselje se je zelo povečalo, vendar je gostoto stanovanj majhna, veliko je kmetijskih površin, prometno omrežje ni racionalno. Slika levo prikazuje tloris naselja leta 1960, na desni sliki pa je tloris leta 2015.

O razširjenosti dograjevanja kot ene od oblik prostorskega razvoja naselij ni mogoče podati natančne ocene pogostosti. Iz obdelanih naselij pa lahko povzamemo, da je (bilo) dograjevanje na način gradnje nadomestnih objektov zelo pogosto, še posebej v naseljih na Dravskem in Ptujskem polju. Ljudje so na mestu nekdanje kmečke hiše postavili novo mestno hišo; s tem so izboljšali bivalne razmere in povečali stanovanjsko površino, ki je bila $v$ hišah panonskega tipa zelo majhna. Prenova avtohtonih hiš je redek način izgrajevanja naselij. Pogostejša je v gričevnatih pokrajinah, še posebej, ko je prenovljena hiša namenjena počitniški dejavnosti.

Oblike prostorskega razvoja se bolj kot z naravnimi razmerami povezujejo z območji poselitve, čeprav tudi te zveze niso zelo izrazite in prepričljive. Samo v obmestjih, največ v mariborskem, so se naselja širila na račun sosesk stanovanjskih hiš znotraj ter zunaj grajene strukture. Ta oblika se je pojavila šele $\mathrm{v}$ zadnjih dveh desetletjih. V večini obmestnih naselij pa je bil najpogostejši način širjenja v obliki posamičnih objektov in na način skupine objektov na robu naselij. V večjih naseljih na urbaniziranem podeželju so bile pogostejše oblike širjenja skupine objektov zunaj strnjenega naselja, manjša naselja pa so se večinoma širila na račun posameznih objektov znotraj ali zunaj grajene strukture. Podobno velja za naselja na manj urbaniziranem podeželju. Zaradi skromnejšega gradbenega razvoja, so tudi oblike prostorskega razvoja po površini majhne in omejene na posamezne objekte.

Oblikovni vidik širjenja in izgrajevanja naselij kaže, da bodo avtohtone kmečke hiše kmalu le še izjema in muzejski primerki. Zanikanje starega in nekritično prevzemanje novega sta povzročila, da je velik del stavbne dediščine izgubljen. $V$ podeželskih naseljih prevladujejo namreč objekti, ki so preneseni iz urbanega okolja. To velja tako za stanovanjske objekte, kot objekte javnih dejavnosti in proizvodne objekte. Ocenjujemo, da je $\mathrm{k}$ vizualni transformaciji bolj prispevala neprimerna oblika objektov, kakor neprimerna umestitev objektov v naselje. V preteklosti je bila oblika objektov posledica 
naravnih razmer (omejitev, prilagoditev ter razpoložljivega gradbenega materiala), danes obliko objektov določajo proizvajalci gradbene in stanovanjske opreme, zato novogradnje nimajo več regionalnih značilnosti, pač pa se ločijo po času izgradnje. Posledica je oblikovna raznolikost novih delov naselij.
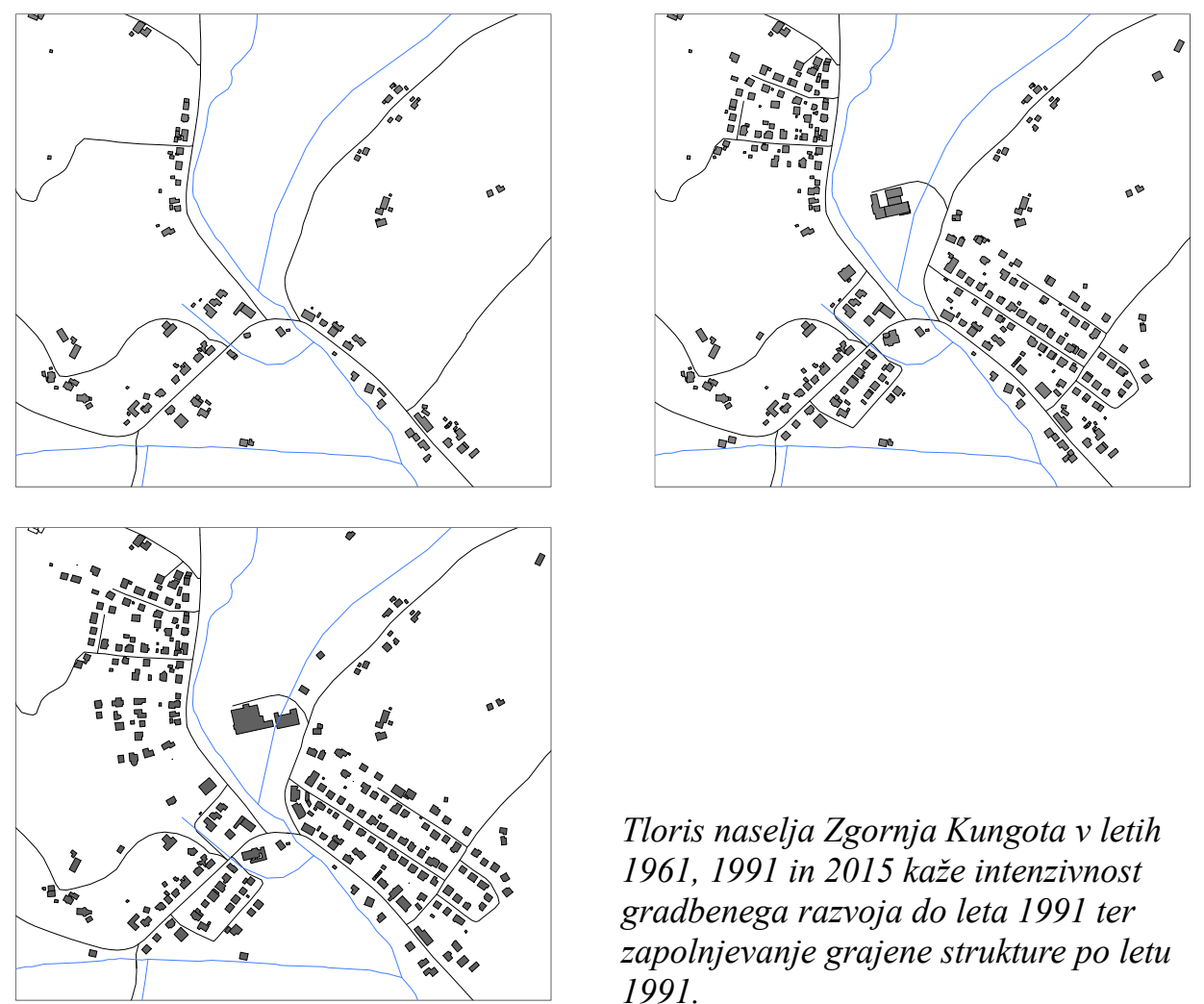

Tloris naselja Zgornja Kungota v letih 1961, 1991 in 2015 kaže intenzivnost gradbenega razvoja do leta 1991 ter zapolnjevanje grajene strukture po letu 1991.

Obdobje med 1961 in 1981 je bilo usodno za podobo slovenskega podeželja in naselij na območju Podravja. V tem obdobju je nastal poselitveni vzorec, ki je povsem »prekril« dotedanjega, hkrati pa je obveljal kot vzorec in podlaga za oblikovanje novega poselitvenega vzorca.

\section{Zaključek}

V zaključku zapisa o oblikah prostorskega razvoja naselij na podeželju je potrebno dodati oceno takšnega prostorskega razvoja. Kot merila za vrednotenje lahko upoštevamo kriterije sodobnega urejanja naselij:

- ekološka ustreznost

- racionalnost rabe zemljišč

- oblikovna ustreznost

Med kriteriji niso upoštevane lastnosti, ki se nanašajo na strukturo naselij, saj to ni bil predmet spoznavanja. Iz ekološkega zornega kota so vse oblike širjenja naselij, katerih posledica so nizke gostote zazidanosti, neracionalne in neprimerne. Nadalje: oblike 
širjenja naselij zunaj grajene strukture so ekološko manj sprejemljive, kot zapolnjevanje nezazidanih površin znotraj grajene strukture ter dograjevanje, saj se s tem povečuje antropogeniziran prostor napram naravnemu. $\mathrm{V}$ pregledanih naseljih smo ugotovili veliko nesorazmerje med zapolnjevanjem in širjenjem, pa tudi gostote pozidanosti novih delov naselij redko presegajo 50 prebivalcev/ha, kar je zelo nizka vrednost.

Racionalnost rabe zemljišč pomeni ustrezno gostoto pozidanosti, racionalno prometno omrežje s preglednimi križišči in priključki, racionalno omrežje tehnične infrastrukture, opremljenost stavbnih zemljišč s komunalnimi priključki. Večina obravnavanih širitev tovrstnih kriterijev racionalnosti ne izpolnjuje. Nasprotno, med stanovanjskimi objekti ostajajo kmetijska zemljišča, ki niso več primerna za intenzivno kmetijsko proizvodnjo, niti nimajo ustrezne urbane funkcije.

Posebej pereča je širitev naselij iz oblikovnega vidika. Oblika številnih novogradenj je v bolečem neskladju z obliko avtohtonega stavbarstva, še posebej je to značilno za objekte iz prvega opazovanega obdobja, ko je bil razširjen tako imenovan tip nove mestne enostanovanjske hiše. Kvadraten tloris, kockast kubus, nizek naklon strehe ter postavitev na sredo parcele, še danes izstopajo v podobi naselij in ustvarjajo novo podobo nekoč agrarnih naselij, v kateri postajajo ohranjene avtohtone hiše vse večja redkost in krajevna posebnost. A tudi nove stanovanjske hiše so po obliki toliko različne, da je tudi podoba novih delov naselij neenotna, neskladna. Tudi položaj novogradenj redko kaže povzemanje preteklih izkušenj, zato pa več prilagajanja tehnološkim zmožnostim sodobnega časa. Številne vedute na naselja so povsem spremenjene in namesto nekdanjih dominant in simbolnih objektov, v njih izstopajo nove stanovanjske hiše.

Pojav razpršene gradnje je $\mathrm{v}$ Podravju, posebej zaradi razpršenega avtohtonega poselitvenega vzorca, ob opisanih načinih prostorskega razvoja naselij postal vsesplošen pojav. Podoba naselij je odraz vzpostavitvenih dejavnikov; ti so danes povsem drugačni, kot so bili v času agrarne družbe. A hkrati je današnja podoba naselij na podeželju zunanji izraz naše (ne)kulture, neupoštevanja izročila, nepoznavanja narave in nepriznavanja pomena skupnosti. Parcialnost urejanja in razpršenost poselitvenega vzorca nista niti tehnično, niti ekonomsko, niti okoljsko pogojena, temveč sta posledica neosveščenosti posameznikov (ne le graditeljev, temveč vseh, ki sodelujejo v procesu priprave urbanistične dokumentacije) in napačnih predstav o urejanju naselij.

Sprememba dosedanjega načina širjenja naselij je mogoča na dva načina:

- s celovitejšim in kakovostnejšim urbanističnim načrtovanjem, ko ne bo obravnavan le en objekt kot samostojen »otok« v naselju, temveč skupaj s sosednjimi objekti v bližnji okolici ali kar celotno potencialno zazidljivo območje.

- naselja je potrebno urejati kot sodobne bivalne enote, kjer je agrarna preteklost razumljena kot priložnost za kulturno nadgradnjo, ne pa podlago, ki se ji prilagaja zasnova urbaniziranih stanovanjskih območij. Doseči je potrebno tudi večjo osveščenost ljudi, predvsem na področju kakovosti bivalnega okolja, spoštovanja kulturnega izročila in sobivanja. Zato: tudi v pouk geografije je potrebno vključiti vsebine iz področja estetike in vsebine, ki se nanašajo na vsakdanje prostorske prakse. Preden se teh sivih lis ne bodo polastile druge vede. 
Opomba

Statistične podatke za analizo in grafični prikaz je pripravil Sebastijan Borko, dipl. geogr., za kar se mu posebej lepo zahvaljujem.

\section{Literatura in viri}

Borko, S., Drozg, V. 2011: Merjenje razpršenosti poselitve. V: Revija za geografijo 6-2/2011. Maribor, s. $99-110$.

Drozg, V. 1999: Poselitvena območja in diferencirana merila za urejanje naselij. V: Lučka Ažman Momirski, Alenka Fikfak: Oblike prostorskega načrtovanja: od mestnega načrta do urejanja naselij. Fakulteta za arhitekturo. Univerza v Ljubljani. Ljubljana, s. 20 - 23.

Drozg, V. 2013: Tipi novodobne enostanovanjske hiše. V: Revija za geografijo 8-1/2013. Maribor, s. $69-82$.

Klemenčič, Marijan M. 2006: Teoretski pogledi na razvojne strukture slovenskega podeželja. V: DELA 25. Filozofska fakulteta. Univerza v Ljubljani, s. 159 - 171.

Rebernik D. 2011: Geografija naselij. Univerza v Ljubljani, Filozofska fakulteta. Ljubljana.

Medmrežje 1: Regije v številkah. Statistični portret slovenskih regij 2017. Urad RS za statistiko. http://www.stat.si/StatWeb/File/DocSysFile/9374 


\title{
Socialno-ekonomski razvoj naselij Cirkovce, Gorišnica, Stoperce in Sveti Tomaž po letu 1996
}

\author{
VLADIMIR KOROŠEC
}

Povzetek Avtor obravnava spremembe $\mathrm{v}$ demografskem, socialnoekonomskem, prostorskem in funkcijskem razvoju $\mathrm{v}$ štirih lokalnih središčih v Spodnjem Podravju po letu 1991. Obravnavana podeželska naselja se danes soočajo z zapleteno demografsko problematiko, ki se ne kaže zgolj $v$ zmanjševanju števila in staranju prebivalcev, temveč tudi $v$ nižji izobrazbeni sestavi v primerjavi s slovenskim povprečjem, šibki pripravljenosti domačinov za izvajanje sprememb in izboljšav na področju novih gospodarskih dejavnosti, urejanja okolja ter izboljševanja bivalnih razmer v naseljih, pa tudi pomanjkanju v delovnih mest. Za uresničevanje razvojnih pobud je v regiji veliko naravnih in družbenih potencialov, ki jih dopolnjujejo nekatere nove razvojne priložnosti, med katere uvrščamo novo lokalno organiziranost, spremenjene življenjske navade prebivalcev, spremenjene navade in potrebe turistov, pa tudi dokončanje avtoceste proti hrvaški meji.

Ključne besede: • podeželska naselja $\bullet$ razvojni potenciali $\bullet$ Cirkovce $•$ Gorišnica $\bullet$ Stoperce $\bullet$ Sv. Tomaž $\bullet$ Podravje $\bullet$

NASLOv AVtoRJA: dr. Vladimir Korošec, Šola za ravnatelje, Dunajska cesta 104, 1000 Ljubljana, Slovenija, e-naslov: vladimir.korosec@ solazaravnatelje.si. 


\title{
Socio-economic development of the villages Cirkovce, Gorišnica, Stoperce and Sveti Tomaž after the year 1996
}

\author{
VLADIMIR KOROŠEC
}

\begin{abstract}
Paper deals with changes in the demographic, socio-economic, spatial and functional development of four local centers in lower Podravje region after the year 1991. The villages in question are today faced with complicated demographic issues that do not only show in decreasing number of the population (and older population), but also in the lower educational set-up when compared to the Slovene average, a weaker readiness of the local population for introducing changes and improvements in the area of new economic activities, environmental maintenance and improvement of living conditions in settlements/villages, while at the same time facing the lack of jobs. There are many natural and social potentials available for the implementation of development initiatives in the region; this is complemented by new development opportunities that also include the local organization, changed living habits of the population, changed demands and needs of tourists as well as finalizing the highway construction towards Croatia.
\end{abstract}

Keywords: - rural settlement • development potential • Cirkovce • Gorišnica $\bullet$ Stoperce $\bullet$ Sv. Tomaž $\bullet$ Podravje $\bullet$

CorResPondence AdDRess: Vladimir Korošec, Ph.D., National School of Leadership in Education, Dunajska cesta 104, 1000 Ljubljana, Slovenia, e-mail: vladimir.korosec@ solazaravnatelje.si. 
GEOGRAFIJE PODRAVJA
V. Korošec: Socialno-ekonomski razvoj naselij Cirkovce, Gorišnica, Stoperce in Sveti

\section{Uvod}

Leta 1996 so slovenski geografi na 17. zborovanju obravnavali območje Spodnjega Podravja s Prlekijo, ki so ga pred tem celostno preučili z vidika naravnogeografskih razmer, okoljskega razvoja, poselitve in urbanizacije, regionalnega in gospodarskega razvoje ter možnosti za razvoj turizma in rekreacije. Rezultati obsežnega in poglobljenega raziskovanja so objavljeni v monografiji Spodnje Podravje s Prlekijo - Možnosti regionalnega in prostorskega razvoja. Preučevanje kompleksne razvojne problematike smiselno dopolnjuje sondna raziskava petih naselij, Cirkovce, Cven, Gorišnica, Stoperce in Sveti Tomaž, iz različnih naravnih in družbeno-ekonomskih okolij Spodnjega Podravja in Prlekije, katere cilj je podrobneje osvetliti razvojne možnosti in tendence vse bolj urbaniziranega in vse manj tradicionalnega kmetijskega prostora (Brečko et al., 1996: 410).

V naseljih so bili obravnavani vsi temeljni razvojni elementi, naravni dejavniki, prebivalstvo, gospodarske razmere s poudarkom na kmetijstvu in infrastrukturna opremljenost, kar v veliki meri identificira razmere in razvojne procese širšega območja ter določa in napoveduje spremembe. Prav slednje je narekovalo odločitev po ponovni preučitvi leta 1996 obravnavanih naselij s ciljem ugotoviti in ovrednotiti spremembe, ki so rezultat tako napredujoče deagrarizacije pa tudi nekaterih novejših družbenih in gospodarskih procesov v regiji in državi.

V raziskavi smo se omejili na štiri naselja Spodnjega Podravja, Cirkovce, Gorišnica, Stoperce in Sv. Tomaž, ki ležijo v različnih naravnih enotah in različnih družbenoekonomskih okoljih. Cirkovce se nahajajo v sklenjeni verigi naselij na južnem robu Dravskega polja, ob železniški progi Ptuj - Pragersko, Gorišnica na skrajnem vzhodnem delu Ptujskega polja na obsežni naplavini med Pesnico in Dravo, Stoperce na skrajnem zahodnem delu visokih in z gozdom poraščenih Haloz, Sv. Tomaž pa v razmeroma položnem svetu vzhodnih Slovenskih goric. Naselji Gorišnica in Sv. Tomaž sta občinski središči, medtem ko sta naselji Cirkovce in Stoperce lokalni središči z nekaterimi centralnimi funkcijami. Naravne razmere, položaj naselij in oddaljenost od zaposlitvenih središč so ključni dejavniki socialno-ekonomskega in prostorskega razvoja podeželskih naselij, v novejšem obdobju pa jih dopolnjujejo številni regionalni in globalni procesi, ki ne spreminjajo samo njihove ruralne zgradbe, temveč $v$ naselja vnašajo povsem nove gospodarske in prostorske strukture in jih s tem $\mathrm{z}$ vidika kakovosti bivanja bogatijo, $\mathrm{z}$ vidika njihove podeželske identitete pa tudi siromašijo. Spreminjajo se demografske razmere in socialni odnosi, dejavnostna sestava prebivalcev, opremljenost naselij in njihove funkcije, lastništvo kmetijskih zemljišč in zemljiško posestna zgradba, kar oblikuje povsem novo socialno-ekonomsko zgradbo podeželja. V luči vseobsežnih in hitrih sprememb se zastavlja vprašanje o položaju podeželskih naselij v odnosu do podeželja in urbanih središč.

Namen raziskave je bil ugotoviti spremembe v štirih lokalnih središčih v demografskem, socialno-ekonomskem, prostorskem in funkcijskem razvoju po letu 1991, preučiti razloge za spremembe ter ovrednotiti položaj lokalnih središč v mreži podeželskih naselij. Izhodišče raziskave je študija razvojnih problemov naselij Cirkovce, Cven, Gorišnica, Stoperce in Sv. Tomaž iz leta 1996, v kateri avtorji predstavijo razvojne procese in smeri nadaljnjega razvoja. 
Gre za primerjavo razvojnih procesov v štirih podeželskih naseljih Spodnjega Podravja v obdobju 1996 - 2016, na podlagi česar je mogoče sklepati o posameznih elementih ali celo skupnih zakonitostih regionalnega razvoja oz. odgovoriti na vprašanje, kakšen bo morebitni prihodnji razvoj podeželskih naselij.

V obeh raziskavah, v raziskavi iz leta 1996 in tudi v raziskavi iz leta 2016, so bili uporabljeni statistični podatki, viri in literatura, opravljeno pa je bilo tudi sistematično zbiranje podatkov na terenu $\mathrm{s}$ pomočjo intervjujev in anketnih vprašalnikov. Pri anketiranju in zbiranju podatkov na terenu leta 2016 so sodelovali študenti Višje strokovne šole na Ptuju, ki obiskujejo program Upravljanje podeželja in krajine. Anketiranih je bilo 72 gospodinjstev v naseljih Cirkovce, Gorišnica, Stoperce in Sveti Tomaž, kar je okrog $15 \%$ vseh gospodinjstev. Anketni vprašalnik je obsegal štiri tematske sklope in sicer: splošni podatki o gospodinjstvu, poselitev, kmetijstvo in turizem. Na podlagi zbranih podatkov so bile opravljene medsebojne primerjave ter prikazane njihove skupne razvojne značilnosti in ovrednotene razvojne specifike širšega območja, v katerem se nahaja obravnavano naselje.

\section{Razvojni potenciali na podeželju}

Sodobni koncepti politik regionalnega razvoja so usmerjeni k utrjevanju gospodarskih struktur, ki temeljijo na lokalnih razvojnih potencialih, omogočajo večjo zaposljivost, spodbujajo uveljavljanje lokalnih iniciativ ter krepijo povezovanje in sodelovanje med prebivalci. Učinkovita regionalna politika, ki temelji na principih trajnostnega razvoja povezuje avtarkično lokalno gospodarstvo z nacionalnim in širšim transnacionalnimi, kar lokalnemu razvoju daje novo vrednost in nove priložnosti. Nobenega dvoma ni, da je okolje glavni dejavnik regionalnega razvoja, saj so naravni viri ključni elementi, ki omogočajo obstoj ljudi in ekosistemov (Korže, 2012: 82) ter zagotavljajo gospodarsko rabo in izboljšujejo kakovost življenja. Seveda ni v ospredju razmišljanja le kmetijstvo, ki zaradi deagrarizacije in številnih strukturnih problemov izgublja položaj nosilne dejavnosti v regionalnem razvoju, čeprav so pogoji za kmetijstvo v pretežnem delu Spodnjega Podravja nadpovprečno ugodni (Lampič, 2011: 134), temveč tudi mnoge druge dejavnosti in možnosti rabe, ki temeljijo na lokalnih naravnih in družbenih virih.

Ko govorimo o razvoju podeželskih naselij v Spodnjem Podravju je v ospredju vprašanje, v kolikšni meri je mogoče njihovo prihodnost graditi v povezavi s kmetijstvom in drugimi nekmetijskimi dejavnostmi, kot so turizem, proizvodna obrt in storitve. Kako povečati učinkovitost regijskega gospodarstva, ki bi glede na naravne in družbene potenciale ter dosedanji razvoj v veliko večjem obsegu lahko temeljilo na kmetijstvu in s kmetijstvom povezanih dejavnostih in kje so razlogi, da kljub vse bolj omejenim možnostim zaposlovanja prebivalci ne prepoznajo priložnosti v dejavnostih, za katere so v regiji razmeroma dobri pogoji. Razlogi za to so številni in raznovrstni, so posledica dosedanjega socialno-ekonomskega razvoja, strukturne razslojenosti $\mathrm{v}$ kmetijstvu in $\mathrm{v}$ drugih dejavnostih, pomanjkanja znanja, šibke povezanosti med deležniki, pa tudi povsem osebnih stališč, zaradi katerih mnogi prebivalci niso pripravljeni sprejemati izzivov in uveljavljati sprememb. Večina prebivalcev podeželskih naselij v regiji je zaposlenih v nekmetijskih dejavnostih v treh regijskih zaposlitvenih središčih, na Ptuju, v Ormožu in Kidričevem ter zaradi zmanjševanja zaposlitvenih možnosti v regiji tudi v 


\section{sosednjih regijah in celo v sosednji Avstriji. Gre pretežno za delovna mesta v industrijskih obratih z nizko dodano vrednostjo.}

\section{Vrednotenje in raba lokalnih razvojnih možnosti oziroma potencialov.}

\begin{tabular}{|c|c|c|c|}
\hline Območje & Dejavnost & Elementi potencialov & Kazalniki slabe rabe potencialov \\
\hline \multirow[t]{4}{*}{$\begin{array}{l}\text { Dravska } \\
\text { ravan }\end{array}$} & Kmetijstvo & $\begin{array}{l}\text { Ravninski svet } \\
\text { Ugodna klima } \\
\text { Vodni viri } \\
\text { Tržne priložnosti } \\
\text { Tradicija kmetovanja }\end{array}$ & $\begin{array}{l}\text { - intenzivna raba } \\
\text { - spreminjanje kmetijske rabe } \\
\text { - neprilagojenost sušnim razmeram } \\
\text { - neizkoriščenost vode za namakanje } \\
\text { - nizka samooskrba } \\
\text { - tradicionalna pridelava (poljedeljstvo, } \\
\text { živinoreja) } \\
\text { - pomanjkanje znanja } \\
\text { - visoka starost lastnikov kmetij } \\
\text { - nepovezanost pridelovalcev }\end{array}$ \\
\hline & Turizem & $\begin{array}{l}\text { Naravne vrednote } \\
\text { Naravni viri } \\
\text { Materialna dediščina } \\
\text { Nematerialna dediščina } \\
\text { Sodobni trendi turizma } \\
\end{array}$ & $\begin{array}{l}\text { - nesprejetost zavarovanih območij } \\
\text { - šibko vključevanje v turistično rabo } \\
\text { - zanemarjanje dediščine } \\
\text { - potvarjanje, zlorabljanje dediščine } \\
\text { - pomanjkanje inovativnih ponudb }\end{array}$ \\
\hline & Industrija in obrt & $\begin{array}{l}\text { Razvoj podjetništva } \\
\text { Infrastruktura }\end{array}$ & $\begin{array}{l}\text { - pomanjkanje inovativnih pristopov } \\
\text { - obsežna ponudba obrtnih območij }\end{array}$ \\
\hline & Poselitev & $\begin{array}{l}\text { Strnjena in gosta } \\
\text { poselitev } \\
\text { Funkcijska zgradba } \\
\text { naselij } \\
\text { Kakovost bivalnega } \\
\text { okolja }\end{array}$ & $\begin{array}{l}\text { - obremenjevanje okolja } \\
\text { - stihijski prostorski razvoj naselij } \\
\text { - pojav neustreznih elementov }\end{array}$ \\
\hline \multirow[t]{4}{*}{ Haloze } & Kmetijstvo & $\begin{array}{l}\text { Geomorfološka pestrost } \\
\text { Ugodna klima } \\
\text { Tržne priložnosti } \\
\text { Tradicija kmetovanja }\end{array}$ & $\begin{array}{l}\text { - zaraščanje kmetijskih zemljišč } \\
\text { - neustrezna raba kmetijskih zemljišč } \\
\text { - nizka tržna usmerjenost } \\
\text { - deagrarizacija, odseljevanje mladih }\end{array}$ \\
\hline & Turizem & $\begin{array}{l}\text { Naravne vrednote } \\
\text { Materialna dediščina } \\
\text { Nematerialna dediščina } \\
\text { Sodobni trendi turizma }\end{array}$ & $\begin{array}{l}\text { - ni inovativnih programov } \\
\text { - izpostavljenost propadanju } \\
\text { - potvarjanje, zlorabljanje dediščine } \\
\text { - šibko razvita infrastruktura } \\
\text { - pomanjkanje ciljne promocije }\end{array}$ \\
\hline & Industrija in obrt & Razvoj podjetništva & - pomanjkanje podjetniških iniciativ \\
\hline & Poselitev & $\begin{array}{l}\text { Razpršena poselitev } \\
\text { Težja dostopnost } \\
\text { Funkcijska zgradba } \\
\text { naselij } \\
\text { Kakovost bivalnega } \\
\text { okolja }\end{array}$ & $\begin{array}{l}\text { - omejevanje gradnje } \\
\text { - nepopolna infrastruktura } \\
\text { - nepopolna oskrba, stihijski razvoj } \\
\text { - vnašanje neustreznih elementov }\end{array}$ \\
\hline \multirow[t]{4}{*}{$\begin{array}{l}\text { Slovenske } \\
\text { gorice }\end{array}$} & Kmetijstvo & $\begin{array}{l}\text { Geomorfološka pestrost } \\
\text { Ugodna klima } \\
\text { Tržne priložnosti } \\
\text { Tradicija kmetovanja }\end{array}$ & $\begin{array}{l}\text { - ekstenzivna raba } \\
\text { - ni prilagajanja sušnim razmeram } \\
\text { - nizka tržna usmerjenost } \\
\text { - deagrarizacija, odseljevanje mladih }\end{array}$ \\
\hline & Turizem & $\begin{array}{l}\text { Naravne vrednote } \\
\text { Materialna dediščina } \\
\text { Nematerialna dediščina } \\
\text { Sodobni trendi turizma }\end{array}$ & $\begin{array}{l}\text { - ni inovativnih programov } \\
\text { - izpostavljenost propadanju } \\
\text { - potvarjanje, zlorabljanje dediščine } \\
\text { - šibko razvita infrastruktura } \\
\text { - pomanjkanje ciljne promocije }\end{array}$ \\
\hline & Industrija in obrt & Razvoj podjetništva & - pomanjkanje podjetniških iniciativ \\
\hline & Poselitev & $\begin{array}{l}\text { Razpršena poselitev } \\
\text { Težja dostopnost } \\
\text { Funkcijska zgradba } \\
\text { naselij } \\
\text { Kakovost bivalnega } \\
\text { okolja }\end{array}$ & $\begin{array}{l}\text { - omejevanje gradnje } \\
\text { - nepopolna infrastruktura } \\
\text { - nepopolna oskrba, stihijski razvoj } \\
\text { - vnašanje neustreznih elementov }\end{array}$ \\
\hline
\end{tabular}


V zadnjem obdobju se na področju storitvenih dejavnosti uveljavlja zaposlovanje v obliki samozaposlitev ali v manjših podjetjih, kar izboljšuje gospodarsko podobo podeželskih naselij in kakovost življenja podeželskega prebivalstva.

Večja in učinkovita raba podeželskih razvojnih potencialov je predvsem odvisna od znanja, motiviranosti in poslovne uspešnosti lokalnega prebivalstva in tistih posameznikov izven regije, ki $\mathrm{v}$ naravnih in družbenih virih prepoznajo osebne in poslovne izzive, kar pa lahko uresničujejo le na podlagi realnih regijskih in nacionalnih razvojnih usmeritev ter v varnem strokovnem, poslovnem in finančnem okolju.

\section{Prebivalci kot dejavnik razvoja podeželja}

Po letu 1991 se nadaljuje zmanjševanje števila prebivalcev v Spodnjem Podravju in tudi $\mathrm{v}$ večini obravnavanih naselij, kar je $\mathrm{v}$ novejšem času nedvomno tudi posledica slabih gospodarskih razmer v regiji in gospodarske recesije na začetku 21. stoletja, ki je ta del Slovenije prizadela bolj kot katero koli drugo območje v državi.

Demografski razvoj Spodnjega Podravja, zlasti podeželskih naselij, je zaradi procesov depopulacije $\mathrm{v}$ drugi polovici preteklega stoletja in s tem povezane neugodne starostne sestave prebivalcev, izjemno občutljiv na gospodarske in družbene spremembe v širšem območju. Tako raziskovalci v študiji »Spodnje Podravje pred izzivi trajnostnega razvoja « na podlagi rasti števila prebivalcev v obdobju 1991 in 2008 ugotavljajo, da se je zaostajanje rasti prebivalcev za slovenskim povprečjem, ki je bilo značilno za obdobje 1961 do 1991, zaustavilo (Rebernik, 2011: 24).

Dokaj optimistična napoved se je izkazala za napačno, saj se po letu 2008 v Spodnjem Podravju nadaljuje zmanjševanje števila prebivalcev, v obdobju 2008 - 2016 za skoraj 2 $\%$. Nadaljnje zmanjševanje števila prebivalcev $\mathrm{v}$ zadnjem desetletju je posledica odseljevanja mladih, ki v domačem okolju ali bližnjih zaposlitvenih središčih ne najdejo ustrezne zaposlitve.

V obdobju 1991 - 2016 je za podeželska naselja Spodnjega Podravja značilen dinamičen demografski razvoj. Na podlagi priseljevanja in $\mathrm{v}$ nekaterih naseljih tudi pozitivnega naravnega prirasta se je število prebivalcev nekoliko povečalo $\mathrm{v}$ širšem suburbanem zaledju Ptuja, v naseljih Krčevina pri Ptuju, Grajena, Kicar in Podvinci, v naseljih z ugodnim prometnim položajem $v$ ravninskem delu regije med Ptujem in Ormožem, kjer po kazalnikih demografskega razvoja izstopa naselje Gorišnica, v nekaterih dobro opremljenih centralnih naseljih $\mathrm{z}$ razpoložljivim prostorom za gradnjo bivališč ter $\mathrm{v}$ naseljih na južnem robu Dravskega polja oz. na območju Vidma, kamor se pretežno priseljujejo prebivalci vzhodnega dela Haloz. Razvoj prebivalstva $\mathrm{v}$ obravnavanih centralnih naseljih kaže nekatere skupne značilnosti in razvojne procese $\mathrm{z}$ naselji $\mathrm{v}$ lokalnem območju.

Pričakovano je zmanjšanje števila prebivalcev v Stopercah, saj se depopulacija v Halozah zaradi socialno-ekonomskih razmer in neučinkovitih razvojnih ukrepov nadaljuje $\mathrm{z}$ nezmanjšano intenzivnostjo. Po podatkih SURS za leto 2015 sta bila v Stopercah pozitivna naravni in tudi selitveni prirast, vendar je ta podatek bolj izjema kot pravilo, saj se skupno število prebivalcev postopno zmanjšuje. V obdobju med letoma 1961 in 2016 
se je število prebivalcev v Stopercah zmanjšalo za več kot $44 \%$. Tako kot v ostalih haloških centralnih naseljih je tudi v Stopercah prisotna tendenca notranjega priseljevanja $\mathrm{s}$ težje dostopnih slemenskih naselij, ali pa celo priseljevanje nekdanjih domačinov $\mathrm{v}$ počitniška bivališča. Rezultati anketiranja gospodinjstev v štirih centralnih naseljih kažejo, da je v Stopercah najnižji delež priseljenih prebivalcev. Po letu 1990 se od 24 anketiranih gospodinjstev v naselje priselijo le tri družine.

Primerjava gibanja števila prebivalcev v obdobju $1991-2016$. Vir: SURS, 2017.

\begin{tabular}{|l|c|c|c|}
\hline Naselje, občina, regija & $\begin{array}{c}\text { Število } \\
\text { prebivalcev 1991 }\end{array}$ & $\begin{array}{c}\text { Število } \\
\text { prebivalcev 2016 }\end{array}$ & $\begin{array}{c}\text { Indeks } \\
2016 / 1991\end{array}$ \\
\hline Cirkovce & 388 & 365 & 94,1 \\
\hline Občina Kidričevo & 6.606 & 6.429 & 97,3 \\
\hline Gorišnica & 685 & 816 & 119,1 \\
\hline Občina Gorišnica & 3.784 & 3.982 & 105,2 \\
\hline Stoperce & 251 & 202 & 80,5 \\
\hline Občina Majšperk & 4.330 & 3.996 & 92,3 \\
\hline Sveti Tomaž & 254 & 259 & 101,9 \\
\hline Občina Sveti Tomaž & 2.242 & 2.031 & 90,6 \\
\hline Spodnje Podravje & 86.323 & 84.642 & 98,1 \\
\hline
\end{tabular}

Čeprav je naselja na Dravskem polju depopulacija zajela že v drugi polovici preteklega stoletja, sta centralni naselji Lovrenc in Cirkovce ohranili skromno rast prebivalcev. Po letu 2010 v obeh naseljih število prebivalcev nazaduje, najhitreje v Cirkovcah, kjer je bilo leta 2016 v starostni skupini do 14 let le $8,8 \%$ prebivalcev, starostni indeks pa je znašal 263 in je bil najvišji v primerjavi z ostalimi obravnavanimi centralnimi naselji. Na odseljevanje prebivalcev vpliva tudi spremenjena socialna zgradbe naselij ter pomanjkanje novega poselitvenega prostora, ki ga omejujeta gosta poselitev in zaščita kmetijskih zemljišč. V naseljih prevladujejo nekmečka gospodinjstva, zaradi česar se zlasti mladi odmikajo od podeželske tradicije.

Starostni indeks v letih 1991 in 2016.

Vir: SURS, 2017.

\begin{tabular}{|l|c|c|}
\hline Naselje, občina & 1991 & 2016 \\
\hline Cirkovce & 56,5 & 262,5 \\
\hline Kidričevo & 55,4 & 138,2 \\
\hline Gorišnica - naselje & 65,3 & 91,7 \\
\hline Gorišnica - občina & 62,1 & 116,1 \\
\hline Stoperce & 62,7 & 181,8 \\
\hline Majšperk & 55,7 & 125,8 \\
\hline Sveti Tomaž - naselje & 34,7 & 118,2 \\
\hline Sveti Tomaž - občina & 64,5 & 119,8 \\
\hline
\end{tabular}

Preoblikovanje nekdanje krajevne skupnosti Tomaž pri Ormožu leta 2006 v samostojno občino je nekoliko upočasnilo odseljevanje prebivalcev iz naselja Sv. Tomaž, saj se je v zadnjem obdobju pomembno izboljšala infrastrukturna opremljenost in $\mathrm{s}$ tem tudi kakovost življenjskega okolja. Sv. Tomaž uvrščamo med naselja z najbolj drastičnimi 
demografskimi spremembami v Spodnjem Podravju. Medtem ko se je v obdobju 1961 1991 število prebivalcev povečalo za $50 \%$, do leta 2011 pa še za dodatnih $12 \%$, se je samo v obdobju 2011 - 2016 oz. v petih letih zmanjšalo za skoraj $10 \%$, hkrati pa se je bistveno poslabšala starostna sestava. Leta 1991 je bilo v starostni skupini do 14 let 28,4 \% prebivalcev Sv. Tomaža, leta 2016 pa le še 12,7 \%. Starostni indeks je v obravnavanem obdobju iz vrednosti 34,7 povečal na 118,2 , kar napoveduje gotovo zmanjševanje naravnega prirasta.

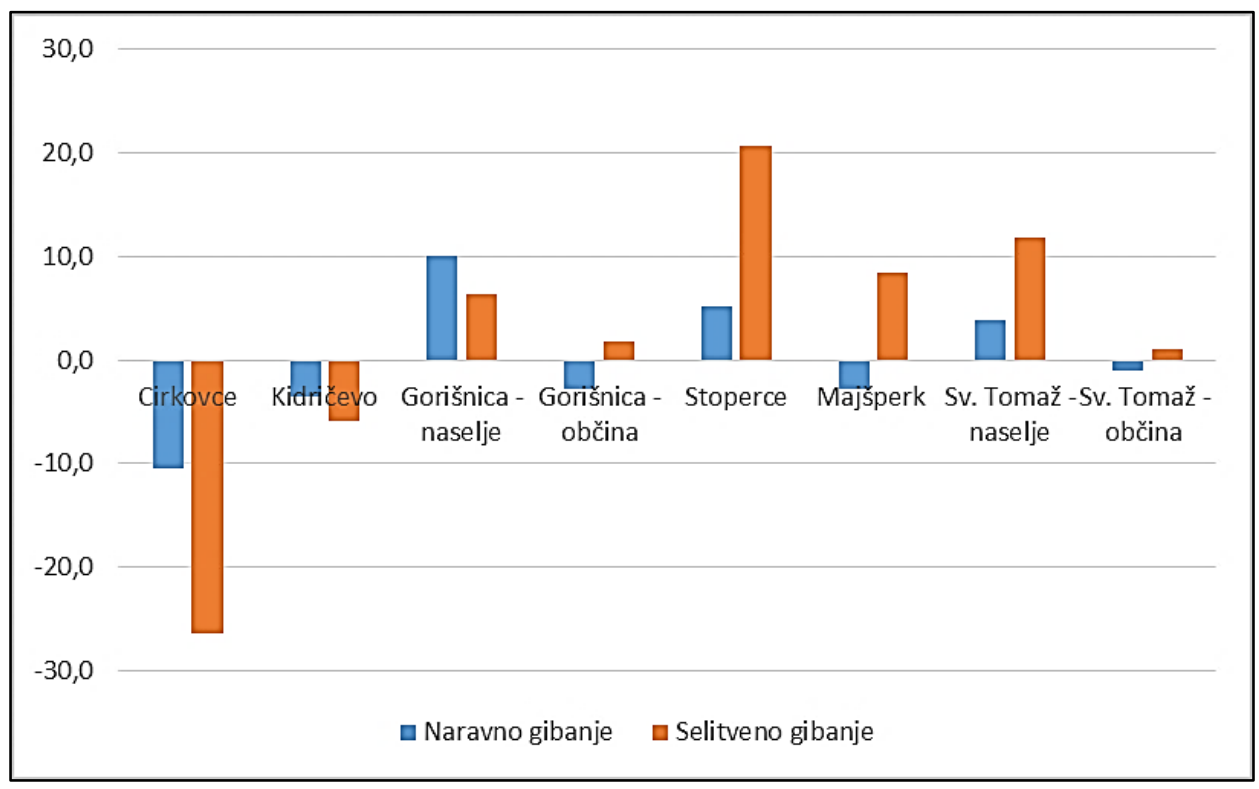

Naravno in selitveno gibanje leta 2015.

Med vsemi obravnavanimi naselji je le Gorišnica ohranila in na nekaterih območjih celo utrdila demografsko vitalnost in pozitivno tendenco demografskega razvoja, kar kažejo podatki o visoki rasti števila prebivalcev po letu 1991 ter uravnoteženi starostni in ugodni izobrazbeni sestavi. Prednosti naselja so zagotovo ugoden prometni položaj, kakovostna javna infrastruktura, razvita oskrbna dejavnost in primeren obseg zazidljivih površin, primernih za individualno stanovanjsko gradnjo. Z Gorišnico primerljiv demografski in poselitveni razvoj imata le Dornava in delno Videm pri Ptuju. Po letu 1991 se je predvsem na račun priseljevanja število prebivalcev povečalo tudi $\mathrm{v}$ treh manjših centralnih naseljih, v Juršincih, Trnovski vasi in Cirkulanah, kjer se je prav tako bistveno izboljšala opremljenost naselij in kakovost življenjskega okolja.

Pod vplivom urbanizacije se spreminja tudi izobrazbena sestava prebivalcev, ki je eden ključnih dejavnikov regionalnega razvoja. V Gorišnici je skoraj ena četrtina prebivalcev Z višjo ali visoko izobrazbo, v Stopercah pa je še vedno 42,8 \% odraslih prebivalcev brez izobrazbe ali zgolj z zaključeno osnovno šolo (SURS, 2017). V vseh naseljih se povečuje neagrarna socialna zgradba in slabi povezanost prebivalcev s kmetijsko dejavnostjo, kar kažejo podatki anketiranja gospodinjstev v marcu 2017. Prevladujejo prebivalci, zaposleni v različnih nekmetijskih dejavnostih izven naselij, v Gorišnici in Cirkovcah je tudi nekaj zaposlitev $\mathrm{v}$ javnih zavodih in storitvenih dejavnostih, metem ko je $\mathrm{v}$ 
kmetijstvu aktivnih manj kot $10 \%$ prebivalcev. Med naselji so pomembne razlike $\mathrm{v}$ deležu kmečkih gospodinjstev. Največ gospodinjstev je s kmetijsko dejavnostjo povezanih v Stopercah, dobrih $45 \%$, najmanj, 17,5 \% pa v Gorišnici, v Cirkovcah tretjina in v Sv. Tomažu dobra četrtina. Zaradi staranja se v vseh naseljih povečuje delež upokojencev; mnogi med njimi opuščajo kmetijsko pridelavo na svojih manjših kmetijah, zato se zmanjšuje število mešanih kmetij.

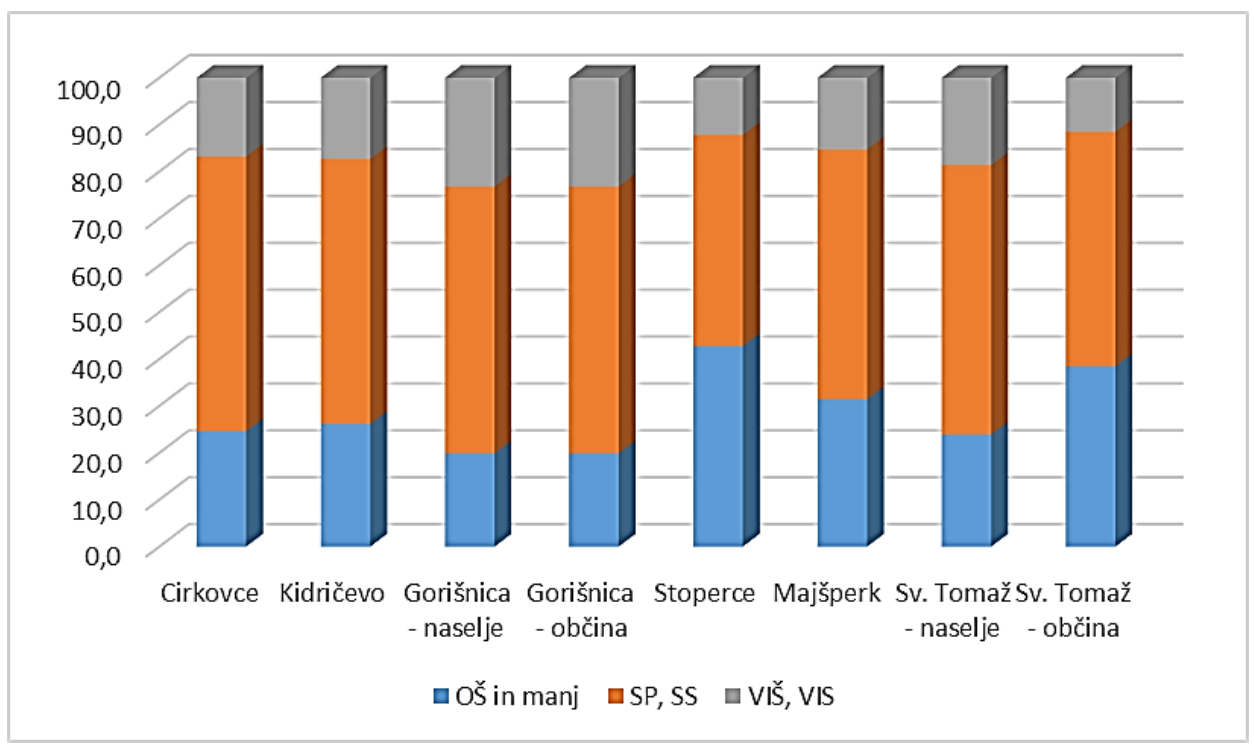

Izobrazbena sestava prebivalcev leta 2016.

\section{Pogoji za bivanje na podeželju}

Po letu 1991, zlasti po ustanovitvi novih občin, se v podeželskih naseljih Spodnjega Podravja, tudi v naseljih $\mathrm{v}$ Slovenskih goricah in Halozah, izboljšujejo bivalni pogoji, zagotovljena je oskrba s pitno vodo, centralna naselja pa se zaradi novih oskrbnih dejavnosti prostorsko in funkcijsko spreminjajo. Kljub izboljšanju infrastrukture in višji kakovosti bivalnega okolja se odseljevanje prebivalcev ne zmanjšuje, kar kaže na šibko gospodarsko vitalnost regije in skromne zaposlitvene možnosti v domačem okolju.

Podeželska naselja Spodnjega Podravja so pretežno bivalna naselja v nekmetijskih dejavnostih zaposlenih prebivalcev (Brečko et al., 1996: 443), v centralnih naseljih pa je vedno bolj pomembna tudi oskrbna funkcija. Večina gospodinjstev $\mathrm{v}$ obravnavanih naseljih živi v hiši svojih prednikov, ali pa so si domovanje zgradili na podedovani parceli. Razmeroma malo je priseljenih družin, še največ je priselitev iz širšega lokalnega okolja je v Gorišnici in Cirkovcah. Kot ključni razlog priselitve navajajo anketirani prebivalci mir in ohranjeno naravo ter v Cirkovcah tudi bližino zaposlitve.

Kakovost naravnega okolja, naravne vrednote in neokrnjeno naravo vidijo prebivalci Stoperc in Sv. Tomaža kot poglavitne prednosti bivanja na podeželju, v Gorišnici sta v ospredju urejenost naselja in primernost pogojev za gradnjo stanovanjskih hiš, v 
Cirkovcah pa prepoznavajo kot prednost možnosti za kmetovanje in s tem povezane nižje življenjske stroške.

$\mathrm{Z}$ dvigom življenjskega standarda se povečujejo tudi vlaganja $\mathrm{v}$ obnovo ali izgradnjo stanovanj. V vseh obravnavanih naseljih je bilo največ stanovanj zgrajenih $\mathrm{v}$ drugi polovici preteklega stoletja, med letoma 1945 in 1991, po letu 1991 pa v Gorišnici in v Stopercah (SURS, 2017). Žal je funkcijski razvoj večine podeželskih naselij povsem naključen.

V morfološki zgradbi naselij se prepletajo bivalne in gospodarske funkcije, $v$ centralnih pa tudi javne in oskrbne. Še največ sistemskega pristopa in celostne prostorske urejenosti zasledimo v Gorišnici, kjer je znotraj poselitvenega prostora dovolj možnosti za različne rabe, za razliko od Cirkovc, kjer gosta poselitev in kmetijska zemljišča povsem omejujejo širitev naselja. Zaradi teh razlogov se povečuje pritisk na spremembo namembnosti kmetijskih zemljǐš v stanovanjsko (Rebernik, 2011: 36), saj je pogosto onemogočen razvoj kmetij oz. gradnja gospodarskih objektov.

Sv. Tomaž je lep primer slemenskega gručastega ter s Ptujem, z Ljutomerom in Ormožem prometno dobro povezanega naselja, ki je kljub modernizaciji ohranilo posamezne elemente tradicionalno podeželske zgradbe, kar povečuje možnosti za priseljevanje in razvoj turizma.

$\mathrm{K}$ zmanjševanju pritiska na rabo poselitvenega prostora $\mathrm{v}$ naseljih ter $\mathrm{k}$ odpravljanju neustrezne rabe in nasprotujočih interesov nedvomno prispeva izgradnja obrtnih con oz. komunalno opremljenih območij, v katere se naseljujejo predvsem mala lokalna podjetja s svojimi storitvenimi in proizvodnimi dejavnostmi. Starejše industrijsko - obrtne cene, Ptuj, Majšperk in Kidričevo, dopolnjujejo številne nove, ki so bolj rezultat prizadevanj podeželskih občin za spodbujanje gospodarskega razvoja, kot pa realnih potreb. Ker je ponudba komunalno urejenih obrtnih lokacij večja od povpraševanja, je v nekaterih conah še vedno veliko nezasedenega prostora. Obrtno - podjetniške cone so nedvomno pomemben zaposlitveni dejavnik in $\mathrm{v}$ začetni fazi pozitiven signal in dobra namera občin za spodbujanje regionalnega razvoja (Potočnik, 2011: 191).

Primerjava funkcijsko - gravitacijskega razvoja centralnih in subcentralnih naselij v Spodnjem Podravju med letoma 1996 in 2016 kaže bistvene spremembe. Na celotnem podeželju se je izboljšala osnovna infrastruktura, vzdrževanje in gradnja cestnega omrežja, oskrba z vodo, kanalizacija in drugo, hkrati pa so se nekoč manjši ruralni centri (Rus, 1996: 282), danes občinska središča, preoblikovali v lokalna oskrbna in storitvena središča in s tem razširili svoj gravitacijski vpliv. Govorimo o decentralizaciji oskrbe, funkcij in razvoja, kar posredno vpliva tudi na strukturiranje centralnih funkcij v bližnjih urbanih središčih. Oskrba $\mathrm{z}$ osnovnimi življenjskimi potrebščinami je odvisna od kakovosti ponudbe $\mathrm{v}$ domačem kraju in od kraja zaposlitve. Prebivalci Gorišnice in Cirkovc se najpogosteje z osnovnimi živili oskrbujejo v domačem kraju, Stoperčani v Majšperku, na Ptuju ali v Rogatcu, prebivalci Sv. Tomaža pa so skoraj v enakem deležu glede oskrbe vezani na Ptuj, Ormož in Ljutomer. Ptuj ima še vedno vodilno vlogo na področju oskrbe z obleko, pohištvom, opremo in stroji. 
Prebivalci podeželskih naselij se na različne načine aktivno vključujejo v družbeno življenje svojega kraja in občin. Razvojne predloge in ukrepe oblikujejo bodisi $\mathrm{s}$ političnim udejstvovanjem $\mathrm{v}$ organih lokalnih skupnosti, $\mathrm{z}$ ustanavljanjem civilnih iniciativ ali kot strokovnjaki in poznavalci razmer $\mathrm{v}$ različnih sistemskih oz. institucionalnih oblikah. Medtem ko so ob koncu preteklega stoletja najpogosteje opozarjali na slabo infrastrukturo in nepopolno oskrbo, je danes njihova skrb usmerjena v reševanje problematike hitrega staranja prebivalcev (Cirkovce), odseljevanja mladih s podeželja zaradi pomanjkanja delovnih mest v nekmetijskih dejavnostih (Stoperce in Sv. Tomaž) ter pomanjkanja ustrezno usposobljenih kadrov za uvajanje proizvodnih in tehnoloških sprememb v različnih dejavnostih (Gorišnica). Zaslediti je torej odmik od prizadevanja za izboljšanje kakovosti bivanja $\mathrm{k}$ realnim in dolgoročnim razvojnim vprašanjem.

\section{Možnosti gospodarskega razvoja}

Gospodarsko in socialno zgradbo podeželskih naselij Spodnjega Podravja določajo naravni pogoji, položaj v odnosu do centralnih naselij, prometna dostopnost, bližina zaposlitvenih središč ter številni lokalno omejeni dejavniki, kot so: zemljiško - ureditveni posegi ter izgradnja javne in poslovne infrastrukture. Zagotovo pa imajo pomembno vlogo tudi družbene in gospodarske spremembe po letu 1991 ter z njimi povezana procesa deindustrializacije in denacionalizacije ter ne nazadnje tudi vključitev Slovenije v Evropsko unijo. Številni, obsežni in kompleksni dejavniki so na podeželju izoblikovali bolj ali manj dinamične gospodarske strukture, v katerih se na različni ravni razvitosti prepletajo elementi tradicionalne ruralne zgradbe s sodobnimi koncepti podjetništva, oskrbe in storitev.

Razvoj obravnavanih naselij danes več ne temelji na kmetijstvu, kot je bilo to še ob koncu preteklega stoletja (Brečko et al., 1996: 443), saj so se v vseh naseljih poleg prevladujočih zaposlitev v bližnjih urbanih središčih, na podlagi potreb in poslovnih priložnosti uveljavile različne nekmetijske ali s kmetijstvom povezane dejavnosti.

Na področju razvoja kmetijstva so med naselji bistvene razlike, ki so se po letu 1991 še poglobile. Zaradi staranja kmečkih prebivalcev in posledično opuščanja kmetovanja se število kmetij najhitreje zmanjšuje v Halozah. V obdobju 1991 - 2016 se je število kmetij v Stopercah zmanjšalo za $30 \%$, v Gorišnici za $28 \%$, v Cirkovcah za 20 \% in v Svetem Tomažu za 15 \% (SURS, 2017). Na Dravskem in Ptujskem polju je opuščanje kmetovanja pretežno posledica izboljšanja socialnega položaja mešanih gospodinjstev, ki jim zaposlitev izven kmetijstva zagotavlja dovolj dohodka, zato kmetijska zemljišča prodajo ali oddajo v najem. Za mnoge slovensko goriške in haloške družine pa so kmetijska zemljišča še vedno priložnost za pridobivanje dodatnega dohodka, saj si na ta način znižujejo življenjske stroške.

$\mathrm{Z}$ opuščanjem kmetovanja $\mathrm{v}$ Halozah se bistveno ne povečuje povprečna velikost tamkajšnjih kmetij, saj za zemljišča na težje dostopnih in strmih terenih ni izkazanega interesa za najem in so zaradi tega pogosto izpostavljena zaraščanju. Več zanimanja za najem kmetijskih zemljišč je med kmetovalci na dravski ravnici, ki želijo pridobiti kakovostna zemljišča $\mathrm{v}$ bližini svojih kmetij, vendar povpraševanje presega ponudbo 
zemljišč. Z najemom kmetije na Ptujskem polju povečujejo obseg poljedelske pridelave, na Dravskem polju pa najpogosteje na ta način povečujejo pridelavo krme za živino.

V obdobju 1991 - 2016 se je v obravnavanih naseljih povečala velikost kmetij, ki so kmetijska zemljišča pridobile z nakupom ali najemom. Največje kmetije so v Cirkovcah, njihova povprečna velikost presega 7 ha kmetijskih zemljišč v obdelavi. Kmetije so se povečevale, zahvaljujoč zgodnjim procesom urbanizacije v 80. letih preteklega stoletja in uspešno izvedenim komasacijam, ki so hkrati velik prispevek k zmanjševanju razdrobljenosti zemljišč in k izboljšanju ekonomičnosti kmetovanja (Korošec, 2006: 35). V Gorišnici, v primerljivem naravnem okolju s Cirkovcami, je povprečna velikost kmetij 5 ha, kar kaže na tradicionalno zemljiško-posestno razdrobljenost in šibko razvojno usmerjenost kmetijstva, saj večina kmetij ne uvaja novosti in sprememb. V Sv. Tomažu povprečna velikost kmetij ne presega 5 ha. V tem delu Slovenskih goric prevladujejo manjše mešane kmetije, ki pretežno kmetujejo zaradi tradicije in za lastne potrebe.

Nizka tržna usmerjenost kmetij, šibko povezovanje med kmetovalci in dejavnostmi na področju kmetijstva, pomanjkanje smelih proizvodnih, tehnoloških in organizacijskih novosti so stalnica na seznamu problemov, ki onemogočajo razvoj kmetijstva in podeželja tako v obravnavanih naseljih, kot v regiji in v državi.

$\mathrm{V}$ anketnem vprašalniku so kmetje med odločilne razloge, zaradi katerih ne uvajajo proizvodnih sprememb, specializacij ali v večjem obsegu dopolnilnih dejavnosti, prav v vseh naseljih uvrstili slabe razmere v kmetijstvu nizko ekonomičnost kmetijstva (Sv. Tomaž), težje pridelovalne pogoje in staranje lastnikov kmetij (Stoperce) ter pomanjkanje delovne sile na kmetijah (Gorišnica, Stoperce). V Cirkovcah in Stopercah so kmetije usmerjene v živinorejo, ki se v Cirkovcah povezuje s poljedelstvom, v Stopercah pa pretežno $\mathrm{s}$ travništvom. V Sv. Tomažu prevladuje mešana pridelava in $\mathrm{v}$ Gorišnici poljedelstvo. Na Ptujskem polju se živinoreja umika tudi z manjših kmetij, na katerih so donedavna živino redili za lastne potrebe.

V Stopercah in Sv. Tomažu je nekaj kmetij registriralo dopolnilno dejavnost v obliki izvajanja strojnih uslug, saj so se mnogi kmetje ob finančni podpori iz programov razvoja podeželja odločili za nakup traktorjev in druge strojne opreme, ki v večini primerov po številu in moči presegajo potrebe kmetij. Žal se kmetje v večjem številu ne odločajo za druge oblike dopolnilnega dela, kot so turistična dejavnost, domače obrti in predelava kmetijskih pridelkov, ki pa zahtevajo veliko znanja, sodelovanja z deležniki in tudi veliko finančnih sredstev. Med nekoliko bolj inovativne pristope uvrščamo povečanje prodaje neposredno kupcem na domačem dvorišču, na tržnicah ali ob različnih drugih priložnostih, ki je med potrošniki vedno bolj uveljavljena oblika oskrbe z živili.

Da ima kmetijstvo na njihovem območju bodočnost so $v$ anketnem vprašalniku potrdili kmetovalci Cirkovc, Gorišnice in Sv. Tomaža, kar 43 \% anketiranih v Stopercah pa je prepričanih, da bo kmetijstvo $\mathrm{v}$ tem delu Haloz postopno nazadovalo. Zaradi visoke stopnje nezaupanja $\mathrm{v}$ bodočnost haloškega kmetijstva skoraj polovica anketiranih kmetovalcev ne ve, ali bodo njihovi nasledniki nadaljevali s kmetovanjem. 
GEOGRAFIJE PoDRAVJA
V. Korošec: Socialno-ekonomski razvoj naselij Cirkovce, Gorišnica, Stoperce in Sveti

Med panoge, ki bi jih bilo smiselno razvijati uvrščajo poljedelstvo in živinorejo, haloški kmetovalci zaznavajo priložnosti pretežno $\mathrm{v}$ živinoreji in tudi v ekološki pridelavi, predvsem pa pričakujejo več specializiranih in tržno usmerjenih kmetij.

V razvojnih strategijah večine občin Spodnjega Podravja in v drugih regijskih programih je razvoj turizma na podeželju opredeljen kot neizkoriščena priložnost s številnimi gospodarskimi, družbenimi in okoljskimi učinki (Območni razvojni program Spodnje Podravje za obdobje 2014 - 2020). Ob tem nekoliko preseneča ugotovitev, da v nobenem od obravnavanih naselij anketirani prebivalci turizma ne ocenjujejo kot razvojne priložnosti, saj menijo, da na podeželju ni možnosti za turizem, ali da so možnosti dokaj skromne. Le okrog 20 \% jih ocenjuje, da so možnosti dokaj ugodne ter ob tem naštevajo naravne in družbene vrednote ter stavbno in nematerialno dediščino, ki lahko prispevajo k večji turistični privlačnosti območja. Za turizem še posebej velja, da je uspešnost razvojnih prizadevanj v veliki meri odvisna od angažiranosti lokalnega prebivalstva in od njegovih znanj, sposobnosti in pripravljenosti za povezovanje (Cigale, 2012: 34). Na podlagi teh spoznaj je mogoče razumeti stališče prebivalcev obravnavanih naselij, da je nezainteresiranost domačinov glavna ovira za razvoj turizma, v Stopercah pa poleg tega opozarjajo na pomanjkanje finančnih sredstev, ki bi omogočila investicije v izboljšanje turistične infrastrukture in kakovostnejšo ponudbo storitev.

Na pomanjkanje zavzetosti, znanja in inovativnosti kažejo tudi razmišljanja domačinov o možnih oblikah turistične ponudbe. Še vedno v večini prisegajo na enodnevni izletniški turizem, ki je usmerjen $\mathrm{v}$ spoznavanje lokalnih naravnih in kulturnih vrednost ter doživljanje kulinaričnih in vinskih posebnosti. V Stopercah in tudi v Sv. Tomažu pa ob tem razmišljajo tudi stacionarnem turizmu na turističnih kmetijah, kar poleg finančnih sredstev zahteva veliko znanja in izvirnosti pri oblikovanju turistične ponudbe.

\section{Zaključek}

Raziskava petih izbranih lokalnih središč leta 1996 je pokazala, da imajo naselja veliko skupnih razvojnih zakonitosti in možnosti za razvoj, kljub različnim razvojnim možnostim ter različnim naravnim in družbeno-ekonomskim pogojem, v katerih se nahajajo. Rezultati naše raziskave in številnih drugih, tudi rezultati raziskave Spodnje Podravje pred izzivi trajnostnega razvoja iz leta 2011, kažejo precejšnje razlike in notranjo diferenciacijo med območji in naselji Spodnjega Podravja, ki so posledica nekaterih sodobnih razvojnih procesov, predvsem deindustrializacije $\mathrm{v}$ zaposlitvenih središčih ter urbanizacije in terciarizacije podeželja.

V strokovnem prispevku, objavljenem v monografiji Spodnje Podravje s Prlekijo, so avtorji raziskave $\mathrm{v}$ zaključnem poglavju zapisali nekaj skupnih razvojnih značilnosti obravnavanih naselij, na podlagi katerih je mogoče prepoznati ključne razvojne spremembe.

V izbranih naseljih so lokalni naravni, družbeni in lokacijski dejavniki, pa tudi številni regionalni in globalni vplivi spodbudili različne razvojne procese, ki so izoblikovali specifično socialno-ekonomsko in prostorsko zgradbo naselij. Na podlagi stopnje urbanizacije lahko izbrana naselja razdelimo v štiri skupine, in sicer: urbano - ruralna (Cirkovce), urbana (Gorišnica), ruralna (Stoperce) in ruralno - urbana (Sv. Tomaž). 
Obravnavana podeželska naselja in celotno Spodnje Podravje se sooča z zapleteno demografsko problematiko, ki se ne kaže zgolj v zmanjševanju števila prebivalcev in staranju populacije, temveč tudi $\mathrm{v}$ nižji izobrazbeni sestavi v primerjavi s slovenskim povprečjem ter šibki zavzetosti domačinov za izvajanje inovativnih sprememb in izboljšav. Ob tem je pomembno zavedanje, da je za uresničevanje razvojnih pobud $\mathrm{v}$ regiji veliko naravnih in družbenih dejavnikov, ki jih dopolnjujejo nekatere nove priložnosti, med katere uvrščamo novo lokalno organiziranost, spremenjene navade potrošnikov in turistov, pa tudi dokončanje izgradnje avtoceste proti hrvaški meji.

Primerjava razvojnih značilnosti in procesov med letoma 1996 in 2016.

\begin{tabular}{|c|c|}
\hline Leto 1991 & Leto 2016 \\
\hline $\begin{array}{l}\text { Vsa naselja se soočajo s problemom } \\
\text { prometne infrastrukture, ki se kaže v } \\
\text { precejšnji oddaljenosti od zaposlitvenih in } \\
\text { oskrbnih središč, slabih cestah in redkih } \\
\text { zvezah javnega prometa. }\end{array}$ & $\begin{array}{l}\text { Po letu } 1991 \text { so se v obravnavanih } \\
\text { naseljih bistveno izboljšali bivalni } \\
\text { pogoji, dostopnost naselij, cestne } \\
\text { povezave in oskrba s pitno vodo, zaradi } \\
\text { novih funkcij pa se naselja prostorsko in } \\
\text { funkcijsko spreminjajo. }\end{array}$ \\
\hline $\begin{array}{l}\text { V obdobju gospodarske recesije so delovna } \\
\text { mesta v bližnjih središčih postala negotova, v } \\
\text { domačih naseljih pa so možnosti za odpiranje } \\
\text { delovnih mest zelo različne, največkrat pa } \\
\text { skromne. }\end{array}$ & $\begin{array}{l}\text { Pomanjkanje delovnih mest } \mathrm{v} \\
\text { nekmetijskih dejavnostih je } \\
\text { najpomembnejši razlog za odseljevanje } \\
\text { mladih. V najnovejšem obdobju se delež } \\
\text { zaposlenih v oskrbnih in storitvenih } \\
\text { dejavnostih v podeželskih naseljih } \\
\text { povečuje. }\end{array}$ \\
\hline $\begin{array}{l}\text { Razvoj vseh naselij temelji na kmetijstvu v } \\
\text { povezavi z zaposlitvijo v neagrarnih } \\
\text { dejavnostih. Poljedelstvo in živinoreja sta } \\
\text { prevladujoči kmetijski dejavnosti. }\end{array}$ & $\begin{array}{l}\text { Kmetijstvo v obravnavanih naselij danes } \\
\text { več ni prevladujoča dejavnost, saj se } \\
\text { niso uveljavile proizvodne spremembe. } \\
\text { Še vedno prevladujeta poljedelstvo in } \\
\text { živinoreja. }\end{array}$ \\
\hline $\begin{array}{l}\text { Podobno kot na širšem območju prebivalstvo } \\
\text { v vseh proučenih naseljih stagnira ali celo } \\
\text { nazaduje. Ker naravnega prirasta ni več, je } \\
\text { gibanje odvisno od selitev. V splošnem delež } \\
\text { mladega prebivalstva nazaduje in raste delež } \\
\text { starega. }\end{array}$ & $\begin{array}{l}\text { Nadaljuje se zmanjševanje števila } \\
\text { prebivalcev in staranje populacije v } \\
\text { obravnavanih naseljih, razen v Gorišnici. } \\
\text { Prebivalce skrbi odseljevanje mladih ter } \\
\text { pomanjkanje usposobljenih kadrov za } \\
\text { uvajanje novosti in razvojnih sprememb. }\end{array}$ \\
\hline $\begin{array}{l}\text { Naselja postajajo spalna naselja drugod } \\
\text { zaposlenega prebivalstva, ki ima različne } \\
\text { motive za bivanje v naseljih. Največ } \\
\text { anketiranih prebivalcev je na prvo mesto } \\
\text { postavilo prijetno, mirno in zdravo bivalno } \\
\text { okolje ter navezanost na domači kraj. }\end{array}$ & $\begin{array}{l}\text { Centralna naselja, zlasti občinska } \\
\text { središča so okrepila svoje centralne } \\
\text { funkcije in utrdila gravitacijski vpliv. } \\
\text { Prebivalci med prednosti bivanja na } \\
\text { podeželju uvrščajo naravo, primerne } \\
\text { pogoje za gradnjo hiš, možnosti za } \\
\text { kmetovanje in nižje življenjske stroške. }\end{array}$ \\
\hline $\begin{array}{l}\text { V vseh naseljih se prepletata kmetijska in } \\
\text { nekmetijska struktura ter funkcija, pri čemer } \\
\text { se kmetijstvo, odvisno od naravnih razmer, v } \\
\text { določenem pogledu krepi, hkrati pa se krepijo } \\
\text { tudi nekmetijski elementi. }\end{array}$ & $\begin{array}{l}\text { Številni in kompleksni dejavniki so } \\
\text { naselja preoblikovali v bolj ali manj } \\
\text { dinamične gospodarske strukture, } \mathrm{v} \\
\text { katerih se prepletajo elementi } \\
\text { tradicionalne ruralne zgradbe s } \\
\text { sodobnimi koncepti podjetništva. }\end{array}$ \\
\hline
\end{tabular}


GEOGRAFIJE PoDRAVJA
V. Korošec: Socialno-ekonomski razvoj naselij Cirkovce, Gorišnica, Stoperce in Sveti 187

Tomaž po letu 1996

\section{Literatura in viri}

Anketiranje gospodinjstev naselij Cirkovce, Gorišnica, Stoperce in Sv, Tomaž, marec 2017.

Cigale, D. 2012: Turizem v Halozah. Geografski obzornik 59, številka 1-2, Ljubljana.

Brečko, V., Klemenčič, M., Korošec, V., Pak, M., Počkaj Horvat, D., Rus, A. 1996: Razvojni problemi in socialnogeografska analiza naselij Cirkovce, Cven, Gorišnica, Stoperce in Sv. Tomaž. Spodnje Podravje s Prlekijo - Možnosti regionalnega in prostorskega razvoja. Zveza geografskih društev, Ljubljana.

Korošec, V. 2006: Vpliv komasacij na kmetijstvo in podeželska naselja na Dravskem in Ptujskem polju. Geografski vestnik 78-1, Ljubljana.

Korošec, V. 2010: Demografski razvoj Haloz po letu 1991 in možnosti regionalnega razvoja. Geografski vestnik 82-1, Ljubljana.

Korže Vovk, A. 2002: Naravni potenciali regij in njihova raba. Dela 18. Ljubljana.

Lampič, B. 2011: Sedanjost in prihodnost kmetijstva. Spodnje Podravje pred izzivi trajnostnega razvoja. GeograFF, Ljubljana.

Potočnik Slavič, I. 2011: Podjetništvo in obrtno-poslovne cone. Spodnje Podravje pred izzivi trajnostnega razvoja. GeograFF, Ljubljana.

Območni razvojni program Spodnje Podravje za obdobje 2014 - 2020, ZRS Bistra Ptuj, 2014 http://www.bistra.si/wp-content/uploads/2012/03/ORP-Spodnje-Podravje-2014-2020potrjen-23.09.2014.pdf (1.3. 2017).

Rebernik, D. 2011: Poselitev in razvoj prebivalstva. Spodnje Podravje pred izzivi trajnostnega razvoja. GeograFF, Ljubljana.

Medmrežje 1: SURS http://pxweb.stat.si/pxweb/dialog/statfile2.asp (1. 3. 2017). 
GEOGRAFIJE PODRAVJA

The GeOgraphies of the Podravje Region 


\title{
Geografski vidiki volitev v Podravju
}

\author{
JERNEJ TIRAN, BOŠTJAN ROGELJ
}

Povzetek Avtorja obravnavata volilno geografijo Podravja s poudarkom na volitvah in referendumih po letu 2011. Prikazana je prostorska razmestitev volilne udeležbe in izidov, rezultati so primerjani z državno ravnijo in prepoznani so dejavniki, ki vplivajo na volilno vedenje. Podravje označuje podpovprečna volilna udeležba v primerjavi s preostalo Slovenijo, politična participacija pa se v večji meri odvija na lokalni ravni. Udeležba je na splošno višja $\mathrm{v}$ okoljih $\mathrm{z}$ bolj ugodnimi družbenogospodarskimi razmerami in politično bolj desno usmeritvijo. Politično levo usmerjena območja so bolj ali manj omejena na mesta, desno usmerjena območja pa na podeželje.

Ključne besede: $\bullet$ Podravje $・$ volitve $\bullet$ volilno vedenje $・$ volilna udeležba - volilni izidi • volilna geografija •

NASLOV AVTORJEv: dr. Jernej Tiran, Geografski inštitut Antona Melika ZRC SAZU, Novi trg 2, 1000 Ljubljana, Slovenija, e-naslov: jernej.tiran@zrc-sazu.si. dr. Boštjan Rogelj, asistent, Univerza v Ljubljani, Filozofska fakulteta, Oddelek za geografijo, Aškerčeva cesta 2, 1000 Ljubljana, Slovenija, enaslov: bostjan.rogelj@ff.uni-lj.si. 


\title{
Geographic aspect of the elections in the Podravje region
}

\author{
JERNEJ TIRAN, BOŠTJAN ROGELJ
}

\begin{abstract}
The authors presents electoral geography of the Podravje region with an emphasis on the elections and referendums after 2011. They studied the spatial distribution of the voter turnout and the results, compared them to the national average, and determined the factors that affect electoral behavior. Podravje region is characterized by a belowaverage voter turnout compared to the rest of Slovenia, while the political participation is mostly focused on the local level. Voter turnout is generally higher in areas with superior socio-economic conditions and a more right-leaning political orientation. Politically left-leaning areas are more or less limited to the cities and the right-leaning to the countryside.
\end{abstract}

Keywords: - Podravje region - elections - electoral behavior • voter turnout • voting results $\bullet$ electoral geography •

CORRESPONDENCE AdDRESS: Jernej Tiran, Ph.D., researcher, Geophical institute Anton Melik ZRC SAZU, Novi trg 2, 1000 Ljubljana, Slovenia, e-mail: jernej.tiran@zrc-sazu.si. Boštjan Rogelj, Ph.D., asistent, University of Ljubljana, Faculty of Arts, Department for geography, Aškerčeva cesta 2, 1000 Ljubljana, Slovenia, e-mail: bostjan.rogelj@ff.uni-lj.si. 


\section{Uvod}

Volilna geografija (tudi geografija volitev) je veja politične geografije, ki z geografskega vidika preučuje volilne procese in rezultate (Shelley in Archer 1997). Osrednjo pozornost posveča prostorskim vzorcem volilnih izidov in vplivu prostora in prostorske organiziranosti nanje. S tem se pomembno loči od politologije, sociologije in drugih ved, ki preučujejo volitve, in tako pomembno prispeva $\mathrm{k}$ celovitejšemu razumevanju družbenih pojavov in procesov. Agnew (1990) volilne raziskave deli v štiri skupine: 1) geografija volilnega vedenja, 2) vpliv geografije na posameznikovo volilno vedenje, 3) geografija volilnih sistemov in 4) odnosi med geografijo volilnega uspeha ter geografijo organiziranosti in mobilizacije političnih strank. V volilno-geografski literaturi prevladujejo raziskave iz prvih dveh skupin: večinoma so to prostorsko-ekološke analize, ki preučujejo prostorske vzorce volilnih izidov in vpliv prostora nanje.

V Sloveniji je volilna geografija slabo uveljavljena in marginalizirana veda, kar lahko pripišemo majhnosti slovenske političnogeografske stroke in njeni osredotočenosti na druge teme, kot so manjšinska in romska problematika, vprašanje meja in geopolitična vprašanja. Volilnogeografskih raziskav je malo. Prvo je 1992 napravil Repolusk, ki je analiziral prostorsko razmestitev izidov parlamentarnih volitev leta 1990. Prvo bolj celovito tovrstno študijo je izdelal politolog Kropivnik (1998), ki je napravil politično regionalizacijo Slovenije na podlagi tipizacije občin. Nekaj je tudi raziskav, ki se posvečajo vplivu prostorskih dejavnikov, na primer povezanosti med volilnimi izidi in stopnjo urbaniziranosti (Tiran, 2011; 2015) in analizi učinka sosedstva (Červ, 2015). Med pomembnejšimi študijami velja omeniti še raziskavo uspešnosti nestrankarskih kandidatov na lokalnih volitvah (Rogelj, 2007), analizo ureditve volilnih enot v državnozborskem volilnem sistemu (Rogelj, 2012) in geografsko analizo volilne udeležbe (Rogelj, Tiran, 2014).

Podravska regija je bila doslej že nekajkrat v ospredju političnega in volilnega dogajanja; nazadnje po mariborskih protestih proti županu leta 2012, ki so sprožili zamenjavo mestne oblasti in razmah vstajniškega gibanja v Sloveniji. Vendar pa je regija razdeljena med dve volilni enoti, zato medijske analize volilnih izidov volitev doslej niso dale jasne in celovite slike, kaj je za Podravje značilno in po čem regija odstopa od preostale Slovenije. Obenem nobena od zgoraj omenjenih raziskav ni podrobneje obravnavala podravske regije.

Namen prispevka je analizirati volilno udeležbo in volilne izide izbranih volitev in referendumov v Podravju in razkriti njihove ključne dejavnike. V prvem delu obeh analiz smo preučili prostorsko razmestitev udeležbe in izidov ter jih primerjali s preostalo Slovenijo, v drugem delu pa smo analizirali njihove dejavnike.

Postavili smo dve hipotezi:

- Volilna udeležba je višja v okoljih z bolj ugodnimi družbenogospodarskimi razmerami in politično bolj desno usmeritvijo.

- Na volilne izide poleg družbenogeografskih dejavnikov pomembno vplivajo tudi prostorski dejavniki. 


\section{Metodologija}

V raziskavi smo uporabili prostorsko-ekološki pristop, ki se pri razlagi osredotoča na vpliv značilnosti prostora, ki na posameznika delujejo v smeri poenotenja volilnega vedenja (npr. Agnew, 1987; Wesley, 2012). Volilni proces smo obravnavali kot »skupinsko doživetje«, v katerem volilna izbira ni posledica značilnosti posameznika, ampak je pod močnim vplivom značilnosti miljeja, v katerem posameznik prebiva ali mu pripada.

V analizi smo se osredotočili na volitve in referendume po letu 2011. Volilno udeležbo in volilne izide v Podravju smo primerjali s Slovenijo s pomočjo indeksov. Analizo prostorske razmestitve smo napravili na ravni 15 podravskih volilnih okrajev, 41 občin in okrog 550 volišč (njihovo število se med posameznimi volitvami razlikuje). Prostorsko razmestitev smo preučili s pomočjo kartografskih prikazov, izdelanih v programu ArcGIS 10.4. V drugem delu analize smo udeležbo in izide skušali pojasniti z izbranimi družbenogospodarskimi, prostorskimi in političnimi kazalniki.

Analizo smo napravili na ravni volišč, najmanjše enote, za katero obstajajo volilni izidi, ki pa smo jih nekoliko preoblikovali. Da bi zadostili načelu statistične zaupnosti in lahko zanje pridobili vse želene družbenogospodarske podatke, smo nekatera manjša volišča združili s sosednjimi tako, da so imela vsaj 170 volilnih upravičencev. Da bi bile nove enote funkcijsko in demografsko čim bolj homogene, smo volišča primarno združevali glede na stičnost poselitve, kot sekundarni kriterij pa smo upoštevali podatek o stopnji urbaniziranosti naselij (Cigale, 2005), pri čemer smo združevali volišča iste ali čim bolj podobne stopnje. Na koncu smo oblikovali 375 prostorskih enot.

Družbenogospodarski kazalniki po teh prostorskih enotah se nanašajo na 1. 1. 2014 in zajemajo vse državljane Republike Slovenije, stare 18 let ali več. Pridobili smo podatke o starostni, izobrazbeni in zaposlitveni sestavi, zaposlenosti po sektorju dejavnosti in bruto dohodkih na prebivalca (Izbrani družbenogospodarski ..., 2016).

Izmed prostorskih kazalnikov smo obravnavali časovno oddaljenost od najbližjega regionalnega središča (Kozina, 2010), gostoto prebivalstva, izračunano po poseljenih območjih, ki jih predstavljajo rastrske celice poseljenih hišnih številk ločljivosti $100 \mathrm{x}$ $100 \mathrm{~m}$ (Tiran, 2017), in stopnjo urbaniziranosti glede na poenostavljeno tipizacijo naselij, $\mathrm{v}$ kateri so naselja razvrščena v mestna, urbanizirana in podeželska (Cigale, 2005).

Za ponazoritev prevladujoče politične usmerjenosti pa smo politične stranke razdelili na levi in desni blok glede na rezultate povezanosti med strankarskimi preferencami in samoopredeljevanjem na osi levo-desno (Politbarometer ..., 2011; 2013; 2014) ter njihove rezultate sešteli. Za večino strank so bili na voljo podatki iz meritve leta 2014 . V levi blok smo uvrstili Socialne demokrate (SD), Pozitivno Slovenijo (PS), Združeno levico (ZL), Zavezništvo Alenke Bratušek (ZAAB), Stranko Mira Cerarja oziroma Stranko modernega centra (SMC) in Demokratično stranko upokojencev (DeSUS), v desni blok pa Slovensko demokratsko stranko (SDS), Novo Slovenijo - Krščanske demokrate (NSi), Slovensko nacionalno stranko (SNS) in Slovensko ljudsko stranko (SLS). Pri analizi smo se omejili na tiste stranke, ki so na posameznih volitvah prejele vsaj $2 \%$ glasov. 
Prostorsko razmestitev volilne udeležbe smo preučili tudi $\mathrm{z}$ metodo razvrščanja $\mathrm{v}$ skupine. Zaradi občutnih prostorskih razlik v udeležbi smo izdelali dve razvrstitvi: prvo na podlagi udeležbe na predsedniških volitvah 2012, predčasnih volitvah v DZ 2014 in volitvah v Evropski parlament 2014, drugo pa na podlagi udeležbe na referendumih o družinskem zakoniku leta 2012 in 2015 ter referendumu o arhivskem gradivu leta 2014. $\mathrm{V}$ obeh primerih smo volišča razdelili $\mathrm{v}$ dve skupini: prvo sestavljajo volišča $\mathrm{s}$ podpovprečno, drugo pa volišča z nadpovprečno volilno udeležbo.

Dejavnike volilne udeležbe in izidov pa smo preučili z multiplo linearno regresijsko analizo (metoda Enter) na ravni preoblikovanih območij volišč. Izbor neodvisnih (pojasnjevalnih) spremenljivk smo naredili $\mathrm{v}$ treh korakih. Najprej smo na podlagi izračunanih korelacijskih koeficientov izločili vse spremenljivke, ki z volilno udeležbo ali izidi niso bile statistično značilno povezane.

Nato smo zaradi problema multikolinearnosti izločili tiste, ki so bile močno povezane z drugimi spremenljivkami. Po izdelavi preliminarnega regresijskega modela pa smo izločili še tiste spremenljivke, ki niso imele statistično značilnega vpliva na vrednost determinacijskega koeficienta.

\section{Prostorske značilnosti volilne udeležbe, splošne značilnosti in primerjava s Slovenijo}

Podravje kot celoto zaznamuje podpovprečna volilna udeležba v primerjavi s preostalo Slovenijo. Na predsedniških, parlamentarnih in evropskih volitvah je bila udeležba od 1992 naprej le nekajkrat v posameznih okrajih višja od državnega povprečja, največkrat v Ormožu in Mariboru VI (slednji obsega južni del mesta). Volilna udeležba se tako kot v Sloveniji na splošno zmanjšuje: na volitvah v DZ 1992 je bila 79,2 \%, na predčasnih volitvah v DZ 2014 pa le še 48,0 \%. Na drugi strani pa se Podravje uvršča med območja, kjer se je udeležba od osamosvojitve naprej najmanj zmanjšala (glej Rogelj, Tiran, 2014).

Na referendumu o malem delu 2011 je bila prvič celo večja kot na državni ravni (indeks 104), podobno velika pa je bila tudi na referendumih o delu na črno, arhivskem gradivu in pokojninski reformi (indeks 98). To hkrati kaže na to, da je tematika zaposlovanja za podravske volivce bolj zanimiva, najbrž zaradi visoke stopnje brezposelnosti v regiji. Nekoliko večja odstopanja beležimo pri predsedniških in državnozborskih volitvah (indeks med 96 in 90), največja pa pri volitvah v Evropski parlament in nekaterih referendumih (indeks pod 90). Na referendumu o družinskem zakoniku leta 2012 je bila udeležba v Podravju skoraj 18 \% nižja kot na državni ravni.

Druga značilnost so relativno velike razlike v volilni udeležbi med referendumi, državnozborskimi, predsedniškimi in evropskimi volitvami, po čemer se Podravje sicer ne razlikuje od preostale Slovenije. Državnozborske volitve stalno beležijo nekoliko višjo udeležbo kot predsedniške. Za volitve v evropski parlament je značilna konstantna nizka udeležba, referendume pa zaznamujejo največja nihanja. Zadnjega referenduma o zakonu o zakonski zvezi in družinskih razmerjih leta 2015 se je udeležilo 36,4 \% volivcev, predzadnjega o zakonu o varstvu dokumentarnega in arhivskega gradiva ter arhivih pa le $11,7 \%$. 


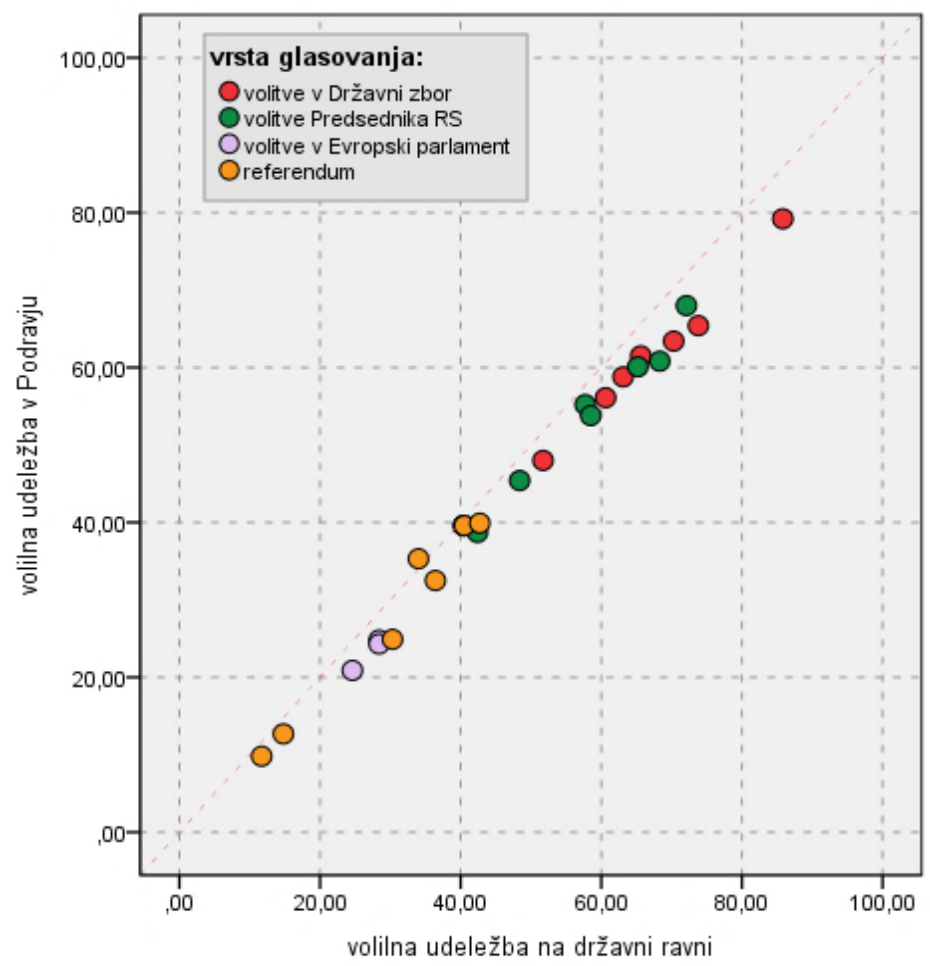

Primerjava volilne udeležbe med Slovenijo in Podravsko regijo na izbranih volitvah in referendumih med letoma 1992 in 2015 (Državna volilna komisija ..., 2015).

Analiza volilne udeležbe po letu 2004 na ravni volilnih okrajev kaže na obstoj pomembnih razlik znotraj regije. Najvišjo udeležbo, ki se večinoma giblje blizu državnega povprečja, nekajkrat pa tudi nad njim, imajo mariborski okraji I, II in VI ter okraja Ptuj II in Ormož. V prvem primeru gre za območje obmestnih naselij zahodno in južno od Maribora, v drugem pa za območje mesta Ptuj in občine Ormož. Najslabšo udeležbo pa imajo okraji Ptuj III, Pesnica, Lenart in mariborski okraji III, V in VII. Gre za območje Haloz in Slovenskih goric ter delov Maribora na desnem bregu Drave in njegovega vzhodnega obmestja.

»Posebna zgodba« pa so lokalne volitve, kjer je bila volilna udeležba leta 2014 v kar 32 od 41 občin višja od državnega povprečja; v občini Sveti Andraž v Slovenskih goricah je bila celo $86,2 \%$, kar je največ izmed vseh slovenskih občin. Nasploh je volilna udeležba precej višja v manjših, podeželskih občinah kot $\mathrm{v}$ večjih in gosteje poseljenih, kar sicer velja tudi za preostalo Slovenijo.

V Mariboru je bila na primer, kljub burnemu lokalnemu političnemu dogajanju zadnji dve leti pred tem, samo $37,9 \%$, v drugem krogu pa še dobrih $6 \%$ nižja. Na volilno udeležbo je vplivala tudi izenačenost županskih kandidatov $-\mathrm{v}$ štirih občinah $\mathrm{z}$ najnižjo udeležbo izvoljeni kandidat ni imel protikandidata. 
GEOGRAFIJE PODRAVJA

Primerjava volilne udeležbe v podravskih volilnih okrajih z državnim povprečjem na izbranih volitvah 2004-2014 (Državna volilna komisija ..., 2015).

\begin{tabular}{|c|c|c|c|c|c|c|c|c|}
\hline \multirow[b]{2}{*}{ Volilni okraj } & \multicolumn{8}{|c|}{ Indeks volilne udeležbe v volilnem okraju (Slovenija=100) } \\
\hline & $\begin{array}{l}\text { ঠ } \\
\text { N } \\
\text { N }\end{array}$ & $\begin{array}{l}\infty \\
\stackrel{2}{0} \\
\text { N }\end{array}$ & $\begin{array}{l}\bar{O} \\
\text { N } \\
\text { Ô }\end{array}$ & $\begin{array}{l} \pm \\
\text { } \\
\text { N }\end{array}$ & $\begin{array}{l}\stackrel{8}{8} \\
\text { N } \\
\text { II }\end{array}$ & $\begin{array}{l}\stackrel{\nabla}{\circ} \\
\stackrel{\sim}{0} \\
\stackrel{0}{I}\end{array}$ & ర્ટું & 边 \\
\hline Slovenska Bistrica & 90,4 & $\overline{92,5}$ & $9 \overline{94,3}$ & $9 \overline{94,1}$ & 92,0 & 81,5 & 94,5 & 94,5 \\
\hline Ruše & 96,4 & 97,1 & 94,7 & 95,3 & 81,7 & 83,3 & 99,6 & 92,9 \\
\hline Maribor I & 95,8 & 98,6 & 97,0 & 100,5 & 90,7 & 92,5 & 99,3 & 98,7 \\
\hline Maribor II & 94,8 & 98,2 & 98,8 & 97,0 & 97,2 & 81,5 & 99,2 & 97,1 \\
\hline Maribor III & 91,7 & 93,7 & 94,2 & 93,1 & 79,2 & 77,5 & 91,8 & 88,7 \\
\hline Maribor IV & 91,9 & 93,7 & 90,1 & 94,6 & 96,6 & 100,9 & 92,3 & 94,1 \\
\hline Maribor V & 90,4 & 90,9 & 87,9 & 90,2 & 82,9 & 86,0 & 90,4 & 89,0 \\
\hline Maribor VI & 95,8 & 100,1 & 97,6 & 101,5 & 89,9 & 94,2 & 99,1 & 100,2 \\
\hline Maribor VII & 87,3 & 89,8 & 87,8 & 88,6 & 80,2 & 80,0 & 90,1 & 85,7 \\
\hline Ormož & 97,4 & 93,0 & 95,1 & 89,4 & 95,9 & 92,7 & 105,5 & 98,6 \\
\hline Lenart & 89,1 & 90,3 & 92,7 & 87,3 & 79,0 & 73,0 & 95,5 & 90,7 \\
\hline Pesnica & 86,3 & 91,5 & 90,7 & 89,5 & 84,6 & 75,9 & 87,6 & 84,4 \\
\hline Ptuj I & 94,4 & 87,9 & 96,6 & 91,2 & 88,0 & 88,9 & 100,2 & 101,9 \\
\hline Ptuj II & 96,9 & 94,7 & 96,2 & 96,8 & 90,3 & 95,5 & 97,6 & 99,3 \\
\hline Ptuj III & 89,0 & 86,1 & 89,4 & 82,0 & 80,0 & 77,5 & 94,7 & 88,1 \\
\hline
\end{tabular}

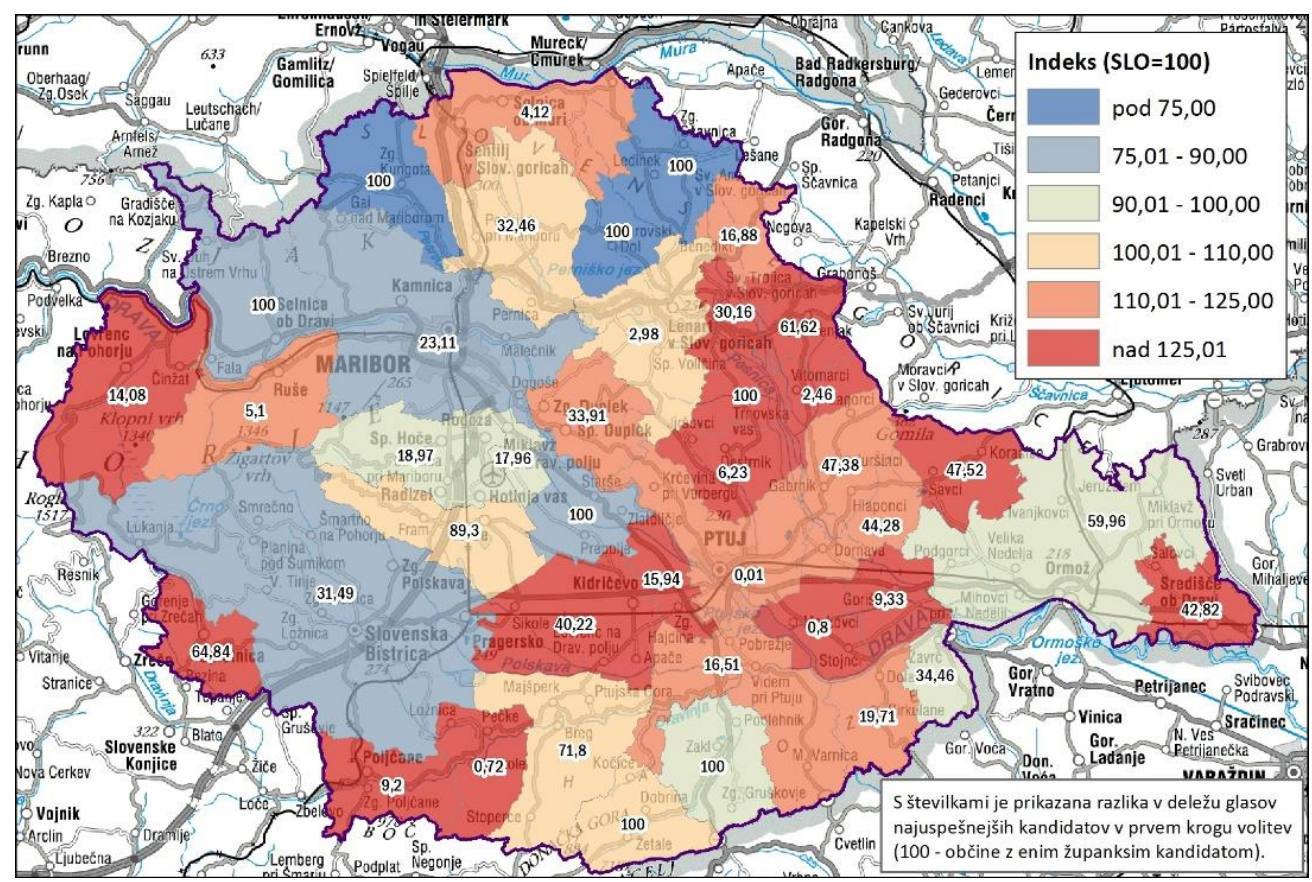

Volilna udeležba na lokalnih volitvah 2014. 


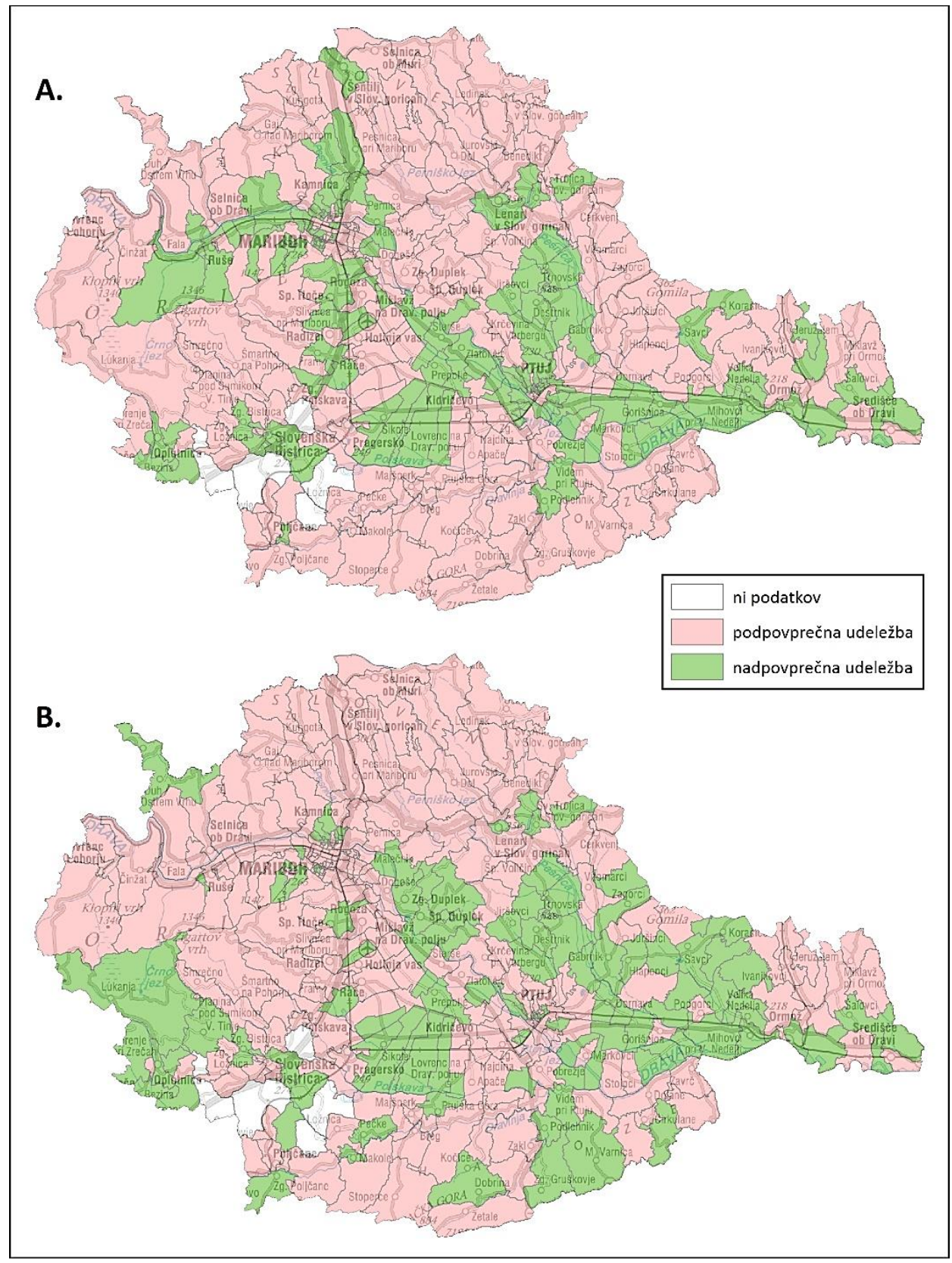

Razvrstitev volišč v skupine po volilni udeležbi (A: volitve, B: referendumi).

Zelo podobne rezultate dobimo, če volilno udeležbo analiziramo na ravni volišč. V razvrstitvi A (»volitve«) so območja z višjo volilno udeležbo skoncentrirana na dveh oseh: prva poteka ob Dravi od Ruš prek Maribora in Ptuja do Ormoža, druga pa ob avtocesti od Slovenske Bistrice prek Maribora do Šentilja. Višja volilna udeležba je značilna tudi za nekatera manjša občinska središča, kot so Oplotnica, Lenart, Trnovska vas, Destrnik, Podlehnik in Videm pri Ptuju ter za del Dravskega polja med Pragerskim 
in Kidričevim. Po nadpovprečni volilni udeležbi izstopajo tudi posamezna volišča $\mathrm{v}$ Mariboru (Nova vas, Pekre in del »meščanskega« dela mesta na levem bregu Drave) in Ptuju (redkeje poseljeni deli). Nižja udeležba je značilna za večji del Slovenskih goric, Haloz in Pohorja, nekatera volišča v Mariboru (v starem mestnem jedru in na območjih z prevladujočim industrijskim značajem, kot so Studenci, Tezno in Melje) in Ptuju (staro mestno jedro).

V razvrstitvi B (»referendumi«) pa je težišče območja z višjo volilno udeležbo v okolici Ptuja, v trikotniku Lenart - Ormož - Slovenska Bistrica. Nasprotno od prve razvrstitve je višja udeležba značilna za dobršen del Haloz ter južni del Slovenskih Goric, nižja pa za območje Maribora in Ptuja ter Dravsko dolino vzhodno od Ruš. Ob tem velja omeniti, da so v občini Duplek in Destrnik istočasno z referendumom 2012 potekale nadomestne županske volitve, kar je udeležbo precej povečalo. Razlike med obema razvrstitvama nakazujejo na pomembne razlike v dejavnikih, ki vplivajo na volilno udeležbo na volitvah oziroma referendumih.

\section{Analiza dejavnikov volilne udeležbe}

V prvi končni regresijski model smo vključili osem kazalnikov oziroma neodvisnih spremenljivk, s katerimi smo skušali pojasniti volilno udeležbo na predčasnih volitvah v Državni zbor 2014.

Rezultati regresijskega modela vpliva družbenogospodarskih, prostorskih in političnih dejavnikov na volilno udeležbo predčasnih volitev v Državni zbor 2014.

\begin{tabular}{|l|c|c|c|}
\hline & $\mathrm{B}$ & SE B & $\beta$ \\
\hline Konstanta & 46,61 & 3,24 & \\
\hline Osnovnošolska izobrazba &,- 37 &, 05 &,$- 57^{* *}$ \\
\hline Uspešnost desnih strank &, 17 &, 03 &, $38^{* *}$ \\
\hline Upokojenci &, 23 &, 05 &, $24^{* *}$ \\
\hline Ostali neaktivni &,- 47 &, 12 &,$- 23^{* *}$ \\
\hline Brezposelnost &,- 53 &, 12 &,$- 19^{* *}$ \\
\hline Kvartarni sektor &, 14 &, 06 &, $14^{*}$ \\
\hline Oddaljenost regionalnega središča &, 07 &, 03 &, $11^{*}$ \\
\hline Mestno naselje & $-1,31$ &, 65 &,$- 11^{*}$ \\
\hline $\begin{array}{l}\text { Prilagojen } \mathrm{R}^{2}=, 55^{* *} \\
* \mathrm{p} \leq, 05, * * \mathrm{p} \leq, 01\end{array}$ & & & \\
\hline
\end{tabular}

$\mathrm{B}=$ multipli regresijski koeficient, $\mathrm{SE} \mathrm{B}=$ standardna napaka multiplega regresijskega koeficienta, $\beta=$ standardizirani multipli regresijski koeficient

Model je statistično značilen, pri čemer nam uspe pojasniti malo manj kot 55 \% variance odvisne spremenljivke. Volilna udeležba je na splošno manjša na območjih z nižjo stopnjo izobrazbe $(\beta=-0,57)$ in večja na območjih s prevladujočo desno politično usmeritvijo $(0,38)$, pa tudi večjim deležem upokojencev $(0,24)$, manjšim deležem ostalih neaktivnih (skupina vključuje prejemnike socialnih in drugih pomoči ter nadomestil, gospodinje, prejemnike državnih pokojnin in podobno) $(-0,23)$ in brezposelnih $(-0,19)$. K regresijskemu modelu statistično pomembno prispevajo še delež zaposlenih v kvartarnem sektorju, oddaljenost regionalnega središča in stopnja urbaniziranosti, a njihov vpliv ni 
zelo izrazit. Rezultati so tako skladni s prvo od postavljenih hipotez. Rezultati so podobni tistim v raziskavi, ki sta jo za celotno Slovenijo na ravni volilnih okrajev napravila Rogelj in Tiran (2014), v kateri pa nista upoštevala prostorskih in političnih kazalnikov.

V drugi končni regresijski model pa smo vključili šest kazalnikov oziroma neodvisnih spremenljivk, s katerimi smo skušali pojasniti volilno udeležbo na referendumu o družinskem zakoniku 2015.

Model je statistično značilen, pri čemer nam uspe pojasniti malo več kot 48 \% variance odvisne spremenljivke. Izkaže se, da je na višjo volilno udeležbo odločilno vplivala predvsem desna politična usmerjenost $(\beta=0,66)$. Po pojasnjevalni moči zanjo precej zaostajata dva družbenogospodarska dejavnika - delež prebivalcev z osnovnošolsko izobrazbo ali manj $(-0,34)$ in stopnja brezposelnosti $(-0,27)$. Volilna udeležba je na splošno višja na podeželskih območjih $(0,21)$ in na območjih $z$ večjim deležem zaposlenih v kvartarnem sektorju $(0,16)$, vpliv deleža ostalih neaktivnih pa je tokrat skoraj zanemarljiv $(-0,13)$. Tudi ti rezultati so skladni s prvo od postavljenih hipotez, a je tako velika pojasnjevalna moč politične usmerjenosti kar nekoliko presenetljiva. Rezultati kažejo na to, da je mobilizacija nasprotnikov predlaganega zakona večinoma (uspešno) potekala $\mathrm{v}$ desno usmerjenih političnih okoljih.

Rezultati regresijskega modela vpliva družbenogospodarskih, prostorskih in političnih dejavnikov na volilno udeležbo predčasnih volitev na referendumu o družinskem zakoniku 2015.

\begin{tabular}{|l|c|c|c|}
\hline & $\mathrm{B}$ & $\mathrm{SE} \mathrm{B}$ & $\beta$ \\
\hline Konstanta & 32,25 & 2,84 & \\
\hline Uspešnost desnih strank (DZ 2014) &, 31 &, 029 &, $66^{* *}$ \\
\hline Osnovnošolska izobrazba &,- 24 &, 06 &,$- 34^{* *}$ \\
\hline Brezposelnost &,- 80 &, 13 &,$- 27^{* *}$ \\
\hline Podeželsko naselje & 2,56 &, 65 &, $21^{* *}$ \\
\hline Kvartarni sektor &, 17 &, 06 &, $16^{* *}$ \\
\hline Ostali neaktivni &,- 29 &, 13 &,$- 13^{*}$ \\
\hline $\begin{array}{l}\text { Prilagojen } \mathrm{R}^{2}=, 48^{* *} \\
* \mathrm{p} \leq, 05, * * \mathrm{p} \leq, 01\end{array}$ & & \\
\hline
\end{tabular}

$\mathrm{B}=$ multipli regresijski koeficient, $\mathrm{SE} \mathrm{B}=$ standardna napaka multiplega regresijskega koeficienta, $\beta=$ standardizirani multipli regresijski koeficient

\section{Prostorske značilnosti volilnih rezultatov, splošne značilnosti in primerjava s Slovenijo}

V 1. krogu volitev predsednika republike 2012 so kandidirali Borut Pahor, Danilo Türk in Milan Zver. Njihovi rezultati na ravni podravske regije ne odstopajo bistveno od preostale Slovenije. Izstopata predvsem nadpovprečni podpori Zveru v Spodnjem Podravju in Türku v Mariboru, kar lahko pripišemo tudi njunemu krajevnemu izvoru: Zver je mladost preživel v Destrniku pri Ptuju, Türk pa v Mariboru. V 2. krogu volitev je Pahor prepričljivo premagal Türka in dobil več glasov v vseh podravskih okrajih, podprlo pa ga je tudi veliko tistih, ki so v 1. krogu glasovali za Zvera. S tem lahko pojasnimo tudi razliko v volilnem rezultatu Türka med Mariborom in preostalim delom Podravja, ki je 
še večja kot v 1 . krogu volitev.

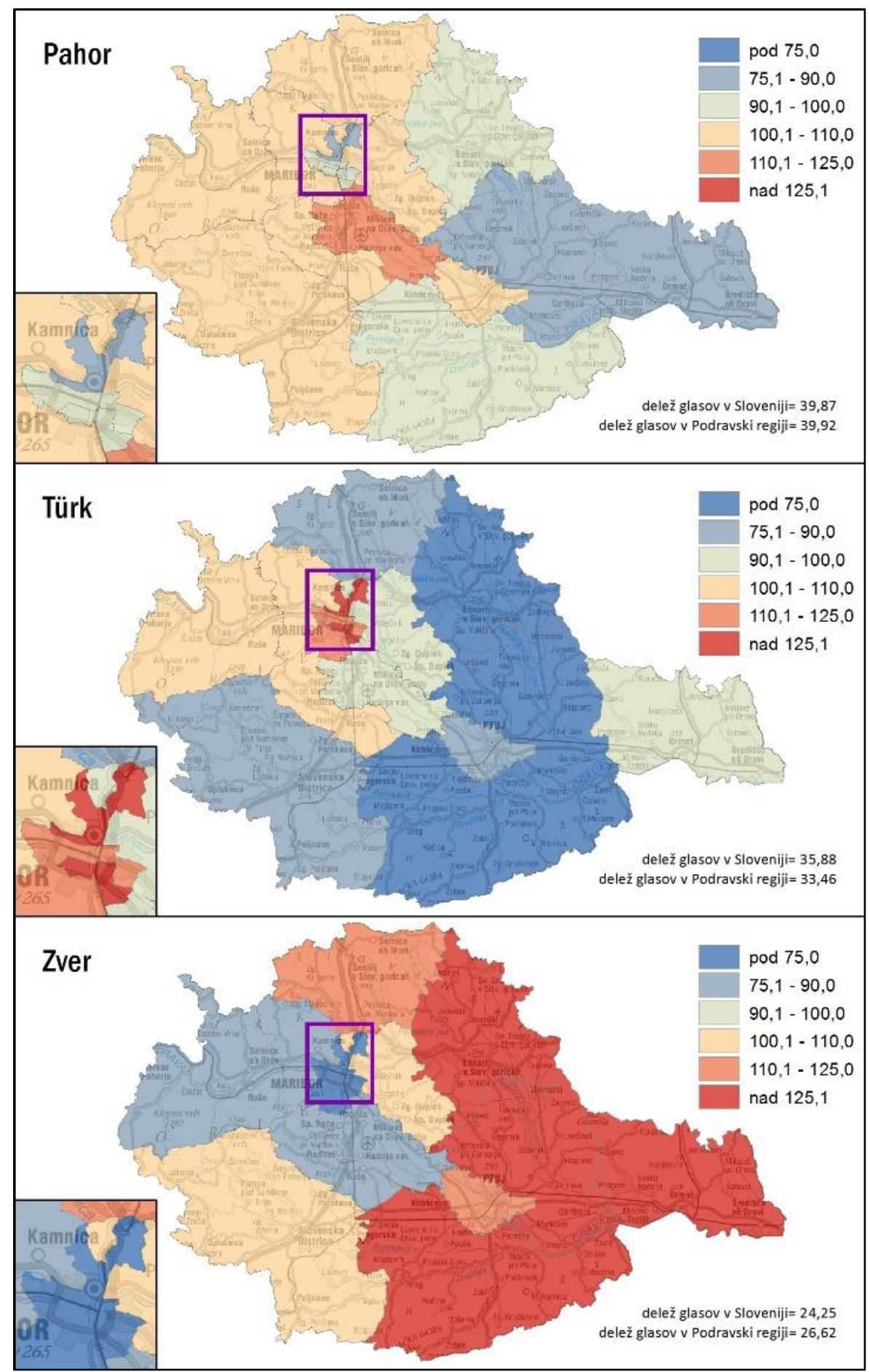

Rezultati predsedniških volitev 2012 (1. krog). 
Iz spodnjih dveh slik so razvidne izrazite prostorske razlike med uspešnostjo levih in desnih strank na predčasnih volitvah v DZ 2014.

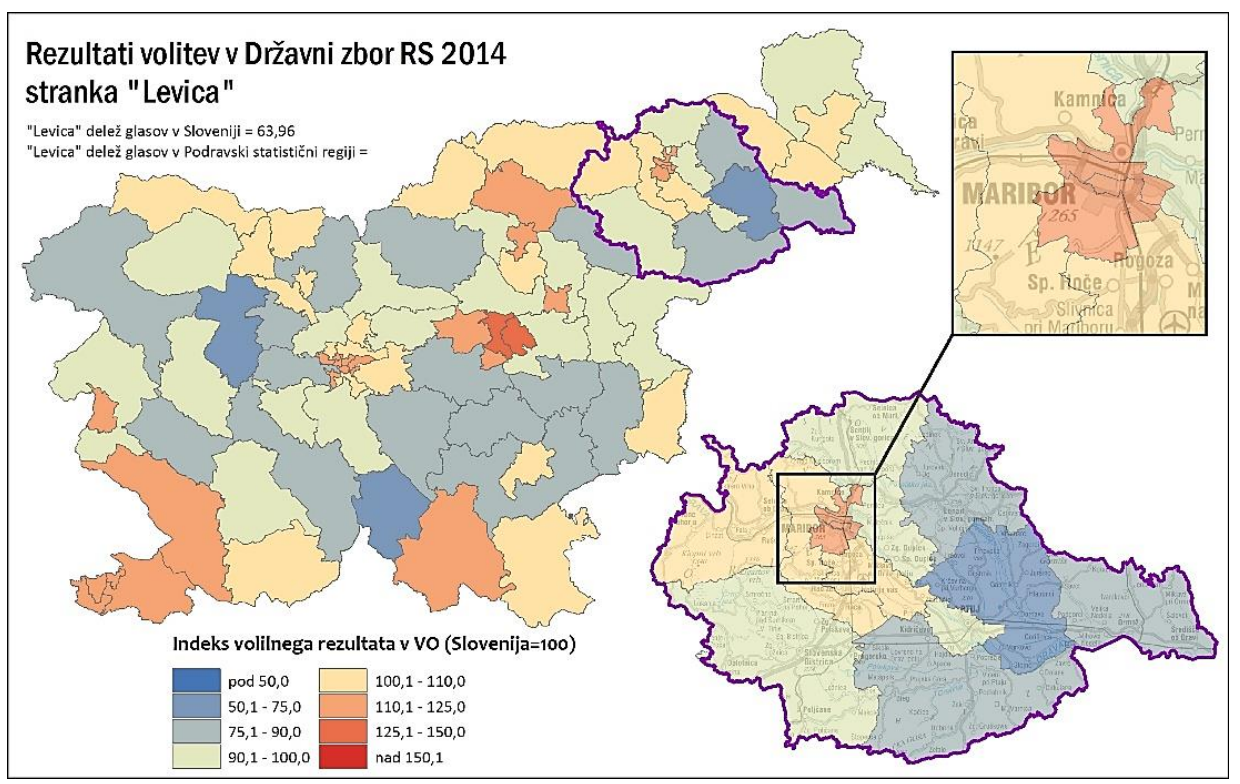

Uspešnost strank levega bloka na predčasnih volitvah v Državni zbor 2014.

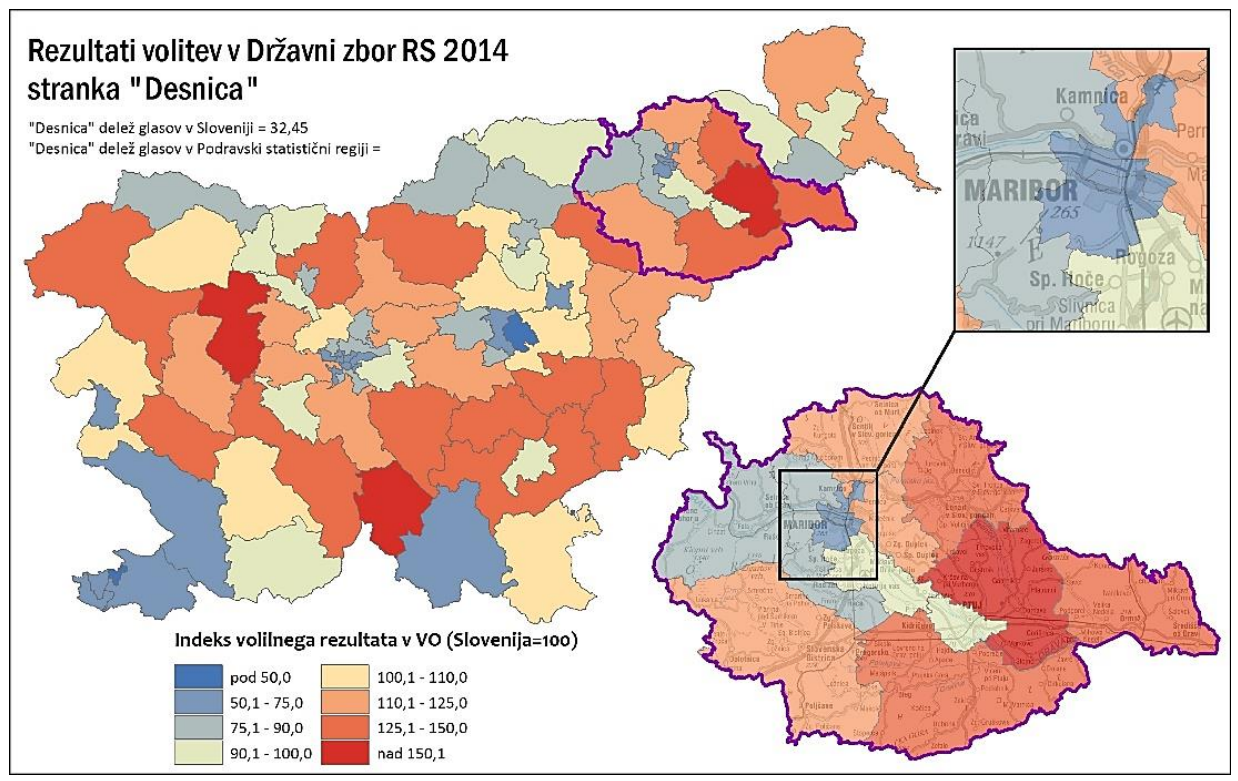

Uspešnost strank desnega bloka na predčasnih volitvah v Državni zbor 2014.

Podpora levim strankam je največja v Mariboru, od koder dokaj enakomerno upada proti obrobju. Največje sklenjeno območje s prevladujočo levo politično usmerjenostjo je v Mariboru z okolico. Levica je nadpovprečno podporo prejela še v večjem delu Ptuja ter 
manjših mestih, kot so Slovenska Bistrica, Lenart, Ormož in Kidričevo. Desna politična usmerjenost prevladuje v Slovenskih goricah, Halozah, Dravinjskih goricah, torej skoraj izključno na podeželju.

Podrobnejši vpogled v rezultate posameznih strank razkriva nekatere zanimivosti: SNS, ki sicer ni presegla parlamentarnega praga, je v Podravju prejela občutno večjo podporo kot v večini preostale Slovenije. Razen v dveh ptujskih in lenarškem okraju so podravski volivci nadpovprečno naklonjeni stranki DeSUS. Nadpovprečno podporo DeSUS-u v Podravju lahko pojasnimo z dejstvom, da je stranka leta 1990 nastala iz jedra članov Društva upokojencev Maribor-center in ji je vse do danes uspelo ohraniti močno regionalno volilno bazo. Močno zaledje volivcev ima v Podravju tudi SLS, v manjši meri tudi SDS, a je omejeno na podeželske predele. Podpora ZL-ju, SD-ju in SMC-ju je podpovprečna in večja na urbanih območjih; bolj enakomerna je razmestitev glasov za SMC, a je tudi iz nje vidna ločnica med mestnimi in podeželskimi območji. Najbolj podpovprečna pa je podpora PS-ju, kar ni presenetljivo, če vemo, da je njen najbolj prepoznavni član Zoran Janković, mlada stranka pa v času od svoje ustanovitve ni uspela vzpostaviti močnejših regionalnih strankarskih struktur. Tudi podpora NSi-ju je v Podravju precej manjša kot na državni ravni, a pozitivno izstopa njen rezultat v Ormožu (9,5 \%; indeks 169,3), ki je v tem okraju vedno dosegala dobre rezultate, prepoznavni član stranke in nekdanji poslanec Alojz Sok pa je dandanes ormoški župan.

\section{Deleži glasov za stranke na volitvah 2014 v Podravju in Sloveniji.}

\begin{tabular}{|l|c|c|c|}
\hline Stranka/skupina strank & Slovenija (\%) & $\begin{array}{c}\text { Podravje } \\
(\%)\end{array}$ & Indeks \\
\hline SMC & 34,5 & 34,2 & 99,2 \\
\hline SDS & 20,7 & 21,2 & 102,3 \\
\hline DeSUS & 10,2 & 12,3 & 120,7 \\
\hline SD & 6,0 & 5,6 & 93,6 \\
\hline ZL & 6,0 & 5,3 & 89,5 \\
\hline NSI & 5,6 & 3,9 & 70,5 \\
\hline ZAAB & 4,4 & 3,9 & 87,9 \\
\hline SLS & 3,9 & 4,6 & 116,6 \\
\hline PS & 3,0 & 1,7 & 58,6 \\
\hline SNS & 2,2 & 3,7 & 170,3 \\
\hline Levica & 64,0 & 63,0 & 98,5 \\
\hline Desnica & 32,4 & 33,5 & 103,2 \\
\hline Neparlamentarne stranke & 12,7 & 13,6 & 106,9 \\
\hline
\end{tabular}

V lokalni politični areni je za Podravje značilna nadpovprečna zastopanost političnih strank v primerjavi z nestrankarskimi kandidati glede na preostalo Slovenijo. Na lokalnih volitvah 2014 je bila politična stranka predlagatelj izvoljenega župana v 22 od 41 občin (53,7 \%): 10-krat je bila to parlamentarna stranka, 9-krat neparlamentarna stranka in 3krat koalicija strank. Politične stranke »obvladujejo« lokalno politično areno predvsem na podeželju, pri čemer močno prednjačijo stranke desnega političnega spektra: največ županov imata SLS (8) in SDS (7), NSi ima 2, od ostalih strank pa imata župana samo še SD in LDS (po enega). Ob tem je treba poudariti, da se je število županov, ki prihajajo iz nestrankarskih vrst, v primerjavi z lokalnimi volitvami 2006 občutno povečalo, in sicer za 15 oz. 36,6 \%. To nas napeljuje k sklepanju, da je v Podravju na lokalni ravni do 
nadomeščanja strankarskih kandidatov $\mathrm{z}$ nestrankarskimi prišlo pozneje kot $\mathrm{v}$ večini preostale Slovenije (glej tudi Rogelj 2007). Po številu županskih kandidatov pa izstopa Maribor (17), sledijo mu Ptuj, Ruše (po 9) in Hoče-Slivnica (8).

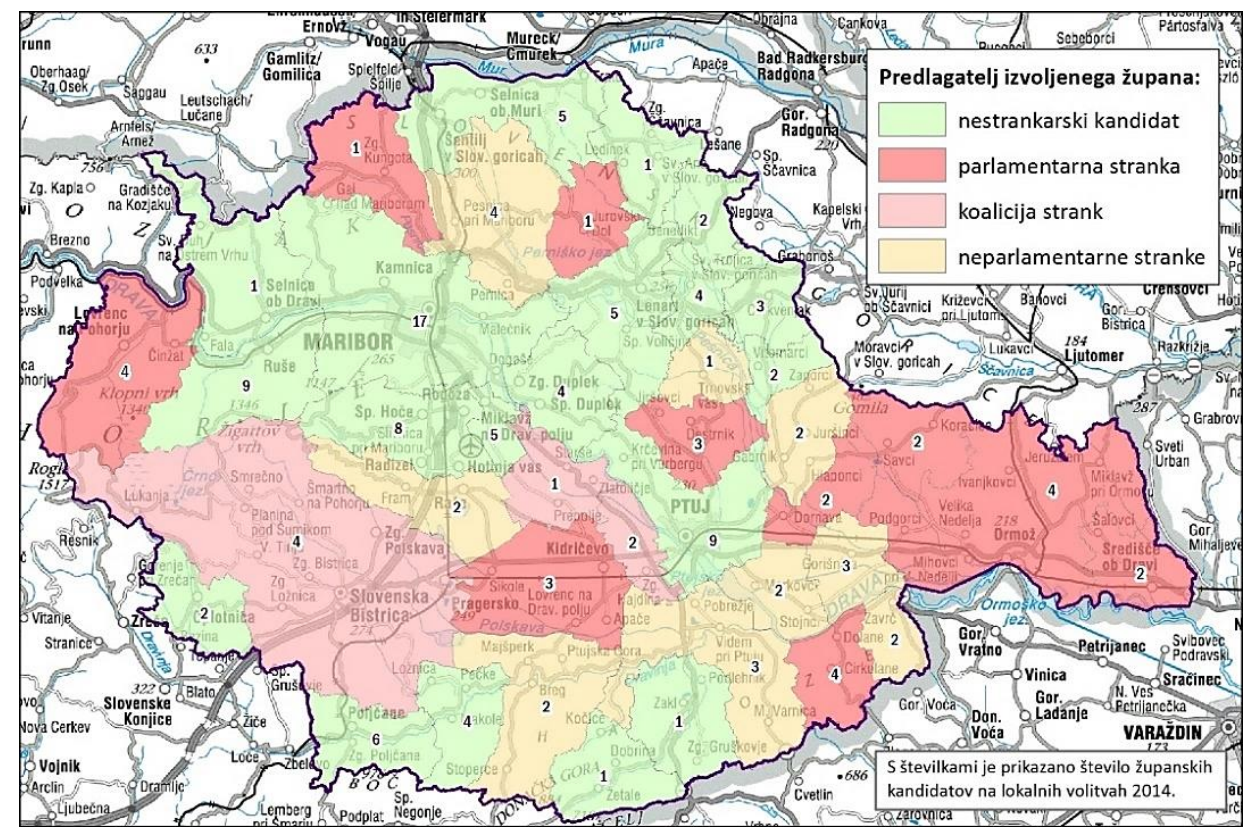

Politični izvor predlagateljev izvoljenega župana in število županskih kandidatov na lokalnih volitvah 2014.

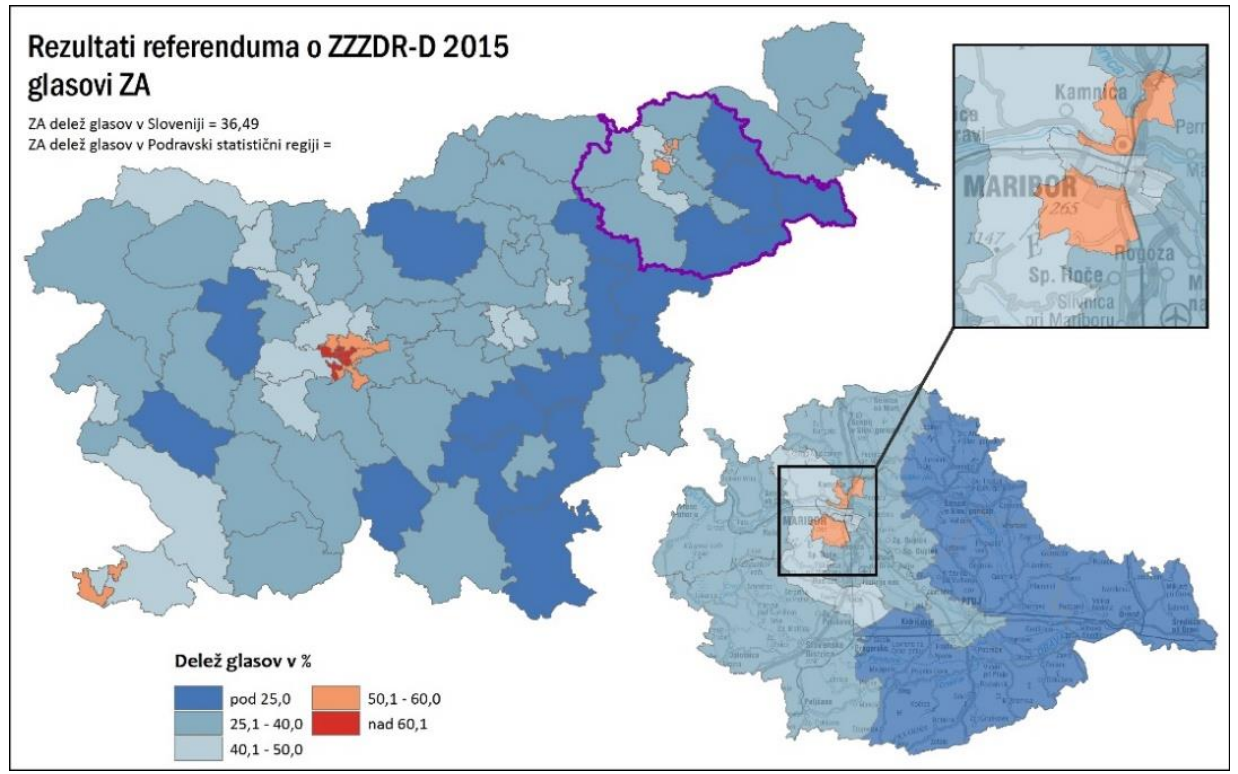

Delež glasov »za« na referendumu o družinskem zakoniku 2015. 
Referendum o noveli Zakona o zakonski zvezi in družinskih razmerjih 2015 je bolj ali manj potrdil politično razdeljenost Podravja na »levo-liberalni« Maribor in »desnotradicionalno« podeželsko zaledje. Razmestitev glasov se namreč precej ujema z razmerjem glasov med levico in desnico na predčasnih volitvah v DZ 2014. Zakon je bil sicer, tako kot v Sloveniji, tudi v Podravju prepričljivo zavrnjen. Poleg večine mariborskih okrajev je bil delež glasov glede na državno raven nadpovprečen še v okraju Ptuj II. Analiza glasov po voliščih razkrije, da je bila podpora družinskemu zakoniku največja na levem, »meščanskem« bregu Drave, kjer je bila primerljiva z Ljubljano in večinoma več kot $60 \%$. Po nizki podpori pa izstopajo predvsem Haloze, kjer je zakon prejel samo okrog $13 \%$ podporo, na petih tamkajšnjih voliščih celo brez enega samega glasu za predlagani zakon.

\section{Analiza dejavnikov volilnih rezultatov}

Rezultati regresijskega modela vpliva družbenogospodarskih, prostorskih in političnih dejavnikov na volilni izid strank desnega bloka na predčasnih volitvah v Državni zbor 2014.

\begin{tabular}{|l|c|c|c|}
\hline & B & SE B & $\beta$ \\
\hline Konstanta & 67,91 & 5,10 & \\
\hline Osnovnošolska izobrazba &, 44 &, 07 &, $30^{* *}$ \\
\hline Starost (nad 50 let) &,- 65 &, 09 &,$- 27^{* *}$ \\
\hline Primarni sektor &, 54 &, 12 &, $20^{* *}$ \\
\hline Oddaljenost od regionalnega središča &,- 27 &, 06 &,$- 19^{* *}$ \\
\hline Brezposelnost & $-1,09$ &, 21 &,$- 17^{* *}$ \\
\hline Gostota prebivalstva &,- 02 &, 01 &,$- 14^{* *}$ \\
\hline Podeželska naselja & 3,24 & 1,09 &, $13^{* *}$ \\
\hline Mestna naselja & $-2,99$ & 1,28 &,$- 11^{*}$ \\
\hline $\begin{array}{l}\text { Prilagojen } \mathrm{R}^{2}=, 69 * * \\
* \mathrm{p} \leq, 05, * * \mathrm{p} \leq, 01\end{array}$ & & \\
\hline
\end{tabular}

$\mathrm{B}=$ multipli regresijski koeficient, $\mathrm{SE} \mathrm{B}=$ standardna napaka multiplega regresijskega koeficienta, $\beta=$ standardizirani multipli regresijski koeficient

V končni regresijski model pa smo vključili osem kazalnikov oziroma neodvisnih spremenljivk, s katerimi smo skušali pojasniti uspešnost strank desnega političnega bloka (SDS, NSi, SLS in SNS) na predčasnih volitvah v DZ 2014. Model je statistično značilen in uspe pojasniti visokih $69 \%$ variance odvisne spremenljivke. Izkaže se, da je na prevladujočo desno politično usmerjenost najbolj vplivata slabša izobrazbena sestava (ß $=0,30)$ in mlajša starostna sestava $(-0,27)$ : stranke desnega političnega spektra so torej večjo podporo dobile zlasti $\mathrm{v}$ okoljih $\mathrm{z}$ večjim deležem volivcev $\mathrm{z}$ osnovnošolsko izobrazbo, manjšo pa v okoljih z večjim deležem volivcev, starejših od 50 let (slednje si lahko razložimo z volilno bazo stranke DeSUS, ki se uvršča v levi del političnega spektra). Na volilni uspeh desnih strank poleg deleža zaposlenih v primarnem sektorju $(0,20)$ in stopnje brezposelnosti $(-0,17)$, pomembno vplivajo tudi prostorski dejavniki. Stranke desnega političnega bloka imajo večjo podporo v območjih, ki so bolj oddaljena od regionalnega središča $(-0,19)$, manj gosto poseljena $(-0,14)$ in podeželskega značaja $(0,13)$, kar nakazuje na vpliv miljeja na volilne izide. 


\section{Sklep}

V prispevku smo s prostorsko-ekološkim pristopom na ravni volilnih okrajev in volišč analizirali volilno udeležbo in volilne izide izbranih volitev in referendumov v Podravju in razkrili njihove ključne dejavnike. Ugotovili smo, da Podravje zaznamuje podpovprečna volilna udeležba $\mathrm{v}$ primerjavi s preostalo Slovenijo. Vendar pa hkrati Podravje sodi med območja, kjer se je udeležba od osamosvojitve naprej najmanj zmanjšala, na nekaterih referendumih na temo dela in zaposlovanja pa je bila celo višja od državnega povprečja. Politična participacija se v večji meri odvija na lokalni ravni, saj je bila na lokalnih volitvah 2014 udeležba v kar 32 od 41 občin višja od državnega povprečja. Najvišjo udeležbo na predsedniških, državnozborskih in evropskih volitvah imajo območje obmestnih naselij zahodno in južno od Maribora, Nova vas, Pekre in del »meščanskega« dela mesta na levem bregu Drave, Ptuj s širšo okolico in občina Ormož. Najslabša udeležba pa je značilna za območje Haloz, Slovenskih goric, vzhodnega obmestja Maribora in predele Maribora s prevladujočim »industrijskim« značajem (Tezno, Studenci, Melje). Volilna udeležba je na splošno večja na območjih z višjo stopnjo izobrazbe in prevladujočo desno politično usmeritvijo - slednja je imela odločujoč vpliv na udeležbo na referendumu o družinskem zakoniku. Prvo hipotezo, da je volilna udeležba višja $v$ okoljih $\mathrm{z}$ bolj ugodnimi družbenogospodarskimi razmerami in politično bolj desno usmeritvijo, lahko na podlagi dobljenih rezultatov potrdimo.

Podravje se notranje občutno razlikuje tudi po prevladujoči politični usmerjenosti, ki se oblikuje na osi urbano-ruralno. Stranke levega bloka so uspešnejše v Mariboru z okolico, v večjem delu Ptuja ter manjših mestih in občinskih središčih, kot so Slovenska Bistrica, Lenart, Ormož in Kidričevo. Desna politična usmerjenost pa prevladuje v Slovenskih goricah, Halozah in Dravinjskih goricah, torej skoraj izključno na podeželju. Posebnost Podravja je večja zastopanost političnih strank v primerjavi z nestrankarskimi kandidati na lokalni ravni. Na prevladujočo politično usmerjenost najbolj vplivata izobrazbena in starostna sestava, pomembno pa tudi zaposlitvena sestava in prostorski dejavniki, kot so oddaljenost od regionalnega središča, gostota poselitve in stopnja urbaniziranosti. Drugo hipotezo, da na volilne izide poleg družbenogeografskih pomembno vplivajo tudi prostorski dejavniki, tako lahko potrdimo.

Ugotovitve raziskave odpirajo nove iztočnice za prihodnje raziskave. Mehanizme volilne udeležbe in volilnega vedenja bi bilo smiselno preučiti tudi na ravni individualnih, javnomnenjskih podatkov in rezultate primerjati z agregiranimi podatki. Tako bi lažje in bolj nedvoumno odgovorili na vprašanje, koliko je volilno vedenje posledica demografskih značilnosti posameznikov in kolikšen vpliv ima na to okolje oziroma milje, v katerem posameznik živi. Vsekakor je podrobnejše obravnave vredno tudi razmerje med participacijo na lokalni in državni ravni, ki je v Podravju izrazito v prid prvi. Na podlagi razlik v udeležbi med lokalnimi in ostalimi volitvami lahko izpeljemo sklep, da ne gre za odsotnost politične participacije, temveč zgolj njeno drugačno obliko. Vehovar in Tiran (2016) na primeru Slovenije sklepata, da šibkost višje, državne ravni okrepi procese družbene integracije na ravni lokalne skupnosti. Zdi se, da je Podravje ena izmed regij, kjer je ta proces najbolj izrazit, verjetno tudi zaradi večjega nezadovoljstva $z$ državnimi političnimi institucijami, katerih sedeži so od ljudi tudi prostorsko precej oddaljeni. 


\section{Literatura in viri}

Agnew, J. A. 1987: Place and politics. The Geographical Mediation of State and Society. Boston. Agnew, J. A. 1990: From political methodology to geographical social theory? A critical review of electoral geography, 1960-87. Developments in Electoral Geography. London in New York.

Cigale, D. 2005: Posodobitev Ravbarjeve tipizacije naselij z vidika stopnje urbaniziranosti na podlagi RPE 2002. Ocena ponudbe in povpraševanja po zemljiščih za gradnjo na nivoju regije in države - priprava vhodnih podatkov in izvedba ankete: 1 . fazno poročilo. Univerza v Ljubljani, Filozofska fakulteta, Oddelek za geografijo (podatkovni sloj).

Červ, A. 2015: Vpliv učinka poznanstva in sosedstva na volilno vedenje v volilnem okraju Tolmin. Dela 44. https://doi.org/10.4312/dela.44.1.25-43

Državna volilna komisija: Rezultati volitev in referendumov po volilnih okrajih in voliščih. 2016. Javne informacije Slovenije, Geodetska uprava Republike Slovenije, Državna pregledna karta v merilu $1: 250.000 .2016$.

Javne informacije Slovenije, Geodetska uprava Republike Slovenije, Volišča za volitve v Državni zbor (Register prostorskih enot). 2016.

Kozina, J. 2010: Časovna oddaljenost naselij od regionalnih središč po cestnem omrežju v Sloveniji. Geografski inštitut Antona Melika ZRC SAZU (podatkovni sloj).

Kropivnik, S. 1998: Slovenski volivci v geografskem, družbenem in ideološkem prostoru. Ljubljana.

Politbarometer 03/2011. Medmrežje: https://www.ip-rs.si/fileadmin/user_upload/Pdf/novice/politbarometer2011.pdf

Politbarometer 01/2013. Center za raziskovanje javnega mnenja. Medmrežje: https://www.iprs.si/fileadmin/user_upload/Pdf/razno/politbarometer_1-2013.pdf

Politbarometer 6/2014. Center za raziskovanje javnega mnenja. Medmrežje: http://www.cjm.si/ul/2014/PB_6_14.pdf

Repolusk, P. 1992: Geografska analiza volitev leta 1990. Geographica Slovenica 23.

Rogelj, B. 2007: Uspeh nestrankarskih kandidatov na lokalnih volitvah 2006. Dela 27. http://dx.doi.org/10.4312/dela.27.9.163-181

Rogelj, B. 2012: Ureditev volilnih enot v državnozborskem volilnem sistemu. Dela 37. Ljubljana. DOI: $10.4312 /$ dela.37.6.107-128

Rogelj, B. in Tiran, J. 2014: Geografska analiza volilne udeležbe v Sloveniji. Geografski vestnik 86-2.

Shelley, F. M. in Archer, J. C. 1997: Electoral Geography. Directions in Political Geography.

Izbrani družbenogospodarski podatki po preoblikovanih voliščih za volitve v Državni zbor. Stanje na dan 1. 1. 2014. Statistični urad Republike Slovenije. Ljubljana, 2016.

Tiran, J. 2011: Settlement area type as a factor of electoral behaviour in Slovenia. Hrvatski geografski glasnik 73-1. Zagreb.

Tiran, J. 2015: Urbano proti ruralnemu: (nov) razcep v slovenskem političnem prostoru? Teorija in praksa $52-1 / 2$.

Tiran, J. 2017: Gostota poselitve v podravski regiji. Geografski inštitut Antona Melika ZRC SAZU (podatkovni sloj).

Vehovar, U. in Tiran, J. 2016: Oris izbranih kazalnikov retradicionalizacije slovenske družbe. Družboslovne razprave 32-83.

Wesley, J. 2012: Voter turnout in Manitoba. An ecological analysis. Canadian Political Science Review 6-2/3. 
GEOGRAFIJE PoDRAVJA

The GeOgRAPHIES OF THE PODRAVJe REgION 


\section{GEOGRAFIJE URBANE POKRAJINE}

\section{THE GEOGRAPHIES OF URBAN \\ LANDSCAPE}





\title{
Demografski razvoj in značilnosti prebivalstva $v$ mestu Maribor
}

\author{
UROŠ HORVAT
}

Povzetek Avtor opredeli faze razvoja prebivalstva v mestu Maribor. Hitri rasti števila prebivalstva $\mathrm{v} 60$. letih 20 . stoletja je sledila stagnacija $\mathrm{v} 80$. letih in nato depopulacija $\mathrm{v} 90$. letih in po letu 2000. V primerjavi z drugimi večjimi mesti v Sloveniji je bila depopulacija najbolj intenzivna prav v Mariboru. Naravni prirast je v mestu konstantno negativen vse od leta 1985 dalje, selitveni prirast pa je bil med letoma 1992 in 2007. Maribor med večjimi slovenskimi mesti izkazuje tudi najbolj neugodno starostno sestavo prebivalstva $\mathrm{z}$ najvišjim deležem starega prebivalstva in najvišjim indeksom staranja, po zadnjem popisu prebivalstva pa zaostaja za drugimi mesti tudi po deležu prebivalstva $\mathrm{z}$ višje ali visoko šolsko izobrazbo, čeprav je drugo največje univerzitetno mesto v Sloveniji.

Ključne besede: • demografski razvoj • nataliteta $\bullet$ starostna sestava • izobrazbena sestava $\bullet$ Maribor •

NASLOV AVTORJA: dr. Uroš Horvat, docent, Univerza v Mariboru, Filozofska fakulteta, Oddelek za geografijo, Koroška cesta 160, 2000 Maribor, Slovenija, e-naslov: uros.horvat@um.si. 


\title{
Demographic development and population characteristics in the city of Maribor
}

\author{
UROŠ HORVAT
}

\begin{abstract}
Author identified stages of demographic development in the city of Maribor (Slovenia). Population growth in the 1960s was followed by stagnation of population in the 1980s and depopulation in the 1990s and after 2000. In Maribor, compared with other major cities in Slovenia, depopulation have been more intensive. Natural growth is constantly negative from 1985 onwards, and net migration was negative between 1992 and 2007. Maribor is also showing the most unfavorable age structure of the population with the highest proportion of the elderly population and the highest aging index. Furthermore, according to the last census it lags behind other towns in the share of population with high school education, although it is the second largest university town in Slovenia.
\end{abstract}

Keywords: - demographic development $\bullet$ natality $\bullet$ age structure $\bullet$ educational structure • Maribor •

CORRESPONDENCE ADDRESS: Uroš Horvat, Ph.D., Assistant Professor, University of Maribor, Faculty of Arts, Department for geography, Koroška cesta 160, 2000 Maribor, Slovenia, e-mail: uros.horvat@um.si. 
U. Horvat: Demografski razvoj in značilnosti prebivalstva v mestu Maribor

\section{Uvod}

Mesto Maribor po številu prebivalcev in tudi drugih kriterijih velja za drugo največje mesto v Sloveniji. Zavodnik et al. (2008: 306) ga opredeljujejo kot srednje veliko mesto $\mathrm{z}$ mednarodnim pomenom, čeprav je potrebno ob tem seveda poudariti tudi mnenje Pelca (2012: 22), da če Ljubljano z okoli četrt milijona prebivalcev morda še lahko uvrstimo med srednje velika evropska mesta, tega za Maribor najbrž ne moremo storiti.

V prispevku je analiziran demografski razvoj v mestu Maribor od sredine 19. stoletja dalje, s poudarkom na razvoju $\mathrm{v}$ zadnjih petih desetlejih, predstavljene pa so tudi demografske značilnosti prebivalstva v zadnjih treh desetletjih. Prebivalstveni razvoj v Mariboru jev obravnevanem obdobju sledil glavnim razvojnim tendencam $v$ drugih slovenskih mestih, vendar pa je imel tudi specifične značilnosti in je v nekaterih elementih celo najbolj izstopal, predvsem v negativni smeri. Depopulacija se je med večjimi slovenskimi mesti pojavila najprej prav v Mariboru in bila tam v 80., še bolj pa v 90. letih 20. stoletja tudi najbolj intenzivna (Horvat 2006: 42). Maribor ima med večjimi mesti v Sloveniji tudi najvišji delež starega prebivalstva in najvišji indeks staranja prebivalstva, kar bo odločilno vplivalo na njegov nadaljnji gospodarski in družbeni razvoj.

$\mathrm{V}$ analizo so zajeti podatki popisov prebivalcev, ki opredeljujejo spremembo števila prebivalstva v mestu, za njihovo razumevanje pa so po letu 1979 uporabljeni tudi podatki naravnega in selitvenega prirasta prebivalstva. Med prebivalstvenimi sestavami je največji poudarek namenjen starostni sestavi (deleži prebivalstva po osnovnih starostnih kontingentih, indeks staranja prebivalstva), med t. im. socio-ekonomskimi pa se analiza osredotoča na izobrazbeno sestavo (zlasti na delež prebivalstva z višjo in visoko šolo), saj izobraževanje v razviti družbi vse bolj postaja dejavnik spodbujanja gospodarske rasti, izboljševanja socialne kohezije in zmanjševanja družbenih neenakosti.

Zaradi vpliva različnih socialnih in ekonomskih dejavnikov se demografske razmere seveda razlikujejo po posameznih delih mesta. Analiza prikazuje razmere po 38 delih mesta (bivših krajevnih skupnostih) in nakazuje pomembno soodvisnost med demografskimi gibanji ter razvojem funkcij, vrsto in obdobjem izgradnje posameznega dela mesta, kvaliteto bivalnega okolja, stopnjo dostopnosti javnih dobrin, idr.

\section{Metodologija}

Pri interpretaciji podatkov je potrebno opozoriti na problem, ki izhaja iz spremembe metodologije in vira zajema podatkov tekom opazovalnega obdobja. Leta 2008 je prišlo do zadnje spremembe statistične definicije prebivalstva v Sloveniji (Medmrežje 1, 2015). Po predhodni definiciji, ki je veljala od leta 1995, se je za prebivalca Slovenije štela oseba, ki je v Sloveniji prijavila stalno in/ali začasno prebivališče, niso pa se upoštevali tisti državljani Republike Slovenije s prijavljenim stalnim prebivališčem v Sloveniji, ki so prijavili začasno odsotnost iz Republike Slovenije za tri mesece ali več. Dolžina prebivanja v Sloveniji torej ni bila pomembna. Nova definicija iz leta 2008 pa je kot ključno merilo za uvrstitev osebe med prebivalstvo Slovenije uvedla prav dolžino prebivanja v Sloveniji. Prebivalci Republike Slovenije so po spremenjeni statistični definiciji osebe (ne glede na državljanstvo) s prijavljenim prebivališčem v Sloveniji, ki v Sloveniji prebivajo ali imajo namen prebivati eno leto ali več in niso začasno odsotne iz 
Republike Slovenije eno leto ali več. Prebivalci Slovenije so tako tudi tuji državljani in teh je v mestih bistveno več kot v nemestnih naseljih, kar vpliva na rezultate predvsem pri analizi selitvenega gibanja prebivalstva. Sprememba metodologije pomeni prelom v časovni vrsti podatkov, zato podatki po novi definiciji (v preglednicah $\mathrm{v}$ tej analizi vključno od leta 2009 dalje) niso neposredno primerljivi s podatki za predhodna leta.

Bistvena sprememba metodologije je torej vidna predvsem $\mathrm{v}$ drugačni prostorski prerazporeditvi prebivalstva in večjem obsegu selitvenega gibanja prebivalstva. Po novi definiciji namreč štejejo osebe, ki imajo poleg stalnega prijavljeno tudi začasno prebivališče, na naslovu začasnega prebivališča, če imajo začasno prebivališče prijavljeno za eno leto ali več. Po stari definiciji so te osebe šteli na naslovu stalnega prebivališča. Posledica prerazporeditve prebivalstva je spremenjeno število prebivalcev zlasti v mestnih naseljih v Sloveniji. V mestnih naseljih se je število prebivalcev zaradi navedene spremembe »administrativno « relativno najbolj povečalo, saj se v njih nahajajo ustanove, ki jim nova zakonodaja določa prijavno obveznost (kot so npr. domovi za starejše občane, dijaški in študentski domovi in podobno), v njih pa je tudi največ tujcev. Tako se npr. v mestu Maribor med letoma 2008 in 2009 beleži povečanje števila prebivalstva za več kot 2.824 oseb, vendar pa je to povečanje posledica navedene statistične spremembe ter tudi dejstva, da so podatki za selitve tujcev pred letom 2008 temeljile le na ocenah, saj so se zbirali po drugem viru zajema podatkov. Obenem se v podatkih za leto 2009 upošteva tudi priključitev naselja Košaki (in njegova ukinitev) k mestu Maribor.

\section{Število prebivalcev v Mariboru}

V obdobju od sredine 19. stoletja do danes lahko demografski razvoj v Mariboru razdelimo v naslednja razvojna obdobja (Pak, 1994: 57-59; Počkaj Horvat, 1997: 46-49; Horvat, 2006: 41-62):

- obdobje od sredine do konca 19. stoletja - za katerega je značilna hitra rast števila prebivalstva, ki je celo presegala povprečno rast v drugih večjih mestih v Sloveniji. Med letoma 1850 in 1900 se je število prebivalcev povečalo iz 5.700 na 31.300 prebivalcev. Rast sta pospeševali razvoj trgovine in nastajajoča industrija, ki se je razvila po izgradnji južne železnice med Dunajem in Trstom in obdravske koroške železnice. Poselitev se je pričela širiti tudi na desnem bregu Drave, kjer je v 60. letih 19. stoletja na Studencih nastala prva delavska stanovanjska kolonija, v 80. letih pa se je gradbeno začelo zapolnjevati območje Tabora med današnjo Metelkovo ulico, kadetnico in bolnišnico.

- obdobje od začetka 20. stoletja do konca druge svetovne vojne - demografska rast se je umirila in zaostaja za razvojem v drugih večjih mestih v Sloveniji. V tem obdobju so bila zgrajena obsežna stanovanjska območja na desnem bregu reke Drave (Studenci, Tabor), levi breg pa je pridobil podobo meščanske četrti (Drozg, Pak, 1994: 48). Leta 1931 je v Mariboru živelo nekaj več kot 46.200 prebivalcev.

- obdobje po drugi svetovni vojni do leta 1981 - za to obdobje je značilna nadpovprečna demografska rast, ki je bila povezana $\mathrm{z}$ intenzivno 
industrializacijo in priseljevanjem prebivalstva s podeželja. Mestu so bila priključena stanovanjska območja na vzhodu (Tezno in Pobrežje), največjo spremembo $\mathrm{v}$ prostorskem razvoju mesta pa pomeni širitev na jug (t. im. območje Maribor-Jug). Poleg večstanovanjskih je bila intenzivna tudi gradnja individualnih stanovanjskih hiš, tako v mestu samem kot na njegovem obrobju (Belec, Drozg, 1994: 37). Med letoma 1948 in 1981 se je število prebivalcev povečalo z okoli 62.700 na okoli 106.100 prebivalcev.

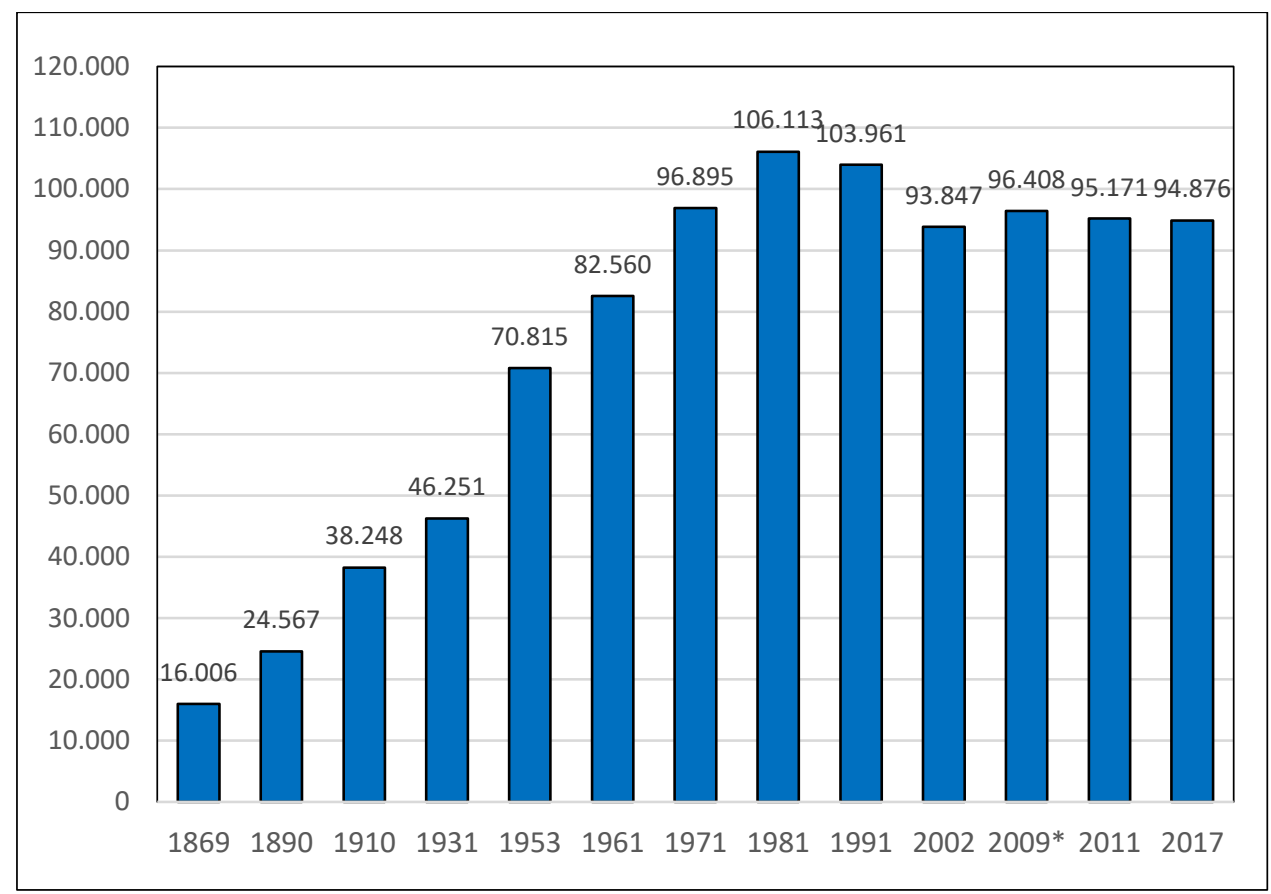

Opomba: SURS od leta 2008 uporablja spremenjeno statistično definicijo prebivalstva. Po novi definiciji štejejo osebe, ki imajo poleg stalnega prijavljeno tudi začasno prebivališče, na naslovu začasnega prebivališča, če imajo le-to prijavljeno za eno leto ali več (po stari definiciji so bile te osebe štete na naslovu stalnega prebivališča). To pomeni prelom $v$ časovni vrsti podatkov, zato podatki od leta 2008 dalje niso neposredno primerljivi s podatki za predhodna leta. Število prebivalcev se je v Sloveniji »administrativno« relativno najbolj povečalo v mestnih naseljih, v katerih se nahajajo ustanove, ki jim zakonodaja določa prijavno obveznost (kot so npr. domovi za starejše občane, dijaški in študentski domovi in podobno) in kjer je največ tujcev. Obenem se v podatkih za Maribor v letu 2009 upošteva tudi priključitev naselja Košaki k Mariboru.

Število prebivalcev v naselju Maribor med letoma 1869 in 2016.

Indeks spremembe števila prebivalcev v naselju Maribor med letoma 1869 in 2016

(v primerjavi z letom 1981).

\begin{tabular}{|l|c|c|c|c|c|c|}
\hline Leto & 1869 & 1890 & 1910 & 1931 & 1953 & 1961 \\
\hline Indeks (1981) & 15 & 23 & 36 & 44 & 67 & 78 \\
\hline Leto & 1971 & 1981 & 1991 & 2002 & 2011 & 2017 \\
\hline Indeks (1981) & 91 & 100 & 98 & 88 & 90 & 89 \\
\hline
\end{tabular}


- obdobje med letoma 1981 in 1991 - v začetku 80. let je proces klasične urbanizacije s priseljevanjem prebivalstva iz manj razvitih območij SV Slovenije in drugih republik bivše Jugoslavije postopoma pričel nadomeščati proces suburbanizacije z razseljevanjem mestnega prebivalstva v okolico, ki ga je še pospešilo zaostajanja $v$ gospodarskem razvoju Maribora. Obenem se je močno zmanjšala tudi rodnost prebivalstva, tako da je bil naravni prirast prebivalstva v mestu konstantno negativen vse od leta 1985 dalje. Stagnacija oziroma zmanjšanje števila prebivalstva je bila v Mariboru opazna prej kot v drugih večjih mestih v Sloveniji in je vplivala, da se je med letoma 1981 in 1991 število prebivalcev v mestu zmanjšalo za 2.152 oseb (za $2 \%$ ).

- obdobje med letoma 1991 in 2002 (po nekaterih podatkih do 2008) predstavlja obdobje močne depopulacije. Zaradi gospodarske stagnacije in propada velikih industrijskih podjetij ter družbeno-gospodarskega zaostajanja za območjem osrednje Slovenije se je močno zmanjšala rodnost in tudi priseljevanje v mesto, obenem pa se je okrepilo odseljevanje (zlasti v obmestje Maribora, pa tudi širše, zlasti v Ljubljano). Nekaj prebivalcev je v mesto pritegnil razvoj visokega šolstva in razvoj drugih kvartarnih dejavnosti, ki je nekoliko zajezil odseljevanje visokokvalificiranih kadrov. Leta 1991 je v Mariboru živelo 103.961 prebivalcev, leta 2002 pa le še 93.847, kar pomeni zmanjšanje za 10.114 oseb (t. j. za 9,7 \% oziroma s povprečno letno stopnjo okoli $1 \%$ ). V primerjavi z drugimi večjimi mesti v Sloveniji izkazuje Maribor v tem obdobju največjo depopulacijo, ki se je nadaljevala tudi po letu 2002, vendar natančni podatki o številu prebivalcev v mestu med letoma 2002 in 2008 tudi na SURS niso dostopni, analiza naravnega in selitvenega gibanja prebivalstva pa kaže, da se je depopulacija po letu 2002 nadaljevala.

- obdobje med letoma 2009 in 2015 - predstavlja obdobje ponovne stagnacije števila prebivalstva. V začetku leta 2008 je v Mariboru živelo 93.584 prebivalcev, njihovo število se je po spremembi metodologije »administrativno« povečalo za nekaj tisoč, zlasti na račun upoštevanja stanovalcev v študentskih domovih v Mariboru, tujcev, k mestu pa so priključili tudi naselje Košaki z nekaj več kot 1.000 prebivalci. Podatki po letu 2009 kažejo na stagnacijo ali celo na majhno zmanjšanje števila prebivalcev v mestu (94.876 prebivalcev v letu 2017).

Primerjava Maribora z drugimi mesti v Sloveniji kaže, da je tudi v njih v obdobju intenzivnega gospodarskega razvoja v 60. in 70. letih 20. stoletja na prebivalstveni razvoj in rast mest močno vplivala predvsem velika selitvena mobilnost prebivalstva. Prevladujoča smer selitev je bila usmerjena iz vasi v mesta, kar je vplivalo na deagrarizacijo podeželja na eni in naglo večanje mest na drugi strani. K temu je dodatno prispevalo priseljevanje prebivalstva iz drugih republik bivše Jugoslavije, ki je bilo tudi usmerjeno v največja industrijska zaposlitvena središča. Tako so v obdobju med letoma 1961 in 1981 beležila rast vsa velika mesta v Sloveniji; npr. Ljubljana za okoli 54 \%, Celje $35 \%$, Kranj $56 \%$ in Koper $115 \%$, nekoliko manjša mesta pa so imela še višjo rast, npr. Novo mesto 181 \%, Nova Gorica 164 \% in Slovenj Gradec 94 \%. Maribor je že v tem obdobju izstopal, saj je bila rast prebivalstva najnižja (le 29 \%) (Horvat, 2006: 42). 
Po letu 1981 se je rast mestnega prebivalstva v Sloveniji umirjala. Do leta 1991 se je delež mestnega prebivalstva sicer povzpel na 50,7 \%, vendar se je povprečna letna stopnja rasti znižala na $1,4 \%$, ob tem da je skupno prebivalstvo v Sloveniji naraščalo po $1,0 \%$ letni stopnji. Tako se je proces koncentracije prebivalstva $\mathrm{v}$ mestih zmanjševal $\mathrm{v}$ korist urbanizacije širše pokrajine, kar je pomenilo prehod iz sekundarne $\mathrm{v}$ terciarno, postindustrijsko urbanizacijo (Ravbar, 1989: 219). Opisani proces urbanizacije podeželja se v novejši geografski literaturi označuje s pojmom suburbanizacija. Le-ta je bila v manjšem obsegu prisotna že v 70. letih, ko je zajela predvsem najbližja obmestna naselja v Ljubljani, v 80. letih, še bolj pa v 90. letih 20. stoletja pa se je močno intenzivirala. Mestno prebivalstvo Slovenije se je pričelo razseljevati v vedno bolj oddaljena obmestna naselja, kar je bilo povezano s prostorsko preobrazbo obmestnih naselij in tudi depopulacijo v mestih (Rebernik, 1999: 42).

Proces suburbanizacije, močno zmanjšana rodnost $v$ mestih, posledično pa staranje mestnega prebivalstva, so povzročili, da je v večini velikih mest v Sloveniji prišlo do depopulacije. Podatki kažejo, da se je med letoma 1991 in 2002 število prebivalcev v Ljubljani zmanjšalo za $3 \%$, v Celju za 7,1 \%, Kranju za 2,4 \% in v Kopru za 4 \%. Depopulacija je bila (poleg Murske Sobote) najbolj intenzivna prav v Mariboru, kjer se je pojavila že v 80., še povečala pa v 90. letih 20. stoletja, kar je vplivalo na zmanjšanje števila prebivalcev za kar 9,7\%.

\section{Naravno in selitveno gibanje prebivalstva}

Analiza naravnega in selitvenega gibanja prebivalstva omogoča opredeliti procese, ki so vplivali na zmanjšanje števila prebivalcev v mestu po letu 1979. Naravni prirast prebivalstva je bil $v$ začetku 80. let še pozitiven, vendar se je že močno zmanjšal v primerjavi s predhodnim obdobjem. Že leta 1985 je bilo v Mariboru število rojenih prvič manjše od števila umrlih. V drugi polovici 80 . let je razlika med številom rojenih in umrlih znašala okoli -100 oseb na leto. Selitveni prirast prebivalstva je bil velik in še vedno pozitiven (v mesto se je priselilo okoli 400 oseb na leto več kot se jih je odselilo), kar je vplivalo na rast števila prebivalcev (Horvat, 2006: 46).

V prvi polovici 90. let 20. stoletja se je negativni naravni prirast še povečal (razlika med rojenimi in umrlimi je v povprečju znašala že okoli -220 oseb na leto), temu pa se je v tem obdobju pridružil tudi negativni selitveni prirast (razlika med priseljenimi in odseljenimi je znašala okoli -450 oseb na leto). Odseljevanje se je še intenziviralo v drugi polovici 90. let (ko je razlika med priseljenimi in odseljenimi znašala že več kot -800 oseb na leto), tako da se je v drugi polovici 90. let število prebivalcev v Mariboru v povprečju zmanjšalo za več kot 1.100 oseb na leto. Enaki trendi so se nadaljevali tudi v obdobju med letoma 2000 in 2007 (razlika med rojenimi in umrlimi je v povprečju znašala okoli -300 oseb na leto, razlika med priseljenimi in odseljenimi pa več kot -800 oseb na leto), tako da se je število prebivalcev v mestu v povprečju zmanjšalo za več kot 1.100 oseb na leto. Posebej dramatično je dejstvo, da se je med letoma 1997 in 2007 število prebivalcev v Mariboru zmanjšalo v povprečju za več kot 1.000 oseb na leto.

V Mariboru je naravni prirast konstantno negativen vse od leta 1985 dalje (v Sloveniji npr. le v obdobju med letoma 1997 in 2005), selitveni prirast pa med letoma 1992 in 2007, ter predstavlja tisti odločilen dejavnik, zaradi katerega je bila depopulacije v mestu v zadnjih desetletjih tako intenzivna. Negativni selitveni prirast je po letu 1991 celo 2- do 
3-krat presegel negativni naravni prirast prebivalstva. Analize namreč kažejo, da je k zmanjšanju števila prebivalstva okoli $30 \%$ prispevalo negativno naravno gibanje, okoli $70 \%$ pa negativno selitveno gibanje prebivalstva (Horvat, 2006: 59). Če je bilo v mestu $\mathrm{v} 60$. in 70 . letih 20 . stoletja, zaradi velike gospodarske rasti, zelo intenzivno priseljevanje, se je po letu 1991 to obrnilo povsem v nasprotno smer. Zaradi pomanjkanja delovnih mest je bilo močno tudi izseljevanje v druge občine Slovenije (zlasti v Ljubljano, od koder se po študiju velik del diplomantov ni vrnil).

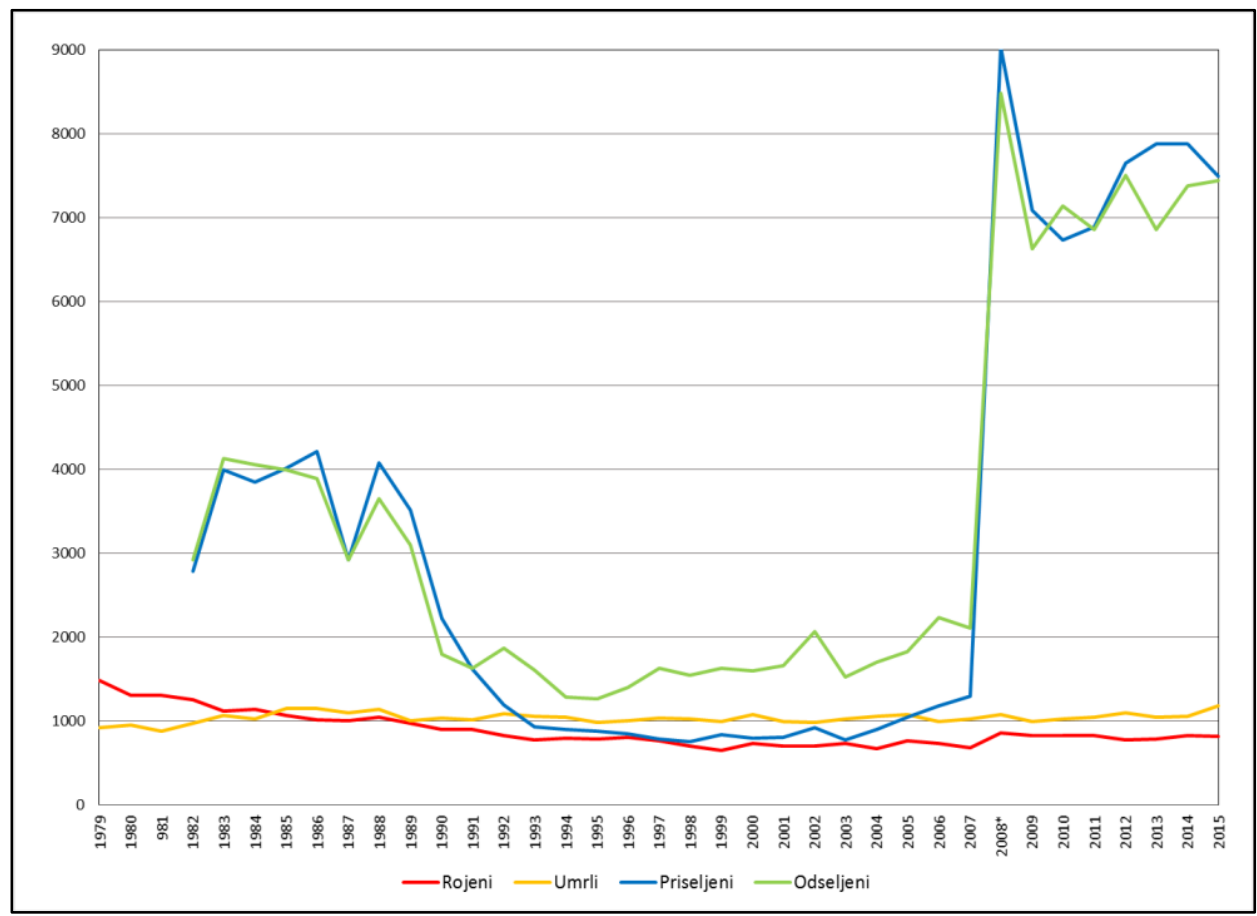

Opomba: SURS od leta 2008 uporablja spremenjeno statistično definicijo prebivalstva (od leta 2008 se upoštevajo tudi selitve tujcev, ki bivajo v Sloveniji več kot eno leto), zato podatki za selitve prebivalstva niso primerljivi s podatki za predhodna leta.

\section{Število rojenih, umrlih, priseljenih in odseljenih prebivalcev v naselju Maribor med letoma 1979 in 2015.}

V letu 2008 se je spremenila metodologija ugotavljanja selitev prebivalstva, ki od takrat upoštevajo tudi tujce, ki bivajo v Sloveniji več kot eno leto (pred tem so podatki temeljili le na ocenah). Zaradi tega podatki selitvenega prirasta od leta 2008 dalje niso primerljivi s predhodnimi podatki, vendar nakazujejo sedanje demografske trende v Mariboru, ki so mnogo bolj odvisni od selitvenega kot od naravnega gibanja prebivalstva. Naravni prirast prebivalstva je po letu 2008 še vedno konstantno negativen (razlika med rojenimi in umrlimi v povprečju znaša okoli -250 oseb na leto), ob upoštevanju večinoma zopet pozitivnega selitvenega prirasta pa gibanje števila prebivalstva po letu 2008 kaže v povprečju stagnacijo prebivalstva, v letu 2015 pa ponovno depopulacijo.

Podrobni podatki o selitvenem gibanju prebivalstva za mesto Maribor niso bili dostopni, lahko pa za interpretacijo uporabimo podatke za občino Maribor (saj prebivalci mesta 
predstavljajo okoli $85 \%$ prebivalstva občine Maribor). Podatki kažejo vpliv pozitivnega selitvenega prirasta $\mathrm{s}$ tujino na demografsko gibanje prebivalstva $\mathrm{v}$ občini, ki bi občutilo še večjo depopulacijo, če priseljevanja iz tujine ne bi bilo. Selitveni prirast med občinami v Sloveniji je bil namreč med letoma 1995 in 2011 konstantno negativen (s povprečno vrednostjo okoli -650 oseb na leto med letoma 1995 in 2007), selitveni prirast s tujino pa pozitiven (s povprečno vrednostjo okoli 300 oseb na leto.

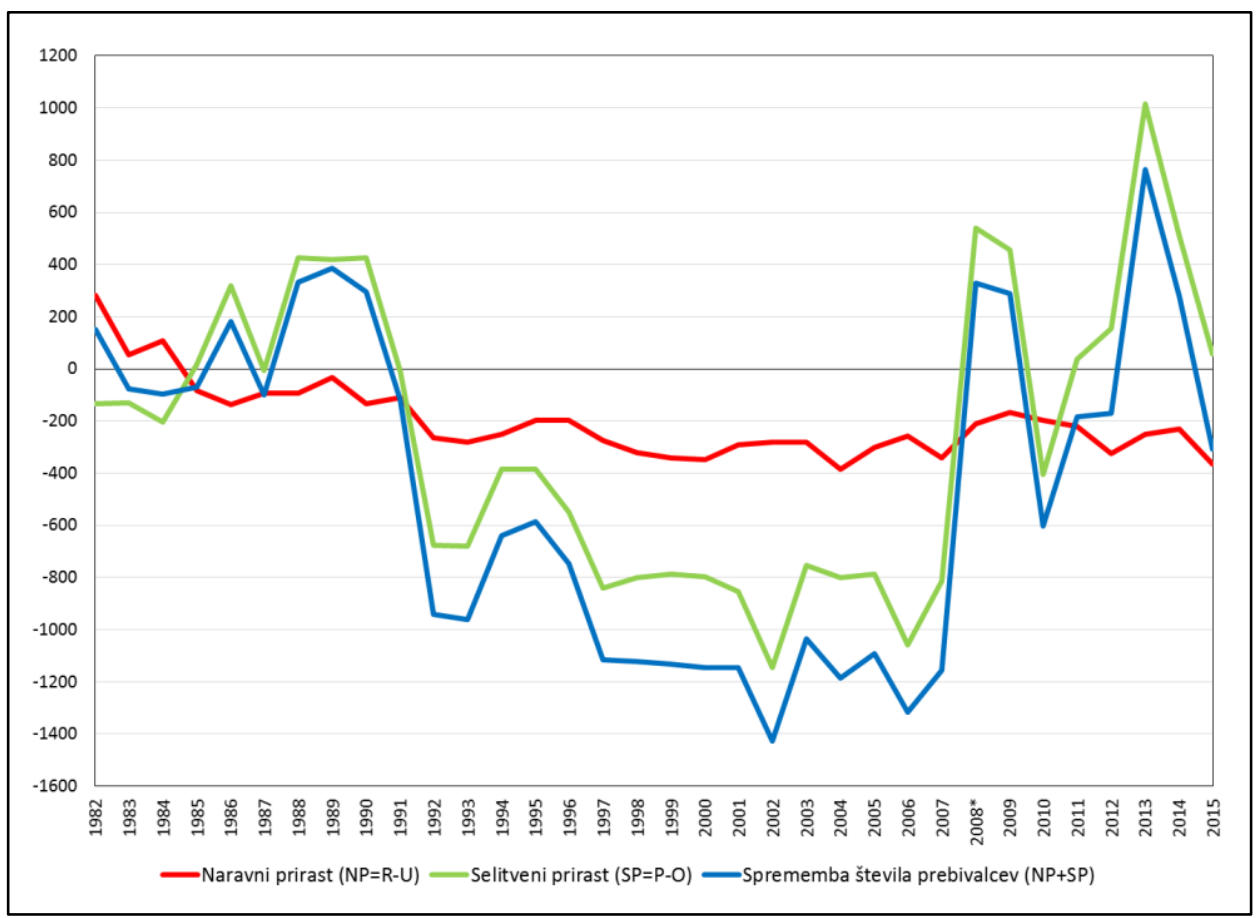

Opomba: SURS od leta 2008 uporablja spremenjeno statistično definicijo prebivalstva (od leta 2008 se upoštevajo tudi selitve tujcev, ki bivajo v Sloveniji več kot eno leto), zato podatki za selitve prebivalstva niso primerljivi s podatki za predhodna leta.

Naravni prirast $=$ Rojeni - Umrli, Selitveni prirast $=$ Priseljeni - Odseljeni, Sprememba števila prebivalcev $=$ Naravni prirast + Selitveni prirast.

Naravno in selitveno gibanje prebivalstva v naselju Maribor med letoma 1982 in 2015.

\section{Sprememba števila prebivalstva po posameznih delih Maribora}

Zaradi vpliva različnih socialnih in ekonomskih dejavnikov se demografske razmere razlikujejo po posameznih delih mesta. Podatki o spremembi števila prebivalstva so bili analizirani po 38 delih mesta, ki se skladajo z nekdanjimi krajevnimi skupnostmi (v nadaljevanju KS) na območju mesta (opomba: številke KS v tekstu se ujemajo $\mathrm{s}$ številkami na karti).

Že v obdobju med letoma 1981 in 1991 se je število prebivalcev zmanjšalo kar v 28-ih od 38-ih krajevnih skupnostih. Depopulacija je bila izrazita predvsem v središču mesta ter na območju starejše gradnje na levem in desnem bregu Drave, kjer se je število 
prebivalcev zmanjšalo v vseh KS, razen v KS-1 Ob parku, KS-5 Boris Kidrič in KS-3 Talci (zaradi novogradenj ob novi avtobusni postaji). Na levem bregu se je število prebivalcev povečalo le na območju Ribniškega sela in Počehove. Povečanje je bilo najbolj izrazito na desnem bregu, zlasti na območju novejše blokovske gradnje v soseskah S-23, Nova vas in Borova vas ter na območju Radvanja. Izstopajo KS-28 I. Zagernik Joco, KS-27 D. K. Tomaž in KS-29 Radvanje. Na območju starejše gradnje na Taboru in $\mathrm{Zg}$. Betnavi ter na območju Studencev pa se je število prebivalcev zmanjšalo, podobno tudi v večini KS na območju Teznega in Pobrežja.

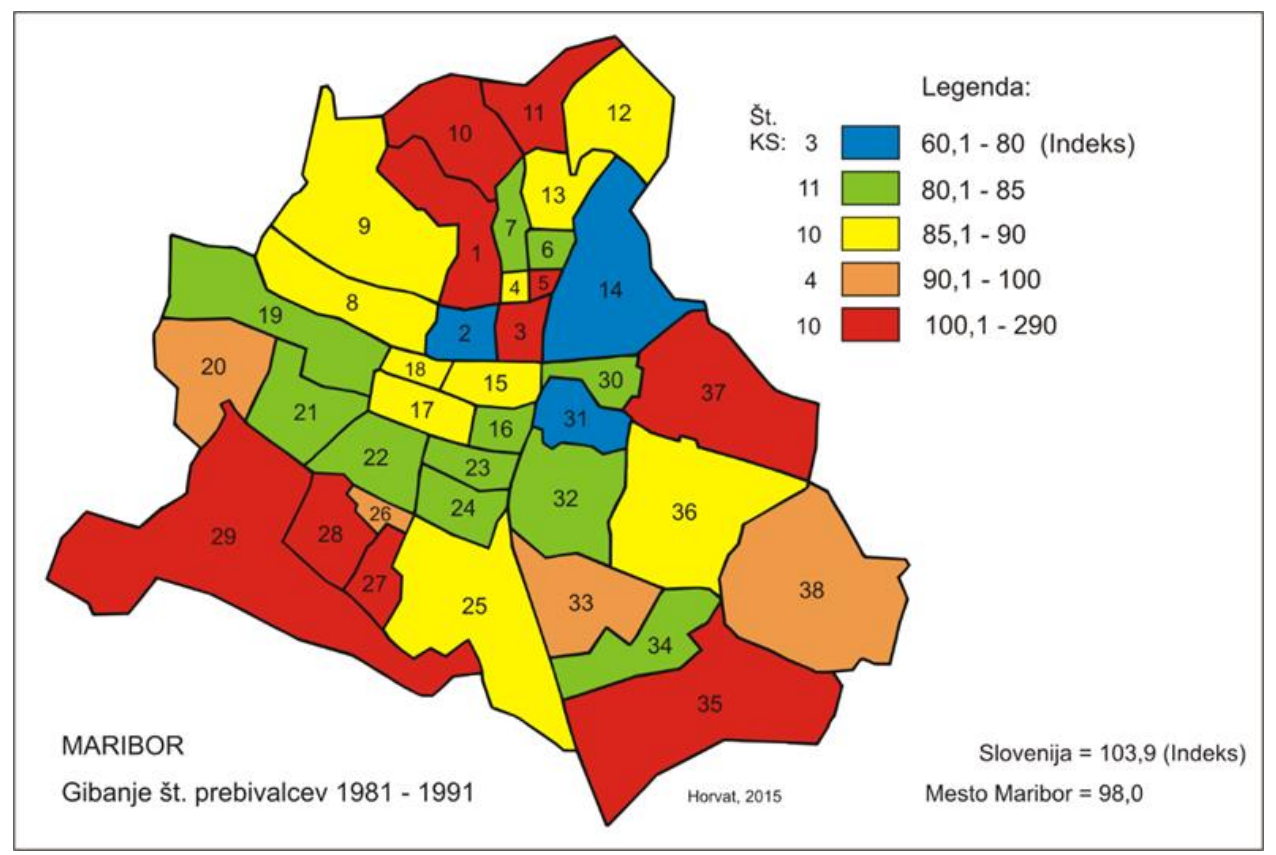

Indeks gibanja števila prebivalcev po krajevnih skupnostih v Mariboru v obdobju med letoma 1981 - 1991.

Za obdobje med letoma 1991 in 2002 je značilna močna depopulacija skoraj v celem mestu, saj se je število prebivalcev zmanjšalo kar v 32-ih od 38-ih KS. Pomembneje se je povečalo le v treh KS, v katerih je bilo v tem obdobju zgrajeno večje število stanovanj v večstanovanjskih ali individualnih stanovanjskih hišah; t. j. v KS-29 Radvanje ter na Pobrežju v KS-32 H. Vojka (ob Stražunu) in KS-38 Jože Lacko. Manjša rast ali manjše zmanjšanje je opazno tudi na ostalem območju Pobrežja, Tezenske Dobrave in Studencev, kjer so se z zazidavo zapolnjevale proste površine, oziroma večje individualne stanovanjske hiše omogočajo bivanje dvema ali trem generacijam, s čemer se lažje rešuje stanovanjski problem mladih družin.

Depopulacija je bila najbolj izrazita v središču mesta, na levem bregu prav v vseh KS, na desnem bregu pa v vseh KS, razen na Taboru v KS-17 Juga Polaka, kjer se je zaradi gradnje in revitalizacije območja ob severnem delu Betnavske ceste število prebivalcev prenehalo zmanjševati. Na drugi strani pa se je v območjih, v katerih so po letu 1981 zgradili pomemben delež novih stanovanj, povečalo število prebivalcev; npr. V JZ 
(zahodni del Nove vasi, Borova vas, Borštnikovo naselje, Radvanje) in JV delu mesta (Pobrežje, Sp. Pobrežje, Tezno).

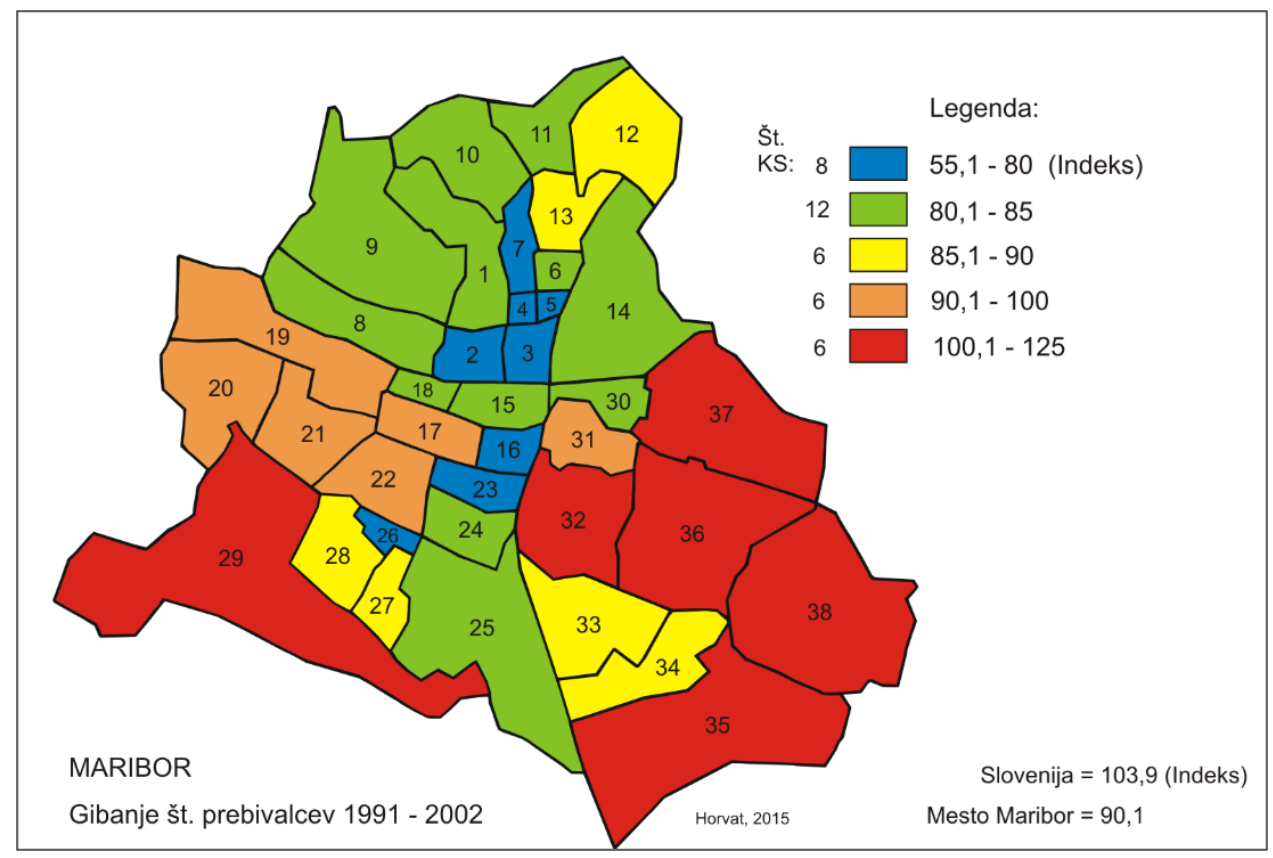

Indeks gibanja števila prebivalcev po krajevnih skupnostih v Mariboru v obdobju med letoma 1991 - 2002.

Zaradi spremenjene definicije prebivalstva iz leta 2008 je potrebno podatke za gibanje števila prebivalstva v obdobju med letoma 2002 in 2015 kritično vrednotiti, saj ne kažejo največje povečanje prebivalstva le $\mathrm{v}$ KS $\mathrm{v}$ katerih je prišlo do izgradnje novih stanovanjskih sosesk (npr. v KS-17 Juga Polak v MČ Magdalena, v KS-20 Pohorski bataljon - območje pod Pekrsko gorco, v KS-25 Slavko Šlander v MČ Tabor - območje Betnave, idr.) pač pa tudi v tistih KS, v katerih se nahajajo študentski domovi (npr. v KS8 Koroška vrata) in domovi za upokojence.

Prav izgradnja novih večstanovanjskih objektov znotraj mesta je pripomogla k revitalizaciji nekaterih mestnih območij (npr. v MČ Magdalena in MČ Tabor), v katerih se je v prejšnjih obdobjih kazala izrazita depopulacija.

Med letoma 2002 in 2015 se je število prebivalcev zmanjšalo v 21-ih od 38-ih krajevnih skupnostih. Depopulacija je značilna predvsem za območja večstanovanjske gradnje iz 60. in 70. let 20. stoletja (npr. t. i. območja Novi Tabor, naselje Jugomont, vzhodni del Nove vasi, Greenwich). Iz manjših pretežno delavskih stanovanj (povprečne velikosti 45 $-55 \mathrm{~m}^{2}$ ) se je odselila generacija (že odraslih) otrok, tako da je v teh območjih ostalo večinoma starejše neaktivno prebivalstvo. Povprečno v tem območju živita v stanovanju manj kot 2 osebi. V območjih s prevladujočo individualno gradnjo in večjimi stanovanji (npr. v KS-29 Radvanje) oziroma v območjih, v katerih so zapolnjevali vmesne površine z novejšo gradnjo, je depopulacija manjša. 


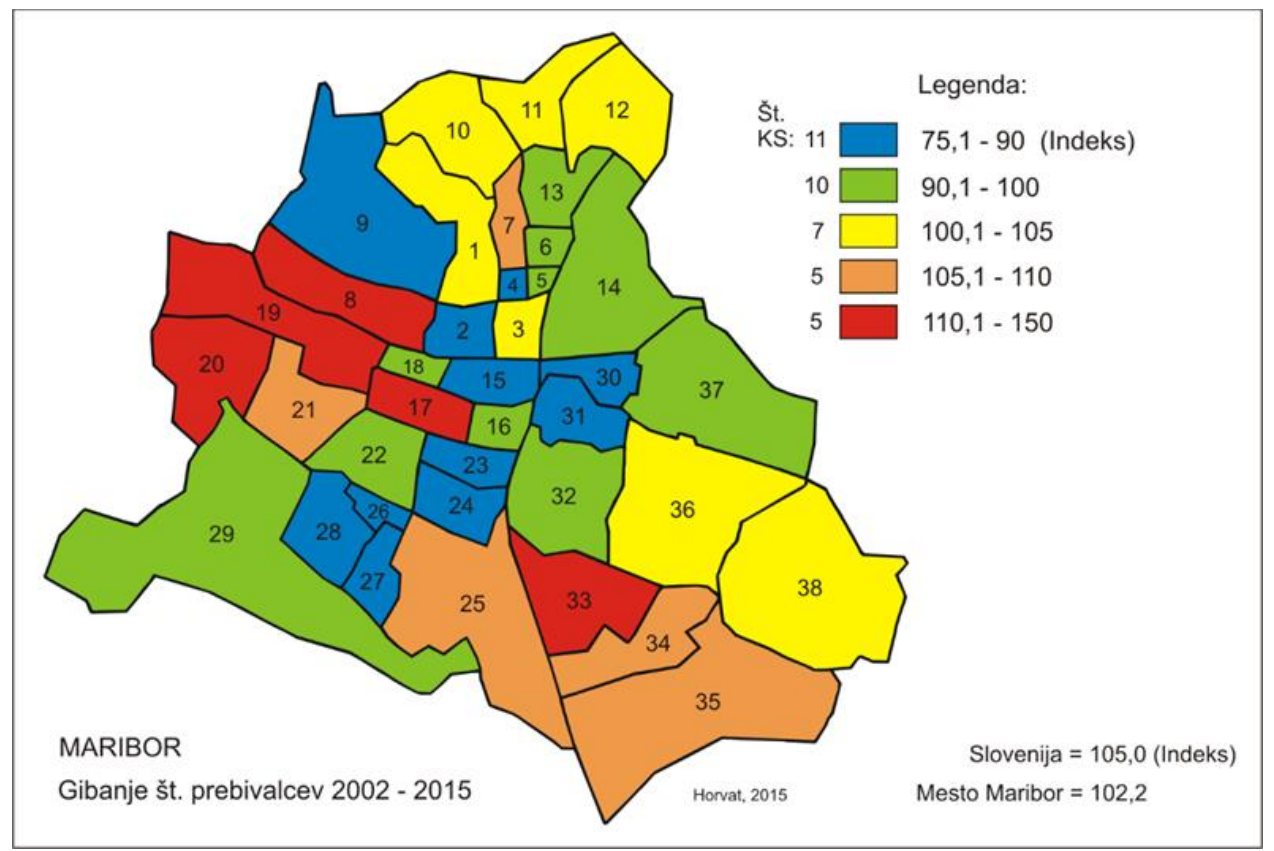

Indeks gibanja števila prebivalcev po krajevnih skupnostih v Mariboru v obdobju med letoma 2002 in 2015.

\section{Starostna sestava prebivalstva}

Staranje prebivalstva je, tako kot v svetu, tudi v Sloveniji proces, ki se mu ni mogoče izogniti. Podaljševanje življenjske dobe je najbolj značilen demografski pojav vsake sodobne družbe in skupaj z nižanjem rodnosti vodi v staranje prebivalstva. $Z$ upadanjem števila rojenih in upočasnjevanjem umrljivosti se spreminja tudi starostna sestava prebivalstva. Pod pojmom staranje prebivalstva se najpogosteje razume povečanje deleža starega prebivalstva, t. j. prebivalstva $v$ starostni skupini 65 let in več. Glede na vsesplošno (globalno) staranje prebivalstva ter dejstvo, da je proces $\mathrm{v}$ polnem zamahu $\mathrm{v}$ evropskih državah, se je nekoliko spremenila opredelitev kdaj velja neka populacija za staro. V sodobni literaturi se govori o tipu starega prebivalstva takrat, ko je delež oseb starih 65 let in več med 8 in $12 \%$, če pa je njihov delež višji od $12 \%$ se govori o tipu izrazito starega prebivalstva (Nejašmić 2005, 179).

Leto 2004 je bila Slovenija na 20. mestu med državami z najvišjim deležem starega prebivalstva na svetu (Kinsella, Phillips, 2005: 7). Med letoma 2002 in 2015 se je delež starega prebivalstva v Sloveniji še povečal; in sicer z okoli $15 \%$ na $18 \%$. Takšno stanje je v največji meri posledica podaljševanja pričakovanega trajanja življenja, predvsem pa nizke rodnosti prebivalstva. Dolgoročne projekcije prebivalstva, ki jih je za države članice EU pripravil Eurostat na podlagi enotne metodologije, do leta 2050 kažejo na še nadaljnje naraščanje deleža starejših. Delež prebivalcev v starosti nad 65 let naj bi se tako v Sloveniji povečal na $31 \%$, občutno pa se bo povečal tudi delež prebivalstva starejšega od 80 let. 
Delež mladega prebivalstva je v Sloveniji višji v območjih s sorazmerno višjo rodnostjo in $\mathrm{v}$ območjih $\mathrm{s}$ pozitivnim selitvenim prirastom. Zlasti območja $\mathrm{Z}$ izrazitejšo suburbanizacijo, kamor se priseljuje prebivalstvo v zgodnejši ali zreli rodni dobi, imajo tudi višjo rodnost in s tem višji delež mladega prebivalstva. Na drugi strani so v Sloveniji območja depopulacije $\mathrm{z}$ višjim deležem starega prebivalstva, ki se širijo predvsem $\mathrm{v}$ perifernih, gričevnatih in hribovitih ter gospodarsko manj razvitih območjih. Proces staranja prebivalstva pa je v zadnjem obdobju zelo opazen tudi v urbanih središčih. V večjih mestih se je namreč $v$ zadnjih dvajsetih letih močno povečal delež starega prebivalstva in posledično indeks staranja. Oba precej presegata vrednosti v območjih v okolici mest.

Mesto Maribor med večjimi slovenskimi mesti že od leta 1981 dalje izkazuje najbolj neugodno starostno sestavo prebivalstva. Izstopa $\mathrm{z}$ najmanjšim deležem mladega prebivalstva (v starosti 0-14 let), najvišjim deležem starega prebivalstva (v starosti 65 let in več) in posledično najvišjim indeksom staranja (razmerjem med starim in mladim prebivalstvom) in povprečno starostjo prebivalstva (Horvat, 2007: 83).

Že leta 1981 je indeks staranja z vrednostjo 50 presegel vrednost, ki označuje začetek procesa staranja prebivalstva. V letu 2002 je Maribor, v primerjavi z drugimi mesti v Sloveniji, izstopal po precej višjem deležu starega prebivalstva, močno pa je narasel tudi indeks staranja (142); v Ljubljani je znašal 115, državno povprečje pa je bilo 96. Staranje prebivalstva je še posebej očitno v zadnjih letih, saj so se razmere v primerjavi s stanjem v Ljubljani in državnim povprečjem še poslabšale. Tako se je indeks staranja v Mariboru leta 2015 povečal na vrednost 180 (v Ljubljani je v istem obdobju znašal 129, državno povprečje pa je bilo 121), delež starega prebivalstva pa se je povečal na 20,8 \% (državno povprečje je 17,9 \%). Tudi druga večja mesta v Sloveniji imajo (glede na državno povprečje) nadpovprečno visok delež starega prebivalstva in indeks staranja, vendar se z visokim deležem starejšega prebivalstva in visoko vrednostjo indeksa staranja Mariboru v zadnjem desetletju približuje edino Murska Sobota.

Zaradi negativnega naravnega in selitvenega prirasta se je število prebivalcev v mestu Maribor od sredine 90. let 20. stoletja pa do leta 2007 v povprečju zmanjšalo za več kot 1.000 oseb na leto. Analize kažejo, da je k zmanjšanju števila prebivalstva okoli $30 \%$ prispevalo negativno naravno gibanje, okoli $70 \%$ pa negativno selitveno gibanje. Selila se je predvsem mlajša in srednja aktivna generacija, kar je še zmanjšalo rodnost v mestu. V starostni piramidi se ti trendi kažejo v bistveno zoženem spodnjem delu piramide, saj se je število rojenih od leta 1982 iz 1.262 zmanjšalo na 905 leta 1991 in 672 oseb leta 2004. Leta 2014 se je v mestu rodilo 830 oseb.

Leta 2015 je tako delež mladega prebivalstva (v starosti do 14 let) znašal le 11,6 \%, delež starega prebivalstva (v starosti 65 let in več) se je zvišal na $20,8 \%$, v starosti 75 let in več pa je bilo 10,0 \% prebivalstva. Povedano drugače, starejših od 65 let je bilo skoraj 20.000 oseb, starejših od 75 let pa skoraj 9.600 oseb. Starostna piramida prebivalstva Maribora ima tako vse bolj razširjen vrh, najširša pa je starejša aktivna generacija v starosti med 50. in 59. letom. Glede na navedeno, se bo v naslednjih 10 do 15 letih bistveno povečal delež prebivalstva $v$ starosti 65 let in več, kar bo zahtevalo nove oblike organiziranja dejavnosti $\mathrm{v}$ mestu in prilagajanja starejši populaciji na vseh področjih (promet, zdravstvo, socialno varstvo, idr.) 


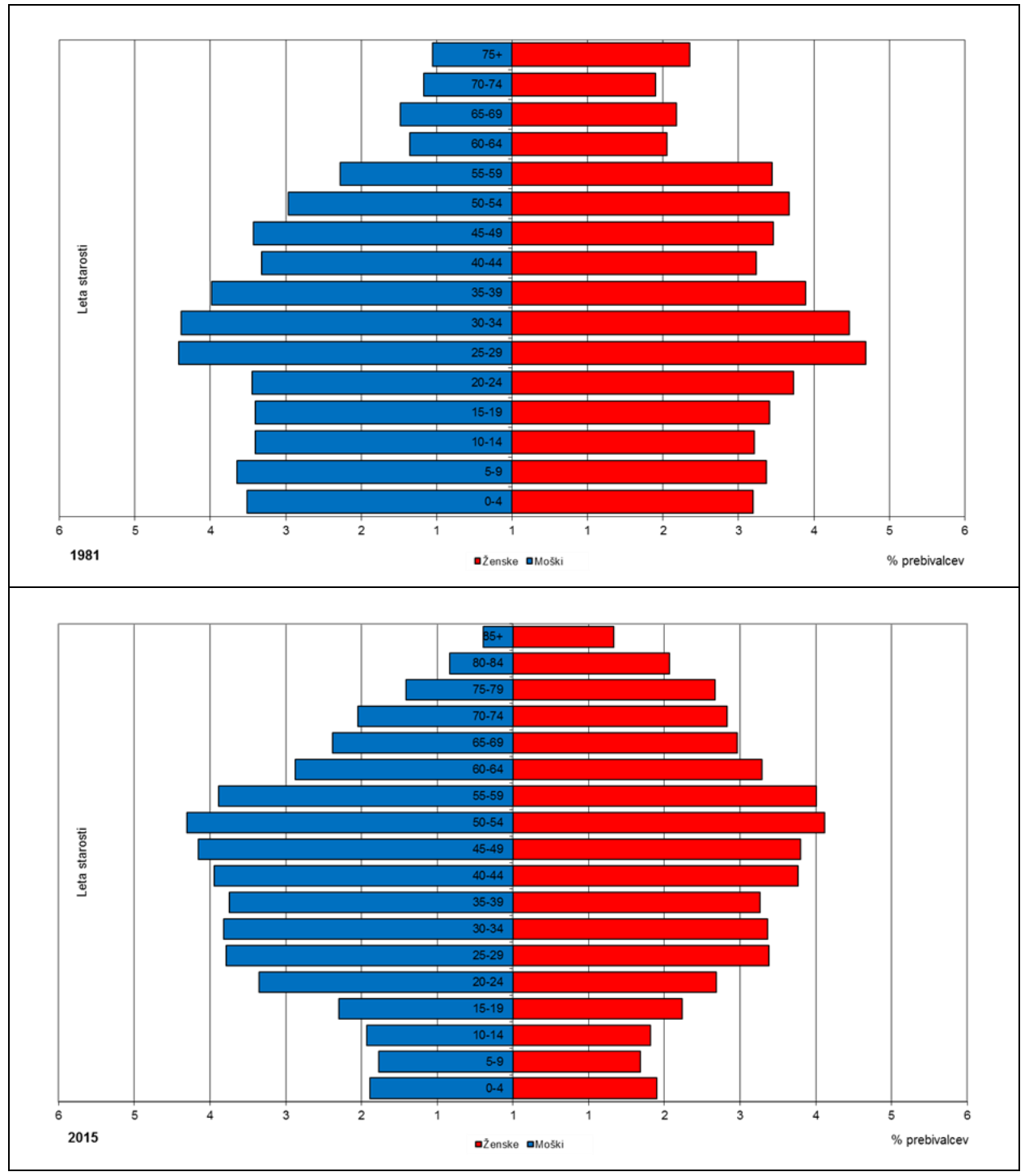

Starostna piramida prebivalstva mesta Maribor leta 1981 in 2015.

Tudi mestna občina Maribor v celoti izkazuje neugodno starostno sestavo prebivalstva. Pred nekaj desetletji so druga nemestna naselja v občini zaradi procesa suburbanizacije izkazovala dokaj ugodne razmere, po letu 2000 pa se tudi njih razmere slabšajo. Indeks starosti se je v njih v letu 2015 povečal na 160 in le za 20 indeksnih točk zaostaja za vrednostmi v mestu. S takšnimi vrednostmi indeksa staranja in deleža prebivalstva $\mathrm{v}$ starosti 65 let in več se mestna občina Maribor uvršča med demografsko najbolj ogrožene občine v Sloveniji.

\section{Starostna sestava prebivalstva po posameznih delih Maribora}

Analiza indeksa staranja kaže, da se je proces staranja prebivalstva v posameznih delih 
mesta pričel že leta 1981. Že takrat je imelo prebivalstvo v več kot polovici krajevnih skupnosti (v $22 \mathrm{KS}$ ) indeks staranja nad vrednostjo 50, demografi pa pri vrednostih nad 40 že govorijo o začetku procesa staranja prebivalstva. Le-to je bilo opazno zlasti na območju levega brega mesta, kjer je povprečni indeksa staranja znašal 71 in s tem dosegel prag negativne naravne rasti prebivalstva.
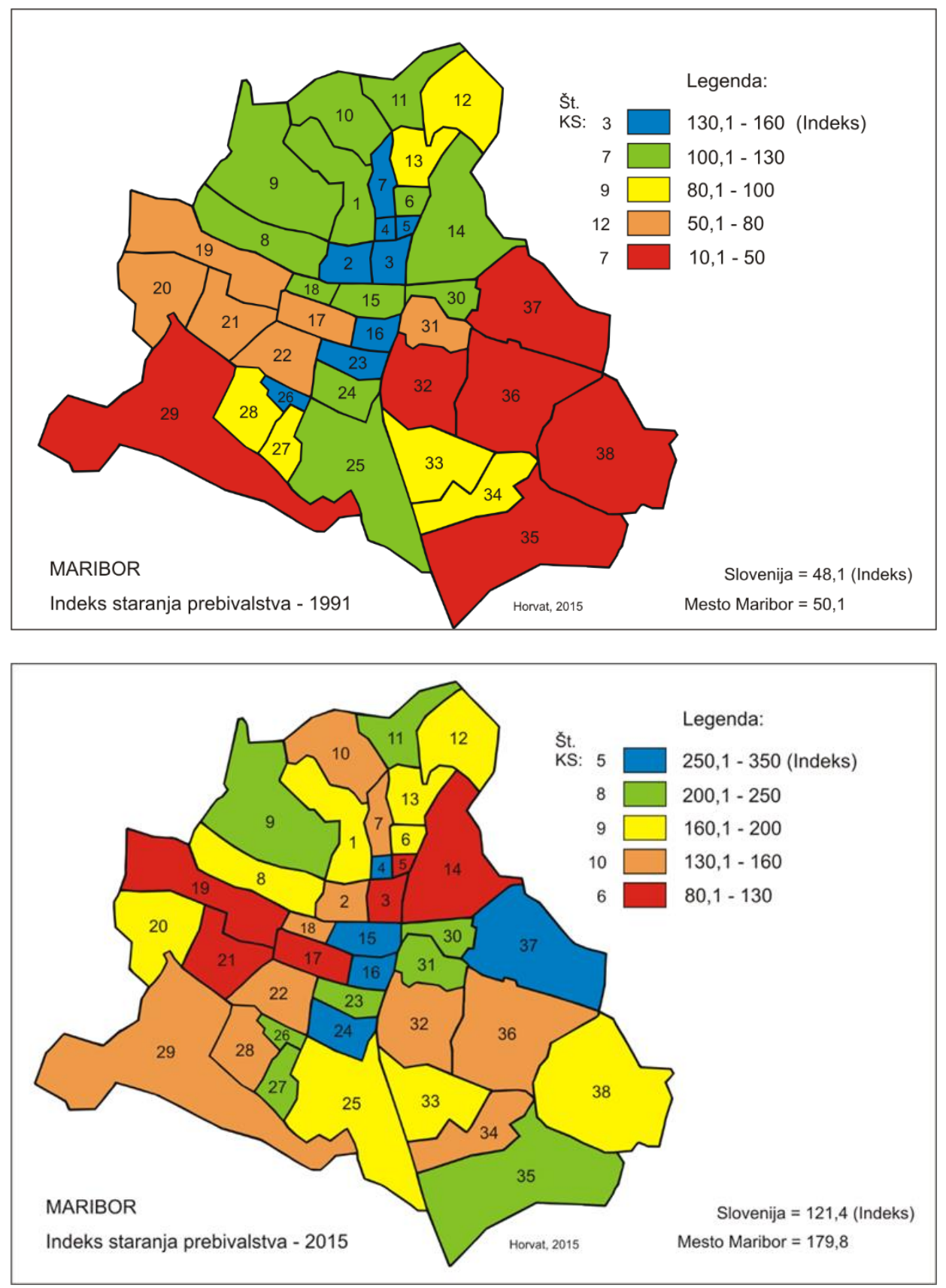

Indeks staranja prebivalstva po krajevnih skupnostih v Mariboru leta 1991 in 2015. 
Leta 1991 se je število KS z ugodnim indeksom staranja (pod 40) zmanjšalo na vsega 6. Vse so bile na desnem bregu Drave; na območju Nove vasi, Radvanja ter Pobrežja in Tezna. Območje na levem bregu Drave je izkazovalo zelo zaskrbljujoče starostne razmere. Povprečni indeks staranja je tu dosegel vrednost 92, v nekaterih krajevnih skupnostih pa celo presegel vrednost 150 (KS-6 Anton Aškerc, KS-9 Prežihov Voranc). Tako na levem bregu Drave ni bilo niti ene krajevne skupnosti s še ugodno starostno sestavo prebivalstva. V tem obdobju je proces staranja prebivalstva zajel tudi območja na desnem bregu Drave, saj se vrednosti indeksa staranja nad 100 pojavljajo že v 6 krajevnih skupnostih; zlasti na območju Tabora, Studencev in najstarejšega dela Maribor-Jug (npr. v KS-15 Moša Pijade, KS-22 F. Rozman Stane, KS-25 Slavko Šlander).

Zaradi intenzivnega zmanjšanja natalitete, povečanja negativnega naravnega prirastka in staranja prebivalstva so se po letu 1991 razmere v Mariboru zelo poslabšale. Leta 2002 so med 38 krajevnimi skupnostmi indeks staranja z vrednostjo pod 100 zabeležili le v 5; vse so se nahajale na desnem bregu Drave.

Podatki za leto 2015 kažejo nekoliko spremenjeno podobo razporeditve krajevnih skupnosti v Mariboru glede na indeks staranja. Če so imele v prejšnjih dveh desetletjih najnižji indeks staranja KS z novogradnjami na obrobju mesta, ga imajo sedaj KS znotraj mesta, kjer so z gradnjo novih stanovanj in revitalizacijo nekaterih območij pritegnili mlado prebivalstvo. Zaradi večje rodnosti in večjega števila mladega prebivalstva imata dve krajevni skupnosti (KS-14 Melje in KS-17 Juga Polak) še vedno indeks pod vrednostjo 100 .

Na intenzivno staranje prebivalstva kaže podatek, da leta 1991 nobena krajevna skupnost ni imela vrednosti indeks staranja nad 160, leta 2015 pa ga ima že $22 \mathrm{KS}$. Izrazito prevlado starega prebivalstva kažejo nekatere KS na območju MČ Magdalena (KS-15 Moša Pijade in KS-16 Miloš Zidanšek), MČ Tabor (KS-24 Jožica Flander) in MČ Pobrežje (KS-37 Tone Čufar, KS-30 Greenwich), v katerih vrednosti indeksa presegajo 200, ponekod pa dosegajo celo vrednost 350 (KS-16 Miloš Zidanšek), kar pomeni, da na enega prebivalca v starosti 0-14 let živi v tem območju 3,5 prebivalcev v starosti 65 let in več.

Proces staranja prebivalstva najbolj izrazito prikazuje delež prebivalstva v starosti 65 let in več. Leta 1981 je imelo v tej starosti več kot $15 \%$ prebivalstva le 7 krajevnih skupnosti, leta 1991 12, leta 2002 28, leta 2015 pa že kar 33 KS. V letu 2015 se v 8 KS njegove vrednosti gibljejo celo med 26 - 30\%. Izstopajo nekatere KS na območju MČ Magdalena (KS-15 Moša Pijade in KS-16 Miloš Zidanšek), MČ Tabor (KS-24 Jožica Flander), MČ Nova vas (KS-26 Proleterskih brigad) in MČ Pobrežje (KS-37 Tone Čufar, KS-31 Avgust Majerič).

Zaradi spremenjene definicije prebivalstva iz leta 2008 in novogradenj, oziroma priselitve mlajšega prebivalstva $\mathrm{z}$ otroci, izkazujejo nekatere KS podpovprečen delež starega prebivalstva. Zanimivo je, da je npr. KS-17 Juga Polak (v MČ Magdalena) imela leta 1981 najvišji delež starega prebivalstva v Mariboru (18,2 \%), zaradi popolne revitalizacije tega območja pa ima leta 2015 najnižjega (12,3\%). 


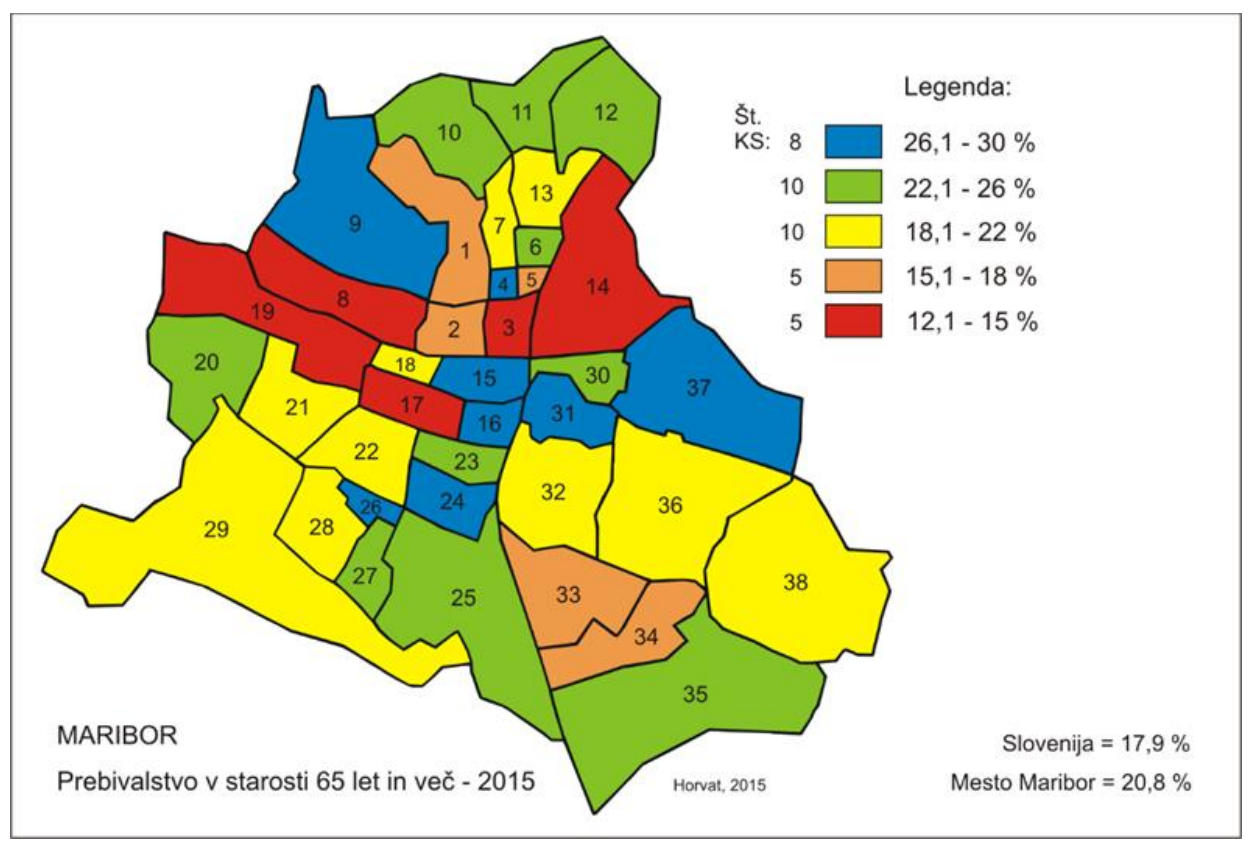

Delež prebivalstva starega 65 let in več po krajevnih skupnostih v Mariboru leta 2015.

\section{Izobrazbena sestava prebivalstva}

V sodobnih družbah je izobrazbena sestava ključna prvina, ki zaznamuje razvoj. Ne označuje le strokovne usposobljenosti za opravljanje poklicev, pač pa posredno tudi inovacijsko sposobnost okolja za prilagajanje sodobnim izzivom v postindustrijski družbi. Čim višja je stopnja izobrazbene ravni prebivalstva, tem višja je običajna absorpcijska moč družbe pri nastajanju t. i. »učečih se regij«. Zato je stopnja izobraženosti prebivalstva (zlasti delež prebivalstva z visokošolsko in univerzitetno izobrazbo) eden najpomembnejših analitskih kazalnikov gospodarske in splošne družbene razvitosti določenega območja.

Med letoma 1991 in 2014 se je izobrazbena sestava prebivalstva Slovenije precej izboljšala. Leta 1991 je imela še skoraj polovica prebivalstva končano le osnovno šolo ali manj, leta 2014 pa le še okoli četrtina. Delež prebivalstva s končano srednjo izobrazbo, se je močno povečal do leta 2002 , nato pa se je pričel zmanjševati na račun močnega povečanja deleža prebivalstva $\mathrm{z}$ višjo ali visoko izobrazbo, ki je narasel na več kot $20 \%$ v letu 2014. Moški imajo v povprečju višjo izobrazbo kot ženske.

Podatki kažejo, da mesto Maribor, kot drugo največje mesto in univerzitetno mesto, glede na delež prebivalstva $z$ doseženo višje ali visoko šolsko izobrazbo $(24,2 \%)$ izgublja svoj položaj. Poleg Ljubljane (31,1 \%), ga z višjim deležem presegajo Novo mesto $27,4 \%$ ), Nova Gorica $(24,8 \%)$ in celo Murska Sobota $(26,1 \%)$. Razlog lahko iščemo predvsem $\mathrm{v}$ dejstvu, da se je $\mathrm{v}$ procesom suburbanizacije iz mesta izseljevalo predvsem bolj izobraženo prebivalstvo, obenem pa se velik del študentov, ki gre iz mesta na študij $v$ Ljubljano, po zaključku študija ne vrne $\mathrm{v}$ Maribor, predvsem zaradi velikega pomanjkanja ustreznih delovnih mest $\mathrm{v}$ mestu. 
Prebivalstvo z višje ali visokošolsko izobrazbo je nadpovprečno zastopano v mestnem središču in njegovem obrobju na levem bregu Drave, med KS pa izstopajo KS-6 Anton Aškerc in KS-4 Ivan Cankar (v MČ Ivan Cankar) ter KS-10 Za tremi ribniki (v MČ Center.

Z osnovnošolsko izobrazbo ali celo manj izstopajo območja v bližini starih industrijskih območij (tako na levem kot desnem bregu Drave), ki so bila poseljena pretežno z delavskim prebivalstvom v obdobju najhitrejše rasti mesta. Med krajevnimi skupnostmi z najvišjim deležem izstopajo KS-14 Melje (v MČ Center), KS-18 Maks Durjava (v MČ Magdalena), KS-30 Greenwich (v MČ Pobrežje) in KS-34 Martin Konšak (v MČ Tezno). S srednješolsko izobrazbo izstopajo območja na vzhodnem in zahodnem delu mesta, kjer izstopajo KS-19 (v MČ Studenci) in KS-33 Slava Klavora (v MČ Tezno).

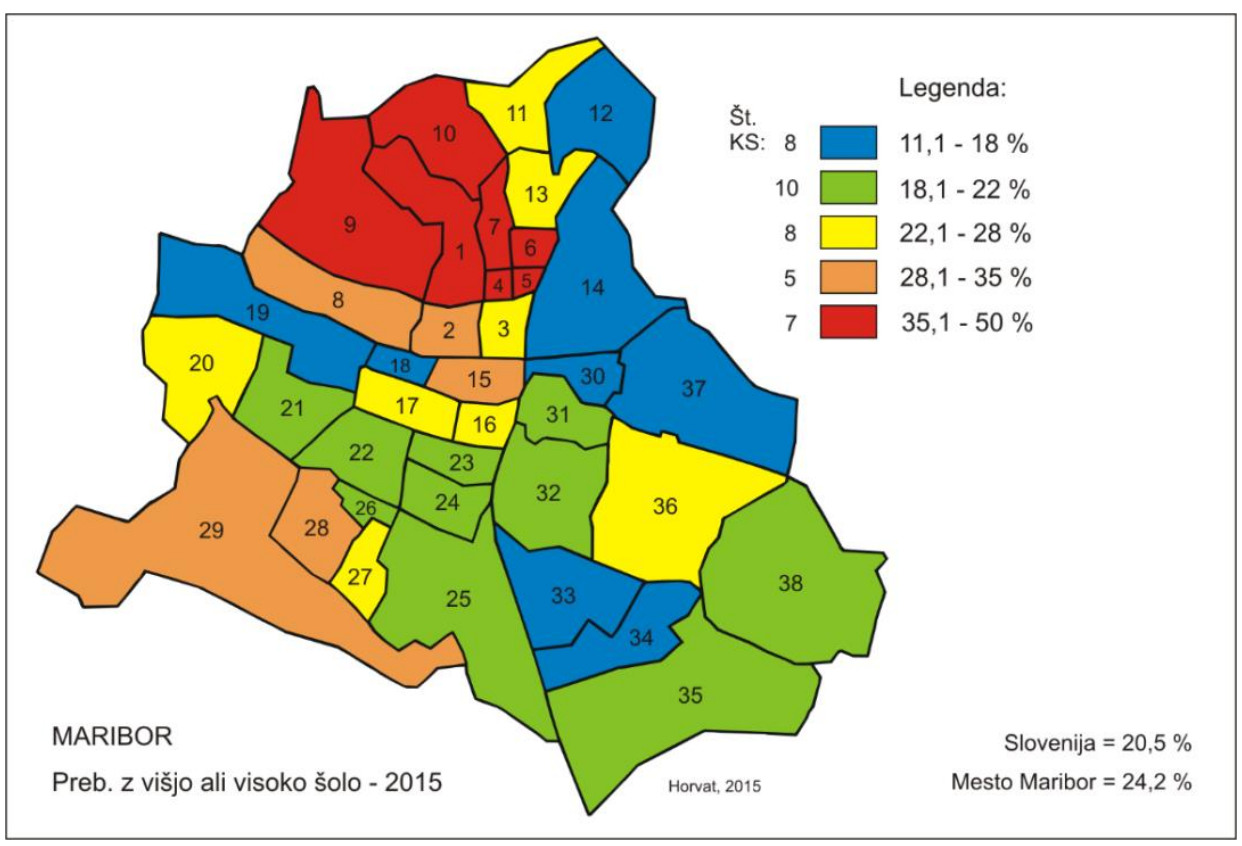

Delež prebivalstva $v$ starosti 15 let in več s končano višjo ali visoko šolo po krajevnih skupnostih v Mariboru leta 2015.

\section{Zaključek}

Staranje prebivalstva predstavlja zaskrbljujoč proces, ki utegne v prihodnosti močno vplivati na ekonomski in prostorski razvoj mest v Sloveniji. V začetku 80. let 20. stoletja je namreč $v$ večjih slovenskih mestih proces klasične urbanizacije s priseljevanjem prebivalstva iz manj razvitih območij Slovenije in drugih republik bivše Jugoslavije pričel postopoma nadomeščati proces suburbanizacije $\mathrm{z}$ odseljevanjem mestnega prebivalstva v okolico. Pri tem procesu predstavlja močan dejavnik zlasti selitev mladih družin. V 90. letih se je tudi iz Maribora močno okrepilo odseljevanje, ki ga je še posebej pospešil propad velikih industrijskih podjetij, visoka brezposelnost, visoki življenjski stroški v mestu pa tudi splošno družbeno-gospodarsko zaostajanje območja za osrednjo Slovenijo. 
Suburbanizacija ter močno zmanjšana rodnost, posledično pa staranje mestnega prebivalstva so povzročili, da se je v obdobju med letoma 1991 in 2002 število prebivalcev v mestu Maribor zmanjšalo kar za 9,7 \%, kar pomeni zmanjšanje za več kot 1.000 oseb na leto. Analize kažejo, da je k zmanjšanju okoli $30 \%$ prispevalo negativno naravno gibanje, okoli $70 \%$ pa negativno selitveno gibanje. Naravni prirast je v Maribor namreč konstantno negativen že vse od leta 1985 dalje (v Sloveniji npr. le v obdobju med letoma 1997 in 2005), selitveni prirast pa med letoma 1992 in 2007, ter predstavlja tisti odločilen dejavnik, zaradi katerega je bila depopulacije v Mariboru v zadnjih desetletjih tako intenzivna. Negativni selitveni prirast je po letu 1991 celo 2 do 3 krat presegel negativni naravni prirast prebivalstva in $\mathrm{v}$ primerjavi $\mathrm{z}$ drugimi večjimi mesti $\mathrm{v}$ Sloveniji izkazuje Maribor v tem obdobju največjo stopnjo depopulacije. Iz Maribora se je selila predvsem mlajša in srednja aktivna generacija, kar je še zmanjšalo rodnost $v$ mestu.

Poseben problem predstavlja tudi izseljevanje predvsem bolj izobraženega prebivalstva, obenem pa se velik del študentov, ki gre iz Maribora na študij v Ljubljano ali drugam, po zaključku študija ne vrne v Maribor, predvsem zaradi velikega pomanjkanja ustreznih delovnih mest v mestu. Zadnji podatki celo kažejo, da mesto Maribor, kot drugo največje mesto in univerzitetno mesto, glede na delež prebivalstva $\mathrm{z}$ doseženo višje ali visoko šolsko izobrazbo izgublja svoj položaj drugega najpomembnejšega mesta v državi. Poleg Ljubljane, ga z višjim deležem presegajo Novo mesto, Nova Gorica in celo Murska Sobota.

Po spremembi metodologije (t. j. statistične definicije prebivalstva, ki je zajelo kot prebivalce $\mathrm{v}$ mestu tudi tiste, ki so imeli v naselju prijavljeno začasno bivališče za leto dni ali več) se je število prebivalcev v Mariboru v letu 2009 »administrativno« povečalo (zlasti na račun upoštevanja stanovalcev v študentskih domovih in domovih za starejše, idr.), vendar pa tudi podatki po letu 2009 kažejo na stagnacijo ali rahlo zmanjšanje števila prebivalcev. Ker je prebivalstvo Maribora je vsako leto v povprečju starejše, demografske projekcije za v prihodnje kažejo na nadaljnje zmanjševanje števila prebivalcev.

Med večjimi slovenskimi mesti Maribor že od leta 1981 izstopa z najmanjšim deležem mladega prebivalstva (v starosti 0-14 let), najvišjim deležem starega prebivalstva (v starosti 65 let in več) ter posledično z najvišjim indeksom staranja (razmerjem med starim in mladim prebivalstvom) in povprečno starostjo prebivalstva. Že leta 1981 je indeks staranja $\mathrm{z}$ vrednostjo 50 presegel vrednost, ki označuje začetek procesa staranja prebivalstva. V letu 2002 je Maribor, v primerjavi z drugimi mesti, izstopal po precej višjem deležu starega prebivalstva, močno pa je narasel tudi indeks staranja. Staranje prebivalstva je še posebej očitno v zadnjem desetletju, saj so se razmere v primerjavi s stanjem v Ljubljani in državnim povprečjem še poslabšale. Tako se je indeks staranja v Mariboru leta 2015 povečal na vrednost 180 (v Ljubljani je v istem obdobju znašal 129, državno povprečje pa je bilo 121).

V starostni piramidi prebivalstva v Mariboru se ti demografski trendi kažejo v bistveno zoženem spodnjem delu piramide, saj se je število rojenih od leta 1982 z 1.262 zmanjšalo na 672 v letu 2004, leta 2014 pa se je v mestu rodilo 830 oseb. Leta 2015 je tako delež mladega prebivalstva (v starosti do 14 let) znašal le 11,6 \%, delež starega prebivalstva (v starosti 65 let in več) se je zvišal na 20,8 \%, v starosti 75 let in več pa je bilo kar 10,0 \% prebivalstva. Starostna piramida prebivalstva Maribora ima tako vse bolj razširjen vrh, 
najširša pa je starejša aktivna generacija v starosti med 50. in 59. letom. Glede na navedeno, se bo v naslednjih 10 do 15 letih bistveno povečal delež prebivalstva $v$ starosti 65 let in več, kar bo zahtevalo nove oblike organiziranja dejavnosti v mestu in prilagajanja starejši populaciji.

Staranje prebivalstva $v$ starejših stanovanjskih območjih na desnem bregu Drave je povezano predvsem $\mathrm{z}$ visokim negativnim naravnim prirastom in odseljevanjem mlajšega in zrelega aktivnega prebivalstva. V starejših blokovskih soseskah in soseskah enodružinskih hiš prevladujejo generacije v starosti nad 50 let (in tudi nad 65 let), katerih potomci so se v fazi oblikovanja svojih gospodinjstev odselili od staršev, po navadi na mestno obrobje oziroma v novejše stanovanjske soseske. To velja še zlasti za območja majhnih delavskih stanovanj, ki so bila zgrajena pretežno v obdobju intenzivne gradnje v 50., 60. in 70. letih 20. stoletja v bližini industrijskih območij na območju Tabora vse do območja Maribor-Jug, na območje Greenwicha in ob Nasipni ulici, ob JZ delu Ptujske ceste na Teznem, idr. V nekaterih delih mesta so se tako oblikovala demografsko pasivna območja $\mathrm{z}$ visokim deležem starega prebivalstva, kar vodi v socialno degradacijo in celo v getoizacijo teh območij. Iz manjših pretežno delavskih stanovanj (povprečne velikosti $45-55 \mathrm{~m}^{2}$ ) se je odselila generacija (že odraslih) otrok, tako da je v teh območjih ostalo večinoma starejše neaktivno prebivalstvo z nizko stopnjo izobrazbe.

\section{Literatura in viri}

Belec, B., Drozg, V. 1994: Razvoj Maribora. Maribor - Marburg : prispevki h geografiji prijateljskih mest v Sloveniji in Nemčiji. Pedagoška fakulteta, 1994, str. 23-39

Horvat, U. (2006) Razvoj prebivalstva v mestu Maribor v obdobju med letoma 1981 in 2002, Revija za geografijo - Journal for Geography, 1-1, Maribor, str. 41-62.

Horvat, U. (2007) Starostna sestava prebivalstva v mestu Maribor v obdobju med letoma 1981 in 2002, Revija za geografijo - Journal for Geography, 2-2, Maribor, str. 81-100.

Kinsella, K., Phillips, D. R. (2005) Global Aging: The Chalange of Success, Population Reference Bureau, http://www.prb.org/pdf05/60.1GlobalAging.pdf, 28. 10. 2007.

Nejašmić, I. (2005) Demogeografija: stanovništvo u prostornim odnosima i procesima, Školska knjiga, Zagreb.

Pak, M. 1994: Razvoj in struktura prebivalstva Maribora. Maribor-Marburg, prispevek h geografiji prijateljskih mest v Sloveniji in Nemčiji, str. 57-78. Maribor.

Pelc, S. (2012) Demographic characteristics of population of slovenian cities in the first decade of 21st century, Revija za geografijo - Journal for Geography, 7-2, Maribor, str. 7-24.

Počkaj Horvat, D. 1997: Demografske značilnosti Maribora in njegova notranja členitev. Geografski vestnik 69, str. 45-72. Ljubljana.

Ravbar, M. (1989) Novejši tokovi urbanizacije v SR Sloveniji, Dela 6, Ljubljana, str. 218-229.

Rebernik, D. (1999) Prebivalstveni razvoj Ljubljane po letu 1945, Geografski vestnik 71, Ljubljana, str. 41-60.

Zavodnik Lamovšek, A., Drobne, S., Žaucer, T. (2008) Small and medium-size towns as the basis of polycentric urban development, Geodetski vestnik, 52/2008-2, Ljubljana, str. 290-312.

Medmrežje 1: SURS, http://www.stat.si/StatWeb/glavnanavigacija/podatki/prikazistaronovico?IdNovice=1608, 1.10.2015.

Popis prebivalstva, gospodinjstev in stanovanj 1981, 1991, 2002. SURS, Ljubljana. 


\title{
Industrializacija, deindustrializacija in regeneracija Maribora
}

\author{
LUČKA LORBER
}

Povzetek Avtorica obravnava strukturne gospodarske spremembe v Mariboru, ki so bile posledica procesov industrializacije in deindustrializacije, zlasti $v$ obdobju družbeno-gospodarske tranzicije po osamosvojitvi Slovenije. V obdobju industrializacije, ki se je pričela v drugi polovici 19. stoletja, se je $\mathrm{v}$ Mariboru razvila klasična delovno intenzivna industrija v industrijskih conah, ki so bile oblikovane na osnovi starih lokacijskih faktorjev. Mariborsko gospodarstvo se v šestdesetih letih 20. stoletja ni pravočasno odzvalo na nujno potrebno prestrukturiranje klasičnih proizvodnih dejavnosti. Znaki gospodarske krize mesta so se pokazali v osemdesetih letih 20. stoletja. Gospodarska kriza se je stopnjevala v začetku devetdesetih let, ko je nastopilo tranzicijsko obdobje in se je krepil proces negativne deindustrializacije. Strukturne spremembe $\mathrm{v}$ kriznih dejavnostih mariborskega gospodarstva $\mathrm{v}$ tranzicijskem obdobju so potekale $\mathrm{v}$ štirih fazah. $\mathrm{V}$ prispevku je predstavljena tudi kompleksna strategija reindustrializacije Maribora, ki poteka v zadnjem obdobju in namenja poseben poudarek revitalizaciji starih mestnih industrijskih con. $\mathrm{Z}$ vključitvijo prostorskih komponent $\mathrm{v}$ teoretične razvojne modele gospodarstva se je razvila nova razvojna paradigma regeneracije starih industrijskih mest. V mestu se je okrepilo aktivno sodelovanje univerze, gospodarstva, lokalne skupnosti in države (četverna vijačnica), ki omogoča vzpostavljanje inovativnih okolij za doseganje uravnoteženega in trajnostnega razvoja.

Ključne besede: - Maribor - industrializacija - deindustrializacija • trajnostna regeneracija $\bullet$ inovativno okolje $\bullet$ četverna vijačnica $\bullet$

NASLOV AVTORICE: dr. Lučka Lorber, izredna profesorica, Univerza v Mariboru, Filozofska fakulteta, Oddelek za geografijo, Koroška cesta 160, 2000 Maribor, Slovenija, e-naslov:lucka.lorber@um.si. 


\title{
Industrialization, deindustrialization and regeneration of Maribor
}

\author{
LUČKA LORBER
}

\begin{abstract}
The paper deals with structural economic changes in Maribor, which resulted from the processes of industrialization and deindustrialization, especially in the period of socio-economic transition after Slovenia's declaration of independence. In the period of industrialization that began in the second half of the 19th century, Maribor developed the classic labor-intensive industry in industrial zones, which were created based on the old location factors. In the 1960s, Maribor economy did not timely respond to the necessary restructuring of traditional production activities. Signs of the economic crisis of the city showed in the 1980s. The economic crisis escalated in the early 1990s, when a transition period began and the process of negative deindustrialization strengthened. Structural changes within the critical activities of the Maribor economy in the transition period took place in four phases. The paper presents also a complex strategy of reindustrialization of Maribor, which goes on currently and puts particular emphasis on the revitalization of the old urban industrial zones. With integration of spatial components in the theoretical development models of the economy, a new development paradigm of regeneration of old industrial sites has emerged. In the city, active participation and cooperation of universities, economy, local communities and the state (quadruple helix) have enhanced, and enabled the creation of innovative environments to achieve balanced and sustainable development.
\end{abstract}

Keywords: • Maribor $\bullet$ industrialization $\bullet$ deindustrialization $\bullet$ sustainable regeneration $\bullet$ innovative environment $\bullet$ quadruple helix $\bullet$

CORRESPONDENCE ADDRESS: Lučka Lorber, Ph.D., Associate Professor, University of Maribor, Faculty of Arts, Department for geography, Koroška cesta 160, 2000 Maribor, Slovenia, email:lucka.lorber@um.si. 


\section{Uvod}

Proces industrializacije je bil eden ključnih družbenogospodarskih procesov z najmočnejšim vplivom na spremembe fiziognomije in funkcije geografske pokrajine $v$ devetnajstem in dvajsetem stoletju. Posledice industrializacije so bile vidne v spremembah strukture prebivalstva, tipih naselij, gospodarstvu, pokrajinski fiziognomiji in vplivu na kakovost okolja. Pokrajina se je močno spreminjala, saj so neposredni in posredni učinki industrije vplivali v enaki meri na spremembe tako urbanih kot ruralnih območij ter na sam regionalni razvoj. Regionalno planiranje se je ukvarjalo z vprašanji, kje in kako locirati industrijo, da bodo hkrati upoštevani družbeni interesi, ekonomičnost in prostorske razmere ob upoštevanju različnih posledic in družbenih učinkov, ki jih prinašajo namestitev nove industrije oziroma posledice razvoja stare industrije.

Lociranje industrije v pokrajini je bilo odvisno od številnih dejavnikov, ki običajno ne učinkujejo vsak zase, temveč so med seboj povezani. Določeni lokacijski dejavniki so spreminjali svoj pomen v posameznih razvojnih fazah industrializacije. Dejavniki, ki so bili pomembni ob nastanku industrije, so danes, $\mathrm{z}$ razvojem nove industrije, izgubili svoj pomen. V prvo skupino uvrščamo tiste dejavnike, ki so v širšem smislu odločali o namestitvi oziroma izboru industrijske lokacije klasične industrije. Za ta »makroaspekt« so bili običajno pomembni družbeni sistem, regionalna politika, nekateri socialnoekonomski in ekonomsko-geografski razlogi (npr. razpoložljiva delovna sila, prometne povezave itd.) ter neredko tudi tehnični razlogi. O ožji namestitvi industrijskega podjetja pa so odločali lokacijski dejavniki, kot so na primer razpoložljivost prostora, infrastrukturno omrežje, tehnološki proces in organizacija proizvodnje (Vrišer, 1978, Lorber, 1999).

Prvo industrijsko obdobje zaznamuje čezmerno izkoriščanje surovin, energije in človeka. Razvile so se klasične delovno intenzivne industrijske panoge, značilni sta bili tekstilna in kovinska industrija. Posledica pomanjkanja tehnološkega razvoja in nezavedanja škodljivosti nekaterih tehnologij (industrijski odpadki, odpadne vode, emisije) je bil nastanek degradiranih območij v takrat industrijsko razvitih državah.

Industrijski razvoj Maribora je bil v tesni povezavi z izgradnjo južne železnice Dunaj Maribor (1846) - Trst (1857). V Mariboru so se takrat oblikovale stare industrijske cone, ki danes predstavljajo prednostna območja urbane regeneracije - industrijske cone Melje, Studenci in Tezno. Na osnovi industrijskega razvoja je v času med obema svetovnima vojnama Maribor postal drugo največje industrijsko središče nekdanje Jugoslavije, z razvitimi klasičnimi proizvodnimi dejavnostmi. Vodilno vlogo je mesto začelo izgubljati v šestdesetih letih 20. stoletja, ko je prišlo do sprememb v strukturi gospodarstev razvitih držav. Te države so z razvojem novih proizvodov in tehnologij prešle v postindustrijsko družbo, za katero je značilen močan proces deindustrializacije in terciarizacije gospodarstva. Zamujene priložnosti za strukturne spremembe gospodarstva so v šestdesetih letih 20. stoletja pomenile stagnacijo in uvod v krizo mariborske industrije. Ta kriza se je še poglabljala v osemdesetih letih prejšnjega stoletja.

Ob osamosvojitvi Slovenije v devetdesetih letih 20. stoletja in prehodu v tržno gospodarstvo so družbene in gospodarske spremembe povzročile negativno deindustrializacijo mariborskega gospodarstva. Zanjo je bilo značilno izrazito zmanjšanje števila zaposlenih $\mathrm{v}$ delovno intenzivnih proizvodnih panogah kot posledica večje 
produktivnosti in globalizacijskih procesov. Razvita okolja, ki so pravočasno omogočila razvoj terciarnega sektorja oziroma so pravočasno izvedla ustrezno prestrukturiranje proizvodnih dejavnosti, so tako zagotovila nadomestna delovna mesta. Zato pravimo, da je tam potekala pozitivna deindustrializacija. Žal v Mariboru proces ni potekal v tej smeri. Ker se v mariborskem gospodarstvu proizvodne dejavnosti niso uspele pravočasno prestrukturirati, je Maribor doživel vse posledice negativne deindustrializacije in usodo starih industrijskih mest, ki se sama niso zmogla revitalizirati. V tistem obdobju je bil terciarni sektor tudi premalo razvit, da bi lahko absorbiral presežek delovne sile. Pomanjkanje kapitala in tujih investicij, odliv izobražene delovne sile, visok delež brezposelnih (28 \% leta 1994) in neustrezna nacionalna politika v času tranzicije države so položaj mesta samo še poslabšali. Propad klasične industrije je potekal v več fazah in je imel za posledico nastanek »rjavih območij« (brownfields), kakor imenujemo degradirana območja starih mestnih industrijskih con.

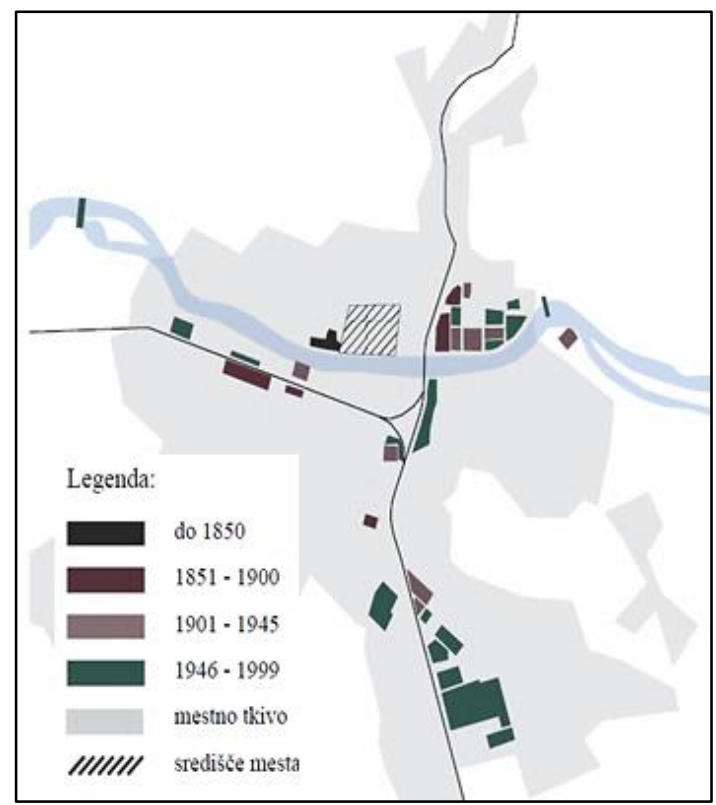

Umeščanje industrije v Mariboru v različnih časovnih obdobjih. Vir: povzeto po Berden, 2015 (Retina, 2011, Curk, 1991)

Nekoč industrijski Maribor danes še vedno išče svojo novo identiteto. Mesto potrebuje ukrepe gospodarske, socialne ter prostorske sanacije na območjih, ki so nekoč generirala njegov razvoj. Stare industrijske cone Maribora so območja z visokimi in raznolikimi deleži degradiranih ali neizkoriščenih površin in predstavljajo kar $40 \%$ mestnih površin. Maribor ima med vsemi slovenskimi mesti najvišji delež degradiranih površin, ki imajo izjemno velik vpliv na ekonomski in urbani razvoj samega mesta. Regeneracija mesta je ključna za prihodnji razvoj mesta, ki je $\mathrm{v}$ rokah lokalne oblasti, gospodarstva, prebivalstva in institucij znanja (četverna vijačnica ali »quadruple helix«). S celostnim pristopom in poznavanjem primerov dobrih praks regeneracije zapuščenih in/ali depriviligiranih območij bodo lahko vsi deležniki v mestu skupaj ustvarili nove pogoje za trajnostno urbano prenovo mesta ter njegov gospodarski in trajnostni razvoj. 
Strateški načrt regeneracije nekdanjih in obstoječih industrijskih območij lahko mestu prinese nova urbana kakovostna območja, ki bodo programsko raznolika in bodo vzpodbudno vplivala na nadaljnji urbani razvoj. Cilj strateškega načrtovanja regeneracije nekdanjih industrijskih območij je vzpostavljanje novih, inovativno zasnovanih urbanih območij, ki bodo omogočila procese trajnostnega razvoja mesta. Načrt regeneracije industrijskih con naj bi razkril prednostna razvojna območja, na katerih bo mogoče izvajati (istočasno ali $\mathrm{s}$ faznim, koordiniranim zamikom) vse ključne strategije regeneracije (reindustrializacije) mesta.

\section{Teoretična izhodišča}

Po definiciji Združenih narodov je industrijska dejavnost (manufacturing) »mehanična ali kemična transformacija anorganskih ali organskih snovi v nove proizvode, pri katerih se delo opravi s stroji, ki jih žene mehanska energija, ali pa ročno, in se odvija v tovarni ali pri delavcu doma ter se proizvodi prodajajo veletrgovini ali trgovini na drobno«. Že od nekdaj proučujemo, kaj povzroča in ustvarja bogastvo narodov in kakšna je vloga industrije in proizvodnje v tem procesu (zgodnji prispevek, Smith, 1776). Za vsa razvita gospodarstva, še posebej od leta 1960 dalje, velja, da je prišlo do relativnega upada proizvodnje v strukturi BDP in upada deleža zaposlenih v proizvodnji (Kitson in Michie, 1997). Razvoj industrije temelji na konkurenčnih prednostih, uvajanju inovacij, novih proizvodih in tehnologijah ter na človeškem kapitalu.

\section{Industrializacija}

Začetki industrijske proizvodnje segajo v drugo polovico osemnajstega stoletja. Za prvo industrijsko revolucijo je značilna uvedba mehanske proizvodnje na osnovi vodne in parne energije. $Z$ iznajdbo tekočega traku je prišlo do druge industrijske revolucije, za katero je značilna masovna proizvodnja, temelječa na delitvi delovne sile, poganjala jo je električna energija. V šestdesetih letih 20. stoletja je prišlo do integracije znanosti in tehnologije ter prenosa vrhunskih tehnologij v proizvodnjo, kar je povzročilo tehnološki napredek in strukturne spremembe $v$ industriji. Nastopilo je obdobje industrij visokih tehnologij in informacijske družbe. V začetku sedemdesetih let prejšnjega stoletja je hiter razvoj elektronike in informacijskih tehnologij vodil v tretjo industrijsko revolucijo, za katero sta značilni avtomatizacija in robotizacija proizvodnje. Človeštvo prehaja v postindustrijsko obdobje, ki vzpostavlja odprt mednarodni gospodarski trg.

Integracija znanosti in tehnologije je povzročila strukturne spremembe tudi v industriji. Znanje, kreativnost in iniciativnost strokovnjakov postajajo dominantni lokacijski dejavnik, ki ob spremenjeni strukturi industrijske proizvodnje omogoča lociranje industrije tam, kjer si je do sedaj ni bilo mogoče niti zamisliti. Središča vrhunske industrije na pragu postindustrijskega obdobja so locirana čim bližje institucijam znanja oziroma najbolj kreativnim kadrom. Kakovost industrije ugotavljamo s panožno strukturo, s tehnološko in kapitalno razvitostjo, s konkurenčno sposobnostjo na globalnem trgu, prav tako pa $\mathrm{z}$ ustrezno strukturo delovne sile, $\mathrm{z}$ ekološko prijazno proizvodnjo in možnostjo nadaljnjega razvoja. Bistvene razlike so med produktivnimi in neproduktivnimi, ekspanzivnimi in stagnantnimi, tehnološko razvitimi in nerazvitimi industrijami, v moči njihovega vpliva na prostor. Sodobna inovativna industrijska dejavnost tudi $\mathrm{v}$ postindustrijski dobi ostaja ključna gospodarska panoga. Rast proizvodno usmerjenega storitvenega sektorja je proces, ki podpira terciarizacijo 
gospodarstva. V zadnjem obdobju govorimo o začetku četrte industrijske revolucije, ki jo opredeljujejo kibernetsko-fizični proizvodni sistemi. »Industrija 4.0« naj bi nastala pod vplivom dveh na prvi pogled nasprotujočih si pojavov. Prvi je pojav bolj zmogljivih računalnikov, ki omogočajo, da informacijska moč ni več koncentrirana na manjšem številu mest, temveč je vedno bolj decentralizirana. Drugi pa je pojav, ko se nekoč na videz nepovezljive naprave in/ali tehnologije povezujejo z namenom, da uporabnikom ustvarijo čim boljšo izkušnjo, možnost ali priložnost. Nastaja »internet stvari« (Internet of Things), v katerem se resnični in navidezni - to je informacijski - svet vedno bolj prepletata, $v$ njem je vedno več podatkov, ki jih je treba smiselno obdelati in z njimi skrbno ravnati. Zaposleni v podjetjih bodo morali uresničiti nov koncept proizvodnje, pri katerem digitalne tehnologije povezujejo poslovne procese, ustvarjajo pametne tovarne in uporabnikom prilagojene storitve.

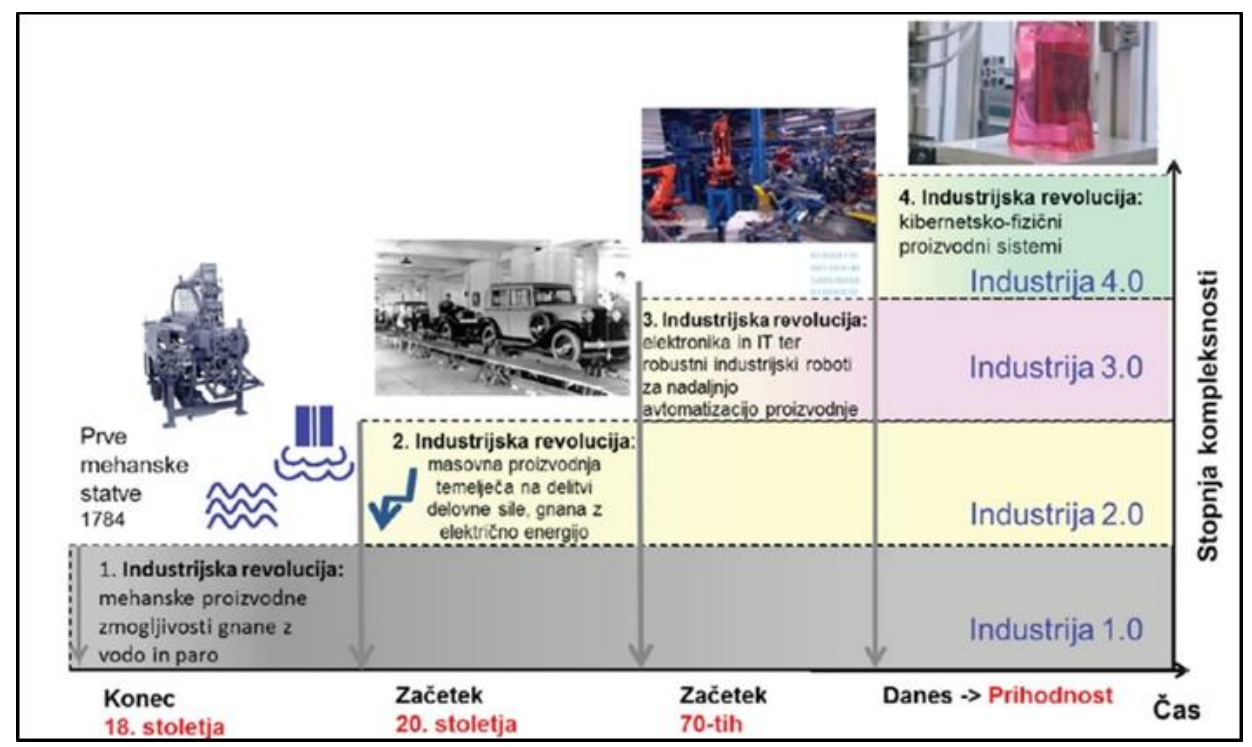

Pomembni mejniki v razvoju industrije - industrijske revolucije. Vir: Herakovič, 2016.

\section{Deindustrializacija}

Danes je v razvitem svetu prevladujoč proces deindustrializacije, ki je tako intenziven, da lahko govorimo o postindustrijski dobi. Padec zaposlenosti v predelovalnih dejavnostih $\mathrm{v}$ industrializiranem svetu ni nov pojav, zanj obstaja niz možnih razlag, od produktivnosti do globalizacije (Bernard et al., 2016). Običajno je potrebno razlikovati med dvema vrstama deindustrializacije - pozitivno in negativno (Rowthorn in Wells, 1987; Clavijo et al., 2014). Prvotno je bil padec števila zaposlenih v proizvodnji posledica prerazporeditve delavcev $\mathrm{v}$ storitveni sektor zaradi razlik $\mathrm{v}$ rasti produktivnosti. V skladu $\mathrm{s}$ tem je deindustrializacija naravna posledica uspešnega gospodarskega razvoja, povezanega $\mathrm{z}$ rastjo življenjskega standarda $\mathrm{v}$ razvitih gospodarstvih in pod vplivom gibanja produktivnosti v storitvenem sektorju (Rowthorn in Ramaswamy, 1997). Deindustrializacija pomeni tudi vzpon storitvenega sektorja gospodarstva, zlasti tistega dela, ki skrbi za vse večjo potrošnjo, ustvarja vedno nove ideje in simbolno dodano vrednost materialnim proizvodom (Bole, 2008). S povečanjem zaposlovanja v 
storitvenem sektorju vplivamo na temelje gospodarstva in na življenjski standard ne glede na stopnjo razvoja.

Negativne posledice deindustrializacije lahko razlagamo kot posledice pretresov $\mathrm{v}$ gospodarskem sistemu (globalna finančna kriza) in spodbujanja struktur, ki podpirajo proizvodnjo za domači trg (Greenaway in Nam, 1998), pa tudi kot posledice političnega in ekonomskega razpada tržišč (Damiani in Uvalić, 2014). Do leta 1990 so deindustrializacijo obravnavali kot trend, značilen samo za razvite države. S propadom komunizma in socializma je prišlo do znatnega padca deleža industrijske delovne sile $\mathrm{v}$ državah, ki jih razvrščamo med tranzicijske, srednje razvite, s slabo razvitim terciarnim sektorjem. Zato se je povečalo zaposlovanje v kmetijskem/primarnem sektorju. Visoka stopnja deindustrializacije ni pokazatelj optimalne poti tranzicije (Mickiewicz in Zalewska, 2002). Vzrok je v strukturnih spremembah industrijskega sektorja, ki so nujne in so posledica prejšnje gospodarske politike ter zapoznelega razvoja v predtranzicijskem obdobju (Kuttor in Hegyi-Kéri, 2014).

Na proces deindustrializacije je vplivalo več dejavnikov, kot so: dvig poceni proizvodnje konkurentov, povečanje uvozne penetracije (offshoring) in premestitev proizvodnih dejavnosti iz zahodnih držav na lokacije nižjih proizvodnih stroškov v svetovnem gospodarstvu; tehnološki napredek, ki zmanjšuje povpraševanje po delovni sili na enoto proizvoda; neustrezne naložbe in inovacije; usmeritev potrošnikov k večji rabi storitev. Prevladuje mnenje, da ta proces dejansko ni problematičen in ga je potrebno obravnavati kot »pozitivno deindustrializacijo«. Presoja je, da bi se morala zahodna napredna gospodarstva osredotočiti na znanje, storitve, finance in tako imenovane »kreativne sektorje« ter prepustiti proizvodnjo novo industrializiranim in industrializiranim državam. Bančna in finančna kriza, do katere je prišlo konec leta 2007, je povzročila veliko recesijo in posledično uvedbo varčevalnih programov $\mathrm{v}$ številnih zahodnih državah. Dozorelo je spoznanje, da so zahodna gospodarstva postala preveč neuravnotežena in odvisna od ozkega spektra storitev, zlasti finančnih, ter da je potrebno uravnotežiti gospodarstva in za gospodarsko rast in odpornost dodeliti večjo vlogo proizvodnim dejavnostim (Christopherson et al., 2014).

Deindustrializacija je le naravna posledica uspešnega gospodarskega razvoja in je pogosto povezana $\mathrm{z}$ naraščajočim življenjskim standardom. To ne pomeni, da ni povezana s težavami v proizvodnem sektorju in v gospodarstvu kot celoti. Neposredna posledica pretresov globalnih trgov (gospodarstev $v$ tranziciji, globalne finančne krize) je izguba delovnih mest $\mathrm{v}$ proizvodnji. $\mathrm{V}$ teh okoliščinah storitveni sektor ne zmore absorbirati nenadno povečane ponudbe delovne sile, kar povzroča višjo stopnjo brezposelnosti in s tem padec rasti življenjskega standarda (Rowthorn in Ramaswamy, 1997).

\section{Globalizacija}

»Globalizacija je proces interakcije in povezovanja med ljudmi, podjetji in vladami različnih držav, proces, ki ga pospešujejo mednarodna trgovina in naložbe s podporo informacijskih tehnologij. Proces ima učinke na okolje, kulturo, politične sisteme, na gospodarski razvoj in blaginjo ter na človekovo dobro počutje v družbah po vsem svetu« (Levin institute, State University of New York). K procesu globalizacije so pomembno pripomogli trije glavni faktorji: liberalizacija kapitalskih gibanj in deregulacija predvsem 
finančnih storitev, nadaljnje odpiranje trgov za trgovino in investicije, kar je povzročilo rast mednarodne konkurenčnosti, in kot ključen faktor uporaba informacijskokomunikacijskih tehnologij (IKT) v gospodarstvu.

\section{Rjava območja (brownfields), regeneracija in revitalizacija starih industrijskih mest}

Tehnološko zastarela klasična industrija je bila velika onesnaževalka okolja. Po fazi zamujene prilagoditve novo nastalim razmeram je prišlo do njenega propadanja. Klasične industrijske cone sedaj predstavljajo degradirana območja s slabo javno podobo. $\mathrm{Ob}$ pomanjkanju zazidljivih razpoložljivih območij (zelena območja) in za zagotavljanje trajnostnega razvoja so rjava območja postala pomembna zemljišča za nadaljnji razvoj. Pri vključevanju teh zemljišč v razvojne načrte lokalnih skupnosti je potrebno upoštevati njihovo dejansko stanje. Pri načrtovanju njihove revitalizacije in razvoja je potrebno predhodno proučiti vplive onesnaženja cone, kulturno in zgodovinsko dediščino, vpetost $\mathrm{v}$ okolico in lastništvo. Predlagane rešitve morajo biti v soglasju z okoliškim prebivalstvom, lokalno in širšo družbeno skupnostjo (Lorber, 2011).

Regeneracija je opredeljena kot pozitivna preobrazba prostora - bivalnega, poslovnega ali odprtega - v katerem smo že lahko zasledili znake fizičnega, socialnega in/ali gospodarskega upada (Meecham, 2005). Regeneracija pokriva širok spekter javnih politik. Omogoča obnovo družbene pravičnosti in lahko blaži napetosti v skupnosti (Tyler et al., 2010). Regeneracija je celostni proces spreminjanja smeri gospodarskega, fizičnega in socialnega nazadovanja na območjih, kjer tržne sile ne bodo zadostne za razvojni preboj (APS Group, 2011). Razmerje med obnovo in gospodarskim razvojem je soodvisno - trajne gospodarske rasti ne moremo zagotoviti brez izboljšanja območij z omejenimi možnostmi. Uspešne regeneracije ni mogoče izvajati brez naložb v lokalna gospodarstva in brez zagotavljanja trajnih delovnih mest.

Za blažitev posledic negativne deindustrializacije so potrebni ukrepi aktivne politike trga dela za tiste, ki so izgubili zaposlitev (prekvalifikacije, posredovanje delovnih mest); politike socialnega varstva za zaščito ranljivih skupin delavcev in skupnosti, neposrednih žrtev deindustrializacije; prostorske in urbane politike regeneracije za razvoj mest ali regij, ki jih je deindustrializacija močno prizadela; in industrijske politike ter drugi ukrepi za spodbujanje neproizvodnih dejavnosti, ki lahko ustvarjajo delovna mesta in prispevajo k rasti (Tregenna, 2015).

Regeneracija rjavih območij je ključni politični cilj pri soočanju s problemi zagotavljanja ustreznega prostora zaradi trenda naraščanja prebivalstva $v$ urbanih območjih nekaterih delov Evropske unije. Rjava območja se pogosto nahajajo ali so dobro povezana znotraj mestnih meja in kot taka ponujajo konkurenčno alternativo »greenfield « investicijam (Bartke, 2013). Ugotovitve kažejo, da se regenerirana degradirana območja nahajajo v občinah $\mathrm{z}$ večjim lokalnim razvojnim potencialom (ki ga predstavljajo delež lokalnih poslovnih dejavnosti, dostopnost do regionalnega centra in glavnega cestnega omrežja ter kakovost lokalne infrastrukture). Velikost degradiranih območij, njihova predhodna industrijska raba in obstoj kontaminacije okolja niso dokončne ovire za regeneracijo, če se degradirana območja nahajajo na privlačnih območjih in tamkajšnji lastniški odnosi niso zapleteni (Frantál et al., 2013). 


\section{Razvoj Maribora v času industrializacije}

Posamezne faze gospodarskega razvoja na slovenskem etničnem ozemlju sovpadajo s prelomnimi dogodki v Evropi. Prvo obdobje opredeljuje čas odprave fevdalnih obveznosti in uveljavljanja liberalnega kapitalizma v Avstrijski monarhiji, katere sestavni del je bilo vse do konca prve svetovne vojne in razpada Avstro-Ogrske leta 1918 tudi slovensko etnično ozemlje.

Industrijski razvoj v Sloveniji je bil močno odvisen od razvoja v avstro-ogrski državi, čeprav je Slovenija z nastopom industrijske dobe že imela nekatere pomembne rudnike in manufakturne delavnice. Industrializacija je vplivala na proces deagrarizacije podeželja in urbanizacije naselij. Ocene, ki jih je napravil Živko Šifrer, kažejo, da se je delež industrijskega prebivalstva od celotnega slovenskega prebivalstva od leta 1880 do leta 1910 povečal z 11 na $12,8 \%$. Med večjimi slovenskimi mesti tistega obdobja je najmočnejšo industrializacijo doživel Maribor. Po popisu prebivalstva iz leta 1910 je imelo mesto Maribor 25,7 \% aktivnega industrijskega prebivalstva (skupaj z zaposlenimi v obrti).

Z izgradnjo obeh glavnih in pozneje še drugih železniških prog na ozemlju današnje Slovenije ter sosednjih avstrijskih pokrajin je postal Maribor v širokem prostoru med Bruckom, Trstom in vzhodno Tirolsko zelo pomembno prometno geografsko središče (Zgonik, 1983). Izgradnja železnic je v veliki meri vplivala na usmeritev mestnega obsega ter kazala pot nadaljnji zazidavi. Namestitev glavnega kolodvora je razširila trgovski promet na Graško predmestje. Bližina kolodvora je postala za gospodarske obrate bolj privlačna kot bližina dravskega pristana, ob sedanji Partizanski cesti so zrasle nove trgovine, obrtne delavnice in gostilne (Leskovec, 1983). Namestitev velikih železniških delavnic ob Koroškem kolodvoru je povzročila, da so v Magdalenskem predmestju in v bližnjih Studencih nastale večje delavske kolonije, ki dajejo vsaj deloma še danes značaj temu delu mesta. Z železniškimi delavnicami na Studencih je leta 1863 Maribor dobil tudi prvo veliko kovinsko industrijsko podjetje, ki že od prvih začetkov zaposluje preko 1.000 delavcev (Zgonik, 1983).

V manufakturno industrijskem obdobju je bilo v Mariboru nameščenih 19,1 \% vseh podjetij na slovenskem prostoru. Prevladovala je predelovalna, lahka industrija, ki je nastajala na osnovi skromnih virov naravnih surovin, delovne sile in tradicije. V podjetjih je prevladoval tuji kapital z lastništvi pretežno v središčih na Dunaju, v Gradcu in v Trstu.

Drugo obdobje je čas med prvo in drugo svetovno vojno, ko je bila večina slovenskega etničnega ozemlja pripojena novo nastali jugoslovanski državi. V obdobju po prvi svetovni vojni od leta 1918 do leta 1945 se je v novonastali državi razvoj industrije preusmeril iz živilske, usnjarske in lesne v tekstilno in kovinsko industrijo. Maribor je postal prvo jugoslovansko središče tekstilne in kovinske industrije. Konec leta 1938 je imel Maribor 27 tekstilnih tovarn, v katerih je bilo zaposlenih 6.293 delavcev ali 35,7 \% vseh slovenskih tekstilnih delavcev. Kovinska industrija je takrat zaposlovala 3.700 delavcev. Na osnovi razvoja klasičnih industrijskih panog so se oblikovale tudi prve industrijske cone: Melje, Studenci in Tezno. Intenzivnejši proces industrializacije so zavirali šibkost slovenskega kapitala, interesi tujega kapitala in splošna družbenogospodarska kriza v Jugoslaviji. V tem obdobju je začelo obratovati 13 industrijskih 
obratov ali 23,6 \% vseh, ki so bili delujoči še leta 1991. To je obdobje druge, mnogo močnejše industrializacije.

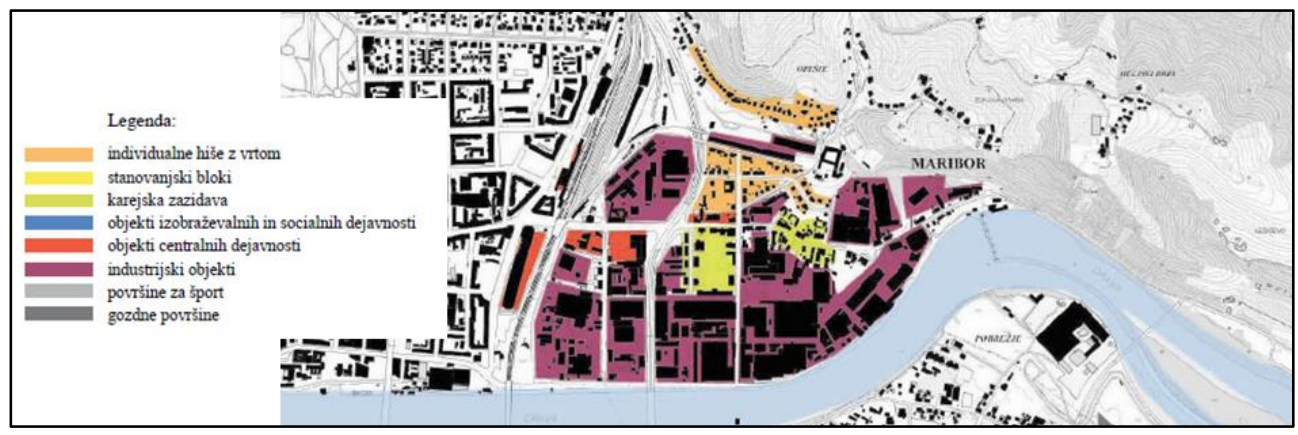

Tipologija objektov in raba prostora - Industrijska cona Melje. Vir: povzeto po Berden, 2015

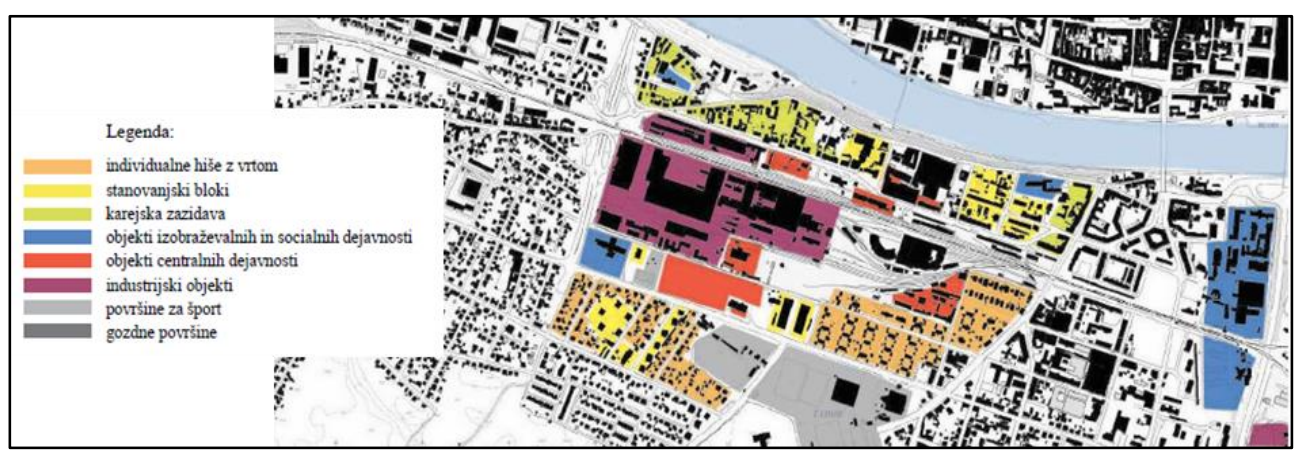

Tipologija objektov in raba prostora - industrijska cona Studenci.

Vir: povzeto po Berden, 2015.

Proučevanje zastopanosti deleža nedelavskih poklicnih skupin nam prikaže izrazito delavski značaj mesta Maribor - pri Mariboru izkazujejo nedelavske poklicne kategorije že manjše deleže od 4/10, medtem ko je pri Celju ta delež še nekoliko večji od 4/10, pri Ljubljani pa se njihova zastopanost med aktivnim prebivalstvom približuje že 6/10 (375 :435 :571). Razvijajoča se industrija Maribora je med obema vojnama, predvsem od sredine dvajsetih let ter po koncu depresijskega obdobja v tridesetih letih 20. stoletja, potrebovala vedno nove kontingente delovne sile, kar se je odrazilo $\mathrm{v}$ migracijskih procesih in ob koncu vojne ob popisu prebivalstva leta $1948 \mathrm{v}$ popolnoma spremenjeni demografski strukturi s kar 2/3 v Maribor preseljenega prebivalstva ter s samo $1 / 3 \mathrm{v}$ mestu rojenega prebivalstva (340:660). Nekoliko več kot polovica v mestu stalno živečega prebivalstva se je priselilo z ostalega območja Ljudske republike Slovenije, torej gre predvsem za notranjo migracijo, znotraj regije oziroma republike ob praznjenju prenaseljenega podeželja (Matjašič, 1983). Maribor je bil pred drugo svetovno vojno živahno mesto in številne fotografije pričajo o tamkajšnjih gospodarskih, kulturnih in športnih dogodkih.

V povojnem obdobju je Podravska (Mariborska) regija s svojo industrijo, ki se je razvila na osnovi klasičnih industrijskih dejavnikov, predstavljala temelj slovenskega in 
takratnega jugoslovanskega gospodarskega razvoja. S centralno-plansko politiko se je še okrepil njen gospodarski položaj, močno vezan na jugoslovanski trg.

V času socialističnega administrativno-centralističnega obdobja (1945-1952) je sledil najintenzivnejši gospodarski razvoj mesta. Z nacionalizacijo, ki je bila izvedena v letih 1946 in 1948, je bilo nacionaliziranih šestdeset večjih in manjših industrijskih podjetij. V Mariboru je bilo leta 1951 šestintrideset industrijskih podjetij, ki so nastala $\mathrm{z}$ združitvijo devetinosemdesetih tovarn, obratov in obrtnih delavnic. Elektrifikacija in razvoj hidroenergetskega sistema na Dravi sta omogočila povečanje proizvodne zmogljivosti in razvoj novih industrijskih panog. Do leta 1952 se je v mestu razvilo trinajst industrijskih panog. Vodilno vlogo je leta 1952 prevzela kovinska industrija z 48,2 \% vseh industrijskih delavcev, tekstilna industrija je s 33,6 \% delavcev ustvarila največji delež narodnega dohodka mestne industrije. Sledili sta lesna industrija s 6,2\% ter proizvodnja in predelava električne energije s 3,8\% zaposlenih v mariborski industriji. $\mathrm{V}$ družbeno-ekonomskih razmerah tega obdobja je nastala $\mathrm{v}$ Mariboru izrazito enostranska gospodarska struktura s poudarkom na proizvodnji prometnih sredstev, sredstev za delo, investicijske opreme in tekstila.

Mariborska industrija je v šestdesetih letih dosegla zrelo stopnjo razvoja. Na prvem mestu so bile še vedno kovinska s $45 \%$, tekstilna z 19,8\% in elektrotehnična industrija z 9,5\% zaposlenih v industriji. Pojavile so se tri nove industrijske panoge: barvna metalurgija, industrija gradbenega materiala in proizvodnja naftnih derivatov. Industrijski povojni razvoj je v glavnem temeljil na širitvi tradicionalnih industrijskih panog.

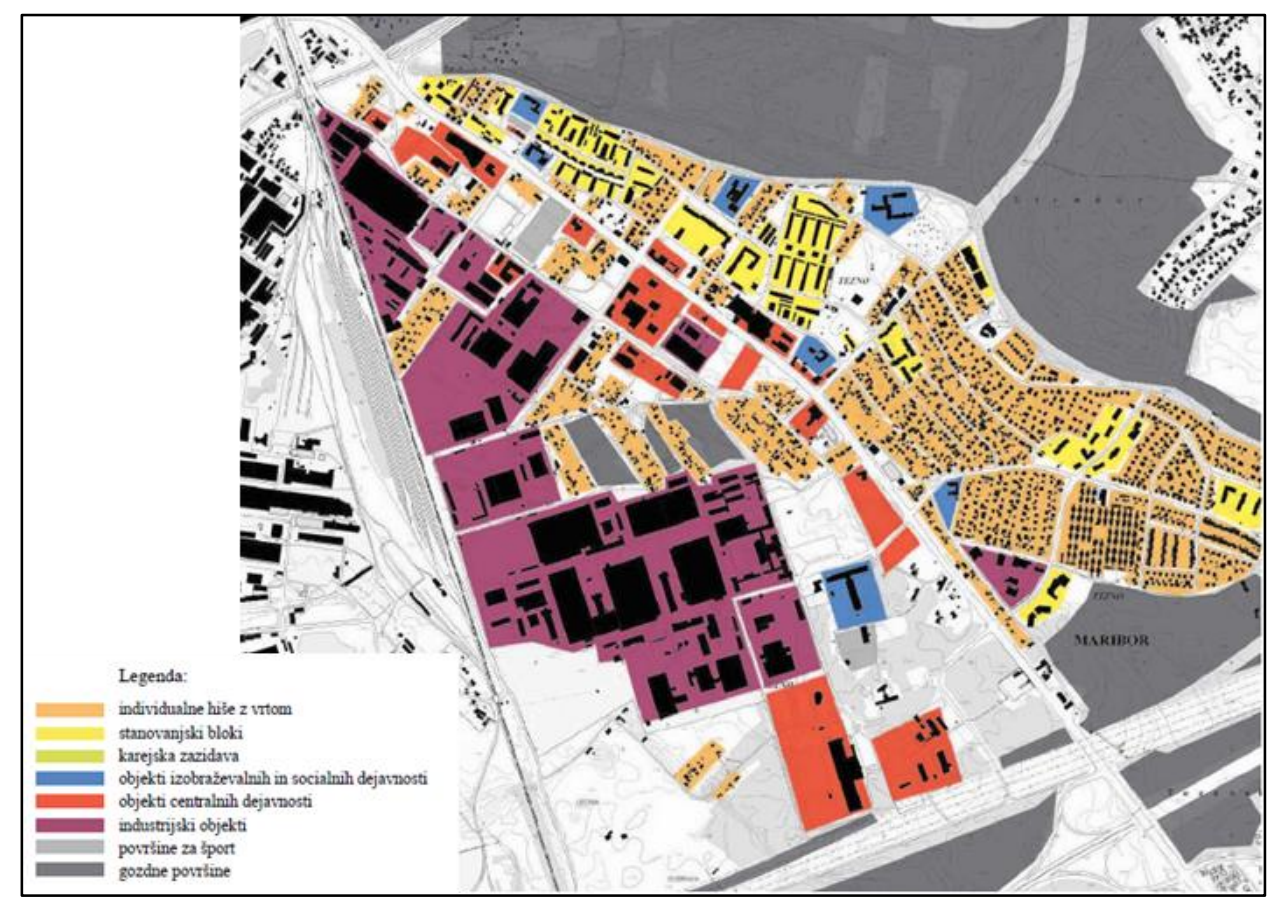

Tipologija objektov in raba prostora - industrijska cona Tezno.

Vir: povzeto po Berden, 2015. 
V času samoupravnega gospodarjenja (1952-1989) je država s svojo politiko posegala v organizacijo poslovnih sistemov. Ekonomska politika socialističnega sistema ni dopuščala pravočasnega prestrukturiranja klasične industrije v skladu z zahtevami tržnega gospodarstva in novih ekonomij, ki so se začele razvijati v evropskem prostoru $\mathrm{v}$ šestdesetih letih 20. stoletja. Primer je stihijski razvoj mariborske industrije.

$\mathrm{V}$ sedemdesetih letih je mariborska industrija prešla $\mathrm{v}$ fazo stagnacije in zaostajanja za slovenskim razvojem. Zniževala so se vlaganja $v$ investicije, industrijska podjetja so postajala zaprta, razdrobljena in tehnološko zastarela. Nova paradigma gospodarskega razvoja je nekoč enovita podjetja reorganizirala. Podjetja so se organizacijsko preoblikovala $\mathrm{v}$ temeljne organizacije združenega dela - TOZD. Med petinpetdesetimi podjetji jih je kar 43 razpadlo na TOZD-e. Ta organizacijski ukrep je povzročil zaposlitveni plaz, kar se je odrazilo v padcu produktivnosti in s tem dražji proizvodnji. Zaradi zaprtosti trga in dogovorne cenovne politike se posledice niso pokazale takoj.

Osemdeseta leta 20. stoletja pomenijo za mariborsko gospodarstvo obdobje nazadovanja, ki se je kazalo v zaustavljeni rasti prebivalstva, zmanjševanju števila delovnih mest, padcu deleža družbenega proizvoda in stopnji novih investicij, ki je bila pod republiškim povprečjem. V osemdesetih letih, zlasti pa po letu 1989, je Maribor zajela gospodarska kriza. Vzroke lahko iščemo v začetkih razpada jugoslovanskega trga. Večino mariborske industrije so predstavljale klasične delovno intenzivne panoge. Izpada prodaje na reguliranem notranjem trgu mariborska industrija ni mogla nadomestiti z večjim izvozom $\mathrm{v}$ tržno usmerjena gospodarstva, ker zaradi ekstenzivne zaposlitvene politike in neustrezne organiziranosti proizvodnje ni bila konkurenčna. Gospodarska politika socialističnega sistema ni dopuščala pravočasnega prestrukturiranja industrije v skladu z zahtevami tržnega gospodarstva, ki se je v evropskem prostoru oblikovalo po letu 1960. Ustreznih ukrepov se ni izvajalo kljub opozarjanju na odliv visokokvalificirane delovne sile iz Maribora v druge centre ter na odliv kapitala, ki bi se moral v večji meri namenjati za razvoj novih tehnologij, proizvodov in znanja. Družbena podjetja so se zanašala na ukrepanje države (eksogeni pristop). Maribor je doživel gospodarsko krizo, značilno za stara industrijska mesta razvitih držav. Prišlo je do stagnacije razvoja mesta in začetka propadanja industrijske proizvodnje. Še leta 1965 je mariborsko gospodarstvo ustvarjalo preko $10 \%$ republiškega družbenega proizvoda, konec osemdesetih let pa le še slabih 6 $\%$.

V obdobju prehoda na tržno gospodarstvo (1991-1997) se je pod vplivom trga oblikovala nova razvrstitev lokacijskih dejavnikov industrije. Mesto se je v tem obdobju srečalo s težavami starih industrijskih mest držav $\mathrm{v}$ tranziciji, ki niso uspela pravočasno prestrukturirati svojega gospodarstva za vključitev na mednarodni trg. Integracijski procesi $\mathrm{v}$ evropskem prostoru so istočasno pomenili tudi oblikovanje modelov decentralizacije moči in oblikovanje razvojnih polov. Oblikovanje skupnega svetovnega gospodarstva je narekovalo tudi integriranje evropskega trga. Razlike $\mathrm{v}$ razvitosti posameznih nacionalnih ekonomij so zlasti v postsocialističnih državah zahtevale razvoj in prilagajanje tržnemu gospodarstvu ter sposobnost konkurenčnega nastopa na svetovnem trgu. Gospodarsko in prostorsko vključevanje v Evropo sta v Sloveniji mišljena kot procesa, ki pomenita razvojno moč in zahtevata politično angažiranost ter izražen nacionalni interes. 
Priključitev na infrastrukturne koridorje in informacijske mreže predstavlja vključitev v evropske razvojne osi. Na prehodu v postindustrijsko obdobje je potrebno prednosti lokacijskih faktorjev mariborske industrije opredeliti izhajajoč iz ekonomskih zakonitosti prestrukturiranja mariborske industrije in možnosti prostorskega razvoja mariborske regije (Lorber, 1999).

\section{Maribor v času postindustrializacije - tranzicijsko obdobje}

Stare industrijske dejavnosti so potrebovale za izvajanje proizvodnega procesa obsežne površine za proizvodne in skladiščne prostore ter ustrezno razvit notranji transportni sistem. Zato je bilo zelo pomembno, da je bilo zemljišče v enem velikem kosu (tudi do več 10 ha), dobro infrastrukturno in komunalno opremljeno ter prometno dostopno. Tako so se oblikovala industrijska območja in urbane industrijske cone z razvitimi klasičnimi delovno intenzivnimi industrijskimi panogami. S prostorskega vidika so le-te omogočale racionalno uporabo mestnega zemljišča, učinkovitejšo izgradnjo prometne infrastrukture in boljše povezovanje industrije $\mathrm{s}$ tržiščem, surovinami ter $\mathrm{z}$ drugo spremljajočo industrijo.

Industrijska območja spreminjajo svojo fiziognomijo. V razvitih državah postajajo industrijske cone multiplikatorji razvoja, povezujejo se $\mathrm{z}$ raziskovalnimi in $\mathrm{z}$ gospodarsko-poslovnimi dejavnostmi. Predstavljajo centre moči, usmerjajo družbenogospodarski razvoj in oblikujejo svoja gravitacijska območja.

Mariborsko gospodarstvo v okviru slovenskega vključevanja na skupni evropski trg zaostaja za ciljem Evropske unije, da aktivno ustvarja »najbolj dinamično, konkurenčno in trajnostno, na znanju temelječe gospodarstvo na svetu, ki bo uživalo polno zaposlenost ter ekonomsko in socialno kohezijo«, kot je leta 2000 določila lizbonska strategija. Cilji lizbonske strategije predstavljajo politično usmeritev pri uresničevanju evropske razvojne strategije, ki temelji na gospodarstvu, socialni politiki in okolju za povečanje evropske konkurenčnosti na globalnem trgu. Kljub velikim težavam pri uresničevanju teh ciljev Evropska unija ne odstopa od ključnih načel, kar pomeni, da tem načelom sledijo tudi nacionalne strategije članic oziroma posameznih regij (Vmesno poročilo o uresničevanju lizbonske strategije Wima Koka, november 2004).

S prehodom v nov družbeni sistem je posledice najprej čutilo mariborsko gospodarstvo, zlasti industrijska dejavnost. Slovenska država ni bila sposobna čez noč vzpostaviti instrumentov za prehod na tržno gospodarstvo. Leta 1991 se je le malokdo zavedal učinkovitosti zakonitosti tržnega gospodarstva v družbenem okolju. Z nastopom velikih političnih neusklajenosti se je ustavil tudi proces preoblikovanja gospodarstva. Ob izgubi jugoslovanskega trga in pomanjkanju kapitala ni bilo možno izpeljati prestrukturiranja mariborske industrije. Čeprav gre za drugo najpomembnejše slovensko gospodarsko in populacijsko območje z močnim gravitacijskim območjem, ni definirana nacionalna strategija za prestrukturiranje največjega slovenskega industrijskega centra.

Maribor, nekoč vodilno gospodarsko in industrijsko središče, je bil v času tranzicije prvi na udaru strukturnih sprememb. Vzrokov za krizo mariborskega gospodarstva je bilo več in niso vsi nastali »preko noči«: 
- zamujen čas nujne posodobitve tehnoloških procesov v šestdesetih letih 20. stoletja;

- nizka dodana vrednost na enoto proizvoda;

- čas privatizacije - večinsko notranje lastništvo, ki je izredno razdrobljeno;

- pomanjkanje svežega kapitala, ki bi zagotavljal posodobitev proizvodnje in nove investicije;

- odsotnost panožnega povezovanja predelovalnih dejavnosti;

- proizvodnja se ni usmerila v specializirano proizvodnjo;

- počasno odzivanje na zahteve sodobnega globalnega trga;

- podrejenost gospodarskih odločitev političnim odločitvam;

- pomanjkanje sposobne managerske strukture;

- dodeljevanje državnih finančnih subvencij, ki so dodeljene brez predloženih razvojnih strategij, ki bi upoštevale zakonitosti tržne ekonomije;

- nacionalni interesi so prevladali nad nujnimi ukrepi, ki jih zahteva ekonomsko prilagajanje svetovnemu globalnemu trgu;

- mestna politika, ki je zaradi socialne stabilnosti zagovarjala ohranjanje delovnih mest za vsako ceno.

V stagnantnih okoljih so industrijske cone postale degradirana in ekološko uničena območja, zaviralke družbenega razvoja, spreminja pa se tudi namembnost izrabe njihovih površin (Lorber, 1999). Strukturne spremembe mariborskega gospodarstva $\mathrm{v}$ času postindustrializacije in $\mathrm{v}$ obdobju tranzicije lahko razvrstimo $\mathrm{v}$ več faz, ki imajo vse značilnosti negativne deindustrializacije. Zaposleni $\mathrm{v}$ proizvodnih dejavnostih so predstavljali večino zaposlenih mariborskega gospodarstva. Slabo razvit terciarni sektor ni nudil zaposlitvenih možnosti presežni delovni sili, kar je imelo za posledico hitro nadpovprečno rast brezposelnih. Medtem ko ugotavljamo, da je kriza v proizvodnji gospodarskih vozil, proizvodnji investicijske opreme in v tekstilni dejavnosti neposredno povezana s problemi prehoda na tržno gospodarstvo in nepravočasnega prestrukturiranja v dejavnostih, za krizo v gradbeništvu velja, da je posledica svetovne finančne krize, katero je povzročil prenapihnjen trg nepremičnin.

Prva faza strukturnih sprememb (1988 - 1995) je bil začetek krize v podjetjih za proizvodnjo gospodarskih vozil, v katero je bila vključena tudi namenska proizvodnja za potrebe jugoslovanske armade. Ta del proizvodnje je bil voden brez upoštevanja tržnih zakonitosti. Leta 1988, ko se je pričela jugoslovanska politična kriza, je jugoslovanska vojska prenehala kupovati namenska vozila. Podjetja niso bila pripravljena na enostransko prekinitev sodelovanja, politična vodstva pa so verjela $\mathrm{v}$ normalizacijo poslovanja ter $\mathrm{s}$ tem neposredno pripomogla $\mathrm{k}$ propadu teh dejavnosti. Vključevanje države v razreševanje problemov je temeljilo na državnih subvencijah, ki so se namenjale za »ohranitev delovnih mest oziroma plače delavcev«, ne pa za prestrukturiranje proizvodnje in iskanje novih strateških partnerjev. Tak pristop državnih intervencij je bil v razvitih gospodarstvih poznan v sedemdesetih letih prejšnjega stoletja. Pri vodstvih podjetij je sprožil učinek »glej in čakaj«. Uveljavil se je model »top-down«, ki je temeljil na osrednji vlogi države in strategiji pasivnega sprejemanja državnih sredstev za ohranjanje obstoječih delovnih mest. Posledica je bila, da je delež v prihodkih te dejavnosti padel s 34,9\% v letu 1987 na 3,1 \% v letu 1995. Te industrijske dejavnosti so bile locirane v starih industrijskih conah Tabor (TVT) in Tezno (TAM). Posledica je bila degradacija okolja. 


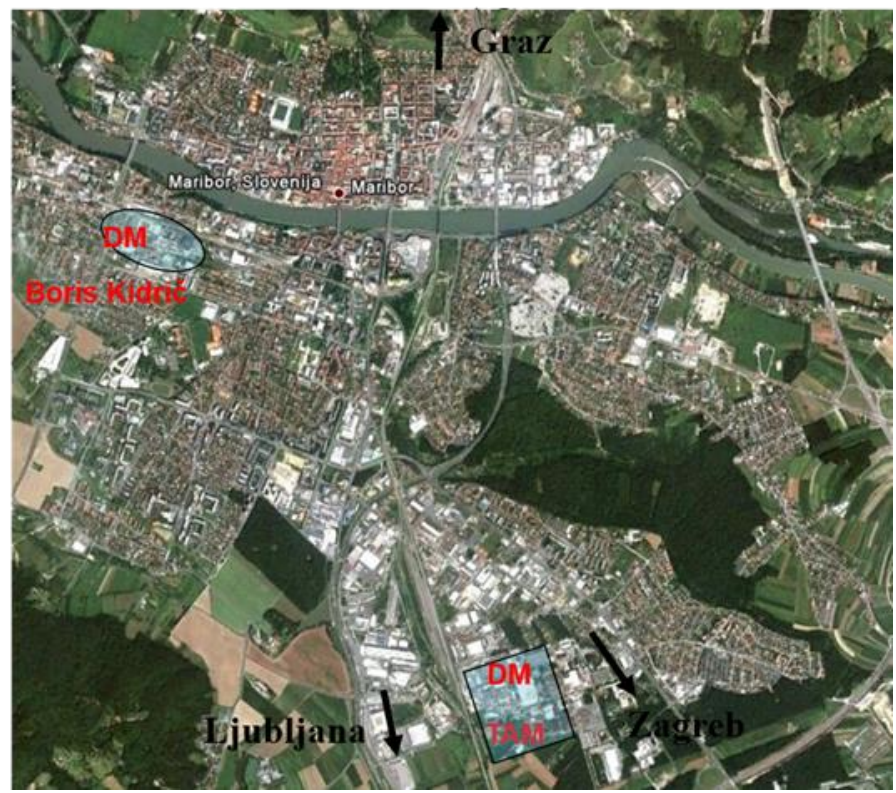

Lokacije podjetij proizvodnje vozil DM.

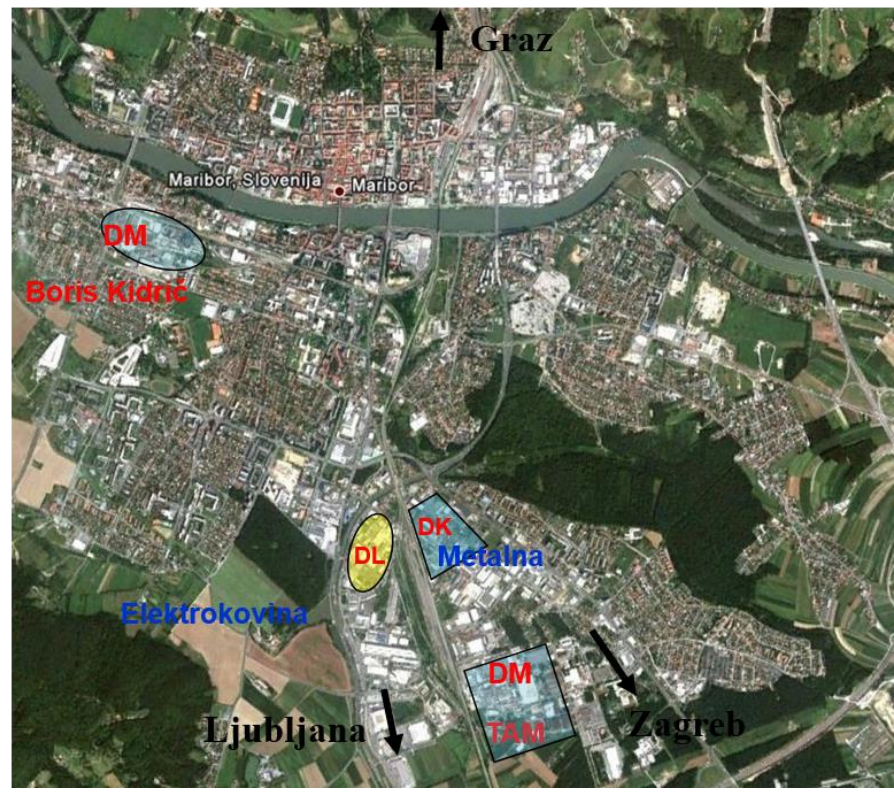

Lokacije podjetij proizvodnje investicijske opreme $D K$ in $D L$.

Druga faza (1992 - 1996) je pomenila krizo v podjetjih za proizvodnjo investicijske opreme. Za ta podjetja je bilo značilno, da so v preteklosti delovala pretežno na skupnem jugoslovanskem trgu in skupaj z velikimi državnimi podjetji na tujih trgih tretjega sveta. Jugoslovanski trg in kooperacijske izvozne posle so izgubila z razpadom skupne države. Posledica oteženega dostopa do finančnega trga ob izgubi tržišč je bilo njihovo 
propadanje. Hkrati pa je bil ravno manjši del zaposlenih iz teh okolij nosilec ustanavljanja malih podjetij - tako proizvodno kot uslužnostno naravnanih. Učinek teh novo nastalih podjetij je delno ublažil problem brezposelnih iz dejavnosti, vendar je bil premajhen, da bi ga lahko opredelili kot primer pozitivne deindustrializacije.

Tretja faza strukturnih sprememb (1995 - 2005) predstavlja krizo v tekstilnih podjetjih. Tekstilna dejavnost je doživela tri krizna obdobja. Prvo obdobje je bilo leta 1995, ko je bilo ukinjenih več kot $25 \%$ vseh delovnih mest $\mathrm{v}$ tej dejavnosti. V drugem obdobju leta 1998 je bilo ukinjenih preko $30 \%$ preostalih delovnih mest, tako da je število zaposlenih prvič padlo pod 2.000. Zadnja kriza sega v leti 2004 in 2005, ko je bilo dodatno izgubljenih preko 300 delovnih mest. Tekstilna industrija je vezana na ceneno delovno silo in na zaposlovanje žensk. Z globalizacijo trgovine in s prehodom na tržno gospodarstvo je bilo neizogibno, da je ta industrijska dejavnost pričela naglo nazadovati in propadati. Problem so predstavljala velika tekstilna podjetja, ki niso sledila svetovnim trendom tekstilne in oblačilne dejavnosti razvitih držav. Vzrok propada je bil v nepravočasnih vlaganjih $\mathrm{v}$ razvoj novih sodobnih tkanin in $\mathrm{v}$ maloserijske oblikovno atraktivne modne kolekcije oblačil (Lorber, 2002). Te industrijske dejavnosti so bile locirane v starih industrijskih conah Melje (MTT, PIK), Tabor (MTT, Merinka) in Pobrežje (Svila). Posledica je bila degradacija okolja.

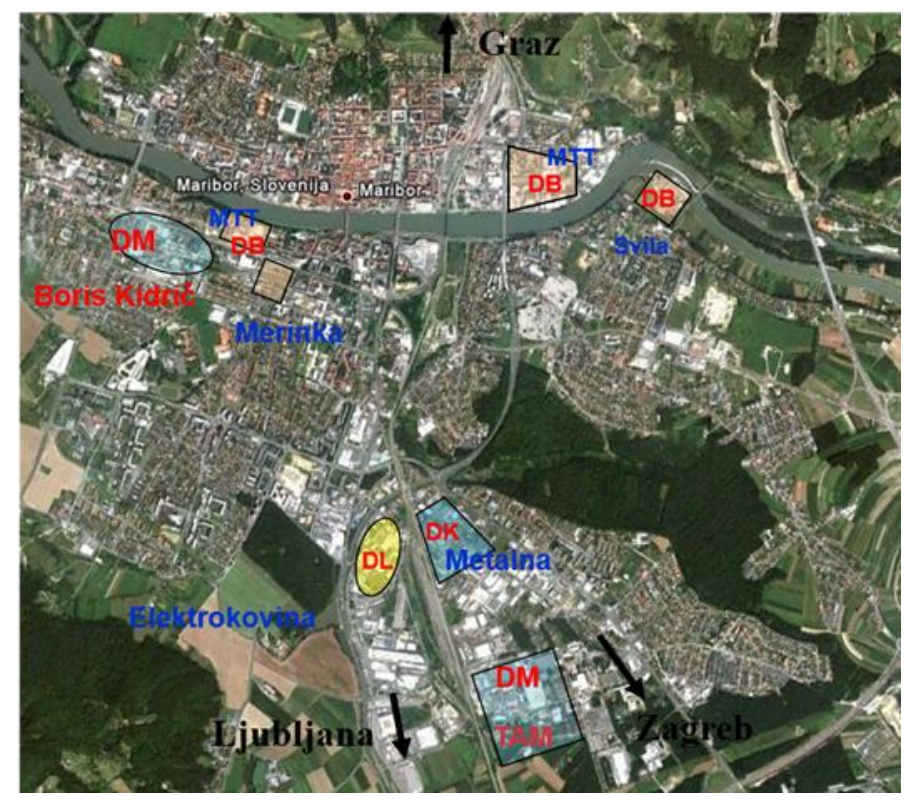

\section{Lokacije tekstilnih podjetij $D B$.}

Četrta faza (2009 - 2013) je obdobje krize podjetij v gradbeništvu. Po vstopu Slovenije v Evropsko unijo leta 2004 se je nepremičninski trg močno napihnil tudi v Mariboru. Ugodni stanovanjski krediti in splošno optimistično okolje ob gospodarski rasti tistega obdobja so povzročili zelo veliko povpraševanje po nepremičninah. Cene kvadratnega metra stanovanj so hitro rastle, kar je povzročilo, da so gradbena podjetja pospešila gradnje. Problem je bil, da se je gradnja za trg financirala večinoma iz kreditov, zavarovanih s hipotekami, tudi $\mathrm{z}$ obremenitvijo novogradenj. $\mathrm{Z}$ zlomom svetovnega 
nepremičninskega trga je prišlo do svetovne finančne krize. Nepremičninski trg se je sesul. Padec prodaje nepremičnin je povzročil izpad dohodka gradbincev, ki niso bili več sposobni odplačevati kreditov. Finančna kriza je vplivala tudi na zmanjšanje javnih investicij. Tako so propadla mariborska gradbena podjetja. Posledično je propadlo veliko manjših obrtnikov in malih podjetij, ki so kot kooperanti sodelovali z gradbinci.

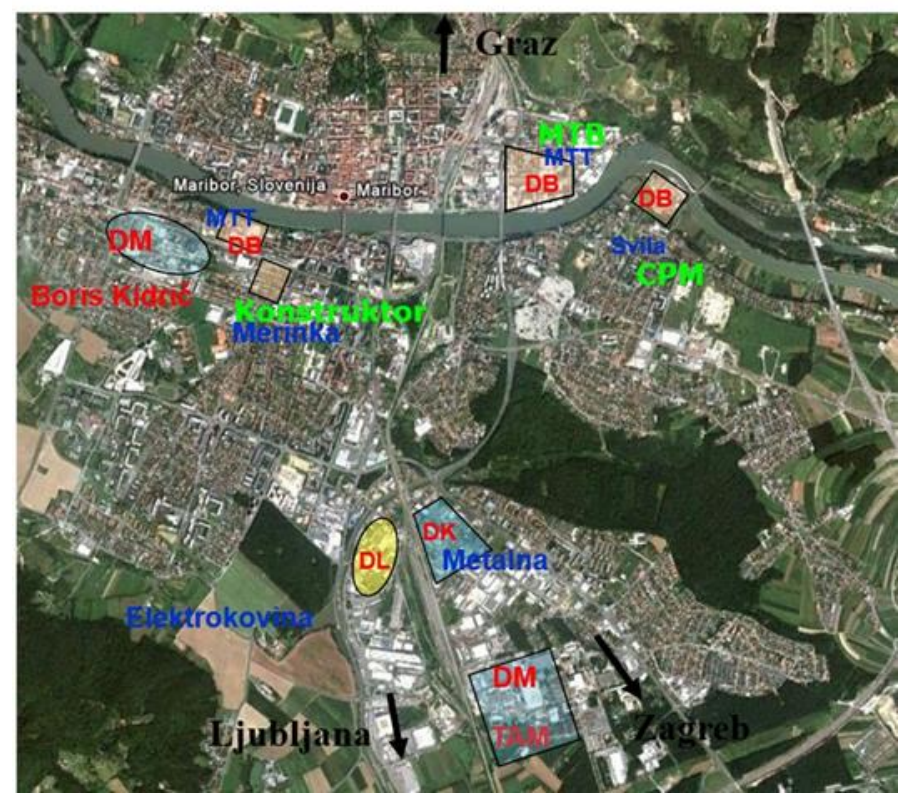

\section{Lokacije gradbenih podjetij-CPM (Cestno podjetje Maribor), MTB, Konstruktor.}

Gospodarske, tehnološke in družbene spremembe so vzrok funkcionalnih in fizionomskih sprememb v prostoru. Proces deindustrializacije je sprožil propad tradicionalnih industrijskih panog in starih zaposlitvenih centrov, ki se niso prilagodili strukturnim spremembam gospodarstva in globalizaciji trga. Posledice propada velikih podjetij v gradbeništvu se odražajo v nedokončanih stavbah v mestu in opuščenih gradbenih jamah.

\section{Oživitev gospodarskih dejavnosti v Mariboru}

V preteklosti je bila regionalna gospodarska politika regeneracije večinoma uporabljena na manj razvitih in obrobnih območjih. Za dosego cilja spodbujanja splošne trajnostne gospodarske rasti je potrebno ravnovesje investicij na vseh področjih - tako šibkih kot močnih (APS Group, 2011). Pod pojmom družbeno trajnostni razvoj razumemo, kako posamezniki, skupnosti in družbe sobivajo in kako določajo in izbirajo skupne cilje za izbrane razvojne modele ob upoštevanju fizičnih omejitev svojega prostora in planeta Zemlje kot celote (Colantonio in Dixon, 2009).

$\mathrm{V}$ preteklosti je najmočnejšo degradacijo prostora s svojim vplivom povzročala industrija. Stare industrijske cone so v vseh okoljih predstavljale izrazita degradirana območja. Bivanje v teh conah je bilo manj kakovostno, zato se je s širitvijo industrijske dejavnosti prebivalstvo selilo iz industrijskih con v nove (obmestne) stanovanjske cone. 
Krčenje urbanih območij zaznamujejo upadanje prebivalstva in z njim povezani pojavi, kot so prazna stanovanja, premalo izkoriščene družbene infrastrukture in širjenje različnih vrst degradiranih območij. Glavni vzroki krčenja so povezani $z$ deindustrializacijo in delovnimi emigracijami, suburbanizacijo in demografskimi spremembami, kot je padec rodnosti. Z novo prebivalstveno strukturo, z oblikovanjem srednjega družbenega razreda in $z$ višjim osebnim življenjskim standardom se pojavlja tudi potreba po vse bolj razviti servisni in uslužnostni dejavnosti ter po oblikovanju družbeno-gospodarskega geografskega (kulturnega) okolja, ki bo zadostilo potrebam prebivalstva in zagotavljalo nadaljnji razvoj.

Funkcionalne spremembe industrije, čista in fleksibilna tehnološka proizvodnja, ki ne potrebuje več novega prostora za svojo širitev, terciarizacija sekundarnega sektorja ter upoštevanje logistike poslovanja oblikujejo nov značaj in videz industrijskih con, ki se s propadom velikih podjetij preoblikujejo v sektorsko mešane cone.

Kriza v industrijskih dejavnostih se je začela leta 1965, ko se mariborska industrija ni vključila v procese prestrukturiranja. Z zapiranjem notranjega jugoslovanskega trga leta 1988 se je pričel proces negativne deindustrializacije. Maribor je čutil posledice klasične industrije v starih industrijskih conah Melje, Studenci in Tezno. Kljub gospodarskemu razvoju in prestrukturiranju industrije ta mestna območja še vedno niso dovolj razvojno opredeljena in funkcionalno izkoriščena. Za uspešno prestrukturiranje mariborske industrije je potrebno vzpodbuditi sinergijo med industrijo in znanostjo. Vključitev na svetovni trg bo uspešna le $\mathrm{z}$ rastjo podjetij $\mathrm{s}$ tehnološko zahtevnejšimi proizvodi in postopki $\mathrm{v}$ proizvodnih in storitvenih dejavnostih. Vlaganja $\mathrm{v}$ raziskave in razvoj so primarni pogoj za gospodarski razvoj regije. Ključno za ustrezno prestrukturiranje gospodarstva in uspešen regionalni razvoj je oblikovanje kreativnega miljeja, ki omogoča individualno kreativnost in ustvarjalnost kot osnovo družbenega razvoja.

Znanstvenoraziskovalna in izobraževalna dejavnost univerze lahko $\mathrm{v}$ lokalnem ekonomskem razvoju predstavlja učinkovit instrument za premostitev ovir med ekonomijo, zunanjo tehnologijo in drugimi razvojnimi dejavniki, ki vplivajo na ekonomsko vrednost proizvodov in procesov. Za dosego tega cilja je potrebno oblikovati strategijo univerze, ki je tehnološko usmerjena, aplikativno in razvojno naravnana ter močno integrirana $v$ razvoj gospodarstva.

Univerza lahko skupaj z gospodarstvom oblikuje inovativna in visokotehnološka podjetja za uvajanje novih tehnologij in proizvodov, izdelavo prototipov in preizkusne proizvodnje, ki je ekološko neoporečna, znotraj tehnoloških centrov oziroma parkov.

Izobraževalni sistem vpliva na strukturo delovne sile in je predpogoj razvoja regije. Zaposlovanje visokokvalificirane delovne sile, ki bo sposobna inovativnega ustvarjanja, agresivnega nastopa na konkurenčnem trgu in ki bo s permanentnim usposabljanjem kos zahtevam svetovnega trga, zagotavlja uspešen gospodarski razvoj. Možnost zaposlovanja velikega števila brezposelnih je odvisna od uspešnosti njihovega prestrukturiranja. Univerza v Mariboru je s svojim poslanstvom tudi graditelj partnerstev v regionalnem prostoru in s svojim mednarodnim institucionalnim povezovanjem omogoča povezovanje $\mathrm{z}$ nosilci gospodarskega razvoja $\mathrm{v}$ evropskih regijah. Uvajanje mobilnosti raziskovalcev in študentov omogoča še večji pretok znanj ter vključevanje v mednarodne raziskovalne projekte in gospodarske tokove. 
Maribor mora biti sposoben razviti zavest o nujnosti regionalnega povezovanja in oblikovati vizijo regionalnega razvoja. Vzpostaviti mora partnerski odnos z regionalnimi središči v nacionalnem prostoru, s katerimi ga družijo skupni interesi. Prometna lega mu omogoča, da se poveže $\mathrm{z}$ regionalnimi središči obmejnega prostora, zlasti $\mathrm{V}$ gravitacijskem območju Maribora, in oblikuje ekonomsko-funkcijske (nodalne) regije v okviru evropskega prostora. $\mathrm{V}$ prihodnosti bo pri lociranju industrijske proizvodnje ključno vlogo igral okoljevarstveni vidik. Vedno ostrejši ekološki standardi vplivajo na izbor tehnološko napredne proizvodnje in $\mathrm{s}$ tem pripomorejo $\mathrm{k}$ ohranjanju kakovosti okolja.

$\mathrm{V}$ zadnjem obdobju lahko govorimo o zavedanju in potrebi po vzpostavitvi novih razvojnih konceptov, ki s celostnim pristopom in implementacijo četverne vijačnice mestu in regiji omogočajo vzpostavitev pogojev, ki bodo privabili investitorje in kapital.

Družbena trajnost se pri trenutnih politikah regeneracije in dobrih praksah urbane prenove odraža v sledečih dimenzijah trajnosti in političnih področjih:

- demografske spremembe (staranje in mobilnost prebivalstva),

- izobraževanje in usposabljanje,

- zaposlovanje,

- skrb za zdravje in varnost,

- urejeno bivalno okolje in zdravo življenjsko okolje,

- identiteta, občutek pripadnosti prostoru in kulturi,

- sodelovanje, krepitev vloge lokalnih okolij in zagotavljanje dostopnosti,

- družbeni kapital, družbeno prepletanje in kohezija,

- cilji zagotavljanja dobrega počutja, sreče in kakovosti življenja (Colantonio in Dixon, 2009).

Izgradnja infrastrukturne mreže, ki je priključena na razvojne osi evropskega prostora, in ureditev mestne prometne infrastrukture pomenita začetek sprememb pri oblikovanju novih gospodarskih con.

\section{Projekt Revitalizacija starih industrijskih con - Revitalization of Traditional Industrial Areas (ReTInA)}

Geografski oddelek Filozofske fakultete Univerze v Mariboru je kot partner sodeloval pri mednarodnem projektu Revitalizacija starih industrijskih con - Revitalization of Traditional Industrial Areas (v nadaljevanju ReTInA) v okviru programa Jugovzhodna Evropa. Projekt je bil razpisan v okviru evropskega programa za prostorsko razvojno politiko s ciljem analizirati položaj izbranih starih industrijskih con ter na osnovi pregleda dejanskega stanja v državah Jugovzhodne Evrope in primerov dobrih praks v razvitih državah opredeliti potrebne sistemske rešitve za revitalizacijo rjavih con $\mathrm{z}$ interdisciplinarnim (celostnim) pristopom pri pripravi regionalnih in lokalnih prostorskih načrtov.

Glavni namen in cilj projekta ReTInA je bil razviti uporabno metodologijo revitalizacije starih industrijskih območij v Jugovzhodni Evropi na podlagi modela, ki je izhajal iz študije primerov dobre prakse in je vključeval lokalne in regionalne zainteresirane institucije (stakeholderji). Dolgoročni cilj projekta je revitalizacija izbranih starih 
industrijskih območij in s tem zagotovitev kakovostnih novih delovnih mest in trajnostnega razvoja prostora ter vzpostavitev sinergijskih učinkov z zagotavljanjem kakovosti bivanja, socialne varnosti in kulturne dejavnosti.

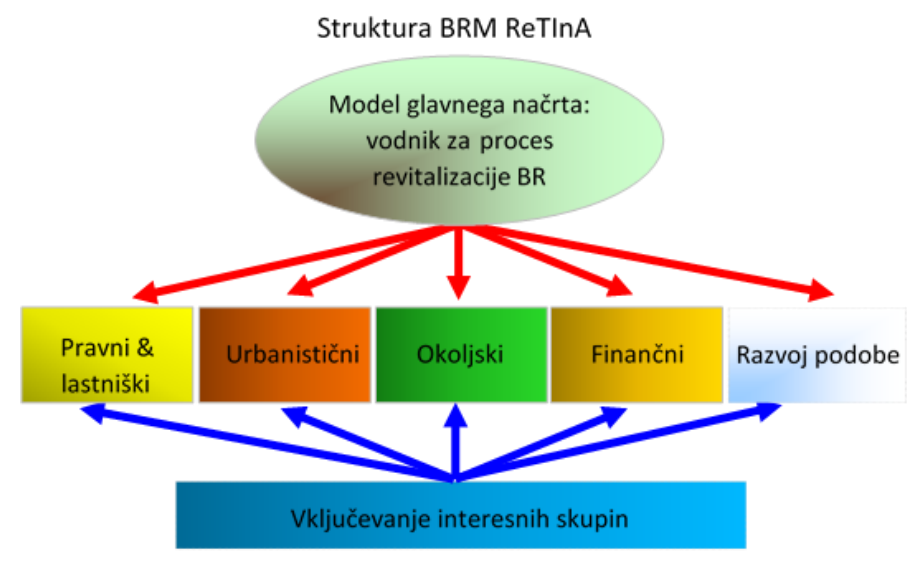

Struktura metodologije za revitalizacijo rjavih con.

Univerza v Mariboru je bila zadolžena za izdelavo Metodologije za revitalizacijo rjavih con v Jugovzhodni Evropi (Brownfield Revitalisation Methodology SEE - BRM), kar predstavlja končni cilj projekta. Inovativni pristop $\mathrm{k}$ načrtovanju in izvajanju revitalizacije je upošteval interdisciplinarnost in je vključeval delo interesnih skupin. Interesne skupine so pristopile $\mathrm{k}$ analizi in proučevanju stanja po posameznih vsebinskih sklopih. Prva skupina se je ukvarjala z vprašanji pravnih in lastniških razmerij ter načini financiranja, ki jih omogočajo nacionalne zakonodaje. V tej ekspertni skupini so sodelovali pravniki, ekonomisti in predstavniki lokalnih institucij. V drugo skupino so bili vključeni strokovnjaki s področij prostorskega načrtovanja, geografije, arhitekture, urbanizma in ekologije. Ta skupina je pripravila predloge za dopolnitev mestnih prostorskih načrtov, ki upoštevajo obnovo in opredeljujejo nove možne funkcije starih industrijskih con. Na osnovi poznavanja splošnih tehnoloških procesov in uporabljenih tehnologij ter medsebojne odvisnosti procesov in potencialnih virov onesnaževanja je bil pripravljen tudi pregled možnih onesnaževalcev, prisotnih v industrijskih območjih.

Posebna pozornost je bila namenjena negativni podobi starih industrijskih con, območij oziroma industrijskih mest. Kako vplivati na razvoj pozitivne podobe degradiranih območij, je bilo vprašanje, s katerim so se ukvarjali strokovnjaki v tretjem sklopu.

Na podlagi vseh opravljenih študij in rednega usklajevanja partnerjev projekta je bila narejena osnovna struktura Metodologije za revitalizacijo rjavih con. Delovne skupine so v končni rezultat projekta vključile tudi pričakovanja interesnih skupin (stakeholderjev) in izdelale Vodnik za procese revitalizacije starih industrijskih območij, ki predstavlja vodilo, kako v praksi pristopiti k revitalizaciji starih industrijskih območij. Na osnovi izdelane metodologije so bila pripravljena priporočila (ReTInA Policy Recommendations) za nacionalne organe šestih sodelujočih držav in za organe Evropske unije. Nacionalna priporočila predlagajo, da se rjave cone vključi v nacionalne strateške dokumente in akcijske načrte. Prav tako je potrebno vključiti revitalizacijo rjavih con v operativne programe za koriščenje strukturnih skladov Evropske unije ter razvijati 
spodbude za naložbe $\mathrm{v}$ rjave cone in zmanjšati privlačnost naložb v zelena območja (greenfields). Doseženi projektni rezultat je omogočil oblikovanje agende za organe Evropske unije, s katero smo opozorili na nujnost krepitve podpore revitalizaciji rjavih con v okviru doseganja strateških ciljev Unije, zlasti zagotavljanja trajnostnega razvoja, kakovosti okolja, ohranitve kmetijskih zemljišč in komprimiranja mest.

Mestna občina Maribor je sprejela Metodologijo za revitalizacijo rjavih con kot instrument, na podlagi katerega bo v prihodnosti lahko koncipirala občinsko prostorsko politiko, ki omenjenih industrijskih območij ne bo izključevala iz urejanja mesta, temveč jih bo z mestom povezovala. Rezultate projekta ReTInA bo Mestna občina Maribor uporabila za dokončno pripravo mestnega prostorskega načrta. Mesto bo v prvi fazi pristopilo k ekološki in vizualni revitalizaciji starih industrijskih con, da bi povečali možnosti za privabljanje novih investitorjev, saj v njih še vedno prevladuje degradiran prostor. Ureditev robnih območij lahko Cono Tezno še bolj poveže z mestom. Cona Tezno ne sme biti nekakšno sivo območje iz polpretekle dobe, temveč odprto območje (Kancler, 2011).

$\mathrm{V}$ obdobju hitrega tehnološkega razvoja in nove ocenitve hierarhije lokacijskih dejavnikov industrije dobiva prostor industrijskih con nov pomen in vrednost. Razvoj temelji na razvoju novih industrij, ki so vezane na razvoj znanosti in tehnologije s ciljem dviga dodane vrednosti na enoto proizvoda. Nove cone nastajajo z namenom oblikovanja podjetniškega podpornega okolja za prenos znanja $\mathrm{v}$ proizvodnjo in zagotavljajo oblikovanje poslovno-tehnoloških in logističnih sistemov z vertikalno in horizontalno integracijo.

Poseben poudarek je namenjen razvoju, delovanju in povezovanju inkubatorjev in inovacijskih centrov. Sodobne industrijsko-poslovne cone omogočajo racionalnejšo rabo mestnih zemljišč, oblikovanje skupne logistične mreže, vključevanje v globalne informacijsko-komunikacijske mreže ter zagotavljajo ekološko ravnovesje oziroma varnost.

Stare industrijske cone so se v preteklosti velikokrat razvijale ločeno od mesta. Območja con so bila namreč »zaprta« in so se razvijala po lastnem načrtu in ne kot sestavni del mesta. Glede nadaljnjega razvoja klasičnih con se mnenja razlikujejo. Mestne občine in načrtovalci prostorskega razvoja se zavzemajo za odprto zasnovo con, ki bi omogočala prepletanje različnih funkcij in bi sledila interesom uporabnikov. Spet drugi pa bi želeli stare cone ohraniti »zaprte«, namenjene zgolj industriji, poslovnim in v manjši meri tudi storitvenim dejavnostim.

Za projekt uspešne regeneracije je potreben skrben in strokoven fazni pristop:

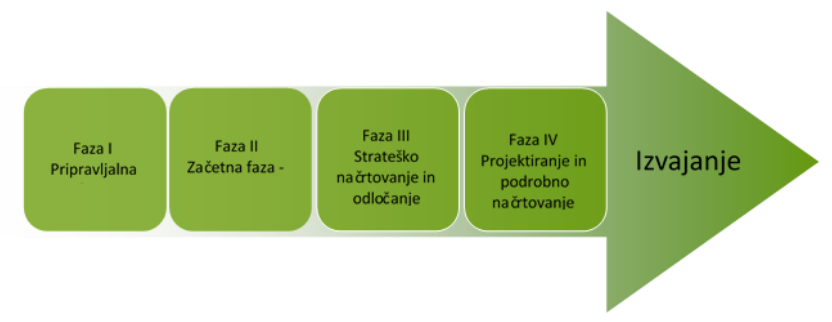


Za celotni proces načrtovanja, za vsako fazo, je potrebno opredeliti vsebine:

- $\quad$ kaj narediti $=>$ pričakovani rezultati faze;

- pomembni vidiki, ki jih je treba zajeti: lastništvo, okolje, urbanistični vidiki, viri in tehnike financiranja;

- $\quad$ kako narediti => potrebni koraki;

- $\quad$ kdo naj kaj naredi => strokovnjaki, interesne skupine;

- katere metode uporabiti za izvedbo posameznih korakov;

- osredotočenje na kakovost;

- ocena in obvladovanje tveganja.

Pri tem moramo upoštevati razmere:

- glavne značilnosti rjavih con;

- zakonski okvir (na primer evidence, zemljiško knjigo) in organiziranost pobudnika;

- nujnost profesionalnega upravljanja projekta;

- nujnost/smiselnost vključevanja interesnih skupin oziroma razvitost/razvijanje kulture sodelovanja;

- nujnost prilagodljivosti pri načrtovanju in izvajanju;

- dosegljivost javnih finančnih sredstev (vključno s sredstvi Evropske unije);

- pomen razvoja podobe in trženja za privabljanje zasebnega kapitala.

Zaključki in priporočila projekta ReTInA.

Za lokalne (regionalne) deležnike:

- osredotočenje na širši gospodarski in socialni okvir;

- priprava načrta revitalizacije v širšem okviru načrtovanja trajnostnega mesta;

- vključitev ustreznih interesnih skupin;

- vključitev tržnih vidikov in trženjskih elementov v zgodnji fazi načrtovanja;

- načrtovanje vključevanja javnih sredstev (zadostni obseg in trajanje);

- načrtovanje uspešnega izvajanja projekta že $v$ začetni fazi načrtovanja: kakovost, stalnost, zmanjšanje/odstranitev (političnih) tveganj;

- profesionalno vodenje projekta ter profesionalna promocija in upravljanje cone;

- načrtovanje podpore za privabljanje investitorjev.

Za nacionalne organe:

- vključitev rjave cone v nacionalne strateške dokumente in akcijske načrte;

- vključitev revitalizacije rjavih con $\mathrm{v}$ operativne programe za koriščenje strukturnih skladov Evropske unije;

- razvijanje spodbude za naložbe v rjave cone;

- zmanjšanje privlačnosti naložb v zelena območja (greenfields);

- izboljšanje splošne poslovne klime za privabljanje investitorjev. 
Za organe Evropske unije:

- (še) večja in bolj osredotočena podpora revitalizaciji rjavih con v okviru doseganja strateških ciljev: Evropska unija naj postane boljši kraj za življenje, investiranje in delo;

- vključitev revitalizacije rjavih con med prednostne naloge (okolje, ohranitev kmetijskih zemljišč, trajnostni razvoj, komprimiranje mest itd.);

- nadaljevanje in krepitev razvoja ter razširjanja znanja in dobrih praks;

- spodbujanje nacionalnih/regionalnih/lokalnih deležnikov k pripravljanju strategij in načrtov, programov spodbujanja in shem spodbud za revitalizacijo rjavih con;

- povečanje namenskih sredstev za deležnike, vključene v revitalizacijo rjavih con, vključno z zasebnimi investitorji in različnimi oblikami partnerstev (javna partnerstva, javno-zasebna partnerstva).

Metodologija, znanje in partnerstva, ki so nastala v okviru projekta ReTInA, so uporabni za načrtovanje in izvajanje prenove in uvajanje novih funkcij v stare industrijske lokacije tako v Mariboru kot drugod po Sloveniji:

- za spodbujanje pobud, pomoč pobudnikom in načrtovalcem na lokalni ravni,

- za načrtovalce ukrepov politik na nacionalni ravni,

- za razvoj kakovostnih izvajalskih struktur ter

- za večjo vpetost $\mathrm{v}$ čezmejno sodelovanje in povečanje mednarodne konkurenčnosti.

\section{Zaključek}

Pomen procesov prestrukturiranja mariborske industrije je v prilagajanju razmeram na svetovnem trgu, ki izhajajo iz ekonomskih ciljev dolgoročne rasti dodane vrednosti in produktivnosti. Ti procesi bodo omogočili primeren standard prebivalstvu in zagotovili uspešen regionalni razvoj. Doseganje teh ciljev je odvisno od ustreznega razvoja predelovalnih dejavnosti, ki so tesno povezane z ostalimi gospodarskimi dejavnostmi. Razvite predelovalne dejavnosti so generator razvoja storitvenih dejavnosti, vezanih na industrijo. Te storitvene dejavnosti nudijo možnosti za zaposlitev delovne sile, ki je zaradi racionalizacije proizvodnih procesov in večje produktivnosti dela izgubila delovna mesta $\mathrm{v}$ predelovalni dejavnosti v procesih negativne deindustrializacije.

Izkušnje so pokazale, da strukturnih problemov mariborskega gospodarstva ni mogoče uspešno reševati le z zunanjimi razvojnimi spodbudami (investicije, državna sredstva, pritegovanje novih podjetij) v skladu s pričakovanimi učinki »top-down« modela (Parker, 2000). Mestu in gospodarskim subjektom manjka razvojna vizija. Strategija »bottom-up« modela je pokazala nemoč mariborskega gospodarstva, saj so bili kvalitativni in kvantitativni učinki zaradi skromnega razvojnega potenciala manjši od pričakovanih. Endogeno (bottom-up model) zasnovan pristop k spodbujanju razvoja, ki temelji na izkoriščanju lastnih razvojnih možnosti mariborskega gospodarstva, je v tej razvojni fazi nujen. Vendar bi se moral čim prej povezati z modelom lokalno-globalnega partnerstva, da bi dosegli večjo učinkovitost $\mathrm{v}$ razvoju s povezovanjem mednarodnih in državnih sredstev, kakor tudi z zasebnimi sredstvi, in izgraditi javno-zasebno partnerstvo. 
Za izboljšanje položaja mariborskega gospodarstva in uspešno implementacijo razvojnega programa je potrebno spodbuditi strateške nosilce njegovega razvoja (prometna - logistična dejavnost, finančne in poslovne storitve, turizem, veliko in malo podjetništvo). Tako $\mathrm{v}$ regionalnem kot nacionalnem interesu je izkoristiti ugoden geostrateški položaj in razvojno perspektivo v funkciji čezmejnega sodelovanja. Povečati je potrebno javna in zasebna vlaganja $\mathrm{v}$ izobraževanje, zlasti $\mathrm{v}$ znanost in nove tehnologije, ki bi skupaj $\mathrm{z}$ vlaganji $\mathrm{v}$ podjetništvo tvorile osnovo za preobrazbo mariborskega gospodarstva in regeneracijo degradiranih industrijskih con in mestnih predelov.

S programom Obzorja 2020 je Evropska unija zagotovila raziskavam in inovacijam največji obseg finančnih sredstev doslej - v obsegu osemdeset milijard evrov. Prednost pri črpanju sredstev znotraj posamezne članice imajo manj razvite kohezijske regije. Za uspešnost izvedbe projektov, ki zagotavljajo regionalni gospodarski razvoj, imajo največjo priložnost in odgovornost institucije znanja. Odgovorne so za spremljanje globalnih razvojnih trendov tako na teoretični (nove metode) kot praktični ravni (prenos dobrih praks). Njihova stalna obveza in dolžnost je, da vzpostavljajo sodelovanje z lokalnim in regionalnim okoljem na podjetniški in institucionalni ravni. Model četverne vijačnice in odprtih inovacij omogoča sinergijo različnih deležnikov tako na področju izmenjave in nadgradnje znanj kot možnosti dostopa do uporabe skupne znanstvenoraziskovalne opreme. Z vključevanjem in povezovanjem (trojna/četverna vijačnica) institucij znanja $v$ posamezne inovativno razvojne projekte bo zagotovljen dolgoročni trajnostni razvoj. Univerza v Mariboru je vodilna institucija znanja v Vzhodni kohezijski regiji. S podpornimi institucijami inovacijskega ekosistema, ki delujejo znotraj univerzitetnega okolja, se dejavno vključuje v lokalni, regionalni in mednarodni prostor (Medmrežje 1).

Cilj uspešne regeneracije Maribora je trajnostna urbana prenova. Trajnostno urbano prenovo razumemo kot sinergijo med regeneracijskimi akcijami, politikami in procesi v mestu, ki obravnavajo medsebojno povezane tehnične, prostorske in družbenogospodarske probleme, da bi zmanjšali negativen vpliv na okolje in izboljšali kakovost življenja v urbanem sistemu. Tehnične rešitve niso dovolj za doseganje trajnostne urbane prenove. Ta cilj zahteva, da združujemo različne, pogosto nasprotujoče si, agende na različnih ravneh in v raznovrstnih gospodarskih sektorjih, da bi dosegli skladnost ter dolgoročne rešitve (Houk et al., 2015). Učinkovita regeneracija lahko odstraniti ovire za gospodarsko rast, krepi lokalno skupnost in prispeva k odprtju novih delovnih mest. Po drugi strani gospodarska rast omogoča boj proti prikrajšanosti in propadanju - pomaga pri obnavljanju in oživljanju gospodarskega utripa. Regeneracija v najširšem smislu lahko zares uspe in je trajnostna, če so izbrani pravi osnovni pogoji z zdravim zasebnim sektorjem gospodarstva.

\section{Literatura in viri}

APS Group 2011: Regeneration Strategy - Achieving A Sustainable Future, APS Group Scotland DPPAS12130 (11/11), Published by the Scottish Government, 56.

Bartke, S. (ed.) 2013: Brownfield Regeneration, Science for Environment Policy, Thematic Issue 39 , str. 20.

http://ec.europa.eu/environment/integration/research/newsalert/pdf/39si_en.pdf. 
Berden, K. 2015: Reurbanizacija treh degradiranih industrijskih območij ob železnici v Mariboru, Univerza v Ljubljani, Biotehniška fakulteta, Oddelek za krajinsko arhitekturo, magistrsko delo.

Bernard, A.,B., Smeets, V. in Warzynski, F. 2016: Rethinking Deindustrialization, CEP Discussion Paper No 1423, str. 37, http://cep.lse.ac.uk/pubs/download/dp1423.pdf.

Bole, D. 2008: Ekonomska preobrazba slovenskih mest, Založba ZRC, Geografija Slovenije 19, Ljubljana.

Clavijo, S., Vera, A. in Fandino, A. 2014: Deindustrialization in Colombia: Quantitative

Analysis of Determinants, Lambert Academic Publishing.

Christopherson, S., Martin, R., Sunley, P. and Tyler, P. 2014: Reindustrialising regions: rebuilding the manufacturing economy? Cambridge J Regions Econ Soc 7 (3): 351-358, https://doi.org/10.1093/cjres/rsu023.

Colantonio, A. and Dixon, T. 2009: Measuring Socially Sustainable Urban Regeneration in Europe, Oxford Institute for Sustainable Development (OISD), str .129,

http://oisd.brookes.ac.uk/sustainable_communities/resources/Social_Sustainability_and_Urban_ Regeneration_report.pdf.

Damiani, M., Uvalić, M. 2014: Industrial Development in the EU: What Lessons for the

Future Member States? Croatian Economic Survey, 16 (1), 5-48.

Frantál, B., Kunc, J., Nováková, E., Klusáček, P., Martinát, S. and Osman, R. 2013: Location Matters! Exploring Brownfields Regeneration in a Spatial Context (A Case Study of the South Moravian Region, Czech Republic), Moravian Geographical Reports, Vol. 21, 2/2013, http://www.geonika.cz/EN/research/ENMGRClanky/2013_2_FRANTAL.pdf.

Greenaway, D. and Nam, C., H. 1988: Industrialisation and Macroeconomic Performance in Developing Countries under Alternative Trade Strategies, Kyklos, Vol 41, Fasc 3, 419-435.

Herakovič, N. 2016: Nekateri tehnološki izzivi Industrije 4.0, Ventil 22 /2016/ 1, http://193.2.78.22/ventil/revije/2016/Nekateri_tehnoloski_izzivi_Industrije_4_0.pdf.

Houk, M. (ed.), Koutsomarkou, J. (ed.), Moulin, E. (ed.) and Scantamburlo, M. (ed.) 2015: Sustainable regeneration in urban areas, Urbact ii capitalisation, Published by URBACT, http://urbact.eu.

Kancler, T. 2011: Mestno prostorsko načrtovanje - vključevanje Cone Tezno City Spatial Planning - Inclusion of BIZ Tezno, v: Lorber, Lučka (ur.), ReTInA : revitalizacija starih industrijskih območij, Cona Tezno = revitalization of traditional industrial areas, BIZ Tezno, Maribor, Filozofska fakulteta, 2011, 32-36.

Kitson, M., J. Michie 1997: Does Manufacturing Matter?, International Journal of the Economics of Business, 4(1), 71-95.

Kuttor, D. in Hegyi-Kéri, A. 2014: Reasons or Effects of the Deindustrialization in Visegrad Countries, Journal of Global Strategic Management, V. 8.

Leskovec, A. 1983: Upravni in gospodarski razvoj Maribora v 19. stoletju. V: Vodopivec, P. (ur.), Kronika - časopis za zgodovino in narodopisje, letnik 31, št. 1-2, posvečen zgodovini Maribora, 167-175.

Lorber, L. 1999: Procesi prestrukturiranja industrije Maribora i njihov utjecaj na transformaciju prostora: doktorska disertacija, Zagreb, 1999.

Lorber, L. 2002: The impact of the textile industry on the development of the city of Maribor, v: Aubert, A. (ur.), Csapó, J. (ur.), Settlement dynamics and its spatial impacts = Siedlungsdynamik und ihre Räumliche Wirkungen : 16-18th September, 2002 Szombathely, Hungary, Pécs, 88-98.

Lorber, L. 2006: Development of the industrial areas of Maribor and change of their intended function, v: MAIER, Jörg (ur.), Stadt und Stadtregion Maribor: Strukturen, Entwicklungen, Probleme, (Arbeitsmaterialien zur Raumordnung und Raumplanung, Hft. 250), Bayreuth, $35-48$

Lorber, L. 2011: Interdisciplinary methodological approach to the process of brownfield revitalisation of traditional industrial areas, Revija za geografijo 6, št. 1,7-21.

Lorber, L. 2014: Holistic approach to revitalised old industrial areas, v: EFE, Recep (ur.), 3rd International Geography Symposium, Procedia - social and behavioral sciences, New 
York: Elsevier, vol. 120, 326-334, http://www.sciencedirect.com/science/article/pii/S1877042814016401.

Matjašič, M. 1983: Demografsko ekonomski aspekti strukture mariborskega mestnega prebivalstva, v: Vodopivec, P. (ur.). Kronika - časopis za zgodovino in narodopisje, letnik 31, št. 1-2, posvečen zgodovini Maribora, $240-246$.

Meecham, P. 2005: Rethinking the Regeneration Industry, Museums for changing lives? Regeneration, Issue 17, str. 7, http://www.engage.org/downloads/18BA16BC7_17.\%20Pam\%20Meecham.pdf.

Medmrežje 1: http://www.um.si/univerza/iot/Strani/default.aspx, (18.2.2017).

Mickiewicz, T., Zalewska, A. (2002) Deindustrialisation, Lessons from the Structural

Outcomes of Post-Communist Transition, William Davidson Institute Working Paper 463.

Parker, P. 2000: Global Oppotunities and Regional Strategies: Contrasting Canada's Technology Triangle and Australia's Multi - Function Polis, v Regional Cohesion and Competition in the Age of Globalization.

Rowthorn, R., Wells, J. 1987: De-industrialization and foreign trade, Cambridge University Press.

Rowthorn, R., Ramaswamy, R. 1997: Deindustrialization its Causes and Implication, Economic Issue 10, International Monetary Fund, Washington D.C., http://www.imf.org/external/pubs/ft/wp/wp9742.pdf.

Smith, A. 1776: An Inquiry into the Nature and Causes of the Wealth of Nations, W.

Strahan and T. Cadell, London.

Slavec Gornik, A. 1992: Industrija Maribora : magistrsko delo, Ljubljana.

Tregenna, F. 2015: Deindustrialisation, structural change and sustainable economic growth, Research, Statistics and Industrial Policy Branch Working Paper 2/2015, 64.

Tyler, P., Warnock, C. and Provins, A. 2010: Valuing the Benefits of Regeneration, Economics paper 7: Volume I - Final Report, Cambridge Economic Associates with eftec, CRESR, University of Warwick and Cambridge Econometrics, Department for Communities and Local Government, 131.

Vrišer, I. 1978: Regionalno planiranje, (Tokovi), Ljubljana, Mladinska knjiga.

Zgonik, M. 1983: Vloga geografskega okolja na začetke in rast Maribora, v: Vodopivec, P. (ur.), Kronika - časopis za zgodovino in narodopisje, letnik 31, št. 1-2, posvečen zgodovini Maribora, 103-114. 


\title{
Kakovost bivalnega okolja v Mariboru
}

\author{
JERNEJ TIRAN, SIMON KOBLAR
}

Povzetek Kakovost bivalnega okolja v Mariboru na začetku drugega desetletja 21. stoletja smo izmerili na objektiven način $\mathrm{s}$ seštevanjem standardiziranih neobteženih kazalnikov stanovanjskih razmer, varnosti, estetske vrednosti, dostopnosti mestnih dobrin, obremenjenosti okolja, družbenega okolja in pogojev za mobilnost. Ugotovili smo, da v najbolj kakovostnem okolju živijo prebivalci širšega mestnega središča na levem bregu Drave, predela Maribor - jug in pod Pohorjem, $v$ najmanj kakovostnem pa prebivalci $\mathrm{v}$ bližini industrijskih območij, kot so Studenci, Tezno in Melje. Rezultati raziskave so potencialno koristni za mestne oblasti in urbanistične načrtovalce kot podpora pri prostorskemu odločanju, bodisi za konkretno sanacijo bivalnega okolja bodisi določanje primernih lokacij za stanovanjsko gradnjo.

Ključne besede: • urbanistično načrtovanje $・$ urbana geografija $\bullet$ bivalno okolje $\bullet$ zgradba mesta $\bullet$ Maribor •

NASLOV AVTORJEv: dr. Jernej Tiran, Geografski inštitut Antona Melika ZRC SAZU, Novi trg 2, 1000 Ljubljana, Slovenija, e-naslov: jernej.tiran@zrc-sazu.si. Simon Koblar, sodelavec, Oddelek za geografijo Filozofske fakultete v Ljubljani, Aškerčeva 2, 1000 Ljubljana, Slovenija, e-naslov: koblar.simon@gmail.com. 


\title{
Quality of residential environment in Maribor
}

\author{
JERNEJ TIRAN, SIMON KOBLAR
}

\begin{abstract}
The research objectively evaluated the quality of residential environment in Maribor at the outset of the second decade of the 21st century using the method of summing the unweighted standardized indicators of dwelling characteristics, safety, aesthetics, accessibility to urban amenities, environmental strain, social environment, and transportation conditions. We determined that the most high-quality environment includes the wider city centre on the left bank of the Drava River, Maribor - south, and under the Pohorje Mountains, and the lowest quality areas feature areas in the vicinity of industrial areas, such as Studenci, Melje, and the older part of Tezno. The study results can be useful to city authorities and urban planners as a support in the decisionmaking for management and planning; for example, as the basis for improving the residential environment or for determining the appropriate locations for residential construction.
\end{abstract}

Keywords: • urban planning $\bullet$ urban geography $\bullet$ residential environment - town structure $\cdot$ Maribor •

CoRRESPONDENCE AdDRESS: Jernej Tiran, Ph.D., Researcher, Geophical institute Anton Melik ZRC SAZU, Novi trg 2, 1000 Ljubljana, Slovenia, e-mail: jernej.tiran@zrc-sazu.si. Simon Koblar, Coworker, University of Ljubljana, Faculty of Arts, Department for geography, Aškerčeva 2, 1000 Ljubljana, Slovenia, e-mail: koblar.simon@gmail.com. 


\section{Uvod}

Mesta so zapleten, dinamičen in protisloven prostorski ter družbeni pojav. V mestih se prepletajo in si nemalokrat nasprotujejo interesi različnih akterjev in družbenih skupin, ki jih je treba nenehno usklajevati. Bivanje v mestu pomeni soočenje $z$ vrsto pozitivnih in negativnih učinkov, ki se spreminjajo v času in prostoru ter na različne načine vplivajo na odnos med človekom in njegovim bivalnim okoljem (npr. Mira s sodelavci, 2005). Zato ne preseneča, da je prizadevanje za kakovostno bivalno okolje $v$ mestih, kjer dandanes živi že več kot polovica svetovnega prebivalstva (World's population increasingly ..., 2014), postalo pomembna sestavina urbanističnega načrtovanja ter prostorskih dokumentov na lokalni, državni in mednarodni ravni.

Bivalno okolje je večplasten pojem, kompleksen preplet številnih vsebin, ki imajo različno prostorsko razsežnost, zato ga je zelo težko opredeliti. Preučevanje kakovosti bivalnega okolja se je uveljavilo tudi v geografiji, ki je s celostnim in prostorskim pristopom pomembno pripomogla $\mathrm{k}$ napredku tega raziskovalnega področja. Kakovost bivalnega okolja je tipičen sintezni kazalnik razmer na nekem območju, saj združuje različne vidike prostorskih razmerij, pomembnih za kakovost bivanja. Pod celostnim pristopom razumemo tudi izrazito vključevalno obravnavo bivalnega okolja $\mathrm{z}$ vidika njegovih vsebin. Geografske raziskave so $\mathrm{z}$ vključevanjem prostorskih in okoljskih vsebin pomembno pripomogle k vsebinskemu bogatenju tovrstnih raziskav (npr. Cutter, 1985; Pacione, 1986; Krevs, 2001).

Kakovost bivanja in bivalnega okolja pa se ne spreminjata le od človeka do človeka, temveč tudi od prostora do prostora. Geografske raziskave kakovosti bivalnega okolja in kakovosti življenja se zato od drugih razlikujejo predvsem po uporabi prostorskega referenčnega okvirja na praviloma nižjih prostorskih ravneh, kot so soseska, krajevna skupnost ali mestna četrt. Prostorski pristop se osredotoča na preučevanje razmestitve pojavov, njihove prepletenosti in velikosti prostorskih razlik (npr. Knox, 1975; Černe, 1997; Krevs 1998).

Maribor je drugo največje slovensko mesto ter je gospodarsko, kulturno, izobraževalno, zdravstveno, oskrbovalno in prometno središče severovzhodne Slovenije (Senegačnik, 1995). Maribor je v slovenskem urbanem sistemu nekakšna posebnost, saj je edino mesto velikostnega reda okrog 100.000 prebivalcev. Je edino mesto poleg Ljubljane, ki ima mednarodni pomen in je primerljivo s srednje velikimi evropskimi mesti (Drobne et al., 2014). Večja mesta pa imajo praviloma tudi bolj heterogeno notranjo zgradbo, tudi $\mathrm{z}$ vidika kakovosti bivalnega okolja. To velja tudi za Maribor, kjer je bilo na to temo že opravljenih nekaj raziskav. Drozg (1994b, 1997) je v analizah, ki ju je napravil z vrednotenjem na podlagi urbanističnih normativov kazalnikov opremljenosti, dostopnosti, ekološke obremenjenosti in urejenosti na ravni 32-ih strukturno homogenih stanovanjskih območij, ugotovil, da med območji obstajajo precejšnje razlike glede opremljenosti, urejenosti in dostopnosti. To sta tudi zadnji tovrstni analizi na ravni celotnega mesta.

Osrednji namen prispevka je izmeriti kakovost bivalnega okolja v Mariboru na začetku drugega desetletja 21. stoletja na t. i. objektiven način, na podlagi različnih kazalnikov. Pri tem smo izhajali iz podmene, da se kakovost bivalnega okolja znotraj Maribora izrazito razlikuje. 


\section{Opredelitev bivalnega okolja}

Bivanje je ena od temeljnih človekovih funkcij. Potreba po bivanju je prisotna vedno in povsod ter je posredno ali neposredno povezana $\mathrm{z}$ vsemi drugimi področji človekovega življenja. Z bivanjem je neposredno povezano stanovanje, ki je njegova prostorska materializacija in človekov temeljni življenjski prostor (Drozg, 2014). Gre za splet sob, povezanih $\mathrm{v}$ funkcionalno celoto, prostor $\mathrm{z}$ jasno določenimi mejami, ki je zgrajen tako, da je ločen od okolice (Schmeidler, 2008). Vendar funkcija bivanja ni omejena samo na stanovanje, pač pa ima širši prostorski okvir. To dokazujejo tudi empirične raziskave, ki kažejo, da na zadovoljstvo s stanovanjem pomembno vpliva zadovoljstvo s sosesko, lokalno skupnostjo ali celo življenjem v regiji (npr. Sirgy in Cornwell, 2002). Okolica stanovanja, ki jo, poenostavljeno, lahko razumemo tudi kot njegovo lokacijo, je z njim neločljivo povezana in ima pomembno vlogo tudi pri izboru oziroma iskanju stanovanja. Kot takšna ima pokrajinske učinke, saj vpliva na primer na oblikovanje socialno homogenih območij in je tako pomemben dejavnik socialne členitve mestnega prostora (npr. Špes, 1998).

Vsebine bivalnega okolja so $\mathrm{v}$ literaturi številne in raznovrstne, saj se raziskovalci soočajo s pomanjkanjem oprijemljivih, trdnih in široko sprejetih teoretskih izhodišč. Izbor vsebin je zato marsikdaj odvisen od subjektivne presoje raziskovalca ali dostopnosti ustreznih podatkov. Obenem bivalno okolje z različnimi pristopi preučujejo številne znanstvene vede in stroke - poleg geografije tudi urbanistično in prostorsko načrtovanje, arhitektura, krajinska arhitektura, sociologija, psihologija in ekonometrija. V literaturi zato najdemo veliko sorodnih pojmov in konceptov (na primer prijetnost za življenje, kakovost prostora, stanovanjska blaginja, življenjska raven, kakovost življenja), raziskave pa se metodološko, vsebinsko in prostorsko močno razlikujejo (glej Tiran, 2017). Van Kamp s sodelavci (2003) zato poudarjajo nujnost sprejetja interdisciplinarnega konceptualnega okvira, s katerim bi presegli obstoječe delitve med znanstvenimi disciplinami in omogočili raziskovalni preboj.

Med redkimi teoretskimi deli, ki pojem bivalnega okolja podrobneje razčlenjujejo, izpostavljamo prispevek Drozga (1994a), v katerem je bivalno okolje obravnaval kot prostorsko in urbanistično kategorijo. Pri poskusu opredelitve bivalnega okolja, njegovih vsebin in kazalnikov se je oprl na temeljne človekove potrebe, ki so združene okrog funkcije bivati/stanovati, in na temeljne človekove dejavnosti oziroma funkcije - poleg bivanja še delo, oskrbo, komunikacijo, izobraževanje in rekreacijo (Ruppert et al., 1981). Te ustvarjajo prostorska razmerja in so med seboj močno prepletene in odvisne. Tudi Pust (1988) ugotavlja, da je za celovito razumevanje bivalnega okolja in njegovo kakovostno načrtovanje treba upoštevati vse človekove potrebe in dejavnosti. Podobno se je na eno od prvih in najbolj znanih tovrstnih teorij, Maslowovo teorijo potreb, naslonil Frey (1999) in jo uporabil za določitev kriterijev za uresničevanje paradigme trajnostnega razvoja na področju načrtovanja mest. Frey trdi, da lahko mesta zagotavljajo kakovost življenja svojim uporabnikom le, če stremijo k udejanjanju vseh potreb, ne le temeljnih, pač pa tudi potreb višjega reda, kakršna je na primer potreba po estetiki.

Ključne vsebine bivalnega okolja smo tudi v pričujoči raziskavi opredelili na podlagi različnih družbenih teorij, kot so teorija temeljnih človekovih funkcij (Ruppert et al., 1981), teorije človeških potreb (na primer Doyal in Gough, 1992), teorija dobrin (Glaeser, Kolko in Saiz, 2001) ter spoznanj empiričnih raziskav o najpomembnejših dejavnikih 
kakovosti bivanja v mestih in bivalnih preferencah (npr. Sirgy in Cornwell, 2002; Florida, Mellander in Stolarick, 2010; Leyden, Goldberg in Michelbach, 2011). Razvrstili smo jih v sedem sklopov:

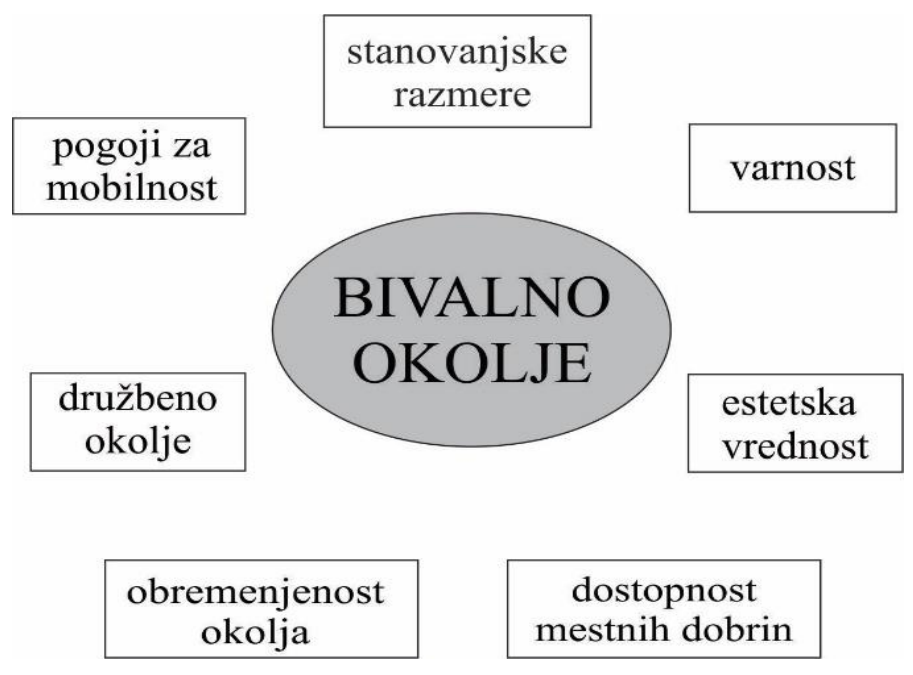

Vsebinski sklopi bivalnega okolja.

- Stanovanjske razmere - opredeljujejo fizične značilnosti stanovanja ali najožjega bivalnega okolja, ki pomembno vplivajo na zadovoljevanje številnih potreb, kot so zasebnost, varnost, sprostitev in komunikacija.

- Varnost je ena najpomembnejših človekovih vrednot in potreb, tudi v bivalnem okolju, kjer človek preživi največ svojega časa, vsebinsko pa je večplastna.

- Estetska vrednost bivalnega okolja - je v mestih še posebej pomembna, saj so mesta v očeh ljudi pogosto prepoznana kot manj kakovostna življenjska okolja ali celo kot »antiteza« narave. Načrtovanje urejenih, prijetnih in človekovemu merilu prilagojenih stanovanj, sosesk in mestnega prostora je tudi eno od temeljnih poslanstev urbanističnega načrtovanja in arhitekture.

- Dostopnost mestnih dobrin - opredeljuje družbena infrastruktura, pomembna za opravljanje izbranih temeljnih človekovih funkcij, to je oskrbe, storitev, izobraževanja in prostega časa. Ocenjena je $\mathrm{z}$ vidika dostopnosti oziroma lastnosti kraja, ki se nanaša na premagovanje prostorskega upora do izbranih lokacij v prostoru in času.

- Obremenjenost okolja - zaradi zgostitve prebivalstva in najrazličnejših dejavnosti v mestih na eni strani ter omejenih samočistilnih sposobnosti na drugi pomembno vpliva na zdravje in počutje prebivalcev, pravica do zdravega življenjskega okolja pa je celo ustavna kategorija.

- Družbeno okolje - pomembno vpliva na kakovost bivanja, ki ga prek posrednega potencialnega vpliva na družbene odnose in estetsko vrednost bivalnega okolja (videz stavb in okolice) $\mathrm{v}$ raziskavi ponazarjajo socioekonomske značilnosti lokalnega prebivalstva.

- Pogoji za mobilnost - se nanašajo na zmožnost premikanja oseb med različnimi prostori in prizorišči, kjer potekajo dejavnosti. S tem je nekakšen predpogoj za opravljanje ostalih funkcij, ki so z njo neločljivo povezane oziroma od njih odvisne. 
Bivalno okolje smo tako opredelili kot lastnosti stanovanja ter njegove ožje in širše okolice, ki so pomembne za zadovoljevanje splošnih človekovih potreb in opravljanje temeljnih človekovih funkcij: stanovanjske razmere, varnost, estetska vrednost, dostopnost mestnih dobrin, obremenjenost okolja, družbeno okolje in pogoji za mobilnost. Kakovost bivalnega okolja pa je celovita ocena razmer in pogojev za bivanje na določenem območju, ki temelji na objektivno merljivih značilnostih bivalnega okolja $\mathrm{z}$ različnimi kazalniki.

\section{Metodologija}

V raziskavi smo kakovost bivalnega okolja v Mariboru izmerili na objektiven način, to je z različnimi kazalniki, ki temeljijo na objektivni, kvantitativno podprti oceni. Vse vhodne podatke smo skušali pridobiti na čim nižji prostorski ravni ali pa smo prostorske enote, po katerih smo jih zbirali, določili tako, da naj bi bila znotraj njih kakovost bivalnega okolja čim bolj podobna. Kakovost bivalnega okolja smo izmerili na stanovanjsko stavbo natančno oziroma stavbam pripisali vrednosti rastrskih celic velikosti 25 x $25 \mathrm{~m}$, saj se kakovost bivalnega okolja $\mathrm{v}$ prostoru domnevno spreminja na zelo kratke razdalje.

Kakovost bivalnega okolja smo izmerili s skupno 31 kazalniki, ki ponazarjajo 18 vsebin in 7 vsebinskih sklopov. Razdelitev vsebinskih sklopov na vsebine, podvsebine in njihove kazalnike je prikazana v preglednici. Pri izboru vsebin in pripadajočih kazalnikov smo sledili načelom merljivosti, sodobnosti, reprezentativnosti in dostopnosti. To pomeni, da smo v raziskavo vključili podatke, ki so številske vrednosti, čim novejšega datuma, dobro ponazarjajo določeno vsebino bivalnega okolja in jih je mogoče pridobiti brez večjih stroškov.

Kakovost vsebin bivalnega okolja smo ponazorili z delnimi indeksi, kakovost bivalnega okolja kot celote pa s skupnim indeksom. Za združevanje kazalnikov v indekse smo po zgledu Smitha (1973) in Krevsa (1998 in 2002) uporabili metodo seštevanja standardiziranih neobteženih kazalnikov. Kazalnike ali delne indekse smo pred seštevanjem s standardizacijo v z-vrednosti pretvorili na isto mersko lestvico, da so bili med seboj primerljivi. Z-vrednosti predstavljajo odstopanja vrednosti posameznega kazalnika oziroma delnega indeksa od njegove povprečne vrednosti za vse poseljene stavbe ali poseljene rastrske celice na območju celotnega mesta glede na administrativno mejo naselja. Kot poseljena območja smo opredelili območja s 50-metrskim polmerom okrog hišnih številk, kjer je 1. 1. 2014 živel vsaj en prebivalec (Centralni register prebivalstva 2014, Evidenca hišnih številk 2014). Predpostavili smo, da so posamezne vsebine in njihovi kazalniki med seboj enakovredni, zato jih pred seštevanjem nismo obtežili in so bili v seštevku v vsebinskem smislu enakovredno upoštevani.

Delne indekse, ki so sestavljeni iz večjega števila vsebin, podvsebin ali kazalnikov, smo izračunali v več korakih. Vrednosti kazalnikov vsake vsebine smo vselej najprej standardizirali in jih nato sešteli. Ker so vrednosti delnih indeksov podvsebin, vsebin in vsebinskih sklopov pod vplivom števila členov vsote, smo pred nadaljnjim računanjem standardizirali tudi posamezne delne indekse, da so bili med seboj primerljivi. Pri računanju smo morali biti pozorni na smer vpliva (predznak) posameznega kazalnika na kakovost bivalnega okolja kot celoto. V nekaterih primerih ni bil izpolnjen pogoj o normalnosti porazdelitve, zato so bile z-vrednosti kazalnikov izredno visoke. Zaradi tega smo vrednosti delnih indeksov pred nadaljnjim računanjem zamejili na interval $-/+3, \mathrm{~s}$ 
čimer smo nekoliko ublažili vpliv skrajnih vrednosti na skupni indeks.

Vhodni podatki, iz katerih smo izračunali kazalnike vsebin bivalnega okolja, se razlikujejo po prostorski ločljivosti, potrebi po nadaljnji predelavi in uporabljenih metodah za predelavo. Razvrstimo jih lahko v štiri skupine:

- podatki iz raziskav z dobro prostorsko ločljivostjo (obremenjenost okolja),

- registrski podatki, agregirani na ravni različnih prostorskih enot (stanovanjske razmere, družbeno okolje, stopnja kriminalitete),

- podatki iz registrov in raziskav, iz katerih je bilo kazalnike razmeroma preprosto izračunati z obdelavo s prostorskimi statistikami (poplavna varnost, prometna varnost, estetska vrednost) ter

- podatki iz različnih registrov ali satelitskih posnetkov, ki smo jih obdelali in nato kazalnike izračunali s kompleksnejšo metodologijo (dostopnost mestnih dobrin, pogoji za mobilnost).

Za nekatere kazalnike iz zadnjih dveh skupin podrobneje predstavljamo metodologijo izračuna. Kazalnike peš dostopnosti mestnih dobrin smo izračunali na podlagi koncepta zmanjševanja z razdaljo (ang. distance-decay), ki se opira »prvi zakon geografije «, po katerem so »vse stvari v prostoru povezane, toda bližnje so bolj povezane kot bolj oddaljene ... « (Tobler, 1970: 236). Za vrednotenje razdalj smo uporabili rezultate spletne ankete med Ljubljančani, v kateri smo skušali odgovoriti na vprašanje, koliko so prebivalci pripravljeni prehoditi do posameznih mestnih dobrin (Tiran, 2014). Pri merjenju dostopnosti smo upoštevali oddaljenost najbližje mestne dobrine, pri nekaterih dobrinah pa tudi njihovo okoliško ponudbo glede na število. Dostopnost smo izračunali z mrežno analizo na podlagi topološko urejene mreže pešpoti (Tiran et al., 2016).

Z mrežno analizo smo izračunali tudi dostopnost avtobusnega mestnega potniškega prometa. To smo storili po nekoliko prilagojeni metodologiji PTAL (Public transport accessibility level). Metoda poleg prostorske dostopnosti avtobusnih postajališč upošteva tudi pogostost voženj avtobusnih linij. Podrobnejši opis metode je v člankih Tirana, Mladenoviča in Koblarja (2014 in 2015).

Vegetacijo smo določili iz barvnega digitalnega ortofota $\mathrm{z}$ nadzorovano pikselsko klasifikacijo na podlagi 32-ih vnaprej izbranih »učnih vzorcev« pozidanih in nepozidanih površin. V zadnjem koraku smo vso vegetacijo združili in obravnavali kot eno kategorijo, ostala zemljišča pa kot drugo. Vpliv bližine vizualno motečih objektov smo izračunali s funkcijo Mihaescuja in vom Hofeja (2012), ki ponazarja vpliv oddaljenosti degradiranih urbanih območij na cene nepremičnin. Avtorja sta ugotovila, da so cene nepremičnin, ki so več kot 300 m oddaljene od najbližjega degradiranega urbanega območja, za več kot 20 \% višje od tistih v njegovi neposredni bližini (podrobneje v Tiran, 2017). Degradirana urbana območja smo predhodno opredelili na podlagi obstoječih raziskav (Rebernik, 2009, Evidenca degradiranih površin, 2011) in subjektivne presoje na podlagi barvnega ortofota (2014). 
Vsebinski sklopi bivalnega okolja s pripadajočimi vsebinami in kazalniki.

\begin{tabular}{|c|c|c|c|c|c|}
\hline $\begin{array}{l}\text { Vsebinski } \\
\text { sklopi }\end{array}$ & \multicolumn{2}{|c|}{$\begin{array}{l}\text { Vsebine in } \\
\text { podvsebine }\end{array}$} & Kazalniki & $\begin{array}{l}\text { Vhodni podatek } \\
\text { (vir) }\end{array}$ & $\begin{array}{l}\text { Smer } \\
\text { vpliva }\end{array}$ \\
\hline \multirow[t]{4}{*}{$\begin{array}{l}\text { Stanovanjske } \\
\text { razmere }\end{array}$} & \multicolumn{2}{|c|}{$\begin{array}{l}\text { Starost stanovanjske } \\
\text { stavbe }\end{array}$} & $\begin{array}{l}\text { Leto izgradnje } \\
\text { stanovanjske stavbe }\end{array}$ & $\begin{array}{l}\text { Podatki o } \\
\text { stanovanjih ..., } \\
2011\end{array}$ & + \\
\hline & \multicolumn{2}{|c|}{$\begin{array}{l}\text { Opremljenost s } \\
\text { komunalno } \\
\text { infrastrukturo }\end{array}$} & $\begin{array}{l}\text { Odsotnost } \\
\text { priključka na } \\
\text { kanalizacijsko } \\
\text { omrežje }\end{array}$ & $\begin{array}{l}\text { Register } \\
\text { nepremičnin, } 2014\end{array}$ & - \\
\hline & \multirow{2}{*}{\multicolumn{2}{|c|}{ Velikost stanovanja }} & $\begin{array}{l}\text { Uporabna površina } \\
\text { stanovanja na } \\
\text { prebivalca }\end{array}$ & $\begin{array}{l}\text { Podatki o } \\
\text { stanovanjih ..., } \\
2011\end{array}$ & + \\
\hline & & & $\begin{array}{l}\text { Stevilo sob na } \\
\text { prebivalca }\end{array}$ & $\begin{array}{l}\text { Podatki o } \\
\text { stanovanjih ..., } \\
2011\end{array}$ & + \\
\hline \multirow[t]{3}{*}{ Varnost } & \multicolumn{2}{|c|}{$\begin{array}{l}\text { Lokalna poplavna } \\
\text { ogroženost }\end{array}$} & Verjetnost poplav & $\begin{array}{l}\text { Območja dosega } \\
\text { poplav, } 2013\end{array}$ & - \\
\hline & \multicolumn{2}{|c|}{$\begin{array}{l}\text { Lokalna prometna } \\
\text { varnost }\end{array}$} & $\begin{array}{l}\text { Število prometnih } \\
\text { nesreč z udeležbo } \\
\text { pešcev v 500- } \\
\text { metrskem polmeru }\end{array}$ & $\begin{array}{l}\text { Podatki o } \\
\text { prometnih ..., } 2016\end{array}$ & - \\
\hline & \multicolumn{2}{|c|}{$\begin{array}{l}\text { Stopnja } \\
\text { kriminalitete }\end{array}$} & $\begin{array}{l}\text { Število izbranih } \\
\text { vrst kaznivih dejanj } \\
\text { na } 1000 \\
\text { prebivalcev }\end{array}$ & $\begin{array}{l}\text { Število } \\
\text { obravnavanih ..., } \\
2015\end{array}$ & - \\
\hline \multirow[t]{3}{*}{$\begin{array}{l}\text { Estetska } \\
\text { vrednost }\end{array}$} & \multicolumn{2}{|c|}{$\begin{array}{l}\text { Pokrovnost } \mathrm{z} \\
\text { vegetacijo }\end{array}$} & $\begin{array}{l}\text { Delež vegetacije v } \\
100 \text {-metrskem } \\
\text { polmeru }\end{array}$ & $\begin{array}{l}\text { Barvni digitalni } \\
\text { ortofoto ..., } 2014\end{array}$ & + \\
\hline & \multicolumn{2}{|c|}{$\begin{array}{l}\text { Pestrost kulturne } \\
\text { dediščine }\end{array}$} & $\begin{array}{l}\text { Število vrst enot } \\
\text { nepremične } \\
\text { kulturne dediščine } \\
\text { v } 50 \text {-metrskem } \\
\text { polmeru }\end{array}$ & $\begin{array}{l}\text { Register } \\
\text { nepremične } \\
\text { kulturne } \\
\text { dediščine ..., } 2014\end{array}$ & + \\
\hline & \multicolumn{2}{|c|}{$\begin{array}{l}\text { Bližina vizualno } \\
\text { neprivlačnih } \\
\text { objektov }\end{array}$} & $\begin{array}{l}\text { Oddaljenost } \\
\text { degradiranih } \\
\text { urbanih območij }\end{array}$ & $\begin{array}{l}\text { Rebernik, 2007, } \\
\text { Evidenca } \\
\text { degradiranih } \\
\text { površin } 2011 ; \\
\text { Barvni digitalni } \\
\text { ortofoto ..., } 2014\end{array}$ & - \\
\hline \multirow[t]{4}{*}{$\begin{array}{l}\text { Dostopnost } \\
\text { mestnih dobrin }\end{array}$} & \multirow[t]{2}{*}{$\begin{array}{l}\text { Oskr- } \\
\text { ba }\end{array}$} & $\begin{array}{l}\text { Vsako- } \\
\text { dnevna } \\
\text { oskrba }\end{array}$ & $\begin{array}{l}\text { Peš dostopnost } \\
\text { trgovin z izdelki za } \\
\text { vsakdanjo rabo }\end{array}$ & $\begin{array}{l}\text { Podatki o } \\
\text { izbranih ..., } 2014\end{array}$ & + \\
\hline & & $\begin{array}{l}\text { Občasna } \\
\text { in izjemna } \\
\text { oskrba }\end{array}$ & $\begin{array}{l}\text { Peš dostopnost } \\
\text { hipermarketov in } \\
\text { nakupovalnih } \\
\text { središč }\end{array}$ & $\begin{array}{l}\text { Podatki o } \\
\text { izbranih ..., } 2014\end{array}$ & + \\
\hline & \multirow{2}{*}{\multicolumn{2}{|c|}{$\begin{array}{l}\text { Primarne } \\
\text { izobraževalne } \\
\text { ustanove }\end{array}$}} & $\begin{array}{l}\text { Peš dostopnost } \\
\text { najbližjega vrtca }\end{array}$ & $\begin{array}{l}\text { Podatki o } \\
\text { izbranih ..., } 2014\end{array}$ & + \\
\hline & & & $\begin{array}{l}\text { Peš dostopnost } \\
\text { najbližje osnovne }\end{array}$ & $\begin{array}{l}\text { Podatki o } \\
\text { izbranih ..., } 2014\end{array}$ & + \\
\hline
\end{tabular}


GeOgrafiJe Podravja

J. Tiran, S. Koblar: Kakovost bivalnega okolja v Mariboru

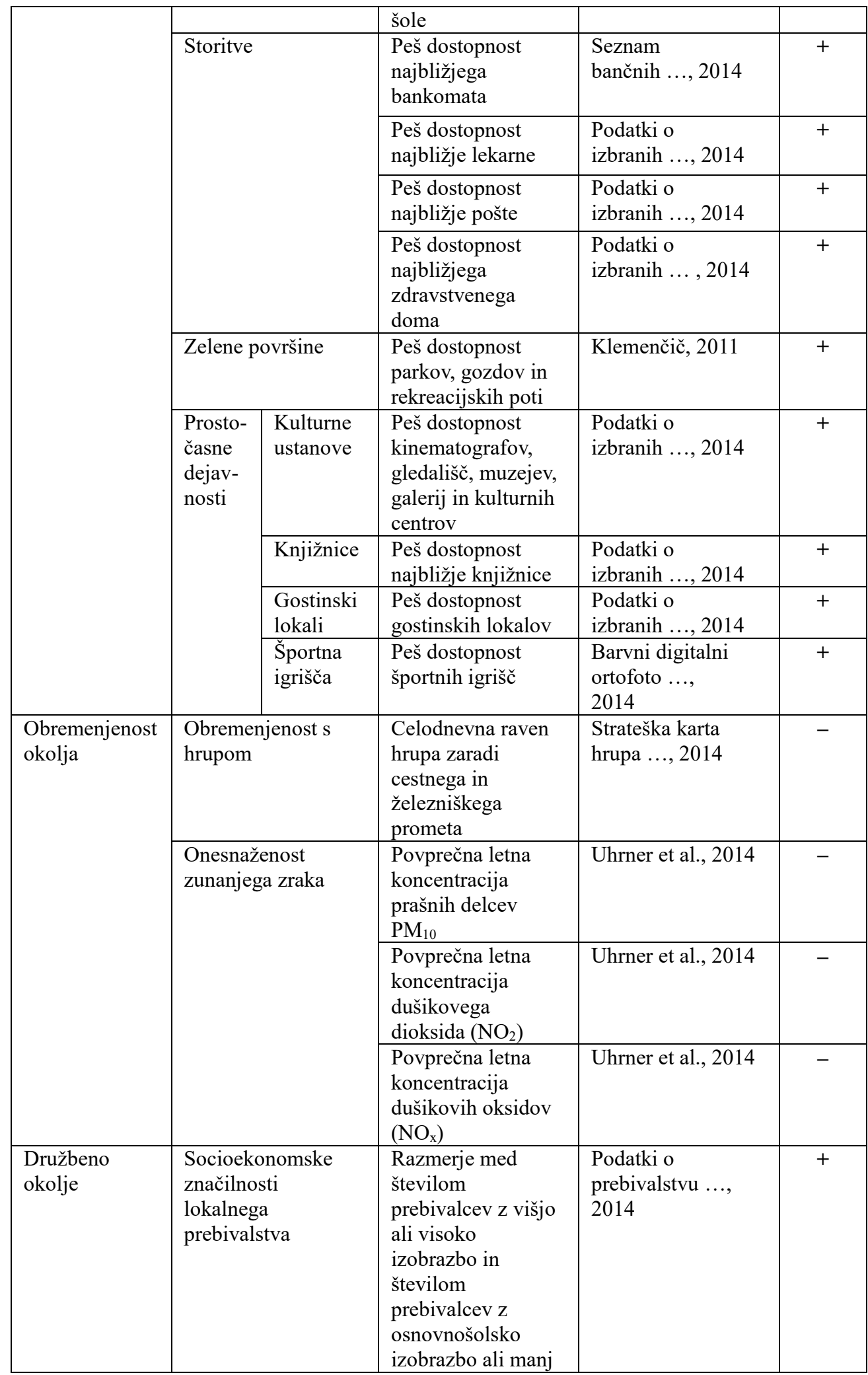




\begin{tabular}{|l|l|l|l|c|}
\hline & & $\begin{array}{l}\text { Stopnja registrirane } \\
\text { brezposelnosti }\end{array}$ & $\begin{array}{l}\text { Podatki o } \\
\text { prebivalstvu ..., } \\
2014\end{array}$ & - \\
\cline { 3 - 5 } & & $\begin{array}{l}\text { Bruto osnova za } \\
\text { dohodnino na } \\
\text { prebivalca }\end{array}$ & $\begin{array}{l}\text { Podatki o } \\
\text { prebivalstvu ..., } \\
2014\end{array}$ & + \\
\hline $\begin{array}{l}\text { Pogoji za } \\
\text { mobilnost }\end{array}$ & $\begin{array}{l}\text { Dostopnost javnega } \\
\text { potniškega prometa }\end{array}$ & $\begin{array}{l}\text { Koeficient } \\
\text { dostopnosti } \\
\text { avtobusnega } \\
\text { potniškega prometa }\end{array}$ & $\begin{array}{l}\text { Lokacije } \\
\text { avtobusnih } \\
\text { postajališč, 2014, } \\
\text { Vozni redi, 2014 }\end{array}$ & \\
\hline
\end{tabular}

\section{Kakovost bivalnega okolja v Mariboru}

V poglavju so opisno in kartografsko prikazani rezultati vrednotenja bivalnega okolja po posameznih vsebinskih sklopih in bivalnega okolja kot celote, do katerih smo prišli po zgoraj opisani metodologiji. Vrednosti indeksov na zemljevidih so prikazane po poseljenih stavbah in so pretvorjene $\mathrm{v}$ z-vrednosti oziroma standardni odklon od povprečne vrednosti posameznega indeksa. Rdeči barvni odtenki na vseh zemljevidih ponazarjajo nadpovprečne (ugodne), modri pa podpovprečne (neugodne) vrednosti.

\section{Stanovanjske razmere}

Stanovanjska območja v Mariboru se občutno razlikujejo predvsem po starosti stavb in po velikosti stanovanj. Kanalizacijsko omrežje v Mariboru je namreč zgrajeno skoraj v celoti, brez priključka je bilo leta 2015 samo 840 prebivalcev na posameznih ulicah na robnih območjih Košaškega dola, Damiševega naselja, Studencev in Teznega (Register nepremičnin, 2014; Akcijski načrt, ... 2015).

Najboljše stanovanjske razmere imajo prebivalci dandanes že močno preobraženih meščanskih vilskih četrti na levem bregu Drave in manjših območij sodobne organizirane eno- ali večstanovanjske gradnje, na primer v Zgornjem Radvanju pod Pohorjem, ob Koroški cesti (Dravske terase), Brezjah in v prenovljenem delu Lenta. Ponašajo se zlasti $\mathrm{z}$ visokim površinskim stanovanjskim standardom: od 39 do $49 \mathrm{~m}^{2}$ uporabne površine na prebivalca in od 1,5 do 1,7 sobe na prebivalca. Nadpovprečne stanovanjske razmere imajo tudi prebivalci novejših območij enostanovanjskih hiš, zgrajenih konec 60. let ali pozneje, na primer v Novi vasi, pod Pohorjem, v Studencih, Taboru in Brezjah, vrstnih hišah na Bezenškovi ulici v Koroških vratih, večinoma z okrog $35 \mathrm{~m}^{2}$ uporabne površine in 1,5 sobe na prebivalca. Najslabše stanovanjske razmere pa imajo starejše delavske kolonije na Studencih, Magdaleni, Teznem in Melju, večinoma zgrajene konec 19. in na začetku 20. stoletja. Po površinskem kriteriju jih lahko označimo za stanovanjsko prenaseljena, saj so $\mathrm{z}$ večinoma pod $20 \mathrm{~m}^{2}$ uporabne površine na prebivalca močno pod občinskim povprečjem, ki je $28,2 \mathrm{~m}^{2}$. Zaradi zelo starega (in dotrajanega) stavbnega fonda ima podpovprečne stanovanjske razmere tudi večji del starega mestnega središča.

\section{Varnost}

Poplavno ogrožena območja so izmed poseljenih območij omejena na majhen del poplavne ravnice Radvanjskega potoka pod Mariborskim Pohorjem, zato imata največji vpliv na prostorske razlike $\mathrm{v}$ varnosti prometna in osebna varnost. 


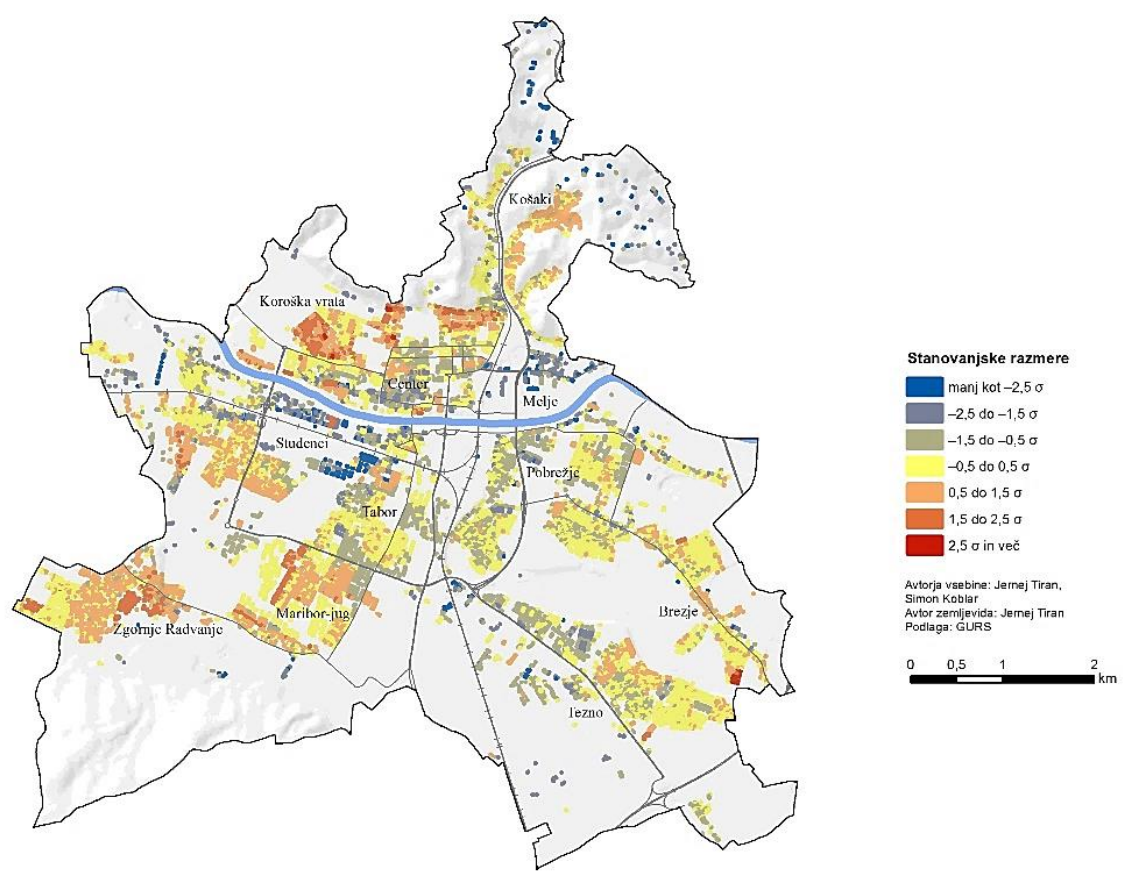

Indeks stanovanjskih razmer v Mariboru.

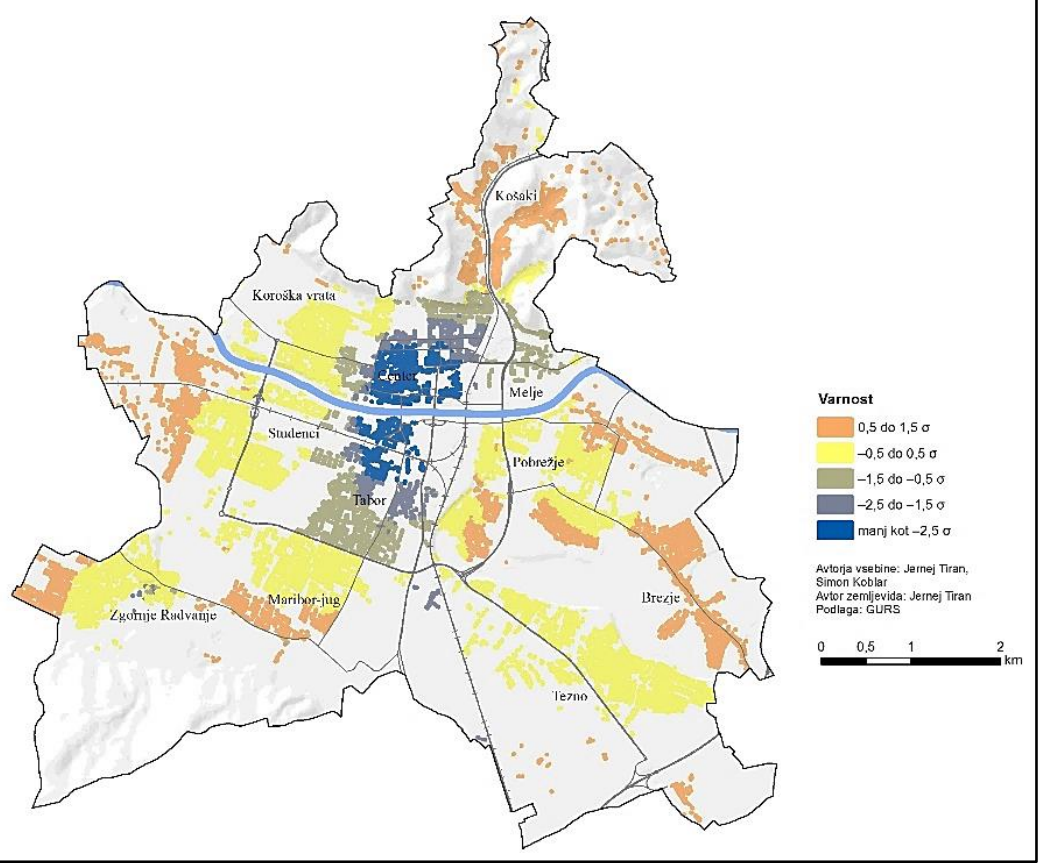

Indeks varnosti v Mariboru. 
Območje, kjer sta ti skupno najslabši, se razteza ob Dravi med mestnim središčem in Magdaleno. Za to območje je značilno največje število prometnih nesreč z udeležbo pešcev, katastrski občini Tabor in Grad, ki obsegata mestno četrt Magdalena ter del centra in Tabora, pa imata nadpovprečno število kaznivih dejanj. To lahko pojasnimo z dejstvom, da se na tem območju zadržuje največ ljudi, predvsem občasnih obiskovalcev, s čimer prihaja do večjega števila interakcij med ljudmi, tako kaznivih dejanj kot konfliktov med pešci in motornimi vozili. Po slabi prometni varnosti izstopata predvsem Glavni trg in območje okrog Dvorakove ulice in Trga revolucije.

\section{Estetska vrednost}

Po visoki estetski vrednosti izstopa večji del levega brega Drave, ki se ponaša s pestro kulturno dediščino in veliko pokrovnostjo z vegetacijo, še posebej meščanski vilski četrti pod Kalvarijo in Piramido. Razlike znotraj mesta glede na pokrovnost z vegetacijo in pestrost kulturne dediščine so majhne, občutno večje pa so po bližini vizualno motečih objektov. Degradiranih urbanih območij je največ na desnem bregu, kjer je zaradi ekstenzivnega prostorskega razvoja nastalo veliko praznih ali neprimerno izrabljenih površin znotraj strnjenega naselja (Drozg, 1997, Rebernik, 2009). Zaradi sanacije in ponovne rabe površin se je v Mariboru obseg degradiranih urbanih območij v zadnjih dveh desetletjih občutno zmanjšal (Rebernik, 2009), kar je razvidno tudi iz Evidence degradiranih urbanih območij (2011), a ta proces ne poteka vodeno, celovito in sistematično (Rebernik, 2009). Po najslabši estetski vrednosti izstopajo Studenci, ki jim oceno močno znižuje bližina degradirane industrijske cone, kjer so nekdanje železničarske delavnice.

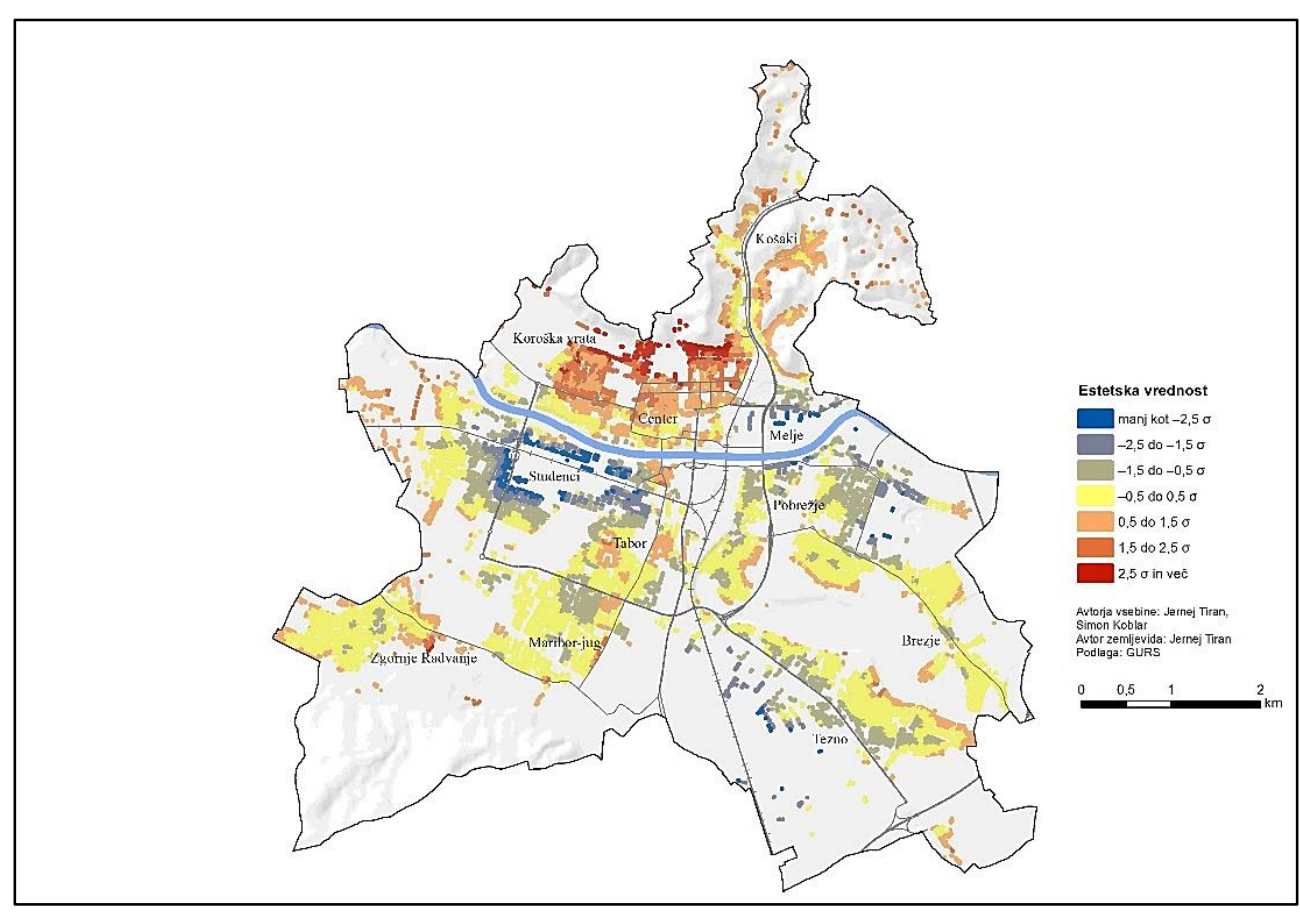

Indeks estetske vrednosti v Mariboru. 


\section{Dostopnost mestnih dobrin}

Dostopnost mestnih dobrin je pričakovano najboljša v mestnem središču na levem bregu Drave, kjer je največja zgostitev oskrbnih, storitvenih, izobraževalnih in prostočasnih dejavnosti, pa tudi edini večji mestni park. Nadpovprečno dostopnost imajo tudi Magdalena, Tabor in Maribor-jug, pa tudi deli Pobrežja in Teznega. Najslabšo dostopnost imajo robna območja, zlasti Košaki in Košaški dol, Damiševo naselje ter in robni deli Rožne doline pod Pohorjem, Teznega in Brezij. V primerjavi s stanjem na začetku 90. let, ko je Drozg ugotavljal, da se razmestitev centralnih območij na desnem bregu ne ujema $\mathrm{z}$ razmestitvijo prebivalstva, je stanje $\mathrm{v}$ sodobnosti boljše, saj so bila $\mathrm{v}$ tem času zgrajena nekatera nakupovalna središča s koncentracijo oskrbnih in storitvenih dejavnosti, nekatera so nastala na nekdaj degradiranih zemljiščih (na primer Europark, Planet Tuš). Še vedno pa je prisotno neravnovesje med obema deloma mesta. To je povezano $s$ prostorskim razvojem mesta, saj so na desnem bregu skozi čas večinoma nastajala le stanovanjska in industrijska območja, terciarne in kvartarne dejavnosti pa so se krepile na levem bregu. Takšna koncentracija funkcij v mestnem središču je glede na velikost Maribora neprimerna (Drozg, 1997).

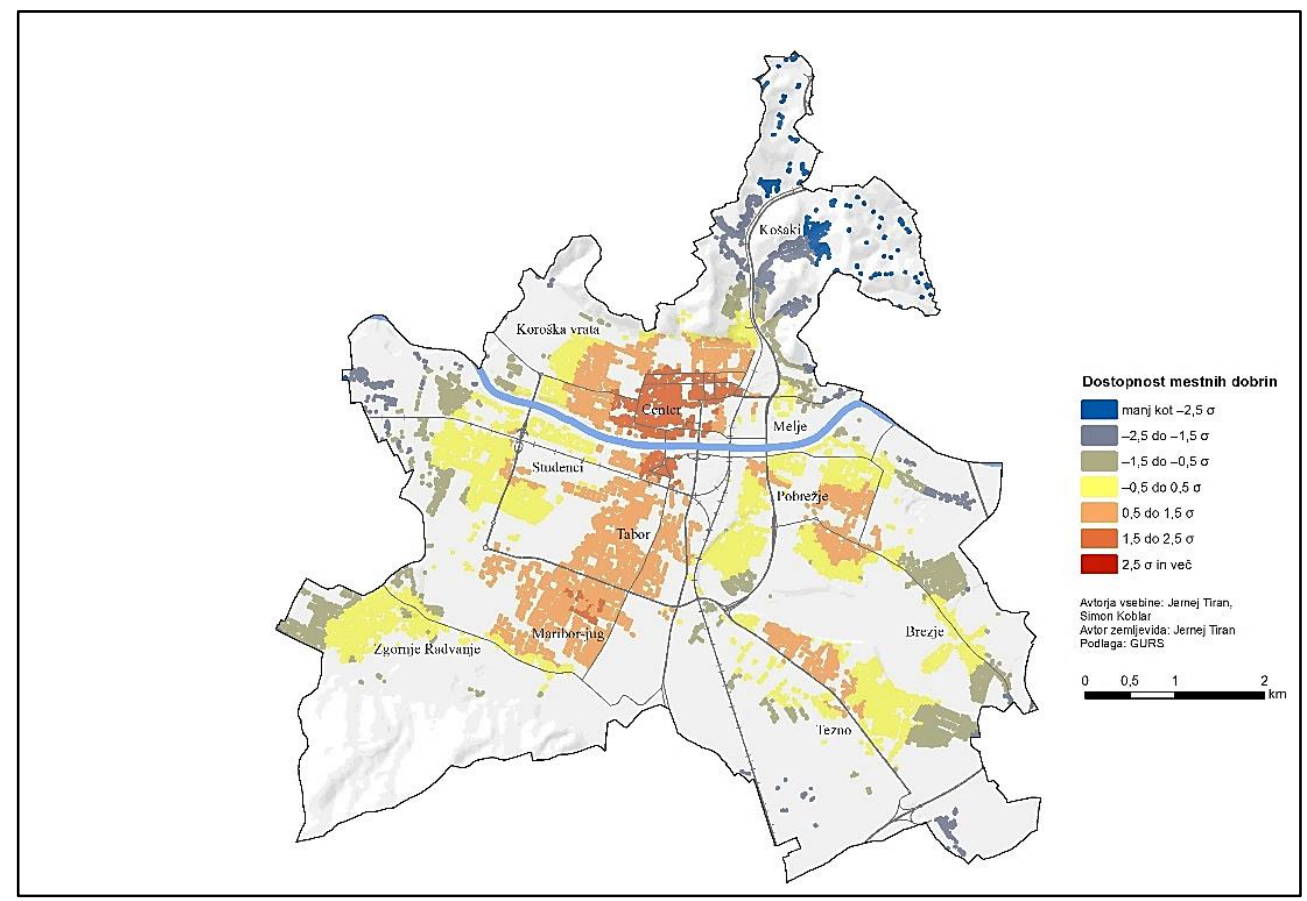

Indeks dostopnosti mestnih dobrin v Mariboru.

\section{Obremenjenost okolja}

Onesnaženost zraka in obremenjenost $\mathrm{s}$ hrupom sta $\mathrm{v}$ Mariboru večinoma posledica virov hrupa in onesnaževal iz cestnega prometa, ki prostorsko precej sovpadajo, zato se tudi njune imisije razmeščajo izrazito linijsko. Med okoljsko najmanj obremenjenimi območji izstopajo Zgornje Radvanje pod Mariborskim Pohorjem, območje Koroških vrat pod Kalvarijo in Košaški dol, ki ležijo dovolj daleč stran od prometnejših cest. Območja, kjer 
je obremenjenost največja, so v ozkem, med 100 in 150-metrskem pasu vzdolž prometnejših cest, zlasti glavnih mestnih vpadnic, kjer hrup marsikje dosega tudi več kot 70 decibelov, koncentracije NOx pa več kot $40 \mu \mathrm{g} / \mathrm{m}^{3}$. Tam so tudi številna stanovanjska območja, večinoma $v$ obcestni zazidavi: starejše enostanovanjske hiše ob Cesti XIV. divizije med Pobrežjem in Brezjami, staro mestno jedro ob Koroški cesti in Glavnem trgu, starejše eno- in večstanovanjske hiše ob Ulici Pariške komune v Magdaleni in delavska kolonija ob Titovi cesti nasproti Telekomove poslovne stavbe. Okoljsko močno obremenjeni so tudi nekateri prostostoječi starejši bloki iz socializma, na primer ob Ljubljanski ulici na Taboru, blokovska soseska S-23 na križišču Kardeljeve ceste in Ceste Proletarskih brigad, del soseske Jugomont na Goriški ulici in ob Ulici Moše Pijada. Problematična je zlasti hrupna obremenjenost. Vrednostim nad 55 decibelov, ki po podatkih Svetovne zdravstvene organizacije povzroča vznemirjenost ali motnje spanja, je v Mariboru izpostavljenih kar $49 \%$ stavb, v katerih živi $67 \%$ prebivalcev, vrednostim nad 65 decibelov, ki predstavlja mejno vrednost kazalcev hrupa za ceste in železnice na območjih s III. stopnjo varstva pred hrupom, pa $13 \%$ stavb, v katerih živi $26 \%$ prebivalcev (Strateška karta hrupa ... 2014).

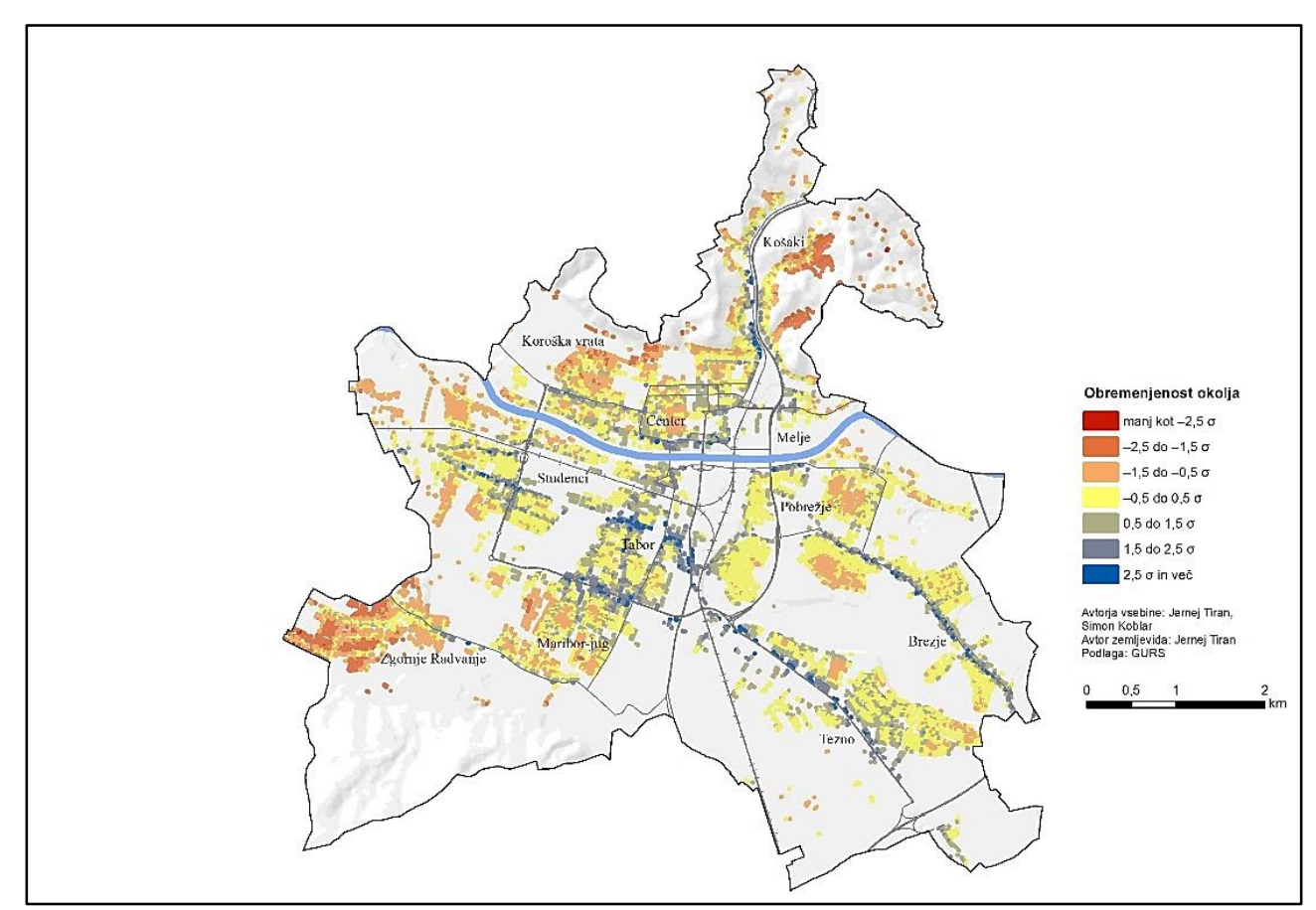

Indeks obremenjenosti okolja v Mariboru.

\section{Družbeno okolje}

Za Maribor so značilne zelo velike razlike $\mathrm{v}$ socioekonomski sestavi lokalnega prebivalstva. Ta je najboljša na meščanskem levem bregu Drave, novejšem predelu pod Mariborskim Pohorjem in na območju enostanovanjskih hiš v Novi vasi, najslabša pa na območjih z izrazito delavsko-industrijskim značajem, kot so Studenci, Melje in Tezno.

Močno podpovprečna je tudi $\mathrm{v}$ starem mestnem jedru in $\mathrm{v}$ blokovskih stanovanjskih 
soseskah na Pobrežju in Taboru. Tako lahko ugotovimo, da je delitev Maribora na levi, meščanski breg, in desni, delavski breg, ki je zelo prisotna v zavesti Mariborčanov, še vedno značilna, čeprav ni več tako očitna kot nekoč. Še vedno pa so razlike med posameznimi območji zelo velike. Tako je v delu starega mestnega jedra in Teznega stopnja brezposelnosti skoraj $35 \%$, pod Mariborskim Pohorjem in v uličnih blokih mestnega središča pa le malo več kot $10 \%$. Podobno velike razlike so v izobrazbeni sestavi, ki je izrazito najbolj ugodna v meščanskem delu mesta (razmerje med višje in osnovnošolsko izobraženimi je v prid prvih tudi do 9,3-krat), v območjih Teznega, Melja in Studencev pa je, obratno, delež prebivalcev z osnovnošolsko izobrazbo ali manj skoraj dvakrat višji od tistih z višjo ali visoko izobrazbo. Podobno velja za dohodke, saj imajo prebivalci nekaterih uličnih blokov mestnega središča več kot dvakrat večje dohodke od najmanj premožnih prebivalcev, ki prebivajo v Studencih in delih Teznega.

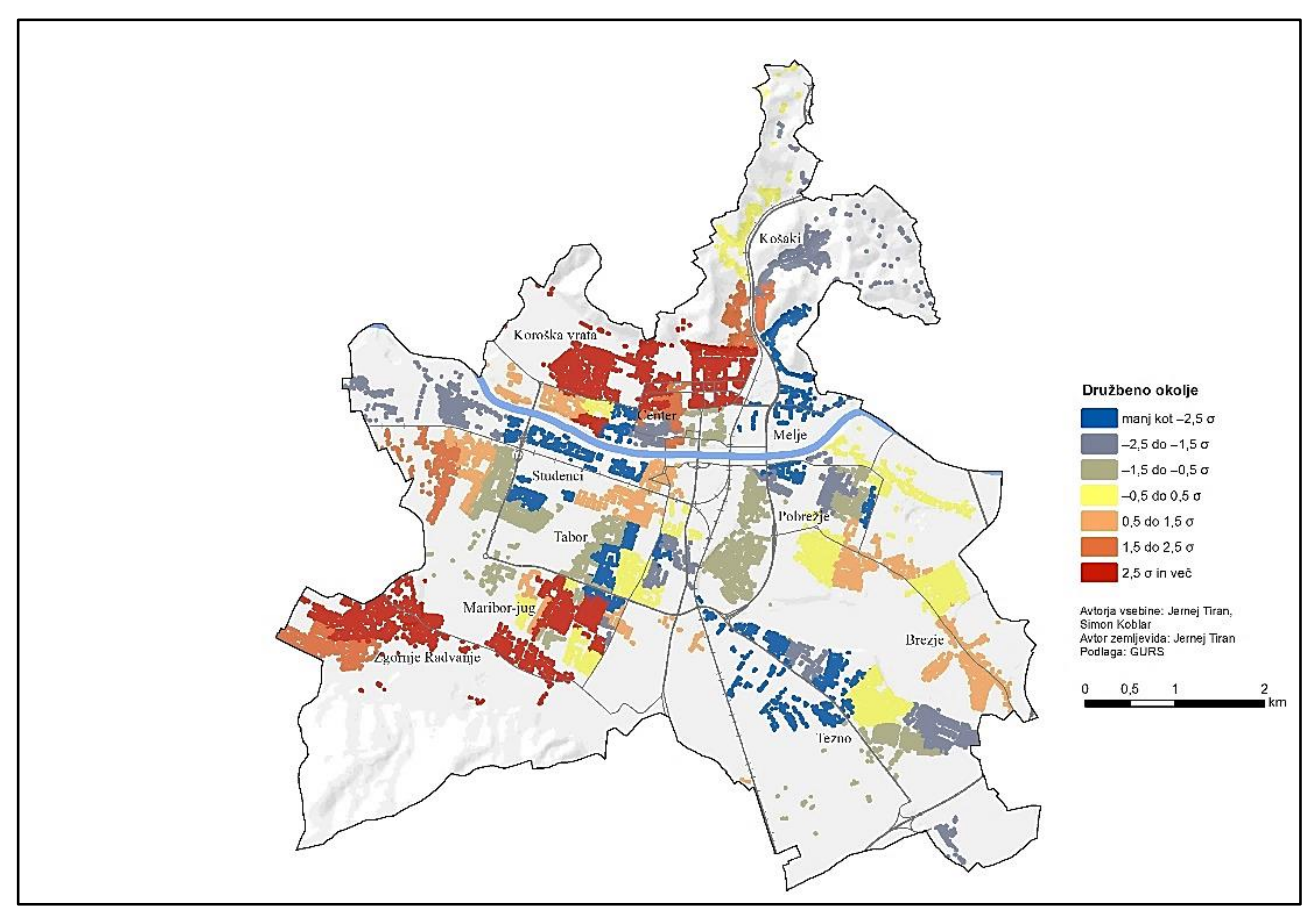

Indeks družbenega okolja v Mariboru.

\section{Pogoji za mobilnost}

Pogoje za mobilnost smo zaradi pomanjkanja ustreznih podatkov ponazorili zgolj z dostopnostjo do mestnega avtobusnega potniškega prometa. Prostorska razmestitev avtobusnih postajališč je glede na poselitev ustrezna. Zunaj 640-m dostopnosti do postajališč, ki ustreza 8 minutam hoje, živi samo 1113 prebivalcev oziroma $1 \%$ prebivalstva, največ v Košaškem dolu in skrajnemu severozahodnem delu Studencev. Slabša pa je dostopnost, če upoštevamo tudi pogostost avtobusnih voženj. Zelo dobra ali odlična dostopnost je namreč izrazito omejena na mestno središče, kamor se steka večina avtobusnih linij. Večji del stanovanjskih območij v Mariboru pa ima slabo dostopnost to pomeni, da tam vozita ena ali največ dve liniji z manjšo pogostostjo voženj, večinoma v 30-minutnem intervalu. Slabša dostopnost manj gosto poseljenih območij je z vidika 
rentabilnosti razumljiva, vendar pa med območji s slabšo dostopnostjo najdemo tudi številne gosto poseljene blokovske soseske, na primer v Mariboru jug, na Teznem in v Pobrežju.

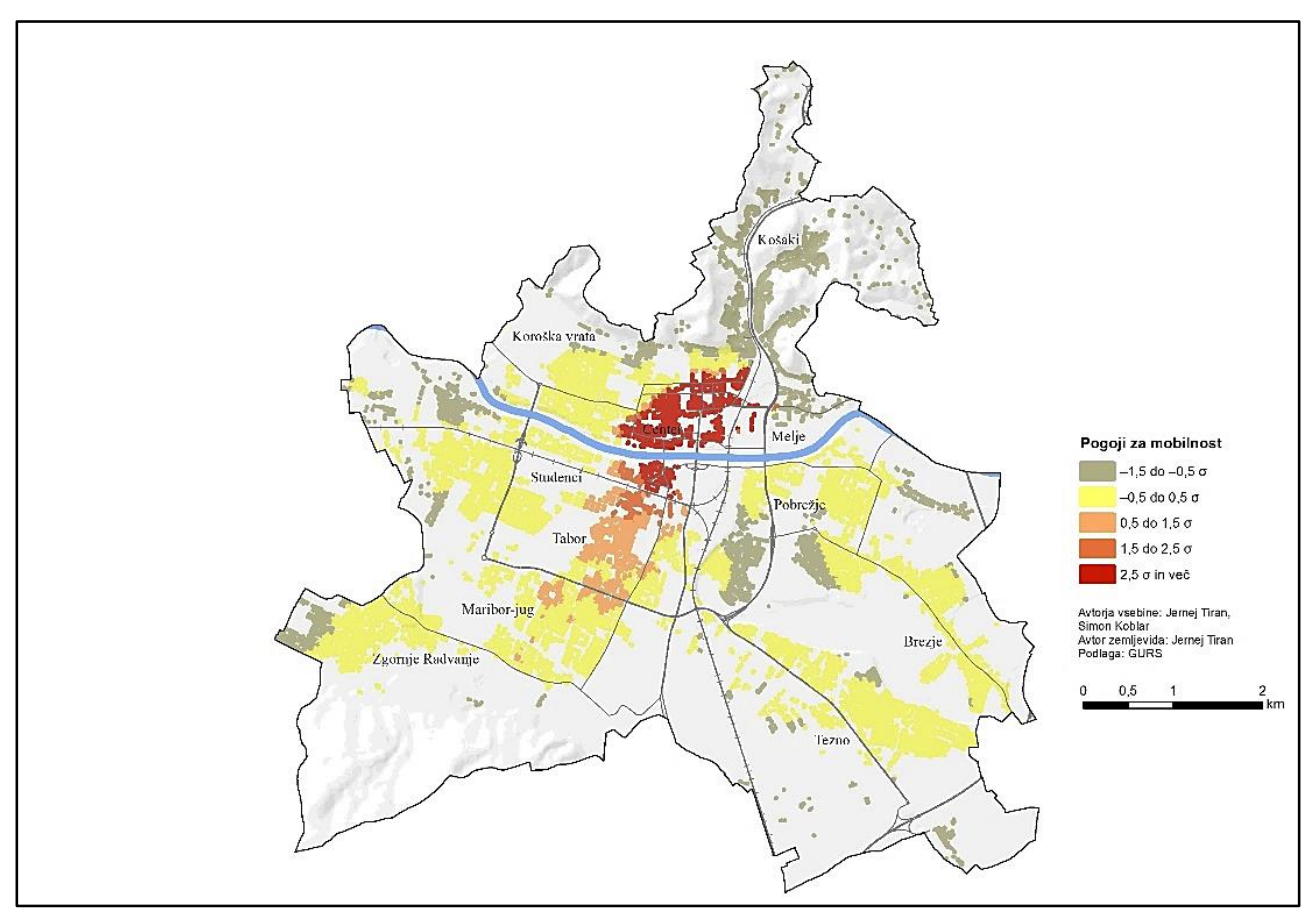

Indeks pogojev za mobilnost v Mariboru.

\section{Kakovost bivalnega okolja kot celote}

Z najboljšo kakovostjo bivalnega okolja kot celote se ponaša večji del mestnega središča na levem bregu Drave: gre za območje meščanskih vil in enodružinskih hiš pod Kalvarijo in Piramido. Ta mestni predel izstopa po zelo ugodnih stanovanjskih razmerah, visoki estetski vrednosti, majhni obremenjenosti okolja in zelo dobri socioekonomski sestavi prebivalstva. Tudi po varnosti, dostopnosti mestnih dobrin in avtobusnega prometa je vsaj povprečno ocenjeno. Dobro kakovost bivalnega okolja ima tudi območje karejske zazidave (zlasti med Partizansko cesto in Aškerčevo ulico). Ima izrazito nadpovprečno dostopnost avtobusnega prometa in mestnih dobrin, skupno oceno pa mu nekoliko znižujeta slabši varnost in stanovanjske razmere in večja obremenjenost okolja. Do zelo podobnih rezultatov je prišel tudi Drozg (1997), ki dodaja, da so omenjena območja zgrajena po enotni zamisli, dobro opremljena $\mathrm{z}$ infrastrukturo, $\mathrm{s}$ primerno gostoto prebivalstva, morfološko razpoznavna in dajejo vtis mestnosti.

Kakovostno bivalno okolje ima tudi predel Maribor-jug. Njegovi glavni odliki sta dobra dostopnost do vseh vrst mestnih dobrin in ugodna socioekonomska sestava. Negativno izstopa le blokovska soseska S-23, ki leži neposredno ob zelo prometni cesti Proletarskih brigad, kar ji zaradi večje obremenjenosti okolja izdatno zmanjšuje skupno oceno. Maribor-jug sicer zaznamuje preplet blokovskih sosesk in območij enodružinskih hiš: v slednjih je kakovost bivalnega okolja še boljša zaradi višjega površinskega standarda. 
Podobno ugodno kakovost bivalnega okolja ima tudi predel pod Pohorjem, kjer je bilo v zadnjih letih zgrajenih veliko stanovanj $\mathrm{v}$ okviru organizirane stanovanjske gradnje. Območje odlikujejo zlasti nadpovprečne stanovanjske razmere (nova in prostorna stanovanja), majhna obremenjenost okolja in ugodna socioekonomska sestava.

Poseben primer je staro mestno jedro, ki ga označujejo izrazito »bipolarne« bivalne razmere. Na eni strani ga označujejo slabše stanovanjske razmere (velika starost stavb in manj prostorna stanovanja), slabši osebna in prometna varnost (stopnja kriminalitete je med najvišjimi v mestu, prav tako število prometnih nesreč z udeležbo pešcev), na drugi strani pa odlična dostopnost avtobusnega prometa in mestnih dobrin. Na kakovost negativno vpliva tudi dotrajanost stavbnega fonda, s katero so nezadovoljni tudi tamkajšnji prebivalci (Tiran, 2015). Fizična in funkcijska prenova starega mestnega središča se je sicer v Mariboru začela sredi 80. let 20. stoletja, a je zaradi pomanjkanja finančnih sredstev in nerešenih vprašanj okrog lastništva pozneje zastala (Drozg, 1997).

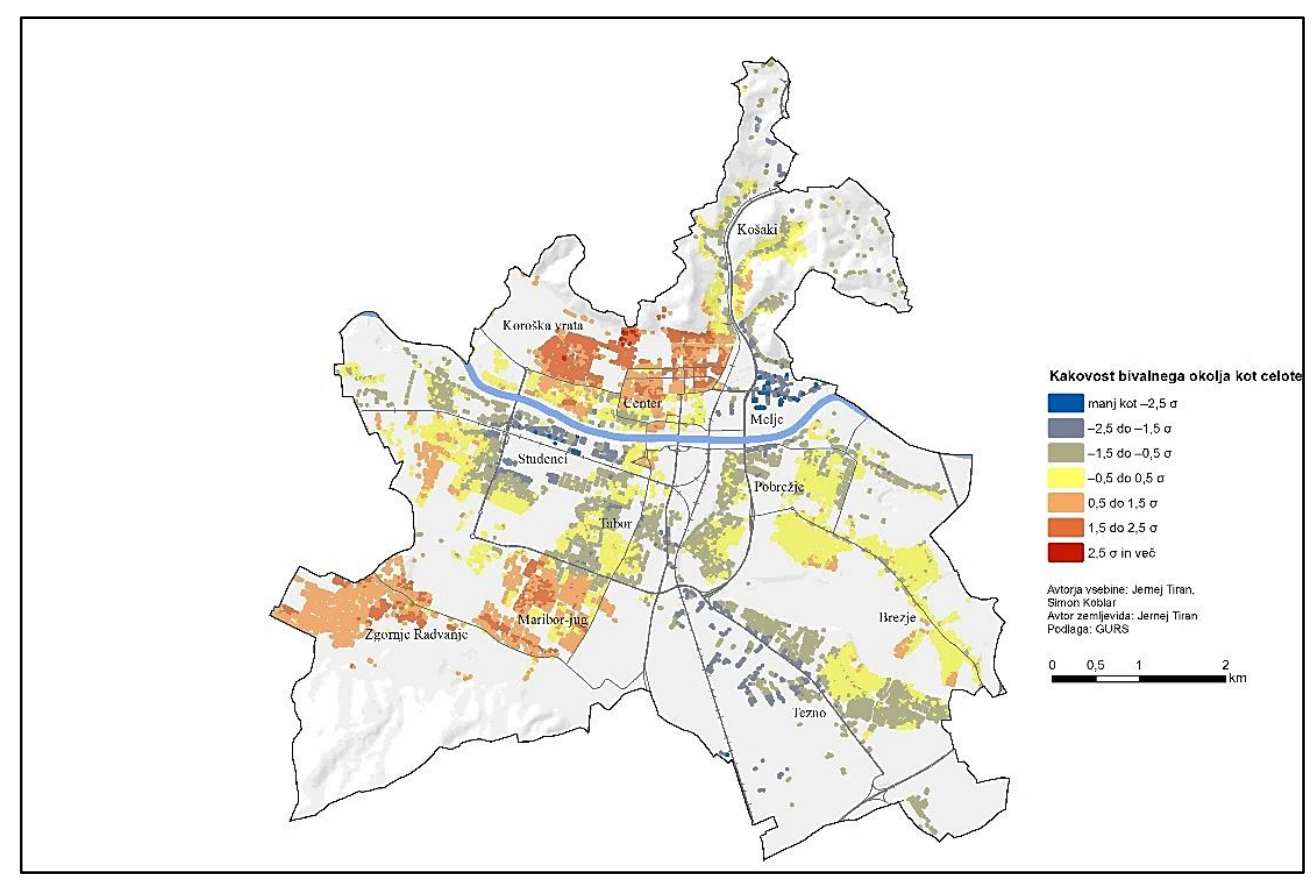

Skupni indeks bivalnega okolja v Mariboru.

Najslabše bivalno okolje v Mariboru pa imajo predeli v bližini industrijskih območij: Melje, Studenci in starejši del Teznega, ki jih avtorji zaradi slabe kakovosti stavb, pomanjkljive infrastrukturne opremljenosti, neurejenih javnih površin in razpršene gradnje večinoma uvrščajo med degradirana stanovanjska območja (npr. Drozg, 1997, Rebernik, 2009). Z vidika morfološke zgradbe tam prevladujejo večstanovanjske delavske kolonije in starejše enostanovanjske hiše. Naša analiza je pokazala, da imajo ti predeli slabšo kakovost bivalnega okolja zlasti zaradi slabih stanovanjskih razmer, bližine degradiranih urbanih območij, večinoma velike obremenjenosti okolja in zelo slabe socioekonomske sestave. V območjih torej prihaja do izrazitega kopičenja neugodnih bivalnih razmer; nadaljnjo funkcijsko, socialno in vizualno degradacijo bi bilo treba 
zaustaviti s celovito in sistematično prenovo.

\section{Zaključek}

V prispevku smo izmerili kakovost bivalnega okolja v Mariboru na začetku drugega desetletja 21. stoletja na t. i. objektiven način $\mathrm{s}$ seštevanjem 31 neobteženih standardiziranih kazalnikov, ki ponazarjajo 18 vsebin in 7 vsebinskih sklopov. Potrdili smo domnevo, da se kakovost bivalnega okolja znotraj mesta izrazito razlikuje. V najbolj kakovostnem okolju živijo prebivalci v bližini mestnega središča na levem bregu Drave, predela Maribor - jug in pod Pohorjem, v najmanj kakovostnem pa prebivalci v bližini (degradiranih) industrijskih območij, kot so Studenci, Tezno in Melje. Posebnost je staro mestno središče, ki ga označujejo »bipolarne« bivalne razmere: kakovost nekaterih vsebin je namreč izrazito ugodna, kakovost nekaterih pa izrazito neugodna. Za Maribor kot celoto je, tako kot po mestni strukturi (Drozg, 1997), tudi po kakovosti bivalnega okolja razvidna določena dvojnost.

Rezultati pričujoče raziskave so lahko koristni za različne deležnike. Mestnim oblastem in urbanističnim načrtovalcem so lahko v podporo pri prostorskemu odločanju, tako za upravljavske kot načrtovalske namene. Iz izdelanih zemljevidov je namreč na enostaven in pregleden način mogoče prepoznati kakovost bivalnega okolja na določenem območju. Takšna informacija je lahko podlaga bodisi za konkretno sanacijo bivalnega okolja bodisi za določanje primernih lokacij za stanovanjsko gradnjo. Če bi pojem merili zgolj na subjektiven način, torej $\mathrm{z}$ anketiranjem prebivalstva, bi morebitno zadovoljstvo $\mathrm{z}$ bivanjem lahko odražalo nepoznavanje razmer, kar je značilno za ranljive skupine ljudi. Rezultati so lahko koristni tudi za prebivalce, saj bi na njihovi podlagi lažje zahtevali izboljšanje tistih vidikov bivalnega okolja, ki so v pristojnosti mestnih oblasti. V pomoč so jim lahko tudi pri iskanju stanovanja, saj je na enem mestu zbrana celovita in nepristranska informacija o stanju bivalnega okolja.

Kljub vloženemu trudu pri merjenju nekaterih kazalnikov, dobre prostorske natančnosti merjenja, prednosti geografskega pristopa in potencialne aplikativnosti rezultatov, pa $\mathrm{v}$ sklepu velja opozoriti na nekatere pomanjkljivosti raziskave. Zaradi pomanjkanja ustreznih podatkov smo številne vsebine bivalnega okolja izmerili zgolj posredno. Pri tem izpostavljamo stanovanjske razmere: dejanska kakovost stanovanj je odvisna še od številnih drugih dejavnikov, ki niso nujno posledica starosti stanovanj in njihove velikosti: razporeditev in velikost posameznih prostorov (tloris), stanovanjska mikroklima (vlaga, osončenost, temperatura), toplotna in zvočna izolacija in podobno. Podobno velja za estetsko vrednost: vidike, kot so urejenost, oblikovna enotnost in upoštevanje človekovega merila, je namreč zelo težko objektivno ovrednotiti, saj zanje nimamo trdnih meril, zajem tovrstnih podatkov in njihova analiza pa bi bila izredno zahtevna. Posredno smo izmerili tudi kakovost družbenega okolja, ki pa je bila v raziskavi koristna, saj socioekonomske značilnosti lokalnega prebivalstva praviloma odsevajo ravno omenjene, težje izmerljive lastnosti bivalnega okolja.

Nekatere vsebine bivalnega okolja smo uspeli oceniti bolj natančno, vendar pa so bile meritve $\mathrm{z}$ nekaterih vidikov nekoliko okrnjene. Ocena hrupa na primer ne vsebuje hrupa $\mathrm{z}$ ulice ali s prireditev, zato je na območjih z živahnim uličnim dogajanjem (na primer v mestnem središču) pomanjkljiva. Modelska ocena onesnaženosti zraka pa je okrnjena zaradi pomanjkljivih podatkov o malih kuriščih. Za celovitejši oris lokalnih pogojev za 
mobilnost bi bilo več kot smiselno obravnavati tudi ureditev mirujočega prometa $\mathrm{v}$ stanovanjskih območjih, ki posredno razkriva možnosti za enostavno uporabo avtomobila, vendar so podatki o številu parkirnih mest in njihovi zagotovljenosti v Registru nepremičnin zelo pomanjkljivi.

Izpostaviti velja tudi vidik velikosti prostorske enote, po katerih smo pridobili nekatere vhodne podatke. Soočili smo se namreč z načelom statistične zaupnosti, zato so morale biti enote dovolj velike. Tako smo podatke o velikosti stanovanj pridobili na podlagi členitve stanovanjskih območij na morfološke enote (Drozg, 2008), podatke o socioekonomskih značilnosti lokalnega prebivalstva na ravni volišč za državnozborske volitve, podatke o stopnji kriminalitete pa zgolj na ravni katastrskih občin. To seveda zakriva prostorske razlike znotraj enot.

Z uporabljeno metodo smo na eni strani obdržali raven objektivnosti raziskave, na drugi pa smo $\mathrm{Z}$ njo lahko opredelili zgolj stopnjo nadpovprečnosti (»ugodnosti«) ali podpovprečnosti (»neugodnosti«), ne pa tudi dejanske kakovosti bivalnega okolja. Povprečne vrednosti, s katerimi smo primerjali posamezne vrednosti kazalnikov in indeksov, namreč niso mejne vrednosti oziroma urbanistični normativi, ki so cilj v urbanističnem načrtovanju (Drozg, 1994a). Dobljeni rezultati bi bili obenem drugačni, če bi v analizo zajeli tudi 21 naselij mestnega območja, ki skupaj z Mariborom tvorijo funkcijsko in morfološko celoto. Žal nam je to preprečila nedostopnost nekaterih podatkov.

Prihodnje merjenje kakovosti bivalnega okolja v Mariboru je tako smiselno dopolniti s subjektivnimi meritvami, dodatnimi napori pri objektivnem merjenju nekaterih kazalnikov in vrednotenjem na podlagi urbanističnih normativov, hkrati pa ocene vseskozi posodabljati. Mesto je namreč dinamična tvorba, ki nenehno doživlja gospodarsko, prostorsko in družbeno preobrazbo, zato rezultati takšnih raziskav lahko kaj kmalu zastarijo.

\section{Literatura in viri}

Akcijski načrt 2015-2020, Pregled neizgrajene kanalizacije v Mestni občini Maribor (prispevno območje centralne čistilne naprave Maribor) in ocena investicijskih stroškov, Mestna občina Maribor, Urad za komunalo, promet in prostor, Maribor, 2015, www.maribor.si/dokument.aspx ?id=27306.

Barvni digitalni ortofoto posnetek DOF 050, Javne informacije Slovenije, Geodetska uprava Republike Slovenije, Ljubljana, 2014.

Centralni register prebivalstva, stanje na dan 1. 1. 2014, Ministrstvo za notranje zadeve, Ljubljana.

Cutter, S. L. 1985: Rating Places: A Geographer's view on quality of life, Washington, DC.

Černe, A. 1997: Geografija - prostorski koncept in planiranje, Dela 12.

Doyal, L., Gough, I. (1992) A theory of human need, Houndmills, DOI: 10.1007/978-1-34921500-3.

Drobne, S., Žaucer, T., Foški, M., Zavodnik Lamovšek, A. 2014: Continuous built-up areas as a measure for delineation of urban settlements, Geodetski vestnik 58-1, https://doi.org/10.15292/geodetski-vestnik.

Drozg, V. 1994a: Kvaliteta bivalnega okolja - poskus interpretacije, Znanstvena revija: Družboslovje in filozofija, 6-1.

Drozg, V. 1994b: Kvaliteta bivalnega okolja v stanovanjskih območjih v Mariboru, Mednarodni simpozij Trajnostni urbani razvoj, Maribor. 
Drozg, V. 1997: Nekatere značilnosti ustroja Maribora, Geografski vestnik, 69.

Drozg, V. 2008: Načini zazidanosti v Mariboru. Podatkovni sloj, Filozofska fakulteta Univerze v Mariboru, Maribor.

Drozg, V. 2014: Značilnosti tlorisa stanovanj iz 20. stoletja (mariborska izkušnja), Dela 42, http://dx.doi.org/10.4312/dela.42.3.51-73.

Evidenca degradiranih površin, Podatkovni sloj, Filozofska fakulteta Univerze v Ljubljani, Ljubljana, 2011.

Evidenca hišnih številk, Stanje na dan 1. 1. 2014, Javne informacije Slovenije, Geodetska uprava Republike Slovenije, Ljubljana.

Florida, R., Mellander, C., Stolarick, K. 2010: Beautiful Places: The Role of Percieved Aesthetic Beauty in Community Satisfaction, Regional Studies 45-1. https://doi.org/10.1080/00343404.2010.486784.

Frey, H. (1999) Designing the city: towards a more sustainable urban form, New York.

Glaeser, E. L., Kolko, J., Saiz, A. 2001: Consumer City, Journal of Economic Geography 1-1, http://dx.doi.org/10.1093/jeg/1.1.27.

Klemenčič, M. 2011: Zeleni sistem mesta Maribor s poudarkom na vzpostavitvi javnih zelenih površin v novem delu južno od Drave, Diplomsko delo, Biotehniška fakulteta Univerze v Ljubljani, Ljubljana.

Knox, P. L. 1975: Social well-being: a spatial perspective, London.

Krevs, M. 1998: Geografski vidiki življenjske ravni prebivalstva v Sloveniji, Doktorska disertacija, Filozofska fakulteta Univerze v Ljubljani, Ljubljana.

Krevs, M. 2001: Geographical contribution to the level of living research, II. Kongres na geografite od Republika Makedonija so stručen seminar za nastavnicite po geografija, Skopje.

Krevs, M. 2002: Geografski vidiki življenjske ravni prebivalstva Ljubljane, Geografija Ljubljane, Ljubljana.

Leyden, K. M., Goldberg, A., Michelbach, P. 2011: Understanding the Pursuit of Happiness in Ten Major Cities, Urban Affairs Review 47-6, http://dx.doi.org/10.1177/1078087411403120.

Lokacije avtobusnih postajališč, Podatkovni sloj, E-daljinar, 2014.

Mihaescu, O., vom Hofe, R. 2012: The impact of brownfields on residential property values in Cincinnati, Ohio: a spatial hedonic approach, The Journal of Regional Analysis and Policy, 42-3.

Mira, R. G., Uzzell, D. L., Real, J. E., Romay, J. 2005: Housing, Space and Quality of Life, Burlington.

Območja dosega poplav, Podatkovni sloj, Ministrstvo za okolje in prostor, Agencija Republike Slovenije za okolje, 2013, http://gis.arso.gov.si/wfs_web/faces/WFSLayersList.jspx, 24. 2. 2015.

Pacione, M. 1986: Quality of life in Glasgow: an applied geographical analysis, Environment and Planning A, 18-11, http://dx.doi.org/10.1068/a181499.

Podatki o prometnih nesrečah v Ljubljani med 2011 in 2015, Javna agencija Republike Slovenije za varnost prometa, Ljubljana, 2016.

Podatki o stanovanjih po izbranih morfoloških enotah, Registrski popis 2011, Stanje na dan 1. 1. 2011, Statistični urad Republike Slovenije, Ljubljana.

Podatki o prebivalstvu po izbranih prostorskih enotah, Stanje na dan 1. 1. 2014, Statistični urad Republike Slovenije, Ljubljana, 2014.

Podatki o izbranih poslovnih subjektih, Poslovni register Slovenije, Stanje na dan 3. 4. 2014, Agencija Republike Slovenije za javnopravne evidence in storitve, Ljubljana, 2014.

Pust, V. 1988: Modeli stanovanjske gradnje in zazidave $\mathrm{z}$ ozirom na spreminjajoče potrebe, Doktorska disertacija, Fakulteta za arhitekturo Univerze v Ljubljani, Ljubljana.

Rebernik, D. 2009: Novejši procesi v prostorskem razvoju Maribora, Geografski vestnik, 81-2.

Register nepremične kulturne dediščine, Podatkovni sloj, Ministrstvo za kulturo, Direktorat za kulturno dediščino, Informacijsko-dokumentacijski center za dediščino, Ljubljana, 2014.

Register nepremičnin, Stanje na dan 15. 12. 2014, Javne informacije Slovenije, Geodetska uprava Republike Slovenije, Ljubljana.

Ruppert, K., Schaffer, F., Maier, J., Paesler, R. 1981: Socijalna geografija, Zagreb. 
Schmeidler, K. 2008: Stanovanjski trendi in trendi v razvoju urbanizma v Češki republiki, Urbani izziv 19-1, http://dx.doi.org/10.5379/urbani-izziv-2008-19-01-004.

Senegačnik, J. 1995: Ljubljana, Krajevni leksikon Slovenije, Ljubljana.

Seznam bančnih avtomatov v Sloveniji, april 2014, Bankart, http://www.bankart.si/assets/ATMList/Seznam-BA-v-SLO-april-2014.xls, 20. 5. 2014.

Sirgy, M. J., Cornwell, T. 2002: How neighborhood features affect quality of life, Social Indicators Research 59-1, DOI: 10.1023/A:1016021108513.

Smith, D. M. 1973: The geography of social well-being in the United States, New York.

Strateška karta hrupa mesta Maribor za leto 2011, Maribor, 2014.

Špes, M. 1998: Degradacija okolja kot dejavnik diferenciacije urbane pokrajine, Ljubljana.

Število obravnavanih kaznivih dejanj po izbranih sklopih od leta 2011 do 2014 (prvo polletje) v Republiki Sloveniji, po občinah in katastru, Ministrstvo za notranje zadeve, Policija, Ljubljana, 2015.

Tiran, J. 2014: Anketa o pripravljenosti za hojo do izbranih objektov in njihovem pomenu med prebivalci Ljubljane.

Tiran, J. 2015: Geografsko vrednotenje bivalnega okolja v izbranih slovenskih mestih. Doktorska disertacija, Filozofska fakulteta Univerze v Ljubljani. Ljubljana.

Tiran, J. 2017: Kakovost bivalnega okolja v Ljubljani, Georitem 28, Ljubljana.

Tiran, J., Drobne, S., Lakner, M., Ortar, J. 2016: Metodologija merjenja peš dostopnosti do mestnih dobrin na podlagi koncepta padanja $\mathrm{z}$ razdaljo, Interno gradivo, Ljubljana.

Tiran, J., Mladenovič, L., Koblar, S. 2014: Računanje dostopnosti do javnega potniškega prometa v Ljubljani z metodo PTAL, GIS v Sloveniji 12: Digitalni prostor, Ljubljana.

Tiran, J., Mladenovič, L., Koblar, S. 2015: Dostopnost do javnega potniškega prometa v Ljubljani po metodi PTAL, Geodetski vestnik, 59-4. http://dx.doi.org/10.15292/geodetskivestnik.2015.04.723-735.

Tobler, W. R. 1970: A computer movie simulating urban growth in the Detroit region, Economic Geography 46, http://dx.doi.org/10.2307/143141.

U. Uhrner, B. C. Lackner, R. Reifeltshammer, M. Steiner, R. Forkel in P. J. Sturm 2014: InterRegional Air Quality Assessment. Bridging the Gap between Regional and Kerbside PM Pollution. Results of the PMinter Project. Graz.

Van Kamp, I., Leidelmeijer, K., Marsman, G., de Hollander, A. 2003: Urban environmental quality and human well-being, Towards a conceptual framework and demarcation of concepts: a literature study, Landscape and Urban Planning, 65/1-2, http://dx.doi.org/10.1016/s01692046(02)00232-3.

Vozni redi, 2014, Marprom, http://www.marprom.si/vozni-redi/ (16. 9. 2014).

World's population increasingly urban with more than half living in urban areas, http://www.un.org/en/development/desa/news/population/world-urbanization-prospects2014.html (15. 5. 2016). 
GEOGRAFIJE PODRAVJA

THE GeOgraphies of THE Podravje Region 


\title{
Potovalne navade Mariborčanov - kaj je drugače kot v Ljubljani?
}

\author{
Marjan Lep, Beno Mesarec, Matej Gabrovec
}

Povzetek V letu 2016 so bile v Mariboru na vzorcu 1.200 gospodinjstev izvedene ankete o potovalnih navadah. Ankete so bile narejene po enaki metodologiji kot v Ljubljani leta 2013 in 2003, zato nam rezultati dajejo odlično možnosti primerjalnih analiz. Razlike $\mathrm{v}$ potovalnih navadah med Ljubljano in Mariborom pojasnjujemo $\mathrm{z}$ demogeografskimi in gospodarskimi razlikami med obema mestoma. $V$ luči anketnih rezultatov interpretiramo tudi spremembe potovalnih navad voznikov ob izbranih prometnih ukrepih $\mathrm{v}$ Mariboru $\mathrm{v}$ preteklih letih, kot je bila na primer začasna zapora Koroške ceste in uvedba okoljske cone.

Ključne besede: $\cdot$ potovalne navade $\cdot$ mobilnost $\cdot$ redukcija cestnega prometa $\bullet$ Maribor $\bullet$ Ljubljana $•$

NASLOV AVTORJEV: dr. Marjan Lep, docent, Univerza v Mariboru, Fakulteta za gradbeništvo, prometno inženirstvo in arhitekturo, Smetanova ulica 17, 2000 Maribor, Slovenija, e-naslov: marjan.lep@um.si. mag. Beno Mesarec, Univerza v Mariboru, Fakulteta za gradbeništvo, prometno inženirstvo in arhitekturo, Smetanova ulica 17, 2000 Maribor, Slovenija, e-naslov: beno.mesarec@um.si. dr. Matej Gabrovec, Geografski inštitut Antona Melika ZRC SAZU, Gosposka ulica 13, 1000 Ljubljana, Slovenija, e-naslov: matej@zrc-sazu.si. 


\title{
Travel patterns in Maribor: A comparison to Ljubljana
}

\author{
Marjan LeP, Beno Mesarec, Matej Gabrovec
}

\begin{abstract}
The research objectively evaluated the quality of residential environment in Maribor at the outset of the second decade of the 21st century using the method of summing the unweighted standardized indicators of dwelling characteristics, safety, aesthetics, accessibility to urban amenities, environmental strain, social environment, and transportation conditions. We determined that the most high-quality environment includes the wider city centre on the left bank of the Drava River, Maribor - south, and under the Pohorje Mountains, and the lowest quality areas feature areas in the vicinity of industrial areas, such as Studenci, Melje, and the older part of Tezno. The study results can be useful to city authorities and urban planners as a support in the decisionmaking for management and planning; for example, as the basis for improving the residential environment or for determining the appropriate locations for residential construction.
\end{abstract}

Keywords: - travel behaviour - mobility - road traffic reduction • environmental zone $\bullet$ Maribor $\bullet$ Ljubljana •

CoRRESPONDENCE AdDRESS: Marjan Lep, Ph.D., Assistant Professor, University of Maribor, Fakulty of Civil Engineering, Transportation Engineering and Architecture, Smetanova ulica 17, 2000 Maribor, Slovenia, e-mail: marjan.lep@um.si. Beno Mesarec, M.S., Researcher, University of Maribor, Fakulty of Civil Engineering, Transportation Engineering and Architecture, Smetanova ulica 17, 2000 Maribor, Slovenia, e-mail: beno.mesarec@um.si. Matej Gabrovec, Ph.D., researcher, Geographical institute Anton Melik ZRC SAZU, Gosposka ulica 13, 1000 Ljubljana, Slovenia, e-mail: matej@zrc-sazu.si 


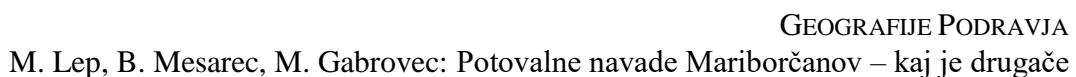

\section{Uvod}

Ljubljana in Maribor sta edini slovenski mesti, ki ju lahko opredelimo kot središči mednarodnega pomena in imata več kot 100.000 prebivalcev (Nared et al., 2017). Zato je zanimiva primerjava potovalnih navad Mariborčanov in Ljubljančanov, morebitne razlike odražajo ali razlike $\mathrm{v}$ morfologiji in velikosti obeh mest ali pa so posledice različne gospodarske usmerjenosti, socioekonomskih in drugih značilnosti prebivalstva ali morebitnih drugih dejavnikov. Druga slovenska regionalna središča, tudi tista, ki jim lahko pripišemo višji nivo centralnosti (Drozg, 2005), za Mariborom in Ljubljano močno zaostajajo po številu prebivalcev, kar seveda pomembno vpliva tudi na potovalne navade.

Potovalne navade so odvisne od izbire aktivnosti in njihove lokacije ter izbire načina in časa potovanja. Izbira aktivnosti je odvisna od osebne življenjske situacije vsakega posameznika, prostorska organizacija in značilnosti prometnega sistema vplivajo na dolžino potovanj in izbiro prevoznega sredstva (Gärling, 2005, Stradling in Anable, 2008, Lep in Mesarec, 2015). Dosedanje slovenske geografske raziskave so se pri proučevanju potovalnih navad osredotočile predvsem na dnevno mobilnost šolajočih se in zaposlenih (Pelc, 1988, Gabrovec in Bole, 2009, Bole in Gabrovec, 2012). Te raziskave so se opirale na podatke popisov prebivalstva, v okviru katerih je bilo v letih 1981, 1991 in 2002 tudi vprašanje o načinu potovanja na delo in v šolo. Statistični urad ne zbira podatkov o mobilnosti prebivalstva zaradi drugih namenov, kot je rekreacija, nakupovanje, obiski in podobno. Tovrstne podatke je možno pridobiti le z anketiranjem. Drozg (2012) je tako s pomočjo vprašalnikov, ki jih je izpolnilo 536 oseb, ugotavljal, kako se razlikuje mobilnost glede na življenjski stil v različnih socioekonomskih območjih. Časovna in prostorska primerljivost raziskav je možna le $\mathrm{z}$ uporabo standardiziranih vprašalnikov (Gather, Kagermeier in Lanzendorf, 2008).

Podatki o potovalnih navadah postajajo vse pomembnejši pri sodobnem načrtovanju mest. "Pametna mesta« in »trajnostno načrtovanje prometa in mobilnosti« sta izraza, $\mathrm{s}$ katerima želijo upravljavci in načrtovalci mest sporočiti, da se je v zadnjih desetletjih spremenil vrednostni sistem, kaj je dobro in želeno, ter da so se pojavile tehnologije (imenovane »pametne«), ki morda omogočajo reševanje še pred kratkim nerešljivih zagat. Pri tem se tako imenovane "nove vrednote» in problemi, ki bi jih naj reševali $\mathrm{v}$ mestih, definirajo predvsem opisno (kvalitativno). Na področju prometa in mobilnosti operiramo z izrazi, kot so zmanjšati zastoje, povečati varnost, zmanjšati okoljske vplive prometa, povečati dostopnost in podobno. Oštevilčenih vrednosti, koliko ljudi v resnici trpi zaradi tako imenovanih zastojev, koliko ljudi je v resnici izpostavljeno čezmernemu hrupu, koliko ljudi se tudi na nerazumno kratkih poteh vozi z osebnimi avtomobili, koliko meščanov je objektivno izključenih iz družbe, ker ne posedujejo in vozijo osebnega avtomobila, in podobno, praviloma ne poznamo in navajamo spekulativne vrednosti, kjer je metodologija pridobivanja povsem nejasna. Proizvajalci in prodajalci sodobnih (»pametnih«) tehnoloških rešitev za sledenje vozilom in ljudem trdijo, da omogočajo skoraj popolno določanje obsega premikov vozil ali oseb na območju mesta, vključno s statistično ustreznim razvozlavanjem namena in načina potovanj. Tako se na primer mobilnemu telefonu, ki se premika s hitrostjo pet kilometrov na uro vzdolž neke prometnice, pripiše »pešačenje», premiku mobilnega telefona z določenim naročniškim paketom ob sedmih zjutraj s hitrostjo petdeset kilometrov na uro po neki prometnici se pripiše "vožnja z osebnim avtomobilom « z namenom »na delo« in podobno. Pa vendar 
ostaja vrsta lastnosti potovanj, ki načrtovalca prometa v mestih zanimajo, nedoločljiva. Tako ostaja klasična metoda intervjujev oziroma zapisovanje potovalnih dnevnikov zadostnega števila meščanov še vedno zelo dobrodošla in nujno potrebna za določanje nekaterih ključnih podatkov o potovalnih navadah v določenem mestu.

Metoda je finančno zahtevna, zato je pri prometni stroki veliko dvomov o tem, ali je bila izvedena res korektno. Po drugi strani pa se je skoraj nemogoče izogniti stratifikaciji oziroma dokazati, da so vsi tipični potovalni vzorci zajeti v primernem deležu. Vse težje je pritegniti meščane, da bi pri teh raziskavah sodelovali. Zato se v prometni stroki (prepogosto) zatekamo k prenosom podatkov. Pri tem moramo vedeti, kateri pokazatelji (količine) potovalnih navad so invariantni - se ne spreminjajo bistveno. Želimo vedeti oziroma razumeti, kako se količine, ki opisujejo mobilnost, spreminjajo skozi čas (če sploh se) in kako se spreminjajo med različnimi območji. V Sloveniji imamo možnost, da prikažemo in analiziramo zgoraj zastavljeno vprašanje. Metodološko identična raziskava potovalnih navad se je izvajala $\mathrm{v}$ Ljubljani in $\mathrm{v}$ Ljubljanski urbani regiji v letih 2003 in 2013 (Anketa..., 2003, Klemenčič et al., 2014), kar omogoča analizo časovnega spreminjanja nekaterih pokazateljev potovalnih navad, enaka metodologija pa je bila uporabljena tudi v Mariboru leta 2016 (Mesarec et al., 2016), kar omogoča analizo geografske prenosljivosti nekaterih pokazateljev mobilnosti znotraj sorodnega kulturno zgodovinskega okolja.

Samo ugotavljanje potovalnih navad ne omogoča razumevanja, kako bi opazovana populacija reagirala na spremembe v ponudbi. Ta lastnost je za načrtovalce prometa in mobilnosti morda najbolj pomembna, saj omogoča solidno napovedovanje učinkov ukrepov. V splošnem imamo dva pristopa:

- izjave (»stated intentions«), ko anketiranci na orisano novo (še neobstoječo) ponudbo podajajo izjave, kako bi potovali v drugačnih razmerah,

- merjenje dejanskega odziva, če se neka sprememba $\mathrm{v}$ ponudbi dogodi (»revealed preferences «). Druga metoda vsaj delno omogoča tudi spremljanje dinamičnega odziva.

V Mariboru smo imeli dva tovrstna eksperimenta, kjer je prišlo do bistvene spremembe v prometnem sistemu mesta:

- uvedba okoljske cone v obdobju od oktobra 2012 do aprila 2013, ko je bil znatnemu delu motornih vozil s prometnim znakom prepovedan vstop v mestno središče

- zapora dela Koroške ceste za motorna vozila v septembru 2015 (Mesarec, 2015).

\section{Metoda anketiranja in izbrani pokazatelji za analizo}

V Sloveniji je število klasičnih raziskav potovalnih navad prebivalstva $\mathrm{z}$ metodo intervjuja in zapisovanja potovalnih dnevnikov, opravljenih na večjih vzorcih prebivalstva izbranega mesta in njegove okolice, izredno majhno. Mednje lahko uvrščamo zgolj zgoraj omenjene tri raziskave v Ljubljani in Mariboru. Vse tri raziskave so bile opravljene po identični metodi intervjuja z zapisovanjem potovalnih dnevnikov. Podobnost strukture vzorcev anketirancev (gospodinjstev in njihovih članov) in 
GEOGRAFIJ PODRAVJA
M. Lep, B. Mesarec, M. Gabrovec: Potovalne navade Mariborčanov - kaj je drugače

uporabljenih anketnih vprašalnikov omogočajo primerljivost rezultatov vseh treh anket ter podrobno analizo sprememb potovalnih navad tako v času kot prostoru. Razlike med naštetimi anketami potovalnih navad lahko opazimo pri velikosti območja anketiranja, velikosti anketnega vzorca, naboru dodatnih specifičnih vprašanj ter načinu izvedbe anketiranja - a te razlike ne zmanjšujejo primerljivosti rezultatov opravljenih anket.

Primerjava števila anketiranih gospodinjstev in števila anketirancev.

\begin{tabular}{|l|c|}
\hline Anketiranje & Število anketiranih gospodinjstev \\
\hline Ljubljana 2003 & 6000 \\
\hline Ljubljana 2013 & 2000 \\
\hline Maribor 2016 & 1200 \\
\hline
\end{tabular}

Pri vseh treh anketah je osnovno enoto raziskovanja predstavljalo gospodinjstvo, znotraj katerega je bilo obvezno izpolniti vprašalnik za vse člane gospodinjstva, stare 7 let ali več. Vprašalniki so bili sestavljeni iz dveh delov - splošnega ali t. i. gospodinjskega vprašalnika, ki je zajemal družbenoekonomske značilnosti gospodinjstev, in osebnih podvprašalnikov, ki so zajemali 24-urni popis vseh opravljenih poti in njihovih značilnosti vseh članov anketiranega gospodinjstva. Splošni vprašalnik in osebne podvprašalnike je lahko za vse člane gospodinjstva izpolnil polnoletni član gospodinjstva, vendar pa je moral obvezno za vsakega člana gospodinjstva izpolniti ločen osebni podvprašalnik. Na ta način so bili zbrani vsi podatki, ki so potrebni za razumevanje dejavnikov, ki pomembno vplivajo na mobilnostne navade. Tako je med drugim možno ugotoviti, kako vpliva višina dohodkov gospodinjstva, število članov gospodinjstva in osebnih avtomobilov $\mathrm{v}$ lasti gospodinjstva ter posedovanje parkirnega prostora na izvedbo potovanj po namenu, sredstvu, času, trajanju in dolžini.

Osnovni vir za vzorčenje gospodinjstev v omenjenih raziskavah so bili podatki Statističnega urada RS, Centralnega registra prebivalstva RS, telefonski imenik in seznami spletnih panelov. V raziskavah v Ljubljani leta 2013 in Mariboru leta 2016 so bila posamezna gospodinjstva izbrana naključno in kasneje dejansko anketirana, če so zadostila naslednjim kriterijem:

- vzorec gospodinjstev mora odražati strukturo števila gospodinjstev po prostorskih enotah raziskave (npr. četrtnih skupnostih oz. mestnih četrtih) in

- vzorec gospodinjstev mora odražati strukturo gospodinjstev v izbrani prostorski enoti glede na število članov v gospodinjstvu.

Anketiranje leta 2013 v Ljubljani in leta 2016 v Mariboru je v celoti potekalo v digitalni obliki, kar velja tudi za anketiranje na terenu $\mathrm{z}$ anketarji. S pomočjo aplikacije, v kateri so anketarji oz. anketiranci na digitalnem zemljevidu označili lokacijo začetka in lokacijo konca vsakega opravljenega potovanja, so bili neposredno ob reševanju zbrani geokodirani prostorski podatki. V okviru uporabljene aplikacije za reševanje vprašalnikov je bil vzpostavljen tudi sistem za odkrivanje logičnih napak in nepopolnih vnosov podatkov. V primeru nelogičnosti oziroma nepopolno izpolnjenih vprašalnikov je bil onemogočen zaključek in s tem oddaja vprašalnika. Pred analizo zbranih anketnih podatkov so bili le-ti ustrezno uteženi in ekspandirani na vrednosti statističnih podatkov o številu članov gospodinjstev, v primeru Ljubljane iz registrskega popisa leta 2011, v 
primeru Maribora iz Centralnega registra prebivalcev (Klemenčič et al., 2014; Mesarec et al., 2016).

V nadaljevanju obravnavamo več prvin potovalnih navad, to je število dnevnih potovanj, izbor prevoznega sredstva glede na namen in dolžino potovanj ter porazdelitev potovanj glede na čas začetka potovanj. Pri posameznih prvinah se med Mariborom in Ljubljano pojavljajo pomembne razlike.

\section{Število potovanj po starostnih skupinah}
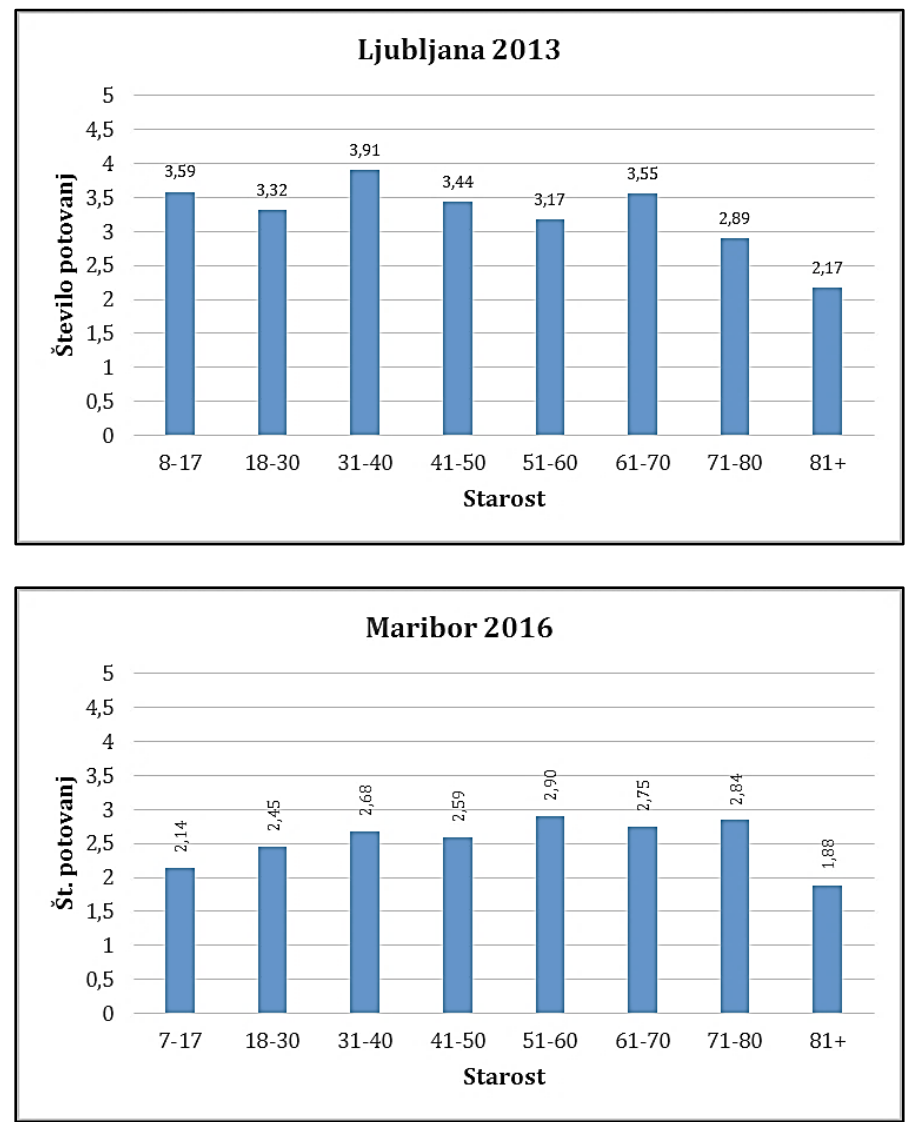

Število potovanj prebivalcev MO Ljubljana (leta 2013) in MO Maribor (leta 2016) po starostnih skupinah.

Vir: Klemenčič et al., 2014; Mesarec et al., 2016.

Število dnevnih potovanj je v Mariboru nižje kot v Ljubljani, zanimivo pa je, da razlike niso enake $\mathrm{v}$ vseh starostnih skupinah. Zelo velika je razlika v najnižji starostni skupini, kar kaže na to, da mariborski učenci obiskujejo precej manj izvenšolskih dejavnosti. Manjše število potovanj v starostni skupini od 30 do 50 je verjetno tudi posledica nižje stopnje delovne aktivnosti v Mariboru, v letu 2015 je bila razlika med ljubljansko in mariborsko občino po podatkih SURS kar za 6,5 odstotnih točk. 


\section{Delež potovanj po namenih in prevoznih sredstvih}
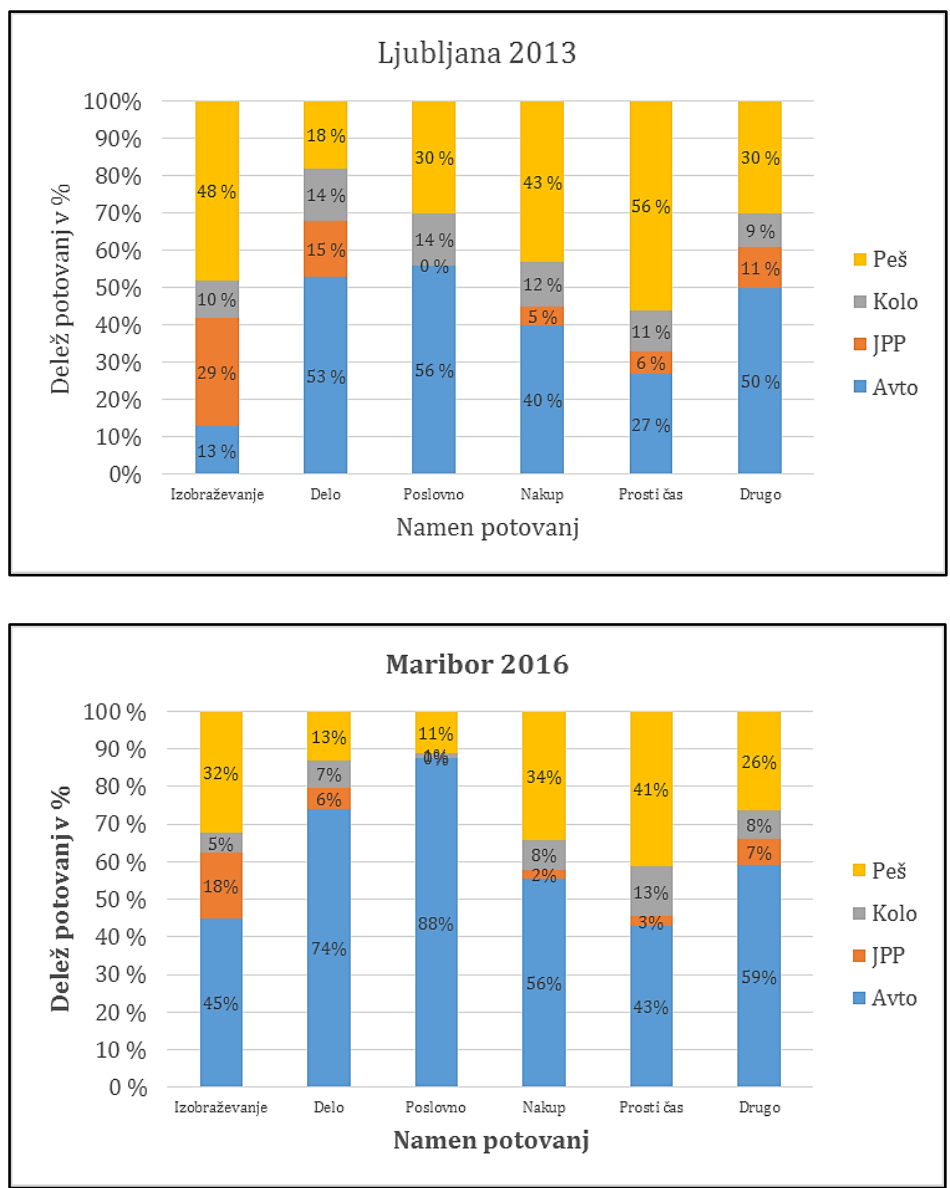

Število potovanj prebivalcev MO Ljubljana (leta 2013) in MO Maribor (leta 2016) po namenih in prevoznih sredstvih.

Vir: Klemenčič et al., 2014; Mesarec et al., 2016.

Med Mariborom in Ljubljano so pri izbiri prevoznih sredstev pomembne razlike. Delež uporabnikov javnega prometa je pri večini namenov v Ljubljani dvakrat višji. V Mariboru posebej izstopa zelo nizka uporaba javnega prometa pri poteh $\mathrm{v}$ šolo oziroma $\mathrm{z}$ namenom izobraževanja, kjer je komaj $18 \%$. To pomeni, da javnega prometa ne uporabljajo niti nepolnoletni učenci, ki se očitno vozijo v šolo kot sopotniki z osebnimi vozili. Nizka uporaba je posledica slabše ponudbe mestnega javnega prometa, v Mariboru so namreč frekvence avtobusnih voženj precej nižje kot v Ljubljani. V mestih z manjšim številom prebivalstva je težje organizirati kakovosten javni potniški promet, slabša je ponudba in posledično povpraševanje.

Maribor tudi zaostaja za Ljubljano pri kolesarjenju. Le to se je v Ljubljani po letu 2003 bistveno povečalo, na eni strani zaradi izboljšanje kolesarske infrastrukture (ki ima sicer še vedno številne pomanjkljivosti), po drugi strani pa zaradi omejevalne parkirne politike 
v središču mesta. Posledično je v Mariboru bistveno večji delež poti opravljen z osebnimi avtomobili. Kot je bilo že ugotovljeno v celostni prometni strategiji (Balant et al., 2015) ima Maribor glede na svoje prostorske značilnosti velik potencial za povečanje hoje in kolesarjenja, javni promet lahko pritegne več potnikov predvsem s povečanjem potovalnih hitrosti in višjimi frekvencami.

\section{Porazdelitev potovanj glede na čas pričetka potovanj}

Razporeditev potovanj preko dneva je pomembna predvsem za načrtovanje javnega potniškega prometa, ob poznavanju teh podatkov lahko ustrezno načrtujemo frekvence voženj in kapacitete avtobusov. Med mestoma ni statistično pomembnih razlik.
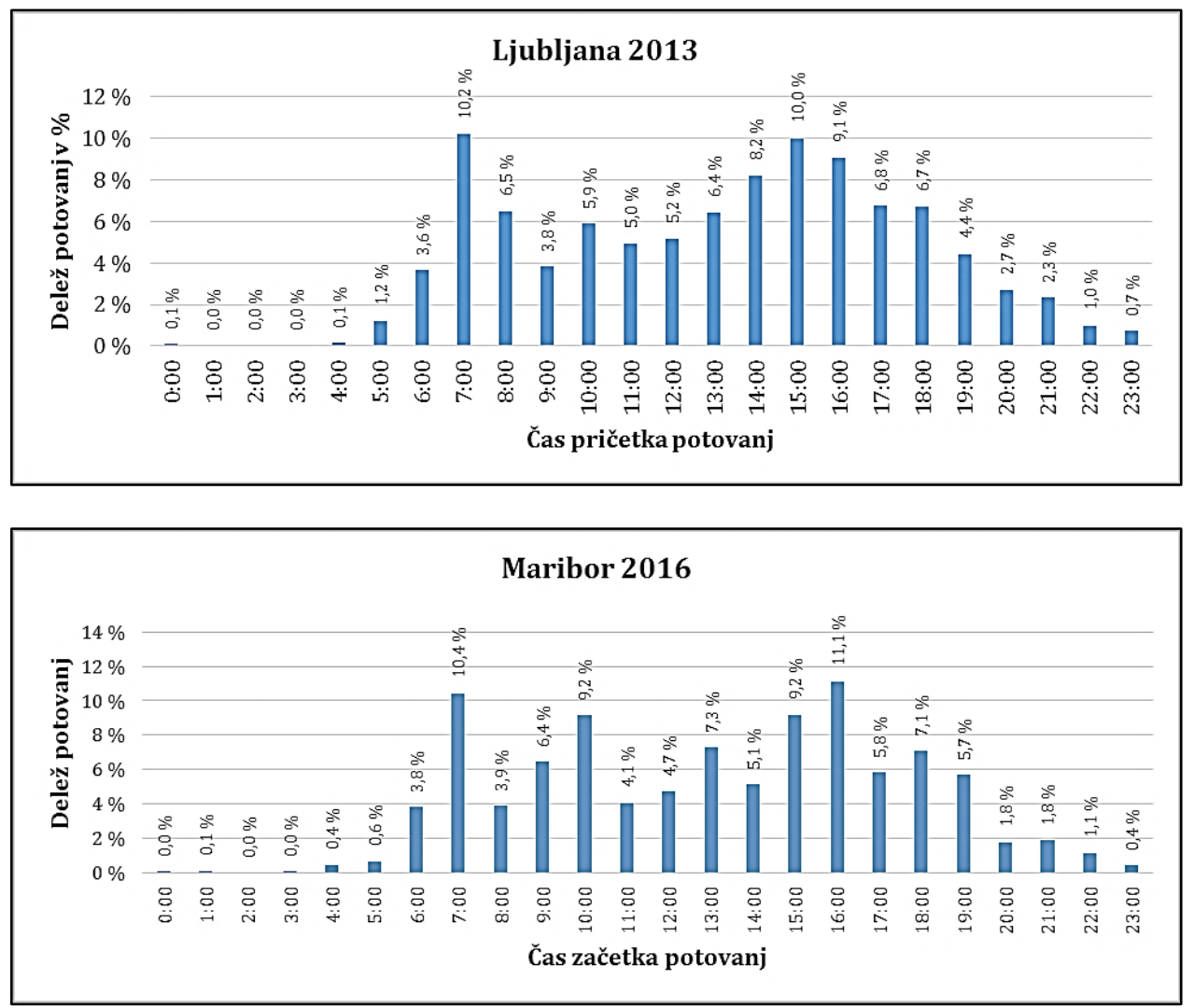

Porazdelitev potovanj prebivalcev MO Ljubljana (leta 2013) in MO Maribor (leta 2016) glede na čas pričetka potovanj.

Vir: Klemencič et al., 2014; Mesarec et al., 2016.

\section{Porazdelitev potovanj po prometnih sredstvih glede na dolžino potovanj}

Medtem ko se v Ljubljani delež potovanj z osebnim avtomobilom po razdaljah giblje med 14 in $80 \%$, pa se v Mariboru giblje med 21 in $100 \%$. V Ljubljani je očitno več pešačenja na kratkih razdaljah, kar je povezano s širitvijo peš con v zadnjih letih. Pri poteh, dolgih nad $8 \mathrm{~km}$, Mariborčani javnega prometa praktično ne uporabljajo. Tu se očitno kaže slabša ponudba javnega prometa v Mariboru. 

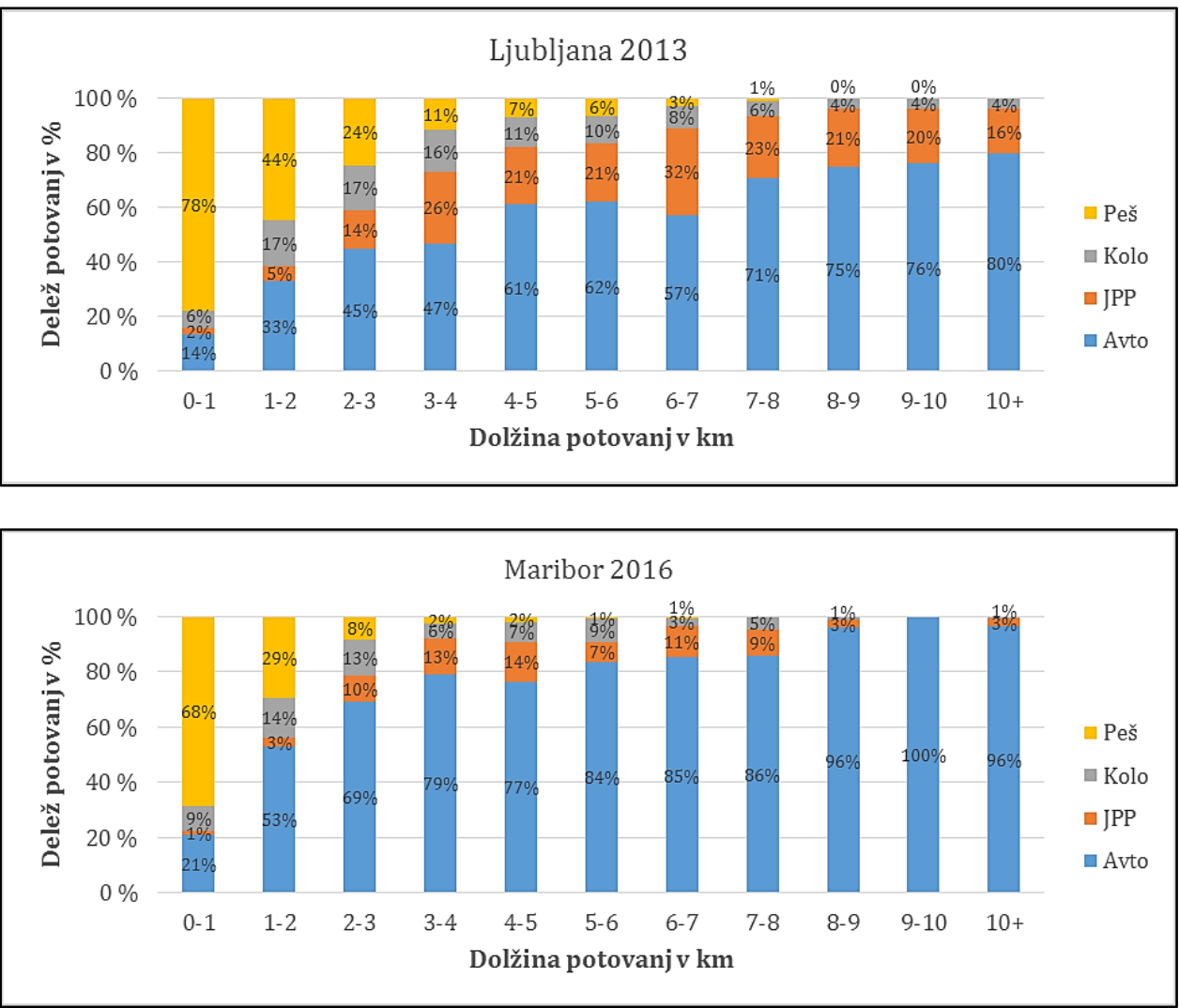

Porazdelitev potovanj prebivalcev MO Ljubljana (leta 2013) in MO Maribor (leta 2016) po prevoznih sredstvih glede na dolžino potovanj. Vir: Klemenčič et al., 2014; Mesarec et al., 2016.

\section{Odzivi na prometne ukrepe v Mariboru}

Okoljska cona je bila prometno tehnično vpeljana s prometnim znakom, ki je prepovedoval vstop $\mathrm{v}$ mestno središče motornim vozilom, ki niso dosegala določenega emisijskega standarda. Ukrep je prizadel manj kot $20 \%$ vseh motornih vozil. Ker ni bilo poostrenega nadzora in sankcij, je imel ukrep ozaveščevalni učinek o vplivu motornega prometa na kakovost zraka. Konkretnih učinkov na spremembo potovalnih navad ali zmanjšanje prometnih obremenitev v mestnem središču ni bilo zaznati.

Koroška cesta je zelo obremenjena prometnica. Po odseku, ki je bil v septembru leta 2015 začasno zaprt za motorna vozila, je dnevno peljalo do 18.000 motornih vozil. Laično javnost je predvsem zanimalo, kam se bo prerazporedilo teh 18.000 motornih vozil, napovedovali so apokaliptične zastoje. Izziv za prometno stroko je bil, ali bomo uspeli ugotoviti (izmeriti) pojav redukcije (tudi evaporacije) prometnega povpraševanja in kako oziroma kako dolgo vozniki izbirajo možne vzporedne ali druge poti. Odzive smo spremljali na dva načina:

- $\quad$ z merjenjem prometnih obremenitev na mostovih čez Dravo in na vseh cestah 
(4), ki na levem bregu povezujejo vzhod in zahod ter

- z izpraševanjem izbranih voznikov, ki so pred zaporo uporabljali odsek Koroške ceste.

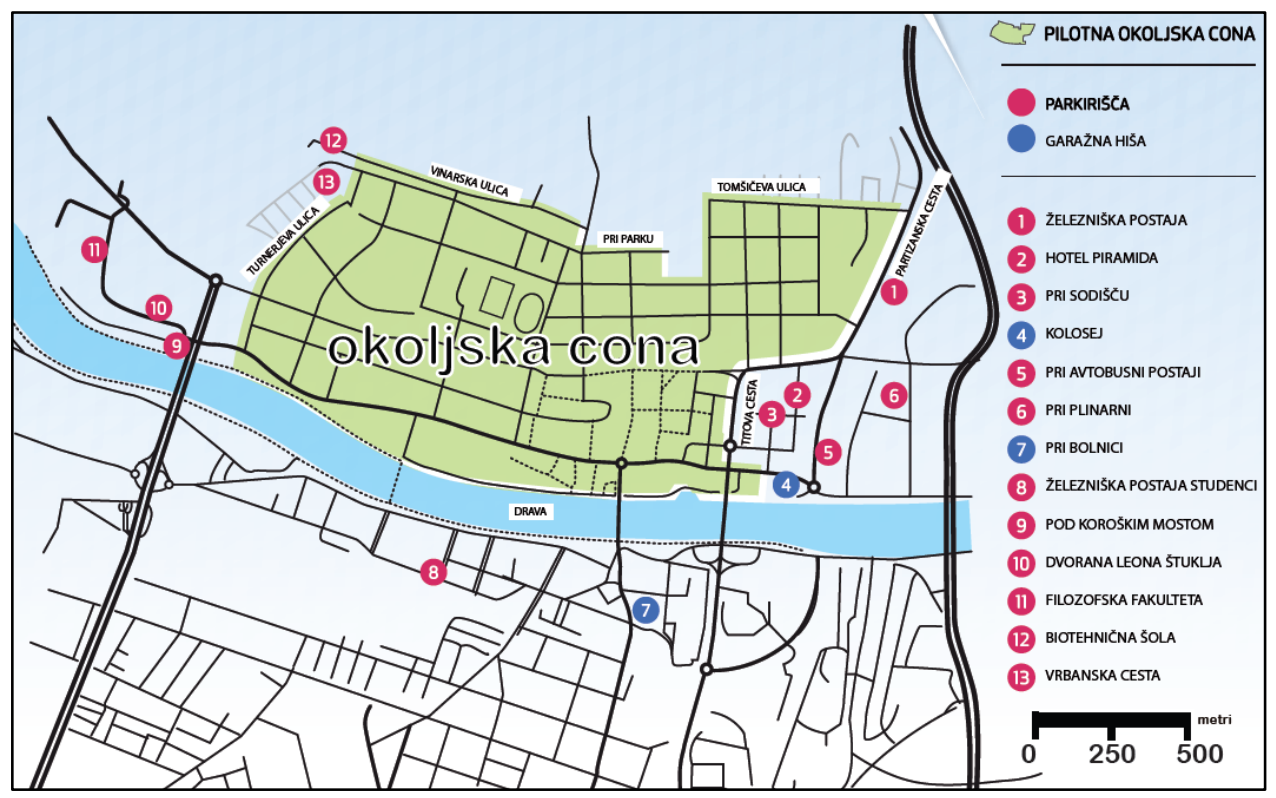

\section{Območje okoljske cone v Mariboru.}

Od 18.000 vozil, ki so pred zaporo vozila po Koroški cesti, smo na vzporednih cestah našteli zgolj prirast 14.000 vozil. Vozniki so se med zaporo Koroške ceste počasi »selili« predvsem na cesto ob Lentu (kjer se je cestni promet podvojil), med tem ko so ostale "prizadete« prometnice dobile manjše prirastke. Zastojev objektivno nismo zaznali. Med izbranimi osebami (vozniki ali sopotniki) v osebnih avtomobilih smo med tistimi, ki so opustili vožnjo z osebnim avtomobilom, zaznali dva prevladujoča odgovora: grem peš, saj sem blizu doma; prej me je voznik pripeljal do vrat, zdaj pa me »odloži « pred zaporo in grem peš. Nismo zaznali prehoda na javni potniški promet. Med vozniki osebnih avtomobilov, ki so spremenili pot, smo pri tistih, ki prihajajo iz desnega brega Drave in so prej vozili skozi mestno središče, zaznali predvsem preusmeritev na Koroški most (strateška sprememba poti) ter vožnjo po vzporedni ulici (lokalna sprememba poti). Pri večini voznikov smo ugotovili tudi, da so med trajanjem zapore menjavali poti ter se po dveh ali treh tednih ustalili.

Ugotovili smo torej, da je eksperimentalna ureditev na posameznih prometnicah dejansko dvignila prometne obremenitve - a po drugi strani bistveno zmanjšala skupno število vozil v ožjem mestnem središču (oz. levem bregu Drave) ter posledično tudi zmanjšala njihove negativne učinke na okolje in ljudi. Strahovi o kolapsu prometnega sistema so se pokazali kot popolnoma neutemeljeni (Mesarec, 2015).

\section{Zaključek}

Potovalne navade Ljubljančanov in Mariborčanov se v nekaterih potezah razlikujejo. 
Velikost mesta vpliva na možnost organizacije učinkovitega javnega potniškega prometa. V Mariboru je zaradi manjšega števila prebivalcev težje organizirati učinkovit javni potniški promet, posledično je zaradi slabše ponudbe tudi njegova uporaba manjša kot v Ljubljani. V Ljubljani se je v zadnjem desetletju povečal delež pešcev in kolesarjev zaradi prometnih ukrepov, začasna zapora Koroške ceste v Mariboru je pokazala, da bi širitev peš con in omejevanje osebnega motornega prometa prineslo pozitivno spremembo potovalnih navad tudi v Mariboru.

\section{Literatura in viri}

Anketa po gospodinjstvih 2003: Raziskava potovalnih navad prebivalcev ljubljanske regije, URBI, PNZ, Ninamedia, Ljubljana.

Balant, M., Klemenčič, M., Kukovec, M., Lep, M., Mesarec, B., Mladenovič, L., Plevnik A., Rotar, J. 2015: Poti do privlačnega mesta in zadovoljne skupnosti, Celostna prometna strategija mesta Maribor, Mestna občina Maribor, Maribor.

Bole, D., Gabrovec, M. 2012: Daily commuters in Slovenia, Geografski vestnik, 84-1.

Drozg, V. 2005: Koncepti policentrične ureditve Slovenije, Dela, 24.

Drozg, V. 2012: Mobility and the lifestyle of the Slovene population, Geografski vestnik, 84-1.

Gabrovec, M., Bole, D. 2009: Dnevna mobilnost v Sloveniji, Georitem, 11, Ljubljana.

Gärling, T. 2005: Changes of Private Car Use in Response to Travel Demand Management, v: Proceedings of ICTTP, Oxford: Elsevier.

Gather, M., Kagermeier, A., Lanzendorf, M. 2008: Geographische Mobilität- und Verkehrsforschung, Berlin, Stuttgart: Gebrüder Borntraeger Verlagsbuchhandlung.

Klemenčič, M., Lep, M., Mesarec, B., Žnuderl, B. 2014: Potovalne navade prebivalcev v Mestni občini Ljubljana in Ljubljanski urbani regiji, Končno poročilo, Univerza v Mariboru, Fakulteta za gradbeništvo in RM Plus, Maribor.

Lep, M., Mesarec, B. 2015: Planiranje prometa, Maribor, Fakulteta za gradbeništvo.

Nared, J., Bole, D., Breg Valjavec, M., Ciglič, R., Goluža, M., Kozina, J., Razpotnik Visković, N., Repolusk, P., Rus, P., Tiran, J., Černič Istenič, M. 2017: Centralna naselja v Sloveniji leta 2016, Acta geographica Slovenica, 57, https://doi.org/10.3986/AGS.4606.

Mesarec, B. 2015: Eksperimentalna ureditev Koroške ceste - analiza preusmeritev prometnih tokov, Elaborat, Maribor.

Mesarec, B., Čelan, M., Jurič, B., Klemenčič, M., Lep, M. 2016: Potovalne navade na območju Mestne občine Maribor in sosednjih občin, Elaborat, Univerza v Mariboru, Fakulteta za gradbeništvo, prometno inženirstvo in arhitekturo, Maribor.

Pelc, S. 1988: Prometna dostopnost do delovnih mest in njen pomen pri urejanju prostora, Magistrsko delo, Fakulteta za arhitekturo, gradbeništvo in geodezijo Univerze v Ljubljani, Ljubljana.

Stradling, S., Anable, J. 2008: Individual Transport Patterns, v: Transport Geographies, Malden, Oxford, Carlton: Blackwell Publishing. 
GEOGRAFIJE PODRAVJA

THE GeOgraphies of THE Podravje Region 


\title{
Prostorsko-časovna razporeditev prometnih nesreč v Mariboru
}

\author{
DANIJEL IVAJNŠIČ, IGOR ŽIBERNA
}

Povzetek V prispevku obravnavamo žarišča prometnih nesreč v mestni občini Maribor v obdobju med letoma 2003 in 2013. S pomočjo tehnologije geografskih informacijskih sistemov, natančneje $\mathrm{z}$ analizo vročih točk, ki temelji na Moranovi metodi prostorske avtokorelacije, s statistiko Getis-Ord Gi* in z funkcijami Kerneljeve gostote, vrednotimo tako prostorski kot časovni vzorec prometnih nesreč na obravnavanem območju. Rezultati kažejo na oblikovanje značilnih prostorskih gruč prometnih nesreč, ki so časovno vezane na interval jutranje in popoldanske prometne konice. Ugotovitve imajo aplikativno vrednost predvsem z vidika prostorskega planiranja v urbanih območjih hkrati pa predstavljajo pomemben doprinos $\mathrm{k}$ pripravi ustreznih strategij za boljše prometne pogoje in zmanjševanje nesreč.

Ključne besede: • GIS • promet • prostorska analiza $\bullet$ žarišča prometnih nesreč • Mestna občina Maribor •

NASLOV AVtoRJEv: dr. Danijel Ivajnšič, docent, Univerza v Mariboru, Fakulteta za naravoslovje in matematiko, Koroška cesta 160, 2000 Maribor, Slovenija, e-naslov: dani.ivajnsic@um.si.dr. Igor Žiberna, izredni profesor, Univerza v Mariboru, Filozofska fakulteta, Oddelek za geografijo, Koroška cesta 160, 2000 Maribor, Slovenija, e-naslov: igor.ziberna@um.si. 


\title{
Spatiotemporal distribution of traffic accidents in Maribor
}

\author{
DANIJEL IVAJNŠIČ, IGOR ŽIBERNA
}

\begin{abstract}
The focus of this study is orientated towards traffic accident Hot spots in the municipality of Maribor considering the 2003-2013 time frame. Geographic information system (GIS) technology, particularly the Hot Spot Analysis based on Moran's spatial autocorrelation, Getis-Ord $\mathrm{Gi}^{*}$ statistics and Kernel density, enabled the evaluation of spatial and temporal patterns of traffic accidents in the study area. Results show that significant spatial clusters of traffic accidents developed, especially in the morning and afternoon traffic rush hours. Our finding are applicable for spatial or urban planners who are obligated to develop appropriate mitigation measures and strategies for traffic and safety improvement.
\end{abstract}

Keywords: • GIS $\bullet$ traffic $\bullet$ spatial analysis $\bullet$ traffic accident hot spots $\bullet$ Municipality of Maribor •

CoRRESPONDENCE ADDRESS: Danijel Ivajnšič, Assistant Professor, University of Maribor, Faculty of Arts, Department for geography, Koroška cesta 160, 2000 Maribor, Slovenia, e-mail: dani.ivajnsic@um.si. Igor Žiberna, Ph.D., associate profesor, University of Maribor, Faculty of Arts, Department for geography, Koroška cesta 160, 2000 Maribor, Slovenia, e-mail: igor.ziberna@um.si. 
D. Ivajnšič I Žiberna: Prostorsko-časovna razporeditev prometnih nesreč v Mariboru

\section{Uvod}

Razumevanje vzrokov, položaja in časa prometnih nesreč je ključnega pomena za izboljšanje prometne varnosti (Xie in Jun, 2008). Prostorsko-časovni vzorec prometnih nesreč je le redko naključen. Najpogosteje prometne nesreče v prostoru tvorijo zgostitve ali tako imenovane vroče točke (ang. Hot spots). Le-te so posledica dejstva, da se prometne nesreče vzdolž določenega cestnega odseka običajno pripetijo zaradi značilne prometne obremenitve in tvorijo prepoznaven vzorec (Black, 1991). Seveda so pomembni še drugi dejavniki, ki sooblikujejo prostorsko razporeditev prometnih nesreč: naravne in okoljske determinante kot so fizično okolje (strma pobočja, ostri zavoji), vreme (dež, sneg, veter in megla), konfiguracija prometnega omrežja s številom vstopnih in izstopnih točk, pomanjkljivo oblikovanje in vzdrževanje cest in avtocest (Xie in Jun, 2008) itd.

Prostorsko analizo točkovnih podatkov, poznano tudi kot Point Pattern Analysis (PPA), že dalj časa uporabljajo številni prostorski statistiki, ki so razvili različne metodološke pristope za opredelitev vročih točk na podlagi točkovnih dogodkov (Bailey in Gatrell, 1995; O'sullivan in Unwin, 2002; Xie in Jun, 2008). Pogosto je v ospredju metoda uporabe gostote jeder (ang. kernel density estimation), ki jo zasledimo v številnih študijah o prometnih nesrečah (Anderson, 2009); analize o nevarnosti gostote prometa za kolesarje (Delmelle in Thill 2008), zaznavanje kritičnih območij za nesreče pešcev (Pulugurtha et al., 2007), analize povozov živali (Krisp in Durot, 2007; Colino-Rabanal in Peris, 2016), analize vročih točk na avtocestnem omrežju (Erdogan et al. 2008), itd. Kot navajajo Lipar et al. (2010) sta glavna indikatorja prostorske asociacije lokalni Moranov indeks in indeks Gethis-Ord $\mathrm{G}^{*}$. Orodja za determinacijo omenjenih kazalcev so na razpolago $\mathrm{v}$ nekaterih komercialnih geografskih informacijskih sistemih (ESRI ArcGIS Spatial Analyst Extenision) ali v pa so integrirana v popularnih prostorskostatističnih programih kot je npr. CrimeStat (Levine, 2004).

V prispevku se osredotočamo na problematiko vseh ter hudih (huda telesna poškodba, smrt) prometnih nesreč v Mestni občini Maribor. Zanima nas časovna in prostorska dinamika dogodkov v časovnem intervalu 2003-2013. Tako obravnavamo:

- trend števila prometnih nesreč z vidika državnega in občinskega nivoja,

- prostorski vzorec prometnih nesreč glede na vzrok, klasifikacijo, uro in število udeleženih,

- tedenski režim prometnih nesreč s poudarkom na vzroku,

- urni režim prometnih nesreč glede na izbrani atribut,

- žarišča vseh in hudih prometnih nesreč v občini Maribor.

\section{Metodologija}

Za potrebe analize prometnih nesreč v občini Maribor smo v prvi fazi pridobili podatke o prometni varnosti na spletni strani slovenske Policije (Medmrežje 1). Sledila je pretvorba tekstovnih datotek $\mathrm{v}$ prostorsko vektorsko obliko ob upoštevanju koordinatnega sistema D48GK (ESRI, 2010). Oblikovali smo prostorsko podatkovno bazo (ESRI Geodatabase) prometnih nesreč v Sloveniji za obdobje 2003-2013 z naslednjimi za raziskavo pomembnimi atributi: lokacija, datum, čas, vzrok, klasifikacija, tip in število udeleženih. Sledilo je filtriranje podatkov na ciljno območje raziskave tj. 
občina Maribor. S pomočjo oblikovane prostorske podatkovne baze smo izračunali gibanje števila prometnih nesreč med letoma 2003 in 2013 tako za Slovenijo kot za občino Maribor. V tem časovnem obdobju smo primerjali trend vseh zabeleženih prometnih nesreč ter tistih z najhujšimi posledicami (huda telesna poškodba, smrt).

V nadaljevanju smo se posvetili tedenskemu režimu prometnih nesreč v občini Maribor s poudarkom na vzroku. S pomočjo Kruskal-Wallis preizkusa (R Development Core, 2008) ter preizkusa primerjave parov po Dunnu (z upoštevanjem korekcije p-vrednosti po Bonferroni metodi) (Pohlert, 2014) smo ugotavljali razlike v vzrokih prometnih nesreč v občini Maribor med delavnikom in vikendom. Urni režim vseh in izbranih (huda telesna poškodba, smrt) prometnih nesreč $\mathrm{v}$ povezavi $\mathrm{z}$ vzrokom, klasifikacijo in številom udeležencev smo prikazali v prostoru glavnih komponent s pomočjo statističnega paketa BiplotGUI (La Grange et al., 2009). V zaključni fazi smo prostorski vzorec prometnih nesreč v občini Maribor vrednotili še z analizo vročih točk (Hot Spot Analisys), ki temelji na Moranovi metodi prostorske avtokorelacije, statistiki Getis-Ord Gi* in funkcijah Kerneljeve gostote (ESRI, 2010).

Mejno vrednost razdalje za potrebe te analize $(400 \mathrm{~m})$ smo določili s pomočjo orodja Incremental Spatial Autocorrelation v sklopu programa ArcGIS 9.3 (ESRI, 2010). Spremenljivko za analizo vročih točk smo oblikovali s pomočjo mreže šestkotnikov $\left(\right.$ širina $\left.=300 \mathrm{~m}, \mathrm{kot}=0^{\circ}\right)($ Jenness, 2012), oblikovane podatkovne baze prometnih nesreč in vektorskih podatkov cestnega omrežja (podatki gospodarske javne infrastrukture [GJI], GURS, 2017). V vsakem šestkotniku smo tako frekvenco prometnih nesreč delili $\mathrm{z}$ dolžino cestnega omrežja in oblikovali vhodni podatek za analizo vročih točk. Dobljene z- in p-vrednosti statistike Getis-Ord Gi* nakazujejo kje v prostoru se pojavljajo zgostitve bodisi visokih ali nizkih vrednosti vhodne spremenljivke. Slednje nam je omogočilo, da smo objektivno identificirali splošna žarišča prometnih nesreč v občini Maribor in žarišča prometnih nesreč z najhujšim izidom (huda telesna poškodba, smrt) v obravnavanem deset-letnem obdobju (2003-2013) ob upoštevanju gostote prometnega omrežja.

\section{Trendi prometnih nesreč}

Število prometnih nesreč se je med letoma 2003 in 2006 postopno povečevalo tako na državnem kot občinskem nivoju. Leta 2003 smo tako v občini Maribor zabeležili nekaj več kot 170 nesreč, leta 2006 pa 3,6-krat več. V splošnem se je v tem obdobju v Sloveniji povečalo število prometnih nesreč za 1,4-krat. Po letu 2006 beležimo trend upadanja prometnih nesreč (slika A). Najmanj nesreč je bilo leta 2009; v Sloveniji 25.783, od tega $3 \%$ oziroma $778 \mathrm{v}$ občini Maribor. Če poenostavimo in primerjamo linearni trend spreminjanja števila prometnih nesreč opazimo, da ni bilo bistvenih razlik v obdobju 2003-2013, če obravnavamo celotno državo in občino Maribor (premici sta vzporedni).

Podatki kažejo večje razlike, če se osredotočimo le na najhujše prometne nesreče; torej tiste, ki imajo za posledico hudo telesno poškodbo ali smrt udeležencev (slika B). Na državnem nivoju je trend značilno negativen $\left(R^{2}=0.89\right)$, vsako leto je skoraj 60 takšnih prometnih nesreč manj. V občini Maribor se je sprva (2003-2004) število hudih prometnih nesreč podvojilo, po letu 2004 pa je zaznaven postopen upad takšnih dogodkov na cestah. Naklon trendne črte nakazuje, da je hitrost zmanjševanje števila prometnih nesreč $\mathrm{z}$ hudo telesno poškodbo ali smrtnim izidom $\mathrm{v}$ občini Maribor celo večja $\mathrm{v}$ primerjavi z trendom za celotno Slovenijo. 


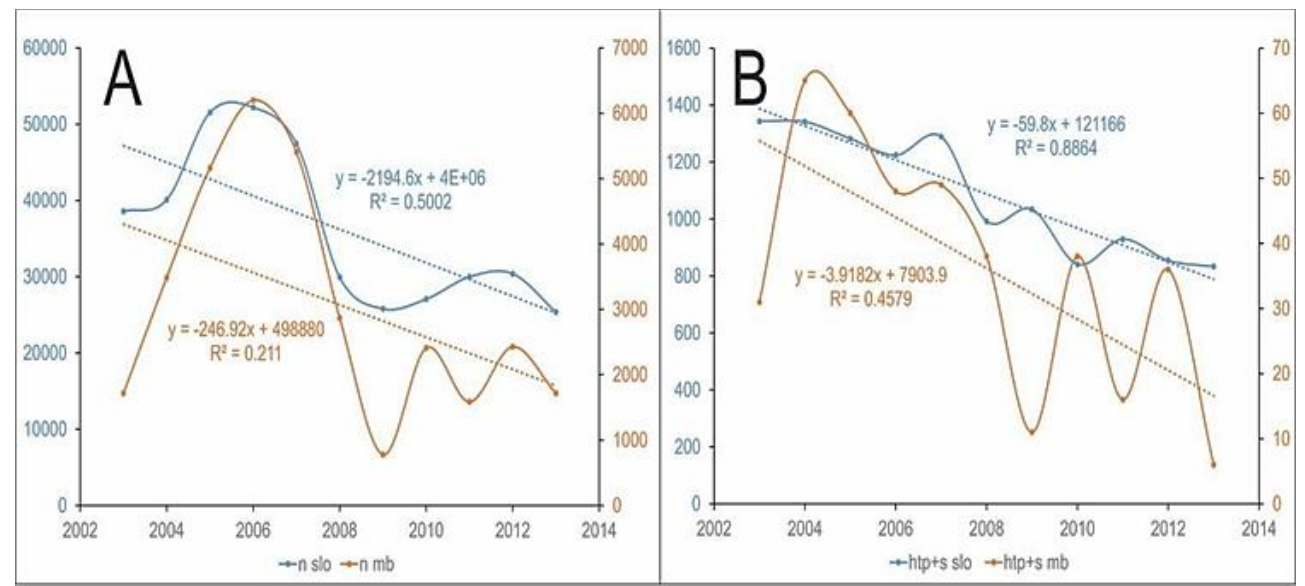

Trend spreminjanja števila vseh (A) in hudih (B) prometnih nesreč v Sloveniji in občini Maribor.

\section{Prostorska razporeditev prometnih nesreč glede na vzrok, klasifikacijo, čas in število udeleženih v obdobju 2003-2013}

Največ prometnih nesreč je v mestu Maribor in bližnji okolici. Najpogostejši vzrok za prometno nesrečo $\mathrm{v}$ obravnavanem obdobju je premik $\mathrm{z}$ vozilom $(45 \%)$, temu sledita neupoštevanje pravil o prednosti in neustrezna varnostna razdalja (oba s 14\%). Pogosta vzroka sta še nepravilna stran/smer vožnje ( $8 \%)$ ter neprilagojena hitrost $(6 \%)$.

Zabeleženih je bilo 22.547 nesreč klasificiranih kot nesreča z materialno škodo, pri 7.163 prometnih nesrečah je bila registrirana lažja telesna poškodba, pri 336 nesrečah huda telesna poškodba, 49 nesreč pa se je končalo z smrtnim izidom. Prav prostorska razporeditev slednjih je zanimivo razpršena (slika B). Največ nesreč se je pripetilo med 10. in 14. uro ter med 15. in 18. uro popoldan. Dogodki so glede na časovno razporeditev prostorsko naključno razporejeni (slika C). Več kot polovica $(56 \%)$ prometnih nesreč v občini Maribor je imela 2-3 udeležence. V 367 primerih (1.2\%) so bile v prometni nesreči udeležene več kot 4 osebe (slika D).

\section{Tedenski režim prometnih nesreč glede na vzrok}

V obdobju 2003-2013 se je v občini Maribor najpogosteje pripetila prometna nesreča ob petkih oziroma ponedeljkih (slika A). Glavni vzroki pri slednjih so premik z vozilom, neustrezna varnostna razdalja in neupoštevanje pravil o prednosti. Po manjši frekvenci dogodkov odstopata sobota in nedelja, ko je nesreč najmanj. Ob koncu tedna je delež različnih vzrokov prometnih nesreč večji v primerjavi z delovnikom.

Pri hudih prometnih nesrečah (huda telesna poškodba, smrt) je tedenski režim nekoliko drugačen (slika B). Najpogosteje se takšne nesreče pripetijo ob sobotah in petkih. V teh primerih so glavni vzroki neprilagojena hitrost, neupoštevanje pravil o prednosti ter nepravilna stran/smer vožnje. Zaznaven je trend povečevanja števila hudih prometnih nesreč zaradi neprilagojene hitrosti od ponedeljka do sobote, hkrati pa se zmanjšuje število le-teh zaradi neupoštevanja pravil o prednosti od začetka proti koncu tedna. 
D. Ivajnšič, I. Žiberna: Spatiotemporal distribution of traffic accidents in Maribor
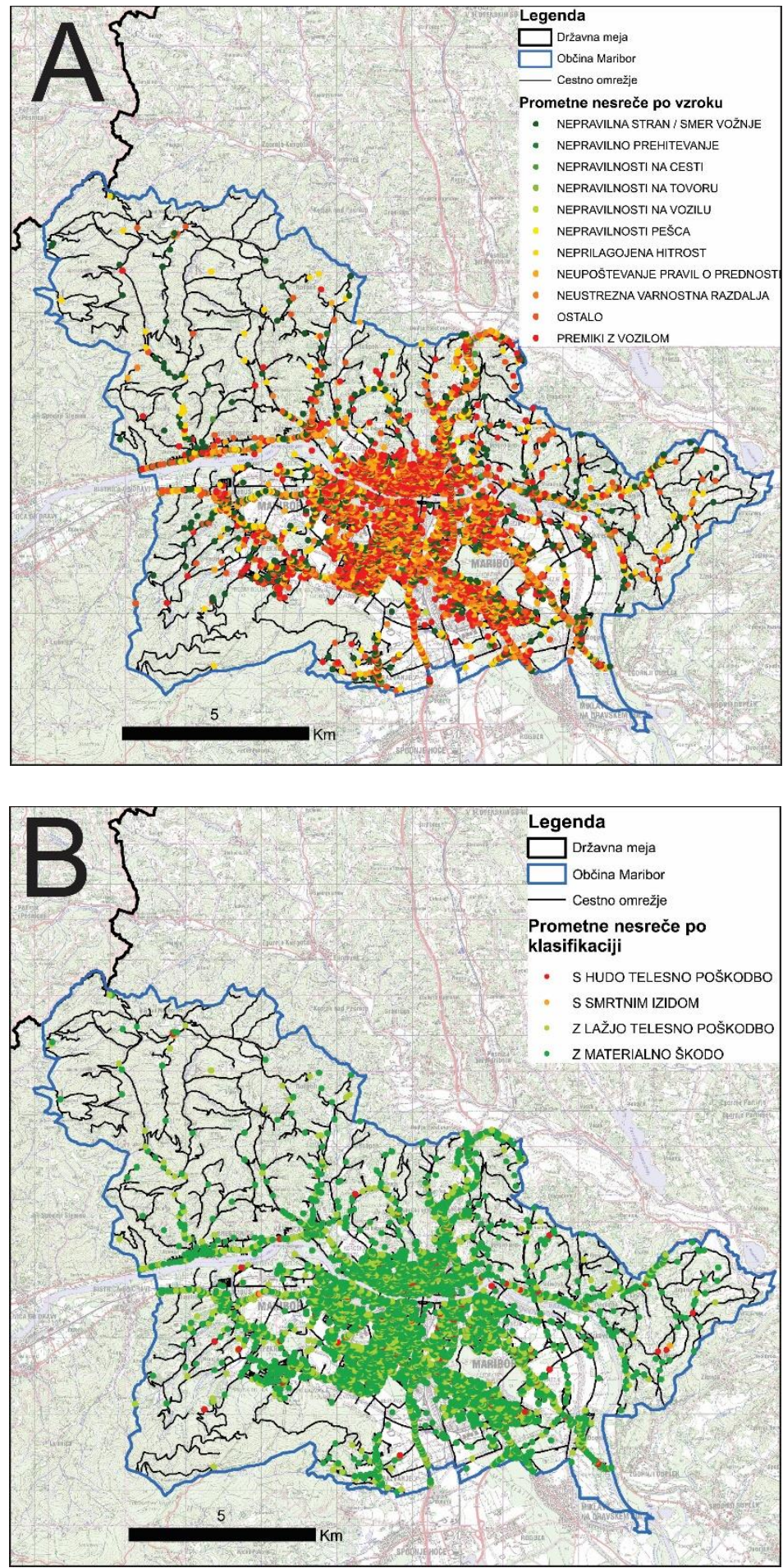

Prostorska razporeditev prometnih nesreč v občini Maribor glede na vzrok (A) in klasifikacijo (B). 
GeOgrafiJe Podravja

295

D. Ivajnšič, I. Žiberna: Prostorsko-časovna razporeditev prometnih nesreč v Mariboru
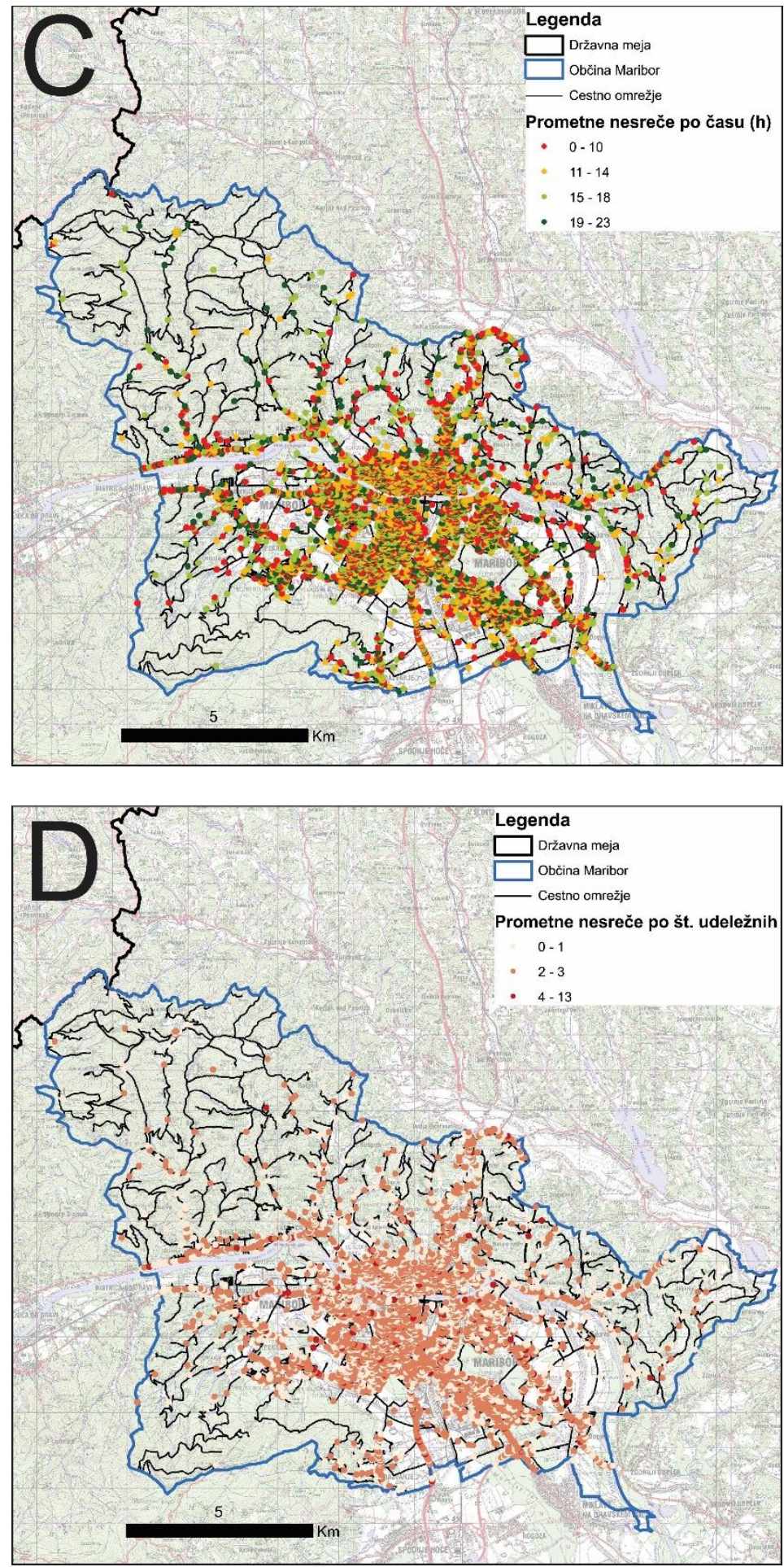

Prostorska razporeditev prometnih nesreč v občini Maribor glede na čas (C) in število udeleženih (D). 


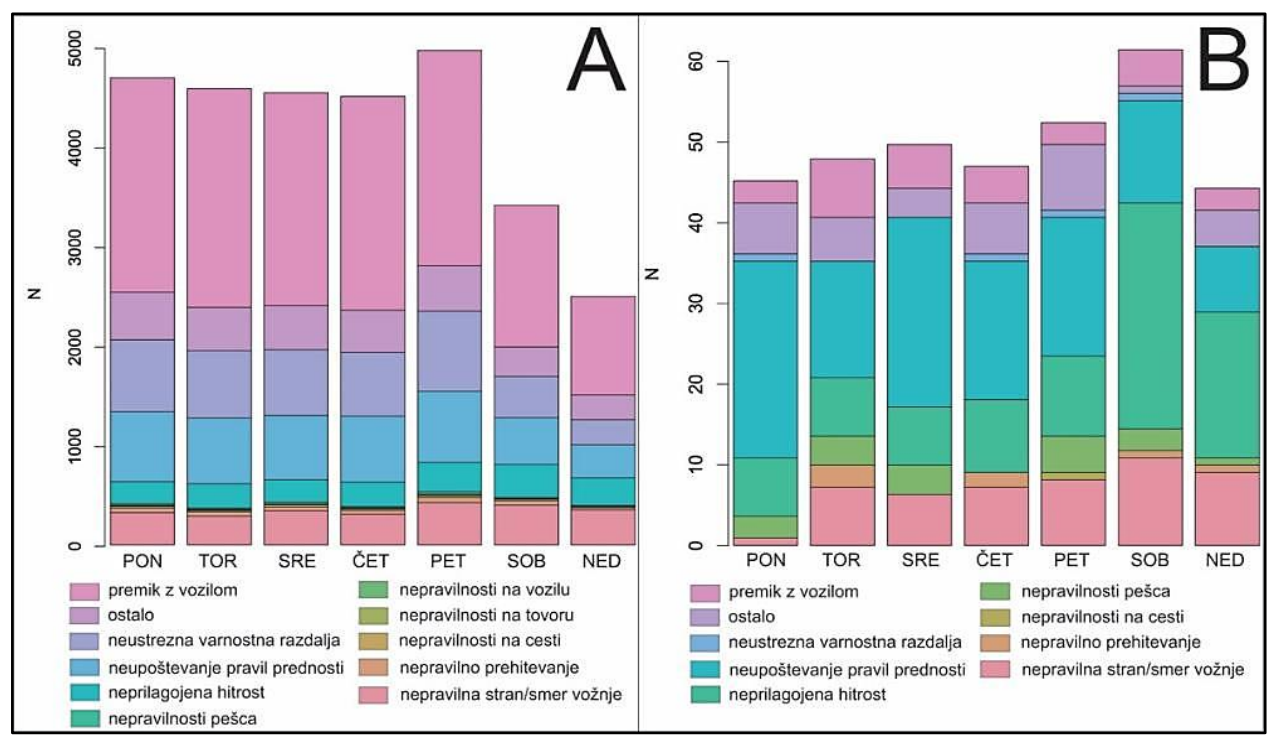

Tedenski režim vseh (A) in hudih (B) prometnih nesreč v občini Maribor glede na vzrok.

Če primerjamo frekvenco vseh prometnih nesreč po dnevih $\mathrm{v}$ tednu glede na vzrok ugotovimo, da obstajajo značilne razlike $(p<0.05, \alpha=0.05)$ med vikendom in delavnikom. Vzroki za prometne nesreče, ki se pripetijo ob nedeljah so značilno drugačni v primerjavi z ostalimi dnevi v tednu (preglednica A). Sobote se jasno ločijo od torkov, četrtkov in petkov med tem, ko med dnevi v delavniku ni razlik. Pri hudih prometnih nesrečah (huda telesna poškodba, smrt) obstajajo statistično značilne razlike $\mathrm{v}$ frekvenci prometnih nesreč glede na vzrok le med ponedeljki in obema dnevoma vikenda (preglednica B).

Korigirane P-vrednosti primerjave parov po Dunnu za vse (A) in hude (B) prometne nesreče po dnevih v tednu.

\begin{tabular}{|c|c|c|c|c|c|c|c|}
\hline \multirow[t]{2}{*}{ A } & PO & TO & SR & ČE & PE & so & NE \\
\hline & & 1.0 & 1.0 & 1.0 & 0.2 & 0.3 & $\underline{0.0}$ \\
\hline \multirow[t]{2}{*}{ PO } & & 00 & 00 & 00 & 85 & 56 & $\underline{00}$ \\
\hline & & & 1.0 & 1.0 & 1.0 & $\underline{0.0}$ & $\underline{0.0}$ \\
\hline \multirow[t]{2}{*}{ то } & & & 00 & 00 & 00 & 06 & 00 \\
\hline & & & & 0.8 & 0.0 & 0.9 & $\underline{0.0}$ \\
\hline \multirow[t]{2}{*}{ SR } & & & & 84 & 90 & 51 & $\underline{00}$ \\
\hline & & & & & 1.0 & $\underline{0.0}$ & $\underline{0.0}$ \\
\hline \multirow[t]{2}{*}{ ČE } & & & & & 00 & $\overline{02}$ & $\overline{00}$ \\
\hline & & & & & & $\underline{0.0}$ & $\underline{0.0}$ \\
\hline PE & & & & & & $\underline{\overline{00}}$ & $\underline{00}$ \\
\hline & & & & & & & 0.2 \\
\hline So & & & & & & & 10 \\
\hline $\mathrm{NE}$ & & & & & & & \\
\hline
\end{tabular}

\begin{tabular}{|llrrrrrr|}
\hline B & PO & TO & SR & \multicolumn{1}{c|}{ ČE } & PE & SO & NE \\
& & 1.0 & 1.0 & 1.0 & 1.0 & $\underline{\mathbf{0 . 0}}$ & $\underline{\mathbf{0 . 0}}$ \\
PO & & 00 & 00 & 00 & 00 & $\underline{\mathbf{0 1}}$ & $\underline{\mathbf{2 3}}$ \\
& & & 1.0 & 1.0 & 1.0 & 0.5 & 1.0 \\
TO & & & 00 & 00 & 00 & 17 & 00 \\
& & & & 1.0 & 1.0 & 0.1 & 1.0 \\
SR & & & & 00 & 00 & 50 & 00 \\
& & & & & 1.0 & 0.1 & 0.8 \\
ČE & & & & & 00 & 27 & 89 \\
& & & & & & 0.8 & 1.0 \\
PE & & & & & & 53 & 00 \\
& & & & & & & \\
SO & & & & & & \\
& & & & & & & \\
NE & & & & & & & \\
\hline
\end{tabular}

\section{Urni režim prometnih nesreč glede na vzrok, klasifikacijo in število udeleženih}

Razporeditev pogostosti vseh prometnih nesreč v občini Maribor glede na čas v dnevu kaže zgostitev dogodkov med 10. in 17. uro, z absolutnim viškom med 14. in 15. uro (slika A). Prometne nesreče zaradi premika vozila, ki je glavni vzrok, se v splošnem dogajajo med 10. in 14. uro, posledice le teh pa so najpogosteje le materialna škoda na 
D. Ivajnšič I Žiberna: Prostorsko-časovna razporeditev prometnih nesreč v Mariboru

vozilu. Neupoštevanje pravila o prednosti in neustrezna varnostna razdalja sta vzroka za številne prometne nesreče $\mathrm{v}$ popoldanski prometni konici (14.-17. ure).

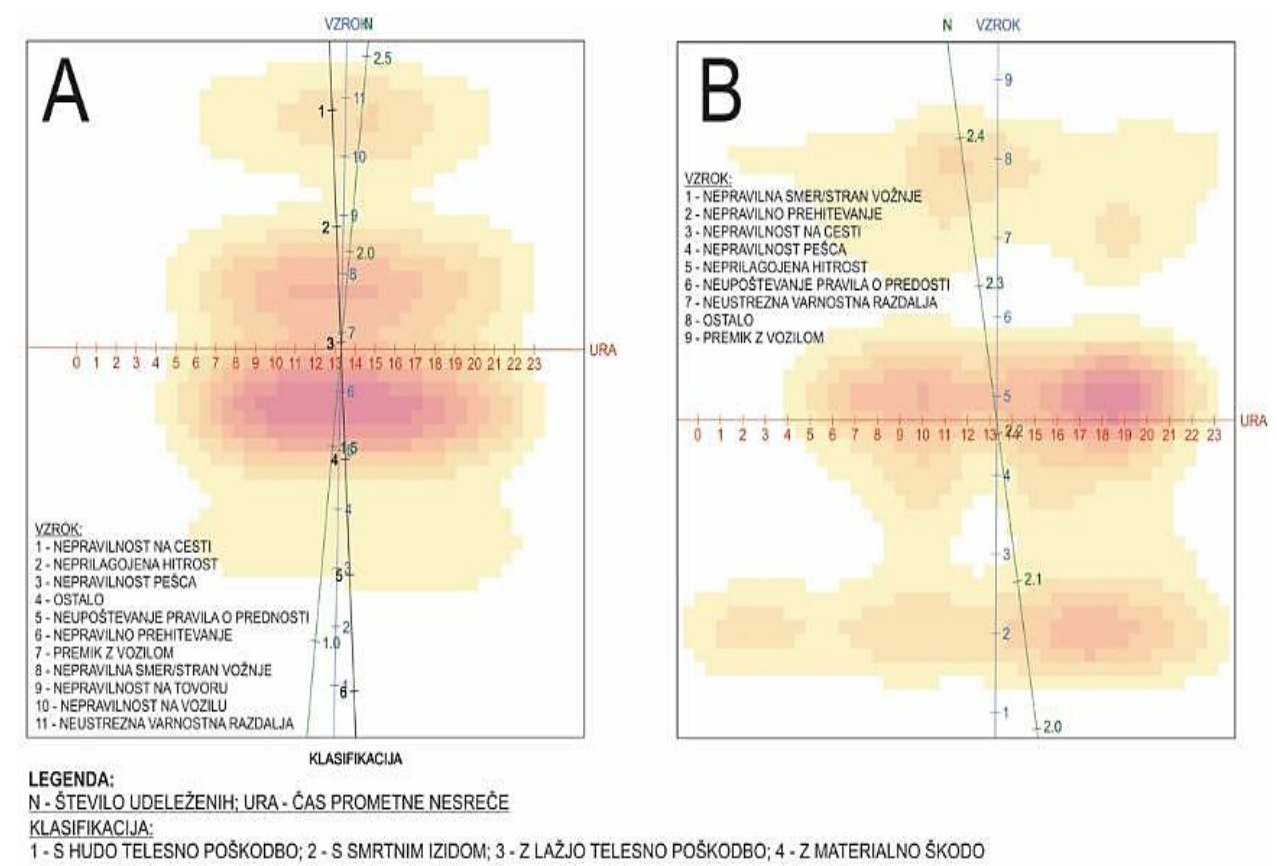

Urni režim vseh (A) in hudih (B) prometnih nesreč v prostoru glavnih komponent.

Zaznaven je tudi podoben časovni vzorec za prometne nesreče z vzrokoma nepravilno prehitevanje in neustrezna varnostna razdalja, ki se najpogosteje pripetijo med 13. in 15 . uro (slika A).

Za hude prometne nesreče (huda telesna poškodba, smrt) sta značilna dva vrhova tekom dneva (slika B). Prvi nastopi po jutranji prometni konici ob 10. uri, drugi pa $\mathrm{v}$ popoldanskih urah, ko se ljudje vračajo iz služb, med 17. in 20. uro. Glavni vzrok v obeh vrhuncih je neprilagojena hitrost, pogosto pa sta udeleženi več kot 2 osebi.

Pri prometnih nesrečah $\mathrm{s}$ hudimi posledicami, ki se pripetijo zaradi nepravilnega prehitevanja, je običajno udeleženih manj oseb, le-te pa so pogoste bodisi zgodaj zjutraj ali pa pozno popoldan. Kadar je pri hudih prometnih nesrečah udeleženih več ljudi, se te po navadi zgodijo med 10. in 12. uro, vzroki pa so različni (ostalo).

\section{Žarišča prometnih nesreč}

Na spodnji sliki A so prikazana območja značilne zgostitve vseh prometnih nesreč (Zvrednost $>2$ Std. Dev.) v občini Maribor v obdobju 2003-2013. Prepoznaven je položaj žarišča v smeri S-J (Šentiljska cesta-Titova cesta-Tržaška cesta) z odkloni v smeri SZ-JV na levem bregu reke Drave in od cone Tezno do predela Tabor-Spodnje Radvanje (Ptujska cesta- Cesta proletarskih brigad). Dodatno izstopajo še manjša žarišča $\mathrm{v}$ predelu Mestnega pokopališča Maribor ter območja Nove Vasi. 
D. Ivajnšič, I. Žiberna: Spatiotemporal distribution of traffic accidents in Maribor
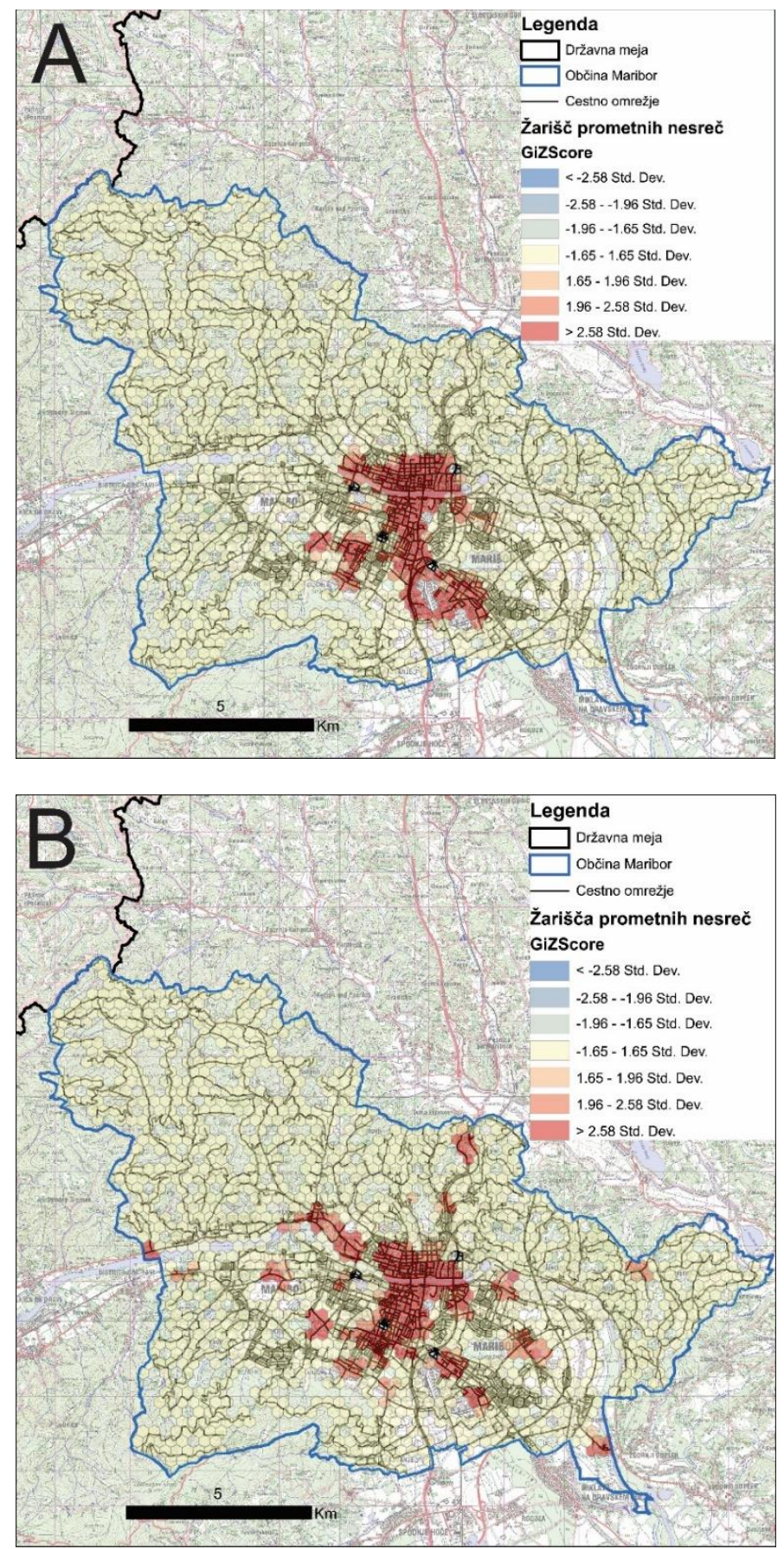

Žarišča (vroče točke) vseh (A) in hudih (B) prometnih nesreč v občini Maribor.

Ob obravnavanju le najhujših prometnih nesreč (huda telesna poškodba, smrt), je prostorski vzorec žarišč bolj razpršen (slika B). Osrednje območje sicer ostaja na osi S-J (Center, Tabor, Tezno) z številnimi manjšimi dislociranimi žarišči. Tako je v smeri Maribor-Dravograd kritičen predel Koroških vrat, naselje Kamnica ter konec naselja 
Jelovec. Na desnem bregu Drave v enaki smeri izstopa predel naselja Laznica (Limbuš) in križišče na Limbuški cesti v smeri podjetja Marles. Na vzhodnem predelu mesta so žarišča locirana še v predelih Tezno, Brezje ter Pobrežje. Pri slednjem predvsem cesta v smeri Malečnika. V skrajnem JV delu občine velja izpostaviti še Dogoše oziroma cesto v smeri Dupleka pred prečkanjem mostu čez Dravo ter odsek ceste v smeri Maribor-Lenart čez malečniški hrib (Nebova). V severnem predelu občine sta locirani še dve manjši žarišči, obe na cestnem odseku hitre ceste in vzporedne lokalne ceste Maribor-Pesnica (Šentiljska cesta). Prvo pri naselju Košaki, drugo pa na območju podjetja Porsche Maribor.

\section{Zaključek}

Zaradi številnih spremenljivk, ki različno vplivajo na razporeditev prometnih nesreč v prostoru, je analiza slednjih zelo kompleksna (Erdogan, 2009). Identifikacija prstorskočasovnega vzorca in žarišč prometnih nesreč bodisi na lokalnem ali regionalnem nivoju, je ključnega pomena za strokovnjake na področju prometne varnosti in prostorskega planiranja, ki s svojim delom vplivajo no realizacijo ustreznih preventivnih ukrepov. V občini Maribor je trend zmanjšsevanja števila prometnih nesreč primerljiv z trendom na državnem nivoju. Glede na to, da se je število prometnih nesreč v Slovenji od leta 1995 do 2004 le malo spreminjalo (Lavrač et al., 2008), so kazalci med letoma 2003 in 2013 veliko bolj vzpodbudni. Tudi hudih prometnih nesreč je vedno manj. Prostorski odtis prometnih nesreč sovpada $\mathrm{z}$ gostoto prometnega omrežja in gostoto prebivalstva $\mathrm{v}$ občini Maribor.

Tudi za občino Maribor velja podobno kot ugotavljajo Lavrač et al. (2008) na nivoju Slovenije, da je vrhunec frekvence prometnih nesreč ob petkih. Rezultati kažejo, da sta v Mariboru začetek in konec delavnika najbolj kritična $\mathrm{z}$ vidika verjetnosti za prometno nesrečo kar je med drugim posledica tedenskih migracij. Vzroki za nastanek prometne nesreče so značilno različni med delavnikom in vikendom. Takšen rezultat je lahko posledica različnega namena potovanja, ljudje ob vikendu vozijo hitreje (več je prometnih nesreč zaradi neprilagojene hitrost), pogosteje tudi pod vplivom alkohola na kar posredno kaže podatek o večjem številu prometnih nesreč zaradi vožnje v napačno smer.

Mednarodne študije poročajo, da so vzroki za prometne nesreče nemalokrat povezani tudi z vremenskimi pojavi (predvsem padavinami [dež, sneg], temperaturo zraka [poledica], vidljivostjo [megla] in hitrostjo vetra [burja]) ob samem času dogodka (Koetse in Rietveld, 2009, Theofilatos in Yannis, 2014).

Podrobnejša dnevna analiza razkriva značilen vrh frekvence prometnih nesreč med 14. in 15. uro popoldan, ko ljudje zapuščajo delovna mesta. Jutranji (med 9. in 10. uro) in popoldanski vrh je zaznaven pri hudih prometnih nesrečah kar je primerljivo z ugotovitvami Flacha et al. (2003), ki izpostavljajo dva vrhova prometnih nesreč, ki sta vezana na jutranji (ob 8. uri) in popoldanski (med 14. in 15. uro) prometni vrvež v Veliki Britaniji.

Iz prostorskega vidika smo v občini Maribor identificirali nekaj žarišč prometnih nesreč. Vroče točke (ang. Hot spots), črne točke (ang. Black spots) ali lokalitete $\mathrm{z}$ visoko frekvenco nesreč (ang. High accident locations) so območja na cestnem in avtocestnem omrežju kjer beležimo večjo frekvenco prometnih nesreč od pričakovane mejne vrednosti 
pri določeni verjetnosti (Choudhary et al., 2015). Tako izstopajo predeli z večjo gostoto cestnega omrežja in večjo prometno obremenitvijo (Šentiljska cesta-Titova cesta-Tržaška cesta, Ptujska cesta- Cesta proletarskih brigad). Vzorec žarišč hudih prometnih nesreč je bistveno bolj razpršen z osredno osjo v smeri S-J in dvema osema v smeri SZ-JV. Ob sami gostoti prometa na glavnih vpadnicah igrajo ključno vlogo še: izoblikovanost površja, preglednost ter mikroklimatski pogoji.

Prometne nesreče povzročajo družbi resne težave zaradi izgube ljudi, nastalih ekonomskih stroškov, stroškov zaradi poškodb nepremičnin ter zdravstvenih stroškov (Theofilatos in Yannis, 2014). Število nesreč z smrtnim izidom po podatkih Svetovne zdravstvene organizacije (WHO, 2013) ostaja na nivoju 1,24 milijona na leto. Takšni podatki opravičeno vzbujajo skrb, posledično pa se s tematiko razumevanja prometnih nesreč v prostoru ukvarja veliko študij. Kljub velikemu prizadevanju znanstvene sfere za izboljšanje prometne varnosti, pa je potrebno še veliko raziskovalnega dela zlasti zato, da bi pridobili boljše poznavanje podrobnih razmer pred prometnimi nesrečami kar omogoča boljšo pro-aktivno upravljanje glavnih cest v cestnem omrežju.

\section{Literatura in viri}

Anderson, T. 2009: Kernel density estimation and K-means clustering to profile road accident hotspots, Accident Analysis Prevention, 41, 359-364.

Bailey, T.C., Gatrell, A.C. 1995: Interactive spatial data analysis, Essex: Longman.

Black, W.R. 1991: Highway accidents: A spatial and temporal analysis, Transportation Research Record, 1318, 75-82.

Choudhary, J., Ohri, A., Kumar, B. 2015: Spatial and statistical analysis of road accidents hot spots using GIS, 3rd Conference of Transportation Research Group of India (3rd CTGR).

Colino-Rabanal, V.J., Peris, S.J. 2016: Wildlife roadkills: improving knowledge about ungulate distributions?, Hystrix - the Italian Journal of Mammology, 27(2), 1-5.

Delmelle, E.C., Thill, J.C. 2008: Urban bicyclists - A spatial analysis of adult and youth traffic hazard intensity, Transportation Research Record: Journal of the Transportation Research Borad of the Natinal Academies, Washington D.C., 21-39, http://dx.doi.org/10.3141/207404.

Erdogan, S., Yilmaz, I., Baybura, T., Gullu, M. 2008: Geographical information systems aided traffic accident analysis system case study: city of Afyonkarahisar, Accident Analysis and Prevention, 40(1), 174-181.

Erdogan, S. 2009: Explorative spatial analysis of traffic accident statistics and road mortality among the provinces of Turkey, Journal of Safety Research, 40, 341-351.

ESRI 2010: ArcGIS Desktop, Release 9. 3, Redlands, CA: Environmental Systems Research Intitute.

Flach, P.A., Mladenic, D., Moyle, S., Raeymaekers, S., Rauch, J., Rawles, S., Ribeiro, R., Sclep, G., Struyf, J., Todorovski, L., Torgo, L., Blockeel, H., Wettschereck, D., Wu, S., Gartner, T., Grobelnik, M., Kavsek, B., Kejkula, M., Krzywania, D., Lavrac, N. and Ljubic, P. 2003: On the road to knowledge: mining 21 years of UK traffic accident reports., Data Mining and Decision Support: Aspects of Integration and Collaboration, 143-155, Kluwer Academic Publishers.

GURS, 2017, Podatki o gospodarski javni infrastrukturi, Geodetska uprava Republike Slovenije, Ljubljana.

Jenness, J. 2012: Repeating shapes for ArcGIS, Jenness Enterprises, http://www.jennessent.com/arcgis/repeat_shapes.htm. 
Koetse, M.J., Rietveld, P. 2009: The impact of climate change and weather on trans-port: an overview of empirical findings, Transport Researc, D: Transportation Environment, 14, 205-221.

Krisp, J.M., Durot, S. 2007: Segmentation of lines based on point densities - An optimisation of wildlife warning sign placement in southern Finland, Accident Analysis and Prevention, 39(1), 38-46.

La Grange, A.M., Le Roux, N.J., Gardner-Lubbe, S. 2009: BiplotGUI: Interactive Biplots in R. Journal of Statistical Software 30(12), 1-37.

Lavrač, N., Jesenovec, D., Trdin, N., Mramor Kosta, N. 2008: Minig Spatio-temporal Data of Traffic Accidents and Spatial pattern Visualization, Metodološki zvezki, 5(1), 45-63.

Levine, N. 2004: CrimeStat III: A spatial statistics program for the analysis of crime incident locations, Houston, TX/Washington, DC: Ned Levine \& Associates/The National Institute of Justice.

Lipar, P., Kostanjšek, J., Žura, M. 2010: Uporaba prostorske statistike za določevanje zgostitev prometnih nesreč, Geodetski vestnik, 54/1, 61-69.

O’Sullivan, D., Unwin, D.J. 2002: Geographic information analysis, Hoboken, New Jersey: John Wiley.

Pohlert, T. 2014: The Pairwise Multiple Comparison of Mean Ranks Package (PMCMR), R package, http://CRAN.R project.org/package=PMCMR.

Pulugurtha, S.S., Krishnakumar, V.K., Nambisan, S.S.2007: New methods to identify and rank high pedestrian crash zones: An illustration, Accident Analysis and Prevention, 39(4), 800811.

Theofilatos, A., Yannis, G. 2014: A review of the effect of traffic and weather characeristics on road safety, Accident Analysis and prevention, 72, 244-256.

Xie, Z., Yan, J. 2008: Kernel Density Estimation of traffic accidents in a network space, Conputers, Environment and Urban Systems, 32(5), 396-406. 
GEOGRAFIJE PODRAVJA

THE GeOgraphies of THE Podravje Region 


\section{GEOGRAPHY ON THE MICRO LEVEL}





\title{
Samooskrba na enem hektarju (na primeru učnega poligona za samooskrbo Dole, Poljčane)
}

\begin{abstract}
ANA VOVK KORŽE
Povzetek V zaselku Dole v občini Poljčane se nahajajo permakulturni vrtovi na površini 1,5 ha. Vzpostavljeni so bili leta $2010 \mathrm{z}$ glavnim ciljem izvajati izobraževanje in lastno samooskrbo za vse generacije. Namen permakulturnih vrtov je identificirati možnosti trajnostne rabe naravnih virov za samooskrbo na področju energije in trajnostnega načina življenja. Samooskrba je široko področje in ni ozko povezana s kmetijstvom.

Ključne besede: - samooskrba • naravni viri • ekoremediacije • permakultura $\bullet$ podnebne spremembe $\bullet$ Dole $\bullet$ Poljčane $\bullet$
\end{abstract}

NASLOV AVTORICE: dr. Ana Vovk Korže, redna profesorica, Univerza v Mariboru, Filozofska fakulteta, Oddelek za geografijo, Koroška cesta 160, 2000 Maribor, Slovenija, e-naslov: ana.vovk@um.si. 


\title{
Self-sufficiency on one hectare of land (on the case of educational polygon Dole in Poljčane)
}

\author{
ANA VOVK KORŽE
}

\begin{abstract}
The permaculture garden of Dole is located in the village of Dole in the Municipality Poljčane in Slovenia and covers 1.5 ha. The permaculture garden was established in 2010 and its main purpose is education in self-sufficiency, for everyone from pre-school education to life-long learning. The focus of the permaculture garden is identifying the possibilities of using natural resources for self-sufficiency in energy and style of living. Self-sufficiency is an extremely broad issue and is not only the domain of the agricultural profession.
\end{abstract}

Keywords: - self-sufficiency $\bullet$ natural resources $\bullet$ ecoremediation • permaculture $\bullet$ climate changes $\bullet$ Dole $\bullet$ Poljčane $\bullet$ Slovenia $\bullet$

CorResPondence AdDRess: Ana Vovk Korže, Ph.D., Full Professor, Professor for Geography, University of Maribor, Faculty of Arts, Department for geography, Koroška cesta 160, 2000 Maribor, Slovenia, e-mail: ana.vovk@um.si. 

GEOGRAFIJE PODRAVJA
A. Vovk Korže: Samooskrba na enem hektarju (na primeru učnega poligona za samooskrbo Dole, Poljčane)

307

\section{Uvod}

Že dolgo časa je živa ideja, da bi vsaka družina imela vsaj en ha zemljišča, na katerem bi živeli in pridelovali lastno hrano, ohranjali domačo obrt in si krepili psihofizični potencial. Velikost enega hektarja je tista površina, ki omogoča zasaditev raznovrstnih rastlinskih vrst in habitatov (gozd, sadovnjak, travnik, vrt, njivo, vodni habitat). S tem omogoča sklenjen krogotok energije ter snovi in je hkrati tako majhna posest, da je ni problem obdelati in ni potrebno intenzivno fizično delo, saj se lahko obdeluje brez mehanizacije. Velikost $1-3$ ha je namreč tista velikost posesti, ki glede na velikost Slovenije, omogoča vsem skupnostim, ki imajo to željo, da bi lahko živele v neokrnjeni naravi z lastno pridelavo hrane.

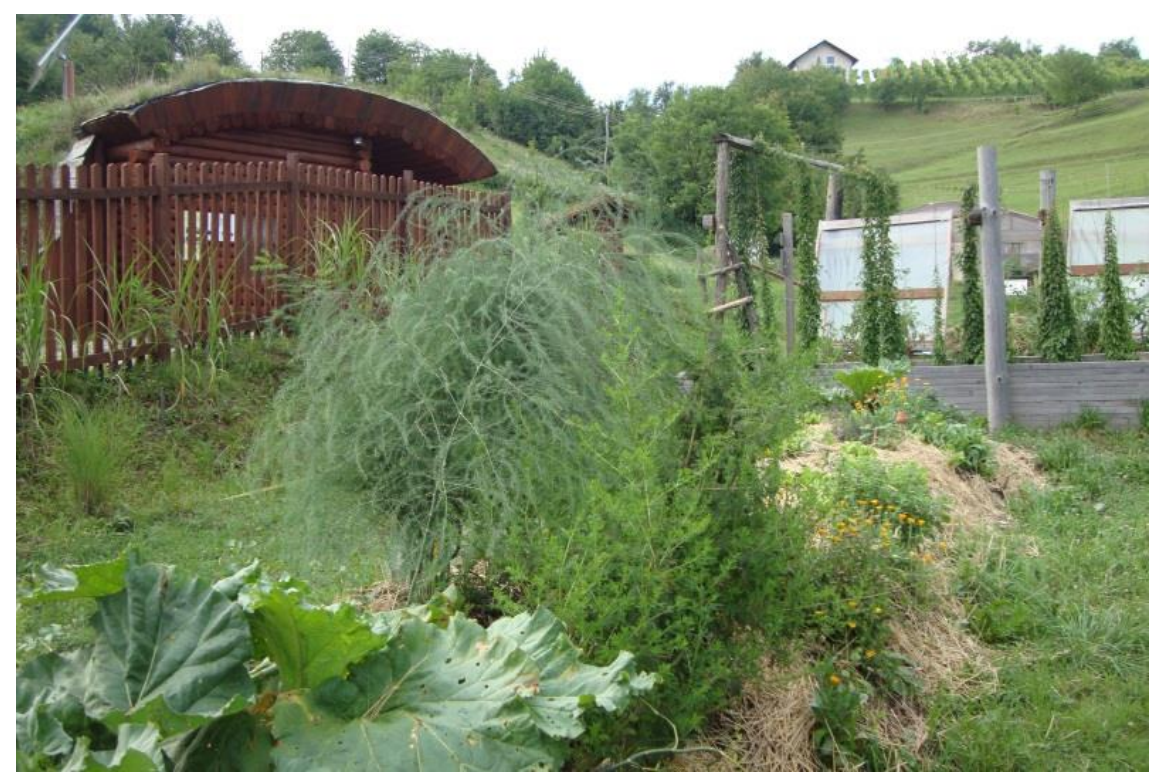

Pogled na učni poligon Dole (Vovk Korže, 2016).

Gozd na posestvu je neke vrste tovarna lesa in prostor za mnoga živa bitja (Piercea, 1990). V njem rastejo raznolika drevesa, užitne grmovnice, gobe in zelišča. Gozd daje tudi nelesne proizvode kot so smolo, plodove dreves, lubje, listje, olja in zdravilne rastline. Sicer gozd skrbi za uravnavanje mikroklime, čisti zrak, izgrajuje prst in ima mnoge pozitivne učinke na hidrološki sistem v pokrajini.

Pestrost mikrohabitatov omogoča stabilnost ekosistema, saj posestva ne prizadene izpad ene kulturne rastline zaredi npr. zmrzali, ujme ali poškodovanosti s strani insektov. Pestrost rastlinskih vrst omogoča dostop do sveže zelenjave in sadja večji del leta. Na manjši površini se oblikuje osebni stik $\mathrm{z}$ naravo. Hrana se prideluje pri sistemu permakulture, brez uporabe fitofarmacevskih sredstev, umetnih gnojil in težke mehanizacije. Pomembno vlogo imajo trajnice kot so gozd, sadovnjak in grmovnice.

Bistvo odgovornega gospodarjenja z zemljo je samozadostnost posesti na majhnih površinah. To pomeni na eni strani čimbolj varčno pridelavo hrane, na drugi strani pa 
A. Vovk Korže: Self-sufficiency on one hectare of land (on the case of educational polygon Dole in Poljčane)

skrb za odpadne snovi, kot so voda in odpadki, ki če delujejo po naravnih principih sploh niso odpadki, ampak surovina, ki kroži v sistemu. Najbolj znan primer je kompostiranje vseh vrst razgradljivih odpadkov (Stutz, Warf, 2005). Pomembno je, da se vse snovi na posestvu vključujejo ali v ponovno rabo (steklo) ali pa se reciklirajo (papir).

Glavne razlike med konvencionalno kmetijo in mini samooskrbnim posestvom.

\begin{tabular}{|l|l|l|}
\hline & Konvencionalna kmetija & Mini samooskrbna posest \\
\hline Namen proizvodnje & Za prodajo - zaslužek & $\begin{array}{l}\text { Za lastno oskrbo, za } \\
\text { duhovno izpopolnitev, } \\
\text { viški za trg }\end{array}$ \\
\hline Delovna sila & Zaposleni, družina & Družina \\
\hline Mehanizacija & $\begin{array}{l}\text { Večina dela se opravi } \\
\text { strojno }\end{array}$ & Delo se opravi ročno \\
\hline Uporaba kemikalij & Veliko & Nič \\
\hline Velikost posestva & Od 10 do več kot 100 ha & 1-3 ha \\
\hline Poljščine & $\begin{array}{l}\text { Koruza, silažna pridelava, } \\
\text { živinoreja, zelenjava, sadje }\end{array}$ & $\begin{array}{l}\text { Sadje, oreški, jagodičevje, } \\
\text { krompir, zelenjava, } \\
\text { zelišča, tehnične poljščine } \\
\text { (lan, sončnice, konoplja, } \\
\text { kopriva), lesni in gozdni } \\
\text { proizvodi, žitarice }\end{array}$ \\
\hline $\begin{array}{l}\text { Integracija človeškega } \\
\text { habitata s kmetijskimi } \\
\text { površinami }\end{array}$ & Nizka ali je ni & Trajnice \\
\hline
\end{tabular}

Glavni značilnosti naravnih bivališč.

Vir: Vovk Korže, 2016.

\begin{tabular}{|l|l|}
\hline Lastnosti & Opis \\
\hline Material & Naravni, iz lokalnega okolja \\
\hline Energija & $\begin{array}{l}\text { Naravne izolacije, obnovljivi viri energije kot so sonce, } \\
\text { biomasa, veter, energija zemlje }\end{array}$ \\
\hline $\begin{array}{l}\text { Krožno gospodarjenje } \\
\text { z naravnimi viri }\end{array}$ & $\begin{array}{l}\text { Večkratna raba deževnice, čiščenje sive vode, kompostni } \\
\text { WC, naravno čiščenje sive vode, kompostiranje }\end{array}$ \\
\hline $\begin{array}{l}\text { Gospodarjenje z } \\
\text { odpadki }\end{array}$ & $\begin{array}{l}\text { Zmanjševanje na izvoru, ponovna raba, recikliranje, } \\
\text { kompostiranje }\end{array}$ \\
\hline Fizično počutje & $\begin{array}{l}\text { Občutek življenja v naravi, brez sevanja in neugodnih } \\
\text { vplivov }\end{array}$ \\
\hline Cena bivanja & $\begin{array}{l}\text { Bistveno nižji stroški bivanja zaradi trajnostnih pristopov } \\
\text { življenja }\end{array}$ \\
\hline Povezanost z naravo & Neposredna in posredna, preko surovin in materialov \\
\hline Duševno počutje & $\begin{array}{l}\text { Občutek aktivnega življenja, osebnega razvoja in polne } \\
\text { odgovornosti za lastni dom }\end{array}$ \\
\hline Vzgojni doprinos & $\begin{array}{l}\text { Velik doprinos mladim, da razumejo delovanje narave in } \\
\text { dobivajo praktične izkušnje življenja z naravo in da } \\
\text { spoznajo pomen odgovornega življenja že v mladosti }\end{array}$ \\
\hline
\end{tabular}


GEOGRAFIJE Podravja 309

A. Vovk Korže: Samooskrba na enem hektarju (na primeru učnega poligona za samooskrbo Dole, Poljčane)

Za gradnjo naravnih bivališč uporabimo naravne materiale, kolikor je to mogoče. Hiše so narejene po sistemu nizkega vpliva na okolje, uporabe obnovljivih virov energije in iz lokalnih surovin, temu pravimo »low impact housing« (Raman, 2006). Uporabljajo se glina, les, kamen, slama, konoplja. Taka bivališča so običajno manjša in se odlično skladajo z okolico.

Uporabljamo tri principe obdelave zemlje in sicer permakulturo, naravno kmetovanje in biointenzivno metodo. Principi se med seboj razlikujejo, zahtevajo različne aktivnosti, imajo pa skupni imenovalec, to je, da posnemajo ritem narave in da ne vnašajo v zemljo ničesar, kar bi motilo naravne procese.

\section{Permakultura}

Beseda permakultura se danes uporablja preozko in je vezana predvsem na vertikalne sisteme ureditve pridelovalnih površin in uporabo slame ter druge biomase za zastirko (Graham, 2010, Whitefield, 2012). Dejansko pa pomeni permakultura celovit pristop in temelji na povezavi komponent $\mathrm{v}$ okolju s ciljem, da zadržimo in ustvarimo novo energijo. Ko se odločimo za permakulturo vstopimo v aktivni način življenja, saj moramo biti učinkoviti, da zadržimo sončno energijo, energijo vetra in da vse ponovno rabimo. Zavedati se moramo, da v permakulturi ni odpadkov, ampak da so samo surovine, ki jih uporabljamo na različne načine. Coniranje v permakulturi je povzeto po tradicionalnih pristopih, kjer so ljudje že zdavnaj imeli ob bivališču vrt, vodo, gozd in pašnike stran od kraja bivanja (Permaculture Free Press, 2013). Čeprav se pogosto sliši, da je permakultura način, da ni potrebno veliko fizičnega dela, to ravno ne drži. Če bi primerjali njivo, ki jo zorjejo s traktorjem v pol ure in posejejo koruzo in pol leta zagotovo nimajo drugega dela, kot da vmes nekajkrat poškropijo s strupi, je v permakulturi vedno delo, znova moramo povezovati elemente, naravni sistemi tudi niso popolnoma večni in jih je treba obnavljati. Vsi, ki imamo permakulturo tudi vemo, da ta sistem nima konca in da je vedno nov izziv povezati še nove sisteme in v resnici smo ves čas zaposleni, tako miselno, kot fizično. Narava namreč nikoli ne počiva in ko sodelujemo z njo, moramo biti tudi sami ves čas aktivni.

Osnovno vodilo permakulture je, da opazujemo dogajanja $\mathrm{v}$ naravi in poskušamo dognanja, pridobljena z opazovanjem, prenesti v človekovo okolje (Hemenway, 2009 in Praterious, 2006). Naravni ekosistemi so trajnostni in če razumemo, kako delujejo, lahko trajnost prenesemo v naše življenje. V naravi se ob najmanjši porabi energije proizvede največ. Poudarek ni na posameznih elementih, ampak bolj na odnosih, zgrajenih med njimi in na način, kako jih postavimo v pokrajino. Permakultura prav tako priznava osnovno življenjsko etiko, ki pripisuje resnično vrednost vsakemu živemu bitju. Drevo ima vrednost samo po sebi, celo če ima s človeškega vidika netržno vrednost. To drevo je živo in njegovo delovanje je vredno veliko. Ima vlogo v naravi: reciklira odpadke, ustvarja kisik, porablja ogljikov dioksid, je zatočišče živalim, gradi zemljo in daje senco ter plodove. Tak način razmišljanja velja za vse sestavine v naravi.

\section{Naravno kmetovanje}

Danes imenujemo pristope naravnega kmetovanja tudi trajnostno kmetijstvo in temelji na 
A. Vovk Korže: Self-sufficiency on one hectare of land (on the case of educational polygon Dole in Poljčane)

čim bolj skladnem posnemanju narave. To pomeni, da moramo poznati delovanje narave, da moramo opazovati procese okoli sebe in potem dobesedno posnemati naravo, na čemer temeljijo tudi ekoremediacije, ki posnemajo procese fizikalno kemijskega delovanja narave. Posnemanje narave ni tako enostavno, kot si morda mislimo, saj narava deluje zelo kompleksno in če imamo samo teoretično znanje, brez prakse, moramo vedeti, da se bomo učili posnemanja kar nekaj let. Omejitev je tudi pristop naravnega kmetovanja, ki ni skladen s konvencionalnimi pristopi in pogosto različnim generacijam ni blizu, saj rastline ne rastejo $\mathrm{v}$ vrstah, pridelki niso takoj zelo veliki in vse izgleda kot pomešano.

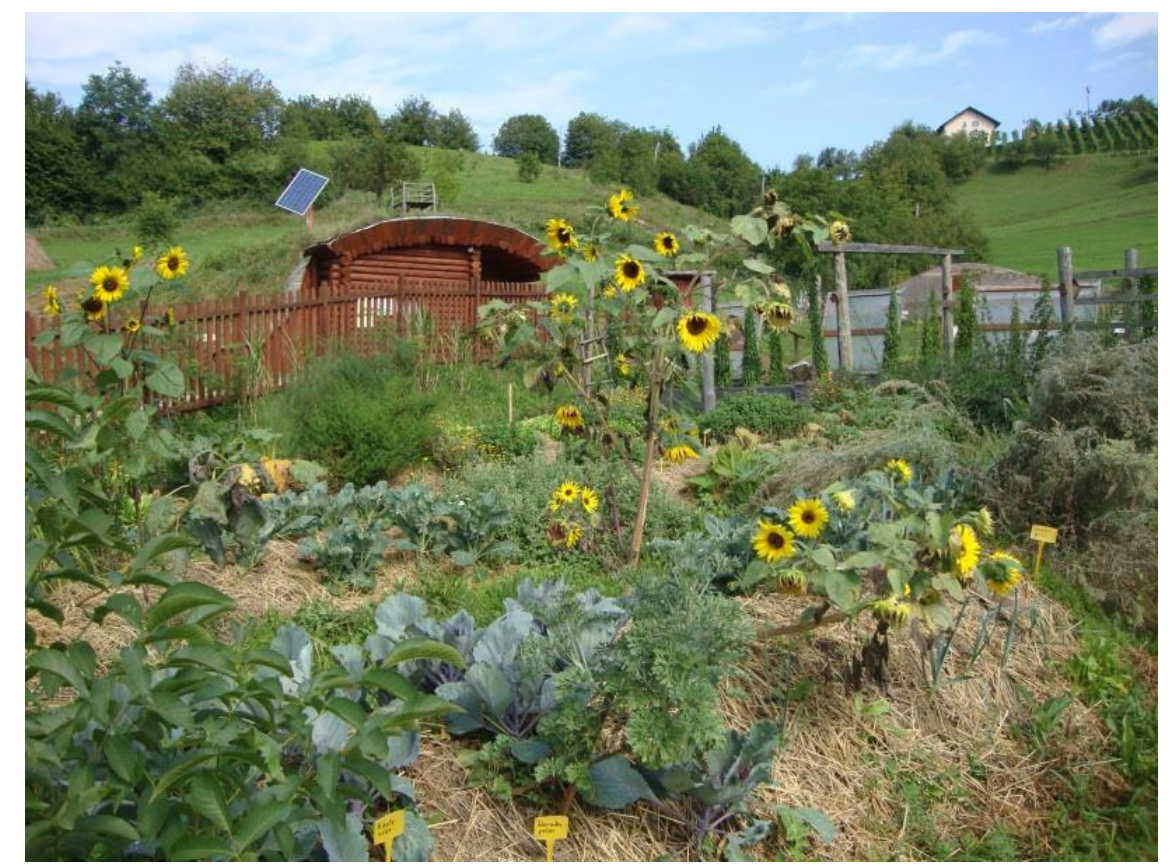

Permakulturni načini pridelave zelenjave z visokimi gredami (Vovk Korže, 2016).

Naravno kmetovanje je smiselno uvajati na manjših površinah in ga potem širimo, sicer nas lahko narava prehiti in ji ne bomo kos. Velik poudarek je na vrsti rastlin, sortah sadnega drevja, če kupimo sadike, ki jih bo treba obrezovati, bomo zelo težko prišli do pridelka, če jih potem ne bomo obrezali, prav tako velja pri drugih vrstah semen in sadik. Zato se moramo na naravno kmetovanje pripraviti in si celoten sistem prilagoditi tako, da nam potem deluje. Vedeti moramo, da kljub trditvam, da naravno kmetovanje ne potrebuje veliko fizičnega dela, mora biti človek zraven, če želi s tem načinom pridelati dovolj hrane zase. Narava sama po sebi ne bo skrbela za nas, če mi sami ne bomo nič storili za to. Najbolj prepoznavni način naravnega kmetovanja je gozdni vrt, ki je permakulturni pristop. Rastline z različnim načinom rasti ne zapolnjujejo le površine temveč tudi višino. $Z$ rastlinami posnemamo razmere v gozdu. Princip gozdnega vrta se uporablja za večje površine, lahko pa ga uvajamo tudi v vrtu tako, da kombiniramo drevesa (sadno drevje) z gredami. Naravno kmetovanje zahteva čas, v katerem se vzpostavi biodiverziteta, kroženje naravnih snovi, zaporedje poljščin postane naravni kolobar in zemlja pridobi na vitalnosti. 

GEOGRAFIJE PODRAVJA
A. Vovk Korže: Samooskrba na enem hektarju (na primeru učnega poligona za

\section{Biointenzivna metoda}

Ta metoda temelji na spoznanju, da na svetu ni dovolj obdelovalnih površin, na katerih bi klasično kmetovali, saj se število ljudi povečuje. Biointenzivno kmetovanje je primerno za mini kmetije, kjer lahko na $400 \mathrm{~m}^{2}$ pridelamo potrebno hrano za enega človeka. Ne uporabljajo se stroji, ne umetna gnojila in tudi ne škropiva. Sistem je takšen, da se na $70 \%$ površin gojijo rž, ječmen, amarat, blitva, to so rastline z velikim deležem ogljika in ustvarijo veliko organske snovi, ki se uporabi za kompost. $20 \%$ površin namenimo zelenjavi z veliko vsebnostjo vitaminov in mineralov kot so zelje, korenje, paradižnik, kumarice in brokoli. Na preostalih $10 \%$ površine gojimo pridelke za prodajo. Biointenzivna metoda torej izhaja iz potrebe po lastni samooskrbi, torej $90 \%$ pridelovalnih površin imamo zase.

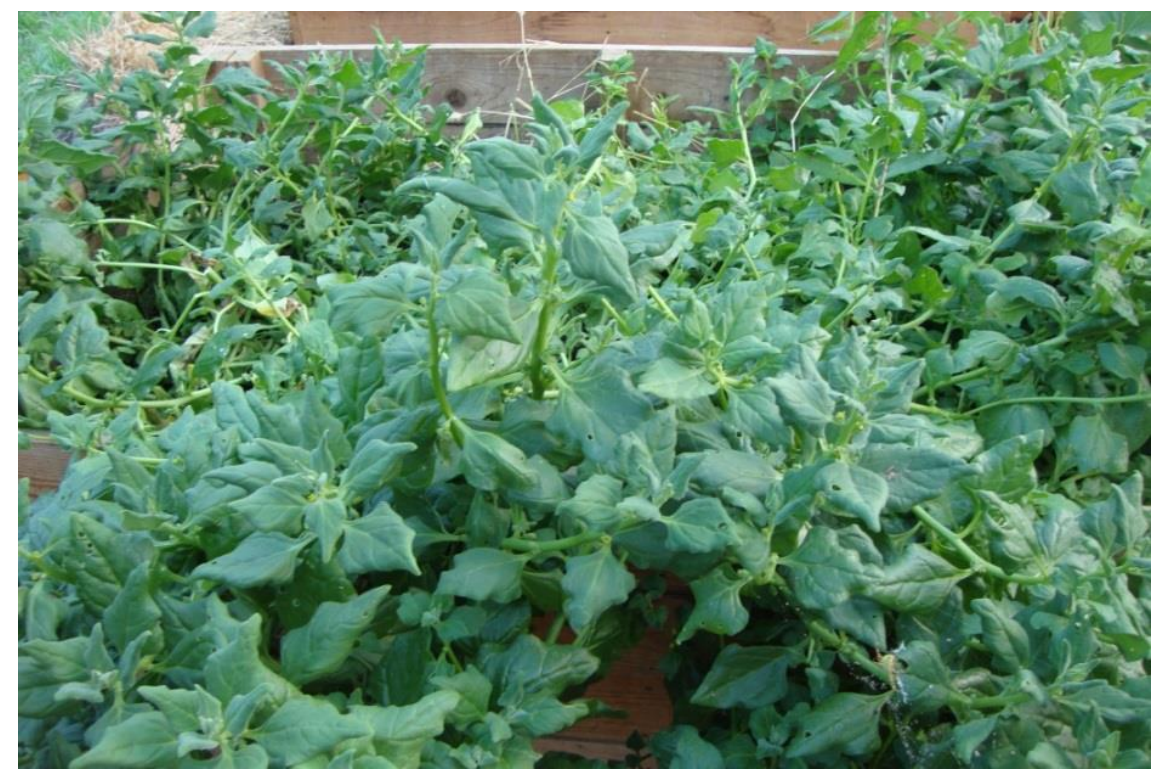

Po biointenzivni metodi na majhnih površinah pridelamo veliko (Vovk Korže, 2016).

Kompostni WC vrača hranila neposredno $\mathrm{v}$ zemljo in brez vmešavanja vode $\mathrm{v}$ naravni cikel, se prihrani veliko energije, kjer ni potrebno potem tega viška vode čistiti. Ustrezno postavljen kompostni WC predela vse patogene organizme in ne onesnažuje podtalnice.

Biointenzivna metoda podpira gosto sajenje rastlin, ki ščitijo mikroorganizme v prsti in zmanjšujejo izhlapevanje vode ter tako povečujejo pridelek. Ustrezno sosedstvo rastlin tudi optimizira porabo hranil, vode, svetlobe, toplote in povečuje pridelek. Poudarek je na organski snovi v tleh, torej na razvoju humusa, ki zadrži vodo in minerale ter hranila in tako podpira trajno kmetovanje, zato se rodnost zemlje s časom povečuje.

\section{Zasnova učnega poligona Dole kot mini rodovna posest za samooskrbo in izobraževanje}

Zamisel za Učni poligon Dole izhaja iz velike potrebe po izkustvenem in praktičnem 
A. Vovk Korže: Self-sufficiency on one hectare of land (on the case of educational polygon Dole in Poljčane)

raziskovanju in učenju. Sedanji čas zahteva poleg spretnosti uporabe mobilnih tehnologij in digitalnih naprav tudi načrtovalsko razmišljanje: kje mora kaj biti, zakaj, kako deluje narava, kako lahko od narave živimo, ne da pretirano posegamo vanjo. S ciljem vzpostaviti območje za raziskovanje in učenje o samooskrbi je bil leta 2010 vzpostavljen učni poligon za samooskrbo Dole. Na tem območju so posebej izpostavljene ureditve, ki vsakomur omogočajo, da si jih lahko uredi zbiranje deževnice, koriščenje energije sonca, gojenje rastlin za hrano, trajnostna bivališča kot so mongolska hiša (jurta) in zemljanka ter posaditev trajnic (dreves in grmovnic).

V ravninskem delu poligona so gomilaste grede, visoke grede in učni profil za raziskave prsti in sedimentov. Za vzgojo semen je postavljen rastlinjak in za shranjevanje pridelkov zemljanka. Tod je tudi poljsko stranišče $\mathrm{z}$ naravnim kompostiranjem. Učne table za samostojno učenje so ob vseh ureditvah na poligonu. Na gričevnatih obrobjih poligona so posajena drevesa lupinarjev in sadna drevesa ter urejene terase. Na zgornjem ravninskem delu je mlaka za zbiranje deževnice, mongolska hiša jurta z zimskim vrtom in umivalnico ter kompostnim straniščem.

Na poligonu so številne vrste gred (na kartonu, dvignjena, z biomaso, greda na ključ, rastoča greda). Na najvišjem delu poligona Dole je urejen raziskovalni prostor za ekoremediacije. Tod se raziskujejo prsti glede na različne rastiščne potrebe. Posajen je vegetacijski pas, vzpostavljen kolobar ter kompostišče. V zgornjem delu poligona je tudi bajer s padavinsko vodo, ki namaka rastline $\mathrm{v}$ rastlinjaku. Za potrebe pitne vode je urejen vodohram, sicer pa poligon ni priključen na javno vodovodno omrežje, saj koristi lastne vode vire. Prav tako ima svoje obnovljive vire sončne energije, zato je odličen primer samooskrbe za vsakogar.

\section{Prst je temelj samooskrbe}

Na območju učnega poligona prevladuje psevdogljena prst. Siva in rjava barva se v profilu prsti psevdoglej izmenjujeta, odvisno od trajanja suhega in vlažnega obdobja. V času oksidacije prevladuje rjava barva, $v$ času redukcije pa siva barva, kar je poglavitni razpoznavni znak tega tipa prsti. Podtalnica $v$ te prsti ne seže, zato ni nikjer enotno sivega horizonta (Repe, 2010). Voda vedno priteka v profil od zgoraj navzdol. Na psevdoglejih, ki zadržujejo v Bg horizontu vodo, so v preteklosti rastli gozdovi hrasta gradna, ki pa so večinoma izkrčeni. Za kmetijsko rabo te prsti niso ugodne, saj so v sušnem obdobju zelo trde, $v$ vlažnem pa mazave. Prav te naravne lastnosti so bile povod za permakulturni način obdelovanja na učnem poligonu v Dolah, saj klasični tradicionalni sistemi obdelave ne bi dali rezultatov.

Lastnosti psevdooglejenih prsti na učnem poligonu Dole.

\begin{tabular}{|l|c|c|ccc|c|c|c|c|}
\hline $\begin{array}{l}\text { Hori- } \\
\text { zont }\end{array}$ & $\mathrm{Cm}$ & $\begin{array}{c}\mathrm{pH} \mathrm{v} \\
\mathrm{H}_{2} 0\end{array}$ & \multicolumn{2}{|c|}{ Tekstura (\%) } & Razred & $\begin{array}{c}\text { Delež } \\
\text { vlage }\end{array}$ & $\begin{array}{c}\text { Delež } \\
\text { org. } \\
\text { snovi } \\
(\%)\end{array}$ & $\begin{array}{c}\text { Delež } \\
\mathrm{CaCO}_{3} \\
(\%)\end{array}$ \\
\hline $\mathrm{A}$ & $0-26$ & 5,5 & 7 & 75 & 18 & MI & 10 & 8 & pod 2 \\
\hline $\mathrm{Bg} 1$ & $26-45$ & 5,3 & 9 & 70 & 21 & MGI & 10 & 5 & pod 1 \\
\hline $\mathrm{Bg} 2$ & $45-56$ & 5,0 & 8 & 68 & 24 & MGI & 12 & 2 & pod 1 \\
\hline
\end{tabular}



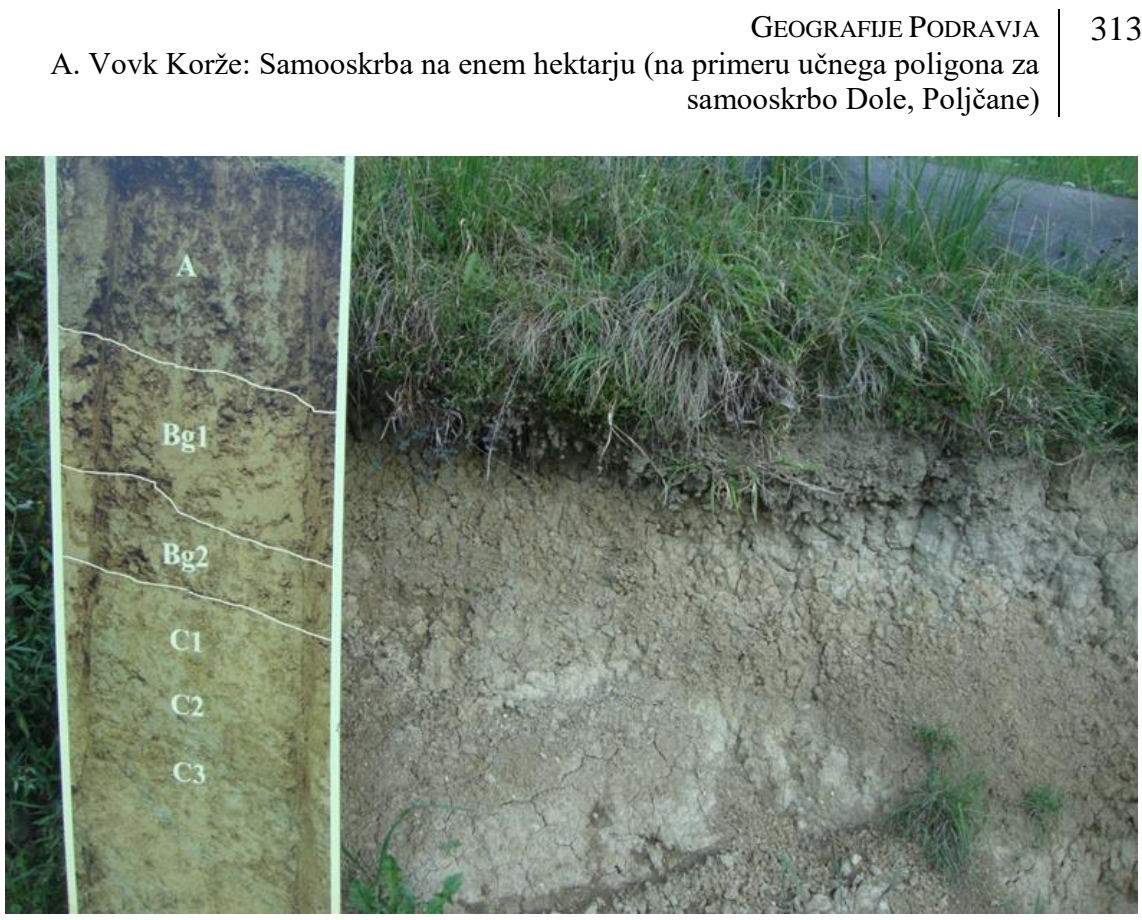

Shematski prikaz tipa prsti psevdoglej (foto: Vovk Korže, 2015).

Opis prsti: psevdoglej ravninski, distričen, srednje globok.

Pedogenetski dejavniki: makrorelief - dolinsko dno, litološka podlaga-fluvioglacialni nanosi ilovice in gline, kmetijska raba prvenstveno travnik, v zadnjih dveh letih njiva s plitvim oranjem in grede.

Kmetijska stroka uvršča psevdogleje med po kakovosti slabše prsti. Njihova glavna pomanjkljivost za kmetijsko rabo je izrazito slab vodno zračni režim. V deževnih obdobjih voda zaradi težko prepustnega Bg horizonta zaostaja na površini. V suhih obdobjih pa se zaradi zbitosti Bg horizonta vrhnji horizont močno izsuši in razpoka (Mahmood et al., 2004). Posevke zato suša močno prizadene. Obdobja z ugodnimi lastnostmi prsti za obdelavo so kratka. Humus opravlja v tej prsti pomembne funkcije in sicer zadržuje stabilnost prsti in ohranja vlažnost, zmanjšuje izpiranje hranil iz zgornjega horizonta in izboljšuje strukturo prsti, ki je bistvena za rast rastlin (Dunphy, Spellman, 2009). Dostopnost zraka in vode koreninam je pomembna za rodovitnost prsti. Prav zaradi zelo slabih naravnih lastnosti psevdooglejnih prsti, smo na kmetijsko rabljenih površinah uvedli uporabo zastirke. $Z$ dodajanjem zastirke povečujemo delež organske skozi (humusa) in na ta način zmanjšamo izhlapevanje vode iz površine prsti ter zaščitimo rastline pred zunanjimi vplivi (močan dež, veter).

Povprečna letna temperatura območja učnega poligona Dole je $9,5^{\circ} \mathrm{C}$, v vegetacijski dobi je $15,5^{\circ} \mathrm{C}$, letno pade $1074 \mathrm{~mm}$ padavin. Letna potencialna evapotranspiracija je $642 \mathrm{~mm}$ (Vovk Korže, 2010).

Še en pokazatelj nastanka prsti je vsebnost kalcijevega karbonata v prsti. Na območju Dravinjskih goric je karbonatov zelo malo, saj je reka Dravinja nasula fluvioglacialne prode in peske iz Pohorja, ta material pa ne vsebuje karbonatov. Vrednost $\mathrm{pH}$ je podatek o koncentraciji vodikovih ionov v prsti, pri čemer je odnos med $\mathrm{pH}$ in vodikovimi ioni inverzen in logaritmičen. Pri obdelovanih prsteh je zaželeno, da se giblje med 6 in 7, na 
A. Vovk Korže: Self-sufficiency on one hectare of land (on the case of educational polygon Dole in Poljčane)

poligonu pa je 5, zato je bilo potrebno oboje dodati, to je karbonate in dvigniti $\mathrm{pH} \mathrm{z}$ naravnimi dodatki kot so mlete jajčne lupine (vsebujejo kalcij) in mleti apnenčasti pesek. Optimalno rast dosegajo pri nevtralni do slabo alkalni reakciji (Nayak, Prasanna, 2007).

Ugodna reakcija prsti je namreč pomembna tudi za naravno čiščenje prsti. Z bioremediacijo in naravno rehabilitacijo prsti lahko namreč pospešimo pedogenetske procese (Okolo, Amadi, Odu 2005), kar ugodno vpliva na nastajanje in zorenje prsti.

Organska snov v prsti velja za bistveno sestavino zdravih tal, njeno zmanjšanje povzroča degradacijo (Vovk Korže, 2016). Ugoden vpliv permakulture se kaže v tem, da organski ogljik v prsti podpira njeno strukturo, saj izboljšuje fizično okolje za korenine, da predirajo skozi tla. Organska snov tudi vsrkava vodo in jo zadrži. Tla, ki vsebujejo organsko snov, imajo boljšo strukturo, ki izboljša pronicanje vode ter zmanjša dovzetnost tal za zbitost, erozijo in plazove (Zdruli et al., 2004). Dostopnost zraka in vode koreninam je bistvenega pomena za rodovitnost prsti. Le ta pa je povezana s tipom prsti. Skozi avtomorfne prsti se voda nemoteno pretaka, $v$ hidromorfnih pa zaostaja in preprečuje normalen razvoj profila .

\section{Vrednotenje naravnih virov ekosistemskih storitev za potrebe samooskrbe}

Vsoto vseh materialnih sestavin okolja, surovin in energije imenujemo zaloge planeta, ki postanejo naravni vir takrat, ko jih začne uporabljati človek zaradi svojih potreb po hrani, obleki, bivanju, ogrevanju, prevozu. Zato so naravni viri temeljni za preživetje in napredek človeške vrste, vendar so omejeni $\mathrm{z}$ velikostjo in sposobnostjo Zemlje, da jih obnavlja. Za naravne vire se uporabljajo različni izrazi kot npr. naravni potenciali, naravni kapital, naravni resursi, geopotenciali, pokrajinski viri in naravno bogastvo (Green, 2012). Pomen besede naravni vir je širok.

Naravni viri so tiste sestavine naravnega okolja (ozračje, voda, prst, zemljišča, rudniki, minerali), ki jih uporablja človek in njihova opredelitev je predvsem odvisna od procesa človekovega odkrivanja njihove uporabnosti. $V$ tehničnem smislu postane naravna danost bogastvo, ko ga začne izkoriščati človek. V šolski enciklopediji Geografija (1993) je naravni vir tisto, kar je v naravi koristnega za ljudi, to pa je lahko skoraj vse: npr. veter, voda, kamnine, prsti, surovine in celo pokrajina sama. V Enciklopediji Slovenije (št. 7, geslo naravni vir) je le ta definiran kot obnovljiva ali neobnovljiva naravna prvina, ki je gospodarsko uporabljiva. Nekateri obnovljivi naravni viri nastajajo sproti (les, ribe, divjad), na druge izkoriščanje bistveno ne vpliva (hidroenergija, sončna energija). V širšem smislu so naravni viri vse sestavine in značilnosti okolja, ki omogočajo obstoj življenja na Zemlji (zrak, voda, prst) oz. lahko zadovoljujejo posamezne potrebe ljudi, npr. proizvodne (rude, energetski viri, obdelovalna zemlja) ali rekreacijske (rekreacijska območja). Naravne vire delimo v dva osnovna tipa: $v$ zaloge ali neobnovljive vire in prilive ali obnovljive vire.

Neobnovljivi naravni vir so snovi, ki postopoma nastajajo v geološki zgodovini. Imajo fizične omejitve $\mathrm{v}$ količini, porabimo jih dejansko lahko toliko, kolikšna je njihova dejanska količina. Obnovljivi naravni vir so naravni viri, ki so obnovljivi v primerno kratkem obdobju z vidika človeka oziroma njegovega življenja. Med obnovljive naravne vire prištevamo tudi ekosistemske storitve (kroženje hranil, uravnavanje plinov, podnebja 


\section{GEOGRAFIJE PODRAVJA \\ A. Vovk Korže: Samooskrba na enem hektarju (na primeru učnega poligona za

in vodnih razmer, zaščita pred erozijo, samočistilne zmogljivosti).

Pri uporabi naravnih virov nastajajo različne emisije, ki onesnažujejo okolje. Z večjo rabo neobnovljivih virov zmanjšujemo njihove omejene zaloge in obremenjujemo okolje. Prav tako lahko s prekomerno rabo obnovljivih virov ogrožamo njihov obstoj, v primerih, ko raba presega naravno obnovljivost in se prekine tok obnavljanja. Vsi obnovljivi naravni viri imajo svoja kritična območja rabe, v kolikor te presežemo, naravni viri ne morejo več opravljati vseh brezplačnih storitev, ki omogočajo življenje družbe in razvoj gospodarstva.

Ekosistemske storitve za vodne, gozdne in travniške ekosisteme.

\begin{tabular}{|c|c|c|c|}
\hline Storitve & Vodni ekosistemi & Gozdni ekosistemi & Travniški ekosistemi \\
\hline $\begin{array}{l}\text { Vzdrževanje } \\
\text { in podpora } \\
\text { ekosistemov }\end{array}$ & $\begin{array}{l}\text { Vodni cikel, } \\
\text { kroženje snovi in } \\
\text { hranil, } \\
\text { nastajanje prsti }\end{array}$ & $\begin{array}{l}\text { Primarna } \\
\text { proizvodnja, } \\
\text { sekundarna } \\
\text { proizvodnja, } \\
\text { fotosinteza, } \\
\text { kroženje snovi in } \\
\text { hranil, } \\
\text { kroženje vode }\end{array}$ & $\begin{array}{l}\text { Primarna } \\
\text { proizvodnja, } \\
\text { sekundarna } \\
\text { proizvodnja, } \\
\text { fotosinteza, } \\
\text { kroženje snovi in } \\
\text { hranil }\end{array}$ \\
\hline $\begin{array}{l}\text { Preskrba } \\
\text { ekosistema }\end{array}$ & $\begin{array}{l}\text { Pitna voda, } \\
\text { biološki viri, } \\
\text { proizvodnja } \\
\text { električne energije, } \\
\text { življenjski prostor } \\
\text { živali, } \\
\text { transportne poti }\end{array}$ & $\begin{array}{l}\text { Sečnja lesa, } \\
\text { življenjski prostor } \\
\text { živalim, } \\
\text { gozdni sadeži in } \\
\text { gobe, } \\
\text { izlov divjadi, } \\
\text { čebelarstvo }\end{array}$ & $\begin{array}{l}\text { Pridelava krme, } \\
\text { zdravilne rastline, } \\
\text { življenjski prostor } \\
\text { živalim, } \\
\text { pridobivanje medu }\end{array}$ \\
\hline $\begin{array}{l}\text { Delovanje } \\
\text { ekosistemov }\end{array}$ & $\begin{array}{l}\text { Vpliv na lokalno } \\
\text { klimo }\end{array}$ & $\begin{array}{l}\text { Vpliv na lokalno } \\
\text { klimo, } \\
\text { varovalna vloga, } \\
\text { biotska raznovrstnost, } \\
\text { preprečevanje erozije, } \\
\text { ponor ogljikovega } \\
\text { dioksida }\end{array}$ & $\begin{array}{l}\text { Biotska } \\
\text { raznovrstnost, } \\
\text { preprečevanje erozije, } \\
\text { preprečevanje } \\
\text { zaraščanja površin }\end{array}$ \\
\hline $\begin{array}{l}\text { Kulturne } \\
\text { storitve }\end{array}$ & $\begin{array}{l}\text { Rekreacija, } \\
\text { sprostitev, } \\
\text { turizem, } \\
\text { izobraževanje (vodne } \\
\text { učne poti) }\end{array}$ & $\begin{array}{l}\text { Rekreacija, } \\
\text { sprostitev, } \\
\text { turizem, } \\
\text { izobraževanje } \\
\text { (gozdne učne poti) }\end{array}$ & $\begin{array}{l}\text { Rekreacija, } \\
\text { Izobraževanje } \\
\text { (travnik kot učilnica) }\end{array}$ \\
\hline
\end{tabular}

Pri načrtovanju rabe naravnih potencialov je potrebno obravnavati različne potrebe in interese razvoja $\mathrm{v}$ prostoru glede na razpoložljive potenciale ter zagotoviti usklajenost gospodarskih, družbenih in okoljskih vidikov.

Šele z zaznavanjem negativnih posledic industrializacije, urbanizacije in naraščanja števila prebivalstva na okolje, smo se začeli zavedati velike vrednosti in pomena vseh oblik življenja in njihovega življenjskega prostora. Ekosistemi so torej različne naravne 
A. Vovk Korže: Self-sufficiency on one hectare of land (on the case of educational polygon Dole in Poljčane)

enote, ki jih sestavljajo življenjske združbe živih bitij (mikrobi, rastline, živali, človek) ter njihov življenjski prostor (podnebni in talni pogoji). Šele z nepovratno degradacijo posameznih ekosistemov in s spreminjanjem našega naravnega okolja smo spoznali njihove šroke funkcije, storitve in dobrine, na katerih temelji naš obstoj.

Delimo jih lahko na:

- podporne storitve (omogočajo delovanje ostalih ekosistemskih storitev fotosinteza, kroženje hranil, kroženje vode, tvorba tal);

- oskrbovalne storitve (vlaknine, hrana, viri za preskrbo z energijo, genetska pestrost, kemikalije naravnega izvora, mineralne surovine);

- regulacijske storitve (prispevek k čiščenju zraka, vode in tal, vpliv na klimo (vezava $\mathrm{CO} 2$, vlažnost zraka), zmanjševanje erozije in opraševanje, zmanjševanje naravnih nevarnosti - suše, poplave, veter);

- kulturne storitve (nematerialne koristi: rekreacija, estetska vrednost, duhovna obogatitev).

Koncept ekosistemskih storitev je bil razvit, da nam pomaga razumeti človeško uporabo in upravljanje z naravnimi viri. Naše zdravje in dobro počutje je odvisno od storitev, ki jih zagotavljajo ekosistemi in njihove komponente: voda, tla, hranila, organizmi. Ekosistemske storitve so torej procesi, s katerimi narava proizvaja za nas čist zrak, vodo, hrano in surovine. Ekosistemske dobrine in storitve imajo ključno vlogo pri ohranjanju življenja na vseh ravneh, vendar se na njih najbolj opirajo podeželske skupnosti v državah v razvoju.

\section{Vrednotenje ekosistemskih storitev na učnem poligonu v Dolah}

Raziskavo smo izpeljali tako, da smo vrednotili posamezne podskupine ekosistemskih storitev kvalitativno $\mathrm{z}$ odgovori da, delno in ne, glede na rabo tal na učnem poligonu $\mathrm{v}$ Dolah. Spraševali smo se, ali z obstoječo rabo tal podpiramo ekositemske storitve:

Ali z obstoječo rabo tal v Dolah podpiramo podporne storitve ekosistemov?

\begin{tabular}{|l|c|c|c|}
\hline Podporne storitve & $\mathrm{Da}$ & Delno & $\mathrm{Ne}$ \\
\hline Nastajanje tal & $\mathrm{X}$ & & \\
\hline Fotosinteza & $\mathrm{X}$ & & \\
\hline Primarna proizvodnja (rast rastline) & $\mathrm{X}$ & & \\
\hline Prehrambeni krog & $\mathrm{X}$ & & \\
\hline Vodni krog & $\mathrm{X}$ & & \\
\hline Skupaj ocena & 6 & & \\
\hline Delež (\%) & $100 \%$ & & \\
\hline
\end{tabular}

Rezultat vrednotenja kaže, da $\mathrm{z}$ naravnimi pristopi pridelave in skrbi za zemljo popolnoma podpiramo podporne ekosistemske storitve, kar je temelj za vse ostale podskupine teh storitev. Iz tega sklepamo, da je zelo pomembno vzpostaviti trajnostne načine pridelave hrane kot so ekološko kmetijstvo, permakultura in druge oblike naravnega kmetovanja. 
Ali z obstoječo rabo tal v Dolah podpiramo preskrbovalne storitve ekosistemov?

\begin{tabular}{|l|c|c|c|}
\hline Preskrbovalne storitve & Da & Delno & $\mathrm{Ne}$ \\
\hline Hrana & $\mathrm{X}$ & & \\
\hline Genetski viri (semena) & $\mathrm{X}$ & & \\
\hline Biokemični viri (substance) & $\mathrm{X}$ & & \\
\hline Vlakna & & $\mathrm{X}$ & \\
\hline Naravna zdravila & $\mathrm{X}$ & & \\
\hline Farmacevtski izdelki & & $\mathrm{X}$ & \\
\hline Okrasni viri & $\mathrm{X}$ & & \\
\hline Skupaj ocena & 5 & 2 & \\
\hline Delež (\%) & 71,4 & 28,6 & \\
\hline
\end{tabular}

Preskrbovalne storitve so odgovor na to, kaj pridelamo, s čim se lahko oskrbimo. Na poligonu ne pridelujemo vlaken (rastlin za vlakna) ter farmacevskih izdelkov, imamo pa druge biokemične vire, ki prav tako omogočajo vzdrževanje zdravja po naravni poti.

Ali z obstoječo rabo tal v Dolah podpiramo regulacijske storitve ekosistemov?

\begin{tabular}{|l|c|c|c|}
\hline Regulacijske storitve & Da & Delno & Ne \\
\hline Regulacija zraka & $\mathrm{X}$ & & \\
\hline Regulacija podnebja & $\mathrm{X}$ & & \\
\hline Regulacija erozije & $\mathrm{X}$ & & \\
\hline Regulacija vode & $\mathrm{X}$ & & \\
\hline Čiščenje vode & $\mathrm{X}$ & & \\
\hline Regulacija $»$ škodljivcev« & $\mathrm{X}$ & & \\
\hline Regulacija bolezni & $\mathrm{X}$ & & \\
\hline Regulacija naravnih nevarnosti & $\mathrm{X}$ & & \\
\hline Opraševanje & $\mathrm{X}$ & & \\
\hline Skupaj ocena & 9 & & \\
\hline Delež (\%) & 100 & & \\
\hline
\end{tabular}

$\mathrm{Z}$ zelenimi sistemi, ki temeljijo na naravnih pristopih docela podpiramo regulacijske storitve ali storitve uravnavanja. To je izredno pomembno v času prilaganja na podnebne spremembe, saj bomo lahko $\mathrm{z}$ varstvenimi načini rabe tal zagotovili manj poplav, erozij in suš.

Ali z obstoječo rabo tal v Dolah podpiramo kulturne storitve ekosistemov?

\begin{tabular}{|l|c|c|c|}
\hline Kulturne storitve & Da & Delno & Ne \\
\hline Duhovne in verske vrednote & & $\mathrm{X}$ & \\
\hline Sistemi znanja & $\mathrm{X}$ & & \\
\hline Navdih & $\mathrm{X}$ & & \\
\hline Izobraževalne vrednote & $\mathrm{X}$ & & \\
\hline Rekreacija in ekoturizem & $\mathrm{X}$ & & \\
\hline Estetske vrednote & $\mathrm{X}$ & & \\
\hline Ocena skupaj & 5 & 1 & \\
\hline Delež (\%) & 83,3 & 16,7 & \\
\hline
\end{tabular}


A. Vovk Korže: Self-sufficiency on one hectare of land (on the case of educational polygon Dole in Poljčane)

Kulturne storitve so najbolj poznana oblika ekosistemskih storitev in imajo številne možnosti. Na poligonu nimamo duhovnih in verskih vrednot (spomeniki, kipci, cerkve, kapele), imamo pa vse ostale oblike kulturnega turizma.

Pri skupni oceni vrednotenja ekosistemskih storitev upoštevamo delne ocene podpornih, proizvodnih, regulacijskih in kulturnih storitev ter dobimo kvantitatino oceno vpliva rabe tal na delovanje ekosistemskih storitev. Pomembno je, da dosežemo čimvečjo podporo ekosistemskim storitvam, saj na ta način dokazujemo, da je raba tal skladna z naravnimi značilnostmi območja.

$\mathrm{Z}$ oceno 89,35 izkazujemo visoko podporo ekosistemskim storitvam, kar je pomembna informacija, da je vzpostavljena raba tal skladna $\mathrm{z}$ naravni viri. Naša prizadevanja pri samooskrbi na majhnih površinah gredo prav to smer, da vzpostavimo take posesti, ki maksimalno upoštevajo naravne zakonitosti območja.

\begin{tabular}{|l|c|c|c|}
\hline $\begin{array}{l}\text { Skupna ocena (v \%) ekosistemskih } \\
\text { storitev }\end{array}$ & Da & Delno & Ne \\
\hline Podporne storitve & 100,0 & & \\
\hline Preskrbovalne storitve & 74,1 & 28,6 & \\
\hline Regulacijske storitve & 100,0 & & \\
\hline Kulturne storitve & 83,3 & 16,7 & \\
\hline Skupaj vse storitve & 89,35 & 22,65 & \\
\hline
\end{tabular}

\section{Zaključek}

Samooskrba na enem hektarju izhaja iz geografskih značilnosti območja in vključuje poznavanje reliefa, naklona, ekspozicije, saj ti parametri pokrajine odločilno vplivajo na oblike rabe tal. Tudi prst je drugačna na severni legi kot na južni, in sicer so razlike $v$ debelini, v zadrževanju vlage in $\mathrm{v}$ nastajanju humusa (na južnih legah je večje preperevanje kot na severnih). Odločilno vlogo pri samooskrbi ima voda, zato je poznavanje vodnih virov in njihovih značilnosti nepogrešljivo. Naravni izviri na pobočjih so značilni za območja iz laporja, ker se pojavijo izcedni tipi izvirov. Taki primeri so tudi na učnem poligonu $\mathrm{v}$ Dolah in to vodo lahko uporabimo $\mathrm{v}$ krožnem samooskrbnem gospodarjenju za zalivanje, tudi za pitje, v kolikor je voda mikrobiološko neoporečna.

Mikroklima neposredno vpliva na saditvene vzorce. Rastline občutljive na mraz posadimo nad termalnim pasom in na južne ter jugozahodne lege. Upoštevanje mikroklime je pri rastlinah zelo pomembno in vpliva na pridelavo hrane. Trajnostno zasnovani objekti s koriščenjem energije zemlje in sonca so prikaz alternativnega načina življenja. Zaključimo lahko, da ima geografija kot znanstvena disciplina izredno veliko možnosti pri načrtovanju trajnostnih načinov gospodarjenja in življenja, saj združuje opazovanje in meritve naravnih in družbenih komponent pokrajine, kar je tudi značilnost rodovnih posesti. 


\section{GEOGRAFIJE PODRAVJA \\ A. Vovk Korže: Samooskrba na enem hektarju (na primeru učnega poligona za samooskrbo Dole, Poljčane)}

\section{Literatura in viri}

Dunphy, A., Spellman, G. 2009: Geography fieldwork, fieldwork value and learning styles. International Research in Geographical and Environmental Education 18(1), 19-28. DOI: 10 1080/10382040802591522

Enciklopedija Slovenije,1996, štev. 7, Mladinska knjiga, Ljubljana.

Geografija, šolska enciklopedija, 1993. Mladinska knjiga, Ljubljana.

Graham, B. 2010: Permaculture Garden. ARA Publisher, Ljubljana.

Green, M. 2012: Place, sustainbility and literacy in environmental education: Frameworks for teaching and learning. RIGEO Review of International Geographical Education Online 2(3), Winter 2012, 326-346. (ISBN: 2146-0353).

Hemenway, T. 2009: Gia's Garden: A Guide to Home-Scale Permaculture. Chelsea Green Publishing, e-Book 9781603582230.

Mahmood, R., Legates, D.R., Meo, M. 2004: The role of soil water availability in potential rainfed rice productivity in Bangladesh: applications of the CERES-Rice model. Applied Geography 24(2), 139-159.

Nayak, S., Prasanna, R. 2007: Soil pH and its role in cyanobacterial abundance and diversity in rice field soils. Applied Ecology and Environmental Research 5(2), 103-113.

Okolo, J.C., Amadi, E.N., Odu, C.T.I. 2005: Effects of soil treatments containing poultry manure on crude oil degradation in a sandy loam soil. Applied Ecology and Environmental Research 3(1), 47-53.

Permaculture Free Press 2013: http://permaculturefreepress.com/?p=401 (accessed xx/08/16).

Piercea, J. 1990: The Food Resource. Longman Scientific \& Technical, New York, 334 pp.

Praterious, P. 2006: A Permaculture School Garden. Teaching Green 78, 6-10.

Raman, S. 2006: Agricultural Sustainability - Principles, Processes and Prospects. Food Products Press, New York, $474 \mathrm{pp}$.

Stutz, F., Warf, B. 2005: World Economy. Resources, Location, Trade and Development. Pearson/Prentice Hall, Upper Saddle River, New Jersey, 543 pp.

Whitefield, P. 2012: Permaculture in a Nutshell. Permanent Publications. Permaculture Association, London.

Zdruli, P., Jones, R.J.A., Montanarella, L. 2004: Organic Matter in the Soils of Southern Europe. European Soil Bureau Technical Report, EUR 21083 EN, 16 pp. Office for Official Publications of the European Communities, Luxembourg.

Vovk Korže, A. 2010: Trajnostna zasnova regionalne agende. Doktorska disertacija, Filozofska fakulteta Ljubljana.

Vovk Korže, A. 2016: Rodovitna zemlja. Inštitut za promocijo varstva okolja. Nazarje. 
GEOGRAFIJE PoDRAVJA

THE GeOgraphies OF THE PodRAVJe Region 


\title{
Kompetence učiteljev in razvijanje lastne profesionalnosti za poučevanje geografije na prostem
}

\author{
KARMEN KOLNIK
}

\begin{abstract}
Povzetek Poučevanje geografije na prostem temelji v prvi vrsti na kompetenčno usposobljenem učitelju, ki prepoznava pomen izkustvenega počenja geografije. $Z$ analizo izobraževanja učiteljev geografije ob vstopu $\mathrm{v}$ poklic in nato na področju stalnega strokovnega spopolnjevanja $\mathrm{s}$ področja poučevanja geografije na prostem, sta bila proučevana pogoja za razvoj učiteljevih kompetentnosti s področja znanja in dispozicij učiteljev začetnikov ter refleksije dela učiteljev praktikov, ki jih posameznik razvija ob vključevanju v izobraževalno prakso oz. v nadaljevanju tudi nadgradnji lastne profesionalnosti s stalnim strokovnim spopolnjevanjem. Izkušnje v poučevanju geografije na prostem, kot pomembna podlaga kompetentnosti za pedagoško refleksijo, so bile proučevane s primerjalno analizo učne prakse, objavljene v člankih učiteljev geografije v Geografiji v šoli (ZRSŠ), v dveh časovnih obdobjih: obdobju med leti 1999 in 2005 ter 2006 in 2016.
\end{abstract}

Ključne besede: $\bullet$ kompetence $\bullet$ učitelj $\bullet$ geografija $\bullet$ učenje na prostem • didaktična analiza $\bullet$ revija Geografija v šoli •

NASLOV AVTORICE: dr. Karmen Kolnik, redna profesorica, Univerza v Mariboru, Filozofska fakulteta, Oddelek za geografijo, Koroška cesta 160, 2000 Maribor, Slovenija, e-naslov: karmen.kolnik@um.si. 


\title{
Geography teachers competencies and developing their professionalism for outdoor teaching
}

\author{
KARMEN KOLNIK
}

\begin{abstract}
Outdoor geography teaching is primarily based on competency qualified teacher who are recognizing the importance of student's experience in learning by doing geography. That is why we have to investigate whether teachers have the appropriate education during training for the profession as well as in the time of working as teachers. Firstly, we analyzed whether geography university study programs enable the future geography teachers to develop competence in the field of knowledge and skills necessary for successful outdoor teaching and secondly, we analyzed the possibilities of in-service training of geography teachers to upgrade their own professionalism with the examination of the offer of number and content of teaching seminars for them in the period 1995-2017. Experience in teaching outdoor geography as an important basis of competence for pedagogical reflection, were studied with a comparative analysis of geography teaching practice, published in the papers in the journal Geography at school (RS) in two periods: the period between 1999 and 2005 and 2006 and 2016.
\end{abstract}

Keywords: • competencies $\bullet$ teacher $\bullet$ geography $\bullet$ outdoor learning • didactic analysis $\bullet$ journal Geography at school $\bullet$

CorResPondence AdDREss: Karmen Kolnik, Ph.D., professor of geography, University of Maribor, Faculty of Arts, Department for geography, Koroška cesta 160, 2000 Maribor, Slovenia, e-mail: karmen.kolnik@um.si. 
GEOGRAFIJE PODRAVJA
K. Kolnik: Kompetence učiteljev in razvijanje lastne profesionalnosti za poučevanje geografije na prostem

\section{Uvod}

Raziskovalci konceptov pouka že več kot desetletje poudarjajo (Marentič Požarnik, 2005; Wartschaw, 2005; Spajić, 2007; Uzelac, 2008; O' Connor, 2015), da poučevanje ni le prenašanje vnaprej pripravljenih znanj temveč urjenje učencev za samostojno pridobivanje znanja ter razvoj veščin (raziskovanja, zastavljanja vprašanj, reševanja problemov, uporabe virov...) in kritičnega mišljenja. Poudarjajo dejstvo, da učni cilji niso konec neke poti, temveč njen sestavni del, ki jo morajo učenci prehoditi sami, učitelj pa jih na poti vzpodbuja, vodi in usmerja. Prednost imajo na izkustvih temelječe učne metode, ki vzpodbujajo reševanje problemov in so naravnane na celostno dojemanje učnih informacij. Razumevanja problemov sodobnega sveta in zagotavljanje pomena trajnostnosti v izobraževanju je pomemben izziv in poslanstvo sodobne šole, tudi (ali še zlasti) geografije. Zasnovan je tako na izobraževalnih kot vzgojnih temeljih soodgovornega ravnanja slehernega posameznika. Učenje na prostem temelječe na izkustvenem učenju ima pomembno vlogo mostu $\mathrm{v}$ medpredmetnih korelacijah in $\mathrm{v}$ prenosu izobraževalne (šolske) teorije v življenjsko prakso.

Lipovšek (2016) je v raziskovanju odnosa slovenskih učiteljev geografije in učencev do terenskega dela ugotovil, da: « ... je terensko delo zaželena oblika pouka tako med učenci kot učitelji. Nismo pa uspeli raziskati, zakaj je tako zaželena...« (prav tam: 132). Avtor tudi na osnovi intervjujev učiteljev geografije, izvedenih v letu 2011 s skupino 12 osnovno in srednješolskih učiteljev geografije, posredno sklepa, da se odgovor na to vprašanje kaže v učiteljevem pojmovanju terenskega dela, ki je: « ...vprašanje vsebine in ne vprašanje ciljev « učenja (Lipovšek, 2016: 132) Ugotavlja tudi, da so intervjuvani učitelji geografije izpostavili motiviranost učencev in razvoj veščin (npr. terenske meritve, reševanje nalog) kot prednostno iztopajoče pri poučevanju geografije na prostem, učitelji geografije tudi cenijo svoje dosedanje izkušnje na tem področju dela. (prav tam).

Ugotovljeno sovpada oz. potrjuje pred desetimi leti pridobljene izsledke didaktične analize objav učiteljev geografije o učenju na prostem v reviji Geografija v šoli (Kolnik, 2006a), kjer je bilo ugotovljeno, da se v polovici analiziranih prispevkov učenja na prostem, kaže morda odsotnost $\mathrm{v}$ didaktični povezanosti med motiviranjem učencev, pridobivanjem, utrjevanjem, preverjanjem in vrednotenjem učenčevega znanja in sposobnosti (veščin). » $\mathrm{V}$ veliki večini analiziranih člankov je bilo zaslediti odsotnost predstavitve didaktične pomembnosti opazovane pokrajine ( geografskega pojava, procesa) ter njihov pomen $\mathrm{z}$ vidika doseganja učnih ciljev in namena praktičnega dela. $\mathrm{V}$ analiziranih člankih praktično ni bilo učnih prilagoditev (diferenciacije in individualizacije), premalo ali enolično je bilo predvidevanje medpredmetnih korelacij. Samo del učiteljev je v svojih prispevkih (predvsem v zaključkih) zapisal nekatere svoje izkušnje in spoznanja kot način samoevalviranja» (Kolnik, 2006a: 18).

\section{Metodološka opredelitev raziskave}

Ali lahko na osnovi predstavljenih raziskav sklepamo, da ni bilo v zadnjih petnajstih letih doseženih kvalitetnih premikov na področju poučevanja in seveda posledično tudi učenja geografije na prostem? V okviru tega raziskovalnega vprašanja se bomo usmerili v ugotavljanje kompetentnosti učiteljev geografije za poučevanje na prostem. 
K. Kolnik: Geography teachers competencies and developing their professionalism for outdoor teaching

$\mathrm{Na}$ osnovi pedagoškega neeksperimentalnega raziskovanja smo izdelali tri analize izbrane pedagoške dokumentacije: $\mathrm{z}$ analizo visokošolskega izobraževanja bodočih učiteljev geografije, z vidika razvijanja kompetenc poučevanja geografije na prostem na primeru Dvopredmetnega magistrskega pedagoškega študijskega programa Geografija Filozofske fakultete Univerze $\mathrm{v}$ Mariboru, ter analizo oblik stalnega strokovnega spopolnjevanja s področja poučevanja geografije na prostem in razvijanja kompetenc poučevanja geografije na prostem $\mathrm{z}$ vidika njihove številčne zastopanosti ter namenske in vsebinske raznolikosti (KATIS), sta bila proučevana pogoja za razvoj in nadgrajevanje kompetentnosti s področja znanja in dispozicij, ki jih posameznik razvija ob vključevanju $\mathrm{v}$ izobraževalno prakso in $\mathrm{v}$ nadaljevanju tudi lastne profesionalnosti. Izkušnje $\mathrm{v}$ poučevanju geografije na prostem, kot pomembne podlaga kompetentnosti za pedagoško refleksijo, so bile proučevane na osnovi primerjalne analize učne prakse objavljenih člankov učiteljev geografije v Geografiji v šoli (ZRSŠŠ) v obdobju med leti 1999 in 2005 (prvo primerjalno obdobje) ter 2006 in 2016 (drugo primerjalno obdobje).

\section{Izobraževanje bodočih učiteljev geografije in razvijanje kompetenc poučevanja geografije na prostem}

V Sloveniji se izobraževanje bodočih učiteljev geografije na univerzitetni stopnji izvaja na treh oddelkih za geografijo: na Filozofski fakulteti Ljubljana, Fakulteti za humanistične študije v Kopru in Filozofski fakulteti v Mariboru. S študijskim letom 20082009 smo v Sloveniji pričeli s t. i. bolonjskimi študijskimi programi na univerzitetnem izobraževanju, ki so zasnovani tako, da je za vstop v učiteljski poklic zahtevano 5 letno univerzitetno izobraževanje.

Vsi, v Sloveniji akreditirani študijski programi za izobraževanje bodočih učiteljev geografije, imajo enotna izhodišča $\mathrm{v}$ obsegu (čas trajanja in število kreditnih točk), izobraževalnih ciljih in pričakovanih kompetentnostih diplomantov ter minimalnih pedagoških standardih, ki še zagotavljajo doseganje ciljev kakovostnega izobraževanja učiteljev (Merila za akreditacijo študijskih programov za izobraževanje učiteljev 2008: 2493). Le-ti opredeljujejo minimalno 60 kreditnih točk s področja izobraževanja za pedagoški poklic (pedagoški, didaktični, psihološki,...študijski predmeti) in v tem okvirju minimalno 15 kreditnih točk praktičnega usposabljanja na eni dvopredmetni študijskipovezavi.

Izobraževanje bodočih učiteljev geografije in razvijanje kompetenc poučevanja geografije na prostem je analizirano na primeru študijskih programov akreditiranih na Oddelku za geografijo Filozofske fakultet Univerze v Mariboru, pri tem je potrebno zapisati, da so med nacionalnimi pogoji za akreditacijo bile zapisane tudi zahteve o mednarodni primerljivosti s sorodnimi študijskimi programi in seveda, pozitivna recenzijska mnenja geografskih ekspertov iz Slovenije. Zato imajo vsi trije geografski oddelki, ki v Sloveniji izobražujejo bodoče učitelje geografije tudi primerljive študijske programe.

Triletno dodiplomsko izobraževanje je usmerjeno $\mathrm{v}$ izobraževanje kadrov, ki bodo $\mathrm{z}$ dokončanjem študijskega programa pridobili znanja, spretnosti in sposobnosti, ki po mednarodnih standardih veljajo za temeljna iz področja geografije in je pogoj za vpis na podiplomsko izobraževanje pedagoške geografije. V študijski program so vključene učne 


\section{GEOGRAFIJE PODRAVJA \\ K. Kolnik: Kompetence učiteljev in razvijanje lastne profesionalnosti za poučevanje geografije na prostem}

enote, ki zajemajo temeljne geografske predmete, metodološke in aplikativne predmete ter izbirne predmete, ki se povezujejo z vsemi omenjenimi področji. Študenti pri temeljnih geografskih predmetih (brez metodoloških, aplikativnih in izbirnih predmetov) pridobijo 21,3 \% ECTS pri predmetih s področja fizične geografije, 27,7 \% ECTS pri predmetih s področja družbene geografije in $13,3 \%$ ECTS pri predmetih s področja regionalne geografije. Preostalih 35,7 \% ECTS pridobijo z metodološkimi, aplikativnimi in izbirnimi predmeti. Predmetnik vsebuje tudi od $10 \%$ do $20 \%$ praktičnega dela študentov (terenske vaje, ekskurzije), različno glede na semester (Dvopredmetni študijski program 1. stopnje Geografija, 2008/2009: 31).

Dvopredmetni magistrski pedagoški študij geografije traja dve leti in ob uspešnem zaključku diplomanti pridobijo strokovni naziv magister profesor geografije. Dvopredmetni magistrski pedagoški študijski program Geografija FF UM, se je prvič pričel izvajati v študijskem letu 2011- 2012. Sestavljata ga dva sklopa študijskih predmetov: študijski predmeti s področja geografije (30 kreditnih točk) ter študijski predmeti s področij pedagogike, didaktike in psihologije (60 kreditnih točk) v okviru t. i. PDP modula, ki zajema obvezne študijske predmete: Pedagogika, Didaktika, Psihologija razvoja in učenja, Delo z otroki s posebnimi potrebami in Opazovalno prakso ter glede na izbrano študijsko področje predmetno specifične didaktične študijske predmete. $V$ primeru geografije so to: IKT pri pouku geografije, Didaktika geografije 1, Didaktika geografije 2, Didaktika geografije 3, Pedagoški praktikum 1 in Pedagoški praktikum 2. Z vidika razvoja kompetentnosti na področju poučevanja geografije na prostem velja izpostaviti tudi izbirne študijske predmete: Šola $\mathrm{v}$ naravi, Terensko delo pri pouku geografije - Fizična geografija, Terensko delo pri pouku geografije - Družbena geografija, ki imajo v učnih načrtih vsi zapisane cilje izgrajevanja kompetentnosti geografskega terenskega raziskovanja. V okviru Predmetnega praktikuma 1 in 2 študentje neposredno sodelujejo $\mathrm{v}$ osnovnih in srednjih šolah in tako povezujejo teoretično in praktično znanje. Delež predmetne pedagoške prakse $\mathrm{v}$ študijskem programu za izobraževanje učiteljev se določi v obsegu 16 ECTS za oba izbrana predmeta dvopredmetnega študija. Predmetna pedagoška praksa se izvaja $v$ strnjeni in razpršeni obliki (Javornik Krečič in drugi, 2011).

Z vidika razvoja kompetenc poučevanja geografije na prostem velja posebej opozoriti tudi na razpršeno pedagoško prakso (Pedagoški praktikum 2), kjer so študentje usmerjeni $\mathrm{v}$ naloge učiteljev geografije, ki jih zaradi organizacije in časovne enotedenske izvedbe ne doživijo na strnjeni pedagoški praksi, kot so: šolske ekskurzije, terensko delo, šola v naravi, geografska tekmovanja, nacionalni preizkusi znanja (osnovna in srednja šola) ter pri tem razvijajo kompetence s področja: organizacijskih spretnosti in sposobnosti (vodenje skupine, izdelava in samostojna ter skupinska izvedba načrtov dela...); sposobnosti načrtovanja, izvajanja, reflektiranja, evalviranja in razvijanja osebnostnega, študijskega in bodočega profesionalnega dela (iskanje, priprava, uporaba, refleksija in evalvacija kompleksnega pedagoškega dela); senzibilnosti za družbene potrebe (spretnosti in sposobnosti aktivnega delovanja v šolski ter ožji in širši družbeni skupnosti) in kritično samoozaveščanje in kolegialno kritično ozaveščanje ter posledična odprtost v inovativnosti, kreativnosti in $\mathrm{v}$ dinamičnem osebnostnem in profesionalnem razvoju (hospitacije, analize hospitacij, primerjave in preizkušanje izdelanih učnih konceptov (Dvopredmetni pedagoški magistrski študijski program Geografija: 2016/2017). 
K. Kolnik: Geography teachers competencies and developing their professionalism for outdoor teaching

Analitični pregled posameznih učnih načrtov študijskih predmetov Dvopredmetnega pedagoškega magistrskega študijskega programa Geografija FF UM (2016/2017) rezultira $\mathrm{v}$ ugotovitvi, da so predvideni študijski rezultati - kompetence diplomantov po zaključku študija za poučevanje geografije na prostem naslednji: usposobijo se za načrtovanje in izvajanje ter vrednotenje različnih učnih oblik in metod dela poučevanja na prostem; razvijejo sposobnosti organiziranja, vodenja ter pedagoškega refleksije interdisciplinarnih šolskih ekskurzij, terenskega dela, taborov ter učenja $v$ šoli v naravi ; usposobijo se za delo v učilnici na prostem oz. v različnih naravnih (gozd, park, obala, ...) in družbenih (muzej, mestna ulica, ...) učnih okoljih; pridobijo znanja in razvijejo veščine dela v interdisciplinarnih izobraževalnih timih; usposobijo se za uporabo izobraževalne in informacijsko komunikacijske tehnologije ter njenega povezovanja $\mathrm{z}$ različnimi oblikami učenja na prostem; usposobijo se za povezovanje teoretičnega znanja različnih interdisciplinarnih področij in za njihovo prevajanje v praktično izkušnjo poučevanja na prostem; prepoznajo pomen in značilnosti učenja na prostem kot aktivnega učnovzgojnega doživetja ter odgovornega državljanstva; razvijajo miselne veščine (kompleksno mišljenje, pedagoška refleksija, samoregulacija); usposobijo se za prevzemanje odgovornosti za proces raziskovanja, študija in pedagoškega dela (pisno samovrednotenje, samospoznavanje) na osnovnošolskem in srednješolskem nivoju izobraževanja; usposobijo se za načine poučevanja, ki aktivirajo različno zmogljive učence in jih motivirajo za učenje geografije; razvijejo spretnosti različnih vrst osebne in medosebne komunikacije (pisna, verbalna, grafična, ...) (prav tam). Ob njihovem dejanskem doseganju lahko ugotovimo, da imajo diplomanti vse potrebne predpogoje za uspešno vključitev v poklic učitelja geografije in $\mathrm{s}$ tem začetno poučevanje geografije na prostem.

\section{Stalno strokovno spopolnjevanje učiteljev geografije in razvijanje kompetenc poučevanja geografije na prostem $\mathrm{z}$ vidika analize ponudbe programov in njihove številčne zastopanosti ter namenske in vsebinske raznolikosti.}

Izobraževanje učiteljev je dinamičen proces, ki mora biti večplastno in sistemsko zasnovan. Omogočati in upoštevati mora raznolike oblike formalnega, neformalnega in informalnega izobraževanja in predvsem dvigniti povpraševanje po nenehnem izobraževanju ter strokovnem spopolnjevanju in razširitvi njihove ponudbe. V motiviranosti učiteljev geografije za osebni izobraževalni in profesionalni razvoj je bilo možno opaziti (Kunaver, 2002; Kolnik, 2006b; Kolnik, 2010) določeno stagnacijo v zadnjih petnajstih letih. Ugotovljeno je, da je pozitiven odnos do vseživljenjskega izobraževanja in pripravljenost zlasti za formalne oblike le-tega večji pri mlajših učiteljih, kot pri starejši generaciji učiteljev geografije. Posledično je bilo opozorjeno, da je v naslednjih letih potrebno nameniti večjo pozornost tistim učiteljem geografije, ki so t. i. fazi konservatizma (zanjo značilno stabiliziranje, stagniranje in zmanjšanje poklicnih ambicij) v njihovem profesionalnem razvoju (Huberman, 1993, povzeto po Javornik Krečič, 2008) in imajo v poprečju več kot 20 let delovnih izkušenj. Delno so razlog za to demografski trendi, saj se povečuje delež starejših učiteljev geografije in, kot je v navedenih raziskavah ugotovljeno, udeležba učiteljev geografije $\mathrm{v}$ nadaljevalnem izobraževanju in usposabljanju močno upada s starostjo. Drugi razlog pa je dosedanje prevladujoče osredotočanje na, še ne razrešene probleme mladih učiteljev pripravnikov in učiteljev začetnikov, (ki jih je v celotni učiteljski populaciji vedno manj) in pozabljanje na probleme starejših učiteljev (Kunaver, 2002). 


\section{GEOGRAFIJE PODRAVJA \\ K. Kolnik: Kompetence učiteljev in razvijanje lastne profesionalnosti za poučevanje geografije na prostem}

$\mathrm{V}$ predhodnih raziskavah o novih nalogah in novih kompetencah učiteljev geografije (Kolnik, 2005, 2008) je bilo ugotovljeno, da del učiteljev geografije (srednja generacija ter moški izraziteje kot ženske) ne doživlja stalno strokovno spopolnjevanje kot pomembnega za svoje delo. Velik del anketiranih učiteljev je v teh raziskavah izkazoval precejšnjo pasivnost $v$ iskanju možnosti za stalno strokovno spopolnjevanje in ob prvih ovirah (ne vzpodbudne reakcije vodstva, malo financ, oddaljenost seminarja, manj primeren čas njegovega izvajanja) hitro izgubil motiviranost zanj. Med delom učiteljev geografije je še vedno prisotno mnenje, da je strokovno spopolnjevanje dodatno delo in napor in ne nujno potreben pogoj za nenehno profesionalno rast. (Kolnik, 2008; Leva, 2016) Konečnik Kotnikova in Javornik Krečičeva (2011) v svoji raziskavi Učitelji geografije v poklicnih biografijah o vplivih na svoj profesionalni razvoj, predstavita poglobljen prikaz učiteljeve poklicne poti s perspektive učitelja samega. V osebnih zapisih učiteljev geografije je, med drugimi, predstavljen tudi zapis učiteljice geografije v sekundarnem izobraževanju, ki se po dvajsetih letih dela v šoli čuti:«...utrujena, naveličana, izpraznjena, prenasičena. To zagotovo niso lastnosti dobrega učitelja.« (prav tam: 16) Avtorici ugotavljata, da se v času učiteljevega profesionalnega razvoja pojavijo različne razvojne faze in predlagata, da: " ...bi bilo modro okrepiti neodvisne individualne spremljave oz. svetovalne kapacitete, ki bi lahko bile posameznim učiteljem opora, podkrepitev, povratna informacija, razvojni potencial in (ponovni) motivacijski vzgib, ki bi močno podpiral osebnostne vidike profesionalnega razvoja..« (Konečnik Kotnik, Javornik Krečič, 2011: 17).

Vsi učitelji, ki so zaposleni v šolstvu so dolžni nadgrajevati in poglabljati svoje znanje, potrebno za uspešno realizacijo njihovih nalog, zato imajo pravico (in dolžnost) do permanentnega izobraževanja. Že v prejšnjem desetletju smo ugotavljali (Kunaver, 2002; Kolnik, 2005), da imajo učitelji geografije na voljo vedno več seminarjev ter hkrati raznoliko ponudbo njihovih izvajalcev. Res pa je, da so v preteklosti največ pobud za organizacijo pedagoških izobraževanj prevzeli oddelka za geografijo iz Maribora in Ljubljane ter Zavod za šolstvo.

Konec devetdesetih let dvajsetega stoletja in v prvem desetletju novega tisočletja je bilo zaznati tudi nove organizatorje in izvajalce stalnega strokovnega usposabljanja za učitelje geografije. Ministrstvo za izobraževanje, znanost in šport RS vsako leto objavi programe za strokovno spopolnjevanje učiteljev v Katalogu programov stalnega strokovnega spolnjevanja strokovnih delavcev na področju vzgoje in izobraževanja. V katalogu so predstavljeni različni programi, ki si jih učitelji izberejo glede na svoje potrebe in interese. Namen kataloga je, da bi učitelji v naboru objavljenih programov našli tiste, ki bodo prispevali k njihovemu boljšemu profesionalnemu razvoju, ki bi zadovoljili njihove potrebe po strokovni in osebni rasti in pripomogli $\mathrm{k}$ dvigu kvalitete vzgojnoizobraževalnega dela.

V analizo programov stalnega strokovnega spopolnjevanja za predmetno področje geografije med leti 1995 in 2016, ki je bil narejen na podlagi Kataloga programov nadaljnjega izobraževanja in usposabljanja strokovnih delavcev v vzgoji in izobraževanju za šolska leta od leta 1995 do leta 2016 (Ministrstvo za šolstvo in šport RS; Ministrstvo za izobraževanje, znanost in šport RS) smo vključili: celotno število ponujenih programov za področje geografije v letu izvedbe, število programov s področja učenja geografije na prostem in število izvajalcev ponujenih programov. Iz primerjave ponudbe 
K. Kolnik: Geography teachers competencies and developing their professionalism for outdoor teaching

programov stalnega strokovnega spopolnjevanja za predmetno področje geografije, ki so razpisani na nacionalnem nivoju v okviru resornega ministrstva in jih lahko udeleženci uveljavljajo tudi v okviru napredovanj na delovnem mestu, je moč ugotoviti, da se je po šolskem letu 1996-1997 zaključilo obdobje številčnejše ponudbe le-teh, kot tudi najvišje število ponujenih programov s področja učenja geografije na prostem. Njihovo število je bilo najnižje v šolskem letu 2010/2011 (en sam) in se je, v naslednjih treh letih, ustalilo pri ponudbi štirih programov za učitelje geografije na leto. V večini primerov je bil edini izvajalec Zavod za šolstvo RS. Spremembo prinese šolsko leto 2015/2016 v rahlem povečanem številu programov (6 programov), kot tudi številu izvajalcev. Šolsko leto 2016/2017 potrdi zaznani trend dviga števila programov v primerjavi s predhodnimi leti, saj je razpisanih 11 programov strokovnega spopolnjevanja za učitelje geografije. Manj pa je razveseljiv podatek, da so samo tri inštitucije, ki jih ponujajo, ZRSŠ pa je izvajalec 9 od 11 programov.

Vsebinska analiza ponujenih programov stalnega strokovnega spopolnjevanja učiteljev geografije v opazovanih obdobjih kaže, da so programi s področja poučevanja geografije na prostem bili zastopani $\mathrm{v}$ vseh opazovanih časovnih obdobjih, je pa njihovo število nihalo od petih programov (šolsko leto 1996/1996 in šolsko leto 2016/2017) do enega programa (šolska leta 2010/2011, 2013/2014 in 2014/2015). Torej lahko povzamemo, da so učitelji geografije vedno imeli na razpolago vsaj eno strokovno spopolnjevanje s področja učenja geografije na prostem. Iz Kataloga programov nadaljnjega izobraževanja in usposabljanja strokovnih delavcev v vzgoji in izobraževanju 2016/2017 (KATIS) lahko tudi povzamemo vsebinsko raznolikost ponujenih programov za učenje geografije na prostem in učnih dejavnosti glede na naslove programov: Terensko raziskovanje s pomočjo IKT, Geografske mobilne aplikacije in spletni GIS kot podpora obravnavi izbrane geografske tematike v domačem okolju, Drugačna geografija: raziskovanje porečja, Učiteljski raziskovalni tabor, OFK- učenje z igro zunaj učilnice z uporabo IT-ja, $\mathrm{S}$ terenskim delom dosegati minimalne standarde $\mathrm{UN}$ o vodi (prav tam). Glede na njihove naslove in kratke opise ciljev lahko sklepamo, da so vsi usmerjeni v predstavitev novosti s področja geografije ter novosti s področja uporabe novih učnih pripomočkov, eden pa s področja vrednotenja (merjenja) terenskega dela.

Programi stalnega strokovnega spopolnjevanja za predmetno področje geografije za izbrano časovno obdobje med leti 1995 in 2016.

Vir: Katalog programov nadaljnjega izobraževanja in usposabljanja strokovnih delavcev $v$ vzgoji in izobraževanju za šolska leta od leta 1995 do leta 2016

\begin{tabular}{|c|c|c|c|}
\hline $\begin{array}{c}\text { Šlsko leto } \\
\text { izvedbe }\end{array}$ & $\begin{array}{c}\text { Stevilo } \\
\text { programov }\end{array}$ & $\begin{array}{c}\text { Število programov: } \\
\text { učenje geografije na } \\
\text { prostem }\end{array}$ & $\begin{array}{c}\text { Število } \\
\text { organizacij } \\
\text { oz. izvajalcev }\end{array}$ \\
\hline $1995 / 1996$ & 17 & 5 & 4 \\
\hline $1996 / 1997$ & 15 & 4 & 4 \\
\hline $2010 / 2011$ & 1 & 1 & 1 \\
\hline $2011 / 2012$ & 4 & 2 & 2 \\
\hline $2013 / 2014$ & 4 & 1 & 3 \\
\hline $2014 / 2015$ & 4 & 1 & 2 \\
\hline $2015 / 2016$ & 6 & 3 & 4 \\
\hline $2016 / 2017$ & 11 & 5 & 3 \\
\hline
\end{tabular}


GEOGRAFIJE PODRAVJA

K. Kolnik: Kompetence učiteljev in razvijanje lastne profesionalnosti za poučevanje

geografije na prostem

\section{Učna praksa in izkazane didaktične vrednosti učenja geografije na prostem v člankih v reviji Geografija v šoli}

Primerjalna analiza, kot osnovna raziskovalna tehnika, je bila narejena na osnovi člankov, ki predstavljajo izbrano problematiko učenja geografije na prostem in so bili objavljeni v reviji Geografija v šoli (ZRSŠ v prvem opazovalnem obdobju (med leti 1999 in 2005) in drugem opazovalnem obdobju (od leta 2006 do leta 2016).

V prvem primerjalnem obdobju so učitelji geografije objavili 24 prispevkov na temo učnih poti, terenskega dela, ekskurzij in praktičnega dela v geografskih opazovalnicah, kar je bilo poprečno 1,5 prispevka na izdano številko (od januarja leta 1999 do septembra 2005 je izšlo 16 številk revije). Nekatere izmed njih so bile izdane kot tematske številke in so bile posvečene naši izbrani temi. Takšna je bila prva dvojna številka revije v letu 1999, ki je prinašala primere geografskih učnih poti. (Kolnik, 2006a) Osnovna ugotovitev izdelane analize je dvom, da učitelji geografije $\mathrm{v}$ analiziranih prispevkih, ali niso bili vešči v svojem prispevku zajeti celovitega prikaza opravljenega dela, ali pa imajo še vedno pomembne težave $\mathrm{v}$ samem didaktičnem postopku: tako $\mathrm{v}$ fazi priprav in organiziranja, kot $\mathrm{v}$ fazah izvajanja ter vrednotenja (ocenjevanja) praktičnega dela učenja na prostem ter refleksije opravljenega dela (tako učenja kot poučevanja). Najpogostejše zaznane pomanjkljivosti in napake so bile: slabo definiranje (ali pa ga sploh ni) namena praktičnega dela ter odsotnost načrtovanih pričakovanih rezultatov. Iz objav je bilo zaznati, da so učitelji prepogosto zadovoljni že z izpolnjenim delovnim listom in učenčevim zbiranjem podatkov in izpolnjevanjem npr. preglednic ter, da je to bil (oz. je postal) osrednji cilj učnega dela na prostem. V analiziranih prispevkih je prav tako zaznati, da učitelji niso usmerjeni v razmišljanje, da učence uče raziskovalnega postopka (vseživljenjsko in kroskurikularno učenje), da je potrebno oblikovati in zapisati raziskovalne hipoteze, ob koncu dela pa oblikovati sintezne ugotovitve. Redka so bila napotila za usmerjanje interpretacije dosežkov. V analiziranih prispevkih manjkajo refleksije oz. komentarji in opažanja o poteku dela in rezultatih (npr. predlogi za izboljšanje ) tako s strani učencev kot učiteljev. V analiziranih člankih je bilo pogrešano ustvarjalno učno delo, takšno katerega sokreator bi bil/i učenec/i (npr. pobude katere prostorske probleme oz. procese raziskovati, kje, zakaj, itd.), kot tudi ni spodbud v obliki napotkov za samostojno terensko raziskovanje (njegovo širjenje in poglabljanje) (Kolnik, 2006a).

V drugem opazovalnem obdobju (2006 - 2016) smo prav tako analizirali članke v reviji Geografija v šoli, ki pa so bili izbrani na osnovi treh (razširjenih) kriterijev: v prvi skupini so zapisi učiteljev geografije, kot primeri njihove dobre učne prakse izvedene v okviru pouka geografije (učno terensko delo, šolska ekskurzija, učna pot, idr.). V drugo skupino prispevkov pa smo uvrstili tiste, ki prinašajo geografske opise različnih regij, pojavov in procesov s sporočilno učno vrednostjo (ekskurzija - geog. opis, učna pot - geog. opis, učni poligon - geog. opis, terensko delo - naravni rezervat, učilnica v naravi) in niso zapisi učnih dejavnosti, dajejo pa učiteljem možnost, da jih didaktično preoblikujejo v učno izkušnjo. V tretjo skupino pa so bili uvrščeni didaktični prispevki s področja učenja na prostem (terensko delo - didaktična analiza, terensko delo-medpredmetno povezovanje, terensko delo - inovativno učenje, terensko delo - geografsko tekmovanje, terensko delo - planinska šola, terensko delo - izobraževanje o okolju) in prispevki, ki predstavljajo nove metode in tehnike dela ter učne pripomočke za delo na terenu 
K. Kolnik: Geography teachers competencies and developing their professionalism for outdoor teaching

(terensko delo - nove metode in tehnike dela), torej prinašajo nova didaktična spoznanja.

$\mathrm{Z}$ razširitvijo primarnega kriterija didaktične analize prispevkov o učenju na prostem (obdobje 1995 - 2006), ki so prinašali samo zapise učiteljev geografije o njihovih primerih dobrih učnih praks na dve dodatni skupini izbranih prispevkov (geografske in didaktične) učenja geografije na prostem, smo želeli ugotoviti ali učitelji geografije lahko $\mathrm{v}$ analizirani reviji pridobivajo tudi informacije, ki osvetljujejo izkustveno učenje geografije na prostem tudi z vidika novih geografskih vsebin kot tudi didaktičnih novosti izbrane tematike.

Število in vrsta objavljenih prispevkov v reviji Geografija v šoli s področja učenja na prostem za obdobje 2006 - 2016.

Vir: revija Geografija v šoli: izbrani primeri člankov med leti 2006 - 2016, ZRSŠ

Opomba: leta 2015 revija ni izšla

\begin{tabular}{|c|c|c|}
\hline Leto & $\begin{array}{l}\text { Število } \\
\text { prispevkov }\end{array}$ & Vrsta prispevka \\
\hline 2006 & $\begin{array}{llll} & 1 \\
\end{array}$ & $\begin{array}{l}\text { Šolska ekskurzija, učna pot, učno terensko delo, } \\
\text { terensko delo-didaktična analiza }\end{array}$ \\
\hline 2007 & 5 & $\begin{array}{l}\text { Učna pot, terensko delo-didaktična analiza, ekskurzija- geo. } \\
\text { opis, terensko delo-medpredmetno povezovanje }\end{array}$ \\
\hline 2008 & 1 & Šolska ekskurzija-medpredmetno povezovanje, \\
\hline 2009 & 3 & $\begin{array}{l}\text { Učno terensko delo - izkustveno učenje, učna pot- geog. opis, } \\
\text { terensko delo - inovativno učenje }\end{array}$ \\
\hline 2010 & 7 & $\begin{array}{l}\text { Učna pot, šolska ekskurzija, geog. tabor, terensko delo - } \\
\text { projektni dnevi, terensko delo - planinska šola, terensko delo } \\
\text { - izobraževanje o okolju }\end{array}$ \\
\hline 2011 & 3 & $\begin{array}{l}\text { Terensko delo - geografsko tekmovanje, šolska ekskurzija, } \\
\text { učno terensko delo, }\end{array}$ \\
\hline 2012 & 5 & $\begin{array}{l}\text { Šolska ekskurzija, ekskurzija - geog. opis, terensko delo - } \\
\text { nove metode in tehnike, učni poligon - geog. predstavitev, } \\
\text { terensko delo - naravni rezervat }\end{array}$ \\
\hline 2013 & 4 & $\begin{array}{l}\text { Vremenska opazovalnica, terensko delo - nove metode in } \\
\text { tehnike, učno terensko delo - medpredmetno povezovanje, } \\
\text { učna pot - geog. opis }\end{array}$ \\
\hline 2014 & 4 & $\begin{array}{l}\text { Orientacijski tek - medpredmetno povezovanje, terensko delo } \\
\text { - geog. oris }\end{array}$ \\
\hline 2016 & 2 & Učilnica v naravi, terensko delo - geog. oris \\
\hline
\end{tabular}

Med leti 2006 in 2016 so učitelji geografije objavili 12 prispevkov na temo učnih poti, učnega terenskega dela, šolskih ekskurzij in izkustvenega učenja geografije. Da je izkustveno učenje geografije (ne glede na obliko izvedbe) pomembno (tako za avtorje, ki pišejo prispevke, kot tudi za uredništvo, ki jih uvrsti v objavo) lahko sklepamo na osnovi podatkov. Na to temo sta bila letno $\mathrm{v}$ zadnjem desetletju povprečno objavljena po dva prispevka, najmanj en članek leta 2008 in leta 2016 in največ leta $2006 \mathrm{~s}$ petimi prispevki. Glede na organizacijsko obliko izvedbe pouka geografije na prostem je mogoče opaziti trend upada prikazov učnega terenskega dela vse od leta 2007 dalje, še posebej pa v primerjavi z izrazito prevlado tovrstnih prikazov dobrih učnih praks $v$ prvem opazovanem obdobju. Predstavitve primerov šolskih ekskurzij so v celotnem obdobju 


\section{GEOGRAFIJE PODRAVJA \\ K. Kolnik: Kompetence učiteljev in razvijanje lastne profesionalnosti za poučevanje geografije na prostem}

ohranjale približno enak številčni delež, tako v obdobju 2006 - 2016, kot tudi v primerjavi $\mathrm{z}$ njihovim deležem $\mathrm{v}$ prvem opazovanem obdobju. V drugem opazovalnem obdobju je zaznati večjo vsebinsko raznolikost prispevkov učiteljev geografije, kot tudi večje število različnih avtorjev (17 različnih avtorjev: geografi in negeografi, učitelji geografije, svetovalci za geografijo, visokošolski učitelji, študentje geografije). Ni pa mogoče soditi koliko je to posledica odzivnosti učiteljev geografije oz. politike uredniškega odbora revije.

Podrobnejša didaktična analiza prispevkov učnega terenskega dela izvedenega v okviru pouka geografije pokaže, da so učitelji zelo domiselni v izdelavi učnih listov, kjer so naloge raznolike, tako glede na tehniko reševanja, kot same geografske vsebine, manj pa glede uporabe različnih terenskih metod in tehnik zbiranja podatkov ter obdelovanja in predstavitve geografskih informacij. $\mathrm{V}$ analiziranih prispevkih se še vedno ponavljajo enake pomanjkljivosti in napake, ki so bile ugotovljene $\mathrm{v}$ didaktični analizi prvega opazovanega obdobja, to so: ni opredelitve namena praktičnega dela, ni načrtovanja pričakovanih rezultatov, pomanjkljivo je učenje raziskovalnega postopka, manjkajo sintezne ugotovitve, ni interpretacij učnih dosežkov, manjkajo refleksije opravljenega dela ter napotki za samostojno terensko raziskovanje učencev. Upoštevanje teh didaktičnih elementov $\mathrm{v}$ načrtovanju, izvedbi in evalvaciji učenja na prostem, bi pomembno prispevalo $\mathrm{k}$ dvigu kvalitete.

Velja opozoriti na dober primer prispevka Obnovljiva energija Pomurja - izziv za geografe v šoli (Balajc, 2011), kjer lahko zasledimo elemente problemsko zastavljenega terenskega učnega dela: opredelitev raziskovalnega problema in učnih ciljev, načrtovanje in priprava na terensko delo (učiteljeva in učenčeva), oblikovanje raziskovalnih hipotez, opis izvedbe in dejavnosti za doseganje ciljev, predstavitev rezultatov in refleksija dela.

\section{Zaključek}

Učitelji niso le porabniki oz. prenašalci profesionalnega znanja, ki ga proizvajajo drugi, ampak morajo biti tudi proizvajalci tega znanja. Njihova naloga ni samo reagirati na spremembe (zakonodaje, družbene realnosti, novih znanstvenih spoznanj,...), razvijati morajo sposobnost predvidevanja prihodnjega lastnega razvoja in potreb učečih se, t. i. proaktivnost, ki je zasnovana tako na izobraževalnih kot vzgojnih temeljih soodgovornega ravnanja slehernega pedagoga. S proaktivnim učnim pristopom lahko učitelji vzgajajo in izobražujejo učeče se v zavedanju njihovih pravic, kot tudi njihove družbene odgovornosti.

Učitelji geografije se, v slovenskih geografskih didaktičnih raziskavah s področja geografskega poučevanja (Kunaver, 2002; Kolnik, 2006a, 2007, 2010; Resnik Planinc, 2008; Lipovšek, 2016) vedno pozitivno opredeljujejo do pomena poučevanja (in učenja) geografije na prostem. V anketi bralcev revije Geografija v šoli (Poljšak, 2016) so anketirani učitelji geografije kot najbolj kakovostne ocenili prispevke didaktične narave, kamor so uvrstili tudi prispevke s področja učenja na prostem. Med predlogi anketirancev, kaj spremeniti oz. dodati v prihodnjih številkah osrednje revije za primarno in sekundarno geografsko izobraževanje na slovenskem, je bilo med zapisanimi osmimi predlogi tudi: »več primerov terenskega in eksperimentalnega dela« (prav tam: 104).

Znanje, izkušnje in vrednote so predispozicije, ki jih je učitelj geografije razvil ob vključevanju v poklic, prepoznavanje in udejanjanje lastne kompetentnosti za poučevanje 
K. Kolnik: Geography teachers competencies and developing their professionalism for outdoor teaching

geografije na prostem v vsakodnevni pedagoški praksi ter nadgrajevanje le-te v okviru stalnega strokovnega spopolnjevanja so bila tri raziskovalna izhodišča, ki smo jih analizirali $\mathrm{z}$ vidika kvalitete dosedanjega razvoja poučevanja geografije na prostem. Izobraževanje bodočih učiteljev geografije in razvijanje kompetenc poučevanja geografije na prostem ob vstopu v poklic učitelja geografije je bilo analizirano na primeru Dvopredmetnega pedagoškega magistrskega študijskega programa akreditiranega na Filozofski fakulteti Univerze v Mariboru, kot eni izmed treh institucij, ki v Sloveniji izobražujejo bodoče učitelje geografije. Ob dejanskem doseganju načrtovanih kompetenc kot pričakovanih rezultatov ob zaključku študija lahko ugotovimo, da imajo diplomanti vse potrebne predpogoje za uspešno vključitev $\mathrm{v}$ poklic in $\mathrm{s}$ tem začetno poučevanje geografije na prostem.

Stalno strokovno spopolnjevanje učiteljev geografije in razvijanje kompetenc poučevanja geografije na prostem $\mathrm{z}$ vidika analize ponudbe programov in njihove številčne zastopanosti ter namenske in vsebinske raznolikosti je pokazala, da so imeli učitelji geografije od leta 1996 do leta 2016 vedno možnost spopolnjevanja s področja poučevanja geografije na prostem. Njihovo število je sicer nihalo od petih programov (šolsko leto 1996/1996 in šolsko leto 2016/2017) do 1 programa (šolska leta 2010/2011, $2013 / 2014$ in 2014/2015). Torej lahko povzamemo, da so učitelji geografije v zadnjih dvajsetih letih vedno imeli na razpolago vsaj eno strokovno spopolnjevanje s področja učenja geografije na prostem.

Učna praksa izkazana $\mathrm{v}$ primerjalni didaktični analizi vrednosti učenja geografije na prostem v člankih v reviji Geografija v šoli med leti 1996 - 2006 in leti 2006 - 2016 je pokazala, da je v vsakem opazovanem letu bil najmanj en objavljen članek, ki ga je zapisal učitelj geografije kot primer dobre učne prakse poučevanja na prostem. Skupno so učitelji geografije v prvem opazovalnem sedemletnem obdobju napisali 24 tovrstnih prispevkov, drugem opazovalnem obdobju (2006-2016) pa je bilo osemnajst tovrstnih prispevkov. Je pa bilo $\mathrm{v}$ tem časovnem obdobju tudi še štiriindvajset člankov, ki so prinašali geografske opise različnih regij, pojavov in procesov z geografsko sporočilno učno vrednostjo in lahko dajejo učiteljem možnost, da jih didaktično preoblikujejo v izkustveno učenje ter didaktični prispevki s področja učenja na prostem ter prispevki, ki predstavljajo nove metode in tehnike dela ter učne pripomočke za delo na terenu. Primerjava elementov didaktične analize izbranih člankov pokaže, da se v novejših člankih še vedno ponavljajo enake pomanjkljivosti in napake, ki so bile ugotovljene v didaktični analizi prvega opazovanega obdobja, to so: ni opredelitve namena praktičnega dela, ni načrtovanja pričakovanih rezultatov, pomanjkljivo je učenje raziskovalnega postopka, manjkajo sintezne ugotovitve, ni interpretacij učnih dosežkov, manjkajo refleksije opravljenega dela ter napotki za samostojno terensko raziskovanje. Žal se napotilo za njihovo dopolnitev oz. upoštevanje zapisano pred desetletjem še ni v večji meri realiziralo in tako prispevalo k dvigu kvalitete ne samo zapisov dobre učne praksa, ampak upamo tudi prakse same.

Kje so torej razlogi da, pri načrtovanju, izvajanju in evalviranju učenja na prostem nismo v zadnjih desetih letih pri poučevanju geografije (sodeč po analiziranih zapisih) naredili kvalitetnejšega frontalnega razvojnega koraka, ko pa smo že leta 2006 (Kolnik, 2006a) ugotavljali, da so dotedanje izkazane izkušnje učiteljev pomembne in lahko, ob samoanalizi doseženega usmerjajo v še bolj didaktično domišljeno poučenje geografije 


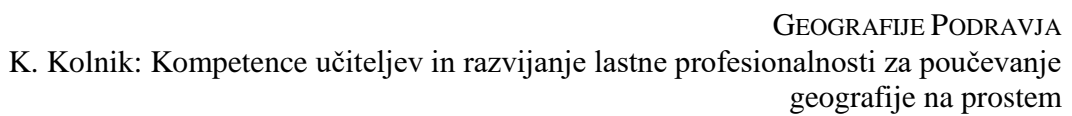

kot dela praktičnega vseživljenjskega učenja. Da tega učitelji »niso dobili in zaznali« v okviru uvajanja v delo z prenovljenimi učnimi načrti geografije, niti ne med ponujenimi programi stalnega strokovnega spopolnjevanja, kot ne iz objavljenih didaktičnih analiz o učenju na prostem v strokovni periodiki. Del odgovora se prav gotovo kaže v zelo redkih refleksijah opravljenega terenskega dela (čeprav se zavedamo, da $\mathrm{v}$ vseh do sedaj izvedenih didaktičnih raziskavah niso nikoli zajeti vsi učitelji geografije), kot tudi, da v analizo stanja nismo zajeli vseh aktivnosti geografskega učenja na prostem (npr. geografskih šolskih tekmovanj in praktičnega dela maturitetnega izpita). Velika vrzel v strokovnem spopolnjevanju učiteljev (tudi učiteljev geografije) se kaže izrazitem pomanjkanju individualne spremljave učiteljevega dela ter možnosti bolj ciljno usmerjenega svetovanja pri njegovem napredku. Čeprav sodobna informacijskokomunikacijska tehnologija omogoča učiteljem nove načine sodelovalnega dela (npr. spletne učilnice in klepetalnice), pa očitno ne omogoča osebne komunikacije in socialnostrokovnih stikov. Učitelji geografije že vrsto let tudi opozarjajo, da je z reorganizacijo nekdanjih predmetnih aktivov učiteljev bila izrazito zmanjšana možnost imeti ustrezne sogovornike pri iskanju povratnih informacij (in primerjav) ter učnih evalvacij. (Resnik Planinc, Kolnik, 2016)

\section{Literatura in viri}

Balajc, D. 2011. Obnovljiva energija Pomurja-izziv za geografe v šoli. Geografija v šoli, letnik 20, št.2, str.48-53. ZRSŠ.

Dvopredmetni pedagoški študijski program geografija, Oddelek za geografijo Filozofska fakulteta Univerza v Mariboru, http://www.ff.um.si/oddelki/geografija/studijski-programi.dot; privzeto 23.januar 2017

Javornik Krečič, M., Kacjan, B., Kolnik, K., Konečnik Kotnik, E., Kukovec, M., Pulko, S., Tavčar Krajnc, M. 2011: Priročnik za praktično pedagoško usposabljanje študenta, Filozofska fakulteta Univerza v Mariboru.

Katalogu programov stalnega strokovnega spolnjevanja strokovnih delavcev na področju vzgoje in izobraževanja (KATIS), Ministrstvo za izobraževanje, znanost in šport, http://www.mizs.gov.si/si/storitve/izobrazevanje/nadaljnje_izobrazevanje_in_usposabljan $\mathrm{je} /$ privzeto november 2016

Kolnik, K. 2005: Učenje za odgovorno prihodnost: primer učenja za kompetentno ravnanje s prostorom. Didactica Slovenica - pedagoška obzorja, št.3-4, str.58-67.

Kolnik, K. 2006a: Učenje geografije v učilnici na prostem in didaktična analiza dosedanje učne prakse. Geogr. šoli, letnik15, št. 2, str. 13-22. ZRSŠŠ.

Kolnik, K. 2006b: Didaktična vrednost učenja geografije na prostem. Didactica Slovenica pedagoška obzorja, št.1, str. 48-56.

Kolnik, K. 2008: Učenje za održivi razvoj i uloga geografskog obrazovanja. Cjeloživotnoučenje za održivi razvoj, v Uzelac, V., Vujičić, L., (ur.) Učiteljski fakultet Sveučilišta Rijeka, Svezak 2, str.101-106.

Kolnik, K. 2010: Lifelong learning and the professional development of geography teachers: a view from Slovenia. J. geogr. high. educ., February 2010, vol. 34, no. 1, str. 53-58.

Konečnik Kotnik, E., Javornik Krečič, M. 2011: Učitelji geografije v poklicnih biografijah o vplivih na svoj profesionalni razvoj. Revija za elementarno izobraževanje, Letnik 3. št.4. str. 5-18, Pedagoška fakulteta Univerza v Mariboru.

Kunaver, J. 2002: Strokovni in osebnostni razvoj učitelja geografije v vseh življenjskih obdobjih. Geografija v šoli, letnik 11, št. 1, str. 3-9. ZRSŠ.

Leva, K. 2016: Značilnosti in razvoj profesionalnosti pri učiteljih geografije. Diplomsko delo. Filozofska fakulteta Univerza v Mariboru. 
K. Kolnik: Geography teachers competencies and developing their professionalism for outdoor teaching

Lipovšek, I. 2016. Optimiziranje terenskega dela pri pouku geografije. Magistrsko delo. Filozofska fakulteta Univerza v Mariboru.

Študijski programi, Geografija, Oddelek za geografijo Filozofska fakulteta Univerza v Mariboru http://www.ff.um.si/oddelki/geografija/studijski-programi.dot; privzeto 12. januar 2017.

Marentič-Požarnik, B. 2005: Vpetost v sodobna pojmovanja učenja in pouka - nujnost in hkrati izziv za geografsko izobraževanje. Slovenska šolska geografija s pogledom v prihodnost, DZS, str.19-23.

Merila za akreditacijo študijskih programov za izobraževanje učiteljev, UL RS 70/11. 7. 2008

O' Connor, M. 2015: Ten powerful concepts for inspired teaching and learning. https://teachingcommons.stanford.edu/teaching-talk/ten-powerful-concepts-inspiredteaching-and-learning, privzeto, 11.januar 2017.

Resnik Planinc, T. 2008. Vrednote prostora v procesu geografskega izobraževanja. Dela. Št.29, str.21- 35. Filozofska fakulteta Univerza v Ljubljani.

Resnik Planinc, T., Kolnik, K. 2016: Delo z učenci s posebnimi potrebami - mnenja in izkušnje učiteljev geografije. Dela. Št.46. Filozofska fakulteta Univerza v Ljubljani. Revija Geografija v šoli: vse številke za obdobje 1996 - 2016, Zavod Republike Slovenije za šolstvo.

Spajić, V. 2007: Europske integracije i obrazovanje za demokratsko građanstvo u cjeloživotnoj perspektivi. Pedagogija prema cjeloživotnom obrazovanju i društvu znanja.

Uzelac, V. 2008: Teorijsko-praktični okvir cjeloživotnog učenja za održivi razvoj. Cjeloživotnoučenje za održivi razvoj, v Uzelac, V., Vujičić, L., (ur) Učiteljski fakultet Sveučilišta Rijeka, Svezak 1, str. 27-54.

Wartschaw, K. 2005: Teaching Concepts. Instructoral Design. Smith \& Ragan. 


\title{
Pokrajina - učiteljica geografije?
}

\begin{abstract}
ANDREJ ČERNE
Povzetek Prispevek je razmišljanje o pokrajini , o ontoloških pomenih tega pojava, predvsem pa o načinih, kako je pokrajino mogoče razumeti ter spoznavati. Avtor izpostavlja nekaj ključnih vprašanj o možnostih objektivnega razumevanja pokrajine napram subjektivnim zaznavam, sooča mnenja številnih avtorjev o predmetu in vsebini spoznavanja geografije, izpostavlja dilemo o pokrajini kot kompleksni, nedeljivi celoti in pokrajini kot mozaiku številnih sestavnih delov, pojasnjuje večno vprašanje med vsebino analize pokrajine in stvarno pokrajino, kritično prikazuje vse večjo drobljenje pokrajine na manjše dele, zaradi česar pokrajine kot celote ne vidimo in ne razumemo več. Besedilo je poziv geografom $\mathrm{k}$ samorefleksiji o izhodiščih in metodah spoznavanja pokrajine.
\end{abstract}

Ključne besede: - pokrajina - geografija - fenomenologija • epistemologija • teorija geografije •

NASLOV AVTORJA: dr. Andrej Černe, upokojeni redni profesor, Univerza v Ljubljani, Filozofska fakulteta, Aškerčeva cesta 2, 1000 Ljubljana, Slovenija, e-naslov: andrej.cerne@ ff.uni-lj.si. 


\title{
Landscape - a geography teacher?
}

\section{ANDREJ ČERNE}

\begin{abstract}
This contribution is a reflection on the landscape, about the ontological significance of this, especially about how the landscape can be understood and how we can get to know it. The author highlights some of the key issues on possibilities of objective understanding of the landscape relative to subjective perceptions, analyzing the opinion of many authors on this topic and the content of learning about geography; highlights the dilemma of the landscape as a complex, indivisible whole, as well as the landscape as a mosaic of many components; it explains the eternal question of the content analysis of the landscape and the real landscape, critically showing the increasing fragmentation of the landscape to smaller parts, resulting in the fact that we don't see the landscape as a whole anymore, and therefore don't understand it. This text is a call for geographers for self-reflexion on the perspectives and methods of knowing the landscape.
\end{abstract}

Keywords: • landscape $・$ geography $\bullet$ phenomenology $\bullet$ epistemology $\bullet$ theory of geography •

CORRESPONDENCE ADDRESS: Andrej Černe, Full Professor (Retired), University of Ljubljana, Faculty of Arts, Department for geography, Aškerčeva cesta 2, 1000 Ljubljana, Slovenia, e-mail: andrej.cerne@ff.uni-lj.si. 


\section{Izhodišča}

Senekov aksiom pravi, da človek izgubi oblast nad celim svetom, ko si poskuša prilastiti njegov del (Seneka, 2004).

Pokrajina je izgubila svojo središčnost v geografiji. Pokrajina je ločena na analize številnih prostorskih enot, pojavov in procesov v prostoru. Opis, ki ne zadeva cele pokrajine, je vedno nepopoln. Pokrajino sicer lahko obravnavamo kot, da jo sestavljajo naravni in družbeni dejavniki, pojavi in procesi ter funkcionira kot celota, kar pa nič ne pove o sami pokrajini. Strabo je bil mnenja, da je geograf oseba, ki poskuša opisati posamezne dele zemlje, Ptolomej pa je imel geografijo za vedo, ki poskuša zasnovati pogled na celoto. Geografijo je ločil od vede o stvareh v prostoru, saj je bil mnenja, da horologija opisuje samo dele, ne pa celote. Hartschorne je zapisal, da je geografija zadolžena za pripravo natančnih, urejenih in racionalnih opisov in interpretacij spremenljivih značilnosti oziroma potez zemeljskega površja. Za Hartshorna je geografija veda, ki proučuje območja in kraje na zemeljskem površju z vidika njihovih razlik in njihovih prostorskih razmerij. Hettner je imel geografijo za regionalno-opisno disciplino (Černe, 2005: 238).

Geografi ne vidimo več celotne pokrajine, marveč samo še številne posamezne prostorske enote, pojave in procese v pokrajini. Geografska znanost poskuša opisati pokrajino zgolj $\mathrm{z}$ naštevanjem značilnosti prostorskih enot, pojavov in procesov, in njihovih razmerij, ki so v pokrajini. Po Lotmanovi teoriji semiosphere (Westphal, 2011: 50) razmerja v pokrajini, z vidika neenakomerne razporeditve prostorskih enot, pojavov in procesov, niso notranji del pokrajine, marveč so rezultat njihovega prepletanja.

Pokrajina je postala zgolj okvir za interpretiranje posameznih prostorskih enot, pojavov in procesov. Kaj ostaja geografom, ko arhitekti iz pokrajine vzamejo hiše, urbanisti naselja, demografi prebivalce, krajinarji zunanjo podobo, hidrologi vodne površine, ... Členitev zemeljskega površja na posamezne prostorske enote, pojave in procese ustvarja iluzijo, da geografi obvladujemo pokrajino. Podrobnejše geografske analize in členitve pokrajine bi lahko primerjali z umetniškim pristopom: iz marmornega bloka kipar $\mathrm{z}$ odstranjevanjem materiala ustvari podobo, $\mathrm{z}$ uporabo kepe gline pa ustvari podobo $\mathrm{z}$ dodajanjem, gnetenjem in preoblikovanjem gline. V geografiji moramo biti neprizanesljivi do pretiranega analitičnega razčlenjevanja, saj geografija predstavljala sintezo. Geografske regionalizacije, členitve in analize posameznih prostorskih enot, pojavov in procesov morajo biti del procesa razvijanja sinteze.

Geografi se ob tej členitvi počutimo suvereni v odnosu do prostora. Regionalizacija je »okno« za geografa, ki pa je »virtualno okno«, ki predstavlja standardizirani pogled, ki ga imamo geografi na prostor. $V$ tem kontekstu je pomembno vprašanje, ali je pokrajina zgolj nosilka »prostorsko logičnega« inventarja (Lefebvre to imenuje produkcija prostora). Geografska opredelitev pokrajine je na nek način poskus razlage številnih dejstev o prostorskih enotah, pojavih in procesih. Te razlage seveda niso nujno »pravilne«, saj lahko dejstva razložimo na zelo različne načine. Poleg tega imamo velikokrat opravka samo z geografskimi interpretacijami in ne z dokazi. Vendar geografi ne smemo samo navajati in naštevati dejstev, marveč jih moramo tudi vrednotiti. Namen geografije ne bil smel biti samo v zbiranju številnih novih dejstev in uporabljanju tistih raziskovalnih metod, ki temeljijo na zbiranju empiričnih opazovanj in njihovem 
združevanju, temveč $\mathrm{v}$ novih pogledih na svet in položaj človeka z njim. »Dejstva geografije so dejstva o krajih. Njihova povezanost daje temelje konceptu pokrajine«, je zapisal Sauer (Leighly, 1963: 321). Vendar dejstva ne pojasnjujejo vrednot.

Govorimo o varovanju narave, o parcelah, naseljih, rabi zemljišč, prebivalcih in tako v nedogled, saj vse tvori (pripada) pokrajino. Znotraj geografskega koncepta se sprašujemo o pokrajini ali sestavnih delih pokrajine, prostorskih enotah, pojavih in procesih, ki v medsebojnem součinkovanju »ustvarjajo« pokrajino. Prevelike podrobnosti lahko zameglijo bistvo - celoto. Celoto pa je mogoče zapopasti ravno s tem, da potlačimo in zameglimo podrobnosti. Načelo popolnosti (Supiot, 2013: 64) govori o tem, da nobena celota ne more pripadati sama sebi in ne more predpostavljati same sebe.

Moderne znanosti - družboslovne in naravoslovne - kar naprej razgrajujejo in razbijajo prostor na številne raznovrstne in vedno manjše sestavne dele. Pokrajina je postala prazen zaboj, zgolj ozadje, kulisa za proučevanje posameznih prostorskih enot, pojavov in procesov. Pokrajina ni seveda prazen zaboj Evklidove geometrije. »Pokrajina ni nikoli prazna, marveč ima vedno vsebino in substanco, ki izhaja (izvira) iz človekovih namenov in predstav ter iz značaja same pokrajine. Takšna »materialna (snovna) pokrajina je »modra barva neba, kot meja med vidnim in nevidnim; je praznina puščave, prostor smrti, je zmrznjen prostor ledenega pobočja; ... depresiven prostor puščave v viharju « (Relph, 1876: 56).

Pokrajina je upoštevana kot raznovrsten prostor procesov in pojavov, ki so v pokrajini, zato je podrejena pragmatični materialnosti. Postala je nepomembna kot celota, multiplicirala se je, prostorsko je razbita na posamezne prostorske enote, pojave in procese, in se vedno bolj diverzificira. Pokrajina se vedno bolj izmika geografski sintezi. Znotraj pokrajine obstajajo prostori vseh vrst in vseh velikosti, za vsako analizo in uporabo ter za vsako funkcijo. Lefebvre govori o treh prepoznavnih načinih razumevanja prostora in časa: (1) prostor kot nekaj, kar materialno občutimo, (2) prostor kot nekaj, kar kenceptualiziramo in (3) prostor kot nekaj, kar doživljamo, oziroma »prostorsko prakso, predstave prostorov in prostor predstav« (Lefebvre, 2013: 60-61).

Geografi smo ujeti v logiko podrobnih analiz prostorskih enot, pojavov in procesov, posameznosti in posebnosti. Številne ideje v geografskem razmišljanju se nanašajo na specifičnosti, koncepte enkratnosti (originalnosti), konkretnosti in idiografičnosti. Pokrajin seveda ne moremo razumeti drugače, kot v vsej njihovi heterogenosti. Pokrajine se razlikujejo med seboj. Razlike niso navidezne (namišljene), marveč so dejanske značilnosti pokrajin. Cezanne je imel za temeljni kamen umnega življenja dojemanje razlik, utemeljenih na podobnostih. Bil je prepričan, da pelje poudarjanje enakosti v »smrt zavedanja nasprotij«. Heterogenost je značilnost vseh postmodernih opredelitev pokrajin. Mnogovrstnost vstopa skoraj v vsako geografsko raziskavo pokrajine. Pred heterogenostjo pokrajine geografi ne moremo ubežati. Heterogenost pa se pogosto reducira na geografsko analizo prsti, vode in zraka, prebivalstva, naselij; geomorfologija se nanaša na bistvene lastnosti površja in ne na pokrajino. Če rečemo, da ima pokrajina razgiban relief, s tem označujemo lastnosti reliefa pokrajine in ne razmerij teh lastnosti do oziroma s pokrajino. Deleuze pri opredeljevanju geofilozofije trdi, da je prostorska podoba »heterogena mešanica, ki deluje kot celota« (Westphal, 2011: 59). Lefebvre zapiše: »Prav tako, kakor lahko belo svetlobo, ki je enotna v njeni pojavnosti, razčlenimo 
v barvni spekter, lahko pokrajino razčlenimo na posamezne sestavne dele, ki so predmet analize«. (Lefebvre, 2013: 103)

Če je pokrajina rezultat prepletanja tako številnih dejavnikov, pojavov in procesov, se zastavlja vprašanje, ali je primerno oziroma možno, da pokrajino proučujemo izven tega konteksta, kot končni fenomen, sam po sebi.

\section{Strokovne podlage}

Problematiziranje predmeta geografije, razprave in razprtije o predmetu geografije, so del predmeta same geografije. So nekakšno polje razprav, kjer potekajo razprave o vsem, kar zadeva geografske vsebine. Vprašanje, pokrajina - učiteljica geografije, se zato nanaša najprej na temeljno splošno ontološko vprašanje: o geografiji kot vedi, ki ima svoj predmet proučevanja. Gnoseološke vprašanje je, ali je predmet geografskega proučevanja sploh dostopen znanstveni raziskavi, ali je spoznanje predmeta proučevanja, sploh dosegljivo. Hevristično vprašanje pa se nanaša na metode geografskega proučevanja. Meja med tem, kaj geografi obvladamo, in česa ne, ni očitna, sploh pa ne samim nam geografom. Geografi vemo, da smo vešči analitiki, ni pa nujno, da vemo, kje so meje stroke in naših sposobnosti. Geografi moramo jasno določiti mejo med tistim, kar lahko vemo, in tistim, o čemer lahko govorimo.

Entrikin navaja opredelitev predmeta geografije, ki jo je podal komite za znanstveno geografijo: »Moderna geografska znanost utemeljuje njen predmet iz človekovih občutkov o kraju in njegove radovednosti za prostorske značilnosti (atribute) zemeljskega površja in atmosferskega ovoja zemlje« Entrikin (1991: 46).

Harvey se pri poskusu opredeljevanja »geografskega uma« sprašuje: »Kako geografska znanja produciramo in uporabljamo? Nima smisla raziskovati nekaj, kar je vendar očitno, vendar pa se izkaže, da je ta očitnost krinka za nekaj precej bolj problematičnega. Zvijačnost geografskega uma je precej bolj prefinjena in zapletena od zvijačnosti zgodovine. Kaj je torej geografski um«? (Harvey, 2011: 159) Harvey se sklicuje na Pattisona in njegove »štiri tradicije geografije«: (1) prostorsko tradicija; (2) tradicijo področnih študij, (3) tradicijo človeške zemlje in tradicijo zemeljskih znanosti. Prostorska tradicija poudarja pomen lokacije, razdalj, smeri in prostorskih vzorcev pri organiziranju političnega in ekonomskega življenja. Tradicija področnih študij je osredotočena na naravo krajev, njihovo diferenciacijo, torej na njihove edinstvene lastnosti. Tradicija človeške zemlje je izredno stara in se nanaša na iskanja odgovorov na vprašanja o človekovem položaje v naravnem redu. Tradicija zemeljske znanosti pa je povezana $\mathrm{s}$ specializiranimi znanostmi o zemlji: geologijo, klimatologijo, meteorologijo, hidrologijo, oceanografijo, paleontologijo, geomorfologijo.

Relph (1976: 4) navaja nekatere avtorje, ki so poskušali opredeliti geografijo. »Vsakdo, ki proučuje svet okoli njega je do neke mere geograf in razvija geografsko epistemologijo, ki temelji na geografijah, ki so sestavljene iz neposrednih izkušenj, spominov, fantazij, sedanjih okoliščin in prihodnjih namenov«. (Lowenthal, 1961) »Geografija je ogledalo za človeka, saj odseva in odkriva človekovo naravo in išče red in pomen v izkušnjah, ki jih imamo o svetu« (Tuan, 1971). »Značaj (narava) geografske stvarnosti se nanaša na najbolj celovito raziskavo o neposrednih izkušnjah sveta, ki zadevajo samo geografijo. Ravnina ali gora, ocean ali ekvatorski gozd, pokrajino sestavljajo različni prostori .... 
Pokrajina je enkratna; ima svoja imena. Je refleksija človekovega temeljnega zavedanja sveta, njegovih izkušenj in namenskih stikov z njenim prostorom. Je pomemben prostor določene kulture, ki je humaniziran $\mathrm{z}$ imenovanjem krajev, s kakovostmi za človeka in $\mathrm{s}$ spreminjanjem zaradi boljšega služenja potrebam človeštva. (Dardel, 1952). »Geografijo moramo nujno razumeti, ne kot nek zaprt sistem, kjer se človek podvrže raziskovanju in opazovanju, kakor opazovanju insektov v laboratoriju, marveč kot način na podlagi katerega človek uresničuje njegov obstoj, prav tako kot je zemlja bistveni vidik njegove usode«. (Relph, 1976: 72).

»Geografska znanost ima fenomenološko podlago«, pravi Relph, saj izhaja iz geografskega zavedanja. Razumevanje pokrajin v kontekstu fenomenoloških temeljev geografije se nanaša na razumevanje pokrajine kot dvo-dimenzionalnega, kognitivnega, kartografskega prostora. »Na eni strani geograf razvija to zavedanje in vpliva na višjo stopnjo zavesti družbe o geografiji, na drugi strani, pa je razvoj geografske znanosti odvisen od obstoja pred znanstvene in geografske zavesti ...; geografi in geografija obstajata samo v družbi z geografskim občutkom (z občutkom za geografijo)«. (Relph, 1976: 18) Ključne fenomenološke razsežnosti človekovega doživljanja pokrajine se nanašajo na spoznanje, da pokrajine ne razumemo samo v smislu našega videnja sveta $\mathrm{z}$ geografske perspektive, ampak tudi v smislu naše integracije s pokrajino, saj je človek s pokrajino tudi na podlagi njegovih čustev in asociacij.

Foucault in Chomski sta prepričana, da človek pojmuje svoj življenjski prostor kot »del neke velike celote, ki se razteza onstran vsakršnih določljivih meja. Njegovo orientiranje in interpretiranje sveta se nujno razširjata v smeri vseobsegajoče celote: zvezde razlaga kot taborne ognje umrlih (Avstralija) ali pa jih v nočnih pomorskih plovbah uporablja kot kozmične orientacijske točke (Polinezija)« (Foucault, Chomski, 2007: 17).

Geografija mora temeljiti na spoznanjih o celostni naravi človekovega življenjskega okolja. »Sem svoje telo, « trdi Gabriel Marcel. »Jaz sem tisto, kar me obdaja,« nam pojasnjuje Wallace Stevens. »Jaz sam sem tam, kjer sem, « ugotavlja Noel Arnaud. »Jaz sam sem sebi svet«, sklepa Ludwig Wittgenstein. »Razumevanje v resnici ni neka kakovost, ki bi prišla v človeško resničnost od zunaj, je njen lasten način bivanja, « pravi Jean-Paul Sartre. Sartre trdi, da se rodimo v svet, ki je sam po sebi za nas najpomembnejši vir znanja. (Pallasmaa, 2007: 110) Geografi raziskujemo pokrajino tudi zato, da bi spoznali in razumeli, »kako se nas svet dotika«, kot je Merleau-Ponty zapisal ob Cezannovih slikah. »Ko ustvarjamo svoj svet, ustvarjamo projekcije in prispodobe lastnih miselnih pokrajin. Bivamo v pokrajini in pokrajina biva v nas. «»Pokrajina misli sebe v meni in jaz sem njena zavest«, pravi Paul Cezanne (Pallasmaa, 2012: 98).

\section{Pokrajina - vsebinska in metodološka pestrost}

Kompleksnost pojma pokrajine je skrita za lahkotnostjo in rednostjo njene uporabe v različnih in raznovrstnih kontekstih. Pokrajine so nenavaden pojav, čeprav trdimo, da jih vsi poznamo, večina geografov pa nas misli celo, da vemo, kakšne so. Pokrajina je, kakršna je, geografi pa mislimo, da je taka, kot jo geografi prikazujemo. Pri tem velja podčrtati pomembno spoznanje, da je pokrajina lahko tudi drugačna kot geografi mislimo, da je. Geografi poskušamo prevajati pokrajine v znanstveno razpravo. Geografi vemo, da je pokrajina celota in kaj so njeni sestavni deli. Hkrati pa se tudi zavedamo, da je pokrajina kot celota »večja« od njenih sestavnih delov. Pokrajina je več kot vsota 
njenih prostorskih enot, pojavov in procesov, je nekaj več kot vsota specifičnih značilnosti narave in grajenih struktur, ki jih je zasnoval človek s pokrajino. Pokrajina je neke vrste sinteza razlik in njihovega prepletanja. Kaj pa je celota in kaj del? Vprašanje je, koliko in katere analize posameznih prostorskih enot, pojavov in procesov potrebujemo, da predstavimo pokrajino kot celoto?

Težave pri spoznavanju geografskih značilnosti, ki so rezultat analiz različnih prostorskih enot, pojavov in procesov $\mathrm{v}$ pokrajini, so povezane $\mathrm{z}$ vprašanjem $\mathrm{O}$ interdisciplinarnosti, ki jo razumemo na zelo različne načine. Koncept interdisciplinarnosti se nanaša hkrati na metodologijo in na sam predmet analize. Med geografi ne obstaja enotnega mnenja o tem, kakšno je razmerje med geografijo in posameznimi znanostmi, ki sodelujejo na naravoslovnem, družboslovnem in humanističnem področju. Geografska analiza pokrajine pogosto vidi interdisciplinarnost $\mathrm{v}$ ožjem pomenu besede, ki vodi $\mathrm{k}$ različnim strokovnim področjem. Pristop k interdisciplinarnosti je pri geografskih analizah zelo različen, izven in preko sorodnosti med strokovnimi področji. Taka interdisciplinarnost je lahko podlaga za primerjalne analize. $\mathrm{V}$ tem primeru uporablja geografska analiza teoretični okvir, ki ni inherenten $\mathrm{z}$ njeno disciplino ali pa uporablja vire ki so izven področja geografije, ali oboje.

Če trdimo, da lahko pokrajino obravnavamo le interdisciplinarno, se zastavlja vprašanje, kaj naj obravnava geografija pri pokrajini. Geograf, krajinar in etnograf lahko opišejo zelo različne pokrajine. Obstajajo zelo različne in kompleksne predstavitve pokrajin. Delitev strok v bistvu ne ustreza vsakodnevni praksi teh strok. Znanost ne tvori niti pojmovne celote, niti ni raznolikost praks, ki sestavljajo območje znanosti. Vse stroke so bile najprej »umetnosti« (technai pri Grkih). Grški filozofi, predvsem Platon, so vpeljali nove zahteve za posebne stroke: ne zadošča, da imajo te stroke rezultate, rezultati morajo biti dobljeni na pravi način, morajo biti takšni, da jih je mogoče pojmovno formulirati, in pojmi morajo zadostiti splošnim pravilom (logike, argumentiranja) (Feyerabend, 2008).

Obstajata dve pojmovanji o geografski naravi pokrajine. Po enem pojmovanju je pokrajina enostavna in nedeljiva, po drugem pojmovanju ima pokrajina kompleksno naravo, sestavljajo jo različni deli, prostorske enote, pojavi in procesi, ki jih ne zaznavamo kot ločene. Dualen odnos do pokrajine se nanaša na opredeljevanje pokrajine v njenem materialnem, fizičnem bistvu in na pokrajino, ki je tudi temelj človekovega bivanja in njegovega samozavedanja. Holistično bistvo pokrajine pa se nanaša na celovito strukturo, funkcijo in razvoj pokrajine, in sicer v njeni nedeljivosti. Holizem raziskovanj o pokrajinah je velikokrat nadomeščen $\mathrm{z}$ »družbeno fiziko« časovne geografije ali $\mathrm{s}$ funkcijskim holizmom sistemskih analiz. Celovita (holistična) kakovost pokrajine je pravzaprav značilnost našega videnja sveta in ne toliko sama podoba sveta. Pokrajina je geografski ključ za razumevanje sveta, geografija pa je oblika razumevanja sveta.

Geografi gledamo na pokrajino iz številnih zornih kotov in zato so načini, kako jo opredeljujemo, analiziramo, metode, ki jih izberemo, konceptualni aparat, s katerim jo pojasnjujemo itd., odvisni od tega, od kod in iz katerega zornega kota jo gledamo. (Černe, 2008: 6) Pri tem razumemo pokrajino kot objektivni pojav, ki obstaja neodvisno od človekove zavesti in človekovih prepričanj ali pokrajino kot subjektivni pojav, ki je odvisen od zavesti in prepričanj geografa. Obstajajo nasprotja med relativno objektivno, zunanjo podobo utelešeno $\mathrm{v}$ naših teoretskih pogledih, in relativno subjektivnimi 
notranjimi pogledi. Tisto, kar je stvarno s subjektivnega vidika, reduciramo na objektivni vidik ali obratno (skrajni različici pozitivizma in fenomenologije). Kant je trdil, da geografija in antropologija opredeljujeta „pogoje možnosti“ vsega znanja. Ta znanja pa so nujna priprava za vse drugo vedenje. Ustrezno poznavanje geografije je razumel kot nujen osnovni pogoj in tudi končni cilj vseh oblik človeškega raziskovanja. Razlika med geografijo in antropologijo temelji, po Kantovem mnenju, »na razliki med zunanjim znanjem, ki ga prinaša opazovanje človekovega položaja v naravi, in notranjim znanjem subjektivnosti«. (Harvey, 2011: 24) Ta dvojnost se nanaša na razlikovanje med objektom in subjektom, med dejstvi in vrednotami, med znanostjo in umetnostjo.

Gre torej za neko obliko polarnosti geografskega koncepta, ki se nanaša na relativno subjektivni in relativno objektivni pogled. Razumevanje pokrajine je povezan z dostopi do objektivne in subjektivne stvarnosti. Ne poznamo formule za oblikovanje enotnosti subjektivnega in objektivnega. Relativno subjektivni pogled je »središčno« gledanje, kjer je človek del prostora in časa. Relativno objektivni pogled pa je povezan $\mathrm{z}$ decentralizirano perspektivo, kjer je pokrajina nadomeščena $\mathrm{z}$ lokacijo ali nizom generičnih, funkcijskih razmerij. Pri decentraliziranem pogledu pokrajina razpade na njene sestavne dele, na posamezne prostorske enote, pojave in procese. Epistemološke razprave o geografski individualnosti so povezane $\mathrm{z}$ decentraliziranim univerzalizmom in centraliziranim partikularizmom. Gre za razmerja med partikularnimi in univerzalnimi oziroma med subjektivnimi in objektivnimi perspektivami. Pri decentraliziranem pristopu postane pokrajina lokacija ali splošno razmerje, pri centraliziranem pristopu pa ima pokrajina pomen $\mathrm{v}$ povezavi $\mathrm{z}$ individualnimi ali skupinskimi cilji in zanimanjem.

Dualistična kakovost pokrajine je v središču geografskih konceptov kot horološke znanosti, ki proučuje razmerja med ljudmi in njihovim okoljem. Geografija postane sintetična horološka znanost, ki je povezana $\mathrm{z}$ modernimi izhodišči o metafizični celovitosti geografije 18 . stol. Ta se nanaša na poznavanje celovitosti, ki je povezana $\mathrm{z}$ narativnim razumevanjem in je povezano s poskusom »videti stvari skupaj«, kar omogoča partikularno-univerzalni ter subjektivno-objektivni pristop. $\mathrm{V}$ tem kontekstu sta pomembni dve komponenti narativnega razumevanja: geografska analiza in geograf. Geografski pogled na pokrajino bi moral biti povezan s hermenevtično teorijo resnice, ki vidi več stališč in perspektiv, je mnogovrsten, pluralen, demokratičen, kontekstualen, vključevalen, horizontalen in skrbeč. (Levin: "asertorični in alethejski pogled«, Pallasmaa, 2007: 66). Geografija se pogosto nanaša na hermenevtiko, na veščino interpretiranja geografov oziroma načinov geografskih razlag pokrajine.

Geografske misli so torej tesno povezane $\mathrm{z}$ objektivnostjo. Kognitivno zanimanje geografov se nanaša na čim bolj natančno predstavitev pokrajine, kar pomeni uporabo objektivnih pogledov in pristopov. To je seveda možen geografski pogled, ne pa dejstvo, in to seveda tudi ni edini pogled, ki obstaja v geografiji. Kierkegaard je mišljenje povezal s subjektivnostjo mislečih. »Brez subjektivnosti mišljenje nima vsebine in rezultati mišljenja drugih niso razumljivi«. (Billnow, 2011: 48) Presoje so vedno relativne, in sicer relativne $\mathrm{z}$ vidika stališča opazovalca. Včasih je to stališče edino, ki obstaja. To sicer opravičuje verovanje v njegovo objektivnost, toda ne dela ga resničnega.

Spreminjajoče in dinamične geografske perspektive na pokrajino so tiste, ki naredijo pokrajino za entiteto s tisočerimi obrazi. Razumevanje pokrajine kot entitete se nanaša na spoznanje, da pokrajina je, ne pa kaj je pokrajina. Razloček med tem, kaj pokrajina je, 
in načinom s katerim se kaže geografu opazovalcu, je le redko jasno razmejen. Obstaja vsaj toliko pokrajin, kolikor je geografskih oči. Vse, kar vstopa pred geografski pogled ali pred »notranje oko« geografa, se lahko na tak ali drugačen način pretvori v opis pokrajine ali spremeni v pokrajino. Ne govorimo samo o povsem različnih pokrajinah na enak način, tudi na iste pokrajine prenašamo povsem različne razprave. Različni pogledi ne izključujejo drug drugega, temveč lahko soobstajajo, sodelujejo in si lahko pomagajo, se lahko dopolnjujejo. Znanje o pokrajini, izhajajoč iz enega samega zornega kota, je lahko zelo omejeno. Ne gre za enoten opis enega samega sveta. Vidiki se nanašajo, ne nazadnje na razmerja med geografom, pokrajino in geografsko reprezentacijo in interpretacijo pokrajine. Geografska reprezentacija pokrajine prikazuje stvarnost ali bolje rečeno, geografove izkušnje o stvarnosti. Gre za razumevanje stika med pokrajino in geografskimi opisi pokrajin najrazličnejših vrst.

Ponovno se izkaže, kako težko je določiti vsebino pojma pokrajine. To velja navsezadnje tudi za metaforično rabo pojma podobe pokrajine in za njeno razmerje do stvarne pokrajine. Kakšno je razmerje med geografskim opisom oziroma analizo pokrajine in stvarno pokrajino? Ali geografi ustvarjamo geografski opis pokrajine, ali pokrajina ustvarja geografski opis? Vprašanje je, kako se pokrajina preobrazi, ko vstopi v kontekst geografije. Ko geografi pišemo o pokrajini, postanemo pripovedovalci »geografskih zgodb«, in s tem geografi soobstajamo s pisanjem o pokrajini. Opis pokrajine ima vedno mentalen, pokrajina sama pa vedno materialen značaj. Pokrajine ne moremo ločiti od fizikalnega in geometrijskega prostora. Zavedati pa se moramo, da pokrajine strukturirajo tudi pomeni in vrednote, ki se zavestno ali nezavedno odražajo pri posamezniku ali skupnosti. Pokrajina je tudi edinstveno doživetje, ki ga interpretira posameznikov spomin in izkustvo. Vsaka geografska interpretacija pokrajine je koherentna in homogena le sama s sabo, pa še to le ob pogoju, da smo zanjo pred tem izbrali en zorni kot in s tem izborom samim izključili vse ostale. Geografi ustvarimo sintezo pokrajine, medtem ko dobimo z analizo predstavo o njeni stvarnosti (Stengerjeva razmišlja o sintezi in analizi, Westphal, 2011: 56). Realistični empirizem trdi, da je svet realen, da je tam zunaj, da ga zaznavamo $\mathrm{s}$ čuti, kakšen v resnici je, in v resnici je časoven, prostorski, prežet z razmerji vzroka in posledice, in naseljujejo ga objektivna bitja. Racionalizem temelji na predpostavki, da resnico zagotavlja razum, ne izkustvo, do kategorij ne pridemo z indukcijo iz izkustva, marveč so temeljne miselne oblike, ki nam šele omogočajo, da imamo izkustva (model »subjektivnega«, »lokalnega« ali »osebnega« prostora za razliko od »objektivnega« prostora). Obstajajo razlike med geografskim opisom (analizo, sintezo) pokrajine in pokrajino, med pokrajino kot podobo in pokrajino, ki je rezultat geografske analize, ki vedno predstavlja določeno distanco »geografskega očesa «. Podoba pokrajine predstavlja neko vrsto odsotnosti pokrajine. Gre za nihanja med realnostjo pokrajine in podobo pokrajine, med »factum in fictum«. Vprašanje ali pokrajino vedno spremlja podoba ali ne, je lahko sporno. V geografiji bi morali izraz podoba razumeti tudi v pomenu »besede« ali »simbola«. Ko gledamo pokrajino, ne vidimo in ne moremo videti pokrajine ločeno od oblik, strukture, funkcij in barv itd.: pokrajino zaznavamo skupaj.

Leibniz poskuša združiti veljavnost univerzalnih resnic z neizbežnim dejstvom sveta, ki ga sestavlja mnoštvo gledišč. Govori o »razliki med scenografijo in ihnografijo«, med perspektivo in ptičjo perspektivo oziroma tlorisom. Za Heideggerja je Descartovo delo inavguriralo »dobo podobe sveta «. »Kar pripada bistvu podobe, je stanje-skupaj (der Zusammenstand), sistem ... enotnost, ki se razvije iz projekcije objektivnosti tega, kar je«. Descartesova mathesis universalis, je pojem, s katerim je mogoče vse objekte misli 
»ne glede na njihovo snov«, urediti in primerjati. »Naš cilj je, da stvari ne proučujemo ločeno, temveč jih primerjamo ene za drugimi, da bi jih na tej podlagi spoznali«. ».... funkcija poenotenje kot taka se še najprej priznava kot temeljna funkcija uma. Razumska urejenost in razumsko obvladovanje danega brez svojega doslednega poenotenja nista mogoča. Spoznati mnogovrstnost pomeni, postaviti njene člene v tako medsebojno razmerje, da jih, začenjajoč iz določenega izhodišča, lahko preverimo po konstantnem in splošnem pravilu .... Neznano in znano sta udeležena v neki »skupni naravi«. (Crary, 2011: 39) Po Kantu gre za preobrnitev načina mišljenja, pri čemer se »naša predstava reči, kakor so nam dane, ne ravna po predmetih kot rečeh samih na sebi, temveč se ti predmeti kot pojavi ravnajo po našem predstavnem načinu«. William Blake je bil prepričan v: »As the Eye, Such the Object«. Foucault pa pravi, da je oblika neposrednega vedenja, »zaznavno spoznanje«. Ko nekdo reče »vidim«, ta oseba razume, dojema, doume. V angleščini, francoščini in številnih drugih jezikih, je vizija - »vision « sinonim za razumevanje, tudi na drugačen način, v drugačnem smislu. Slišimo argumente ali prisluhnemo razlogom. V francoščini je glagol »savoir« (vedeti, poznati, razpoznati) povezan z besedo »saveur« (okus), obe besedi izhajata iz latinske besede »sapere«, kar pomeni, ne samo videti, temveč tudi, imeti dober okus. Sapere je povezana z besedo „scire“ (vedeti v latinščini). (Crary, 2011: 72, 73) Iz tega bi lahko sklepali, da je znanje doseženo z okusom.

Pokrajina je sestavljena iz številnih posameznih prostorskih enot, pojavov in procesov, ki so med seboj v zelo različnih razmerjih. Vsi so izpostavljeni spremembam, ki pa ne spreminjajo specifičnega značaja pokrajine. Gorenjska pokrajina doživlja številne spremembe prostorskih enot, pojavov in procesov ter njihovih razmerij, a ostaja Gorenjska pokrajina. Gre za neko vrsto relativne stabilnosti pokrajine. Nestabilnost je pravzaprav značilnost enotnosti. Soočamo se s stalnostjo a hkrati tudi s spremembami. In kombinacija teh dveh dejavnikov predstavljala izziv v geografiji. Sprememba je edina kontinuiteta s katero razpolagamo. Geografska reprezentacija ne more opredeliti pokrajine $v$ statičnih pogojih. Geografsko vprašanje pa je, kaj tovrstne spremembe pomenijo z ozirom na bistvo pokrajine?

V pokrajini lahko geograf »vidi« različne pojave in procese v določenih razmerjih skupaj s pokrajino. Geografi se ukvarjamo s pokrajino skozi številna razmerja. Geograf je povezovalec, povezovalni element, katerega naloga je, povezati različne prostore, pojave in procese s pokrajino. (Vattimo, 2004) Pokrajine tvorijo razmerja med lastnostmi njenega prostora ter njeno preteklostjo in sedanjostjo. Pokrajine se spreminjajo s časom, saj preteklosti ni več. Tako kot Heraklitova reka, tudi pokrajina ni nikoli dvakrat enaka. Braudel je ob opredeljevanju geozgodovine zapisal, da je prostor bolj pomemben kot čas. Leta in stoletja minejo, toda »oder na katerem človeštvo igra njeno neskončno, vendar vedno ponovno, komedijo, ostaja enak«. (Westphal, 2011: 27, 28) Toda ali prostor ohranja njegovo strukturo zaradi tega ker se ne spreminja? Leta in stoletja minejo, ampak tudi scena se spreminja. Tudi Josif Aleksandrovič Brodskij (Westphal, 2011: 23) je bil mnenja, da je prostor manj vreden kot čas, in sicer ne zato, ker je manj vreden, temveč zato ker je stvar, medtem, ko je čas ideja o stvari.

Pokrajina nosi s seboj zgodovino (zgodovino življenja), zaradi katere je pokrajina postala to, kar danes je. Bahtin (2010) in Braudel (1991) sta želela postaviti zgodovino in geografijo, časovnost in prostorskost $\mathrm{v}$ določeno perspektivo. Za Braudela je geozgodovina zgodovina, ki jo okolje neprestano nalaga človeku. Prostor je tisto, kar 
ostane po zgodovinskem dogodku. Geozgodovina je tudi zgodba človeka, ki se bojuje s prostorom. Geozgodovina primerja dogodke v kontekstu prostora in razume zgodovino v smislu razmerij človeka do prostorske ureditve. Braudel je s pojmom geozgodovina razumel študij dvojne-povezanosti, narave in človeka in človeka in narave, študij dejanj in ukrepanj, pomešanih, neprestano ponavljajočih v stvarnosti vsakdana. (Westphal, 2011) Pokrajina nam kaže svojo starost in zgodovino kakor tudi zgodbo o svojem nastanku in zgodovino človeške rabe. Pokrajina kaže na to, kako se je počasi spreminjala in oblikovala in s tem na nek način uteleša trajanje. Pokrajina je čas, ki se je spremenil v obliko, strukturo in funkcijo. Je živ fizični in družbeni prostor, zato vselej presega geometrijo in merljivost. Kulturna geografija je naredila številne poskuse, da bi povezovala čas in prostor. Svoje korenine ima v geografiji, ki jo je razvil T. Hagerstraand v šestdesetih in zgodnjih sedemdesetih letih 20. stoletja. »Tidsgeografi« ali časovno geografijo (geografija časa) bi lahko prevedli tudi kot »kronogeografija«.

Obstajajo številne poti za geografsko proučevanje pokrajin in številne možnosti za presojanje določenih geografskih poti. Razlike med geografi pri upoštevanju geografskega koncepta so bolj razlike med različnimi načini vstopanja v pokrajino in pogledov nanjo, kakor pa razlike med predpostavkami glede na vsebinsko opredelitev pokrajine. Vsi pa seveda priznavamo, da obstajajo pomembne razlike. Značaj in pomen teh razlik predstavlja strokovno geografsko vprašanje. Različne znanosti se ukvarjajo bodisi z različnimi vrstami pokrajin, bodisi z istim pokrajinami, vendar pojmovanimi z različnih vidikov in $\mathrm{z}$ različnih stališč. Pokrajine so ujete $\mathrm{v}$ znanstvene, politične, filozofske, literarne, itd. razprave. Znanosti delujejo v svojih specifičnih področjih: matematika se ukvarja s posploševanjem količine, geometrija s posploševanjem prostorskih oblik, fizika s posploševanjem mehanskih lastnosti snovi, kemija $\mathrm{z}$ združevanjem in medsebojnim delovanjem substanc, psihologija z mehaniko čutnega aparata itd. Posploševanje zaradi geografskih razsežnosti ali sinteznih značilnosti pa je funkcija geografa - v nasprotju s specializiranimi posplošitvami drugih strok. Pokrajina je opredeljen s številnih zornih kotov: geografije, ekologije, geopolitike, antropologije, etnologije, arhitekture, krajinske arhitekture, planiranja itd. Arhitekti so povezani z arhitekturnimi pokrajinami, ekonomisti si prilaščajo gospodarske pokrajine, geografi geografske pokrajine in regije. Različne stroke »vstopajo « v eno in isto pokrajino na zelo različne načine. Pokrajino izražamo in vrednotimo $\mathrm{v}$ znanstvenem, geografskem, socialnem, ekonomskem, planerskem, poetičnem, mističnem, instrumentalnem, moralnem in etičnem, ter čustvenem in efektivnem jeziku. Pokrajino opredeljujemo na konkreten pa tudi na abstrakten, simbolni način. Zato imajo nešteto obrazov in vidikov oziroma, bolje rečeno, vse možne obraze in vse možne vidike. Zato so možne različne analize oziroma bolje vse analize (Černe, 2005).

Geografski odnos do pokrajine je izredno raznovrsten, raznovrstna pa je tudi »stvarnost«, ki jo v pokrajini analiziramo. Pokrajina je sama po sebi »politopija«, prostor razumljen v njegovi pluralnosti - objektivna stvarnost in resnični prostor. Govorimo o totalnem prostoru, pantopiji, ki jo je Serres razumel kot kraj »vseh krajev v kraju in vsak kraj v vseh krajih, središče in obsega globalna pogovor« (Westphal, 2007: 40). Nobena predstavitev pokrajine seveda ni popolna kopija »stvarne« pokrajine. Pokrajine živijo s časom zgodovine in s človeškimi družbami in so sestavljene tako iz ljudi in kamnov kakor iz besed. Svet kamnin, jezer, rek, vegetacije, zgradb, je bolj stvaren, kot besedilo ali geografska karta. Johannes Vermeer je na slikah Geograf in Astronom (1668) upodobil »raziskovalca«, zatopljena $\mathrm{v}$ določeno analizo. Astronom proučuje nebesni globus, 
geograf ima pred sabo zemljevid. Oba odvračata pogled od okna, ki se odpira v zunanjost - stvarnost. Zunanji svet ni spoznan z neposrednim raziskovanjem, temveč prek mentalne ocene reprezentacije. Ločitev med ponotranjenim subjektom in eksternim svetom je prvi pogoj vednosti o zunanjem svetu. Vsak raziskovalec razglablja o ključnih lastnostih sveta, o njegovi razsežnosti. Oba se posvečata skupnemu opazovanju vidikov ene nedeljive zunanjosti. Skratka, pokrajino doživljamo $v$ njeni stvarnosti in njeni virtualnosti. Ali to pomeni, da je geografija pokrajine odrezana od materialne stvarnosti? Zemljevid je pravzaprav namenjena temu, da vidimo pokrajino tam, kjer je ni, na papirju. Gre za sposobnost pretvorbe tridimenzionalne pokrajine na papir, ki s svojo ploskovitostjo nikakor v celoti ne ustreza stvarni pokrajini. Na ravni površini prikazujemo pokrajino in s tem na nek način tudi naš pogled na pokrajino. Zemljevid je kot medij v nekem smislu v nasprotju s pokrajino, čeprav nam prikazuje podobo, ki je podlaga za to, da ustvarimo predstavo o pokrajini. Pokrajina ima na površini brezprostorsko podobo, čeprav vabi k razgledovanju po prostoru stvarne pokrajine. Pri tem pa je jasno, da je »geografska karta« prikaz zemeljskega površja na ravni površin,i in nobene potrebe ni, da bi bila nekaj drugega.

Povezava med pokrajino in geografovo reprezentacijo pokrajine ni razjasnjena, njihova razmerja so neopredeljena. Ali je geograf poročevalec o objektivni »stvarni« pokrajini in geografsko predstavitvijo te pokrajine? Ko v geografiji govorimo o abstrakciji, mislimo v prvi vrsti na splošni odmik od reprezentacije - o nekakšnem popačenju pokrajine, ki se ne prilagaja zunanji vidni realnosti, marveč v večji meri geografovem razumevanju te realnosti. Geografska analiza pokrajine je hkrati podobnost in reprezentacija pokrajine, neke vrste rezultat »notranjega očesa « geografa. Geografi smo hkrati »opazovalci« in gledalci«, kot pravi Crary (2012: 7). V splošni rabi sta opazovalec in gledalec sinonima. Opazovalec (observer) je povezan predvsem $\mathrm{z}$ njegovo etimološke resonanco. V nasprotju $\mathrm{z}$ besedo gledalec (spectre), latinskim korenom besede »spectator«, koren besede »observe « v dobesednem smislu ne pomeni »gledati nekaj«, marveč pomeni tudi »ravnati v skladu z, upoštevati pravila«. Kaj smo torej geografi kot opazovalci pokrajine in kaj tvori naše videnje pokrajine, in kako lahko opazovanje posameznih prostorskih enot, pojavov in procesov v pokrajini privede $\mathrm{k}$ verodostojnim sklepom o pokrajini? Gre za razumevanje in določanje razmerja med geografom, tistim ki spoznava, in pokrajino, tistim, kar je del spoznanja, za izbiro stvarnosti, obliko resnice, vključno z merili realnosti in racionalnosti. Ali smo geografi sposobni videti pokrajino kot »atrapo«, to je, ali znamo razločevati med pokrajino samo in načinom pojavljanja pokrajine. Razmerje med pokrajino in njeno geografsko reprezentacijo je akumulirano na podlagi dveh komplementarnih načel: prvo govori o tem, da je pokrajina drugačna od njene reprezentacije, drugo načelo pa reprezentaciji ne daje posebnega pomena pri opredeljevanju pokrajine. Če bi nam šlo za to, da bi razmerje med podobo pokrajine in pokrajino opredelili prostorsko, potem podoba pokrajine ne stopa med nas in pokrajino tam zunaj. Prej je obratno. V dejanju opazovanja se podoba pokrajine izmenja med pokrajino tam zunaj in nami. Pokrajina ostaja tam zunaj, medtem ko je podoba pokrajine v nas samih. S pokrajino moramo imeti vizualen stik, gledati jo moramo z odprtimi očmi, vendar je to samo prvi in po svoje manj pomemben del videnja. Pokrajino moramo poustvariti tudi $\mathrm{v}$ geografskih mislih.

Ko govorimo o možni percepciji pokrajine, smo soočeni $\mathrm{z}$ neskončno možnostjo interpretacij, z notoričnostjo semantične odprtosti in nenazadnje s sugestibilnostjo našega dojemanja (opazovanega in opazovanca). Pokrajine so dane kot možnosti preko 
alternativnih geografskih pogledov. V znanosti je dolgo časa veljalo, da je potrebno odstraniti vse lastne ideje. Pokrajina se mora, čisto taka kot je, odslikavati v mislih. Znanost je imela skupno idejo o obstoju enega sveta in ene odslikave, ter o tem, da moramo svet prikazati povsem natančno in brez lastnega dodajanja. V znanosti se množijo glasovi tistih, ki pomembnih znanstvenih spoznanj ne pripisujejo postopni uporabi strogih metod, temveč drznim prebliskom posameznikov. V obeh primerih je potrebno strokovno znanje. Toda potrebne so tudi ustvarjalne ideje, to je, znanstveniku ni treba zatajiti svoje osebnosti. Znanost je v prvi vrsti določena z ustvarjalno močjo domišljije in ne s stvarnimi dejstvi, ki nas obdajajo.

\section{Zaključek}

Razumevanje pokrajine se nanaša na prizadevanja, da bi odkrili značaj razmerij med človekom in naravo. Naloga geografa ni, da pove, kaj mu je všeč ali kaj ne. To je osebna zadeva, ki usmerja interes v pripovedovanje. Od geografa se ne zahteva, da spreminja pokrajino v kontekstu njegovega mnenja. Geograf mora pokrajino razlagati in ne sme biti samo mislec zunanjosti. Ne gre samo za opazovanje pokrajine, marveč za razumevanje, spoznavanje in tudi doživljanje pokrajine v vsej njeni neposrednosti.

Podrobnejše geografske analize prostorskih enot, pojavov in procesov vplivajo na vlogo pokrajine $\mathrm{v}$ geografiji, tako $\mathrm{s}$ teoretskega in metodološkega, kot $\mathrm{z}$ vsebinskega vidika. Geografi bi se morali zavzemati za prevlado pokrajine nad geografsko analizo posameznih prostorskih enot, pojavov in procesov v pokrajini. Geografska analiza se mora nanašati na opredeljevanje širšega in bolj poudarjenega pomena pokrajine, $\mathrm{v}$ primerjavi s tistimi analizami, ki vsebujejo zgolj prostorske-specifične podobe kakovosti topografije in zgradb.

Geografi moramo $\mathrm{z}$ analiziranjem in pojasnjevanjem prostorskih enot, pojavov in procesov graditi sistem o pokrajini. V teoriji polisistemov (Evan-Zohar, Westphal, 2007: 45) je polisistem »sistem sistemov«, ki je miltiplicirana stratificirana celota, kjer so razmerja med središčem in periferijo nizi priložnosti. Semiotika pokrajine se naslanja na koncept semiotike oziroma tri njene discipline: (1) sintaktiko, ki proučuje medsebojna razmerja med znaki; (2) semantiko, ki proučuje odnose znakov oziroma znamenj z vidika tistega, kar pomenijo oziroma označujejo; (3) pragmatiko, ki se ukvarja z odnosi znakov s stališča njihove uporabnosti oziroma $\mathrm{z}$ vidika tistih, ki jih uporabljajo.

Geografsko razumevanje pokrajine je zasnovano na predpostavki, da je to razumevanje odvisno od obstoja tistih lastnosti prostorskih enot, pojavov in procesov, ter njihovih razmerji, ki ustvarjajo pokrajino.

Geografija prinaša skupaj materialne in nematerialne značilnosti pokrajine, je kontekst, ki poveže stvari s prostorom na podlagi povezovanja različnih prostorov ter pojavov in procesov, ki strukturirajo pokrajino in ji dajejo funkcijo. Geografijo zanima povezanost stvari, ki dajejo poseben značaj določenim pokrajinam. Narativno razumevanje pomeni neke vrste »videti stvari skupaj«, nanaša se na razumevanje povezovanja objektivnih »dejstev« v vseobsežno celoto, in sicer s humanističnega vidika, ki se zavzema za povezavo med geografom in pokrajino. Goethejev »občutek o celoti« povezuje preteklost in sedanjost, čas in prostor, naravo in civilizacije, posameznika s človeštvom, in sicer znotraj konkretnosti. Univerzum $\mathrm{v}$ konkretnosti pomeni videti čas in prostor ter 
zgodovino razprostranjeno na posameznih delih zemeljskega površja. (Entrikin, 1991) Kontekstualisti želijo povezati skupaj dejavnike in strukture, namene in okoliščine, splošnost in posameznost in istočasno iskati razlage za vzročnost.

Pokrajina »drži skupaj« različne prostorske enote, pojave in procese in obratno, prostorske enote, pojavi in procesi »držijo skupaj« pokrajino. Pokrajino držijo skupaj vsi pojavi in procesi. Pojave in procese bi morali proučevati z namenom, da jih pretvorimo $\mathrm{v}$ pokrajino, saj so vsi pojavi in procesi s pokrajino, in obratno. Gre za razmerja med pokrajino in njenimi prostorskimi enotami, pojavi, procesi, strukturo in funkcijo.

Geografi seveda nikoli ne moremo analizirati vsega, kar vsebuje pokrajina, čeprav mora upoštevati vse znane dejavnike, subjektivne in objektivne, saj mora pokazati na pomen celotne vednosti, intuicije, izkustva in vsega tistega, kar je dostopno v smislu realnosti. Geografija ni deterministična disciplina, ki poskuša spoznati in pojasniti vse. Predpostavka je, da ne vemo vsega in da je celo obstoječe geografsko znanje le začasno.

\section{Literatura in viri}

Bahtin, M., M. 2010: K Filozofiji dejanja. Prevedel Blaž Podlesnik; spremna beseda Eda Čufer, Zavod Emanat, Ljubljana.

Billnow, O., F. 2011: Human Space. Translated by C. Shuttleworth. Ed. J. Kohlmaier, Hyphen Press, London.

Braudel, F. 1991: Čas sveta. Materialna civilizacija, ekonomija in kapitalizem, XV.-XVIII stoletje. ŠKUC, Filozofska fakulteta, Ljubljana.

Crary, J. 2012: Tehnike opazovalca. Videnje in modernost v devetnajstem stoletju. Založba Sophia, Ljubljana.

Černe, A. 2008: O pomenih pokrajine. Dela, ISSN 0354-0596. [Tiskana izd.], 2008, 29, str. 5-19. http://www.ff.uni-lj.si/oddelki/geo/Publikacije/Dela/files/dela_29/cerne.pdf.

Entrikin J., N. 1991: The Betweenness of Place. Towards a Geography of Modernity. The John Hopkins University Press, Baltimore.

Feyerabend, P. 2008: Znanost kot umetnost. Sodobna družba, Založba Sophia, Ljubljana.

Foucault, M., Chomski, N. 2007: Človeška narava in zgodovina. Paolo Virno, Krtina, Temeljna dela, Prevod Tone Dolgan, Ljubljana.

Harvey, D. 2011: Kozmopolitstvo in geografija svobode. Založba Sophia, Ljubljana.

Lefebvre, H. 2013: Produkcija prostora. Studia Humanitatis, Ljubljana.

Leighly, J. 1963: Land and Life: A selection from the writings of Carl Ortwin Sauer. Berkeley: University of California Press.

Pallasmaa, J. 2007: Oči kože. Arhitektura in čuti. Prevedel Gregor Moder, Studia humanitatis, Zbirka Varia, Ljubljana.

Pallassmaa, J. 2012: Misleča roka. Eksistencialna in utelešena modrost v arhitekturi. Prevod: Polona Petek, Studia Humanitatis, Ljubljana.

Relph, E. 1976: Place and Placelessness. Research and Planning Design, Pion Limited, London.

Seneka, L., A. 2004: Pisma prijatelju Luciliju. Slovenski prevod Fran Bradač, Modrijan, Ljubljana. Supiot, A. 2013: Duh Filadalfije. Socialna pravičnost proti totalnemu trgu. *cf. Ljubljana.

Vattimo, G. 2004: Filozofska karta 20. stoletja. Tehnika in eksistenca. Založba Sophia, Ljubljana. Westphal, B. 2011: Geoctriticism Real and Fictional Spaces. Translated by Robert T. Tally Jr. Palgrave, Macmillan New York. 



\section{Geografski pogledi na pokrajino med Pohorjem in Slovenskimi goricami}

Iz recenzije: „Geografije Podravja je izvirno znanstveno delo širokega tematskega profila in zato namenjena najprej stroki - geografiji in geografom v različnih ustanovah in šolah, širše pa je primerno gradivo za upravljalce na ravni občin in regije. Menim, da je prav zaradi širine zelo kakovosten vir za študente geografije."
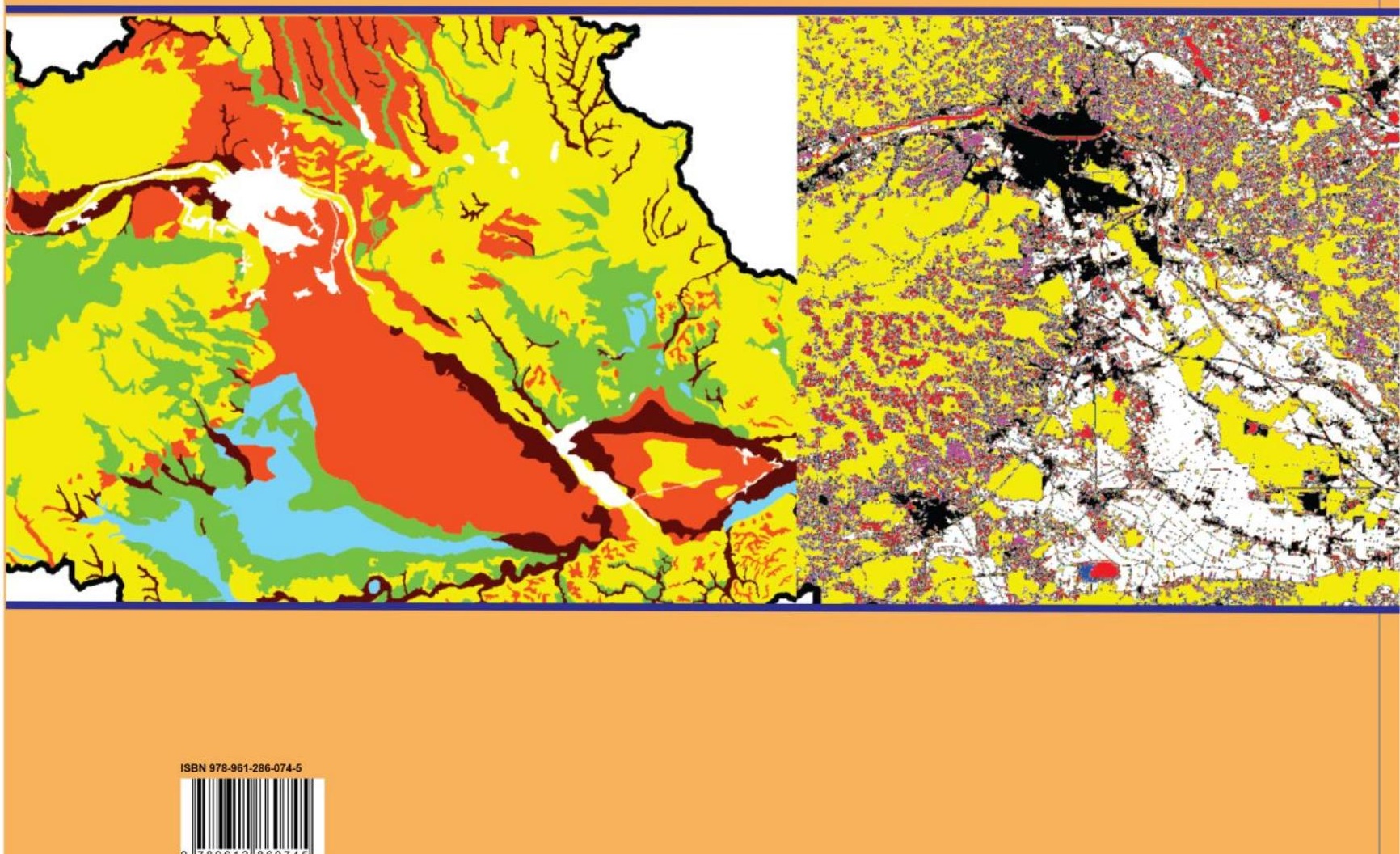